\title{
Legal aspects of the European social dialogue
}

Citation for published version (APA):

Franssen, E. J. A. (2002). Legal aspects of the European social dialogue. [Doctoral Thesis, Maastricht University]. Intersentia. https://doi.org/10.26481/dis.20021030ef

Document status and date:

Published: 01/01/2002

DOI:

10.26481/dis.20021030ef

Document Version:

Publisher's PDF, also known as Version of record

\section{Please check the document version of this publication:}

- A submitted manuscript is the version of the article upon submission and before peer-review. There can be important differences between the submitted version and the official published version of record.

People interested in the research are advised to contact the author for the final version of the publication, or visit the DOI to the publisher's website.

- The final author version and the galley proof are versions of the publication after peer review.

- The final published version features the final layout of the paper including the volume, issue and page numbers.

Link to publication

\footnotetext{
General rights rights.

- You may freely distribute the URL identifying the publication in the public portal. please follow below link for the End User Agreement:

www.umlib.nl/taverne-license

Take down policy

If you believe that this document breaches copyright please contact us at:

repository@maastrichtuniversity.nl

providing details and we will investigate your claim.
}

Copyright and moral rights for the publications made accessible in the public portal are retained by the authors and/or other copyright owners and it is a condition of accessing publications that users recognise and abide by the legal requirements associated with these

- Users may download and print one copy of any publication from the public portal for the purpose of private study or research.

- You may not further distribute the material or use it for any profit-making activity or commercial gain

If the publication is distributed under the terms of Article $25 \mathrm{fa}$ of the Dutch Copyright Act, indicated by the "Taverne" license above, 


\section{LEGAL ASPECTS OF THE EUROPEAN SOCIAL DIALOGUE}




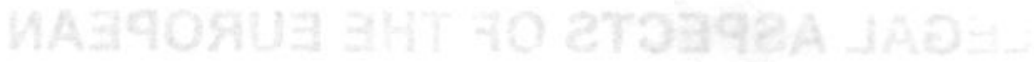
ZUOO JAIO IAPOOE 


\section{LEGAL ASPECTS OF THE EUROPEAN SOCIAL DIALOGUE}

\section{PROEFSCHRIFT}

ter verkrijging van de graad van doctor aan de Universiteit Maastricht, op gezag van de Rector Magnificus, Prof.dr. A.C. Nieuwenhuijzen Kruseman volgens het besluit van het College van Dekanen, in het openbaar te verdedigen op woensdag 30 oktober 2002 om 16.00 uur

door

EDITH JACOMINA ANNETTE FRANSSEN 


\section{Promotores:}

Prof.mr. A.J.C.M. Geers

Prof.mr. G.J.J. Heerma van Voss (Universiteit Leiden)

\section{Beoordelingscommissie:}

Prof.mr. B.E.F.M. de Witte (voorzitter)

Prof.dr. A.J.T.M. Jacobs (Katholieke Universiteit Brabant)

Mr. W.J.M. Rauws

(ㄷ) 2002 Intersentia

Antwerp - Oxford - New York

Van deze studie is een handelsuitgave verschenen bij Intersentia onder ISBN 90-5095-255-0 


\section{PREFACE}

Being interested in labour law and European law, I started this research with a lot of enthusiasm. It was a challenging subject, since the European social dialogue is still very young, and a lot of legal aspects of it are not clear yet. I worked 5,5 years on this thesis, mostly with pleasure, sometimes with ill grace. People who have completed their doctoral degrees often told me that every Ph.D. student has a hard period, mostly two or three years after he/she has started. I am certainly no exception in this regard.

There are a lot of people who have supported and advised me during this period. First of all, my two supervisors, Guus Heerma van Voss and Ad Geers. The idea for this thesis came from Guus. He has read my drafts frequently and commented on them with great patience. Ad has been very cooperative when I indicated that I wanted to broaden my knowledge of labour law, beyond the subject of my thesis. He introduced me to the legal advice centre in Roermond, where I have worked part time for 2,5 years with great pleasure.

I also want to thank the examining committee, consisting of Bruno de Witte, Wilfried Rauws and Antoine Jacobs. Especially with Antoine Jacobs, I had long and interesting discussions about the subject of my thesis. He often came up with original ideas and refreshing points of view. His own thesis has formed an important inspiration source for me.

There are a couple of chapters which deal with European institutional law. Ellen Vos, Hildegard Schneider and Lisa Waddington have read them and commented upon them. Thanks to their fruitful comments, the chapters have taken the form and content they have now. There are also aspects of private international law and European private law in my thesis. Stephan Rammeloo has checked the private international law aspects and Jan Smits the European private law aspects. I want to thank them both for their useful comments. Filip Dorssemont has made some good and interesting comments on the part of my thesis that deals with the legal status of Belgian workers' organisations.

I have interviewed a number of persons working for European social partners organisations: Mr. Clauwaert and Mr. Lapeyre from the ETUC, Mrs. Gava and Mrs. Fredensborg from CEEP, Mrs. Deliederkercke from UNICE and Mrs. Feller from COPA. Furthermore, I have interviewed experts on European labour law in the academic world, such as Prof. Birk and Prof. Bercusson. I am also grateful to experts from the European Commission with whom I could speak about the role of this institution in the European social dialogue. I spoke to Mr. Olsson, Mrs. Thozet and Mr. Morin. 
Since typing was not always easy as a result of repetitive strain injury, I was greatly helped by Remco Coppen. Besides the fact that he did a lot of typing for me, he also came up with good ideas regarding the content of this book. I also thank Nettie Litjens and Bregtje Schwenke, for taking the time consuming job of making this book camera-ready.

Moral support came from my family and friends. They cheered me up when I thought that it was not going to work out. I want to thank them all and in particular my friend Marc who supported me very much during the last period of this research. 


\section{TABLE OF CONTENTS}

Preface

Table of contents.

List of abbreviations

\section{PART I INTRODUCTION}

Chapter 1

Introduction

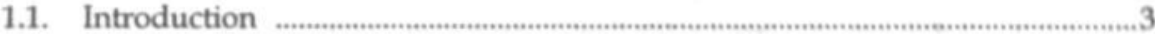

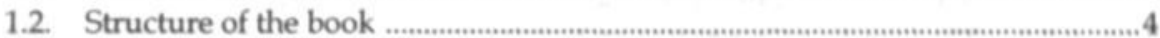

1.3. Research method .......................................................................................................... 5

1.4. Relation with other researches on the European social dialogue .......................5

1.5. Do we need collective agreements at European level? ...........................................6

1.6. Preconditions for the development of a European social dialogue .....................8

1.6.1. The developments of human rights protection in

Community law: a short overview...............................................................

1.6.1.1. Human rights protection in general .........................................

1.6.1.2. Socio-economic human rights ...................................................14

1.6.2. The freedom of association ....................................................................16

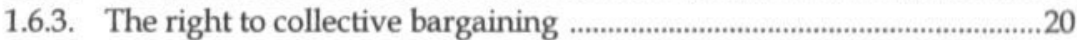

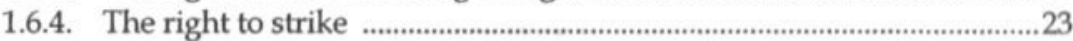

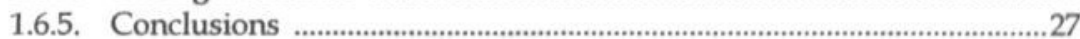

\section{Chapter 2}

Some European social partners' organisations

2.1. Introduction ....................................................................................................29

2.2. Intersectoral organisations representing all categories of workers and employers ......................................................................................29

2.2.1. The European Trade Union Confederation (ETUC) .............................30

2.2.2 The Union of Industrial and Employers' Confederation (UNICE) .......32

2.2.3. The European Centre for Public Enterprises (CEEP) ..............................33

2.2.4. Conclusions ...........................................................................................35

2.3. Intersectoral organisations representing certain categories of workers

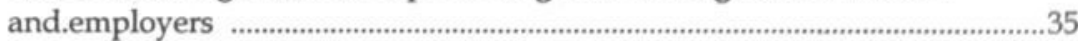

2.3.1. The European Association of Craft and Small and Medium Sized Enterprises (UEAPME) ......................................................................35

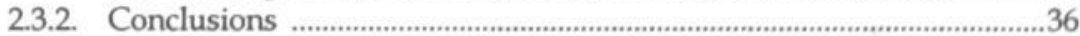

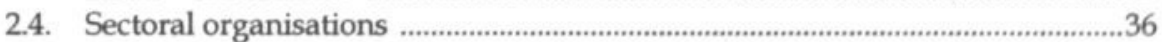

2.5. The legal status of European social partners' organisations ..............................38

2.5.1. Legal personality in general ................................................................38

2.5.2. Which national law is applicable on European social partners' organisations when it comes to legal personality? 
2.5.3. Application of the Belgian law on European social partners' organisations

2.5.4. The choice of certain European social partners' organisations as regards their legal status

2.5.5. Should European social partners' organisations have legal personality?

2.5.6. Conclusions

\section{Chapter 3}

An enhancing role for the European social partners' organisations

3.1. Introduction

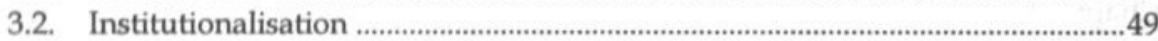

3.2.1. The Economic and Social Committee ......................................................49

3.2.2. Advisory committees for the Commission ...............................................50

3.2.3. The Standing Committee on Employment .............................................52

3.2.4. Tripartite conferences .............................................................................54

3.2.5. The Steering Group and Social Dialogue Committee ............................55

3.2.6. The revival of the sectoral joint committees ............................................56

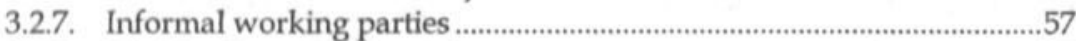

3.2.8. The Employment Committee ...............................................................57

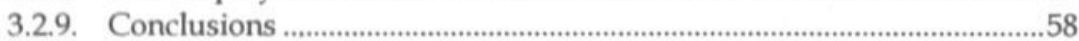

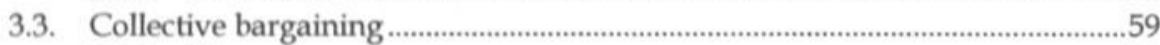

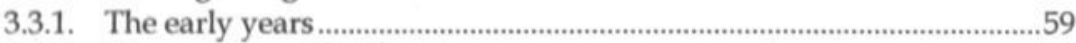

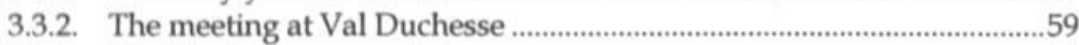

3.3.3 The Single European Act .......................................................................61

3.3.4. The Joint Agreement of 31 October 1991 .................................................62

3.3.5. The Agreement on Social Policy and the Treaty of Maastricht .............65

3.3.6. The Treaty of Amsterdam..........................................................................68

3.3.7. Results of collective bargaining at European level.................................68

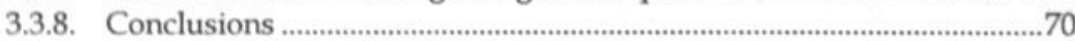

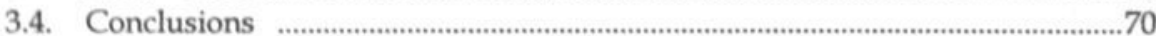

\section{PART II THE CONSULTATION PROCEDURE AND THE CONCLUSION OF EUROPEAN AGREEMENTS}

\section{Chapter 4}

The consultation procedure and its follow-up ..........................................................75

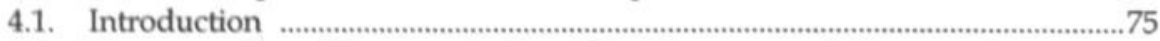

4.2. The promotion of the consultation of the European social partners'

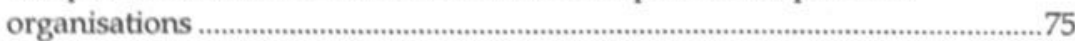

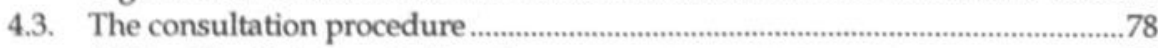

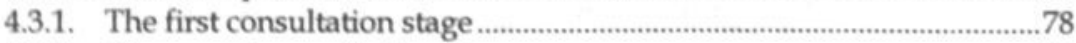

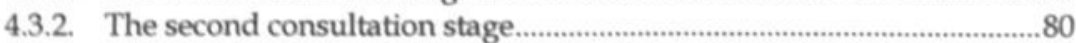

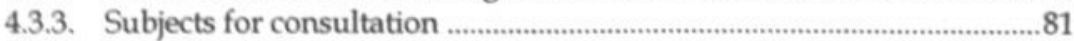

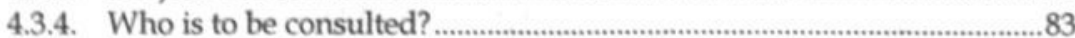

4.3.4.1. Representativity .......................................................................84

4.3.4.2. Analysis of the representativity criteria .....................................85

4.3.4.3. Other ideas for representativity criteria .....................................8 88 
4.3.5. Conclusions

4.4. The start of negotiations between the European social partners'

organisations

4.4.1. At what time may the European social partners'

organisations start their negotiations?

4.4.2. Role of the Commission during the nine-month period ........................99

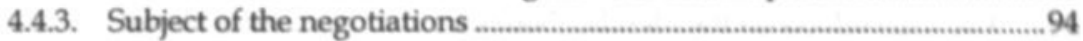

4.4.4 Who is "management and labour" in Article 138(4)? .............................95

4.4.5 What if the European social partners' organisations cannot conclude an agreement? ..............................................................................96

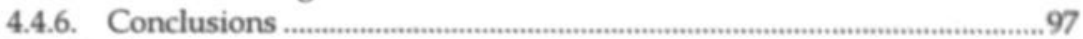

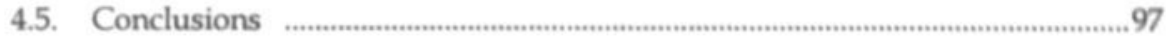

\section{Chapter 5}

The conclusion of European agreements and their legal effects ..............................101

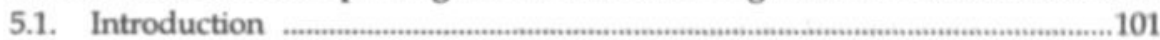

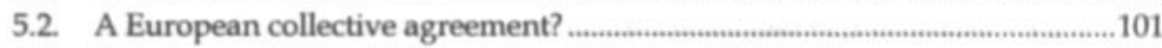

5.3. Requirements for valid European collective agreements .................................105

5.3.1. Requirements with regard to the concluding parties ..........................106

5.3.2. Requirements with regard to the bargaining procedure ......................107

5.3.3. Requirements with regard to the form of the agreement ....................110

5.3.4. Requirements with regard to the content of the agreement ................111

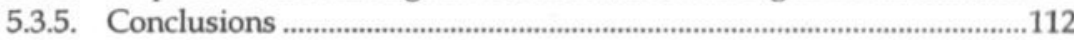

5.4. The legal effects of European collective agreements ........................................113

5.4.1. Which actors can be legally affected? ...................................................113

5.4.2. Legal sources to be used for determining the legal effects resulting from European collective agreements .....................................115

5.5. The legal effects on the signatory parties ...........................................................116

5.5.1. The present situation ................................................................................116

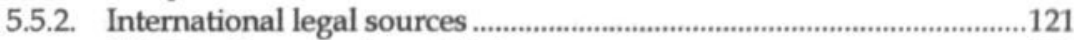

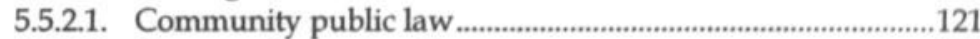

5.5.2.2. Community contract law.........................................................121

5.5.3. ILO documents .......................................................................................125

5.5.4. Alternative idea ........................................................................................125

5.5.5. Content of the legal effects on the signatory parties .............................126

5.5.6. Conclusions ..........................................................................................127

5.6. The legal effects on the national affiliates of the European organisations .....128

5.6.1. Community law .........................................................................................129

5.6.2. The internal rules of the European organisations and private

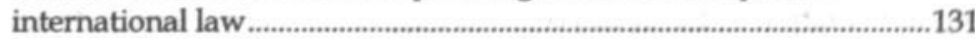

5.6.3. ILO-documents ........................................................................................134

5.6.4. Content of the legal effects on the national affiliates ............................135

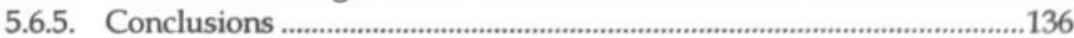

5.7. The legal effects on individual workers and employers ..................................137

5.7.1. The European collective agreement has been implemented through national collective agreements 
5.7.2. The European collective agreement has not been implemented through national collective agreements or has been implemented incorrectly ...............................................................................138

5.7.2.1. Community law............................................................................139

5.7.2.2. Private international law............................................................145

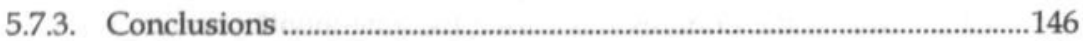

5.8. The legal effects on the Member States...........................................................146

5.8.1. The legal status of the Declaration by Article 139(2) EC Treaty ..........147

5.8.2. The content of the Declaration .............................................................149

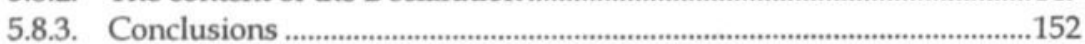

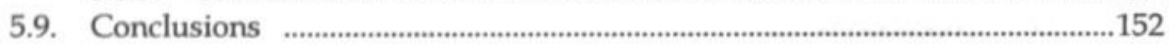

\section{Chapter 6}

Enforcement of European collective agreements ....................................................155

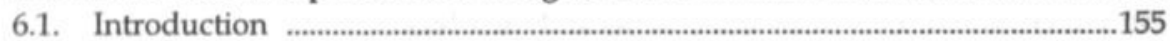

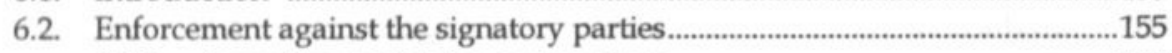

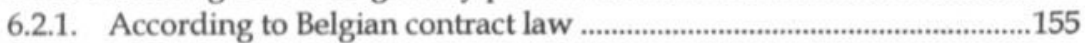

6.2.2. Options for the future ..............................................................................161

6.2.2.1. Obligation to influence their members .....................................162

6.2.2.2. Obligation to refrain from industrial action ............................162

6.2.2.3. Prevention and resolution of industrial disputes ...................162

6.2.3. Conclusions ............................................................................................169

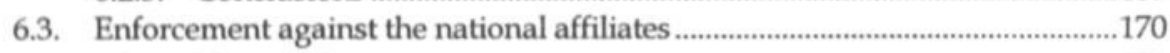

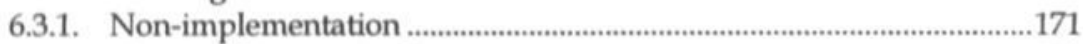

6.3.1.1. Community law ......................................................................171

6.3.1.2. Internal rules of procedure .....................................................172

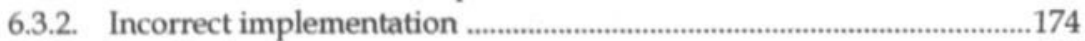

6.3.3. Conclusions ...........................................................................................175

6.4. Enforcement against individual workers or employers ...................................175

6.4.1. The European collective agreement has been implemented correctly.......................................................................................................176

6.4.2. The European collective agreement has not been implemented or has been implemented incorrectly.................................176

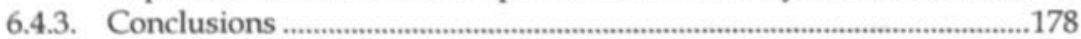

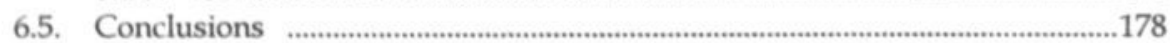

\section{PART III THE CONVERSION OF EUROPEAN COLLECTIVE} AGREEMENTS INTO COMMUNITY LAW

Chapter 7

Implementation of European collective agreements by Council decision ............183

7.1. Introduction .........................................................................................183

7.2. The European collective agreement has to cover matters of Article 137

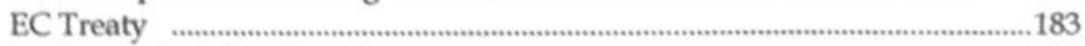

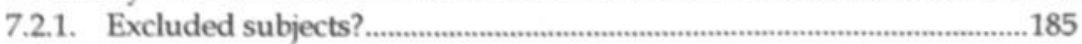

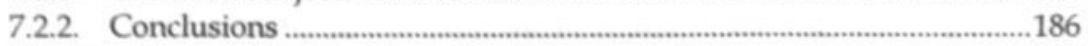

7.3. The signatory parties have to make a joint request ..............................................186

7.4. The Commission has to formulate a proposal ....................................................190

7.4.1. The checks by the Commission ..................................................................190 
7.4.1.1. The representativity of the signatory parties ..........................192

7.4.1.2. The mandate of the signatory parties .......................................199

7.4.1.3. The legality of the European collective agreement ...............203

7.4.1.4. The position of small and medium-sized enterprises ...........204

7.4.1.5. The assessment of the European collective agreement .........207

7.4.2. Rejection of the European collective agreement by the

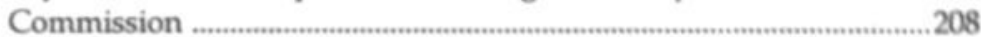

7.4.3. Form of the Commission proposal .....................................................

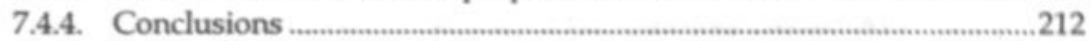

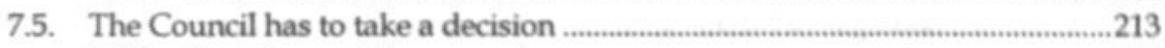

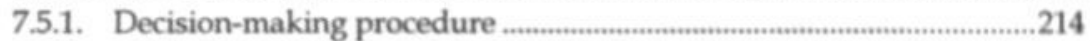

7.5.1.1. Qualified majority or unanimity .............................................214

7.5.1.2. Amendments by the Council? ...........................................217

7.5.2. Rejection of the Commission proposal by the Council ........................223

7.5.3. Form of the Council decision ...........................................................226

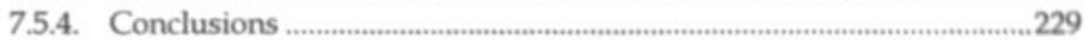

7.6. The role of the European Parliament and the Economic and Social

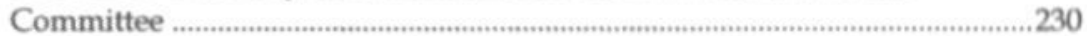

7.6.1. The European Parliament .................................................................230

7.6.2. The Economic and Social Committee .................................................2.235

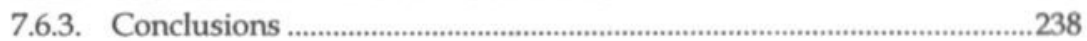

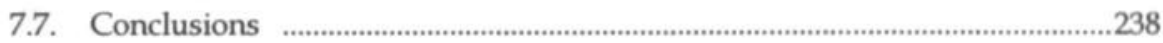

\section{Chapter 8}

Access to the European Court of Justice and/or Court of First Instance for the European social partners' organisations......................................................241

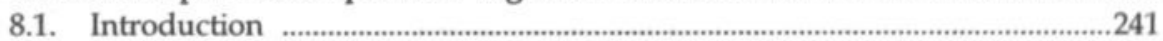

8.2. Article 230 EC Treaty and private parties: conditions for admissability ........241

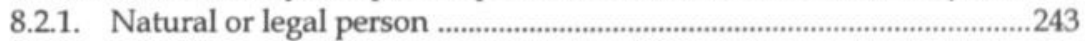

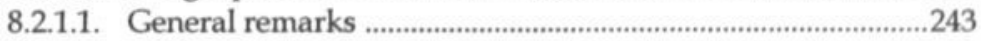

8.2.1.2. Application of the ECJ case law to the European social partners' organisations

8.2.2. The nature of the contested measure .....................................................248

8.2.2.1. The Decision-concept ............................................................248

8.2.2.2. Claims against measures other than Decisions ......................252

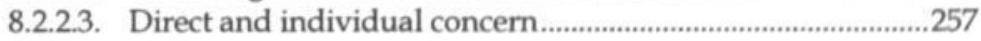

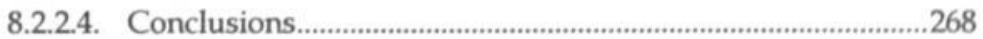

8.2.3. The nature of the contested measure applied to Commission decisions.

8.2.3.1. The support for the European social partners' organisations ..........................................................................270

8.2.3.2. The decision to consult the European social partners' organisations

8.2.3.3. The Commission proposal based on the European

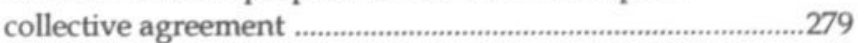

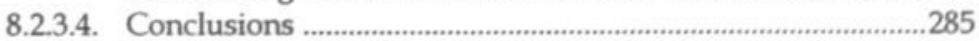

8.2.4. The nature of the contested measure applied to

Council decisions 
Legal aspects of the European social dialogue

8.2.4.1. The Council refuses to turn the European collective agreement into legislation

8.2.4.2. The Council turns the European collective agreement into legislation........................................................289

8.2.4.3. Conclusions .................................................................................291

8.2.5. Time limit and grounds of annulment .....................................................292

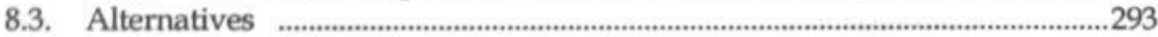

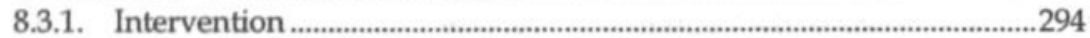

8.3.2. Preliminary procedures on the basis of Article 234 EC Treaty............294

8.3.3. Action against Member States on the basis of Article 226

EC Treaty ......................................................................................................296

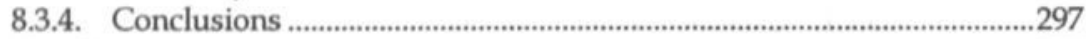

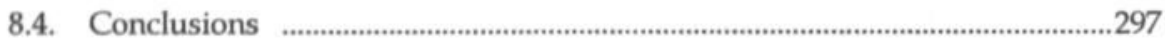

\section{PART IV CONCLUSIONS AND RECOMMENDATIONS \\ Chapter 9}

Conclusions and recommendations .........................................................................303

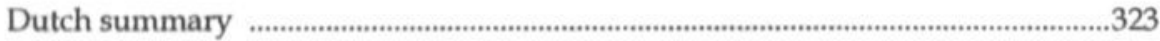

Annex I Overview of Community legislation with the involvement

of the European social partners' organisations .......................................331

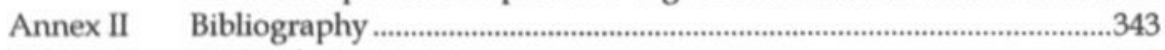

Annex III Table of cases.................................................................................................365

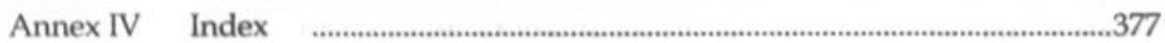

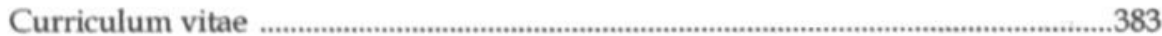




\section{LIST OF ABBREVIATIONS}

\begin{tabular}{|c|c|}
\hline AEA & Association of European Airlines \\
\hline AG & Advocate-General \\
\hline ASP & Agreement on Social Policy \\
\hline CBI & Centre of British Industries \\
\hline CCFE & Community of the European Railways \\
\hline CEC & European Federation of Managerial Staff \\
\hline CEEP & European Centre of Public Enterprises \\
\hline CEI-BOIS & $\begin{array}{l}\text { European Confederation of Woodworking } \\
\text { Industries }\end{array}$ \\
\hline CESI & $\begin{array}{l}\text { European Confederation of Independent Trade } \\
\text { Unions }\end{array}$ \\
\hline CFI & Court of First Instance \\
\hline $\mathrm{CIC}$ & $\begin{array}{l}\text { Confédération Européenne des Organisations } \\
\text { Patronales de la Coiffure }\end{array}$ \\
\hline COESS & European Confederation of Security Services \\
\hline COPA & $\begin{array}{l}\text { Committee of Agricultural Organizations } \\
\text { in the European Union }\end{array}$ \\
\hline DAB & Deutsche Arbeiter Bund \\
\hline DG & Directorate-General \\
\hline DGB & Deutsche Gewerkschafts Bund \\
\hline EA & European Association \\
\hline EBU & European Broadcasting Union \\
\hline EC & European Communities \\
\hline ECA & European Cockpit Association \\
\hline ECB & European Central Bank \\
\hline ECF-IUF & $\begin{array}{l}\text { European Federation of Food, Cathering and } \\
\text { Allied Workers' Unions within the IUF }\end{array}$ \\
\hline ECHR & European Convention on Human Rights \\
\hline $\mathrm{ECJ}$ & European Court of Justice \\
\hline ECOSOC & Economic and Social Committee \\
\hline ECSA & European Community Schipowners' Association \\
\hline EEA & European Economic Area \\
\hline EFA & $\begin{array}{l}\text { European Federation of Agricultural Workers' } \\
\text { Trade Unions }\end{array}$ \\
\hline EFBWW & $\begin{array}{l}\text { European Federation of Building and Wood } \\
\text { Workers }\end{array}$ \\
\hline $\mathrm{EFCI}$ & European Federation of Cleaning Industries \\
\hline EIF & European Industry Federation \\
\hline EMCEF & $\begin{array}{l}\text { European Mine, Chemical and Energy Workers' } \\
\text { Federation }\end{array}$ \\
\hline EMCS & European Mediation and Conciliation Service \\
\hline EMF & European Metal Federation \\
\hline
\end{tabular}




$\begin{array}{ll}\text { EP } & \text { European Parliament } \\ \text { EPSU } & \text { European Public Service Unions } \\ \text { ERA } & \text { European Regional Airline Association } \\ \text { ESC } & \text { European Social Charter } \\ \text { ETF } & \text { European Transport Federation } \\ \text { ETUC } & \text { European Trade Union Confederation } \\ \text { EU } & \text { European Union } \\ \text { EURATEX } & \text { European Apparel and Textile Organisation } \\ \text { EUROCADRES } & \text { European Professional and Managerial Staff } \\ \text { EUROCOMMERCE } & \text { Retail Wholesale and International Trade } \\ & \text { Representatives in Europe } \\ \text { EUROFEDOP } & \text { European Federation of Employees in Public } \\ & \text { Services } \\ \text { EURO-FIET } & \text { European Regional Organisation of the } \\ & \text { International Federation of Commercial, Clerical, } \\ \text { EUROPECHE } & \text { Professional and Technical Employees } \\ & \text { Association of National Organisations of Fishing } \\ \text { rERPA } & \text { Enterprices in the European Union } \\ & \text { cEropean rEaeration or Fènsioners and the } \\ \text { FIEC } & \text { Elderly } \\ \text { FMCS } & \text { European Construction Industry Federation. } \\ \text { FNV } & \text { Federal Mediation and Conciliation Service } \\ \text { FST } & \text { Federation of Dutch Trade Unions } \\ \text { GEOPA } & \text { Federation of Transport Workers } \\ & \text { Employers Group of Agricultural Organizations } \\ \text { HOTREC } & \text { in the EC } \\ & \text { Confederation of National Associations of Hotel, } \\ \text { IACA } & \text { Restaurants, Cafés and Similar Establishments in } \\ \text { the EU and EEA. } & \text { International Air Carrier Association } \\ \text { ILO } & \text { International Confederation of Free Trade Unions } \\ \text { IRU } & \text { International Labour Organization } \\ \text { ITUC } & \text { International Road Transport Union } \\ \text { OJ } & \text { Interregional Trade Union Councils } \\ \text { PEARLE } & \text { Official Journal } \\ \text { PECL } & \text { Performing Arts Employers Associations League } \\ \text { SAC } & \text { Europe } \\ \text { SCE } & \text { Principles of European Contract Law } \\ \text { SDC } & \text { Social Affairs Committee } \\ \text { SEA } & \text { Standing Committee on Employment } \\ \text { SME } & \text { Sectoral Dialogue Committee } \\ \text { STAR } & \text { Single European Act } \\ \text { TEU } & \text { Small and Medium Sized Enterprise } \\ & \text { Treaty the European Union } \\ & \end{array}$


TUC

UEAPME

UNICE
Trade Union Congres

European Association of Craft and Small and Medium Sized Enterprises

Union of Industrial and Employers' Confederation of Europe 

PART I

INTRODUCTION 


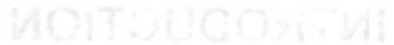




\section{CHAPTER 1 \\ INTRODUCTION}

\subsection{Introduction}

This thesis deals with certain legal aspects of the European social dialogue. The term "European social dialogue" covers two aspects. These are on the one hand the negotiation and conclusion of agreements at Community level (European agreements) between European-level organisations of workers and employers (the European social partners' organisations) and on the other hand the cooperation between the Community institutions and the European social partners' organisations. The thesis will focus on the legal consequences of the conclusion of European agreements between the European social partners' organisations and on the relation between the Community institutions and the European social partners' organisations in the context of Articles 138 and 139 EC Treaty.

In the Maastricht Treaty of 1992, two articles, which are now numbered as Articles 138 and 139 EC Treaty, ${ }^{1}$ have been included which stated:

Article 138:

"1. The Commission shall have the task of promoting the consultation of management and labour at Community level and shall take any relevant measure to facilitate their dialogue by ensuring balanced support for the parties.

2. To this end, before submitting proposals in the social field, the Commission shall consult management and labour on the possible direction of Community action.

3. If, after such consultation, the Commission considers Community action advisable, it shall consult management and labour on the content of the envisaged proposal. Management and labour shall forward to the Commission an opinion or, where appropriate, a recommendation.

4. On the occasion of such consultation, management and labour may inform the Commission of their wish to initiate the process provided for in Article 139. The duration of the procedure shall not exceed nine months, unless the management and labour concerned and the Commission decide jointly to extend it."

1 In the Maastricht Treaty these articles were numbered as Article 3 and 4 of the Agreement on Social Policy which was annexed to the Social Protocol by the Treaty. 
Article 139:

"1. Should management and labour so desire, the dialogue between them at Community level may lead to contractual relations, including agreements.

2. Agreements concluded at Community level shall be implemented either in accordance with procedures and practices specific to management and labour and the Member States or, in matters covered by Article 137 , at joint requests of the signatory parties, by a Council decision on a proposal from the Commission.

3. The Council shall act by qualified majority, except where the agreement in question contains one or more provisions relating to one of the areas referred to in Article 137(3), in which case it shall act unanimously."

The aim of this thesis is to answer the central questions which arise, on the basis of the existing legislation and case law. In addition, recommendations will be made for the future. Where possible, a difference will be drawn between the near future, for which recommendations will be made without special legislation being required, and the more distant future, when the existence of a European collective labour legislation is assumed. Recommendations with regard to the content of this European collective labour legislation will be made.

\subsection{Structure of the book}

In Chapter 2, some European social partners' organisations will be reviewed. Their internal structure, objectives and legal status will be discussed. In Chapter 3, an overview of the history of the European social dialogue will be given, from the Treaty of Rome until the present situation. ${ }^{2}$ In Chapter 4, Article 138 EC Treaty will be scrutinised. This consists in fact of three parts: the support given by the Commission to the European social partners' organisations, the consultation of these organisations, and the negotiations between these organisations. In Chapter 5, the legal consequences for the various actors involved in the conclusion of European agreements, as prescribed in Article 139(1) EC Treaty, will be discussed. Chapter 6 will scrutinise how compliance with the European agreements by the various actors can be enforced. In Chapter 7, the procedure of a European agreement becoming Community legislation, as prescribed in Article 139(2) EC Treaty, will be discussed. Chapter 8 will deal with the possibilities for the European social partners' organisations to attack legally decisions of Community institutions taken on the basis of Article 138 and/or 139 EC Treaty. Finally, in Chapter 9, all conclusions and recommendations in the preceding chapters will be summarised. 


\subsection{Research method}

This research will mainly be based on Community legislation and case law, international treaties such as the ECHR, the ESC, and ILO documents. In Chapters 5 and 6, private international law has also been used to answer certain questions. Furthermore, a number of interviews have been undertaken to find out how certain things work in practice, ${ }^{3}$ for example how the negotiations on a European agreement take place. I have also used the collective labour law of the Member States as a background for my research, when it concerns the question whether certain practices are common in the Member States, such as the resolution of industrial disputes.

\subsection{Relation with other researches on the European social dialogue}

Research on the European social dialogue has been carried out previously. Already in 1986 Jacobs paid attention to the legal aspects of the conclusion of European agreements, ${ }^{4}$ although his thesis mainly dealt with national collective labour law. There are also more recent works, written after the inclusion of the Articles 138 and 139 in the EC Treaty. ${ }^{5}$ I have of course drawn inspiration from these works, especially as regards the relation between the European social partners' organisations and the Community institutions. The legal consequences of the conclusion of European agreements and the enforcement of the compliance with these agreements have not, however, (yet) been extensively discussed. Moreover, in this thesis these items are mainly discussed from a private law view. Furthermore, the possibilities for the European social partners' organisations to institute legal proceedings before the European Court of Justice (ECJ) or Court of First Instance (CFI) are discussed more extensively. Finally, while the other works on the European social dialogue mainly focus on the present situation, this thesis contains recommendations for the future.

3 Approximately 10 interviews were held.

4 A.J.T.M. Jacobs, Het recht op collectief onderhandelen, In: Rechtsvergelijkend en Europees perspectief, Alphen aan de Rijn, 1986.

5 B. Bödding, Die europarechtlichen Instrumentarien der Sozialpartner, Baden-Baden, 1996; B. Hepple, European social dialogue - iAlibi or opportunity?, Londen 1993; L. van Herk, Arbeidsvoorwaardenvorming op Europees niveau, Utrecht 1998; W.E. Lechner and H.W. Platzer, European Union - European Industrial Relations, London/ New York 1998; A. Lo Faro, Regulating Social Europe, Reality \& Myth of Collective Bargaining in the EC Legal Order, Oxford/Portland, 2000; K. Piazolo, Der Soziale Dialog nach dem abkommen über die Sozialpolitik und dem Vertrag von Amsterdam, Frankfurt am Main/Berlin/Bern/New York/Paris/Wien, 1999; B. Sörries, Europăisierung der Arbeitsbeziehungen; Der soziale Dialog und seine Akteure, München/ Mering, 1999; T. Gilles, Das Zustandekommen und die Durchführung von Sozialpartnervereinbarungen im Rahmen des europäischen sozialen Dialogs, Frankfurt am Main/New York, 1997. 


\subsection{Do we need collective agreements at European level?}

Before dealing with the legal aspects of the European social dialogue, a preliminary question to be asked is whether we need collective agreements at European level. In other words: is Euro-bargaining necessary? Is it not sufficient to have collective agreements at national level? Opponents of Eurobargaining say that it does not make much sense since labour markets are still basically national and little cross-European migration takes place. ${ }^{6}$ The very low mobility in Europe is probably due to a variety of factors including the improvement in living conditions and incomes for families, the existence of generous unemployment insurance schemes, major differences in cultures and especially languages between the countries at regions of Europe, and the inadequacy and sometimes inefficiency of the public and private employment services. ${ }^{7}$ One can admit that the mobility of workers from, for example, Greece to Sweden will remain low, due to the factors mentioned above. That is not however so for the mobility of workers in the so called crossborder regions. It is not a big step for a worker in the south of The Netherlands to have a job in a company in Belgium or Germany. We see that in these cross-border regions there is a trend towards the coordination of a collective bargaining policy. For example, in September 1998, the trade unions in Belgium, Germany, Luxembourg, and The Netherlands adopted a joint statement which provided for the coordination of collective bargaining policies and an exchange of information. ${ }^{8}$ The unions of those four members of monetary union undertook to conclude collective agreements in which wage levels corresponded to price trends and increases in labour productivity. Furthermore, in 1996, the Belgian government, the unions, and the employers concluded a tripartite pact which provided that wage increases could not exceed the average wage increases in France, Germany and The Netherlands, Belgium's three main trading partners. A further recent development in cross-border union cooperation was the conclusion in June 2000 by the construction workers trade unions from Belgium, The Netherlands and Germany of a joint declaration on measures to seek harmonisation of working conditions in the industry and a cooperation agreement. ${ }^{9}$ But there are also trends towards a wider coordination of collective bargaining than just in the countries that are border each other. In 1997, the powerful European Metal Workers' Federation (EMF) defined a reference framework

6 J. Rojot, A. Le Flanchec, and C. Voynnet-Fourboul, European Collective Bargaining, new Prospects or much Ado about Little?, In: IJCLLIR, vol. 17, no. 3, 2001, p. 349; A.B. Krueger, From Bismarck to Maastricht: The March to European Union and the Labour Compact, In: Labour Economics, vol. 7, no. 7, 2000, p. 120.

7 E. Traversa, The Consequences of European Monetary Union on Collective Bargaining and the National Social Security Systems, In: IJCLLIR, vol. 16, no. 1, 2000, p. 48.

8 The so called Doorn-group.

9 Eirobserver, Update 6'00, p. 3. 
for national collective bargaining which included the minimum wage levels which must be respected by the trade unions of all Member States. Another example is the Charter on Working Time adopted by the EMF in July 1998, which lays down common standards in order to guarantee that working time does not become a matter for competition at European level. ${ }^{10}$ The European Federation of Public Service Unions (EPSU) agreed in April 2000 to put into place a framework for joint collective action, which it hopes could pave the way to a coordinated system of collective bargaining in Europe's public services. "Finally, in December 2000 the ETUC's executive committee welcomed and endorsed a guideline on the coordination of wage bargaining. ${ }^{12}$ One could say that even these trends do not favour the conclusion of collective agreements at European level. National bargaining could continue, only in a more coordinated way than before. Labour conditions will, however, remain to be determined nationally in such a case, while the internationalisation of companies increases more and more. In the end this can work out badly for trade unions and employees. The number of cross-border mergers and takeovers of companies is increasing. In many cases these mergers and takeovers lead to restructuring which often leads to the loss of jobs. In this sense Euro-bargaining is mainly important for trade unions. ${ }^{13}$ This is also realised by the most important intersectoral European trade union, the European Trade Union Confederation (ETUC), who wants to open discussions with European employers' organisations to reach an agreement in which the scope, content and rules of a European system of industrial relations would be laid down. ${ }^{14}$

A second argument against Euro-bargaining is that it can not be realised since a common system of Euro-bargaining is strongly resisted by the employers. ${ }^{15}$ It is certainly true that at this moment employers' organisations are not exactly itching to conclude European agreements with the trade unions. These same employers' organisations should however realise that important decision making is more and more moving away from the national level

10 E. Traversa, The Consequences of European Monetary Union on Collective Bargaining and the National Social Security Systems, In: IJCLLIR, vol. 16, no. 1, 2000, pp. 49-50.

11 EPSU agrees framework for coordinated action, In: Eironline, July 2000.

12 ETUC executive committee endorses guideline on collective bargaining coordination, In: Eironline, January 2001.

13 R. Huiskamp and K. Vos, EMU, Nederlandse bedrijven en arbeidsvoorwaardenoverleg, In: Tijdschrift voor Arbeidsvraagstukken, vol. 17, no. 2, 2001, p. 138. See also the Report of the High Level Group on Industrial Relations and Change in the European Union, Report for the European Commission, DG V, January 2002, pp. 11-15.

14 Report of the ETUC: Towards a European System of Industrial Relations, Adopted by the IXth Statutory Congress of the European Trade Union Confederation, Helsinki, 29/06-02/07/99.

T. Treu, A New Phase of European Social Policy: the EMU and beyond, In: IJCLLIR, vol. 17, no. 4, 2001, p. 466. 
towards Brussels. By the inclusion of the Articles 138 and 139 in the EC Treaty they are given an exquisite opportunity to influence the content of European labour legislation. ${ }^{16}$ By concluding European agreements which can be turned into Community legislation, the employers' organisations, together with the trade unions, will have the content of this legislation in their own hands. They should use this opportunity because as interest organisations they are more aware of the needs of their members than is the legislator.

Whether the Euro will stimulate the conclusion of European agreements remains to be seen. To some authors it seems plausible to hold that the single currency will favour a kind of mutual influence between the different national systems. ${ }^{17}$ Others think, however, that the Euro will not have very much effect on wages. There are too many differences in productivity, taxes, social security systems, and purchasing power. ${ }^{18}$ These differences can also, however, (partly) disappear in the future. Community legislation towards harmonisation of tax systems and social security systems might be developed, which will make it easier to compare wages in different countries with each other.

There are thus in my view sufficient arguments in favour of Euro-bargaining. This legitimises a research on the legal aspects related to the European social dialogue, of which Euro-bargaining makes part.

\subsection{Preconditions for the development of a European social dialogue}

A major part of this thesis tries to answer legal questions with regard to the conclusion of European agreements. One can say that the conclusion of such agreements is only one aspect of a set of three rights: the freedom of association, the right to collective bargaining, and the right to strike. These three rights are inextricably linked to each other. The question is whether these three rights exist in Community law. It is not my intention to undertake a broad and extensive research with regard to these rights. However, the possibility to conclude European agreements can hardly be seen completely separately from the fundamental social rights mentioned above. Therefore, these rights will be discussed briefly hereafter. First, I will give a short overview of the development of human rights protection in Community law. This will be done in para. 1.6.1. Then I will focus on the freedom of asso-

16 This will be made clear in the Chapters 4 and 7.

17 M. Biagi, The European Monetary Union and Industrial Relations, In: IJCLLIR, vol. 16, no. 1,2000, p. 41.

18 R. Huiskamp and K. Vos, EMU, Nederlandse bedrijven en arbeidsvoorwaardenoverleg, In: Tijdschrift voor Arbeidsvraagstukken, vol. 17, no. 2, 2001, p. 143. 
ciation (para. 1.6.2.), the right to collective bargaining (para. 1.6.3.), and the right to strike (para. 1.6.4.). I will verify whether Community law gives a legal basis for these rights. In para. 1.6.5., some conclusions will be drawn.

\subsubsection{The development of human rights protection in Community law: a short overview}

\subsubsection{Human rights protection in general}

The European legal order started as a functional legal order: it was set up in order to integrate the European peoples and states, mainly through an integration of their national economies. European law has been an instrument for political and social transformation of completely new dimensions for democratic societies, not meant to protect, but rather to change them with a view towards a common European future. Human rights were gradually introduced as limits to the discretion of the supranational institutions. ${ }^{19}$

In the Community Treaties as they were drafted in the 1950s, hardly any references can be found to fundamental rights and freedoms. The European Court of Justice (ECJ) also took a passive stand on the matter of fundamental rights in the Community. This changed at the end of the 1960s, partly under the influence of discussions in German legal circles. ${ }^{20}$ In the Stauder case ${ }^{21}$ the ECJ confirmed for the first time that fundamental human rights were enshrined in the general principles of Community law and were protected by the Court. In the Internationale Handelsgesellschaft case ${ }^{22}$ the ECJ, repeating its statement from Stauder, indicated that whilst the protection of fundamental human rights was inspired by the constitutional traditions common to the Member States, it had to be ensured within the framework of the structure and objectives of the Community. ${ }^{23}$ In the second Nold case ${ }^{24}$ the ECJ said that not only could inspiration be drawn from the constitutional traditions of the Member States, ${ }^{25}$ but that protection of fundamental rights also embraced the fundamental rights guaranteed in international treaties for the protection of human rights on which the Member States have collaborated or of which they are signatories. These treaties can supply guidelines which should be

19 A. von Bogdandy, The European Union as a human rights organization? Human rights and the core of the European Union, In: CMLR, vol. 37, no. 7, 2000, p. 1308.

20 P.J.G. Kapteyn and P. VerLoren van Themaat/ L.W. Gormley, Introduction to the Law of the European Communities, London/The Hague/ Boston, 1998, pp. 282-283.

21 Case 29/69, Judgment of 12/11/1969, Stauder/Stadt Ulm (Rec.1969,p.419), at 425.

22 Case $11 / 70$, Judgment of $17 / 12 / 1970$, Internationale Handelsgesellschaft mbH/Einfuhr- und Vorratsstelle für Getreide und Futtermittel (Rec.1970,p.1125).

23 Case $11 / 70$, at 1134 .

24 Case 4/73, Judgment of 14/05/1974, Nold KG/Commission (Rec.1974,p.491).

25 Case 4/73, at 507-508. 
followed within the framework of Community law. ${ }^{26}$ An example of such a treaty is the European Convention on Human Rights (ECHR). The ECHR, concluded in the framework of the Council of Europe, is interpreted and enforced by the European Court of Human Rights and offers protection to every person coming under the jurisdiction of a contracting party, whatever his or her nationality or place of residence. All EU Member States are contracting parties to the ECHR. Every action taken by a Member State authority, as an implementation of Union law or otherwise, should therefore be compatible with the ECHR. Several courts consider themselves competent to check that compatibility: in the first place national courts and in the second place the European Court of Human Rights. But when an act of a Member State authority comes within the framework of Union law, the ECJ is also competent to enforce the ECHR as part of the general principles of Community law. ${ }^{27}$ This means that, on the one hand, the Strasbourg organs interpret and apply the ECHR. On the other hand, the ECJ has the final say when it comes to the application (and interpretation) of these two treaties in an EU or EC context. This could lead to differing interpretations. ${ }^{28}$ Although the ECJ has insisted that it only takes account of the Convention as a "source of inspiration", in practice it has striven to respect the caso law from Strasbourg. ${ }^{29}$

In various other judgements, the ECJ has cited provisions of the ECHR in support of its reasoning ${ }^{30}$ and has now started to refer directly to the provisions of the ECHR themselves. ${ }^{31}$ This case law has been followed by the

26 Case $4 / 73$, at 507.

27 See e.g. Case C-260/89, Judgment of 18/06/1991, ERT/DEP (Rec.1991,p.I-2925), para. 42. See also K. Lenaerts and E de Smijter, The Charter and the Role of the European Courts, In: Maastricht Journal of European and Comparative Law, vol. 8, no. 1, 2001, p. 91 .

28 A.W. Heringa, Towards an EU Charter of Fundamental Rights?, In: Maastricht Journal of European and Comparative law, vol. 7, no. 2, 2000, p. 114.

P. Oliver, Fundamental Rights in European Union Law after the Treaty of Amsterdam, In: D. O'Keeffe and A. Bavasso (eds.), Judicial Review in European Union Law, Liber Amicorum in Honour Lord Slynn of Hadley, The Hague, 2000, p. 322.

30 Case 36/75, Judgment of 28/10/1975, Rutili/Ministre de l'intérieur (Rec.1975, p.1219); Case 209/78 Order of 30/10/1978, Van Landewyck/Commission (Rec.1978, p.2111); Case 209/78 Judgment of 29/10/1980, Van Landewyck/Commission (Rec. 1980, p.3125); Case 136/79 Judgment of 26/06/1980, National Panasonic/Commission (Rec.1980,p.2033); Case 63/83 Judgment of 10/07/1984, Kirk (Rec.1984, p.2689); Case 222/84 Judgment of $15 / 05 / 1986$, Johnston/Chief Constable of the Royal Ulster Constabulary (Rec.1986,p.1651); Case 222/86 Judgment of 15/10/1987, Unectef/Heylens (Rec.1987, p.4097).

31 See Case 46/87, Order of 26/03/1987, Hoechst/Commission (Rec.1987,p.1549); Case 46/87, Judgment of 21/09/1989, Hoechst/Commission (Rec.1989,p.2859); Case 85/87, Order of 28/10/1987, Dow Chemical Nederland/Commission (Rec.1987, p.4367); Case 85/87, Judgment of 17/10/1989, Dow Benelux/Commission (Rec.1989, p.3137); Cases 97/87, Judgment of 17/10/1989, Dow Chemical lberica and others/ Commission (Rec.1989,p.3165); C-404/92, Judgment of 05/10/1994, X/Commission 
Court of First Instance (CFI). ${ }^{32}$ The ECJ furthermore has referred in its case law to the European Social Charter (ESC) ${ }^{33}$ and the ILO Conventions. ${ }^{34} \mathrm{Hu}$ man rights are, however, protected in Community law in so far as the human right in question is connected with a legal relation which is specifically regulated in the Treaty. ${ }^{35}$ Furthermore, in the Wachauf case ${ }^{36}$ the ECI decided that the requirement of the protection of fundamental human rights in the Community legal order is also binding on the Member States when they implement Community rules. ${ }^{37}$ In the Maastricht Treaty of 1992, Article F(2) was included in the TEU stating:

"The Union shall respect fundamental rights, as guaranteed by the ECHR, signed in Rome on 4 November 1950 and as they result from the constitutional traditions common to the Member States, as general principles of Community law,"

The Article has been taken over in the Amsterdam Treaty of 1998 and has been renumbered as Article 6(2) of the TEU. Since the Amsterdam Treaty, the ECJ now has jurisdiction to ensure that Article 6(2) is observed by the institu-

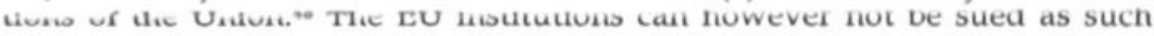
before the European Court of Human Rights, since neither the Union nor the Community is a party to the ECHR. ${ }^{39}$ In the past, the Commission has proposed that the EC should accede to the ECHR. However, in its Opinion Accession by the Communities to the ECHR,40 the ECJ stated that accession would require an amendment of the Treaties.

(Rec.1994,p.I-4737).

32 See Case T-19/91, Order of 07/06/1991, Vichy/Commission (Rec.1991,p.II-265), T19/91 Judgment of 27/02/1992, Vichy/Commission (Rec.1992, p.II-415).

33 Case C-24/86, Judgment of 02-02-1998, Blaizot/Université de Liège and others (Rec. 1988,p.379); Also opinion of AG Lenz in Case 236/87, Judgment of 22/09/1988, Bergemann/Bundesanstalt für Arbeit (Rec.1988,p.5125).

34 C-149/77, ECR 1978, 1365.

35 Conclusion of AG Trabucchi in Case C-118/75, ECR 1976, 1185, p. 1207-1208; Also F, Hendrickx, Fundamentele rechten in de EU, In: R. Blanpain c.S., Europa na het verdrag van Amsterdam. Institutioneel en Sociaal, Leuven, 1998, p. 133.

36 Case 5/88, Judgment of 13/07/1989, Wachauf/Bundesamt für Ernăhrung und Forstwirtschaft (Rec.1989,p.2609).

37 This was repeated in Case C-84/95, Judgment of 30/07/1996, Bosphorus/Minister for Transport, Energy and Communications and others (Rec.1996,p.I-3953) and Case C$177 / 95$, Judgment of 27/02/1997, Ebony Maritime and Loten Navigation (Rec.1997, p.I-1111). Also F.G. Jacobs, Human rights in the European Union: the role of the Court of Justice, In: ELR, vol. 26, no. 4, 2001, pp. 333-335.

38 Article 46 sub d TEU.

39 Decision of the European Commission for Human Rights of 9 February 1990, M. \& Co. v. Germany, Case 13258/87, Y. ECHR (1990), 46. See also the judgement of the European Court of Human Rights of 18 February 1999, Matthews v. United Kingdom, Case 24833/94, Reports (1999-I), para. 32.

40 Opinion 2/94 of 28-03-1996 (Rec.1996,p.I-1759). 
At the Nice European Council in December 2000, the political leaders of the $\mathrm{EU}$ adopted a legally non-binding declaration of intent on the protection of fundamental human rights in the EU: the Draft Charter of Fundamental Rights of the European Union (hereafter referred to as EU Charter ${ }^{41}$ ). It brings together for the first time, in a single document, classic human rights, social and economic rights, as well as rights and freedoms already known from the EC/EU. The EU Charter is to contain the fundamental rights and freedoms and basic procedural rights guaranteed by the ECHR, the ESC and the 1989 Community Charter of the Fundamental Social Rights of Workers (hereafter the Community Charter). A committee, consisting of representatives of national parliaments and governments, the European Parliament (EP) and the Commission, observers from the Council, the ECJ and the Council of Europe, has been set up to examine the possible inclusion of this EU Charter in the Treaty. ${ }^{42}$ The committee is also to consider how the EU Charter might be incorporated into the Treaties: as a political declaration or as a legally binding instrument which might apply to the Community institutions and to the Member States when acting in the sphere of Community law. ${ }^{43}$

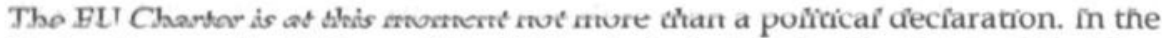
Declaration on the Future of the Union included in the Final Act of the Nice Conference, the European Council stated that it would address the question of the status of the EU Charter at the coming Council meetings. This will be at the earliest in 2004.4 This does not mean however that the ECJ could not refer to the EU Charter as 'supportive evidence' of the Community's commitment to human rights protection. ${ }^{45}$ The ECJ will probably draw inspiration from the EU Charter when it has to identify the contents of Community fundamental rights, in their capacity of unwritten principles of EC law. ${ }^{46}$ According to de Witte, references to international human rights conventions and to common constitutional traditions, as can currently be found in the case law of the ECJ and the CFI, may even be entirely replaced by references to the EU Charter, on the assumption that these other sources are now incorporated in the text of the EU Charter. ${ }^{47}$ Advocate General Tizzano has

41 O.J. 2000, C 364/1.

42 L. Betten, The EU Charter on fundamental rights: a Trojan horse or a mouse? In: IJCLLIR, vol. 17, no. 2, 2001, p. 152-153.

43 C. Barnard, EC employment law, Oxford, 2000, p. 41.

44 Annex IV to the Treaty of Nice, provisional text, Conference of the Representatives of the Governments of the Member States, SN 533/1/00 REV 1, Brussels, 22 December 2000, pp. 83-84.

45 L. Betten, The EU Charter on fundamental rights: a Trojan horse or a mouse? In: IJCLLIR, vol. 17, no. 2, 2001, p. 157.

46 D. Curtin and R van Ooik, The Sting is always in the Tail. The Personal Scope of Application of the EU Charter of Fundamental Rights, In: Maastricht Journal of European and Comparative Law, Vol. 8, no. 1, 2001, p. 110. 
already referred to the EU Charter in his opinion in the BECTU case. ${ }^{48}$ Moreover, the symbolic importance of this document is that it confirms the Court's case law that there is a human rights acquis within the European Union and that a selective choice of fundamental rights has been confirmed by the Member States.99 Furthermore, the Commission might use it as a basis for its social policy, as it used the Community Charter in the similar way for its social policy in the 1990 s.

The EU Charter is intended to offer protection against human rights violations committed by the institutions of the Union: the EP, the Commission, the Council, the ECJ, and the Court of Auditors. Furthermore, the provisions of the EU Charter are addressed to the bodies of the Union which have been set up either by the EU Treaty or on the basis of the EU Treaty. These are, for example, the European Central Bank and advisory organs such as the Economic and Social Committee (ECOSOC) and the Committee of the Regions. The EU Charter furthermore offers protection against acts of bodies/ organs which have been established on the basis of the EC/EU Treaty. Examples of such bodies/organs are the monitoring centres for drugs (in

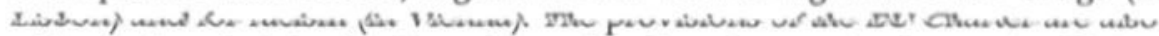
addressed to the Member States but only when they are implementing Union law. ${ }^{50}$ The EU Charter is, however, primarily concerned with the relationship between individuals and EU institutions/bodies. The ECJ and the CFI would therefore often be the competent judges in case of a breach of the EU Charter if it were a legally binding document. Since the EU Charter is also intended to address certain Member States' breaches, the national courts may be confronted with the EU Charter as well. How these national courts should apply the EU Charter very much depends on its legal status. Only if and when the EU Charter has become legally binding, could private litigants, in principle, invoke its rights and freedoms directly before the national courts. ${ }^{51}$

Articles 52(3) and 53 of the EU Charter deal with the relation between the standards of the EU Charter and the standards of the ECHR. According to Article 52(3) of the EU Charter, the protection offered by the ECHR serves as a minimum in determining the meaning and scope of the rights stated in the

tricht Journal of European and Comparative Law, vol. 8, no. 1, 2001, pp. 84-85.

48 Case C-173/99, Judgment of 26/06/2001, BECTU (Rec.2001, p. I-4881), opinion delivered on 8 February 2001.

49 E. Szyszczak, The New Paradigm for Social Policy: a Virtuous Circle?, In: CMLR, vol. 38 , no. 4, 2001 , p. 1158.

50 D. Curtin and R van Ooik, The Sting is always in the Tail. The Personal Scope of Application of the EU Charter of Fundamental Rights, In: Maastricht Journal of European and Comparative Law, vol. 8, no. 1, 2001, pp. 105-108.

51 D. Curtin and R van Ooik, The Sting is always in the Tail. The Personal Scope of Application of the EU Charter of Fundamental Rights, In: Maastricht Journal of European and Comparative Law, vol. 8, no. 1, 2001, pp. 110-112. 
EU Charter that correspond to rights guaranteed by the ECHR. The EU Charter as part of Union law may provide more extensive protection than the ECHR, but not a narrower one. According to Article 53 of the EU Charter, the provisions of the EU Charter can not be interpreted as restricting or adversely affecting human rights and fundamental freedoms as recognized by, among others, the ECHR. ${ }^{52}$

\subsubsection{Socio-economic human rights}

The ECHR is a treaty in which mainly "classic" human rights are laid down, which requires a passive attitude from the governments. Fundamental rights that are more related to socio-economic rights are laid down in the ESC and ILO documents. The ESC recognises the freedom of association (Article 5), the right to bargain collectively and the right to strike (Article 6). All Member States of the EU are a member of the ILO and have ratified ILO Convention no. 87 concerning freedom of association and protection of the right to organise and Convention no. 98 concerning the application of the principles of the right to organise and to bargain collectively. ${ }^{53}$ However, problems associated with enforcement are often seen as the key barrier to implementation of ILO and ESC standards. Infringements of ILO instruments are identified through a system of reporting obligations and by complaints to the ILO Committee on Freedom of Association, but sanctions are rarely applied. Moreover, instruments promulgated by the ILO and Council of Europe are binding in international law on governments, but not on multinational enterprises or employers generally. A further problem is that in a dualist system such as the UK, international instruments are not incorporated into domestic law. The ESC, for example, has not been incorporated into UK law. In the UK the international conventions such as the ILO Conventions and the ESC have limited status: there are no means by which to seek the enforcement of ILO Conventions and the ESC in the national courts. ${ }^{54}$ As mentioned above ${ }^{55}$ the ECJ has occasionally referred to the ESC and ILO documents. This is, however, not enough to presume that the rights mentioned in the ESC and ILO documents form part of Community law.

Also K. Lenaerts and E de Smijter, The Charter and the Role of the European Courts, In: Maastricht Journal of European and Comparative Law, vol. 8, no. 1, 2001, pp. 97 98. The relation between the EU Charter and the ECHR is more extensively discussed by P. Lemmens, The Relation between the Charter of Fundamental Rights of the European Union and the European Convention on Human Rights - Substantive Aspects, In: Maastricht Journal of European and Comparative Law, vol. 8, no. 1, 2001, pp. 4967.

53 Homepage ILO: http://www.ilo.org

54 Also P. Germanotta and T. Novitz, Globalisation and the Right to Strike: The Case for European-Level Protection of Secondary Action, In: International Journal of Comparative Labour Law and Industrial Relations, vol. 18, no. 1, 2002, p. 75. 
The Community Charter recognises the freedom of association, the right to collective bargaining, and the right to strike as well (Article 11-14). The Community Charter has however very limited legal effects. It is not a legal act of the Community but a solemn political declaration adopted by Heads of State or Government of 11 of the then 12 Member States, and it has not been published in the Official Journal. In the Agreement on Social Policy attached to the Maastricht Treaty, the same 11 Member States which adopted the Community Charter were not willing to confer legal effect on the rights to which they had given their political support in the Community Charter. ${ }^{56}$

In the Maastricht Treaty, a reference was made to the ESC and Community Charter, which has been taken over in the Amsterdam Treaty. Article 136, first sentence EC Treaty states that:

\begin{abstract}
"The Community and the Member States, having in mind fundamental social rights such as those set out in the European Social Charter signed at Turin on 18 October 1961 and in the 1989 Community Charter of the Fundamental Social Rights of Workers, shall have as their objectives the promotion of employment, improved living and working conditions, so as to make possible their harmonisation while the improvement is being maintained, proper social protection, dialogue between management and labour, the development of human resources with a view to lasting high employment and the combating of exclusion."
\end{abstract}

This does not mean, however, that the rights set out in the ESC and the Community Charter are directly enforceable against national institutions and private organisations. Direct enforceability is not in line with the traditions in the Member States. Article 136 EC Treaty has to be interpreted in such a way as to say that the Community and the Member States have as their goal the promotion of these social rights. ${ }^{57}$ Furthermore the EU and the EC are, when social rights are concerned, under an obligation to respect fundamental rights. 58

56 Also opinion of Advocate General Jacobs in Case C-67/96, Judgment of 21/09/1999, Albany (Rec.1999,p.I-5751), para. 137.

57 F. Hendrickx, Fundamentale rechten in the EU. In: R. Blanpain, M. Colucci, C. Engels, F. Hendrickx, L. Salas and J. Wouters, Europa na het Verdrag van Amsterdam, Leuven, 1998, p. 125; Lenaerts and Foubert think that because an explicit reference is made to the Community Charter, it is no longer unthinkable that the ECJ might have the power to interpret and enforce the Community Charter. K. Lenaerts and P. Foubert, Social Rights in the Case-Law of the European Court of Justice, In: Legal Issues of Economic Integration, vol. 28, no. 3, 2001, p. 269.

58 A.W. Heringa, Towards an EU Charter of Fundamental Rights?, In: Maastricht Journal of European and Comparative law, vol. 7, no. 2, 2000, p. 113. 
Furthermore, the EU Charter recognizes social rights including collective union rights, such as the freedom of assembly and the right to collective bargaining and the right to strike. I will discuss these three rights more extensively hereafter.

\title{
1.6.2. The freedom of association
}

The freedom of association exists in all Member States of the EU. ${ }^{59}$ Furthermore the freedom of association is recognised in international documents. Article 5 of the ESC mentions the freedom of association. It reads:

\begin{abstract}
"With a view to ensuring or promoting the freedom of workers and employers to form local, national or international organisations for the protection of their economic and social interests and to join those organisations, the Contracting Parties undertake that national law shall not be such as to impair, nor shall it be so applied as to impair, this freedom. The extent to which the guarantees provided for in this Article shall apply to the police shall be determined by national laws or regulations. The principle governing the application to the members of the armed forces of these guarantees and the extent to which they shall apply to persons in this category shall equally be determined by national laws or regulations."
\end{abstract}

In the opinion of the European Committee of Social Rights, Article 5 contains both a positive and a negative obligation for states: states must ensure that national law does not impair the exercise of the right to organise and they are required to take the necessary measures to guarantee the exercise of this right. ${ }^{60}$ The freedom protected by Article 5 is to form or join local, national, or international organisations. Workers must therefore be free to organize at whichever of these levels they wish. National trade union organizations must be free to join international organizations. ${ }^{61}$

Article 11 of the ECHR also protects the freedom of association. The provision reads:

"1. Everyone has the right to freedom of peaceful assembly and to freedom of association with others, including the right to form and to join trade unions for the protection of his interests.

2. No restrictions shall be placed on the exercise of these rights other than such as are prescribed by law and are necessary in a democratic society in the interests of national security or public safety, for the prevention of disorder or crime, for the protection of health or morals or for the protection of the rights and freedoms of others. This Article shall not prevent the

59 C. Barnard, EC employment law, Oxford, 2000, p. 552.

60 C I 31; Also D. Harris and J. Dancy, The European Social Charter, Ardsley, 2001, p. 93.

61 C II 184 (Cyprus); Also D. Harris and J. Darcy, The European Social Charter, p. 94. 
imposition of lawful restrictions on the exercise of these rights by members of the armed forces, of the police or of the administration of the State."

Although not explicitly stated in Article 11, the provision also protects the freedom not to join a trade union. This is the result of the Strasbourg case law. ${ }^{62}$ The right under Article 11 to form trade unions involves the right of trade unions to draw up their own rules, to administer their own affairs, to establish and to join trade union federations. Such trade union rights are explicitly recognized in Articles 3 and 5 of ILO Convention no. 87, which must be taken into account in the present context. Accordingly, in principle trade union decisions in these domains must not be subject to restrictions and control by the states except on the basis of Article 11(2). ${ }^{63}$

Article 11 of the Community Charter also provides for a right of association:

\begin{abstract}
"Employers and workers of the European Community shall have the right of association in oráer to constitute protessional organizations or trade unions of their choice for the defence of their economic and social interests.

Every employer and every worker shall have the freedom to join or not to join such organisations without any personal or occupational damage being thereby suffered by him."
\end{abstract}

Furthermore, the EU Charter recognizes in Article 12(1) the right to freedom of peaceful assembly and the freedom of association. The Article states:

"Everyone has the right to freedom of peaceful assembly and to freedom of association at all levels, in particular in political, trade union and civic matters, which implies the right of everyone to form and to join trade unions for the protection of his or her interests.

Political parties at Union level contribute to expressing the political will of the citizens of the Union."

This provision corresponds to Article 11 of the ECHR. Compared to the ECHR, the Charter contains a clarification of the scope of this freedom, since it states that the said right applies at all levels in particular in political, trade

62 See P. van Dijk and G.J.H. van Hoof (eds.), Theory and Practice of the European Convention on Human Rights, The Hague/London/Boston, 1998, pp. 593-596, where this case law is discussed.

Appl. 10550/83, Cheall v. the United Kingdom, D\&R 42 (1985), p. 185; See also P. van Dijk and G.J.H. van Hoof (eds.), Theory and Practice of the European Convention on Human Rights, p. 597. 
union, and civic matters. This does not seem to constitute a widening of the scope existing under the ECHR. ${ }^{64}$

The freedom of association is also recognised in ILO documents. In ILO Convention no. 87, Article 5 states:

"Workers' and employers' organisations shall have the right to establish and join federations and confederations and any such organisation, federation or confederation shall have the right to affiliate with international . organisations of workers and employers (...)."

This article is interesting because the European social partners' organisations are "international organisations of workers and employers" to which the article refers.

The freedom of association is not directly laid down in the Community Treaties. With regard to the case law of the ECJ however, the opinion of Advocate-General Jacobs in the Albany case is interesting. In Albany, ${ }^{65}$ Brentjens, ${ }^{66}$ and Drijuende Bokken, ${ }^{67}$ the ECJ for the first time had the opportunity to take a position concerning European competition law's relation with its labour law counterpart and the general validity of collective bargaining agreements. The main question was whether these agreements should be subjected to regular antitrust scrutiny. ${ }^{68}$ In his opinion, Jacobs also paid attention to the question whether there was a Community right of association, of collective bargaining and of collective action. ${ }^{69} \mathrm{He}$ started by saying that the EC Treaty itself, although encouraging collective bargaining, does not explicitly grant any of these three rights. ${ }^{70} \mathrm{He}$ subsequently refers to the Community Charter in which these three rights are laid down, but admits at

64 P. Lemmens, The Relation between the Charter of Fundamental Rights of the European Union and the European Convention on Human Rights - Substantive Aspects, In: Maastricht Journal of European and Comparative Law, vol. 8, no. 1, 2001, p. 59.

Case C-67/96, Albany International BV vs. Stichting Bedrijfspensioenfonds Textielindustrie, Judgement of 21 September 1999, (Rec.1999,p. I-5751).

66 Joint Cases C-115/97, C-116/97 and C-117/97, Judgment of 21/09/1999, Brentjens' (Rec.1999,p.I-6025).

67 Case C-219/97, Judgment of 21/09/1999, Drijvende Bokken (Rec.1999,p.1-6121).

68 See for the discussion on these cases E.J.A. Franssen, A.T.J.M. Jacobs, A. Ph.C.M. Jaspers and K.J.M. Mortelmans, Cao's en mededingingsrecht. In: SMA, 2000, no. 7/8, p. 324 and further. See also R.J. Van den Bergh and P.D. Camesasca, Irreconcilable principles? The Court of Justice exempts collective labour agreements from the wrath of antitrust. In: ELR, vol. 25, no. 5, 2000, p. 492 and further. See also S. Evju, Collective agreements and competition law. The Albany puzzle and van der Woude. In: IJCLLIR, vol. 17, no. 2, 2001, p. 165 and further.

69 Para. 134.

70 Para. 135. 
the same time that this Charter has very limited legal effects. ${ }^{n}$ Jacobs focuses, therefore, on the case law of the ECJ. He mentions some cases where the right to form and join associations and the right to take collective action were recognized by the ECJ. ${ }^{72}$ These cases are the Union Syndicale Massa and Kortner case, ${ }^{73}$ and the Bosman case. ${ }^{74}$ In the Union Syndicale Massa and Kortner case it considered a union organising a substantial number of officials and servants of the Community institutions and component bodies established in Brussels. The union was founded on the basis of the Staff Regulations of officials of the European Communities. The ECJ said:

\begin{abstract}
"Under the general principles of labour law the freedom of trade union activity recognised under Article (...) of the Staff Regulations means not only that officials and servants have the right without the hindrance to form associations of their own choosing but also that these associations are free to do anything lawful to protect the interests of their members as employees." 75
\end{abstract}

In the Bosman case in which the system of transfer rules for professional football players was at stake, the ECJ said:

“(...) it must be recognised that the freedom of association, enshrined in Article 11 of the ECHR, and resulting from the constitutional traditions common to the Member States, is one of the fundamental rights, as the Court has consistently held and as is reaffirmed in the preamble of the Single European Act and in Article F(2) of the TEU, are protected in the Community legal order. ${ }^{776}$

On the basis of these cases A-G Jacobs concludes that:

"The Community legal order protects the right to form and join trade unions and employers' associations, which is at the heart of the freedom of association." 77

$71 \quad$ Para. 136 and 137.

72 Para. 139.

73 Case $175 / 73$, Judgment of $08 / 10 / 1974$, Union Syndicale and others/Commission (Rec.1974,p.917).

74 Case C-415/93, Judgment of $15 / 12 / 1995$, Union royale belge des sociétés de football association and others/Bosman and others (Rec.1995,p.I-4921). Jacobs also mentions the Maurissen case joined cases C-193/87 and C-194/87, Judgment of 18-01-1990, Maurissen and Union Syndicale/Court of Auditors, (Rec.1989,p.1045), Cons. 11-16 and 21), although I do not read an express recognition of the freedom of association in these considerations.

75 Para. 14 of case $175 / 73$.

76 Cons. 79 of case C $-415 / 93$.

77 Para. 158 of his opinion. 
In its judgements the ECJ did not explicitly refer to a Community right of association. I think, however, that the ECJ can not deny the international aspects of the freedom of association. There is substantive basis to be found in the international documents which have been signed or ratified by all Member States to assume an international right of association. ${ }^{78}$ So I think that it can be concluded that there exists a freedom of association at Community level.

\subsubsection{The right to collective bargaining}

Article 6(2) of the ESC reads that the contracting parties undertake:

"to promote, where necessary and appropriate, machinery for voluntary negotiations between employers or employers' organisations and workers' organisations, with a view to the regulation of terms and conditions of employment by means of collective agreements."

This means that employers and workers must, "in accordance with legislation or industrial practice," be "at liberty to conclude collective agreements" and that a state must "actively promote the conclusion of such agreements if their spontaneous development is not satisfactory and, in particular, ensure that each side is prepared to bargain collectively with the other."79 The qualifying words "were necessary and appropriate" are to give governments some discretion in cases where satisfactory machinery already exists or where other measures, such as statutory wage fixing machinery, are more appropriate than voluntary negotiating machinery. ${ }^{80}$ In the Swedish Engine Drivers Union case, ${ }^{81}$ where Article 11 of the ECHR was under consideration, the European Court of Human Rights also commented upon the meaning of Article 6(2) of the ESC in the course of interpreting Article 11 of the ECHR. The European Court of Human Rights said that the prudence of the wording of Article 6(2) of the ESC demonstrates that the ESC does not provide for a real right to have a collective bargaining agreement concluded. ${ }^{82}$ It affirms instead the voluntary nature of collective bargaining and collective agreements. Article 11 of the ECHR does not mention collective bargaining as such. The question is whether a right to collective bargaining flows from the freedom of association which is protected by that provision, as discussed in para. 1.6.2. The European Court of Human Rights has carefully avoided concluding that the ECHR guarantees the right to collective bargaining. In the Swedish Engine

See also A.T.J.M. Jacobs, Het recht op collectief onderhandelen in Europees en rechtsvergelijkend perspectief, 1986, p. 390.

79 C I 35; See also D. Harris and J. Darcy, The European Social Charter, p. 101.

80 Rec Proc TC 205.

81 Swedish Engine Drivers Union Case, 20 Eur. Ct. H.R. (ser. A) (1976).

82 Para. 39 of the judgment. 
Drivers Union case the majority of the Commission of Human Rights had argued in favour of the recognition of trade union rights to engage in collective bargaining. The European Court of Human Rights held that it did not have to give a ruling on that question since, it said, such a right was not at issue and was granted to the applicant under the national law. ${ }^{83}$ In Gustaffson ${ }^{84}$ the European Court of Human Rights had to consider a conflict between a trade union and an employer who did not want to take part in the collective bargaining process in his industry. Through boycotts and other actions the trade union exercised pressure on him to join the employers' side of a sectoral collective agreement. The employer contended that compulsion to participate in the collective agreement would in practice amount to compulsion to join an employers' association. Thus, in his view the Swedish government should have intervened in order to protect his negative freedom not to join an employers association. The European Court of Human Rights said that it saw no reason to doubt that the union action pursued legitimate interests consistent with Article 11 of the ECHR. It continued that it should also be recalled in this context that the legitimate character of collective bargaining is recognised by a number of international instruments. ${ }^{85}$

A specific right to negotiate and conclude collective agreements is laid down in the Community Charter and the EU Charter. Article 12 of the Community Charter states:

"Employers or employers' organisations, on the one hand, and workers' organisations, on the other, shall have the right to negotiate and conclude collective agreements under the conditions laid down by national legislation and practice.

The dialogue between the two sides of industry at European level which must be developed, may, if the parties deem it desirable, result in contractual regulations in particular at inter-occupational and sectoral level."

Article 28 of the EU Charter states:

"Workers and employers, or their respective organisations, have, in accordance with Community law and national law and practices, the right to negotiate and conclude collective agreements at the appropriate level and, in cases of conflicts of interest, to take collective action to defend their interests, including strike action."

Article 4 of ILO Convention no. 98 states that:

83 Para. 38 of the judgment.

84 Gustafsson Case, 25 April 1996, Reports 1996-II, Vol. 9.

85 Para. 53 of the judgment. See also P. van Dijk and G.J.H. van Hoof (eds.), Theory and Practice of the European Convention on Human Rights, p. 598. 
"Measures appropriate to national conditions shall be taken, where necessary, to encourage and promote the full development and utilisation of machinery for voluntary negotiation between employers or employers' organisations and workers' organisations, with a view to the regulation of terms and conditions of employment by means of collective agreements."

This means that it only imposes on the contracting states an obligation to encourage and promote collective bargaining. No right is granted. ${ }^{86}$

A-G Jacobs in his opinion on the Albany case stated that it can not be said that there is sufficient convergence of national legal orders and international legal instruments on the recognition of a specific fundamental right to bargain collectively. Moreover, he continued, the collective bargaining process, like any other negotiation between economic actors, is sufficiently protected by the general principle of the freedom of contract. Therefore, a more specific fundamental right to protection is not needed. In any event, the justified limitations on the alleged right to bargain collectively would arguably be identical to those on freedom of contract. ${ }^{87}$ However, Jacobs continues, it is also clear from the analysis of the international instruments, that there is international consensus on the legitimate and socially desirable character of collective bargaining. ${ }^{88}$ This consensus has also been reflected in the EC Treaty.

In 1987, Article $118 \mathrm{~b}$ was incorporated into the EC Treaty stating:

"The Commission shall endeavour to develop the dialogue between management and labour at European level, which could, if the two sides consider it desirable, lead to relations based on agreement."

In the Agreement on Social Policy annexed to the Maastricht Treaty and later in the Amsterdam Treaty this provision was amended and Article 139(1) was included, stating:

"Should management and labour so desire, the dialogue between them at Community level may lead to contractual relations, including agreements."

I agree with Jacobs on his point that the collective bargaining process is sufficiently protected by the freedom of contract. The right to bargain collectively does, however, not mean that every organisation has the right to take part in negotiations that have been started by other organisations. This is confirmed by the CFI in the UEAPME case. ${ }^{89}$ 
The freedom to bargain collectively and conclude collective agreements is thus protected by private law and it is therefore not necessary to have it explicitly protected by Community law. This freedom can not be interpreted as an exclusive right to take part in negotiations.

\subsubsection{The right to strike}

In Article 6(4) ESC it is stated that the contracting parties:

"recognise (...) the right of workers and employers to collective action in cases of conflicts of interests, including the right to strike, subject to obligations that might arise out of collective agreements previously entered into"

The right to strike is not mentioned in the ECHR. According to the European Court of Human Rights, Article 11 ECHR safeguards the freedom to protect the occupational interests of trade union members by trade union action, the conduct and development of which the contracting states must both permit and make possible. ${ }^{90}$ Article 11 does however not necessarily imply a right to strike, since the interests of the members can be furthered by other means. ${ }^{11}$ Strikes are considered by the Strasbourg organs as a very important, but not an exclusive means for union members to protect their interests. Referring to the ESC, the European Court of Human Rights held that a right to strike, assuming that it is protected by Article 11, may in any case be subjected to restrictions by the national legislature. ${ }^{92}$ The authorities have to leave the trade unions sufficient scope to stand up for the interests of the affiliated employees, since trade union freedom would otherwise be illusory, but it is largely for the authorities to decide what means to this end they allow the unions. ${ }^{93}$

The right to strike is also mentioned in the Community Charter. Article 13 first sentence states:

"The right to resort to collective action in the event of a conflict of interests shall include the right to strike, subject to the obligation arising under national regulations and collective agreements."

90 National Union of Belgian Police v. Belgium, 27 October 1975, Eur. Court HR Rep., Series A, 19 (1975), para. 40.

91 Schmidt and Dahlström v. Sweden, 6 February 1976, Eur. Court HR Rep., Series A, 21 (1976), para.36.

92 Schmidt and Dahlström, para. 16. Referred to by the Commission in Appl. 10365/83, S. v. Federal Republic of Germany, D\&D 39 (1984), p. 237 (240).

93 Also P. van Dijk and G.J.H. van Hoof (eds.), Theory and Practice of the European Convention on Human Rights, p. 599. 
Finally, in the EU Charter the right to take collective action, including strike action, is recognised. This right is laid down in Article 28 which has already been cited in para. 1.6.3. The ambit of the right to strike set out in that article only applies under conditions laid down in national laws and practices. The EU Charter thus in effect bases the right to strike in existing national laws and practices. ${ }^{94}$ This means that there is still no Community level regulation on the types of strikes which are permitted or on the limits of the right to strike.

The jurisprudence developed by ILO supervisory bodies relating to the right to strike derives primarily from the interpretation of the guarantee of freedom of association contained in the ILO Convention no. 87 on freedom of association and protection of the right to organise, Convention no. 98 , no. 151 and no. $154 .{ }^{95}$

Article 137(6) EC Treaty specifically excludes the possibility of an EC Directive regulating industrial action ${ }^{96}$ at least where such a Directive is based on Article 137(2) EC Treaty. Article 137(6) EC Treaty states:

"The provisions of this Article shall not apply to pay, the right of association, the right to strike, or the right to impose lock-outs."

The phrase "this Article" indicates that Community legislation based on Article 137 EC Treaty can never cover the issue of strikes. This does however not mean that Community legislation on strikes is completely out of the question. The Community institutions could use another basis in the Treaty to issue legislation on strikes. ${ }^{97}$ The question whether the Community legal order contained a right to take collective action in order to protect occupational interests was also considered by A-G Jacobs in his opinion on the Albany case. Jacobs said:

"In my view, the right to take collective action in order to protect occupational interests in so far as it is indispensable for the enjoyment of freedom of association is (...) protected by Community law." 98

94 Also P. Germanotta and T. Novitz, Globalisation and the Right to Strike: The Case fr European-Level Protection of Secondary Action, in: IJCLLIR, vl. 18, n. 1, 2002, p. 78.

95 L. Betten, The Right to Strike in Community Law, Amsterdam/New York/Oxford, 1985, p. 193.

96 Also P. Germanotta and T. Novitz, Globalisation and the Right to Strike: The Case for European-Level Protection of Secondary Action, In: IJCLLIR, vol. 18, no. 1, p. 76.

97 Also B. Bercusson, Trade Union Rights in EU Law, In: F. Snyder (ed.), The Europeanisation of Law: The Legal Effects of European Integration, Oxford/Portland Oregon, 2000, p. 203. 
He seems to base his conclusion on the judgements of the ECJ in the Union Syndicale Massa and Kortner case, the Bosman case, and the Maurissen case in which the collective right to take action was recognised by the ECJ. In the Union Syndicale Massa and Kortner case, the ECJ did not explicitly mention the right to strike but only the fact that "the associations are free to do anything lawful to protect the interests of their members and employees. The right to action is one of the means available for use by these associations". However, the $\mathrm{ECJ}$ continues by saying:
"Under the Community legal system, (...) the exercise of this right is subject to the conditions determined by the system of forms of action provided for under the Treaties establishing the Communities.
Thus a staff association which fulfils these conditions is entitled, by virtue of the second paragraph of Article 173 of the EEC Treaty, to institute proceedings for annulment against a decision addressed to it within the meaning of that provision." 100

The "right of action" to which the ECJ referred in this case was the right to

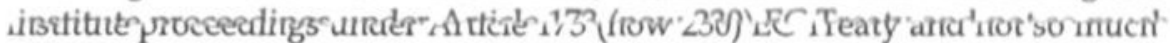
the right to strike. Nor was the right to strike explicitly mentioned by the ECJ in the Bosman and the Maurissen cases. So the "right to take collective action" to which the AG Jacobs refers, does not necessarily mean a right to strike. Moreover, even if an explicit right to strike as such would be recognised, than it is still not clear what the conditions and limits of this right are. These conditions and limits differ from Member State to Member State. According to Betten and other authors, harmonisation of legal structures or Community Regulations by which the legality of certain types of strike action would be expressly recognised, would pave the way for international strike action in cases of international industrial conflicts. ${ }^{101}$ Transnational collective bargaining such as that envisaged in the context of the European social dialogue is not likely to be effective when there is no credible threat of international industrial action. ${ }^{102}$ Shifting production before or during a strike to another unit is a logical reaction on the part of the management of a multinational enterprise to the action of workers. Workers themselves can attempt to prevent this by seeking the solidarity of their colleagues and also by requesting workers at ports, etc. to support them by preventing products or materials from being imported or exported. ${ }^{103}$ In the case of an international solidarity strike, workers face the problem that these actions are judged differently at

\footnotetext{
99 Cons. 24 and 25.

100 Cons. 26 and 27.

101 L. Betten, The Right to Strike in Community Law, p. 125.

102 Also P. Germanotta and T. Novitz, Globalisation and the Right to Strike: The Case for European-Level Protection of Secondary Action, In: IJCLLIR, vol. 18, no. 1, p. 79.

103 L. Betten, The Right to Strike in Community Law, p. 122.
} 
national level. The action falls apart into a number of national actions which may be judged to be lawful in one country and unlawful in the other. At the national level there is still much insecurity with regard to the question of which law is applicable (the law of the country where the original strike action takes place, or the law of the country where the solidarity action takes place) as well as to the conditions of lawfulness of this type of action. At Community level this problem might be solved by creating uniform rules for lawful international solidarity strikes. ${ }^{104}$ According to van Peijpe, ${ }^{105}$ another reason to introduce an explicit right to strike in Community legislation is the tension between the free movement of goods on the one hand and strikes at national level on the other hand. In November 1997, the Commission formulated a proposal for a Regulation for the creation of a mechanism whereby the Commission can intervene in order to remove certain obstacles to trade. ${ }^{106}$ The idea was to give the Commission the power to oblige a Member State by means of a decision to take measures against certain restrictions to the free movement of goods. This proposal must be seen against the background of a procedure which the Commission initiated against France. The reason for this procedure was the failure of the French state to act against actions of French farmers. These farmers protested against the import of agriculturaf products from other Member States. Through the actions of the French farmers the products from the other Member States could not be imported into France. This meant that the free movement of agricultural products was obstructed. In the proposed Regulation there was thus a certain tension between the principle of free movement of goods and the right to strike. This tension could be taken away by recognising explicitly the right to strike at Community level, according to van Peijpe. The case of the French farmers was brought before the ECJ which stated at 9 December 1997 that the French authorities have acted against the Treaty because they did not take all necessary measures to prevent the actions of the French farmers restricting the free movement of agricultural products. ${ }^{107}$ The ECJ in the above mentioned case did not draw a comparison between the free movement of goods and the right to strike. When the Council adopted the proposal ${ }^{108}$ an article was put in it, which did not appear in the proposal. Article 2 of the Regulation states:

104 L. Betten, The Right to Strike in Community Law, p. 128.

105 Also T, van Peijpe, EU en het Stakingsrecht, In: SMA, vol. 53, no. 4, 1998, pp. 149-150.

106 COM(97) 619 def. OJ C 10/14, 15-1-1998.

107 Case C-265/95, Judgment of 09/12/1997, Commission/France (Rec.1997,p.I-6959), Cons. 65 and 66.

108 Council Res lation (EC) No. 2679/98 of 7 December 1998, on the functioning of the internal market in relation to the free movement of goods among the Member States, OJ L 337/8, 12-12-1998. 
"This Regulation may not be interpreted as effecting in any way the exercise of fundamental rights as recognised in Member States, including the right of freedom to strike. These rights may also include the right or freedom to take other actions covered by the specific industrial relations systems in Member States."

So it is already recognised in the Regulation that it may not be interpreted as affecting the right to strike. This means that the tension between the free movement of goods and the right to strike at national level is taken away by the Regulation. It can be argued that the right to strike as such does not need to be laid down at Community level, because it is already recognised in all Member States. However, the need for uniform rules with regard to the limits of the right to strike and the permitted types of strikes at Community level remains because of the reasons given by Betten and other authors as explained above. A right to strike which is laid down in Community law, gives the ECJ/CFI the opportunity to draw the boundaries to this right.

\subsubsection{Conclusions}

Although not explicitly recognised at Community level, the freedom to form or join international organisations of employers and workers will probably not be denied by the CFI/ECJ. This would be contrary to the international documents signed by the Member States. The freedom to collective bargaining and to conclude collective agreements flows from the freedom of contract. An explicit recognition at Community level is therefore not necessary. Only the right to strike should be laid down at Community level. The ECJ/ CFI can in its case law determine which types of strikes are permitted as well as what are the limits of the right to strike. 



\section{CHAPTER 2}

\section{SOME EUROPEAN SOCIAL PARTNERS' ORGANISATIONS}

\subsection{Introduction}

In this chapter I will describe some European social partners' organisations. Since they are the main actors in the European social dialogue, it is useful to have a certain idea of the way they are composed and the way they work. Furthermore I will, in later chapters, discuss the representativity and internal decision making process of those organisations which conclude European agreements, as well as the binding effect of these agreements on the national affiliates of the European organisations. It is therefore important to give a broad description of these organisations.

At the present time, ${ }^{1}$ there exist more than 60 European employers' and workers' organisations. To discuss them all would be excessive in a study on legal aspects of the European social dialogue. I have decided, therefore, to select those which have in one way or another played a role in the European social dialogue.

There are several categories of social partners' organisations at European level. In the first place, there are intersectoral organisations representing all categories of workers and employers. This will be discussed in para. 2.2. Secondly, one finds intersectoral organisations which represent specific categories of workers or undertakings. This will be discussed in para. 2.3. Finally, there are sectoral organisations, representing workers/employers from a particular branch of industry. This will be discussed in para. 2.4. The legal status of European social partners' organisations in general will be discussed in para. 2.5 and I will try to indicate the legal status of the organisations described in this chapter. Finally in para. 2.6 some conclusions will be drawn.

\subsection{Intersectoral organisations representing all categories of workers and employers}

First, the three most important intersectoral organisations, the European Trade Union Confederation (ETUC), the Union of Industrial and Employers' Confederation of Europe (UNICE) and the European Centre for Public Enterprises (CEEP) are discussed. Their internal structure is described to give an idea of how they are organised. This is important because in later chapters the internal decision-making procedures within these organisations are con- 
sidered. Furthermore, I will say something about their main objectives and attitude towards the European social dialogue.

ETUC, UNICE and CEEP played an important role in boosting the European social dialogue. They were the ones who were invited by the President of the European Commission in the mid-80s to give the European social dialogue a new impulse. ${ }^{2}$ Furthermore, they concluded the first three intersectoral agreements on the basis of the Articles 138 and 139 EC Treaty. ${ }^{3}$

\subsubsection{The European Trade Union Confederation (ETUC)}

ETUC was created in 1973, bringing together a number of different trade union bodies at the Community level since the early 1960's. Before 1973, the European trade union organisations were highly fragmented, being split on religious and ideological grounds. However, as a result of the influences of regionalism, détente and the multinationals, these separate trade union organisations decided to dissolve themselves and form a single federation named ETUC. ${ }^{4}$ The ETUC represents some 60 million members who belong to 67 national trade unions from 33 countries. ${ }^{5}$ It also comprises 14 European Industry Federations (EIFs) and 38 Interregional Trade Union Councils (ITUCs). The EIFs represent individual trade unions from a particular sector or from several public or private sectors. The ITUCs are transnational structures, enabling trade unions in various border-regions to cooperate at crossborder level. ${ }^{6}$ Within the ETUCs member confederations, women, young people, pensioners and managerial staff have special interests that cannot be dealt with or taken account of sufficiently by either committees or working groups. The ETUC has therefore set up special bodies designed to help them achieve their aims. Some of these special bodies are e.g. the Women's Committee, ETUC Youth and the European Federation of Pensioners and the Elderly (FERPA).

ETUC consists of 4 organs: the Congress, the Executive Committee, the Steering Committee and the Secretariat. ${ }^{7}$ The Congress stipulates ETUCs policy priorities. It also supervises the work of the other institutions. Furthermore, it elects the members of the Executive Committee, the President, the General

3 The European Framework Agreement on Parental Leave on 14 December 1995, the European Framework Agreement on Part-Time Work on 6 June 1997 and the European Framework Agreement on Fixed-Term Work on 18 March 1999. also B. Barnouin, The European labour movement and European integration, Londen/ Wolfeboro, 1986, p.7-10.

5 R. Blanpain (ed. in chief), Encyclopedia of Labour Law and Industrial Relations, European Labour Law, supll. 231, June 2000, par. 134.

6 Homepage of the ETUC, March 2001. Http://www.etuc.org/en/

7 Article 6 of the ETUC Constitution. 
Secretary, the Deputy General Secretaries and the Auditors. Finally, it can change the Constitution. ${ }^{8}$

The Executive Committee is the highest body between Congresses. Like the Congress, the Executive Committee consists of representatives of national confederations, EIFs and the Womens' Committee, but the division of the seats is different. The Executive Committee generally meets every 3 months and takes the policy decisions required to implement the general strategy adopted by the Congress. It also decides on the positions to be taken vis-a-vis European employers' organisations and the European institutions. It oversees the work of the Steering Committee and of the Secretariat and draws up the internal rules of procedure. Finally, it fixes the level of affiliation fees and approves the budget and the extra-budgetary resources. ${ }^{9}$ Furthermore, it is the organ which plays a leading role in the European social dialogue. It decides on the mandate and the composition of the delegations which negotiate with the European employers' organisations. ${ }^{10}$

The Steering Committee is composed of the President, the General Secretary and a maximum of 15 additional members elected by the Executive Committee. At least three of them must come from the EIFs and one member is provided by the Women's Committee. ${ }^{11}$ It normally meets every 2 months to decide on urgent actions required to implement the strategies laid down by the Executive Committee. It also deals with financial and administrative matters, prepares the Executive Committee's agenda and submits recommendations to the Executive Committee. Finally, it is responsible for overseeing the negotiations with European employers' organisations and representations made to European institutions. ${ }^{12}$

The Secretariat carries out the tasks assigned to it by the 3 decision-making bodies. These tasks include representing trade unions' interests vis-à-vis the European institutions, engaging in dialogue and negotiations with the European employers' organisations and the co-ordination of joint European actions. ${ }^{13}$

The President is the chairman of the Congress, the Executive Committee and the Steering Committee. ${ }^{14}$ The General Secretary is the chief spokesperson of ETUC and the co-ordinator of all its activities. The Deputy General Secretaries assists him/her. ${ }^{15}$

ETUC "aspires to be a unified and pluralistic organisation representing all working people at European level". ${ }^{16}$ The ETUC is an enthusiastic supporter

Article 7 of the ETUC Constitution.

9 Article 12 of the ETUC Constitution.

10 Article 13 of the ETUC Constitution and the ETUC home-page, March 2001.

11 Article 20 of the ETUC Constitution.

12 Article 19 of the ETUC Constitution.

13 Article 23 of the ETUC Constitution.

14 Article 10 of the ETUC Constitution.

15 Article 22 of the ETUC Constitution.

16 Preamble of the ETUC Constitution. 
of a more robust regulation of the EC labour market, and wants a transnational system of labour relations. ETUC is a supporter of Community regulation in order to remove the national differences as much as possible. Such regulation could, inter alia, take place through collective agreements at European level. ETUC is very keen on European-level bargaining, as it believes that only through bargaining can a union organisation achieve legitimacy at a particular level and avoid acting merely as a lobby. ${ }^{17}$ Political issues have generally played a secondary role in ETUCs activities, though the organisation occasionally adopts formal resolutions expressing its support of political freedom, democratic forms of government, strict observance of human and trade union rights, peaceful coexistence and negotiated steps towards disarmament. $^{18}$

\subsubsection{The Union of Industrial and Employers' Confederation (UNICE)}

UNICE was created in 1958. It organises 33 principal business federations from 27 European countries and o rederations as observers. ${ }^{19}$ The two most important bodies are the Council of Presidents and the Executive Committee. The Council of Presidents consists of the representatives of the national affiliates, which are mostly the President of their affiliation. ${ }^{20}$ The Council of Presidents is the supreme decision-making body as regards UNICE's policies and strategies and has full powers. ${ }^{21}$ One of its tasks is to define the attitude to be taken by UNICE and to approve results negotiated in the framework of the dialogue between the social partners. ${ }^{22}$

The Executive Committee consists also of the representatives of the national affiliates, normally the director-general of the national affiliation. Its tasks are, inter alia, to decide on financial and major administrative matters and to direct and supervise UNICE's activities and the implementation of its policies. ${ }^{23}$ Furthermore, there are 5 Policy Committees. Its membership is determined by the Executive Committee on the basis of nominations. ${ }^{24}$ The Committees monitor developments and help devise the Association's policies in their regard, suggest actions to be taken and implement the strategies adopted. ${ }^{25}$ Some 1500 experts from federations and companies in 60 working

17 Maastricht and social policy - part three. In: EIRR, no. 241, February 1994, p. 33.

18 R. Blanpain (ed. in chief), Encyclopedia of Labour Law and Industrial Relations, European Labour Law, suppl. 231, June 2000, par. 142-153 for more examples.

19 Homepage of UNICE. Http://www.unice.org/

20 Article 6.1. of the UNICE Statutes.

21 Article 6.2. of the UNICE Statutes.

22 Article 6.3. of the UNICE Statutes.

23 Article 9.3. of the UNICE Statutes for a complete overview of the tasks of the Executive Committee.

24 Article 12.1 and 12.2. of the UNICE Statutes.

25 Article 121. of the UNICE Statutes. 
groups participate in this work. ${ }^{26}$ The President of UNICE is elected by the Council of Presidents, and he/she chairs the Council of Presidents and the Executive Committee. ${ }^{27} \mathrm{He} / \mathrm{she}$ is the authorised representative of the Council of Presidents and represents UNICE at high level. ${ }^{28}$ The Secretary-General of UNICE is appointed by the Council of Presidents which determines his/ hers tasks and powers. He/she is responsible for the day-to-day running of UNICE. ${ }^{29}$

UNICE believes that the only sure way to fight unemployment and pay for social progress is through improved competitiveness, leading to investment and economic growth. Furthermore, subsidiarity and proportionality must be respected and over-harmonization avoided. ${ }^{30}$ Generally spoken, UNICE's position with regard to legislation in the social policy field can be characterized as reserved. A free internal market is important and this should not be hindered by excessive legislation at European level. However, facing the fact that the Community institutions introduce more policy proposals, it concluded that it was wise to have an influence at the European legislation process. ${ }^{31}$ Until the 90 's, UNICE was resolutely opposed to reforms in the direction of law by collective agreements. However, the Belgian, Dutch and Italian employers' representatives began to break ranks with UNICE's hard line on framework agreements in 1990, arguing that an involvement of employers in European policy-making through bargaining was a far better option than the implementation of new directives via statute. ${ }^{32}$ UNICE started therefore to participate in the framework agreement on parental leave in 1995. Since then, it has concluded 3 intersectoral agreements with the ETUC and CEEP.

\subsubsection{The European Centre for Public Enterprises (CEEP)}

CEEP was created in 1961. CEEP is the association of enterprises or organisations with public participation or carrying out activities of general econo-

26 Home-page of UNICE, February 2000.

27 Article 8.1. and 8.2. of the UNICE Statutes.

28 Article 8.3 of the UNICE Statutes.

29 Articles 14.1. and 14.2. of the UNICE Statutes.

30 R. Blanpain (ed. in chief), Encyclopedia of Labour Law and Industrial Relations, European Labour Law, suppl. 231, June 2000, par. 126. See also R. Hornung-Draus, European employer organisations: Structure and recent developments. In: Industrielle Beziehungen, vol. 5, no. 2, 1998, p. 218-235.

31 See amongst others the position paper of UNICE on the future role of the social partners at European level, 17 June 1991. See also G. Falkner, The Maastricht Protocol on Social Policy: Theory and practice. In: Journal of European social policy, vol. 6, no. 1, 1996, p. 8-9.

32 M. Rhodes, The future of the 'Social Dimension': Labour market regulation in post1992 Europe. In: Journal of Common Market Studies, vol. 30, no. 1, 1992, p. 40. 
mic interest. Members are enterprises, enterprise groups and employers' organisations. Its general secretariat is situated in Brussels.

The institutional bodies of CEEP are the General Assembly and the Council of Administration. The General Assembly consists of representatives of the full members and holds all the powers necessary to permit the achievement of CEEP's objectives. ${ }^{33}$ The General Assembly, among others matters, approves the budget and accounts, is responsible for the modification of the Statute and the dissolution of CEEP and, in that event, the reallocation of its assets. ${ }^{34}$ The Council of Administration consists of a maximum of 2 members per section, representing the member enterprises of CEEP, which are appointed by the General Assembly. ${ }^{35}$ It has all the powers required for management and administrative purposes, except those held by the General Assembly. ${ }^{36}$ There are also Permanent Committees whose task is to make studies and do preparatory work in order to facilitate the decision-making within CEEP. They prepare draft positions for CEEP on technical aspects or points of principle arising in their respective fields. For the European social dialogue, a Committee on Social Affairs exists, which is established on a permanent basis. In the Rules of Procedure of CEEP, a special section is included regarding the internal decision-making procedure of CEEP when it comes to the conclusion of European collective agreements with other organisations. The tasks of the Committee on Social Affairs are outlined therein..$^{37}$ Finally, CEEP has a President and a Secretary-General. The President is elected by the General Assembly, and chairs both the General Assembly and the Council of Administration. The Secretary-General is appointed by the General Assembly.

The purposes of CEEP are, inter alia, to represent its members before the institutions of the European Union and within existing or future Community organisations, agencies, centres, committees, etc. Furthermore, CEEP exercises all the prerogatives and obligations relating to its status as a social partner. It also wants to facilitate and develop contacts and cooperation with the other European social partners and national and European organisations that may help it to achieve its purpose..$^{38}$

CEEP is a warm supporter of the intersectoral as well as the sectoral social dialogue at European level. CEEP wants to see the development of real European economic and social policies. Therefore the scope and themes of the social dialogue must not be limited. ${ }^{39}$

\footnotetext{
33 Article 9 and 10 of the CEEP Statutes.

34 Article 10 of the CEEP Statutes.

35 Article 14 of the CEEP Statutes.

36 Article 17 of the CEEP Statutes.

37 Articles $43-49$ of the Rules of Procedure of CEEP.

38 Article 3 of the CEEP Statutes.

39 CEEP Opinion on the Communication Concerning the Development of the Social Dialogue at Community Level, 18 September 1996.
} 


\subsubsection{Conclusions}

The ETUC is the most important intersectoral trade union at European level. UNICE and CEEP represent the intersectoral employers. These three organisations have played an important role in the stimulation of the European social dialogue. To date they have concluded three intersectoral agreements. While UNICE represents the employers from the private sector, CEEP-members are associations of enterprises or enterprises with public participation. All three organisations have a clear internal structure and a constitution and/or statutes in which the internal relations are described.

\subsection{Intersectoral organisations representing certain categories of workers and employers}

There are also organisations which represent only specific categories of workers or employers. Since most European organisations of workers/employers are structured in more or less the same way, I will not expand on the internal structure of these organisations, as this has already been done for ETUC, UNICE and CEEP. Categories of workers are for example represented by the Confédération Europeénne des Cadres (CEC), which was founded in 1989 and EUROCADRES. The employees that CEC represents are defined by it as those who "perform duties which involve a particularly high degree of responsibility competence and professionalism in the management and implementation of corporate and institutional objectives". EUROCADRES also seeks to represent the managerial and professional staff. So in a way both organisations overlap each other. Categories of undertakings are for example represented by the European Association of Craft and Small and Mediumsized Enterprises, (UEAPME). Another organisation representing certain categories of undertakings is EUROCOMMERCE, which represents the employers in the commerce sector.

\subsubsection{The European Association of Craft and Small and Medium Sized Enterprises (UEAPME)}

I will discuss UEAPME more extensively. Although it has not yet been a party to a European agreement, it was the first European organisation to bring a case before the European Court of First Instance (CFI) regarding the European social dialogue and in particular the issue of representativity. This case is discussed in later chapters. Furthermore, since 1998, UEAPME participates in the negotiations in which UNICE is involved thanks to a cooperation agreement concluded between them on 12 November 1998. This means that it has also been a party, though indirectly, to the Framework Agreement on Fixed-Time Work.

UEAPME was founded in 1979 as a result of the amalgamation of various European trade associations and organisations of medium-sized enterprises. 
It currently represent 10 million businesses employing 50 million people. Its main objectives are:

- To inform its members about developments in European policy;

- To promote joint action on the part of the national organisations at European level;

- To ensure that the interests and views of its members are understood and reflected by the institutions of the EU.40

The organs of UEAPME are the General Assembly, the Administrative Council and the General Secretariat. Furthermore, there are several Committees including the one on Social Affairs. This Committee covers the issues of the European social dialogue. ${ }^{41}$

UEAPME has members in all EU Member States, but also in non-Member States, mainly in Eastern Europe. For several years UEAPME held the view that the 3 intersectoral organisations, the ETUC, UNICE and CEEP formed a closed shop and that the interests of small and medium-sized enterprises were insufficiently represented by them. ${ }^{42}$ However, this problem has been solved thanks to a cooperation agreement with UNICE concluded in 1998. This means that it will be involved in the decision making process within UNICE if the last mentioned is involved in the European social dialogue either by means of consultation or in the negotiation procedure on a European agreement.

\subsubsection{Conclusions}

There are several organisations which represent certain categories of workers or undertakings. UEAPME is an organisation which represents small and medium-sized industries. It was the first European social partners' organisation to bring a claim before the CFI against a Council Directive which was based on a European agreement. In 1998 it concluded a cooperation agreement with UNICE. Thanks to this agreement, UAEPME will in the future be involved in the decision making procedure within UNICE.

\subsection{Sectoral organisations}

Most European social partners' organisations are organised at sectoral level. They represent a specific branch of industry, such as, for example, the agricultural sector. Sectoral European agreements are concluded so far in transport, in particular in civil aviation, in the maritime transport sector and in the rail transport sector. These agreements all cover the issue of working time.

40 Home-page of UEAPME. Http://www.ueapme.com/en/index.html. March 2000. See also Article 3 of the UEAPME Statutes.

41 See the UEAPME Statutes for a broader description of the tasks of the various organs.

42 Stated at a press conference on 10 October 1996. 
Furthermore, a sectoral agreement has been concluded in the agricultural sector.

As regards civil aviation, workers are represented by the European Transport Federation (ETF) and the European Cockpit Association (ECA). Employers are represented by the Association of European Airlines (AEA), the European Regional Airline Association (ERA) and the International Air Carrier Association (IACA). In recent years, there has been increasing competition between providers, mergers between existing airlines and the emergence of new providers. Working time and vocational training are important issues in this sector. An agreement on working time has been concluded on 22 March $2000 .{ }^{43}$

In the maritime transport sector, workers are represented by the Federation of Transport Workers in the European Union (FST) and employers by the European Community Shipowners' Association (ECSA). The social dialogue in this sector has largely focused on the issues of employment, health and safety and working time. An agreement on working time has been concluded on 30 September 1998.4

In the rail transport sector, workers are represented by the Federation of the Transport Workers Unions in the European Union (FST) and employers by the Community of the European Railways (CCFE). Although railway companies remain state-controlled in a number of Member States, recent years have seen increasing moves towards privatisation. This has affected employment and working conditions in the industry. The Commission has already highlighted the particular problems in the railway industry in the absence of the European regulatory framework on working time, in the light of the increasing liberalisation of the market. ${ }^{45}$ On 30 September 1998, the FST and the CCFE concluded an agreement on working time. ${ }^{46}$

In the agricultural sector, workers are represented by the European Federation of Agricultural Workers' Trade Unions (EFA) and employers by the Committee of Agricultural Organisations in the European Union. (COPA). The EFA acts within the framework of the decisions of principle of the ETUC. It is a Trade Union Committee of the ETUC. ${ }^{47}$ It has the goal of contributing

43 European Agreement on the Organisation of Working Time of Mobile Staff in Civil Aviation on 22 March 2000.

44 European Agreement on the Organisation of Working Time of Seafarers on 30 September 1998.

45 The sectoral social dialogue in transport: working time firmly on top of the agenda. In: Eironline, Features, August 1998.

46 Agreement on some aspects of the Organisation of Working Time in the Rail Transport Sector on 30 September 1998.

47 Preamble of the EFA Constitution. 
to reinforce the work of the ETUC as a leading organisation in the agricultural sector within the ETUC. ${ }^{48}$ COPA, which was founded in 1958, has as its tasks among others to influence the European agricultural policy and to defend the interests of farmers at European level. ${ }^{49}$ An agreement on the improvement of paid employment was concluded between EFA and COPA on 24 July 1997.50

There are thus many European social partners' organisations at sectoral level. Also at this level, European agreements have been concluded, most of them on working time.

\subsection{The legal status of European social partners' organisations}

What is the legal status of European social partners' organisations? Do they have legal personality or are they de facto associations? And is it important for them to have legal personality?

\subsubsection{Legal personality in general}

A legal person has the general characteristics that it can operate as an independent unity and that it has its own separate capital. It is capable of having its own legal rights and obligations, distinct from the natural persons of which that legal person is composed. Having legal personality makes it easier for an organisation to conclude contracts and to institute proceedings in court. ${ }^{51}$ In many Member States, unions and employers' organisations have legal personality: for example in Portugal, Luxembourg, Spain, Greece, Denmark, Sweden and The Netherlands. In countries like The Netherlands and Denmark, the organisations are treated as associations and since associations have legal personality in these countries, the unions and employers' organisations have legal personality as well. In Great Britain, Ireland and France, there exists specific legislation with regard to the legal status of trade unions.

48 Article 1(2) of the EFA Constitution.

49 Home-page of COPA, February 2000. Http://www.copa.be/.

50 Recommendation Framework Agreement on the Improvement of Paid Employment in Agriculture in the Member States of the European Union, on 24 July 1997.

51 P. Vlas and R.J.H. Smits, De "apatride" vereniging, Rechtspersonen op het snijvlak van (internationaal) privaat- en publiekrecht, Preliminary Advises for the Dutch Association of International Law, no. 97, October 1988, p. 15. These characteristics are based on a vision that has its roots in corporation law. However, there is also another line of approach. According to this approach, an entity is entitled to certain rights and duties while at the same time no rules are given on the separation of capital or on the (limited) liability for damages. This vision is advocated by V. Simonart and P. Tilquin, Traité des Sociétés, Antwerpen, 1997 and discussed by F. Dorssemont in his thesis: De rechtspositie van de representatieve werknemersorganisaties, Antwerpen, 2000, no. 331-336. 
They do thus not fall under the general legislation on associations like in The Netherlands and Denmark. In Germany, Italy, Belgium and Luxembourg, trade unions do not have legal personality. In the past, these unions have become very frustrated with the interference of the legislator as regards their legal status. ${ }^{52}$ However, all these organisations are national organisations which are subject to a national concept of and national rules on legal personality.

\subsubsection{Which national law is applicable on European social partners' organisations when it comes to legal personality?}

Since we are dealing with European organisations of workers and employers rather than national ones, the first question is which national law is applicable to the question of their legal personality. To answer this, we have to look at certain aspects of private international law. Private international law however, differs from country to country. However, with regard to the issue of legal personality, we can distinguish two theories which are in use in the EC Member States: the Doctrine of Incorporation and the Effective Seat Theory. According to the Doctrine of Incorporation, an organisation is governed by the system of law under which it has been duly established. This covers all matters regarding formation, structure, functioning of organs and dissolution and winding up. There is party autonomy in the sense that those setting up an organisation are endowed with a freedom to choose the lex societas freely. If the organisation has legal personality according to the law of the country where it has been established, it will be subject to that law in other countries as well. ${ }^{53}$ According to the Effective Seat Theory, organisations are subject to the system of law of the legal order where the companies' management and control office resides. This can thus be a country other than the one in which it has been established. Effective Seat means the place where the management is situated, the centre of the board activities. ${ }^{54} \mathrm{~A}$ majority of the EC Member States adheres to the Effective Seat Theory. ${ }^{55}$ The majority of the European social partners' organisations have their management office in Brussels. Belgium adheres to the Effective Seat Theory which means that these organisations are thus subject to Belgian law.

52 A.T.J.M. Jacobs, Het recht op collectief onderhandelen in Europees en rechtsvergelijkend perspectief, p. 95.

53 P. Vlas, Rechtspersonen, Praktijkreeks IPR, deel 9, Deventer, 1999, no. 16 and 18.

54 P. Vlas, Rechtspersonen, no. 28.

55 L.e. Belgium, Luxembourg, France, Germany, Italy, Austria, Greece, Portugal and Spain, In: P. Vlas, Rechtspersonen, no. 144. 


\subsubsection{Application of the Belgian law on European social partners' organisations}

Trade unions and employers' organisations in Belgium are established in accordance with the right of association as laid down in the Belgian Constitution. The fact that they are associations however, does not mean that they therefore automatically possess legal personality, like is the case in the Netherlands. In The Netherlands, an organisation is a legal person if it fulfils certain criteria, whether it wants to be one or not. Trade unions and employers' organisations are associations and according to the Dutch Civil Code, associations have legal personality. ${ }^{56}$ In Belgium, trade unions and employers' organisations can choose to obtain legal personality or not. They can acquire legal personality if they bring their statutes and memorandum of association into conformity with the Act of 31 March 1898 on Professional Associations or with the Act of 27 June 1921 on Associations without Profit Seeking Goals. ${ }^{57}$ However, so far, trade unions have systematically refused this. One of the most important reasons is that they are afraid to be sued in court in order to pay damages. ${ }^{58}$ However, their functioning would be difficult if they never could act on behalf of their members. Therefore, a number of laws have granted them certain competences (bevoegdheden). Examples of these laws are the Act respecting Collective Bargaining Agreements and Joint Committees of 5 December 1968 and the Act to make Provision for the Organisation of the Economic Life of the Country of 20 September 1948. This means that, although they lack legal personality, they are nevertheless able to function as organisations and not as individual natural persons. They have, for example, as an organisation the right to conclude collective agreements ${ }^{59}$ and the right to appear in court ${ }^{60}$ as well as the right to represent the individual workers who are a member of that organisation. These laws provide for a limited capacity to hold certain rights. As a consequence of the legal personality of trade unions in Belgium being limited, their liability for damages is also limited. According to Article 4 of the Act on Collective Agreements of 1968 , they only have to pay damages in case of breach of the collective agreement, if that is explicitly stipulated in the collective agreement itself. ${ }^{61}$ Belgian employers' organisations mostly have legal personality. ${ }^{62}$

56 Article 2:3 of the Dutch Civil Code.

57 P. Humblet, R. Janvier, W. Rauws and M. Rigaux, Synopsis van het Belgisch arbeidsrecht, Antwerpen/Groningen, 1999, par. 566 as well as F. Dorssemont, De rechtspositie van de representatieve werknemersorganisaties, Antwerpen, 2000, no. 507. See Blanpain and Vanachter who mention also some other reasons. R. Blanpain and O. Vanachter, Schets van het Belgisch arbeidsrecht, Leuven, 1997, p. 270.

Article 12 of the Act Respecting Collective Bargaining Agreements and Joint Committees.

60 Article 4 of the Act Respecting Collective Bargaining Agreements and Joint Committees.

61 See also P. Humblet, R. Janvier, W. Rauws and M. Rigaux, Synopsis van het Belgisch 
However, European organisations cannot be subject to the Belgian Act on Collective Agreements of 1968, because this Act has been written for national organisations. ${ }^{63}$ Belgian legislation however, also has a special Act for socalled international associations. International associations are sometimes also called bodies "sans loi". These are organisations which claim that they are not subject to any national law. They are mostly international associations which in turn are made up of national associations, mainly in the field of sports, culture and science. The management board is internationally composed and the meetings of the organisation are held in various countries. ${ }^{\text {of }}$ In many cases the international association does not have a permanent seat in a particular country. Its seat is temporary and is often linked to the chairman's or executive secretary's address. ${ }^{65}$ Recognition of such an association supposes that the association derives its legal personality from a certain system of law. In the case of these "stateless" associations there is no national system of law. Nor does there exist an international law of associations. International conventions regarding the recognition of the legal personality of international associations are lacking. ${ }^{60}$ The Belgian Act of 25 October 1919 foresees a legal framework for international associations. ${ }^{67}$ According to this Act, international associations can be given legal personality by Royal Decree if they fulfil certain criteria with regard to their object and statutes. The association must be open to admission for Belgians and foreigners and must be established in Belgium. The association must have a humane, religious, scientific, artistic or pedagogic goal without pursuit of profit. ${ }^{68}$ This Royal Decree effectively naturalises the international association as a Belgian association, because the rights and duties which are tied to the legal personality given by Royal Decree, are based on Belgian law.

arbeidsrecht, par. 571 .

62 Even the most important Belgian employers' federation, the VBO, has acquired legal personality since 1 January 2002. De Standaard, 29 September 2001, "VBO niet gedreven door winstbejag", article written by J. Rasking.

63 This flows, among others from Article 3 of the Act in which it is stated that employers' and workers' organisations' must be members of the National Labour Council.

64 P. Vlas, Rechtspersonen, no. 141.

65 P. Vlas, and R.J.H. Smits, De "apatride" vereniging, Rechtspersonen op het snijvlak van (internationaal) privaat- en publiekrecht, p. 60.

66 P. Vlas, and R.J.H. Smits, De "apatride" vereniging, Rechtspersonen op het snijvlak van (internationaal) privaat- en publiekrecht, p. 64.

67 Act of 25 October 1919 tot verlening van rechtspersoonlijkheid aan de internationale vereniging met menslievend, godsdienstig, wetenschappelijk, artistiek en pedagogisch doel.

Article 1 of the Act of 25 October 1919. 


\subsubsection{The choice of certain European social partners' organisations as regards their legal status}

Certain European organisations of workers and employers have used the Act of 1919 to determine their legal status. The statutes of UEAPME, CEEP, ECA and CCFE state that UEAPME/CEEP/ECA/CCFE are "an international association by virtue of the Belgian law of 25 October 1919 ". ${ }^{69}$ By referring to this act in their statutes, the organisations indicate that they have asked and been granted legal personality in accordance with Belgian law. ${ }^{70}$ Other European organisations use different concepts. This is the case, for example, with ETUC. ETUC has not stipulated anything in its statutes with regard to its legal status. According to ETUC itself, it is a de facto association and it has no legal personality. ${ }^{71}$ Sometimes, the organisations have stipulated explicitly in their statutes which legal status they have. The UNICE statutes state in Article 1 that UNICE is a de facto association. This means that it denies having legal personality. The reason for the ETUC to deny legal personality is the same as for the Belgian trade unions. The ETUC does not want to run the risk that it will be sued because of the call of strikes.

As regards the sectoral organisations, not all have statutes which are available for publication. Therefore, I will discuss only the ones of those made available to me. The articles of association of ERA do not state anything about the legal status of this organisation. EUROCADRES has been set up within the ETUC. ${ }^{72}$ Although it has its own constitution, there is nothing in this document on the legal status of EUROCADRES. The EFA is a European Industry Federation of the ETUC. Also the EFA has its own constitution, but there is nothing in it about its legal status. ECSA is a non-profit organisation, established under Belgian law. According to ECSA itself, it is a legal person under Belgian law. ${ }^{73}$ The CEC Regulations do not state anything about its legal status.

\subsubsection{Should European social partners' organisations have legal personality?}

Certain European organisations of workers and employers, like their Belgian colleague organisations, do not have legal personality. For Belgian organisations, this is not very problematic since they can operate as social partners' organisations and initiate legal proceedings because there are various natio-

69 Article 1 of the UEAPME Statutes and Article 1 of the CEEP Statutes, as well as the respective Articles 1 of the ECA and CCFE Statutes..

70 This has been confirmed by spokespersons of UAEPME and CEEP in an interview on the telephone on 8 March 2002.

71 Interview with spokesperson of the ETUC on 31 March 2000.

72 Article 1 of the Constitution of EUROCADRES.

73 Interview with spokesperson of the ECSA on the telephone on 4 April 2000. 
nal laws which give them such powers. ${ }^{74}$ But for European organisations, the situation is different. It can happen that a European organisation wants to bring a case against another European organisation. Most probably Belgian law will apply on such a procedure, because all European organisations of workers and employers have their seat in Brussels. Belgian law does not give any specific rules for European organisations to bring a case before their courts, like it does for national trade unions. To create various laws at European level analogous to the Belgian model seems unnecessarily complicated to me. It is, however, possible that, despite the lack of legal personality, European organisations can act in the name of their members on the basis of the mandate-theory. Jacobs is relatively optimistic about the mandate theory as such to be used by workers' and employers' organisations when discussing the binding effect of collective agreements on individual workers and employers. ${ }^{75}$ The question is however, whether this is always very practical. Apparently, in Belgium the views with regard to the refusal to acquire legal personality are changing as well. The most important intersectoral employers' organisation, the Federation of Belgian Enterprises, ${ }^{76}$ in September 2001 announced that it wanted to turn the organisation from a de facto organisation into an organisation with legal personality. 77 The reason was, according to the Federation, that it wants to be more transparent and responsible towards outsiders and that it wants to be a representative spokesperson towards the government, media, trade unions and other non-governmental organisations. The Belgian trade unions reacted with reluctance. They stated that they still have the fear of being sued for calling strikes. They refer to The Netherlands and France and say that in those countries the trade unions are far more reluctant to call or support strikes, for fear that they have to pay damages. The question is whether this fear is realistic. In the first place because, according to Belgian law, for a claim to pay damages to be successful, it has to be clear that the actions can be attributed to the trade union. ${ }^{78}$ This is not always easy to prove. Secondly, because if we look at other countries, where trade unions do have legal personality, like The Netherlands, it is very rare

74 F. Dorssemont, De rechtspositie van de representatieve werknemersorganisaties, no. 458.

75 Although also he has set out in his thesis that there have been difficulties with the mandate theory in other countries. See A.T.J.M. Jacobs, Het recht op collectief onderhandelen in Europees en rechtsvergelijkend perspectief, p. 221-223. Also Dorssemont sees no problems as long as the workers and employers' orgnaisations have clear mandates from their members. Only if such mandates are absent, difficulties can arise, he states. See F. Dorssemont, De rechtspositie van de representatieve werknemersorganisaties, no. 610 .

76 VBO (Verbond van Belgische Ondernemingen).

77 De Standaard 29/09/2001, "VBO niet gedreven door winstbejag".

78 F. Dorssemont, De rechtspositie van de representatieve werknemersorganisaties, no. 456. 
that employers make trade unions liable for the call or support of strikes. ${ }^{79}$ In France this is more common, especially in the case of sit-down strikes. ${ }^{80}$ However, the party that sues has to prove that the French syndicats explicitly gave orders to their members to carry out unlawful actions, which occurred in conjunction with the strike. ${ }^{81}$ This will often be difficult to prove. Thirdly, the liability claims carry the danger that not only an important opponent but also an important social partner will be destroyed. ${ }^{82}$ In Chapter 6 I will argue that in the future it is very well possible that a European social partners' organisation will want to bring a claim against another European social partners' organisation. For example, the ETUC against UNICE. The fact that they lack legal personality can then raise difficulties if the European organisations do not have specific a mandate from their national affiliates to represent them in legal proceedings. European social partners' organisations can have an important interest in bringing a legal claim against another organisation, especially when it comes to European agreements which have been implemented by the national affiliates and not by Council decision. ${ }^{83}$ If European agreements whose provisions can not be enforced are concluded, the European social dialogue will develop towards a meaningless procedure and the agreements concluded will be no more than non-binding recommendations. I consider therefore that it would be better if European social partners' organisations, which are almost all situated in Brussels, should acquire legal personality according to Belgian law, unless they stipulate clearly in their statutes that they have a mandate from their members in certain cases.

Another line of approach which can be followed is to introduce a Community concept of the "association". In 1991, the Commission formulated a proposal for a Council Regulation on the statute for a European association (EA). ${ }^{84}$ The reason was that cross-border cooperation between associations was hampered by legal and administrative difficulties. The introduction of an EA should enable all associations to operate outside their own national

79 F. Dorssemont, De rechtspositie van de representatieve werknemersorganisaties, no. 764. Dorssemont also mentiones Germany as an example where employers rarely make trade unions liable for the call or support of strikes. It has to be born in mind however, that, legally spoken, German trade unions do not have legal personality. They are however treated by the German courts as responsible organisations with a so called de facto personality. They can be brought before a court and be held liable for damages. See A.T.J.M. Jacobs, Het recht op collectief onderhandelen in Europees en rechtsvergelijkend perspectief, p. 100-101.

80 F. Dorssemont, De rechtspositie van de representatieve werknemersorganisaties, no. 777.

81 F. Dorssemont, De rechtspositie van de representatieve werknemersorganisaties, no. 923.

82 F. Dorssemont, De rechtspositie van de representatieve werknemersorganisaties, no. 921.

83 For this implementation method see Chapter 5.

84 Proposal for a Council Regulation (EEC) on the structure for a European association, COM(91)273 final, Brussels, 5 March 1992. 
borders. The Community therefore wanted to provide associations with an adequate legal instrument capable of facilitating the development of their transnational activities. ${ }^{85}$ The idea was that two or more legal entities from different Member States could form an EA. The EA had to demonstrate that it carried out genuine and effective cross-border activities. By the proposal, an annex was included in which these legal entities for each Member State were listed. In general, it concerned associations which had been formed in the respective countries in accordance with the national rules. The proposal formulated rules with regard to the internal organisation of such EAs. It also stated that EAs were to have legal personality. ${ }^{86}$ This would mean that such a European association would always pass the test of "legal person" in Article 230 EC Treaty. An important disadvantage however of the proposal was that it complicated the legal systems of all Member States. Each EA was to be governed by two legal systems: Community law and the law of the Member State in which it was established. Each Member State had to create legislation for EAs which were established on its territory. ${ }^{87}$ Probably for these reasons the proposal has never been adopted. Community legislation on European associations would probably be the best solution. ${ }^{8 s}$ In this way it would be clear that European social partners' organisations which fulfill the conditions of the Community legislation on European associations, would always have legal personality, regardless in which Member State they institute proceedings or perform other acts as an association. Given, however, that the first proposal on a European association has never resulted in Community legislation and also given that it took many years before a similar statute for a European company was adopted, the statute for a European association is not a short term solution for the legal status of the European social partners' organisations.

European organisations also operate at European level, as will be explained in the forthcoming chapters. They serve as advisory bodies for the Commission and they conclude agreements with each other at European level. It can also occur, however, that they institute proceedings against one of the Community institutions. ${ }^{89}$ In Chapter 8, I will discuss the meaning of "legal person" as formulated in the Articles 230 and 232 EC Treaty.

85 Considerations in $\mathrm{COM}(91) 273$ final.

86 Article 2 of $\operatorname{COM}(91) 273$ final.

87 See W.C.L. van der Grinten, Europese verenigingen? In: Stichting \& Vereniging, vol. 7, no. 6, 1992, p. 145 and H.L. Kaemingk, IPR aspecten van Europese rechtspersonen. In: AA, vol. 42 , no. $7 / 8,1993$ p. 521 and further.

88 Similar legislation has been issued for the Societas Europeae. See Council Regulation (EC) no. 2157/ 2001 of 8 October 2001 on the Statute of a European Company, OJ L 294/1, 10-11-2001.

89 Actually, this already happened in the UEAPME case, which will be discussed in Chapter 4,7 and 8. 


\subsubsection{Conclusions}

The concept of legal personality has certain characteristics. There remain, however, differences between the various countries as regards this concept. An association having legal personality in one country might not have this in another country. The question for European social partners' organisations is which national law is applicable to them when it comes to the question whether or not they possess legal personality. On the basis of private international law we can conclude that Belgian law is applicable. According to Belgian law, the organisations can choose whether they want to obtain legal personality or not. Furthermore, Belgium has a special Act for international associations. Certain organisations, such as CEEP and UEAPME have referred to this Act in their statutes and acquired legal personality. Other organisations, such as ETUC and UNICE are de facto associations. In order to develop a genuine European social dialogue with agreements that are really enforceable, it is recommendable that the European social partners' organisations acquire legal personality, because they cannot be put on the same footing as Belgian social partners' organisations, or thoy should put explicitly in their statutes that they are mandated by their national affiliates with regard to the conclusion of European agreements and with regard to the representation of their members in legal proceedings. Furthermore, the fear of having legal personality is probably unfounded if we look at other countries such as The Netherlands and France. A Community concept of association could be developed for the future. Given the difficulties with regard to the withdrawn proposal on a European association, the chance that this will happen in the future is, however, small.

\subsection{Conclusions}

The three most important intersectoral European social partners' organisations are the ETUC for the workers and UNICE and CEEP for the employers. They have played an important role in stimulating the European social dialogue. Furthermore, they have so far concluded three intersectoral agreements which all have been implemented through a Council Directive. They have a clear structure in which the internal rules are described. Besides intersectoral organisations, there are also organisations representing specific categories of workers or employers. One of them is UEAPME, which was the first social partners' organisation to bring a claim before the CFI, seeking the annulment of a Directive based on a European agreement between the ETUC, UNICE and CEEP. Finally, there are sectoral organisations who have concluded agreements at European level as well, mostly on working time. There are European social partners' organisations who have acquired legal personality, such as UAEPME and the CEEP. Other organisations are de facto organisations. For example the ETUC and UNICE. 
Because the European social partners' organisations are subject to Belgian law, they can choose whether or not to acquire legal personality. Application of the Belgian law to European social partners' organisations can lead to difficulties when these organisations want to institute legal proceedings in Belgium. Their position can not be put at on the same footing as Belgian organisations of workers and employers, since for the last mentioned a number of laws have been issued which have granted them certain competences. These laws do not apply on European social partners' organisations. In order to have a European social dialogue with genuine agreements which can, if necessary, be legally enforced it is recommendable that the European social partners' organisations would acquire legal personality. Moreover, since the fear to have legal personality is probably not very realistic, given the experience gained in other countries such as The Netherlands, and France. It is possible that in the future a Community concept of association will be developed. And although this would probably be the best option it will take many years before this is realised. 


\section{CHAPTER 3}

\section{AN ENHANCING ROLE FOR THE EUROPEAN SOCIAL PARTNERS' ORGANISATIONS}

\subsection{Introduction}

In this chapter I will describe the development of the role of the European social partners' organisations, which is twofold. On the one hand is their role as private organisations, influencing European social policy by advising European institutions. On the other hand they function as creators of European collective agreements which can even be turned into Community legislation. Both aspects have a history going back to the beginning of the EC. I will describe, first, the development of the institutionalisation of the European social partners' organisations in para. 3.2. I will then describe the development of their role as social partners concluding agreements with each other in para 3.3. We shall see that the role of the European social partners' organisations as regards their influence on the creation of European labour law has been enhanced over the years. In para 3.4 some conclusions will be drawn.

\subsection{Institutionalisation}

\subsubsection{The Economic and Social Committee}

The Treaty of Rome already provided in 1957 for an Economic and Social Committee (ECOSOC). Its composition and tasks are described in Articles 257-262 EC Treaty, which have not substantially been changed since 1957. It consists "of representatives of the various categories of economic and social activity, in particular, representatives of producers, farmers, carriers, workers, dealers, craftsmen, professional occupations and representatives of the general public".' The ECOSOC has 222 members and is split into 3 groups, namely employers, workers and 'various activities'. The employers' group has members from private and public sectors of industry, small businesses, chambers of commerce, wholesale and retail trade, banking and insurance, transport and agriculture. There is only one European-level employers' organisation represented in the ECOSOC, ${ }^{2}$ the others are national organisations. However, regular exchanges take place between the employers' group and the most important intersectoral employers' organisations at European level, such as UNICE and CEEP. In the workers' group as well, most mem-

1 Article 257 EC Treaty. The provision has not changed since 1957.

2 EUROCOMMERCE. 
bers are national organisations. The majority of these organisations are affiliated to ETUC. ETUC itself and CEC are the only European-level organisations who are in the workers' group of the ECOSOC.

Until the Maastricht Treaty, the ECOSOC was the only way for Europe's interest groups such as trade unions and employers' organisations, to have a formal and institutionalized say on draft EU legislation. The ECOSOC has always advised the Council, Commission and European Parliament. This advisory role has been enhanced by the European Single Act in 1987 and by the Maastricht Treaty. The range of issues on which the ECOSOC can advise has increased over the years. ${ }^{3}$ The ECOSOC must be consulted by the Commission and Council where the Treaty so provides. It can also publish opinions without having been consulted. The ECOSOC may be consulted by the European Parliament. ${ }^{4}$

\subsubsection{Advisory Committees for the Commission}

In the 1960s, the Commission began to set up committees in which employers and workers' organisations were represented. Committees were set up at intersectoral and at sectoral level.

At the intersectoral level, cross-industry advisory committees were being created. This was the first element whereby the social partners were associated with the formulation of Community policies. These committees still exist." They are made up of representatives of national trade unions and employers' organisations and governments. They advise the Commission on drawing and implementing specific policies. ${ }^{6}$ There are six committees: The European Social Fund Committee, the Advisory Committee on Social Security for Migrant Workers, ${ }^{8}$ the Advisory Committee on Freedom of Movement for Workers, ${ }^{9}$ the Advisory Committee on Vocational Training, ${ }^{10}$ the Advisory Committee on Safety, Hygiene and Health Protection at Work ${ }^{11}$

3 Home-page of the ECOSOC, Http://www.ces.eu.int/index800.htm; April 2001.

4 Article 262 EC Treaty.

5 At least at the time that this thesis is written.

6 Commission sets out options for the future of the social dialogue. In: EIRR, no. 276, January 1997, p. 25.

7 Based on Article 147 EC Treaty.

8 Created by Council Regulation (EEC) No. 1408/71 of 14 June 1971, on the application of social security systems to employed persons and their families within the Community; OJ L 149/2, 05-07-1971.

9 Created by Council Regulation (EEC) No. 1612/68 of 15 October 1968, on freedom of movement for workers within the Community; OJ L 257/2, 19-10-1968.

10 Created by Council Decision 63/226/EEC of 2 April 1963, laying down general principles for implementing a common vocational training policy; OJ L 063/1338, 2004-1963.

11 Created by Council Decision 74/325/EEC of 27 June 1974, on the setting- up of an advisory committee on safety, hygiene and health protection at work; OJ L 185/15, 0907-1974. 
and the Advisory Committee on Equal Opportunities for Women and Men. ${ }^{12}$ A major disadvantage of the cross-industry committees is that, except for the one on Equal Opportunities, they are made up of national rather than European-level social partners. This means that the position of the social partners is often not co-ordinated with the views expressed in other forums. ${ }^{13}$ ETUC, UNICE and CEEP submitted in 1993 a recommendation on the functioning of the cross-industry advisory committees. ${ }^{14}$ They recommended that the proposals for nominations of workers' and employers' representatives be made by national organisations (as was already the case), but be channelled through them. Furthermore, they ask the Commission that they be full members of the committees and therefore requested that additional seats be attributed to them.

At the sectoral level, the Commission decided in the 1960 s to set up joint committees in those sectors where "integrated" common policies were developing: coal and steel (already in 1955), agriculture (1963), road transport (1965), inland waterways (1967), sea-fishing (1968) and the railways (1971). These committees were made up of equal numbers of employers' and workers' representatives, appointed by the Commission on the recommendation of employers' organisations and trade unions. ${ }^{15}$ The purpose of the joint committees was described as to keep a watch on economic and social developments in their sectors, to seek to conclude collective bargaining agreements and to submit proposals for Community action towards institutions. ${ }^{16}$ These committees fulfilled a dual role: they kept tabs on the situation, which might result in contributions to the Commission and the Council, and they operated as fora for exchanging views and independent dialogue between the social partners. ${ }^{17}$ The joint committees have only produced opinions and recommendations on employment, working conditions and health and safety.

However, virtually all of these committees failed to establish labour agreements for the various industries, mainly because employers did not wish to enter into European-level obligations. ${ }^{18}$ Only the agricultural sector committee was able to conclude an agreement on working hours. ${ }^{19}$ The agreement

12 Set up by Commission Decision 82/43/EEC of 9 December 1981 and amended by Commission Decision 95/420/EC of 19 July 1995; OJ L 020/5, 28-01-1982.

13 Commission sets out options for the future of the social dialogue. In: EIRR, no. 276, January 1997, p. 25.

14 Recommendation by the ETUC, UNICE and CEEP on the functioning of inter-professional advisory committees, June 1993.

15 The sectoral social dialogue. In: EIRR, no. 224, September 1992, , p. 14.

16 P. Teague, The European Community, The social dimension, London, 1989, p. 91.

17 European Social Dialogue, Status Report 1996, special issue of the European Commission's newsletter, published by the European Commission DG V/D, 1997, p. 8.

18 B. Hepple, European social dialogue - Alibi or opportunity? London, 1993, p. 13.

19 Agreement on the harmonization of working hours of permanent agricultural workers in the EC arable farming sector, 22 March 1978, concluded between COPA and EFA and the Agreement on the harmonization of working hours of permanent agricultural 
took the form of a recommendation, but one could see here a forerunner of a European collective agreement. ${ }^{20}$ The parties merely agreed to recommend the text of the agreement to their member associations for implementation when national collective agreements were being modified or renewed. ${ }^{21}$ The Commission, therefore, issued a Decision dated 20 May 1998.by which these Joint Committees were replaced by Sectoral Dialogue Committees. ${ }^{22}$ The aim was to strengthen the sectoral social dialogue. ${ }^{23}$ These Committees are to be consulted on developments at Community level having social implications and develop and promote the social dialogue at sectoral level. The Committees are established in those sectors where the social partners make a joint request to take part in a dialogue at European level. The organisations have to fulfil certain criteria:

- They shall relate to specific sectors or categories and be organised at European level;

- They shall consist of organisations which are themselves an integral and recognized part of Member States' social partner structures and have the capacity to negotiate agreements, and which are representatives of several member States;

- They shall have adequate structures to ensure their effective participation in the work of the Committees. ${ }^{24}$

In 2000 there were 28 sectoral social dialogue committees. ${ }^{25}$ So far, the sectoral social dialogue has produced a great number of non-binding texts. ${ }^{26}$ It is probably only in highly internationalized sectors like transport (see chapter 2 ), that the sectoral dialogue will produce more binding documents. ${ }^{27}$

\subsubsection{The Standing Committee on Employment}

Where the Treaties required workers' and employers' interests to be represented in various fora such as the Economic and Social Committee, the

workers in the EC livestock farming sector, 10 June 1980, concluded between COPA and EFA.

20 A. Jacobs, Het recht op collectief onderhandelen in Europees en rechtsvergelijkend perspectief, Alphen a/d Rijn, 1986, p. 382.

21 R. Blanpain, Efforts to bring about Community-level collective bargaining. In: $\mathrm{H}$. Günter, Transnational industrial relations, London, 1972, p. 299.

22 Commission Decision 98/500/EC of 20 May 1998, on the establishment of Sectoral Dialogue Committees promoting the dialogue between the social partners at European level, OJ L 225/27, 12-8-1998.

23 Considerations by Commission Decision 98/500/EC

24 Article 2 of Commission decision 98/500/EC.

25 Industrial relations in Europe 2000, published by the European Commission, DG V/D, 2000 , p.15.

26 See Industrial relations in Europe 2000, p. 18 for examples.

27 See also B. Keller and B. Sörries, The sectoral social dialogue and European social policy: more fantasy, fewer facts. In: European Journal of Industrial Relations, 1998, vol. 4, no. 3, p. 339. 
European Coal and Steel Community Consultative Committee and the Committee of the European Social Fund, this has been organised on a national basis. Appointment and nominations have always been through social partners' organisations considered representative at the national level. Representation on many of the bipartite and tripartite bodies set up by the Community institutions for advisory and consultative purposes such as the Advisory Committees on Vocational Training and on Safety, Hygiene and Health Protection at Work, has been organised in a similar way. ${ }^{28}$ However, the representation of European-level social partners' organisations has also been attempted from a relatively early stage. The first formal attempt to identify such organisations at the Community intersectoral level was at the establishment of the Standing Committee on Employment ${ }^{29}$ (SCE). In the annex to the Council Decision, the European social partner organisations are listed. While the employers' organisations were all European, the workers' organisations listed as representative for the SCE were a diverse mixture of European, international and national groupings which reflected the fragmented nature of European trade unionism at the time. ${ }^{30}$ When ETUC emerged in the early 1970 's, this led to a simplification of representation on the SCE. ${ }^{31}$

The task of the SCE was defined as "to ensure, in compliance with the Treaties and with due regard for the powers of the institutions and organs of the Communities, that there shall be continuous dialogue, joint action and consultation between the Council -or where appropriate, the representatives of the governments of the Member States- the Commission and the two sides of industry in order to facilitate co-ordination by the Member States of their employment policies in harmony with the objectives of the Community". 32 Since 1975 it has met twice a year, offering an opportunity for the European social partners to meet the Ministers for Social Affairs and for the ministers in turn to hear the social partners' opinions. However, because of the new Employment Title in the Amsterdam Treaty, a new role for the social partners' organisations was necessary. The monitoring of the employment guidelines demanded an active and comprehensive approach from them. Furthermore, new forms of tripartite dialogue led to an increase of fora, such as the meetings between the Employment and Labour Market Committee Group and the social partners and the meetings between the Troika of Ministers and/or Heads of State and the social partners. These developments required a reform of the SCE to contribute more effectively to the development and implementation of the Employment Guidelines and Broad Economic Orien-

28 The new social partners: trade unions. In: EIRR, no. 244, May 1994, p. 25.

29 Council decision 70/532/EEC of 14 December 1970, setting up the Standing Committee on Employment in the European Communities, OJ L 273/25, 17-12-1970.

30 See the annex to Council decision 70/532/EEC

31 Council Decision 75/62/EEC of 20 January 1975, amending Decision No 70/532/EEC, OJ L 021/17, 28-1-1975.

32 Article 1 of Council Decision 70/532/EEC. 
tations. ${ }^{33}$ Dating from 1975, the Council Decision on the establishment of the SCE has never been revised to take into account the developments affecting the representative organisations. According to the Commission, the composition of the SCE should reflect the approach of the SCE, concentrating on inter-professional organisations at European level. ${ }^{34}$ Debates within the SCE were mainly limited to a succession of interventions setting out each member's position. ${ }^{35}$ The Commission therefore considered that the SCE should be reformed. $^{36}$ The Council adopted a Decision on 9 March 1999, on the reform of the SCE. ${ }^{37}$ Where the old SCE still consisted of social partners' organisations at European, national and international level, as regards the trade union side, the new SCE only accepts representatives of workers and employers at European level. ${ }^{38}$ According to the Council decision of 9 March 1999, "the social partners' delegations shall cover the whole economy, being composed of European organisations representing either general interests or more specific interests of supervisory and professional staff and small and mediumsized businesses". The practical co-ordination of the workers' delegation is to be undertaken by the ETUC, that of the employers by UNICE. ${ }^{39}$

\subsubsection{Tripartite conferences}

The first half of the 1970 s showed an increased interest in the Communities social policy. The high growth, regional disparities, social exclusion and industrial restructuring of the early 1970s had created political awareness about the social implications of integration. ${ }^{40}$ In October 1972, a summit between the Member States was held in Paris. In the final communiqué of this summit, it was stated that the Member States:

"attached as much importance to vigorous action in the social field as to the achievement of economic union (...) (and considered) it essential to ensure the increasing involvement of labour and management in the economic and social decisions of the Community."

33 Commission Communication, Adapting and promoting the social dialogue at Community level, of 20 May 1998; COM(98)322, Brussels, 20 May 1998, p. 10.

34 Commission Communication, Concerning the application of the Agreement on Social Policy; $\operatorname{COM}(96) 448$ final, Brussels, 14 December 1993, point 53.

$35 \operatorname{COM}(96) 448$ final, point 48.

36 See for an overview of the Commission ideas with regard to these reforms: $\operatorname{COM}(96)$ 448 final, points 50-54.

37 Council Decision 1999/207/EC of 9 March 1999, on the reform of the SCE and repealing Dec. 70/532/EEC, OJ L 072/33, 18-3-1999.

38 Article 2(2) of Council Decision 1999/207/EC.

39 Article 2(3) of Council Decision 1999/207/EC.

40 J.E. Dolvik, Redrawing boundaries of solidarity? ETUC, social dialogue and the Europeanisation of trade unions in the 1990s, Dissertation, Oslo, 1997, p. 118. 
Accordingly, the Commission was instructed to draw up a Social Action Programme by the Heads of State and Governments, which it did in 1974. In a Council resolution on this Social Action Programme, the Council sets new aims for the Community's social policy. ${ }^{41}$ These aims are grouped under three principal objectives: full and better employment, improved living and working conditions and greater worker participation. In practice, it mainly focused on employment protection, equal treatment, workers participation and health and safety measures, issues which have come to dominate the social dimension agenda throughout the 1980 s and $1990 \mathrm{~s}^{42}$

As a result of the Social Action Programme of 1974, efforts were made to develop the cooperation at Community level between the Community institutions and management and labour. For this purpose six tripartite conferences were held between 1974 and $1978 .{ }^{43}$ However, the conferences did not satisfy the employers organisations. UNICE remained unwilling to be party to decisions which would bind its constituents, and therefore avoided the development of a centralized European social policy gaining any legitimacy. As a consequence, the ETUC became increasingly frustrated at the lack of concrete progress. In 1978 it threatened to reconsider its participation in future meetings unless proposals were put forward to give a new impetus to the conference's activities. Tripartite conferences, therefore, no longer took place after $1978 .^{44}$

\subsubsection{The Steering Group and Social Dialogue Committee}

In 1989 the Community Charter of Fundamental Social Rights of Workers was adopted. This Charter recognised the right to negotiate and to conclude collective agreements. As a result of the Social Charter, a third Social Action Programme was adopted in 1989 by the Commission. ${ }^{45}$ It provided for consultation of the European social partners on Commission proposals in areas where there were no advisory committees.

In January 1989, a Steering Group was set up on the initiative of the President of the European Commission, Jacques Delors and the new Social Affairs

41 Council Resolution of 21 January 1974, concerning a social action programme. OJ C13/1, 12-2-1974, p. 1.

42 J.E. Dolvik, Redrawing boundaries of solidarity? ETUC, social dialogue and the Europeanisation of trade unions in the 1990 s, p. 118.

43 Among others on the prospects for European social policy (1974), on the economic and social situation in the Community (1975), on the restoration of full employment and stability in the Community (1976) and on growth, stability and employment (1977).

$44 \mathrm{M}$. Hall, Industrial relations and the social dimension of European integration: before and after Maastricht. In: R. Hyman and A. Ferner (eds.), New frontiers in European industrial relations, Oxford, 1994, p. 294.

45 Commission Communication, concerning its action programme relating to the implemantation of the Community Charter of Basic Social Rights for Workers, COM(89)568 final, Brussels 29 November 1989. 
Commissioner Vassa Papandreo. The reason was that they wanted to reinforce the social dialogue structures to ensure an ongoing impetus for social dialogue ${ }^{46}$ The Steering Group was composed of representatives of UNICE, CEEP, ETUC and the Commission. Its tasks included choosing the subjects for discussion, evaluating the results and arbitrating in the event of stalemate in the working parties. The Commission agreed with this group a consultation procedure for certain proposals for legislation to which the social partners attached great importance, but which did not fall within the scope of any of the existing advisory bodies. This included structural programmes and all the Commission's proposed legislation under the Action Programme of 1989. According to this procedure, the social partners were consulted jointly on each proposal in two stages. A first consultation takes place on the basis of a Commission discussion paper. This is followed by a second one held within the following three months on the basis of a fresh Commission working paper, more detailed and closer to the preliminary draft that the responsible departments envisaged presenting to the Commission. After these consultations, the departments of the Commission drew up an inventory of the points of agreement and disagreement, as expressed by the social partners, and passed it on to the Commission for its final deliberations on the proposal. In the context of this two-stage joint consultation process, the Commission departments extended their consultations to other organisations which were representative in both the economic and the social fields. Furthermore, alongside this two-stage joint consultation, the Commission departments conducted additional consultations with representatives of management and labour in some industrial and service sectors and also with other major organisations who did not participate in the Community social dialogue. ${ }^{47}$ In 1992, the Steering Group was replaced by the Social Dialogue Committee. ${ }^{48}$ The Committee meets roughly once a year, bringing together the European social partners at the highest level, i.e. the chairpersons and general secretaries of the UNICE, CEEP and ETUC. The social dialogue is informal in nature and voluntary. The Committee meets under the chairmanship of the Commission.

\subsubsection{The revival of the sectoral joint committees}

In the early 1980s, a revival of the sectoral joint committees started. By 1990, there were joint committees in eight sectors: agriculture, sea-fishing, civil aviation, railways, sea transport, inland navigation, road transport and telecommunications. Postal services were added in 1992. The constitutions of the

46 Community social policy. Current status 1 January 1996, publication of the European Commission, DG V, January 1996, p. 345.

$47 \operatorname{COM}(93) 600$ final, point 16 and 17.

48 See Joint statement of ETUC, UNICE and CEEP on the future of the social dialogue, 3 July 1992. 
joint committees usually provide that they are to assist the Commission in drawing up and implementing policy for the improvement and harmonisation of working conditions in the sector concerned. They produce opinions, reports and studies and are a forum for dialogue. ${ }^{49}$

\subsubsection{Informal working parties}

With the growing problems facing the joint committees in the 1970 s, there was a clear and developing need for a more pragmatic and flexible form of social dialogue, culminating in a more informal social dialogue pattern. Therefore, with the Commission's backing, informal joint working parties were set up in a number of sectors in the mid-eighties. ${ }^{50}$ It is mainly sectors in which the employers' organisations which have been opposed to formalised structures. These include banking and insurance, retail and wholesale trades, textile, leather, clothing, timber and furniture, and cleaning. But these, like the joint committees, are far from being collective bargaining bodies. ${ }^{51}$ The Commission consults the social partners by way of the joint committees and informal working parties on current proposals. The committees and working parties are also useful fora for organising an exchange of views between the Commission and the social partners by providing a basis for dialogue and consultation between occupational and professional organisations in a particular sector. The social partners may also, within the context of these committees and working parties, carry out studies, organise seminars and set in motion exchange or training programmes. ${ }^{52}$

\subsubsection{The Employment Committee}

Council Decision of 24 January 2000 created an Employment Committee. ${ }^{53}$ The Committee consists of inter alia senior officials or experts possessing outstanding competence in the field of employment and labour policy in the Member States. These officials are to be appointed by the Member States and the Commission. Each Member State presents two candidates. ${ }^{54}$ To fulfil its mandate the Employment Committee is meant to consult management and labour, and therefore has to establish contacts with the social partners represented on the Standing Committee on Employment. ${ }^{55}$

49 B. Hepple, European social dialogue - Alibi or opportunity?, p. 18.

50 Social Dialogue; the situation in the Community in 1995. In: Social Europe, 2/95, publication of the European Commision, DG V, Brussels, 1996, p. 26.

51 B. Hepple, European social dialogue - Alibi or opportunity? p. 18.

52 Social Europe, 2/95, p. 27.

53 Council Decision 2000/98/EC of 24 January 2000, establishing the Employment Committee, OJ L29/21, 04-02-2000.

54 Article 2 of Council Decision 2000/98/EC.

55 Article 5 of Council Decision 2000/98/EC. 


\subsubsection{Conclusions}

From the start of the EC in 1957 organisations of workers and employers have been involved in Community decision making. These organisations were initially mainly national, having a seat in the ECOSOC. In the 1960s sectoral and intersectoral committees were set up by the Commission in which employers and workers organisations were represented. There are 6 cross-industry advisory committees who advise the Commission on drawing and implementing specific policies. These advisory committees consist mainly of national social partners organisations. The joint committees which have been set up at sectoral level were replaced in 1998 by Sectoral Dialogue Committees because they were not able to produce more than just opinions and non- binding recommendations. Whether these committees will be able to produce more binding texts than the joint committees which they replaced remains to be seen. In 1970 the Standing Committee on Employment was set up by a Council decision. This was in fact the first formal attempt to identify the European level organisations of workers and employers. The main task of the SCE was to ensure joint action and consultation between the Council, the Commission and the two sides of industry. In 1999 the SCE was reformed. In contrast to the old SCE, the new SCE only accepts representatives of workers and employers at European level.

The reform of the SCE was regarded necessary because in its new form it could better contribute to the development and implementation of the Employment Guidelines and Broad Economic Orientations based on the new Employment title in the Amsterdam Treaty. The main task of the SCE remained, however, the same. Between 1974 and 1978 tripartite conferences were being held between the Community Institutions, and management and labour. These conferences did however not result in any binding decisions which was frustrating mainly for the ETUC. This was the reason that tripartite conferences did not take place anymore after 1978. In 1989 a first attempt for a more or less formal consultation procedure was made by the Commission. A Steering Group was set up composed of representatives of UNICE, CEEP and the ETUC and the Commission. The Commission agreed with the social partners organisations to consult them on proposed legislation in the social policy field. Like the consultation procedure described in the Articles 138(2) and (3) EC Treaty, the consultation of the Steering Group was also a two- stage joint consultation process. The Steering Group was replaced in 1992 by the Social Dialogue Committee, which consists of the same European social partners organisations and serves as a discussion and information forum for these organisations with the Commission. In the early 1980s sectoral joint committees revived. Their purpose, however, is less ambitious than the purpose of the joint committees set up by the Commission in the $1960 \mathrm{~s}$. The new joint committees do not seek to conclude binding agreements. They just choose opinions, reports and studies. In addition, informal working parties were set up in the 1980 s by the social partners 
organisations themselves. The difference between the sectoral joint committees and the informal working parties is not very clear since also the last mentioned serve as a discussion and information forum. In 2000 an Employment Committee was created by means of a Council decision. In the Employment Committee itself management and labour is not represented. The Committee has, however, the duty to consult the social partners organisations that are represented in the SCE.

\subsection{Collective bargaining}

\subsubsection{The early years}

Within a few years after the signing of the Treaty of Rome, the possibility of European collective agreements was being discussed in the literature. Authors saw the advantages of European collective agreements in the sense that they would speed up European integration, create equal competition conditions, promote social justice and promote the free movement of workers. ${ }^{56}$ These ideas, however, remained within the academic world because there was no single sign of any European collective agreements in reality.

\subsubsection{The meeting at Val Duchesse}

Support for European collective bargaining reached an apex in the late $60 \mathrm{~s}$ and early 70s, when Western economies were still fairly prosperous and the trade unions were in a strong position in most member states of the Community. With the advent, however, of the economic crisis after the first oilshock in 1973, the situation changed. Instead of discussing the possibilities of European labour strategies, trade unions became preoccupied with defending their members' jobs at the national level in the face of major redundancies and rationalisation programmes. ${ }^{57}$ Together with the existing negative attitude of the employers, ${ }^{58}$ the support for a European social dialogue from the side of the social partners reached rock bottom. The Community institutions, however, still thought it necessary to strengthen the European social dialogue. In the literature one can find idealistic motives as well as more

56 H.H. Zabel, Europăische Tarifvertrăge und Gemeinsamer Markt. In: Sozialer Fortschritt, vol. 7, no. 12, 1958, p. 268-271. See also K. Erdmann, Europăische Tarifvertrăge? In: Sozialer Fortschritt, vol. 12, no. 10, 1963, p. 217-220; E. Heynig, Europăische Tarifvertrăge? In: Aussenwirtschaftsdienst des Betriebs-Beraters, no. 6, 1968, p. 212-216; G. Schnorr, Rechtsfragen Europăischer Tarifvertrăge. In: Sozialer Fortschritt, vol. 12, no. 7/8, 1963, p. 155-162; F. Steinberg, Der Europalische Tarifvertrag. In: Recht der Arbeit, vol. 24, no. 1/2, 1971, p. 18-25; Finally, G. Sadtler, Europalische Tarifvertrăge. In: Neue Juristische Wochenschrift, vol. 22, no. 22, 1969, p. 962-965.

57 P. Teague, The European Community: The social dimension, p. 95-96.

58 See also S. Walz, Multinationale Unternehmen und internationaler Tarifvertrag, Baden-Baden, 1981, p. 107. 
pragmatic reasons for this attitude. Among the idealistic reasons is the theory that the Community is not just a bilateral arrangement between its institutions and Member States, but a complex policy which engages a wider range of other actors in social policy formation and implementation. ${ }^{59}$ More pragmatic reasons are, for example, that it was important for the Community institutions in general to avoid too much opposition towards their legislation. ${ }^{60}$ The dependence of the Community on Member State co-operation in pursuing its policies meant that it was important to engage powerful national interest groups, such as trade unions and employers' organisations, in the policy process. If trade unions and employers' organisations could be mobilised to support the Community proposals, national opposition might be at least neutralised. ${ }^{61}$ Furthermore, according to Teague, the European Commission was becoming concerned that the Community was getting bogged down with implementing essentially "negative" policies to remove trade barriers and other restrictive practices among the Member States. To help improve its technocratic and faceless image, the Commission proposed that the Community should strengthen its links with the European trade union and emplgver srganisations hyv incoprotating them withir the institutional and decision-making structure operating in Brussels. Through their incorporation it was hoped that the social partners might develop a "European" outlook, and thereby might help to give the Community a "human" face. ${ }^{62}$ Besides these reasons, there were a few developments which resuscitated the social dialogue: in the first place, the temporary economic upturn in the mid-1980s and secondly, the acceleration in European integration after a long crisis, brought about by plans for a European market. ${ }^{63}$ In 1984, therefore, a second Social Action Programme was drawn up. The Council of Ministers stated in its conclusions concerning this Action Programme, that a consensus between the social partners had to be achieved in order to seek full and better employment, to improve living and working conditions, and to realize the full and free circulation of workers. The European social dialogue had to be strengthened and its procedures adapted in order to involve the social partners more effectively in the economic and social decisions of the Community. ${ }^{64}$

59 B. Bercusson, European labour law, p. 72.

60 See also COM(96) 448 final, point 14. Furthermore, in its social action programme 1998-2000, the Commission states that the social dialogue helps to reinforce the legitimacy and effectiveness of European-level activity. See COM(98) 259 final, Brussels, 29-04-1998, Chapter I.

61 B. Bercusson, European labour law, London, p. 72.

62 P. Teague, The European Community: The social dimension, p. 88.

63 D. Buda, On course of European labour relations? In: W.E. Lecher and H.W. Platzer (eds.), European Union - European industrial relations?, London, 1998, p. 23.

64 Conclusions of the Council, 84/C 175/01, of 22 June 1984, concerning a Community medium-term social action programme, OJ C 175/1, 4-7-1984, p. 1-3. 
As a result of these developments and policy of the Community, Jacques Delors, who had become the President of the Commission, invited UNICE ETUC and CEEP in 1985 to a meeting at Val Duchesse, near Brussels. The consequent use of the British veto power with regard to social policy matters was one of the reasons which led Delors to initiate the policy in 1985 of stimulating the European social dialogue as an alternative path to a social dimension for the EC. ${ }^{65}$ The social partners agreed in Val Duchesse to engage in furthering the social dialogue. Val Duchesse accomplished two things: firstly, it brought the main European social partners back together (they had ended regular contacts in 1978) and secondly, it established a continuing dialogue between the two. ${ }^{66}$

Under the Val Duchesse system, the social partners have negotiated a number of joint opinions on important policy matters for submission to the Commission and the Council. While the joint opinions did not impose any obligation or constraint on the parties involved, they did represent a joint policy on issues of particular complexity even at national level. They were often the result of hard-won compromise between the parties concerned and delicate negotiation between their own members.

Unfortunately, the Val Duchesse initiative did not represent the breakthrough hoped for by the Commission in the social policy sphere. UNICE insisted that the outcome of the Val Duchesse talks should be restricted to non-binding joint opinions, without any legislative follow-up. ${ }^{67}$ Furthermore, the social dialogue remained mostly in Brussels and neither the Commission nor the social partners provided any follow-up on the joint opinions at national level.

\subsubsection{The Single European Act}

In spite of the fact that the employers remained unwilling to develop a European social dialogue, the Community institutions continued their efforts to give it an expanded role. There were doubts, however, whether formal agreements between employers and employees at the Community level would be possible without specific legislative authorisation. ${ }^{68}$ In December 1985, the Heads of State signed the Single European Act (SEA), which entered into force on 1 July 1987. With the SEA, a new Article 118B was in-

65 B. Bercusson, The conceptualization of European labour law. In: Industrial Law Journal, vol. 24, no. 1, March 1995, p. 4.

66 R. Geyer, EU social policy in the 1990s: Does Maastricht matter? In: Journal of European integration, no. 1, 1996, p. 22.

67 M. Hall, Industrial relations and the social dimension of European integration: before and after Maastricht. In: R. Hyman and A. Ferner (eds.) New frontiers in European industrial relations, p. 294-295.

68 D. Campbell and S. Cotter (eds.), The law of the European Community. A commentary on the EEC Treaty, New York, 1996, p. 3-752.18(4). 
serted into the Treaty and the Val Duchesse initiative was now given a legal basis. Article 118B stated:

"The Commission shall endeavour to develop the dialogue between management and labour at European level which could, if the two sides consider it desirable, lead to relations based on an agreement."

The promotion of the social dialogue at Community level became one of the official tasks of the Commission. ${ }^{69}$ The aim of the dialogue was to reach common views which would subsequently be presented and discussed with the two sides of industry in each Member State. ${ }^{70}$ Furthermore, the intention was that discussions between the social partners should be the precursor to EC-legislation, in the hope that legislative proposals based on an agreed approach between the two sides of industry would have a stronger chance of being accepted by the Council of Ministers. ${ }^{71}$ Community legislation in the field of social policy would gain greater legitimacy if the social partners played a role in its creation. ${ }^{72}$

Article $118 \mathrm{~B}$ has not been a very successful basis for concluding European collective agreements. No procedures were prescribed, and the legal results of the dialogue were so ambiguous as to be meaningless. Indeed, it was difficult to characterize Article $118 \mathrm{~B}$ as more than a political gesture legitimating the talks which had already begun at Val Duchesse. ${ }^{73}$ Moreover, the European social partners were able to conclude agreements with each other before the introduction of Article $118 \mathrm{~B}$, and this actually happened in the agricultural sector. ${ }^{74}$

\subsubsection{The Joint Agreement of 31 October 1991}

In the Community Charter of Fundamental Social Rights of Workers, which was adopted in 1989 (hereafter Community Charter), it was stated that "dialogue between the two sides of industry at European level, which must

69 According to the ECOSOC, with the enshrinement in the Treaty of Article 118B, the social dialogue has become a major Community instrument. (Opinion 88/C 208/12, of the Economic and Social Committee of 2 June 1988, on social developments in the Community in 1987, OJ C 208/39, 8-8-1988, p. 40).

70 Internal market current status, 1 January 1993. Community social policy, published by the European Commission, 1993, p. 119.

71 M. Hall, Industrial relations and the social dimension of European integration: before and after Maastricht. In: R. Hyman and A. Ferner (eds.) New frontiers in European industrial relations, p. 294.

72 See also M. Blank, Europăische Kollektivvertrăge und Sozialer Dialog. In: W. Dăubler, M. Bobke, K. Kehrman (eds.), Arbeit und Recht. Festschrifte für Albert Gnade, Köln, 1992, p. 653.

73 B. Hepple, European social dialogue - Alibi or opportunity? p. 16.

74 See paragraph 3.2 .2 . 
be developed, may, if the parties deem it desirable, result in contractual relations in particular at inter-occupational and sectoral level" ${ }^{\text {is }}$

On 31 October 1991, UNICE, ETUC and CEEP adopted a Joint Agreement which provided for mandatory consultation with the social partners on Commission proposals in the field of social affairs. An agreement was possible due to various factors and in particular to the divergent interests of the parties involved, namely of the Commission, of the employers' associations and of the trade unions.

The Commission had to conclude that the Community approach to social policy, through the Community Social Charter of 1989 and the Action Programmes, had not been successful. It was therefore looking for other ways to provide the Community with a fair social face. In a Commission paper on the social dialogue, ${ }^{76}$ the Commission launched a new concept of a double dimension of subsidiarity between Community and member state legislation, and between a regulatory and a contractual approach, leading to the question: Is there a place for collective agreements at Community level? ${ }^{n 7}$ The social partners, employers as well as trade union representatives, had to face the fact that their input to the Community legislative process, due in part to the well-known democratic deficit, was rather minimal. Because of the increasing European integration, the autonomy of the national social partners was affected. In concluding their collective agreements, they now not only had to take the national law into consideration, but European legislation as well. A way of influencing this European legislation was by organising themselves at European level.

Trade unions were eagerly looking forward to playing a more effective role at a European level in furthering the interests of their members and the workers. ${ }^{78}$ The employers were, moreover, in a sense afraid of Community legislation, especially labour law directives, which might impose undue restrictive obligations on business. In the late 1970s and earlier 1980s, employers regarded Commission labour market proposals as too interventionary and too pro-trade union. ${ }^{79}$ For UNICE, the consistent ability of employer interests to secure sufficient opposition within the Council of Ministers under the unanimity principle to block key legislative proposals has always been a disincentive to co-operate with initiatives such as the development of a social

75 Article 12 of the Charter.

76 Social dialogue - the role of the social partners in the EC, paper spelled out at an ad hoc meeting on 22 February 1991.

77 J.E. Dolvik, Redrawing boundaries of solidarity? ETUC, social dialogue and the Europeanisation of trade unions in the 1990s, p. 196.

78 R. Blanpain, Labour law and industrial relations of the EU. Maastricht and beyond: from a Community to a Union, Deventer, 1992, p. 48. See also J.E. Dolvik, Redrawing boundaries of solidarity? ETUC, social dialogue and the Europeanisation of trade unions in the 1990s, Chapter 8.

79 P. Teague and J. Grahl, Industrial relations and European integration, London, 1992, p. 84. 
dialogue. By 1991, however, UNICE was faced with the prospect of Treaty revisions enabling extensive use of qualified majority voting for social policy legislation. Although the UK remained strongly opposed to any extension of the EC's social policy role, a compromise on the Social Chapter seemed at least a possibility, given the scope for linkages to be made with other issues of importance to the UK. For this reason and also due to pressure within this organisations from the Belgian, French and Italian employers' organisations, UNICE changed its traditional approach and agreed to a procedure enabling European-level agreements. ${ }^{80}$ These organisations were more in favour of centralised negotiations, often as a result of their own experiences. With legislation threatened in a wide range of areas, and much of it on the basis of qualified majority voting, UNICE has opted for seeking joint regulation rather than awaiting legislative intervention. ${ }^{81}$ UNICE could now fend off, or at least delay, proposals for EC-legislation under the new Treaty provisions, by opting to explore the scope for framework agreements, the implementation of which would be likely in practice to be largely voluntary. ${ }^{82}$

So it is clear that trade unions as well as employers' organisations both wanted to have an increased influence in the creation of European labour law, although each for different reasons. The trade union organisations were interested in the development of a strong social policy, while the employers' organisations cooperated because the alternative is legislation by the Community institutions, on which they formally have no influence. ${ }^{83}$

The agreement of 31 October 1991 contained two provisions which formed the basis for the Articles 3 and 4 of the Agreement on Social Policy, discussed hereafter (now Articles 138 and 139 EC Treaty).

“1. The Commissions' task is to promote the consultation of the social partners at Community level and take any measure to usefully facilitate their dialogue, ensuring a balanced support for the parties.

80 M. Hall, Industrial relations and the social dimension of European integration: before and after Maastricht. In: R. Hyman and A. Ferner (eds.) New frontiers in European industrial relations, p. 295 and 300.

81 The social dialogue- Euro bargaining in the making? In: EIRR, no. 220, May 1992, p. 29.

82 M. Hall, Industrial relations and the social dimension of European integration: before and after Maastricht. In: R. Hyman and A. Ferner (eds.) New frontiers in European industrial relations, p. 300 .

83 On the occasion of the joint agreement of October 1991, which was almost literally carried over into the Social Agreement, Mr. Tyskiewicz of UNICE has said that "what pushed us towards this decision is the fact that we regard the legislator as being incapable of respecting the principle of subsidiarity (...). We find it preferable to negotiate some things because we will do it better than the legislator. We are there to take the place of the legislator. (Interview with Z. Tyskiewicz, "The social dialogue is up and running". In: Social Europe, 2/92, p. 18). 
2. For this purpose, before presenting its proposals in the field of social policy, the Commission will consult the social partners on the possible guidelines for a Community action.

3. If, after this consultation, the Commission considers that a Community action is desirable, it will consult the social partners regarding the content of the envisaged proposal. The social partners transmit to the Commission an opinion or, if appropriate, a recommendation.

4. In the course of this consultation the social partners may inform the Commission of their desire to engage the process provided for in Article 118B, para. 1 and 2 (now Article 139 para. 1 and 2 EC Treaty). This procedure may not exceed nine months' duration, unless an extension is jointly agreed by the social partners concerned."

"1. The dialogue between social partners at Community level can lead, if the latter so desire, to relations based on agreements.

2. Those agreements concluded at the Community level may be realized either according to the procedures and practices appropriate to the social partners and to the Member States or in matters covered by Article 118 (now Article 137), at the joint request of the signatories, on the basis of a decision of the Council on a proposal from the Commission, with regard to the agreements as they have been concluded. This decision will follow the voting procedures of Article 118 (now Article 137)."

\subsubsection{The Agreement on Social Policy and the Treaty of Maastricht}

In 1991, a new Intergovernmental Conference took place in the Dutch town of Maastricht. The social policy agenda of this conference was set by the Commission's proposals for extensive Treaty revisions. Emphasizing the wide gap between the existing Treaty powers and the ambitions set out in the Community Charter, the Commission argued for the establishment of explicit Community competence to legislate on a range of employment and industrial relations issues and for the extension of qualified majority voting. ${ }^{84}$ In addition, the Commission sought to boost the role of the social partners in the Community-level regulation of industrial relation matters. It was understood in many Member States that the legitimacy of legislation in the field of social policy depended to a great extent on consultation and cooperation with the social partners. The traditional EC legislative machinery only recognized this need to a very small degree. ${ }^{85}$

Moreover, the European Parliament was open to relations with the social partners because the organisations could be helpful in enhancing the role of

84 C.J. Crouch, From the neo-liberal decade to beyond Maastricht. In: Tijdschrift voor Arbeidsvraagstukken, no. 1, 1993, p. 23.

85 M. Weiss, Social dialogue and collective bargaining in the framework of social Europe. In: G. Spyropoulos and G. Fragnière (eds.), Work and social policies in the new Europe, 1991, p. 61. 
the Parliament. The organised interests of employers and employee organisations were important to the electability of the members of Parliament, but the social partners could also be mobilised in support of the Parliaments' campaign for a greater role in EC policy-making. ${ }^{86}$

Within the Council of Ministers however, there were different views. At the Maastricht summit, social policy was certainly not at the centre of the agen$\mathrm{da}$, but it became a very controversial issue. The Dutch presidency, foreseeing that social policy would become a hard item for the British, had prepared a compromise proposal. However, even this low-profile compromise was rejected by the British. ${ }^{87}$ The British government stated that it could not agree that European employer and trade union bodies should be given the power to conclude agreements on employment conditions, and to have those agreements imposed by Community law, potentially (namely in case the qualified majority procedure applied), without the agreement of UK government, UK employers and UK employees. ${ }^{88}$ The reason behind the British attitude was that the U.K. prime minister, John Major, was facing intense pressure from Lady Thatcher and her allies not to give ground in social policy. This meant that Majior was faced with the possibility chat, were he to agree to more qualified majority voting in social policy issues at Maastricht, he would face an internal party rebellion, which could cost him the election. ${ }^{89}$ On the other hand, the French and German governments could not accept a treaty which failed to extend qualified majority voting on social policy issues. Delors found a compromise in the form of the Social Protocol and Agreement on Social Policy, annexed to the Maastricht Treaty (hereafter called: Social Agreement), allowing the British to stay out of the social chapter. ${ }^{90}$ The text of the Social Protocol annexed to the Treaty clarified that the UK "shall not take part in the deliberations and the adoption by the Council of Commission proposals made on the basis of this Protocol and the Agreement" (Article 2). In practice, this meant that the British delegation did not

86 B. Bercusson, European labour law, p. 73. See also Resolution A2-141/86 of the European Parliament of 11 November 1986, on the European social area, OJ C 322/48, 15-12-1986 and Resolution A2-144/84 of 11 November 1986, on the role of the social partners in the labour market, OJ C 322/51, 15-12-1986 as well as Resolution A30091/94 of 24 February 1994, on the new social dimension of the Treaty on European Union, OJ C 77/30, 14-3-1994, p. 31. Also the ECOSOC was in favour of an enhanced role of the social dialogue. See Opinion 88/C 208/12 of the ECOSOC of 2 June 1988, on social developments in the Community in 1987, OJ C 208/39, 8-8-1988 and Opinion $87 / \mathrm{C} 356 / 08$ of 19 November 1987 , on social aspects of the internal market, OJ C 356/31, 31-12-1987.

87 J.E. Dolvik, Redrawing boundaries of solidarity? ETUC, social dialogue and the Europeanisation of trade unions in the 1990s, p. 204.

88 Maastricht and social policy- part three. In: EIRR, no. 241, February 1994, p. 33.

89 P. Lange, Maastricht and the Social Protocol: why did they do it? In: Politics \& Society, vol. 21, no. 1, March 1993, p. 26.

90 J.E. Dolvik, Redrawing boundaries of solidarity? ETUC, social dialogue and the Europeanisation of trade unions in the 1990s, p. 204. 
leave the meeting room, but remained passive in Council debates and votes concerning the Social Agreement." If, however, proposals took the route of negotiations between the social partners, the issue became less clear. The Centre of British Industries (CBI) and Trade Union Congress (TUC) are members of UNICE and ETUC respectively, and most of the other social partners' organisations considered representative by the Commission at European level have British members. The British representatives of labour and industry, although traditionally playing only a very limited role in British policies, chose participation in the new model of EC social-policy making. Both the $\mathrm{CBI}$ and TUC indicated their wish to take a full part in the negotiating process as members of UNICE and ETUC and to implement any agreements reached (though $\mathrm{CBI}$ expressed some specific reservations). Confronted with the new situation since Maastricht, British employers saw good reasons for not being absent from the debates on what might one day also be applicable to them. However, if the European partners sought a Council decision to implement their agreement on the basis of Article 4(2) of the Agreement on Social Policy, this decision would be made by, and apply to, only the 14 other Member States.

After the Agreement on Social Policy there were two sets of rules governing social policy. First, there was the conventional route, whereby proposed measures were brought before all 15 Member States using the provisions of the EC Treaty. Second, there was an alternative procedure, which could be followed by all Member States except the UK, according to the Agreement on Social Policy. Under the Agreement on Social Policy it was easier to facilitate the passage of legislation. First, there was the provision for qualified majority voting in 5 important categories of social policy, namely:

- improvement in particular of the working environment to protect workers' health and safety;

- working conditions;

- the information and consultation of workers;

- equality between men and women with regard to labour market opportunities and treatment at work;

- the integration of persons excluded from the labour market, without prejudice to Article 127 EC Treaty. ${ }^{92}$

The second major innovation was to accord the social dialogue an enhanced role in the formulation of social policy. According to the Articles 3 and 4 of the Agreement on Social Policy, the Commission was obliged to consult the social partners at Community level before submitting proposals in the social policy field. Moreover, agreements concluded between social partners' organisations could now become Community legislation through implementation by Council decision. These two aspects were completely new in

91 G. Falkner, The Maastricht Protocol on social policy: Theory and practice. In: Journal of European social policy, vol. 6, no. 1, 1996, p. 9. 
comparison with former Treaty revisions. Furthermore, in the implementation of European social legislation there was a role for the national social partners. Article 2(4) of the Agreement on Social Policy stated that Member States could entrust management and labour, at their joint request, with the implementation of directives.

\subsubsection{The Treaty of Amsterdam}

On 16 and 17 June 1997 a new Intergovernmental Conference took place in Amsterdam. There was consensus on a draft Treaty which was signed in October 1997. It entered into force in 1998.

As regards social policy provisions, the most important change is that the Social Agreement has been incorporated in the EC Treaty, thanks to the new Labour government of the UK (in power since 2 May 1997) which has put an end to the British opt-out. ${ }^{93}$ The Articles 3 and 4, as formulated in the Agreement on Social Policy have been renumbered, but remained the same. For the European social dialogue itself, not very much has changed. Also before the Amsterdam Treaty British trade unions and employers' organisations took part in the negotiations on European agreements, being members of the ETUC and UNICE. The main difference that the Amsterdam Treaty has brought is that if European agreements are to be turned into a Council decision on the basis of Article 139(2) EC Treaty, the UK is also bound by these Council decisions. This was not the case before the Amsterdam Treaty.

\subsubsection{Results of collective bargaining at European level}

In the first years after the conclusion of the Maastricht Treaty no major talks took place between the ETUC and UNICE. In 1995, talks started on the proposal for legislation on parental leave. This led to a framework agreement between them on 14 December 1995. ${ }^{94}$ The agreement has been submitted to the Council, which turned it into a Directive on 3 June $1996 .{ }^{95}$ It was the first time since the Maastricht Treaty that the European social partners used the Articles 3 and 4 of the Social Agreement. Although the content of the Agreement on Parental Leave was hardly shocking, it could serve as an exercise for the social partners to develop a genuine European social dialogue, resulting in agreements which were more than just opinions. Throughout 1996, the

93 The Commission strongly favoured this inclusion. See Commission opinion "Strengthening political union and preparing enlargement". In: Bulletin Quotidien Europe no. 1978, 8 March 1996, p. 3. Also the ETUC wanted the British opt-out (Bulletin Quotidien Europe, no. 1935, 20 May 1995, p. 3).

94 European Framework Agreement on Parental Leave, concluded between ETUC, UNICE and CEEP on 14 December 1995.

95 Council Directive 96/34/EC of 3 June 1996 on the framework agreement on parental leave concluded by UNICE, ETUC and CEEP, OJ No. L 145/4, 19-6-1996. 
social partners also held consultations on issues like directives regarding the burden of proof, European works councils, flexibility at work and worker safety. $\%$ These consultations did not, however, result in agreements. The second intersectoral agreement concluded between ETUC, UNICE and CEEP, on 6 June 1997, was on part-time work. ${ }^{97}$ This agreement has been turned into a Council Directive. ${ }^{98}$ The third intersectoral agreement was on fixed-term work. ${ }^{99}$ This agreement has also been turned into a Council Directive. ${ }^{100}$ The fourth agreement was on telework. ${ }^{101}$ It is the first intersectoral agreement which will not be turned into Community legislation, but will be implemented in accordance with the procedures and practces specific to management and labour in the Member States.

At sectoral level, agreements have also been concluded which have been turned into legislation. In the maritime sector, and the civil aviation sector, agreements were concluded in 1998 on working time. ${ }^{102}$ Both agreements have been turned into a Council Directive. ${ }^{103}$ One agreement has been concluded in the agricultural sector which will not be turned into Community legislation. $^{104}$

96 R. Geyer, EU social policy in the 1990s: Does Maastricht matter? In: Journal of European Integration, no. 1, Fall 1996, p. 22-23.

97 European Framework Agreement on Part-time Work, concluded between ETUC, UNICE and CEEP on 6 June 1997.

98 Council Directive 97/81/EC of 15 December 1997, concerning the Framework Agreement on part-time work concluded by UNICE, CEEP and the ETUC, OJ L 014/9, 20-01-1998.

99 European Framework Agreement on Fixed-term work, concluded between ETUC, UNICE and CEEP on 18 March 1999.

100 Council Directive 1999/70/EC of 28 June 1999, concerning the framework agreement on fixed-term work concluded by ETUC, UNICE and CEEP, OJ L175/43, 10-07-1999.

101 Framework Agreement on Telework, concluded between ETUC, UNICE/UEAPME and CEEP, of 16 July 2002.

102 European agreement on the organisation of working time of seafarers, concluded between ECSA and the FST on 30 September 1998 and European agreement on the organisation of working time of mobile staff in civil aviation, concluded by AEA, EFT, ECA, ERA and IACA, on 22 March 2000.

103 Council Directive 1999/63/EC of 21 June 1999, concerning the Agreement on the organisation of working time of seafarers, concluded between ECSA and the FST, OJ L 167/33, 02-07-1999 and Council Directive 2000/79/EC of 27 November 2000 concerning the European agreement on the organisation of working time of mobile workers in civil aviation, concluded by AEA, EFT, ECA, ERA and IACA, OJ L 302/57, 01-12-2000.

104 Recommendation framework agreement on the improvement of paid employment in agriculture in the Member States of the European Union, concluded by COPA/ GEOPA and EFA/ETUC, 24 July 1997. 


\subsubsection{Conclusions}

From 1957 until the mid- eighties the possibility of European-level collective agreements was not seriously taken into account. For several reasons the interest in European collective bargaining increased in the early 1980s. The Val Duchesse meeting in 1986 between the President of the European Commission and UNICE, ETUC and CEEP was a first step towards European collective bargaining. However for UNICE it was apparently still too early to conclude European level agreements. By the European Single Act in 1987 Article $118 \mathrm{~b}$ was incorporated into the Treaty referring to the social dialogue at European level. However, still no European agreements were concluded. A few years later, in 1991, UNICE, ETUC and CEEP adopted a joint agreement in which they described the procedure with regard to the European social dialogue more extensively than the former Article 118b of the European Single Act. Their suggestions have been almost literally taken over by the Maastricht Treaty in Articles 138 and 139 EC Treaty (at that time Articles 3 and 4 of the Agreement on Social Policy). The reason for UNICE to conclude this agreement was that the alternative, legislation, could be worse. Initially the provisions of the joint agreement were laid down in the Social Protocol and the Agreement on Sacial Policy. By using this form it was possible for the UK to stay out of the Social Chapter. The Social Protocol and Agreement on Social Policy, applied to all Member states except the UK. New aspects of the Agreement on Social Policy were that the Commission was now obliged to consult the social partners organisations before submitting social policy proposals and that agreements concluded at European level could be turned into Community legislation by means of a Council decision. By the Amsterdam Treaty in 1997, thanks to the end of the British opt-out, the Social Protocol has been implemented into the Treaty. Since 1995 a few intersectoral and sectoral agreements at European level have been concluded. All agreements except two have been turned into Community legislation. This legislation has taken the form of a Directive. Only two agreements, on telework and in the agricultural sector, will be implemented through the national affiliates of the European organisations that signed the agreement.

\subsection{Conclusions}

There are many committees in which European level social partners organisations at intersectoral and sectoral level are represented and which serve as advisory and information bodies for each other and the Commission. The difference between these committees is not always easy to see, for example the difference between the sectoral joint committees, the informal working parties and the sectoral dialogue committees. It is possible that discussions on the same subject take place between the same social partners organisations, only in different committees. This puts questions on the efficiency of these discussions. Involving management and labour representatives in 
Community decision making is a development that deserves support. In my view, however, it would suffice if there would be only one committee in which the intersectoral organisations were represented and one type of committees in which the sectoral organisations were represented, for example sectoral joint committees and not also informal working parties and sectoral dialogue committees. These committees could serve as fora for discussion and exchange of information. Within these committees the social partners organisations could prepare their opinions and recommendations for the Commission on the basis of Article 138(2) and (3) EC Treaty. Furthermore European agreements as laid down in Article 139(1) EC Treaty could be concluded within these committees as well.

The development of European collective bargaining has mainly been pushed by the Community institutions, especially the European Commission. The main reason for this support was probably to give more legitimacy to Community legislation by involving the representatives of management and labour in the Community decision making process. Trade unions supported this development because in this way they could play a more effective role at European level. Employers organisations have been more reluctant to engage in European collective bargaining. However, because the alternative, Community legislation, could turn out to be worse than collective bargaining, the employers agreed to collective bargaining. A number of cautiously formulated agreements have been concluded at European level. As regards to the intersectoral agreements, the ETUC, CEEP and UNICE are the main players. Sectoral agreements have so far only been concluded in internationalised sectors, such as maritime and civil aviation. The development of European collective bargaining, especially the conclusion of European agreements, has not yet expanded enormously. At the utmost one or two European agreements are concluded each year, and only two such has not been implemented through a Council decision. Some of the problems with regard to the legal consequences of these European agreements will be discussed in the following chapters. 



\section{PART II}

THE CONSULTATION PROCEDURE AND THE CONCLUSION OF EUROPEAN AGREEMENTS 


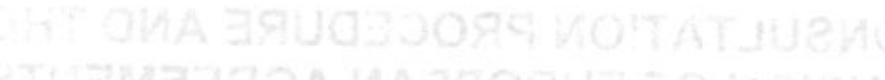

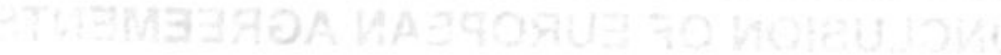




\section{CHAPTER 4}

\section{THE CONSULTATION PROCEDURE AND ITS FOLLOW-UP}

\subsection{Introduction}

Since the Maastricht Treaty of 1992, the management and labour at European level must be consulted by the Commission as regards proposals in the social policy field. This is stated in Article $138 \mathrm{EC}$ Treaty. The consultation procedure raises several questions. What amounts to the "promotion of the consultation" of management and labour, as stated in Article 138(1) EC Treaty? This issue will be dealt with in para. 4.2. A second question is how and under which conditions the consultation of management and labour takes place. This question will be discussed in para. 4.3. A third question is what happens after the consultation. What is the procedure following the consultation process? This question will be answered in para. 4.4. Finally, I

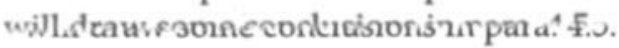

\subsection{The promotion of the consultation of the European social partners' organisations}

Article 138(1) EC Treaty states:

"The Commission shall have the task of promoting the consultation of management and labour at Community level and shall take any relevant measure to facilitate their dialogue by ensuring balanced support for the parties."

What does this provision mean? It actually comprises two obligations for the Commission:

- To promote the consultation of management and labour at Community level;

- To take any relevant measure to facilitate the dialogue between them by ensuring balanced support.

The Commission arguably has a legal obligation to fulfill these tasks. This obligation derives from the word "shall" used in Article 138(1) EC Treaty. Otherwise the provision would not have been so strongly formulated and the word "shall" would have been replaced by "can". In addition, the Commission itself regards the promotion of the social dialogue as an obligation. ${ }^{1}$

The Commission shall take "relevant measures" to facilitate the dialogue between the European social partners'organisations. In its 1993 Communi- 
cation, it has indicated what kind of measures these are. They include the organisation of meetings, support for joint studies or joint working groups and support for technical assistance deemed necessary to underpin the dialogue. ${ }^{2}$ The Commission shall take these relevant measures by ensuring "balanced support". This support is mainly financial. There are two budgetlines from DG V (the Directorate-General for Employment, Industrial Relations and Social Affairs), to the European social partners. One line goes to the trade unions, the other to trade unions and employers together. ${ }^{3}$ The means for supporting the social dialogue, and in particular transnational labourindustry contacts, had for a while been paid mainly to the ETUC. This was because UNICE had not accepted outright funding by the EC. Only in 1995 did the UNICE decide to accept funding for the purposes of specific tasks such as background work or research. ${ }^{4}$ The employers also receive support from DG III (large enterprises) and DG XXIII (small and medium-sized enterprises). The money is only given by the Commission for specific projects. ${ }^{5}$ Employers and workers organisations can submit proposals for financial assistence. For the year 2002 for example, there are two Budget Headings. One for information and training measures for workers' organisations (Budget Heading B3-4002), which is for workers' organisations only, and one for industrial relations and social dialogue (Budget heading B3-4000), which is for workers' organisations and employers' organisations together. Under Budget Heading B3-4002, a commitment appropriation of 11.300 .000 euro is intended to finance information and training measures for workers organisations, deriving from the implementation of Community action on the social dimension of the internal market with participation by representatives of the social partners in the applicant countries. According to this Budget Heading, the eligible applicants are the ETUC, European Trade Union Federations within the ETUC, EUROCADRES, the European Managers Confederation, and other European organisations. Also national, regional, and other organisations may ask finacial assistence from the Commission. The measures for which the financial assistence is requested must meet the objectives of the Budget Heading. Other award criteria are that there must be a link between the measure and Community social policy. Furthermore there must be involvement of the social partners in the measure and there must be a trans-

$\operatorname{COM}(93) 600$ final, point 12 . Jacobs thinks that there is even more. For example the performance of secretarial tasks, providing interpreters, covering the costs of meetings, organising research, informing the public, training negotiators etc. A. Jacobs, The role of the EU-institutions in the European social dialogue. In: P.H. Olsson, B. Bercusson, N. Bruun (eds.), Transnational trade union rights in the EU, Workshop summary, 1998, p. 35.

3 See for example for the year 2002 Budget Heading B3-4002. Information and training measures for workers organisations and Budget Heading B3-4000 Industrial Relations and Social Dialogue.

4 G. Falkner, EU social policy in the 1990s, London, 1998, p. 172.

5 For example for the European Trade Union Institute in Florence. 
national dimension of the measure. The bugdet line which goes to trade unions and employers' organisations together, is intended to cover grants for promoting social dialogue at cross industry and sectoral level in accordance with the Articles 138 and 139 EC Treaty. The appropriations will therefore be used to finance consultations, meetings, negotiations, and other operations to achieve these objectives. Futhermore the budget may also finance operations in the field of industrial relations, especially measures designed to develop expertise and exchange of information on a European basis. Under this budget heading a commitment appropriation of 11.280.000 Euro has been entered for 2002. At least half of the appropriations are intended to support the European social dialogue. Eligible social partners' organisations for financial assistence under this budget are the organisations which are listed in Annex I of the Commission Communication of 1998.6 However, access is also open to European social partners' organisations not covered by the list for operations for involving the preparation and launching of European social dialogue at sectoral level. Financial assistence is given for:

- measures to prepare the European social dialogue, e.g. preparatory surveys, meetings and conferences;

- measures regarded as part of the social dialogue within the meaning of Article 138 EC Treaty, involving negotiating meetings or meetings to prepare for negotiations;

- measures to monitor European social dialogue activities, e.g. conferences and initiatives to disseminate the results of European social dialogue through European or national events;

- measures of European and national social partners to contribute to the European Employment Strategy (EES), including in particular actions in order to monitor and analyse the impact of EES on labour markets.

Award criterea are inter alia the extent to which the operation meets the objectives of the Budget Heading, the involvement of the social partners in the operation and/or link with the European social dialogue, the transnational dimension of the operation and the Community social policy dimension of the subject of the operation.

It is remarkable that organisations of employers and workers are financed by (European) government institutions. According to the ILO Convention no. 87 , it is especially important for workers organisations that they are independent and that they must be able to organise their activities without any interference from the public authorities. ${ }^{7}$ Financing of their activities would endanger this independence. We have to bear in mind, however, that the ILO Conventions and Recommendations are written to be applied at national level. European social partners' organisations cannot always be compared to national ones. Every bargaining system at national level has a history. It pre-

$6 \quad \mathrm{COM}(1998) 322$.

7 ILO-Convention no. 87, Articles 3 and 10. 
supposes social powers driven by a logic of action and interests which are socially and historically typified and recognised. ${ }^{8}$ It must therefore be recognised that Community collective bargaining cannot be viewed as a socially typical phenomenon comparable to anything at national level. It must rather be seen as an instrument of the regulatory objectives pursued by the Community institutions, and especially the Commission. ${ }^{9}$ That is probably the reason that the Commission is willing to finance the European social partners' organisations. Nevertheless, the danger of too much dependency remains and it is advisable that the European organisations do not over-rely on Commission financing. Furthermore, I think that if the Commission supports certain organisations financially, it should do so in such a way that the principle of equality, which is a general principle of Community law, ${ }^{10}$ is not violated. Every organisation which falls under the concept of "management and labour" in Article 138(1) EC Treaty should receive support in an equal manner to other organisations which fall under that concept. This also flows from the words "balanced support" in Article 138(1) EC Treaty. This does not mean that Community institutions must treat everyone alike, but that there must be no arbitrary distinctions between different groups within the Community. ${ }^{11} \mathrm{I}$ also think that when a genuine European collective bargaining system has developed, workers' and employers' organisations should not receive any financial aid anymore from the Commission. Financial aid will endanger their independence from the public authorities.

\subsection{The consultation procedure}

According to Article 138(2) and (3) EC Treaty, the Commission has to consult the social partners before submitting social policy proposals. This consultation procedure raises several questions. How does this procedure work in practice and what is the difference between the first and the second consultation stage? These issues will de discussed in para. 4.3.1. and 4.3.2. Are there specific subjects for consultation? This question will be answered in para. 4.3.3. An important issue is also who should be consulted. This issue will be dealt with in para. 4.3.4.

\subsubsection{The first consultation stage}

The Commission Communications do not give any specific indication on how to promote the consultation of management and labour. However, Article 138(2) EC Treaty continues by stating that:

8 A. Lo Faro, Regulating social Europe. Reality and myth of collective bargaining in the EC legal order, Oxford/Portland, 2000, p. 57. See also Chapter 3, para. 3.3.2.

9 A. Lo Faro, Regulating social Europe. Reality and myth of collective bargaining in the EC legal order, p. 60.

10 T.C. Hartley, The foundations of European Community law, Oxford, 1998, p. 149.

11 T.C. Hartley, The foundations of European Community law, p. 149. 
"To this end, before submitting proposals in the social policy field, the Commission shall consult management and labour on the possible direction of Community action".

Paragraph 1 of Article 138 is in fact the formulation of the general task of the Commission, concerning the European social dialogue. In paragraph 2, specific information is (...) given on how to fulfill this task. This can be derived from the words "to this end", in paragraph 2. Furthermore, the word "shall" in Article 138(2) suggests that the Commission is obliged to consult the social partners'. The consultation is not optional. ${ }^{12}$

How will the consultation procedure work out in practice? The EC Treaty remains silent on specific formal procedures for the consultation. In its Communications of 1993 and 1996, the Commission has described a procedure. The Commission will send a letter to the social partners in which it asks for their opinion. The social partners subsequently send a letter back to the Commission in which they give their views on the possible direction of Community action. However, this view can also be given in an ad hoc meeting between the Commission and the social partners if the latter so desire. ${ }^{13}$ The period of consultation should not be longer than 6 weeks. ${ }^{14}$ This 6 -week period has received some criticism. UNICE recommends a period of at least three months, in order to give time for proper consultation at grassroots level. ${ }^{15}$ CEEP thinks a 3 to 4 -month time limit is reasonable. ${ }^{16}$ In its 1996 Communication, the Commission considered that the time limit for the firststage consultations should be reconsidered. The deadline for consultations should be adaptable and should be fixed by the Commission on a case-bycase basis depending on the nature and complexity of the subject. ${ }^{17}$ However, in its 1998 Communication, the Commission stated that the general six-week

12 See also P.J.G. Kapteyn and P. VerLoren van Themaat, Introduction to the law of the European Communities, London/The Hague/Boston, 1998, p. 1060, who are of the same opinion. See also B. Bödding, Die europearechtlichen Instrumentarien der Sozialpartners, Baden-Baden, 1996, p. 127. See furthermore the CFI in Case T-135/96 Judgment of 17/06/1998, UEAPME / Council (Rec.1998,p.II-2335), cons. 72.

$13 \operatorname{COM}(93) 600$ final, point 19. According to the Economic and Social Committee, a purely written procedure is usually too marginal to be satisfactory. Meetings, between the social partners, and between them and the Commission, should be the norm. (Opinion 94/C 397/17 of the Economic and Social Committee, on the Communication concerning the application of the Agreement on Social Policy presented by the Commission to the Council and to the European Parliament, OJ C 397/40, 31-12-1994, p. 45).

$14 \mathrm{COM}(93) 600$ final, point 9.

15 UNICE position paper on the Commission Communication, concerning the development of the social dialogue at Community level, 26 February 1997.

16 CEEP opinion on the Communication concerning the development of the social dialogue at Community level, 18 September 1996.

$17 \operatorname{COM}(96) 448$ final, point 65. 
time limit for consultations will be maintained but that the deadline in particular can be adapted. ${ }^{18}$

\subsubsection{The second consultation stage}

Article 138(3) EC Treaty states:

"If, after such consultation, the Commission considers Community action advisable, it shall consult management and labour on the content of the envisaged proposal. Management and labour shall forward to the Commission an opinion or, where appropriate, a recommendation."

After the social partners have given their comments, the Commission could decide that further action is not appropriate, according to the terms of Article $138(3)$ EC Treaty. It is thus not obliged to proceed to the second phase. ${ }^{19}$ But if it does, the second phase will be initiated with the receipt of a second letter sent by the Commission, setting out the content of the planned proposal together with the indication of the possible legal basis. On the occasion of this second consultation, the social partners should deliver to the Commission in writing and, where the social partners so wish through an ad hoc meeting, an opinion setting out the points of agreement and disagreement in their respective positions on the draft text. Where appropriate, they should deliver a recommendation setting out their joint positions on the draft text.

The difference between the first and second consultation may be clarified with an example. On 26 June 2000, the Commission issued a consultation document to the European-level social partners asking for their views on how to modernise and improve employment relations. The document invites the social partners to give their views on the possible future direction of Community action. ${ }^{20}$ It was thus the first-stage consultation procedure. The Commission highlighted two areas in which it wished the social partners to consider early action; tele-working was one of these areas. In response to the Commissions initiative, ETUC stated that it would like to see regulation of tele-working at European level. ${ }^{21}$ On 19 March 2001, the Commission launched the second stage of consultations on tele-working. ${ }^{22}$ The Commission provided a list of general principles that should serve as a framework for practical implementation. ${ }^{23}$ Among these principles were guarantees of suitable training, the health and safety of tele-workers and the protection of

$18 \operatorname{COM}(98) 322$, p. 9.

19 Also stated by the Commission itself in $\operatorname{COM}(93) 600$ final, point 19.

20 Commission consults social partners on modernisation of work. In: EIRONLINE, in brief, July 2000 .

21 UNICE offers negotiations on telework. In: EIRONLINE, features, March 2001.

22 UNICE offers negotiations on telework. In: EIRONLINE, features, March 2001.

23 Temporary agency work negotiations break down. In: EIRONLINE, in brief, April 2001. 
the private life and personal data of tele-workers. The Commission formulated a more detailed proposal for the second consultation.

The duration of the second phase must not exceed six weeks. ${ }^{24}$ The ESC feels that the consultation periods for the first as well as the second phase are too short. It leaves the social partners insufficient time to consult their affiliated organisations and to decide if they wish to start the procedure in Article 139 before the Commission produces its proposal. The ESC proposes a consultation period for the first phase of eight weeks and for the second phase of 4 months. Especially in the second phase, the social partners should be able to produce effective critiques of the content of, or detailed amendments to, the proposal or substantive recommendations. ${ }^{25}$ The time limits for consultation do not have a legal basis in the Treaty or secondary Community law. They have been set by the Commission to avoid the consultation period taking too long, which would endlessly delay the decision-making process. So far, the social partners have remained more or less within the limits of the six-week period. ${ }^{26}$ In practice, there are thus not many problems and the time limit seems reasonable. I think also that in case of difficult subjects the Commission would have no problems waiting a few weeks more for the social partners' advice.

Article 138(3) uses the terms "opinion" and "recommendation". The difference is that opinions are given separately. The social partners in that case have different views on the subject. A recommendation is given jointly, the social partners are then unanimous. ${ }^{27} \mathrm{~A}$ joint recommendation has a stronger impact than separate opinions. The Commission will therefore be more inclined to follow a joint recommendation than an opinion. ${ }^{28}$

The Treaty does not explicitly provide for the possibility that the social partners advise the Commission on their own initiative. Neither does it contain a prohibition against this. ${ }^{29}$ It is thus not really necessary that the social partners' organisations receive a specific request from the Commission to give their advice. They can also advise without such request.

\subsubsection{Subjects for consultation}

On which subjects should the social partners be consulted? Article 138(2) EC Treaty states that the social partners should be consulted on proposals in the social policy field. It is clear that if the Commission wants to formulate proposals on the basis of provisions in Title XI (Article 137(2) and (3) and Article 141(3) EC Treaty), it has to consult the social partners first, because this is the title on social policy. The choice of a legal basis for a Community measure

$24 \operatorname{COM}(93) 600$ final, point 19.

25 Opinion 94/C $397 / 17$ of the Economic and Social Committee, p. 44-45.

26 See annex.

$27 \operatorname{COM}(93) 600$ final, point 9.

28 Interview with DG V (Mr. S. Olsson), on 1 April 1998.

29 See also B. Bodding, Die europearechtlichen Instrumentarien der Sozialpartner, p. 128. 
has important political and institutional consequences. As each provision which attributes a power to the Community also lays down the procedure to be followed, the choice of the legal basis determines the position of each of the institutions and the Member States in the legislative process. ${ }^{30}$ The content of the concept "social policy" as such is very heterogeneous and open to changing interpetations. In order to determine correctly the scope of the Community's role in the social field, it is necessary to break through the highly artificial distinction between on the one part market integration and economic policy integration, and, on the other part, social policy and social integration. The welfare gains resulting from the combination of market integration and economic policy integration, for a large part bring direct benefits to the labour factor. Moreover, they increase the economic basis of support for social objectives. For example, the free movement of workers cannot as such be achieved without coordination of the application of national security systems to migrant workers. Another example lies in the field of education: the express emphasis which is placed in Articles 149 and 150 on the quality and availability of education and vocational training - one of the most important conditions for a socially vigilant working population - confirms once again that the possibilities for the Community to act in order to achieve social objectives are broader than those resulting from the social provisions of the EC Treaty themselves. Viewed thus, in the achievement of its' core objectives, the Community can also achieve its social objectives without specific powers directed at social policy being necessary for this purpose. $^{31}$ It appears therefore that the norm of instruction requiring consultation embraces all Community initiatives and proposals which have a social or socio-economic significance, such as measures implementing the Articles 42 and the Articles 158-162, as well as the Articles 125-130 EC Treaty. ${ }^{32}$ Before the European Single Act, a specific power of the Community to take measures in the social policy field was absent. However, Article 136 confirms that such measures could be taken on the basis of the procedures provided for in this Treaty and from the approximation of provisions laid down by law, regulation or administrative action, which was commonly interpreted as a reference to Article 37, 71, 94 and 308 EC Treaty. ${ }^{33}$ I therefore think that social policy measures taken on the basis of these provisions also require first consultation of the social partners' organisations. ${ }^{34}$ The Commission itself

30 R. Barents, The internal market unlimited: some observations on the legal basis of Community legislation. In: CMLR, vol. 30, no. 1, 1993 , p. 89.

31 P.J.G. Kapteyn and P. VerLoren van Themaat, Introduction to the law of the European Communities, p. 1045-1048.

32 P.J.G. Kapteyn and P. VerLoren van Themaat, Introduction to the law of the European Communities, p. 1061.

33 R. Barents, The internal market unlimited: some observations on the legal basis of Community legislation. In: CMLR, vol. 30, no. 1, 1993, p. 99.

34 See also B. Bodding, Die europearechtlichen Instrumentarien der Sozialpartners, p. 128 . 
intends to consult systematically the inter-sectoral social partners' organisations on all developments in the economic and social policy field. ${ }^{35}$ Promoting the consultation of management and labour can therefore be understood as involving the social partners as much as possible in the formulation of European social policy; not only with regard to the formulation of specific legislation, but also on broader issues such as the European employment strategy, commercial policy, the fight against racism or the integration of people with disabilities. ${ }^{36}$ Sectoral social partners' organisations should, according to the Commission, be consulted on more specific issues, relating to their sector. ${ }^{37}$

\subsubsection{Who is to be consulted?}

According to Article 138(2) EC Treaty, the Commission shall consult management and labour. Neither of these is defined. The organisations consulted, however, must be European organisations since par. 1 of Article 138 states that the Commission shall promote the consultation of management and labour at Community level. Purely national organisations must therefore be excluded from the consultation procedure of Article 138 EC Treaty. Even so, there are many European organisations of management and labour ${ }^{38}$ and the question is which ones are included in the consultation procedure and which ones are not.

This question brings us to one of the most thorny issues of the European social dialogue, namely the representativity of the European social partners organisations. The representativity issue is important in three stages of the European social dialogue: with regard to the consultation on the basis of Article 138(2) and (3) EC Treaty, with regard to the negotiations and conclusion of agreements on the basis of Article 138(4) and 139(1) EC Treaty, and finally with regard to the implementation of European collective agreements into Community legislation on the basis of Article 139(2) EC Treaty. In the consultation procedure, the Commission plays a decisive role in the sense that it is this institution that decides which organisations it will ask for an opinion. When it comes to negotiations however, it is the social partners themselves who decide with whom they want to negotiate. If the parties to a European collective agreement want this agreement to be turned into Community legislation, it is the Commission and Council who decide on their representativity. Since I will discuss these three stages in different chapters, ${ }^{39}$ I will discuss the representativity issue in each stage as well.

$35 \operatorname{COM}(98) 322$, para. 3.1.

36 See Forum Special Five years of social policy, Publication of the European Commission, DG V/2, Brussels, 1999, p. 23.

$37 \operatorname{COM}(98) 322$, para. 3.2

38 In 2001 , there were more than 60 organisations.

39 Chapter 4, 5 and 7. 


\subsubsection{Representativity}

The growing importance of the social dialogue enshrined in the European Union Treaty, and the related applications for admission by various organisations which felt excluded from the consultation process, led the Commission to examine existing arrangements. With regard to the representativity of the European social partners' organisations, the Commission undertook a Social Partners Study in the period September 1992 - July 1993.40 The study deals with European federations of employers' and trade union organisations at intersectoral level. Included are federations with member organisations having a clear vocation to represent the interests of their members as either employers or trade union organisations both in the context of negotiations and in consultations. Some organisations were included in the study although it was not $a$ priori fully clear to what extent they would satisfy this criterion. The inclusion of certain federations in the study does not therefore in any way prejudge their representativity. It primarily means that there was a need to have more information about what they represented and about their interrelationships. Some European organisations, which were in themselves much more important than others, were not included because there was no need, within the context of the application of the Social Agreement, to have such clarification about them. ${ }^{41}$ Other organisations were added to the list of relevant organisations, because they had made explicit requests to the Commission. ${ }^{42}$ Furthermore, the study describes how questions of representativity of employers' and trade union organisations are dealt with within the framework of both formal consultations and collective bargaining in each Member State. One of the criteria to establish the representativity of a European organisation of workers or employers is to verify whether the affiliated national organisations are representative in their own country as well. Looking at the results of the study, some criteria for the establishment of the representativity are frequently used in the Member States. For example: the number of members, ${ }^{43}$ the number of seats held in works councils or other advisory bodies ${ }^{44}$ and the financial and/or physical resources of the organisation. ${ }^{45}$ In its 1993 Communication, the Commission states that the study showed that there is a great diversity in the Member States in the systems and mechanisms used for recognition of social partners' organisations and that it is difficult to identify a common denominator which could easily be transposed to the Community level, apart from the principle of mutual recognition for negotiating purposes. Furthermore, the different national systems have all taken many years to grow and develop. It is therefore difficult to see how a European system

\footnotetext{
40 Doc. no. V/6141/93/E.

41 Annex I of the Social Partners' Study: Main findings of the Social Partners' Study, p. 3.

42 Annex I of the Social Partners' Study, p. 2.

43 Germany, France, Ireland, Italy, Luxembourg, The Netherlands.

44 Germany, Spain, Italy, Luxembourg.

45 Germany, France, Ireland, The Netherlands.
} 
can be created in the short term by administrative decision. ${ }^{46}$ Nevertheless, the Commission was able to draw certain criteria on representativity when it comes to consultation.

As a result of the study, the Commission concludes that in order to be consulted under Article 138 EC Treaty, the organisations should:

- be cross-industry or relate to specific sectors or categories and be organised at European level;

- consist of organisations which are themselves an integral and recognised part of Member State social partner structures and with the capacity to negotiate agreements and which are representative of all Member States, as far as possible;

- have adequate structures to ensure their effective participation in the consultation process.

\subsubsection{Analysis of the representativity criteria}

The first criterion does not raise many questions. Cross-industry organisations are, for example, the ETUC, UNICE and CEEP. An organisation representing specific sectors is the Committee of Agricultural Organisations (COPA). Furthermore, the European Association of Craft, Small and Medium-Sized Enterprises (UEAPME) can be qualified as an organisation representing specific categories of employers. Furthermore, they have to be organised at European level. This means that purely national organisations are excluded.

The second criterion is more difficult. If not only for the way it should be read. Does the "capacity to negotiate agreements" relate to the European organisations or to the national members? The same question can be posed for the phrase "which are representative of all Member States". I think that the "capacity to negotiate agreements" relates to the national organisations. However, the phrase "which are representative of all Member States" can in my opinion only refer to the European organisations since a national organisation can never be representative of all Member States.

The Commission does not verify itself whether national affiliates of the European organisations are an integral and recognised part of national social partners' structures.$^{47}$ The three intersectoral European social partners' organisations ETUC, UNICE and CEEP have formulated criteria in their statutes in order to determine which organisations can become a member and which ones cannot. On the one hand, it is logical that the European organisations

$46 \operatorname{COM}(93) 600$ final, point 23.

47 Interview with DG V (Mr. S. Olsson), 1 April 1998 and with J. Morin on 25 March 2002. It would in practice be impossible for the Commission itself to check whether these organisations all fulfill the criteria of representativeness in their respective countries. 
themselves determine which national organisations can become a member. After all, they are private organisations with their own internal rules. However, if certain organisations are recognized as a European social partners' organisation, these organisations will have a certain monopolised position in the creation of European labour law. Therefore, according to Blanpain, the Community government should check whether the existing organisations have an appropriate policy for deciding which national organisation will be a member and which one will not. ${ }^{48}$ Furthermore, if a European organisation were regarded as representative without its national affiliates being an integral and recognised part of the social partners' structures, it would be very difficult to have a European collective agreement implemented by these national affiliates, as described in Article 139(2) EC Treaty ${ }^{49}$ because the national organisations lack legitimacy.

The national organisation must also have "the capacity to negotiate agreements". The capacity of an employers' or workers' organisation to perform certain legal acts derives from its legal status and from its statutes. Difficulties can arise as regards the British CBI and TUC and the German DGB and $\mathrm{DAB}$. They do not have the capacity to negotiate and conclude collective agreements at national level. ${ }^{50}$ However, since the DAB and $\mathrm{CBI}$ are members of UNICE and the TUC and DGB are members of ETUC, ${ }^{51}$ the Commission apparently does not take this criterion too strictly, otherwise it would exclude UNICE and ETUC from consultation.

The European social partners' organisations must also, as far as possible, be representative of all Member States. This means that they must have national member organisations in various Member States. The phrase "as far as possible", implies that the requisite that the European organisations must have affiliates in all Member States is not a law of the Medes and Persians. The ESC thinks that it is sufficient to have member organisations in at least threequarters of the EU Member States. ${ }^{52}$ According to the ETUC, UNICE and

48 R. Blanpain, Sociale partners en de Europese Unie; taak en legitimatie. In: L. Betten, F. Boelhouwer, J.M. Fleuren van Walsem, T. van Peijpe and L.A.J. Schut (ed.), Ongelijkheidscompensatie als roode draad in het recht. Liber Amicorum for Prof. M. Rood, Deventer, 1997, p. 291.

49 T. Gilles, Das Zustandekommen und die Durchführung von Sozialpartnervereinbarungen im Rahmen des Europäischen sozialen Dialogs, Dissertation, Frankfurt, 1997, p. 155.

50 R. Blanpain, Sociale partners en de Europese Unie; taak en legitimatie. In: L. Betten, F. Boelhouwer, J.M. Fleuren van Walsem, T. van Peijpe and L.A.J. Schut (eds.), Ongelijkheidscompensatie als roode draad in het recht. Liber Amicorum for Prof. M. Rood, p. 295.

51 See annex II of the Social Partners' Study: Summary tables presenting an overview of the national affiliates of twelve European federations covered by the Social Partners' Study 1993.

52 Opinion CES 106/97 AH/ss of the ECOSOC of 29 January 1997, on the Commission communication concerning the development of the social dialogue at Community level; OJ C 89/28, 19-03-1997. 
CEEP, however, European social partners' organisations should be represented in all Member States of the EC and, possibly, of the EEA or have participated in the Val Duchesse social dialogue. ${ }^{53}$

The third criterion is rather vaguely formulated. When does an organisation have adequate structures to ensure its effective participation in the consultation process? One can think here of a certain internal structure of a European organisation. The consultation procedure of Article 138 EC Treaty is limited in time, as we have seen before. A European organisation must be internally organised in such a way that it is able to deliver an advice within this time limit. This means that it must have organs which represent the national affiliates and that these organs can act towards EC institutions on behalf of these national affiliates. One can think for example of an organ stipulating the policy line of the European organisation (congress), an organ to handle the daily business on the basis of these policy lines (steering committee) and an organ serving as the spokesman of the European organisation (secretariat).

In its 1996 Communication the Commission noted that certain problems, identified since 1993, suggest that the Commission should re-evaluate the appropriateness of its criteria and ensure that those participating are mandated to do so, and that the views submitted under consultations organised by the Commission are representative. ${ }^{54}$

The Commission will keep under review the list of European organisations to be consulted. The vast majority of respondents to the 1996 Communication were in favour of maintaining the current criteria for determining which organisations should be consulted.55 Since the Maastricht Treaty, several European organisations at sectoral level have concluded a sort of cooperation agreement in which they set out the principles and working methods for a social dialogue between them. ${ }^{56}$ In these agreements, they sometimes state that they meet the representativity criteria of the Commission, although they are not always mentioned in the annex by the 1993 Communication, in which the Commission listed all organisations that it considered representative. ${ }^{57}$

53 Proposals by the social partners for implementation of the Agreement annexed to the Protocol on Social Policy of the Treaty on European Union, 29 October 1993. In: Social Europe 2/95, p. 164-165.

$54 \operatorname{COM}(96) 448$ final, point 61 and 63.

$55 \operatorname{COM}(98) 322$, para. 3.3..

56 Agreement between ECF-IUF and HOTREC on the framework of their social dialogue at European level, concluded at 28 September 1998; Agreement between EFCl and EURO-FIET on establishing a committee for social dialogue in the cleaning sector, concluded at 18 December 1998; Agreement between Eurocommerce and EURO-FIET on establishing of a sectoral dialogue committee in commerce, concluded at 30 November 1998; Memorandum of CEI-Bois and the EFBWW of understanding on engagement in a social dialogue, concluded on 17 June 1994; Agreement between the ECF-IUF and GITES to set up a Joint Information and Consultation Structure, concluded in April 1997.

57 For example in the agreement between EFCI and EURO-FIET. 
They also sometimes state that they expect the Commission to consult them. ${ }^{58}$ Whether the Commission will be influenced by these statements remains to be seen.

The criteria of representativity formulated by the Commission apply to Article 138 EC Treaty as a whole, that is to say for both consultation procedures. In practice, the Commission consults a second time all those organisations which have been consulted the first time. The Commission has selected a number of organisations which it considers representative enough to be consulted. ${ }^{59}$

\subsubsection{Other ideas for representativity criteria}

In addition to the Commission criteria, the European Parliament suggested that eligible organisations are composed of organisations representing employers or workers with membership which is voluntary at both national and European level. ${ }^{60}$ In a report of 1993, the EP suggests furthermore that "it is essential that the consultation procedure provided for in Article 3 (Article 138 after the Amsterdam Treaty), should involve all management and labour organisations which have formed stable and lasting organisational arrangements at Community level, whose members are firmly rooted in the Member States, which are prominent in small medium-sized and large enterprises and which are active in the private and the public sectors." 61 The first criterion of the EP, that membership of a trade union or employers' organisation is voluntary, is easy to check. The second criterion however, raises more difficulties. When have management and labour organisations formed "stable and lasting organisational arrangements at Community level"? And when are the national affiliates "prominent in small, medium-sized and large enterprises"? These points need further clarification.

ETUC, UNICE and CEEP also formulated representativity criteria. ${ }^{62}$ They state that in order to be regarded as social partners in the sense of Article 138 and 139 EC Treaty, organisations should meet the following conditions:

- be organised horizontally or sectorally at European level;

58 For example in the agreement between Eurocommerce and Euro-fiet and in the agreement between ECF-IUF and HOTREC.

59 See annex I by $\mathrm{COM}(98) 322$.

60 Report of the Committee on Social Affairs, Employment and the Working Environment of the EP, on the application of the Agreement on social policy, 20 April 1994, A3-0269/94, PE 207.928/ fin., p. 5.

61 Report of the Committee on Social Affairs, Employment and the Working Environment, on the new social dimension of the Maastricht Treaty, 1 September 1993, A30247/93, PE 205.366/ fin., p. 9.

62 Proposals by the social partners for implementation of the Agreement annexed to the Protocol on Social Policy of the Treaty on European Union, 29 October 1993. In: Social Europe 2/95, p. 164-165. 
- be composed of organisations which are themselves regarded at their respective national levels as representative of the interests they defend, particularly in the fields of social, employment and industrial relations policy;

- be represented in all Member States of the EC and, possibly, of the EEA or have participated in the Val Duchesse dialogue;

- be composed of organisations representing employers or workers, membership of which is voluntary at both national and European level;

- be composed of members with the right to be involved, directly or through their members, in collective negotiations at their respective levels;

- be instructed by their members to represent them in the framework of the Community social dialogue. ${ }^{63}$

Only the fourth and the sixth criterion really add something to the Commission criteria. As regards the voluntary membership, UEAPME, EUROCHAMBRES and SEPLIS are opposed to this criterion. They state that the voluntary nature of membership says nothing about the representativity of the organisations concerned. ${ }^{64}$ The last criterion is evident. European organisations cannot conclude agreements on behalf of their members without their mandate. This is a matter which has to be regulated in the statutes and/ or internal rules of procedure of the European organisations.

Also the Economic and Social Committee, has formulated certain representativity criteria:

- A European representative organisation must be widely spread over the $\mathrm{EU}$. This means that it must have member organisations at the appropriate relevant negotiation level in at least three-quarters of the EU Member States and be seeking to be represented in the others;

- The European organisation must have a mandate from its member organisations to negotiate at European level;

- All the organisations affiliated to the European organisation, either in their own name or through their member organisations, must be entitled to negotiate in the Member States and must be able to implement conventions concluded at European level in accordance with national practices and usages;

- The European organisation must be made up of organisations that are considered in their Member States as representative. ${ }^{65}$

63 Proposals by the social partners for implementation of the Agreement annexed to the Protocol on social policy of the Treaty of the EU, 29 October 1993. In: Social Europe 2/95, p. 164.

64 Synthesis report of responses to Commission Communication COM(93)600 final. SER, April 1997.

65 Opinion CES 106/97 AH/ss of the ECOSOC of 29 January 1997, on the Commission communication concerning the development of the social dialogue at Community level; OJ C 89/28, 19-03-1997. 
It is not clear what is meant by "conventions" as mentioned in the third criterion. This term is not mentioned in Article 138 or 139 EC Treaty. The second criterion is evident in my opinion. The first and last criterion have to do with the legitimacy of the European organisation and the national affiliates. A European organisation whose national affiliates belong to only one or two Member States is not a European representative organisation in my view. Also the fact that the national affiliates must be regarded representative in their own Member State increases the legitimacy of the European organisation.

\subsubsection{Conclusions}

The Commission is obliged to consult the social partners' organisations before submitting proposals in the social policy field. The second consultation is more detailed than the first one. In the Commission Communications, a time limit has been laid down for the consultation. The social partners do not have to wait for a Commission initiative to give their advice; they can also give that on their own initiative. The Commission should consult the European organisations of workers and employers on social policy issues in the broadest sense. Since there is no definition of "management and labour", the Commission has, on the basis of a social partners' study, formulated certain criteria for determining the representativity of European organisations. If they fulfill these criteria they will be consulted by the Commission on the basis of Article 138 EC Treaty. These criteria are regularly reviewed by the Commission. The EP, the ESC and the three intersectoral organisations, ETUC, UNICE and CEEP have also formulated representativity criteria.

I think that from all these criteria we can destillate a few which are the most important: The organisations must be organised at the European level, for Article 138 speaks of "management and labour at European level". They must also consist of national affiliates which are regarded representative in their own Member States and the membership of these organisations must be voluntary. It is in my opinion not necessary that the national affiliates exist for a long time in the Member States. Also young organisations, which have just been founded, must be able to become a member of a European umbrella organisation. As long as the national organisation fulfills the representativity criteria of that Member State. So in this regard I do not agree with the criterion of the EP that the members of the European organisation must be "firmly rooted in the Member States". Furthermore, I think it is important that the European organisation has democratic internal decision-making procedures. They should definitely be mandated by their national affiliates to conclude European agreements on their behalf. The European organisation must also have adequate structures to effectively participate in the European social dialogu, process. Finally, membership of the European organisation should be as equally spread as possible. I agree with the criterion of the ESC 
that the European organisation should have members in at least three quarters of the EU Member States. My list of representativity-criteria is as follows:

- the organisations must be organised at European level;

- the organisations must consist of national affiliates which are regarded representative in their own Member States;

- the membership of the European as well as the national organisations must be voluntary;

- the European organisations must have internal democratic decisionmaking procedures;

- the European organisations must be mandated by their national affiliates to conclude European agreements;

- the European organisations must have adequate structures to effectively participate in the European social dialogue;

- membership of the European organisations should exist in at least three quarters of the EU Member States.

\subsection{The start of negotiations between the European social partners' organisations}

Article 138(4) EC Treaty states:

"On the occasion of such consultation, management and labour may inform the Commission of their wish to initiate the process provided for in Article 139. The duration of the procedure shall not exceed nine months, unless the management and labour concerned and the Commission decide jointly to extend it."

This provision raises several questions. Can management and labour only start to negotiate after first having been consulted? Does the Commission have to remain passive during the nine-month period in which the negotiations take place? On the other hand, can it continue its own legislative procedure alongside the negotiations? Are the social partners in their negotiations bound to the content of the Commission proposal and in what sense? Are management and labour free in the choice of their negotiating partners? Lastly, what happens if management and labour are unable to conclude an agreement?

\subsubsection{At what time may the European social partners' organisations start their negotiations?}

Article 138(4) EC Treaty states that on the occasion of such consultation management and labour may inform the Commission of their wish to start negotiations. The first question is whether the social partners have to wait for a Commission consultation before they can start to negotiate, or whether they also can start to negotiate on their own initiative. To answer this question we 
have to read the Articles 138 and 139 EC Treaty together. Article 139(1) explicitly states that the dialogue between the social partners can lead to agreements and para. 2 of that provision describes the follow-up to such agreements. Article 139 does not state that these agreements can only be concluded if the social partners have first been consulted by the Commission. ${ }^{66}$ Furthermore, the decision of two private parties to start negotiations with each other is not dependent on the decision of a public authority. In addition, according to the ILO, the framework within which collective bargaining must take place, if it is to be viable and effective, is based on the principle of the independence and autonomy of the parties and the free and voluntary nature of the negotiations. ${ }^{67}$ This can be derived from the Declaration of Fundamental Principles and Rights at Work and its Follow-up, adopted in June 1998 by the ILO. Whether the social partners will await the consultation procedure is determined more on political considerations. If the social partners want their agreement to become Community law, they depend on the Commission for a legislative proposal, as described by Article 139(2) EC Treaty. The chance that the Commission will formulate such a proposal will be greater if the European agreement is concluded after the social partners have been consulted. In the consultation procedure, the Commission already has some influence on the content of a possible agreement: it first formulates a proposal for the possible direction of Community action. By the second consultation, it formulates a proposal on the content of the Community action. So in the consultation procedure, there is already a substantial Commission influence. This influence makes itself felt in the European agreement because, when the social partners start to negotiate, this will be on the basis of a more or less concrete Commission proposal. A European agreement will thus resemble the Commission proposal. I therefore consider that the Commission will be more willing to send the agreement to the Council than in case where the social partners conclude an agreement at their own initiative, especially if it is on a subject which has no priority for the Commission.

The second question is what is meant by "such consultation" in Article 138(4) EC Treaty. Is that the first or the second consultation? According to Bödding it is the second consultation. ${ }^{68}$ I concur, but not on legal grounds. As I said before, the social partners do not have to await the consultation of the Commission before they can start negotiating. This means that they can also start to negotiate after the first consultation. However, for political reasons it might be better for them to start after the second consultation. This can be based on para. 2 of Article 138. Para 2 states that the Commission can consult the social partners for the second time if it, after the first consultation, considers

66 See also K. Piazolo, Der Soziale Dialog nach dem Abkommen über die Sozialpolitik und dem Vertrag von Amsterdam, Frankfurt am Main/Berlin/Bern/New York/ Paris/Wien, 1999, p. 103-104.

67 B. Gernigon, A. Odero and $\mathrm{H}$. Guido, ILO principles concerning collective bargaining. In: ILR, vol. 139, no. 1, 2000, p. 34.

B. Bodding, Die Europarechtlichen Instrumentarien der Sozialpartners, p. 136. 
Community action advisable, It is thus possible that the Commission decides after the first consultation that Community action is not advisable. If the social partners nevertheless inform the Commission of their wish to negotiate, they will negotiate on an issue on which the Commission already decided that Community action is not advisable. The chance that the eventual agreement of the social partners would then be implemented through Community legislation would be nihil. Thus, from a political point of view, it is better for the social partners to await the second consultation of the Commission before starting to negotiate.

In order to start negotiations, the social partners also have to agree that they want to negotiate. The moment to start negotiations can be different for the employers on the one hand and the trade unions on the other. This depends on the Commission proposal. The side less satisfied with the envisaged proposal will have an incentive to negotiate and agree to a different standard. The side that is more content may still see advantages in a different agreed standard. The social partners are often able and willing to negotiate derogations from specified standards which allow for flexibility and offer advantages for both sides. ${ }^{69}$ The Commission proposal will always be a minimum standard when it comes to social legislation. If this minimum standard is high, employers probably will be more willing to negotiate, in order to try to lower that standard in exchange for other things. For example: If the Commission standard will be that every parent has the right to three months of unpaid parental leave, employers could try in negotiations with the trade unions to limit this period to one month of paid leave. This could happen, for example, in times when the economy is booming. In such a period, companies have enough money for paid leave, but it is difficult to find employees. The employers will thus try to limit the period of parental leave in exchange for giving extra money.

\subsubsection{Role of the Commission during the nine-month period}

Should the Commission remain passive during the period that the social partners are negotiating? It does not say so explicitly in Article 138(4). The Commission itself thinks that this question has to be examined on a case-bycase basis. ${ }^{70} \mathrm{I}$ consider, however, that the whole idea of involving the social partners in Community social legislation would be useless if the Commission just could continue its own legislative process. An agreement of the social partners, especially if it is the result of negotiations after having been consulted, will often be the basis for Community law. It would therefore be illogical if the Commission just continued its own legislative process alongside the negotiations between the social partners. ${ }^{71}$ Furthermore, in the Joint Agree-

69 B. Bercusson, European labour law, p. 540.

$70 \operatorname{COM}(93) 600$ final, point 30.

71 See also E. Kampmeyer, Protokoll und Abkommen uber die Sozialpolitik der Europăischen Union,Köln/Berlin/Bonn/München, 1998, p. 87. 
ment of ETUC, UNICE and CEEP of October 1991, the provision on which Article 138(4) EC Treaty is based was formulated so as to say that the ninemonth period could be prolonged if the social partners so decided. In the resulting formulation, as now laid down in Article 138(4), the social partners and the Commission together have to decide on prolongation. This joint decision would not be necessary if the Commission just could continue its own legislative process during the nine-month period. ${ }^{72}$

Another question is what would happen if the negotiations break down after, say, 3 months? In negotiations on collective agreements, it often happens that one of the social partners' organisations leaves the negotiation table. That does not, however, mean that there will be no agreement. It is often a matter of tactics when one of the negotiating parties leaves. What should the Commission do in such a case? Immediately take over the legislative process or wait until the prescribed 9 months are over? Article 138(4) EC Treaty says that the negotiation period shall not exceed 9 months. This may imply that it might be shorter than 9 months. I think that the same reasoning can be followed as above. If after three months of negotiations it is absolutely out of the question that an agreement will be concluded, the Commission can continue its own action. If, however, the social partners just want a pause in negotiation, I think that the Commission should give them a reasonable amount of time to see whether they can continue. The negotiations on the European Works Councils broke down after approximately two months. Two months later, the Member States already had reached a common position on a draft Directive. In certain other cases, the employers' organisations ended the negotiations. ETUC then asked the Commission to start the legislative procedure. The Commission could, in such cases, check thoroughly whether the negotiating parties really want to quit the negotiations. If that is the case, the Commission can continue its legislative process, even if the nine-month period is not yet over.

\subsubsection{Subject of the negotiations}

Are the social partners bound to the Commission proposal as regards their negotiations? We should distinguish two aspects: the proposal as regards the direction of Community action (Article 138 para. 1) and, second, the proposal as regards the more detailed content of the Commission proposal (Article 138 para. 2). The Commission states that in their independent negotiations, the social partners are in no way required to restrict themselves to the content of the proposal in preparation within the Commission or merely to making amendments to it, bearing in mind, however, that Community action can

72 Also K. Piazolo, Der Soziale Dialog nach dem Abkommen über die Sozialpolitik und dem Vertrag von Amsterdam, p. 111-112 and B. Bödding, Die Europarechtlichen Instrumentarien der Sozialpartners, p. 139-140, as well as T. Gilles, Das Zustandekommen und die Durchfuhrung von Sozialpartnervereinbarungen im Rahmen des Europaischen sozialen Dialogs, p. 192. 
clearly not go beyond the areas covered by the Commission's proposal. ${ }^{73}$ In other words: according to the Commission, the social partners can negotiate any subject they want but if they want their agreement to be turned into Community legislation, they are well advised to remain as close to the Commission proposal as possible. There is another reason for the argument that the social partners should do so. If the social partners expect the Commission to remain passive during the nine-month period, they should at least negotiate on the same subject as that of the Commission proposal and not negotiate on something wholly different. ${ }^{74}$

When it comes to the detailed content of the Commission proposal, the situation is different. If the social partners would be so limited in their negotiations that they could only negotiate on the exact Commission proposal, it would not be useful at all to involve them in the legislative process. ${ }^{75}$ The negotiation procedure of Article 138(4) is a perfect opportunity for the social partners to adapt the Commission proposal to the specific needs of the workers and employers. This opportunity would be undermined if the social partners would not have any possibility to deviate from any detail of the Commission proposal.

\subsubsection{Who is "management and labour" in Article 138(4)?}

According to Bödding, the social partners who decide to start negotiations on the occasion of the Commission consultation, have to be the same as those who have been consulted by the Commission. ${ }^{76}$ The Commission states in one of its Communications that the social partners who decide to negotiate with each other on the occasion of the Commission' consultation, will be those who decide to negotiate with each other. ${ }^{7}$ This somewhat circular reasoning implies that it is the organisations themselves who choose their negotiating partners. Further, in its 1998 Communication, the Commission states that it cannot intervene in the free choice of negotiating partner. ${ }^{78}$

The number of social partner organisations who are consulted by the Commission depends on the subject. If, however, for example, 12 organisations are consulted, it would be inefficient to require that all these 12 organisations should participate in the negotiations as well. That would block the negotiating process. I agree with the Commission that it are the social partners themselves who choose their negotiating partners. Here again the question is

$73 \mathrm{COM}(93) 600$ final, point 31.

74 Also K. Piazolo, Der Soziale Dialog nach dem Abkommen über die Sozialpolitik und dem Vertrag von Amsterdam, p. 114 and B. Bodding, Die Europarechtlichen Instrumentarien der Sozialpartners, p. 137.

75 Also K. Piazolo, Der Soziale Dialog nach dem Abkommen über die Sozialpolitik und dem Vertrag von Amsterdam, p. 114 and B. Bodding, Die Europarechtlichen Instrumentarien der Sozialpartners, p. 136.

76 B. Bodding, Die Europarechtlichen Instrumentarien der Sozialpartners, p. 135.

$77 \mathrm{COM}(93) 600$ final, point 31.

$78 \operatorname{COM}(98) 322$, para. 5.2 
what they want with their agreement. If they want it to become Community law, they had better ensure that the agreement is being negotiated by organisations that are at least considered representative by the Commission. These are, in any case, organisations that have been consulted. Furthermore, I consider that if the issue concerns an intersectoral agreement, the three most important intersectoral organisations, namely ETUC, UNICE and CEEP, should participate in the negotiations.

\subsubsection{What if the European social partners organisations cannot conclude an agreement?}

It is possible that the social partners cannot conclude an agreement within the nine-month period. Article 138(4) states that this period can be prolonged if the social partners and the Commission jointly so decide. According to Gilles, the Commission cannot really refuse this prolongation if an agreement is very near and the period of prolongation is not very long. ${ }^{79}$ The Commission itself thinks that prolongation of fruitless negotiations should be avoided, because this would block the Commission's ability to regulate. ${ }^{80}$ This implies that the Commission will only permit prolongation if it thinks that an agreement is near. ${ }^{81}$ With regard to the Directive on Parental Leave as well as the Directive on Part-Time work, the period of negotiations was kept within the boundaries of the time limit of nine months. The negotiations on parental leave took 5 months and those on part-time work 7 months.

It is also possible that the social partners conclude an agreement with only a part of the Commission proposal as a basis and that other parts are left unnegotiated. As regards the unnegotiated parts, I consider that the Commission is free to continue its own legislative process without consulting the social partners again. They have already been consulted and they had the chance to negotiate on the basis of the whole proposal. This is also so if the social partners cannot conclude an agreement at all. An example can illustrate this. In September 1997, the social partners in the road transport sector were negotiating a possible agreement on working time for this sector. However, these negotiations broke down. The Commission on that occasion decided to continue it's own legislative process. However, it stated that it would take into account the elements on which the social partners could agree during their negotiations. ${ }^{82}$ Only if the Commission decides to formu-

79 T. Gilles, Das Zustandekommen und die Durchführung von Sozialpartnervereinbarungen im Rahmen des Europäischen sozialen Dialogs, p. 194.

$80 \operatorname{COM}(93) 600$ final, point 32.

81 UNICE expects that the Commission will respect the joint agreement and therefore not make use of its right to veto a joint request of the social partners to prolong the negotiation period. (UNICE position paper on the Social Chapter of the Maastricht Treaty, 25 May 1992).

82 "Wegvervoer, een vastgelopen akkoord weer vlot trekken". In: Europese Sociale Dialoog, no. 7, December 1998, Newsletter from the European Commission, DG V/D. 
late a whole new proposal, which substantially differs from the first one, should it follow the route of Article 138(2) and (3) again. ${ }^{83}$

\subsubsection{Conclusions}

In conclusion, we can say that the social partners may start to negotiate at any time they want. However, if they want their agreement to be implemented by Council decision, they had better await the second consultation of the Commission before starting their negotiations.

Employers' organisations and trade unions both have different reasons to start negotiations. This depends on the content of the Commission proposal. The Commission should in principle remain passive during the period that the social partners are negotiating an agreement. If the negotiations break down before the nine months are over, the Commission can continue its legislative process after it has checked that there is really no chance that an agreement will be concluded.

In their negotiations, the social partners should at least keep to the Commission proposal as regards the subject. However, as regards the detailed content of that subject, they must have the opportunity to adapt the Commission proposal to the specific need of workers and employers.

The social partners themselves choose their negotiation partners. However, for their agreement to become Community law, they have to make sure that they are all considered representative by the Commission. If the social partners cannot conclude an agreement within 9 months, the Commission will probably permit prolongation if it thinks that an agreement will be concluded in a short time. If the social partners leave certain issues unnegotiated, the Commission can continue its legislative process on these issues without consulting the social partners again.

\subsection{Conclusions}

According to Article 138(1) EC Treaty, the Commission is legally obliged to promote the consulation of the European social partners' organisations and to support them. For financial support, social partners organisations, European as well as national ones, can submit proposals for assistence to the Commission. The Commission has developed certain award criteria on the basis of which it grants or refuses such support. For the sake of their independency of the Community institutions, it is recommendable that the

83 Also K. Piazolo, Der Soziale Dialog nach dem Abkommen über die Sozialpolitik und dem Vertrag von Amsterdam, p. 115-116 and B. Bodding, Die Europarechtlichen Instrumentarien der Sozialpartners, p.140-141, as well as T. Gilles, Das Zustandekommen und die Durchführung von Sozialpartnervereinbarungen im Rahmen des Europäischen sozialen Dialogs, p. 194 and M. Heinze, Die Rechtsgrundlagen des Sozialen Dialogs auf Gemeinschaftsebene. In: Zeitschrift für Arbeitsrecht, vol. 4, no. 28, 1997, p. 515. 
European social partners' organisations do not overrely on Commission financing and that they should become financially self supporting as soon as possible.

According to Article 138(2) and (3) EC Treaty, the Commission has a legal obligation to consult the social partners' organisations before submitting social policy proposals. Since the Treaty and secondary Community law does not give any rules on the consultation procedure itself, the Commission has described a procedure in its Communications of 1993 and 1996. There is a time limit for the first and second consultation but deviations from this time limit are possible. If the European social partners' organisations deliver an opinion, this indicates that they are not unanimous in their advise. The views of the different organisations can deviate from each other. If they give a recommendation, this indicates that the organisations which have been consulted agree with each other on the advise given to the Commission. The European social partners' organisations are not obliged to give an advise and neither have they to await a request from the Commission to give their advise. They can also advise the Commission at their own initiative. The subjects on which the Commission has to consult the social partners are not limited to the ones mentioned in Title XI. In fact the social partners should be consulted with regard to proposals having a social or socio-economic significance. This means that they also should be consulted if the Commission submits proposals on the basis of the Articles 42, 158-162, and 125-130 EC Treaty. The Commission has drawn a list of European social partners' organisations which it will consult on social policy proposals. This list has been formulated on the basis of certain representativity criteria which the Commission has formulated itself. On the basis of these criteria the Commission will keep under review the list of organisations to be consulted. The European Parliament, the ECOSOC, and the social partners' organisations ETUC, UNICE and CEEP have formulated criteria on representativity as well. These criteria have not been taken over by the Commission. I think however that certain of the criteria formulated within these other gremia are very valuable and should be seriously considered by the Commission. I have formulated a list of the criteria in para. 4.3.5., which in my view should be used.

The social partners' organisations can try to start negotiations with each other at any moment they want. They do not have to wait until they are consulted by the Commission. However, from a political point of view it can in certain cases be better if the social partners' organisations wait until they have been consulted by the Commission before they start to negotiate. This is especially the case if they want their agreement to be turned into Community law. For this action they are dependent on the Commission, since this is the initiator of Community legislation. Although Article 138(4) EC Treaty does not explicitly state that the Commission has to remain passive during the negotiations between the social partners, I think it should. Article 138(4) EC Treaty reflects the interaction between the Commission and the social part- 
ners' organisations. Especially if the social partners' organisations have been consulted twice and have indicated towards the Commission that they want to try to negotiate an agreement. In such a case it would be no more than reasonable for the Commission to await the outcome of these negotiations, provided of course that they will not take longer than nine months. In their negotiations, the social partners are not bound to the Commission proposal (if such a proposal has been formulated at all). But also here: if they want their agreement to be turned into Community law, it is wise to not deviate too much from the Commission proposal. The same goes for the choice of the negotiating parties. The social partners' organisations are completely free in this choice. However, if they want their agreement to be turned into Community law they better negotiate with those organisations that are also considered representative by the Commission. If the negotiations break down and the social partners cannot conclude an agreement, the Commission is free to continue its own legislative process without consulting the social partners again. This is only different if the Commission formulates a whole new proposal which substantially differs from the previous one. In such a case the consultation procedure of Article 138(2) and (3) EC Treaty has to be followed again. 



\section{CHAPTER 5}

\section{THE CONCLUSION OF EUROPEAN AGREEMENTS AND THEIR LEGAL EFFECTS}

\subsection{Introduction}

So far, several European agreements on working conditions have been concluded at interprofessional and sectoral level between workers' and employers' organisations, organised at European level. The first question is whether these agreements are to be regarded as collective agreements. I will discuss this item in para. 5.2. The second question is whether there are specific requirements for European agreements. I will discuss this in para. 5.3. The third question relates to the legal effects of European agreements. Are legal effects created if a European agreement is concluded? If yes, which ones and for whom? The legal effects of European agreements will be discussed in paragraphs 5.4-5.8. Finally, in paragraph 5.9 some conclusions will be drawn.

It should be noted that in this chapter only the legal basis for the legal effects of European agreements will be discussed. Questions related to enforcement and the actors who can enforce certain rights and obligations will be dealt with in Chapter 6. Furthermore, I will explicitly exclude from this chapter the implementation of the European collective agreement by the Council of Ministers of the EC, as has happened with the three intersectoral agreements and certain sectoral agreements so far. This implementation will be discussed in part III of my thesis. In this Chapter and Chapter 6, I will discuss the European agreement which will be implemented by the national affiliates of the signatory parties, in accordance with the procedure prescribed in Article 139(2), first part EC Treaty.

\subsection{A European collective agreement?}

Article 139(1) EC Treaty states:

"Should management and labour so desire, the dialogue between them at Community level may lead to contractual relations, including agreements."

Article 139(1) EC Treaty mentions "contractual relations, including agreements". This phrase indicates that "contractual relations" is a broader concept than "agreements", for agreements are one form of contractual relations. In the French, German and Dutch texts different terms are used. The French text speaks of "relations conventionelles y compris des accords". The German text uses the term "vertragliche Beziehungen" for contractual relations and "Vereinbarungen" for agreements. The Dutch text uses the concepts of "con- 
tractuele betrekkingen" and "overeenkomsten". The only thing that we can say at this moment is that according to the words in Article 139(2) EC Treaty, agreements are meant to be implemented, while such a requirement is not made for contractual relations. ${ }^{1}$ Furthermore, the European agreements concluded so far all mention in their preamble that they are agreements and not contractual relations. I think therefore that contractual relations must be understood as other forms of understanding which do not take the form of an agreement, for example the arrangement that parties will meet regularly to discuss items of mutual interest.

Can European agreements concluded on the basis of Article 139(1) EC Treaty be regarded as collective agreements? According to Kampmeyer, it is obvious from the words used in Article 139(1) EC Treaty that "agreements" are not collective agreements. Nor can this be derived from the context of this provision. Article 136 EC Treaty refers among others to the Community Charter of the Fundamental Rights of Workers. This Charter in turn distinguishes between "collective agreements" at national level and "contractual regulations" at European level (Article 12). ${ }^{2}$ Indeed, if we look purely at the text, Kampmeyer is right. But do these European agreements not fulfil the requirements of collective agreements? The problem is that each Member State has its own definition of collective agreements. A global definition can be found in ILO documents. ILO Recommendation no. 91, concerning Collective Agreements, gives a definition of collective agreements. In contrast to Conventions, Recommendations of the ILO need not to be ratified by the Member States. Recommendations give rise to no binding obligations but provide guidelines for national policies and action. Nevertheless, Recommendations represent an international consensus on the subject dealt with, and are invariably included in national labour laws. Under Article 19(6) of the ILO Constitution, Recommendations must be brought to the attention of the appropriate national authorities, and governments must submit reports to the supervisory bodies on the action taken to comply with this obligation. ${ }^{3}$ Sometimes a Recommendation is preferred above a Convention because situations with which the subject matter deals vary too much from country to country. That was also the reason for opting for a Recommendation on the subject of collective agreements. ${ }^{4}$ Since all Member States of the EU are a

1 Also T. Gilles, Das Zustandekommen und die Durchführung von Sozialpartnervereinbarungen im Rahmen des Europăischen sozialen Dialogs, p. 195.

2 E. Kampmeyer, Protokoll and Abkommen über die Sozialpolitik der Europăischen Union, p. 89. Also M. Blank, Europăische Kollektivvertrăge und Sozialer Dialog. In: W. Däubler, M. Bobke and K. Kehrmann (eds.), Arbeit und Recht. Festschrifte für Albert Gnade, p. 655.

3 E. Osieke, Constitutional law and practice in the International Labour Organisation, Dordrecht/Boston/Lancaster, 1985, p. 211.

4 R. Blanpain (ed. in chief), Encyclopedia of International labour law and industrial relations, N. Valticos and G. von Potobsky, International labour law., suppl. 163, Octo- 
member of the ILO, 5 the Recommendation might serve as a good source of inspiration to see whether European agreements fulfil the requirements of this definition. In Article 2 of Recommendation no. 91, the term "collective agreement" is defined as:

“(...) all agreements in writing regarding working conditions and terms of employment concluded between an employer, a group of employers or one or more employers' organizations, on the one hand, and one or more representative workers' organizations, or, in the absence of such organizations, the representatives of the workers duly elected and authorised by them in accordance with national laws and regulations, on the other."

So far, European agreements have been:

- in writing

- on working conditions and terms of employment

- between a group of employers and workers' organisations.

However, the provisions of the ILO Conventions and Recommendations are meant to be applied at national level. ${ }^{6}$ European-level bargaining was not foreseen by the ILO, although the right to affiliate to international unions and employers' organisations was explicitly recognised in ILO Convention no. 87 on the Freedom of Association and Protection of the Right to Organise. ${ }^{7}$ Nevertheless, the ILO definition on collective agreements can serve as a valid touchstone. Furthermore, we can properly assume that this definition fits closely with the definition of collective agreements in most Member States. In order to answer questions on the legal consequences of these agreements, we need to define the legal character of European agreements.

Furthermore, Article 6(2) of the ESC can serve as a valid touchstone. This provision states that the parties to the ESC undertake to promote machinery for voluntary negotiations between employers or employers' organisations and workers' organisations with a view to the regulation of terms and conditions of employment by means of collective agreements. From this definition, we can conclude that there are two conditions for collective agreements: they must be the result of voluntary negotiations between employers (organisations) and trade unions, and they must regulate the terms and conditions of

ber 1994, para. 458. Also: International encyclopedia of comparative law, Volume XV, B. Hepple (ed.), Labour law, 1984, Chapter 12, F. Smidt and A.C. Neal, Collective agreements and collective bargaining, point 62 .

5 See home page of the ILO.

6 Also Walz, who is of the same opinion. S. Walz, Multinationale Unternehmen und internationale Tarifvertrag, p. 138; Also the report of G. Lyon-Caen for the European Commission, "Op zoek naar Europese collectieve arbeidsovereenkomsten", October 1972, Doc. V/855/72-N (Limited distribution), p. 19. 
employment. These two conditions have been fulfilled as regards the European agreements concluded so far.

Finally, the case-law of the ECJ gives certain hints as regards a definition of collective agreements. In the opinion of Advocate-General Jacobs in the cases Albany, Brentjens and Drijoende Bokken ${ }^{8}$, a point of departure can be found for the definition of a collective agreement. A-G Jacobs formulated a criterion for determining when a collective agreement falls under the prohibition of Article 81(1) EC Treaty (the anti-trust provision). Although in these cases the definition of collective agreements is linked to the question whether or not they should enjoy antitrust immunity, it can nevertheless serve as a good source of inspiration. He gives three conditions: First a collective agreement must be made within the formal framework of collective bargaining between both sides of industry. Unilateral coordination between employers unconnected with the collective bargaining process should not be automatically protected, whatever the subject of the coordination may be. Secondly, the agreement should be concluded in good faith. In that context account must be taken of agreements which apparently deal with core subjects of collective bargaining such as working time but which merely function as cover for serious restriction of competition between employers on their product markets. Thirdly, the collective agreement must deal with core subjects of collective bargaining such as wages and working conditions and not directly affect third parties or markets. The test should be whether the agreement merely modifies or establishes rights and obligations within the labour relationship between employers and employees or whether it goes beyond that and directly affects relations between employers and third parties, such as clients, suppliers, competing employers, or consumers. ${ }^{9}$ If we apply these three conditions to the European agreements concluded so far, it can be concluded that they serve the definition given by A-G Jacobs and thus can be regarded collective agreements. The ECJ in these cases has given a definition of collective agreements (in the context of the antitrust provisions), which is not as narrow as the one from A-G Jacobs. It its judgement in the Brentjens-case, the ECJ stated that agreements concluded in the context of collective negotiations between management and labour in pursuit of the social policy objectives as laid down in Article 2 and Article 136 EC Treaty must, by virtue of their nature and purpose, be regarded as falling outside the scope of the anti-trust provision of Article 81(1) EC Treaty. ${ }^{10}$ The phrase of A-G Jacobs that "the collective agreement must deal with core subjects of collective bargaining such as wages and working conditions and not directly affect third parties or Judgment of 21-09-1999, Drijvende Bokken (Rec.1999,p.I-6121). In chapter 1, I have already mentioned these cases.

9 Considerations 191-193.

10 Consideration 57. 
markets", is not taken over by the ECJ. For the ECJ it suffices that the agreement has been concluded in pursuit of the social policy objectives as laid down in Article 2 and Article 136 EC Treaty. The ECJ links the social policy purpose as laid down in Article 2 and 136 EC Treaty with the means to achieve that purpose prescribed in Article 139(1) EC Treaty, namely agreements between management and labour. Since this definition of the ECJ is broader than the one given by the A-G, it covers the European agreements concluded so far as well.

The definitions of a collective agreement laid down in international documents and formulated by the ECJ can serve as a valid touchstone for the preliminary conclusion that European agreements can be regarded collective agreements. The European agreements concluded so far fulfil the criteria for collective agreements given by these international documents and the ECJ.

\subsection{Requirements for valid European collective agreements}

In most Member States, ${ }^{11}$ specific rules on valid collective agreements exist. These rules stipulate when an agreement is to be regarded a valid collective agreement. It considers for example rules with regard to the concluding parties, ${ }^{12}$ such as the rule that a collective agreement may only be concluded by representative social partners' organizations. ${ }^{13}$ Furthermore, there can be rules with regard to the decision-making procedure, such as that negotiating parties need a mandate from their members ${ }^{14}$ and the procedure with regard to the negotiations. ${ }^{15}$ There can also be rules on the form that the agreements need to have, such as the requirement that the agreement should be in

11 For the references to the EC countries in the footnotes mentioned in this chapter, I used R. Blanpain (ed. in Chief), International Encyclopedia for Labour Law and Industrial Relations. For Austria: R. Strasser, Austria, suppl. 131, January 1992, point 519-588; For Belgium: R. Blanpain, Belgium, suppl. 185, November 1996, point 1-622; For Denmark: P. Jacobsen and O. Hasselbalch, Denmark, suppl. 209, September 1998, point 617-672; For Finland: A.J. Suviranta, Finland, suppl. 224, September 1999, point 341-392; For France: M Despax and J. Rojot, France, suppl. 77, May 1987, point 547618; For Germany: M. Weiss and M. Schmidt, Germany, suppl. 230, May 2000, point 347-376; For Great Britain: B. Hepple, Great Britain, suppl. 134, April 1992, point 460469; For Greece: T.B. Koniaris, Greece, suppl. 111, April 1990, point 385-409; For Ireland: M. Redmond, Ireland, suppl. 178, February 1996, point 417-441; For Italy: T. Treu, Italy, suppl. 207, June 1998, point 380-468; For Luxembourg : R. Schintgen, Luxembourg, suppl. 123, May 1991, point 491-527; For Portugal: M. Pinto, Portugal, suppl. 107, December 1989, point 680-843; For Spain: M.A. Olea and F.R. Sanudo, Spain, suppl. 239, February 2001, point 589-644; For Sweden: A. Adlercreutz, Sweden, suppl. 199, September 1997, point 511-575.

12 L.e. in Finland, Portugal, Germany, Sweden, and Austria.

13 I.e. in Luxembourg, Spain, France (only for trade unions), Greece, and Belgium.

14 L.e. in Portugal and France.

15 L.e. in Portugal. 
writing ${ }^{16}$ and the obligation to publish or notify ${ }^{17}$ the agreement. Finally, there can be rules on the content of the agreement, ${ }^{18}$ such as the rule that the content may not be contrary to national or international law, ${ }^{19}$ or that it must contain at least one employment condition. ${ }^{20}$ Is it possible to also formulate such rules at European level for European agreements?

The formulation of requirements for valid collective agreements at European level is risky because there is a large variation among the Member States when it comes to this point. I will therefore restrict myself to certain general requirements which are, in my view, necessary to be fulfilled if European collective agreements are to play an important role alongside legislation by the Community institutions. I will discuss four items: requirements with regard to the concluding parties; requirements with regard to the bargaining procedure, requirements with regard to the form of the collective agreement and finally requirements with regard to the content of the agreement. Also here, I will use ILO standards and national standards in various Member States as sources of inspiration.

\subsubsection{Requirements with regard to the concluding parties}

In certain Member States, ${ }^{21}$ it is stipulated in the law that only trade unions and employers' organisations that are representative may conclude legally enforceable collective agreements. In other countries, ${ }^{22}$ such requirement is absent. I am not inclined to formulate a representativity requirement for European organisations as long as their agreements are not turned into Community law. I consider that very small organisations of workers and employers may also conclude valid collective agreements, because the agreements will only apply to the members of the concluding parties. That does not alter the fact, though, that collective agreements can also have a certain effect on sectors or enterprises that are not covered by it, especially when the agreement covers important sectors and/or large enterprises. This effect will, however, be diminished the smaller the organisations are that have concluded the agreement. I do think, though, that trade unions and employers' organisations should be stable organisations and not formed only for the occasion of concluding a European agreement. Economic interest associations

16 I.e. in Finland, Luxembourg, Germany, Spain, Sweden, France, Austria, Greece, Belgium, and The Netherlands.

17 I.e. in Finland, Luxembourg, Belgium, Germany, Spain, France, Austria, and Greece

18 I.e. in Portugal, Luxembourg, Spain, Great Britain, and The Netherlands.

19 I.e. in Denmark, France, Austria, Ireland, Great Britain, and Belgium.

20 I.e. in Finland.

21 See para. 5.3. footnote 13.

22 I.e. The Netherlands, Denmark, Sweden, Great Britain, Ireland, Portugal. 
like cartels and trusts are likewise incapable of concluding a collective labour agreement. ${ }^{23}$

Furthermore, the signatory organisations should be bona fide and their internal decision-making procedures should be democratic, so that there is a guarantee that members are able to influence the actions of their association. They should also have the furtherance of employers' or employees' interests as one of their essential objects. Trade unions should be independent from the employers and vice versa. Employers may not be a member of trade unions or fulfil any functions in the organs of trade unions. The same goes for trade union members towards employers' associations. ${ }^{24}$ Furthermore, trade unions as well as employers' organisations should be independent from the European, national or local authorities. ${ }^{25}$ This is also a requirement mentioned in the ILO Convention no. 87. ${ }^{26}$ Furthermore, for a trade union to acquire the right to negotiate with an employers' organisation, it must have some members employed by the employer with whom they want to negotiate. Trade unions and employers' organisations should also have a corporate structure which guarantees its continuity. Finally, I already argued in chapter 2 that the organisations should have (a European concept of) legal personality.

\subsubsection{Requirements with regard to the bargaining procedure}

The EC Treaty describes no specific procedures for the conclusion of agreements. Neither do the three Commission Communications on the European social dialogue. Nor has the ECJ ruled anything on this issue. The only provision we have is Article 139(1) EC Treaty. From interviews with, and rules of procedures from, the ETUC, UNICE and CEEP, a procedure for the conclusion of collective agreements can nevertheless be described.

First, the respective organisations need the consent of their national affiliates to enter into negotiations on behalf of them. Subsequently, every organisation (ETUC, UNICE and CEEP), composes a negotiating delegation in accordance with its own internal procedures. These delegations negotiate with each other on the content of an agreement. This negotiating phase can take months because consensus has to be reached. There is no voting procedure. Employees as well as employers have certain bottom lines. If they cannot agree, there will be no agreement. In the future, procedural rules are to be

Also the report of G. Schnorr for the Commission, "De mogelijkheid van collectieve arbeidsovereenkomsten op Europees niveau", March 1961, Doc. V/2128/61-N, p. 24.

24 Also the report of G. Schnorr for the Commission, "De mogelijkheid van collectieve arbeidsovereenkomsten op Europees niveau", p. 25.

25 Also the report of G. Schnorr for the Commission, "De mogelijkheid van collectieve arbeidsovereenkomsten op Europees niveau", p. 26. 
further developed with the help of practical experience, but some general rules could be formulated already. Hereafter, I will try to formulate some ideas about such rules.

By concluding an agreement, the European management and labour organisations actually serve as an agent for their national members. They conclude the agreement on behalf of their national member associations. It therefore seems fair to require that they need their explicit authorisation to do that. This authorisation can be derived from the mandate given them by the national members. The issue of the extent to which European-level organisations are mandated to bargain on behalf of their members has long been an obstacle to the development of European-level collective bargaining. In Article 13 of the ETUC Constitution it is stated that the Executive Committee shall determine the composition and mandate of the delegation for negotiations with European employers' organisations in every case. This decision shall have the support of at least two thirds of the member organisations directly concerned by the negotiations. Decisions on the outcomes of negotiations with European employers' organisations shall be taken by the Executive Committee and shall have the support of at least two thirds of the organisations directly concerned by the negotiations, which shall have had the opportunity to hold internal consultations.

The UNICE statutes and rules of procedure do not explicitly state that the negotiating delegations should have a mandate. Like the ETUC, UNICE makes a difference between the decision to enter into negotiations and the decision to accept the outcome of the negotiations. Article 7.8. of its statutes says that:

\footnotetext{
"The decision to enter into negotiations in the framework of the dialogue between the social partners (...) may be approved by the Association only if at least four-fifths of the votes cast are in favour, the members entitled to vote being only those having voting rights and which are affected by the decision in question. Any draft agreement negotiated in the framework of the dialogue between the social partners may only be approved by the Association (i.e. UNICE) on the basis of consensus among all the members having voting rights and which are affected by the agreement in question."
}

According to the CEEP Rules of Procedure (Article 45), the opinion whether a European agreement should be concluded shall be issued by the General Assembly after consulting its Social Affairs Committee. The votes by representatives of the General Assembly shall be counted according to the weighting envisaged for the members of the European Council in Community texts, 
divided by two; fractions are rounded off to the next highest unit. ${ }^{2}$ Moreover, the decisions of the General Assembly shall only be valid if two-thirds of its members are present or represented and if at least half of the Sections are represented. ${ }^{28}$ Subsequently the Social Affairs Committee shall be given a negotiating mandate by the General Assembly, which consists of representatives of CEEP's full members (Article 9 of the CEEP Statutes). This General assembly may, according to Article 48, also revise this mandate at each phase of the negotiations. The General Assembly shall vote in the same way on the definite agreement. ${ }^{29}$

Sectoral organisations do not yet have specific provisions in their statutes regarding European collective bargaining. ${ }^{30}$ The internal decision-making procedure, however, is normally prescribed in such a way that involvement of national organisations is sufficiently guaranteed. For example, the statutes of the European Federation of Employees in Public Services (EUROFEDOP) state that the Congress establishes the policy of EUROFEDOP on all matters within its direct competence (Article 11). All affiliated organisations are member of the Congress (Article 10). Decision-making is done according to a special voting procedure. Every affiliate has a number of votes dependent on the number of its members (Article 13). It will probably be the Congress who decides on the question whether EURODEFOP will take part in the negotiations on European agreements. It is to be recommended that all European organisations who intend to conclude European agreements in the future have clear provisions in their statutes for the internal decision-making process. These will include provisions on the composition of the negotiating delegation, for example, as well as provisions on the internal decisionmaking procedure. There is also a general rule that parties to collective bargaining should have a mandate. Article II(6) of ILO Recommendation 163 of 3 June 1981, concerning the Promotion of Collective Bargaining prescribes that:

"Parties to collective bargaining should provide their respective negotiators with the necessary mandate to conduct and conclude negotiations, subject to any provisions for consultations within their respective organizations."

Ideas on how to streamline the mandating procedure are given by Bercusson. He has several suggestions: A single response could be required from all organisations in one country; common positions could be required among unions in different states or common responses could be required from EC

\footnotetext{
27 Article 10 of the CEEP Rules of Procedure.

28 Article 12 of the CEEP Statutes.

29 Article 49 of the CEEP Rules of Procedure.

30 At least not in 2001.
} 
sectoral organisations. ${ }^{31} \mathrm{I}$ consider that each organisation can make its own rules with regard to its internal decision-making procedure, as long as democratic decision-making is guaranteed. It could for example be required that the majority of the affiliated organisations should agree to a negotiating mandate, whereby "majority" means that at least $51 \%$ of all individual members is represented. Furthermore, I suggest that European organisations who lack a sufficient mandate from their national affiliates should not be allowed to conclude European collective agreements. If nevertheless they do, the agreements cannot be regarded as valid agreements in the sense of Article 139(1) EC Treaty. Furthermore, for example, in The Netherlands, it is prescribed that a trade union or employers' organisation may only conclude valid collective agreements if they are authorised to do so in their statutes. In this way it is avoided that organisations conclude agreements on behalf of their members while this was never the intention. ${ }^{32}$

It is recommendable that the principles for a bargaining procedure be laid down in an agreement between the bargaining organisations. Such an agreement will attach more importance to the bargaining procedure and it will provide a more permanent legal foundation for the bargaining procedure. It has appeared more than once that such agreements provide a very good legal foundation for collective labour agreements where nothing is stipulated about them in the law. ${ }^{33}$ Agreements on the bargaining procedure as regards the European social dialogue already exist between certain European social partners' organisations. ${ }^{34}$ Although these agreements do not prescribe a detailed procedure for collective bargaining at European level, they mark a certain willingness to establish rules on a collective bargaining procedure.

\subsubsection{Requirements with regard to the form of the agreement}

Certain general rules could be formulated with regard to the form of a European collective agreement. One of these rules should be that the agreement has to be concluded in writing. Not only will it be very difficult to prove the existence of the agreement when it remains oral, it is also laid down in inter-

25 P. Herzfeld Olsson, B. Bercusson, and N. Bruun (eds.), Transnational trade union rights in the European Union, p. 29.

32 Also the report of G. Schnorr for the Commission, "De mogelijkheid van collectieve arbeidsovereenkomsten op Europees niveau", p. 75.

33 Also the report of G. Schnorr for the Commission, "De mogelijkheid van collectieve arbeidsovereenkomsten op Europees niveau", p. 39, who gives certain examples from the past.

34 See the protocol between EUROCADRES and CEC for the European social dialogue of 8 July 1999, the agreement between ECF-IUF and HOTREC on the framework of their social dialogue at European level of 28 September 1998 and the memorandum of understanding on engagement in a social dialogue between CEI-Bois and EFBWW of 17 June 1994. 
national as well as national law that a written agreement should be the norm. ${ }^{35}$ Furthermore, Article 139(2) EC Treaty, first sentence speaks of the "signatory parties", which also implies that European agreements should be in writing.

It is also recommendable that the agreement itself stipulates which language version is the official version. This will avoid misunderstandings as regards the interpretation of the agreement.

Finally, agreements should be published in the Official Journal of the EC. ${ }^{36}$ Although it does not concern Community legislation here, it does regard documents which have consequences for many Community workers and employers. In order to create as much legal certainty as possible, they need to know which European collective agreements are in force. Since not many people read the Official Journal of the EC, it might be an idea to publish European collective agreements on the internet as well.

\subsubsection{Requirements with regard to the content of the agreement}

If the European collective agreement is to be regarded a collective agreement in the sense of the ILO definition, it has to contain provisions on working conditions. But it might also contain more general issues, such as provisions on the promotion of employment. As we have seen in para. 5.2., the ECJ stated in the Brentjens case that a collective agreement could be concluded in pursuit of the social policy objectives as laid down in Article 2 and Article 136 EC Treaty. This covers more than just working conditions. A European collective agreement is a private law agreement. It goes without saying that such agreements may not be incompatible with Community law and national law. ${ }^{37}$ Already in the van Gend en Loos case, it was decided that the Community legal order forms a direct source of rights and obligations for the Member State and the Community citizens. Private law agreements may thus not be contrary to these rights and obligations. ${ }^{38}$ Neither may private law agreements be contrary to fundamental human rights or against the public order. ${ }^{39}$ If European collective agreements are implemented by the national social partners' organisations, this will be done through national collective agreements. It is obvious that these agreements cannot be contrary to the national

35 See ILO Convention no. 91, Article 2(1). See furthermore para. 5.3. footnote 16.

36 Also the report of G. Schnorr for the Commission, "De mogelijkheid van collectieve arbeidsovereenkomsten op Europees niveau", p. 41.

37 Also P.J.G. Kapteyn and P. VerLoren van Themaat, Introduction to the law of the European Communities, p. 1061.

38 Case 26/62, Judgment of 05/02/1963, Van Gend en Loos/Administratie der Belastingen (Rec.1963,p.3).

39 Also the report of G. Lyon-Caen for the Commission, "Op zoek naar Europese collectieve arbeidsovereenkomsten", p. 42-43. 
legislation of the respective Member States. Deviation from the national legislation is thinkable if the collective agreement contains provisions which are more favourable for the one who is to be protected by it, than the provisions of the legislation. However, it will not always be easy to determine when a certain provision is more favourable than the national legislation.

\subsubsection{Conclusions}

Since there are no rules on valid European collective agreements as regards the concluding parties, the bargaining procedure and the form and the content of the agreement,,$^{40} \mathrm{I}$ have tried to formulate certain general rules myself. As long as a European collective agreement is not being implemented by Council decision it will only be applicable on the signatory parties and their members. Therefore, requirements with regard to the representative quality of the signatory parties are not necessary. However, for the future, other requirements on the signatory parties can be formulated. These requirements could be summarised as follows:

- The signatory parties should be bona fide;

- The internal decision making procedures should be democratic;

- The organisations should have the furtherance of their employers' or employees' interests as their essential objective;

- They should be independent from each other and the European, national and local authorities;

- They should have a structure that guarantees their continuity;

- They should have legal personality;

- Trade unions must have members by the employer with whom they want to negotiate.

With regard to the bargaining procedure it is essential that the bargaining organizations have a clear mandate from their national affiliates to enter into negotiations. Furthermore European social partners' organizations should be authorized in their statutes to conclude valid collective agreements at European level.

It is recommendable that the agreement is written. In order to avoid misunderstandings as regard its interpretation, it should be determined in the agreement which language version in the official version. The terms of the agreement have to be made available to the members of the signatory parties, since it has consequences for them. It should therefore be in writing and be published in the Official Journal and on the internet. As regards their content I suggest the requirement that European agreements must not be contrary to Community law and fundamental human rights. Neither may they be contrary to the national law of the Member States unless they contain provisions that are more favourable for the worker. 


\subsection{The legal effects of European collective agreements}

In most Member States, collective agreements result in legal rights and obligations for the signatory parties and their individual members. The question is whether legal rights and obligations are also created when European collective agreements are concluded and, if so, for whom? If such rights and obligations are created, will that be on the basis of Community law or on national law, or are perhaps other legal bases thinkable? First, I will give a short overview of all possible actors that will be legally affected by European collective agreements in para. 5.4.1. Then I will scrutinise the legal bases of these effects in para. 5.4.2. As already stated in para. 5.1., this chapter will deal only with agreements that will be implemented by the national affiliates of the signatory European organisations. So far, only two such agreements have been concluded in practice, namely the agreement between COPA and EFA on the improvement of paid work in the agricultural sector and the Framework Agreement on Telework, concluded between ETUC, UNICE/ UEAPME and CEEP. I will therefore use these agreements from time to time as an example in this chapter. Some preliminary remarks have to be made with regard to the agreement in the agricultural sector. On the $24^{\text {th }}$ of July 1997, a Recommendation Framework Agreement on the Improvement of Paid Employment in Agriculture was concluded between GEOPA/COPA, representing the employers and EFA/ETUC, representing the workers. The agreement does not state that it is an agreement in the sense of Article 139(1) EC Treaty. From the side of EFA it has been said that it is not an agreement falling under Article 138/139 EC Treaty. ${ }^{41}$ From the side of GEOPA/COPA the possibility that the agreement could fall under Article 139(1) EC Treaty was not a priori excluded.42 The Framework Agreement on Telework is clearly an agreement in the sense of Article 139(1) EC Treaty, since this Article is explicitly mentioned in Article 12, $1^{\text {st }}$ sentence of the agreement.

\subsubsection{Which actors can be legally affected?}

We have to bear in mind that European collective agreements are of a special kind. The signatory parties are European-level organisations. These European-level organisations consist in turn of national affiliates and these national affiliates have individual members. Therefore, there are various actors who can be legally affected by European collective agreements.

Firstly, the signatory parties, i.e. the European-level organisations. European organisations, for example COPA and EFA, sign an agreement that contains provisions in which rights and obligations are laid down. Some of these provisions are directed towards the signatory parties. In the COPA/EFA

41 Interview on the telephone with spokesperson of EFA, 19 April 2002

42 Interview on the telephone with spokesperson of GEOPA/COPA, 19 April 2002. 
agreement, a clause is included which states that "the signatory parties agree to take concerted action to implement measures to improve the employment situation in the agricultural sector and the rural sector in the EU". Clauses which are directed to the signatory parties are also included in agreements which have been turned into Community legislation. For example, in the three intersectoral agreements and one sectoral agreement (on working time in civil aviation), a clause is included which states that the signatory parties shall review the application/provisions of the agreement after a certain time. Such a clause is also put in the Framework Agreement on Telework. The legal effects on the signatory parties will be discussed in para. 5.5.

Secondly, there are the national affiliates of the European organisations that signed the European collective agreement. Sometimes, provisions in European collective agreements are directed towards the national affiliates of the signatory parties. For example, Article 7 of the agreement on working time in the agricultural sector states that the signatory parties recommend the national and/or regional and/or provincial professional and trade union organisations to develop negotiations of collective agreements on improving paid employment in the agricultural sector, on the basis of the European collective agreement. Article 12, $1^{\text {st }}$ sentence of the Framework Agreement on Telework says that this agreement shall be implemented by the memebers of UNICE/ UEAPME, ETUC and CEEP. Also, where agreements have been turned into Community legislation (on parental leave, part time work and fixed time work), provisions are directed towards the national social partners. Close reading, however, of these provisions shows that the signatory parties already presumed that their agreement would be turned into Community legislation. The provisions often begin with "Member States and/or social partners $(\ldots)^{\prime \prime}$. This implies that the signatory parties took into account that their agreement (when turned into Community law) would be implemented either by the Member States or by the national social partners' organisations on the basis of Article 137(4) EC Treaty. As stated in Article 137(4) EC Treaty, national social partners' organisations may also implement Directives. This is, however, a different kind of implementation than implementation on the basis of Article 139(2) EC Treaty. The legal effects on the national affiliates of the European social partners' organizations will be discussed in para. 5.6.

Thirdly, there are the individual workers and employers in the Member States. The sectoral agreement in the agricultural sector contains certain provisions which specify concrete rights and obligations for individual workers and employers. For example, Article 16.1 of the agreement states that "after a full year of employment, employees shall be entitled to four weeks annual leave $(\ldots)^{\prime \prime}$. Article $7,4^{\text {th }}$ sentence of the Framework Agreement on Telework states that the employer provides the teleworker with an appropriate technical support facility. Clauses for individuals are also included in the other intersectoral agreements. For example, in the European Framework Agreement 
on Parental Leave it is stated that workers, after their parental leave, shall have the right to return to their job. The sectoral agreements which have been, or will be, implemented by Council Decision, refer even more directly to rights and obligations for individual workers and employers. The legal effects on individual workers and employers will be discussed in para. 5.7.

Finally, there are the Member States. Especially in the intersectoral agreements, provisions are included which place obligations on the Member States. For example, in the European Framework Agreement on Parental Leave, Clause 2(7) states that Member States and/or social partners shall define the status of the employment contract or employment relationship for the period of parental leave. In para. 5.8. I will discuss whether obligations can be put on the Member States by means of European collective agreements.

\subsubsection{Legal sources to be used for determining the legal effects resulting from European collective agreements}

The easiest way to answer questions on the legal effects of European collective agreements is to determine, on the basis of private international law, which national law is applicable in each situation. Private international law, however, usually plays a role in relations between two or more parties from different countries. Here, it concerns agreements concluded at European level by European organisations. Furthermore, although private international law has been used in the past for international collective agreements, ${ }^{43}$ I think that for the future we should look for more international-based legal sources to answer question on the legal effects of European collective agreements. The reason is that by using international sources, the acceptance within the Community of European collective agreements will be greater than if we simply apply the law of one Member State to the agreements, especially because the collective labour laws of the Member States vary a great deal and are often the result of separate political and economic developments. Nevertheless, I will answer the various questions on legal effects of European collective agreements first on the basis of existing legislation. Besides this, I will use international-based legal sources in order to give possible solutions for the future. These are Community law, ILO documents, (since I have concluded in para. 5.2. that European agreements fulfil the ILO definition of collective agreements) and finally the so-called Principles of European Contract Law.

43 These cases are discussed in: U. Drobnig and H.J. Puttfarken, Arbeitskampf auf Schiffen fremder Flagge, Kehl am Rein/Arlington/Strasbourg, 1989, p. 43-44. 


\subsection{The legal effects on the signatory parties}

Do European agreements create legal rights and obligations for the signatory parties? In para. 5.2., I have argued that, according to the ILO definition of a collective agreement, European agreements concluded so far can be regarded collective agreements. That does not mean, however, that legal rights and obligations are created automatically for the signatory parties as a result of such agreements. In practically all Member States it is presumed that parties who conclude a collective agreement with each other, are bound to that agreement. Such binding effect can derive from a special act on collective agreements, ${ }^{44}$ or from general contract law. ${ }^{45}$ An exception is the UK, where a collective agreement is usually not a legally enforceable contract between the trade union and employers or employers' association. Nor is it a universally binding legal code. It is true that the UK is exceptional compared to the other Member States in this regard, but it illustrates that it is not self-evident to assume that at European level, the agreements concluded between the social partners create legal rights and obligations between them.

First the question on the legal effects for the signatory parties will be answered for the present situatian in para 5.5.1. The present situation is that on the basis of private international law, it has to be determined which national law is applicable to the legal relation between the signatory parties. On the basis of this national law, the legal character of the European collective agreement has to be determined and from that the legal effects of the European collective agreement on the signatory parties. In paras. 5.5.2., 5.5.3., and 5.5.4. it will be scrutinized whether international legal sources such as Community public law, Community contract law or ILO documents can be used to determine the legal character of the European collective agreement and, on the basis of that, the legal consequences of it for the signatory parties.

If there are legal effects on the signatory parties, how do they take form? In other words: what would be concrete rights and obligations for the signatory parties? I will give some possible answers on this question in para. 5.5.5. In para. 5.5.6. some conclusions will be drawn.

\subsubsection{The present situation}

Since a European collective agreement is an international agreement, the question is whether private international law should be used to determine its legal effects. If we want to use private international law to scrutinise the legal rights and obligations between the signatory parties, we should first investigate whether there is a conflict of laws. A conflict of laws involves situations

44 For example Germany, Spain, Sweden, Finland, The Netherlands and Belgium.

45 For example Italy, and Ireland. 
in which there are ties with more than one legal system. One of the criteria for defining the international character of a contract is when one or more of the obligations of the parties set out in the contract are to be performed in different legal systems. ${ }^{46}$ As regards the legal relation between the signatory parties however, no such situation occurs. The European collective agreements concluded so far have been signed in Brussels and the signatory parties were all residing in Brussels. Furthermore, the performance of their obligations does not take place in another country than Belgium. This means that private international law is not applicable to the legal relationship between the signatory parties and national law is thus applicable. In this case that will be Belgian law ${ }^{47}$ unless the contracting parties decided otherwise. That is, however, not the case for the European collective agreements concluded so far. We cannot, however, take the Belgian Act concerning Collective Bargaining Agreements and Joint Committees of 5 December 1968 as our legal basis (hereafter called the 1968 Act). This Act has been written for collective agreements concluded by specific trade unions and employers' organisations. Only collective agreements concluded by employers' representative organisations and workers' representative organisations fall under the Act. In Article 1(4) in conjunction with Article 3 of the Act, a definition is given of these organisations:
"1. Inter-occupational organisations of workers and employers established at the national level and represented on the Central Economic Council and the National Labour Council (...);
2. the occupational organisations affiliated to, or forming part of, an interoccupational organisation referred to in para. 1;
3 . the employers' organisations which, (...), are declared to be represen- tative by the Crown on the advice of the National Labour Council.
The national inter-occupational and occupational organisations approved under the Act of 6 March 1964 (...) shall also be deemed to be represen- tative employers' organisations." 48

European organisations of workers and employers do not fulfil the conditions of this definition. They are not represented in the Belgium Central Economic Council and the National Labour Council, nor are they declared to be representative by the Belgium Crown on the advice of the National Labour Council. Finally, they are not approved under the Act of 6 March

46 Council Report on the Convention on the law applicable to contractual obligations by M. Giuliano and P. Lagarde, OJ C 282/1, 31-10-1980, p. 10. See also W.J. Slagter, Grensoverschrijdende contracten. In: B. Wessels and T.H.M. van Wechem (eds.), Contracteren in de internationale praktijk, Deventer, 1994, p. 5.

47 See also A. Ojeda-Aviles, Sind Europarische Tarifvertrăge "blosse Empfehlungen", In: T. Klebe, P. Wedde, and M. Wolmerath (eds.), Recht und soziale Arbeitswelt, Festschrift für Wolfgang Dăubler zum 60 Geburtstag, Frankfurt am Main, 1999, p. 536.

48 Translation found in R. Blanpain (ed. in Chief), International Encyclopedia for Labour Law and Industrial Relations, Belgium. 
1964. Therefore it is not possible to use this Act as a legal basis to determine whether there are any legal effects for the signatory parties as a result of the conclusion of a European collective agreement. I have argued in para. 5.2. that the European collective agreements concluded so far are collective agreements, because of the fact that they fulfil the definitions given in international documents of the ILO and in the ESC, as well as the "definition" given by the ECJ. However, to be subject to the $1968 \mathrm{Act}$, it is not only required that it concerns collective labour agreements but also that specific organisations of workers and employers conclude the agreement, namely the ones mentioned in Article 3 of the 1968 Act. Since the European organisations do not belong to these specific organisations, we cannot use the 1968 Act to determine the legal effects of European collective agreements on the signatory parties. So if we apply Belgian law to European collective agreements, we have to determine the legal effects on the signatory parties with the help of other legal sources. One of these sources could be Belgian contract law, if at least we can determine that the European collective agreement falls under the Belgian concept of "contract" as laid down in the Belgian Civil Code. Article 1101 of the Belgian Civil Code defines a contract as "an agreement by which one or more persons obligate themselves toward one or more persons to give, to do or not to do something". One can only speak of a contract if an offer is made by one party to the other party and if the last one accepts the offer. ${ }^{49}$ In short, it can be said that in Belgian law any seriously intended agreement which is not contrary to public order or to a peremptory statutory text is a contract. ${ }^{50}$ It is implied that the parties possess the necessary capacity, and it is implied also that the parties intend to create legal obligations. ${ }^{51}$ Any natural or legal person possesses the necessary capacity to conclude a contract, unless he has been declared incapable thereof by law (an example of an incapable natural person is a minor). ${ }^{52}$ In Chapter 2 I have explained that a number of European social partners' organisations lack legal personality. Do they have the necessary capacity to conclude a contract then? In Belgium, de facto associations do not have the capacity to conclude contracts or to act in legal proceedings, at least in the name of their members, except in cases provided for by the law..$^{53}$ This is different however, if they are mandated by their members to contract in their name or to act in legal proceedings in their name. ${ }^{54}$ Even if an organisation has not such a specific mandate, but has given the impression towards a third party that he had a mandate, he can be held liable for the consequences of his acts towards this third party..$^{55}$ As

49 J. Herbots, Contract law in Belgium, Deventer, 1995, point 37.

50 J. Herbots, Contract law in Belgium, point 44.

51 J. Herbots, Contract law in Belgium, point 35.

52 Article 1123 of the Belgian Civil Code.

53 W. van Eeckhoutte, Sociaal Compendium Arbeidsrecht, 1997-98, , Diegem, 1997, point 310 , where he refers to a number of cases that have been brought before Belgian courts.

54 L. Cornelis, Algemene theorie van de verbintenis, point 30.

55 See the famous Cuivre et Zinc judgment of the Belgian Cour de Cassation (Cass., 20 
regards the intention to be legally bound: such an intention is not present where the agreement contains an express provision negating the intention. Whether a particular phrase has this effect is a question of construction. One often uses the terms "gentlemen's agreement, letters of comfort, letters of intention, memorandum of understanding or heads of agreements". The use of these terms indicates that the parties did not have the intention to be legally bound. ${ }^{56}$ The conduct of the parties has, however, to be considered. If, for example, the parties start to perform on the basis of the agreement, ${ }^{57}$ this could be taken as an intent to be bound.

Let us apply this definition to the European agreements concluded so far. The agreements have been concluded after long and extensive negotiations by which offers have been made and accepted. The parties are bona fide organisations which are established in accordance with (in most cases) Belgian law. They also have the necessary capacity to conclude European collective agreements. But what about the most important aspect: the intention to be legally bound? Provisions on the binding character of the agreement for the signatory parties hardly exist in all European collective agreements concluded so far. In the intersectoral agreement on part time work however, a sentence is included in the preamble which could illustrate an intention to be bound. It states:

"It (the agreement) illustrates the willingness of the Social partners to establish a general framework for the elimination of discrimination against part time workers."

A similar phrase with regard to fixed time work has been included in the agreement on fixed time work. ${ }^{58}$ In the sectoral agreements on working time, there is nothing explicitly stipulated on the willingness to be bound by the signatory parties. The agreement on working time in the agricultural sector also seems to imply little such intent. The agreement uses the words "recommendation framework agreement", and it also states explicitly that it represents a "mutual act of trust". A mutual act of trust can hardly, however, be put on a par with a contract. The Framework Agreement on Telework even calls its agreement a "voluntary agreement". ${ }^{59}$ It is not clear whether these words indicate that it concerns a gentlement's agreement here.

So, from the statements of the concluding parties there are not many clues for the assumption that the signatory parties intend to be legally bound. What

June 1988, J.T. 1989, 547).

56 J. Herbots, Contract law in Belgium, point 135. See also L. Cornelis, Algemene theorie van de verbintenis, Antwerpen, 2000, point 23.

57 L. Cornelis, Algemene theorie van de verbintenis, point 28.

58 Preamble.

59 Article 1, 5 th consideration. 
about their conduct? Before Articles 138 and 139 were included in the EC Treaty, the European social partners' organisations issued many joint opinions on various subjects. These opinions were not intended to be binding on the parties. Since the inclusion of the Articles 138 and 139 into the Treaty, the social partners can still issue such opinions. Alongside these opinions we see that agreements are also concluded in which explicit reference is made to Article 139 EC Treaty. Why would the European social partners' organisations conclude agreements instead of issuing opinions, if they did not want to be bound to these agreements? A possible answer is that the European organisations only wanted to create obligations for their national affiliates by means of these agreements. After all, the idea is that European agreements will be implemented. This is explicitly laid down in Article 139(2) EC Treaty. So far, all agreements except one have been or will be implemented through a Council Decision. As regards the agreement in the agricultural sector there is a different situation since this agreement will not be turned into a Council Decision. The language used in this agreement is also different, compared to the other agreements. The European organisations merely make recommendations and also the title of the agreement is "recommendation framework agreement", while the title of the other agreements is "framework agreement "." Hêre arso, the sociar partners 'organisations have opted tor an agreement and not for a joint opinion, which is an indication that they wanted more than just to state certain ideas without any legal implications. The intention of this agreement is that it serves as a minimum basis for the national affiliates if these start collective negotiations at national level. ${ }^{60}$ This means in my view that the signatory parties also agree to make an effort to influence their national affiliates to implement the agreement. It is their intention to formulate a framework with minimum rules that has to be used for collective bargaining at national level. The formulation of such a framework would make no sense if subsequently nothing would be done with it. I therefore consider that it is at least the intention of the signatory parties to bind themselves and each other with regard to the obligation to influence their members. They bind themselves in the sense that they avoid acting against the words and spirit of the European collective agreement, but also by trying to avoid that their members act against the provisions of the European collective agreement. In this sense, the European collective agreements concluded so far can be regarded contracts in accordance with Belgian contract law. The concluding parties can perhaps not enforce every provision against each other, but I think they can address each other if they act in total nonconformity with the agreement, or allow that national affiliates so do.

60 See Article 7 of this agreement. This is different for the Framework Agreement on Telework, where a clause is included stating that "This agreement does not prejudice the right of social partners to conclude, at the appropriate level, including European level, agreements adapting and/or complementing this agreement in a manner which will take note of the specific needs of the social partners concerned. 


\subsubsection{International legal sources}

\subsubsection{Community public law}

The Commission Communications on the European social dialogue remain silent on the legal effects of European agreements on the social partners which result from the conclusion of a European agreement. The other institutions of the EU, such as the European Parliament, the ECOSOC or the Council of Ministers also remain silent on this issue. And what about the intention of the Treaty makers? Did they intend European agreements to be legally binding documents for the signatories? To answer this question we have to look at the words of Article 139 EC Treaty. Para. 2 of this provision states that agreements shall be implemented. It would be contradictory to order implementation of agreements while at the same time these agreements would not be binding between the signatory parties. ${ }^{61}$ So from the words of Article 139(2) EC Treaty, it seems logical to assume that the Treaty makers wanted legal rights and obligations to be created between the signatory parties. According to Bödding, however, the EC Treaty has been concluded as a treaty under international public law. It contains the rights and duties of the Community institutions towards each other and towards the Community citizens. It is not the intention of Community law to create rules on the relationship between private parties who have entered into a private law agreement. ${ }^{62}$ This might be true, but there are, at Community level, developments towards a harmonisation of contract law. I will discuss this hereafter.

\subsubsection{Community contract law}

At this moment there are already various directives which harmonise the legislation of the Member States on the legal aspects of certain types of contracts. ${ }^{63}$ The Commission has issued a Communication on European contract law. ${ }^{64}$ The areas concerned by the Communication include contracts of sale, and all kinds of service contracts, including financial services. The Communication continues by stating that in certain areas of private law contracts are, given the complexity of relationship between the parties concerned, only one of the tools of regulation. These areas, such as employment law and family

61 Also T. Gilles, Das Zustandekommen und die Durchfuhrung von Sozialpartnervereinbarungen im Rahmen des Europaischen sozialen Dialogs, p. 196; This is however possible in for example the UK. In the UK, the collective agreement is usually not an enforceable contract between the trade union and the employer or employers association. The main legal effect of the collective greement is as an express or implied or customary term of individual contracts of employement, In: R. Blanpain (ed. in Chief), International Encyclopedia for Labour Law and Industrial Relations, the UK.

62 Also B. Bodding, Die europarechtlichen Instrumentarien der Sozialpartner, p. 77

63 See for an overview of these Directives: COM(2001) 398 final, annex 1.

64 See the Communication of the Commission on European contract law, COM(2001)398 final, Brussels 11 July 2001. 
law, give rise to particular issues and are not covered by the Communication. ${ }^{65}$ Therefore, the ideas of the Commission expressed in its Communication and the Directives on the harmonization of certain contracts which already exist, are not very useful for the European collective agreements which are discussed in this thesis. Contract law is however a valid source of inspiration to determine the legal effects of collective agreements on the signatory parties. Jacobs already used contract law in his thesis to assume binding legal effect for signatory parties of a collective agreement, at least for certain countries ${ }^{66}$ Jacobs could, however, only use national contract law because his thesis was mainly about collective labour law in various Member States of the EC. And although we have seen in para. 5.5.1. that Belgian contract law can be used to determine the legal effects of European collective agreements on the signatory parties, it is perhaps for the future better to look for more common rules. This would enhance the acceptance of European agreements in all Member States. Such rules should be based on broad comparative research. The Principles of European Contract Law (hereafter called the PECL) provide an example. ${ }^{67}$

About 1980, a Commission on European Contract Law was formed, to draft the PECL.68 The PECL aro basod upon broad comparative research.69 The Commission consisted of some 17 members recruited from all Member States of the EU, although the members were not selected by their governments and did not represent the countries in an official capacity. They were mostly academics or practising lawyers who were free to make up their minds independently and without any governmental instruction. The PECL are drafted as articles and are accompanied by comments, which include illustrations wherever deemed useful to illustrate their content and scope, and references to other pertinent international instruments of unified law. They are not intended to become legislation, they serve more as a source of inspiration. Since codification of private law is fragmentary, it is important to have available a general set of principles from which inspiration may be derived by national and international courts to interpret the provisions of the existing uniform law, to fill the gaps which it presents and to offer a background, however, informal, for new law to be created. That is also the way in which I will use them. According to Hartkamp, the PECL will certainly have an important scholarly and educational value. Concerning the European legal scene, they will encourage the emerging trend to find the common denomi-

$65 \operatorname{COM}(2001) 398$ final, p. 6.

66 A.T.J.M. Jacobs, Het recht op collectief onderhandelen in rechtsvergelijkend en Europees perspectief, p. 199.

67 The PECL are also sometimes called the Lando-Principles.

68 The first version (part I), was published by Martinus/Nijhoff/Kluwer Academic Publishers i 1995. The complete version (part I and II), was made available for the public in December 1999.

69 There are also the UNIDROIT Principles of Contract Law, but these are only applicable to commercial contracts, and that is not the case here. 
nator of different private law systems in Europe in order to construct a new ius commune Europaeum. The PECL will also, by the sheer fact of their existence, prove that a reasonable compromise between the various legal systems of Europe can be reached. ${ }^{70}$

The question is whether a European collective agreement can be regarded a contract according to the definition of contract given by the PECL.

If we take a look at the PECL we see that in Article 2:101 it is stated:

"A contract is concluded if:

(a) the parties intend to be legally bound, and

(b) they reach a sufficient agreement

without any further requirement."

Let us apply these definitions to the European collective agreements that have been concluded so far.

Intention to be legally bound

Article 2:102 of the PECL states:

The intention of a party to be legally bound by contract is to be determined

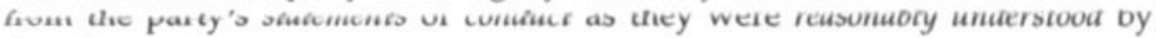
the other party.

As already said in para. 5.5.1., in the European collective agreement concluded so far, there are very few provisions on the binding character of the agreement for the signatory parties. What do the PECL mean by the phrase: "conduct as they were reasonably understood by the other party"?

Conduct can be expressed by the fact that the parties to an agreement have already proceeded to implement the agreement. ${ }^{71}$ It is more difficult to assume binding effect if the validity of the contract is brought into question before either party has performed. ${ }^{72} \mathrm{~A}$ closer look at the actual contract law of the different European legal systems shows that a mere promise with the intention to be legally bound, without any other element of formality or consideration, hardly ever constitutes an adequate reason for enforcing performance. ${ }^{73}$ It must be reasonably apparent to any promisee that something like an intention to be legally bound does not exist as an abstract concept, but is invariably conditioned by the type of transaction and the relevant circumstances, especially the degree of reciprocity involved.

70 A. Hartkamp, Principles of contract law. In: A Hartkamp, M. Hesselink, E. Hondius, C. Joustra and E du Perron (eds.), Towards a European civil code, Nijmegen, 1998, p. 108-111. See also J. Smits, Europees privaatrecht in wording, Metroreeks, no. 32, Intersentia, 1999, p. 53 and further.

71 H. Kötz and A. Flessner, European contract law, Oxford, 1997, p. 43.

72 H. Kötz and A. Flessner, European contract law, p. 47.

73 M. Storme, The binding character of contracts. In: A Hartkamp, M. Hesselink, E. Hondius, C. Joustra and E du Perron (eds.), Towards a European civil code, p. 243. 
It is also reasonably apparent that certain types of statement and conduct, especially if in written form, indicate a more serious intention to be legally bound than others. ${ }^{74}$ The fact that the European collective agreements are all in written form, and bear the signature of the European organisations, indicates more willingness to be bound than if the agreement were in oral form.

As regards the agreement in the agricultural sector, the signatory parties have put pressure on their affiliates in Portugal to adapt their collective agreements to the European collective agreement. ${ }^{75}$ This indicates that they have undertaken efforts to implement the agreement. However, spokespersons of both signatory parties confirmed that there has been hardly any control on the (correct) implementation of the agreement. The Joint Committee, mentioned in Article 17 of the agreement and which has certain control function, has, according to the spokespersons, not undertaken any action since the conclusion of the agreement. The agreement has not been evaluated but nevertheless still exists.

\section{Sufficient agreement}

Article 2:103 of the Principles states:

"There is sufficientagreementif the terms."

(a) have been sufficiently defined by the parties so that the contract can be enforced, or

(b) can be determined under these Principles."

The terms of the contract must leave no room for misunderstandings. It must be possible to enforce a contract; otherwise it is not necessary to enter into one. The clause in the three intersectoral agreements stating that the signatory parties shall review the application/provisions of their agreement after a certain time, seems clear enough to be enforced, although it is not clear before which court. Bödding states that because of the uncertainty with regard to the choice of the court, obligatory effect of European collective agreements must be excluded at this moment. According to him, the parties have no legal means to act when one of them breaks the agreement. The agreements of the social partners have therefore to be regarded as a starting point for further Community action. ${ }^{76} \mathrm{I}$ think that this presumption is too easy. It is true that the EC Treaty does not contain provisions on enforcement of European collective agreements. That does not mean, however, that private law cannot give us any indications on the possible ways to enforce them. There are thus a few indications to presume that the European social partners' organisations had the intention to be legally bound and that there is sufficient agreement between them. The fact that the signatory parties of the

74 M. Storme, The binding character of contracts. In: A Hartkamp, M. Hesselink, E. Hondius, C. Joustra and E du Perron (eds.), Towards a European civil code, p. 246.

75 Interview with Mrs. Feller from COPA, 1 April 1998.

76 B. Bodding, Die europearechtlichen Instrumentarien der Sozialpartners, p. 82. 
agreement in the agricultural sector have put pressure on certain national affiliates to implement the European collective agreement is an indication that they want to oblige their national affiliates to use the European collective agreement as a minimum basis for collective bargaining at national level. As 1 already said in para. 5.5.1. it is also difficult to see this completely separately from the obligations of the signatory parties towards each other. I think that the signatory parties can at least expect from each other that they will not do anything which is against the words or the spirit of the agreement that they concluded. They may also expect from each other that they do their best to implement the agreement by influencing their members. So also according to the PECL, I would say that the European collective agreement concluded in the agricultural sector can be regarded as being a contract.

\subsubsection{ILO documents}

In para. 5.2. I argued that European agreements concluded so far fulfil the conditions of the definition of collective agreements as laid down in ILO Recommendation no. 91. In that same Recommendation, Article 3(1) states:

"Collective agreements should bind the signatory parties thereto and those on whose behalf the agreement is concluded (...)."

This means that also the ILO, of whom all Member States of the EU are a member, recognises a legal relation between the signatory parties as a result of a collective agreement. As I said, however, in para. 5.2., it would be somewhat over-hasty to assume that because of the ILO Recommendation, European agreements are binding between the signatory parties. Nevertheless, the ILO Recommendation can serve as a valid touchstone to argue that collective agreements create legal effects for the signatory parties.

\subsubsection{Alternative idea}

It is questionable whether the signatory parties to the European collective agreements concluded so far, wanted their agreements to be regarded as contracts. The European trade unions who were a party to the European collective agreements probably favour the idea of the agreements being contracts more than do the employers organizations. In order to avoid legal consequences which were not wanted by the signatory parties to European collective agreements I suggest an alternative idea, consisting of two options.

The first option is that legal effects on the signatory parties as a result of European agreements will be presumed, unless the signatory parties explicitly state in their agreement that they do not want these legal effects. The second option is that legal effects will not be presumed unless the signatory parties state in the agreement that their intention is to create legal effects. The 
advantage of this method is that, whatever option is chosen, it is always clear what the parties want and misunderstandings can be avoided.

\subsubsection{Content of the legal effects on the signatory parties}

What should the concrete rights and obligations of the signatory parties of the European agreements be? It is not my intention to make an extensive and detailed list of these rights and obligations. The European social dialogue is still in a sort of experimental phase and only a few agreements have so far been concluded. Moreover, I think also that a difference should be made between intersectoral agreements, sectoral agreements and company agreements. Article 139(1) EC Treaty speaks of agreements in general terms. As in the Member States, different levels of collective bargaining can also take place at European level.

I think that intersectoral and sectoral European agreements can serve as a framework for collective negotiations at national level. They provide the minimum standards for national bargaining. Two basic obligations for the signatory parties should, in my opinion, flow from the conclusion of European collective agreements: the obligation to exercise influence on their members to start collective negotiations at national level on the basis of the provisions of the European collective agreement and the peace obligation. ${ }^{7}$ An obligation for the concluding parties could be to restrain the members of their organisation from violating the provisions of the collective agreement. One could even go a step further and say that the concluding parties should make concrete efforts to influence their national affiliates to start collective negotiations at national level on the basis of the provisions of the European collective agreement. This could, for example, be done by providing precise information about the conclusion and contents of a collective agreement, or by taking measures within the association against recalcitrant members and expelling them if necessary.

In most Member States, it is also a rule that the parties to a collective agreement abstain from industrial action so long as the agreement is in force, the so-called peace obligation. This rule could also be transposed to the European collective agreements, at least as far as the industrial action relates to the provisions of the collective agreement ${ }^{78}$ and as long as the other party keeps up with it's obligations as described in the European collective agreement. For example, the agreement in the agricultural sector states in Article 8, $2^{\text {nd }}$ sentence that the normal effective annual working hours must not exceed 1827 hours per year. It would be reasonable to expect that as long as this agreement is in force, the EFA would not call a strike in order to enforce a

77 Also the report of G. Schnorr for the Commission, "De mogelijkheid van collectieve arbeidsovereenkomsten op Europees niveau", p. 40, 41 and 46.

78 Industrial action at European does take place, although rarely. See chapter 6. 
maximum normal effective working load of, say, 1500 hours per year. I would say that industrial action is legitimate as long as there is no European collective agreement concluded on the matter which is at stake in the industrial action because it is often the only way to force employers to the negotiation table.

Company agreements at European level, for example between a multinational company and its workers in various Member States, can lay down more detailed provisions on working conditions. To avoid misunderstandings about which legal rights and obligations are created for the signatory parties, it would be wise to list these rights and obligations in the agreement. ${ }^{79} \mathrm{I}$ would also say that for company agreements the peace obligation and the duty of the trade union to influence its members to obey the agreement, are the basic obligations for the signatory parties.

\subsubsection{Conclusions}

Private international law cannot be used for scrutinising the legal effects of a European collective agreement on the signatory parties. At this moment Belgian contract law would have to be used for this purpose. There are certain clues, although few, for the assumption that the signatory parties of European agreements concluded so far intend to be legally bound and that the European agreements can therefore be regarded as a contract in accordance with Belgian contract law. Belgian collective labour law is not applicable to European collective agreements because the European social partners' organizations do not fulfil the conditions laid down in the Belgian Act Respecting Collective Bargaining Agreements and Joint Committees of 5 December 1968.

For the future, it is recommendable to use international-based legal sources since the issue is one of European collective agreements concluded between European social partners' organizations. Community public law does not state anything about the legal relation between the signatory parties of a European collective agreement. Nor is there a Community contract law which could serve as an auxiliary construction to determine the legal consequences of European collective agreements for the signatory parties. In the future, instruments could be adopted which harmonise the general contract law of the Member States. In that case there would exist a common concept of a contract that could be used as a touchstone to determine the legal character of European collective agreements. Inspiration for such harmonisation can be found in the Principles of European Contract Law (PECL). If the PECL definition of a contract is applied on the European collective agreement concluded in the agricultural sector, this agreement can be regarded a contract. Finally the ILO Recommendation no. 91 can also serve as an inspiration

79 Also T. Gilles, Das Zustandekommen und die Durchführung von Sozialpartnervereinbarungen im Rahmen des Europarischen sozialen Dialogs, p. 208. 
source for the legal relation of the signatory parties to European agreements, since they prescribe that collective agreements shall bind the signatory parties.

In order to avoid unwanted legal consequences, future rules on European collective agreements could provide the possibility for the signatory parties to lay down in their agreement whether they want to create legal effects towards each other. Concrete legal rights and obligations for the signatory parties could consist of the peace obligation and the duty to influence their member(s) (organisations) to implement the agreement, or at least to abstain from acting in a contrary way to the European collective agreement. Other rights and duties for the signatory parties can better be put in the agreement itself in order to avoid misunderstandings.

\subsection{The legal effects on the national affiliates of the European organisations}

Are there legal effects for the national affiliates of the European organisations after the European collective agreement has been concluded? And if yes, which ones? As in para. 5.5. I will make use of different legal bases in order to answer these questions. As an illustrative example for this paragraph, I will use the recommendation framework agreement in the agricultural sector, as well as the Framework Agreement on Telework, since these are so far the only ones that will be implemented by the national social partners' organisations. Usually, sectoral agreements are more suitable for implementation by the national social partners' organisations than intersectoral agreements. The intersectoral European organisations also have intersectoral national affiliates as their members. In some Member States it is very unusual to bargain at intersectoral level on detailed aspects of labour conditions (Germany, The Netherlands). In other Member states intersectoral agreements are concluded, but they mainly contain recommendations to the sectoral organisations (Sweden, Finland). Moreover, intersectoral agreements cannot regulate all kinds of labour conditions in detail. The differences between the branches and the Member States are too big for intersectoral agreements to remain a good alternative for social legislation at Community level on issues which can best be dealt with by workers and employers instead of the legislator. This is also the case in certain countries where intersectoral collective bargaining takes place (France). Furthermore, intersectoral agreements can be concluded on issues such as the regulation of the relations between the intersectoral organisations and their members. Intersectoral agreements can also be concluded for more specialized conditions when it is practical to have the same rules for all members, such as the equal treatment for part-time workers and full-time workers. This also happens in certain Member States (Denmark). However, when a certain branch of industry wants its labour conditions to be geared to another, sectoral agreements 
are the best instrument. This will especially be the case in sectors which are "internationalised", like the transport sector, and in cross-border regions where workers and employers easily move from one country to another to work. The legal sources to be used for determining the legal effects on the national social partners' organizations will be Community law (para. 5.6.1.), the internal rules of the European organizations in combination with private international law (para. 5.6.2.), and ILO documents (para. 5.6.3.). The content of the legal effects for the national affiliates is discussed in para. 5.6.4. Finally, in para. 5.6.5. some conclusions will be drawn.

\subsubsection{Community law}

Article 139(2) EC Treaty states that agreements concluded at Community level shall be implemented. This will be either by Council decision or by the national social partners' organisations. The words of this provision thus imply that the European agreement cannot stand by itself. Something has to be done with it. The word "shall" is a very strong verb and implies an obligation. The French text uses the word "intervient", the German text the word "erfolgt" and the Dutch text the word "geschiedt". In all four languages the phrase is formulated in such a way as to leave no doubt that agreements are going to be implemented one way or another. ${ }^{80}$ The words "shall be implemented" in para. 139(2) EC Treaty are in my view directed towards the national affiliates or the Council, not to the signatory parties of the European agreement, because the European signatory parties cannot implement the agreement. They can only conclude the agreement. This means that if the Council does not implement the agreement, for whatever reason, the formulation of Article 139(2) suggests that it has to be implemented by the national social partners' organisations.

Are there, besides the text of Article 139(2) EC Treaty, also other arguments thinkable to assume that the Treaty makers wanted to create a legal obligation for national social partners' organisations to implement European agreements? What would be the reason(s) to promote a European social dialogue and to harmonise national collective agreements by obliging the national social partners' organisations to implement European agreements? The tasks of the Community are amongst others "the raising of the standard of living" ${ }^{81}$ Social policy is one of the factors that determine the standard of living. Raising of the standard of living does not only have to be seen from the financial point of view, but it means also the improvement of the social position of the workers by regulation on issues like working time, vacation,

80 For Bercusson the answer whether the word "shall" in Article 139(2) EC Treaty implies a legal obligation, is still not clear. B. Bercusson, Maastricht: a fundamental change in European labour law. In: Industrial Relations Journal, vol. 23, 1992, p. 187 as well as B. Bödding, Die europearechtlichen Instrumentarien der Sozialpartners, p. 97. 
sick pay etc. This requires action from those who are involved in the creation of the common market, i.e. the Member States, but also economic and social bodies. They have to search for solutions at European level. ${ }^{82}$ The Commission affirms that the development of the social dialogue at European level is a key tool for the modernisation and further development of the European social model. One of its actions in order to achieve this objective is to promote interaction between social dialogue at European and national level..$^{83}$ This implies that the Commission regards the link between the social dialogue at European level and its implications at national level as important. The harmonisation of working conditions may not lead to equalisation, but has to serve the objective of social progress. The social dialogue offers a perfect instrument in the form of collective agreements, because such agreements reflect the balance between the social demands on the one hand and the economic possibilities to meet these social demands on the other. ${ }^{84}$ However, favouring the European social dialogue and the implementation of European collective agreements at national level is one thing. Obliging the national social partners' organisations to implement European collective agreements by means of collective agreements at national level is another. I consider that the Community or national government(s) cannot put such an obligation on the social partners' organisations. The right to collective bargaining cannot be turned into an obligation. Public authorities can promote collective bargaining, but the measures taken by them with a view to promoting collective bargaining, shall not be so conceived or applied as to hamper the freedom of collective bargaining ${ }^{85}$ According to Article 4 of ILO Convention no. 98 concerning the application of the principles of the right to organise and to bargain collectively, the public authorities have a duty to take measures to facilitate collective bargaining. Nothing, however, in this Article places a duty on the governments to enforce collective bargaining by compulsory means with a given organisation; such an intervention would clearly alter the nature of the bargaining. ${ }^{86}$ Public authorities should refrain from any interference which would restrict the right to bargain freely or impede the lawful exercise thereof. ${ }^{87}$

82 G. Schnorr, De mogelijkheid van collectieve arbeidsovereenkomsten op Europees niveau, p. 1.

83 Social Policy agenda, COM (2000) 379 final, Brussels, September 2000, points 4.3.1. and 4.3.2.

84 G. Schnorr, De mogelijkheid van collectieve arbeidsovereenkomsten op Europees niveau, p. 3. This is being conformed by the Commission in it's progress report on the implementation of the medium-term social action programme 1995-97, point 17

85 Article 8 of the ILO-Convention no. 154, concerning the promotion of collective bargaining. See also Article 6(2) ESC, which states that the contracting parties to the Charter undertake to promote machinery for voluntary negotiations between employers and workers.

86 Digest of decisions and principles of the Freedom of Association Committee of the Governing Body of the ILO, 1985, para. 614.

87 Digest of decisions and principles of the Freedom of Association Committee of the 
But even if we assume that implementation by the national social partners' organisations is utterly voluntary, there is another problem. A practical aspect is that not all European agreements are suitable for implementation by the national social partners' organisations. For example, the three intersectoral agreements concluded so far contain provisions which are directed to the Member States. The reason is that already before or during the negotiations it was clear that the intention of the signatory parties was to submit their agreement to the Council in order to have it implemented through Community legislation. I think that if an agreement is concluded which contains provisions directed towards Member States, it must be clear beforehand that the Council is willing to turn it into legislation. That requires clear and frequent communication between the European social partners, the Commission and the Council. In such case it will be very rare (but not impossible) that if an agreement is subsequently concluded, the Council will reject it. If the Council nevertheless does and it is not possible to change its mind, I think that the signatory parties should change the agreement in such a way that it is suitable for implementation by their national affiliates, or withdraw the agreement.

\subsubsection{The internal rules of the European organisations and private international law}

Almost all European social partners' organisations have a constitution/ statutes and/or internal rules of procedure. In these documents, the structure of the organisation is laid down and rules are developed on the relation between the European organisation and its national affiliates. It states which organs the European organisation has and what the functions of these organs are. Procedures for internal decision-making are also described. This is to make sure that democratic decision-making is guaranteed and that the European organisation cannot take important decisions without any involvement or without the approval of at least the majority of its members. Also COPA, the European employers' organisation which concluded the agreement in the agricultural sector has internal rules of procedure for the conclusion of European agreements. ${ }^{88}$ COPA's counterpart to this agreement, EFA, is a trade union committee of the ETUC but nevertheless has its own constitution. Special rules on the conclusion of European agreements and their legal effects on the national affiliates are, however, not included in this constitution.

Can national affiliates of European organisations be legally obliged to implement European collective agreements on the basis of the internal rules of the European organisation? In other words: is the fact that they are a member of a European organisation and therefore have accepted its internal rules enough to conclude that they should implement the decisions of the Euro-

Governing Body of the ILO, 1985, para. 583.

88

These rules, however, are not available for publication. 
pean organisation? The answer to this question is related to issues such as mandate and agency.

In earlier works, authors have stated that in certain Member States of the EU there does not necessarily have to be specific legislation on collective agreements to make sure that these agreements will have legal effects on the members of the concluding parties. ${ }^{89}$ Legal effects can also be derived from legal concepts such as agency and mandatory statements. Probably the same can be said of agreements concluded at European level. National affiliates give their mandate to the European organisation for negotiations within the framework of Article 139(1) EC Treaty. If they give their mandate, they do this to let the European organisation conclude an agreement which is intended to be implemented. It would be illogical to assume subsequently that the national affiliates are not obliged to implement the agreement. The European collective agreement would otherwise be meaningless. Because national organisations became a member of the European organisation whose competence it is, among others, to conclude European collective agreements, they are bound to implement these agreements. They have given their permission to the European organisation to start negotiations at European level and they have democratically decided on the approval or disapproval of a draft European collective agreement. Acceptance of a European collective agreement means in my view acceptance of the fact that this agreement should be obeyed when the national organisations start collective bargaining in their own country. Otherwise the conclusion of a European collective agreement does not make any sense at all.

The mandate will be drafted in accordance with a certain internal voting procedure, as described in the internal rules of the European organisations. The internal rules also often state which national law is applicable to them. ${ }^{90}$ This is helpful because issues on mandate can differ from country to country. If the internal rules of a European organisation state which national law is applicable on them, the provisions of that national law on mandate are then to be applied. If the internal rules do not stipulate any specific national law we have to see whether private international law can be of any help to determine which law is applicable. The European agreement is, at least in most of the cases, concluded in Brussels. The obligations of the national affiliates, however, have to be performed in another country. The obligations of the Dutch affiliates have to be performed in The Netherlands, the obligations of the German affiliates have to be performed in Germany etc. I think therefore that the rules of Belgian private international law have to be applied in order to determine which national law is applicable to the internal rules of the

89 See A.T.J.M. Jacobs, Het recht op collectief onderhandelen in Europees en rechtsvergelijkend perspectief, p. 219-222.

90 For example the statutes of CESI, CIC, COESS, EBW, ECSA, Euratex, Eurofedop, FIEC, IRU and UEAPME. 
European organisations.91 Subsequently the mandate rules of the applicable national law have to be used to determine the legal effects on the national affiliates of the European organisations.

And what about the theory of agency? Can that be used to presume legal effects of European collective agreements on the national affiliates? Also at national level, the theory of agency and mandates have been used to explain the legal effects of collective agreements on the members of the signatory parties.92 Agency normally occurs when someone (the principal) authorises another person (the agent) to conclude a contract with a third party. The effect will be that the principal is bound to the third party and that the agent remains an outsider. He is not bound by the contract. Agency is thus about the relation between a principal and a third party because the agent has acted for the principal. ${ }^{33}$ It does not say anything about the relation between the agent and the principal. One could apply the agency construction to the European collective agreement in the agricultural sector as follows: COPA acts as the agent of its national affiliates (the principals) and concludes on behalf of them a contract with EFA (the third party). At the same time, however, EFA is also the agent who concludes an agreement on behalf of its national affiliates (the principals) with COPA (the third party). So both European social partners' organisations are at the same time agent and third party.

For the relationship between the European organisation and its own national affiliates, the agency-construction is thus not very useful, since agency is not about the relationship between the agent and his principle. For the relation between the European organisation and the national affiliates of the other European organisation however, the agency-construction could be useful. The possibility that someone (the principal) may become legally bound and entangled by the acts of someone else (the agent) is the essential characteristic of agency. ${ }^{94}$ The normal legal consequences triggered by the mechanisms of agency and representation are that the rights and obligations arising under the transaction concluded by the agent are automatically attributed to the principal. Where the juridical act executed by the agent is a contract entered into with a third party, the contractual relationship is established directly between the principal and the third party. To a very large extent, this relationship is identical to the relationship that is created when both parties to a contract conclude it personally. The rights and obligations created by the contract are attached to the principal and the third party personally. The

91 Belgian private international law is, with regard to private law agreements, determined by the European Convention on the Law Applicable to Contractual Obligations of 19 June 1980.

92 See A.T.J.M. Jacobs, Het recht op collectief onderhandelen in Europees en rechtsvergelijkend perspectief, p. 219-222.

93 H.L.E. Verhagen, Agency in private international law, The Hague, 1995, p. 6.

94 H.L.E. Verhagen, Agency in private international law, p. 6. 
procedural consequence of this imputation of rights is that in a legal procedure the principal can sue the third party and vice versa. ${ }^{95}$ If we apply the foregoing to European agreements, the result is that, on the basis of the agency-theory, COPA could address the national affiliates of EFA if the lastmentioned would not implement the European agreement within the timelimit given to them. As with the mandate concept, the agency-construction differs from country to country. On the basis of private international law, probably Belgian private international law, it should first be determined which national agency-construction could be applied. An attempt has been made to harmonize the agency-constructions of the several Member States by means of the 1978 Hague Convention on the Law applicable to Agency. The Convention has, however, been ratified by a very few States ${ }^{96}$ and it can therefore not be assumed that the rules on agency laid down in this Convention are applicable to European collective agreements.

On the basis of theories such as mandate and agency, legal effects for national affiliates of European organizations can be assumed. These legal effects will, however, probably be different for the several national affiliates since the legal rules on mandate and agency also differ in the various EC countries. For the future it is therefore recommended that the national affiliates of the European signatory parties also sign the European collective agreement. In this way they will not be bound to the agreement via the mandate or agencyconstruction, but directly, like the European organizations themselves. Furthermore, it could be laid down in the European collective agreement which national law will apply to it. In this way the legal consequences for the national affiliates of the European organizations will be determined on the basis of national law.

\subsubsection{ILO documents}

The ILO documents support the idea that the signing of a collective labour agreement has legal effects for the members of the signatory parties. Article 3(1) of ILO Recommendation no. 91 states that collective agreements should bind the signatory parties and those on whose behalf the agreement is concluded. The phrase "those on whose behalf "probably relates to individual workers and employers, because the norms of the ILO documents are meant to be implemented at national level. However, since ILO Convention no. 87 concerning the freedom of association and protection of the right to organise, recognises that workers' and employers' organisations also have

95 H.L.E. Verhagen, Agency in private international law, p. 6. Also the report of G. LyonCaen for the Commission, "Op zoek naar Europese collectieve arbeidsovereenkomsten", p. 40.

96 I.e. Portugal, Argentina, France, and The Netherlands, see footnote no. 5 on p. 127 in H.L.E. Verhagen, Agency in private and international law. 
the right to affiliate with international organisations, ${ }^{97}$ it can be assumed that according to this ILO Convention legal effects should also apply to national affiliates of European organisations.

\subsubsection{Content of the legal effects on the national affiliates}

It is clear that European collective agreements have to be implemented. But what does the word "implemented" mean? In other words: what are or should be the concrete rights and obligations for the national affiliates? Since Community law does not give any answer to this question, it is the European social partners (and thus indirectly the national social partners' organisations) who decide what should happen with the European collective agreement, as long as something is being done with it. I would say that the European collective agreement should at least serve as a minimum basis when new collective negotiations take place at national level, after the European collective agreement has come into force. This can take several forms. Either the terms of the European collective agreement are translated in the language of the Member State and taken over in the national collective agreement. Or it can be stipulated in the national collective agreement that the European collective agreement is incorporated in it. This is also the view of the parties to the agreement in the agricultural sector.

Article 7 of the agreement between COPA/GEOPA and EFA states that:

"The signatory parties recommend, having regard to national practices and circumstances, the national and/or regional provincial professional and trade union organisations representing employers and workers in the agricultural sector in the Member States of the European Union to develop negotiations of collective agreements on improving paid employment in agriculture, including its working conditions, on the basis of this text.

In particular, the signatory parties recommend that, at the time of the negotiations conducted at national and/or regional and/or provincial level, they lead to the conclusion of agreements on the adaptation of working time on the basis of the minimum provisions proposed below."

It is clear from this text that the European collective agreement serves as a minimum. ${ }^{98}$ This flows also from Article 19(3) which states that:

“During negotiations conducted at national, regional and/or provincial level in order to develop this recommendation framework agreement, the social partners may apply or introduce more favourable provisions than those laid down in this text."

97 Article 5.

98 Such a provision has not been included in the Framework Agreement on Telework. 
Article 19(2) of the agreement states that the national agreements in force shall continue to apply. At first sight this seems to contradict Article 7. However, the idea is that as soon as new negotiations take place at national level, the European collective agreement shall serve as a minimum basis. This flows from the words "at the time of the negotiations conducted at national and/or regional and/or provincial level" in Article 7, second sentence. But as long as there are no new negotiations, existing agreements at national level remain in force, even if they are contrary to the European collective agreement. It is thus clear that the European collective agreement cannot replace existing national agreements, and I think that this is the best we can get at this moment. The European social dialogue is still in an initial phase and as long as there is no statute on European collective agreements, we should be satisfied with the fact that European collective agreements do not immediately replace existing national agreements. Moreover the employment situation in the various Member States differs too much to accept that European collective agreements immediately replace national collective agreements. A comparison can be made in this regard with Directives. For the implementation of Directives, Member States are usually given one or two years. The reason is that, as a rule, a Directive is an instrument of Community intervention, often with a view to the harmonisation of laws in a given complex of interrelated legislative provisions. ${ }^{99}$ European collective agreements which are to be implemented through national collective agreements can be seen as an instrument to harmonise to a certain extent the national collective agreements of the Member States. This harmonisation takes time because the content of these national collective agreements can be very different. It is also possible that the national collective agreements which already exist at the moment that the European collective agreement has been concluded, contain provisions which are contrary to the European collective agreement. This is indeed very likely since it would not be necessary to conclude a European collective agreement if the national agreements already contained the same provisions as the European agreement. The national affiliates who have to implement the European collective agreement, should therefore be given a certain time-limit to adapt their national agreements to the European collective agreement. After this adaptation has taken place, I would say that the national collective agreements may not be contrary to the European collective agreement. This is also so if these national agreements are withdrawn after a certain time and have been replaced by new ones.

\subsubsection{Conclusions}

The EC Treaty clearly states that European collective agreements have to be implemented, either by the Council or by the national social partners' organ-

99 P.J.G. Kapteyn and P. VerLoren van Themaat, Introduction to the law of the European Communities, p. 328. 
isations. Article 139(2) EC Treaty is directed to the Council or the national social partners. I consider, however, that the Treaty makers had better used the word "can" in Article 139(2) EC Treaty, instead of the word "shall". It is not for the legislator to decide whether and when national partners' organisations should conclude collective agreements. This is contrary to international labour law laid down in ILO documents. The obligations for the national affiliates should be determined on the basis of private law. The European organisations can oblige their national affiliates to take the European collective agreement as a minimum basis when they start bargaining at national level. The legal basis for such an obligation would lay in the internal rules of the European organisations in combination with private international law, and in particular in the doctrine of the mandate or mandatory statements. The mandate is often drafted in accordance with the internal rules of the European organisations. If the signatory parties have decided nothing in their agreement on the applicable national law, the rules of Belgian private international law have to be applied in order to determine which national law on mandate is applicable on these internal rules. The agency theory can be very useful to determine the legal relation between a European organisation and the national affiliates of the other European organisation, provided that the European collective agreement can be regarded a contract. Finally, ILO documents support the idea that European collective agreements are binding on the national affiliates of the signatory parties. As regards the content of the rights and obligations for the affiliated organisations, I would say that we should not formulate very far-reaching and detailed rules. It should, nevertheless, at least be clear that the European agreements have to serve as a minimum basis as soon as new negotiations at national level take place after the conclusion of the European agreement. Furthermore, a timelimit should be included in the European agreement for the negotiations to take place at national level.

\subsection{The legal effects on individual workers and employers}

What are the legal implications for individual workers and employers in the Member States as a result of the European collective agreement? In order to answer this question we have to distinguish two situations. The first is when the European collective agreement has been concluded and also been implemented through national collective agreements. The second is when the European agreement has not been implemented through national collective agreements, or has been implemented, though incorrectly. I will discuss each of these situations in the following. 


\subsubsection{The European collective agreement has been implemented through national collective agreements}

In para. 5.6.4., I argued that the obligation on the national affiliates of the European organisations is that they should use the European collective agreement as a minimum basis as soon as they start collective bargaining once European collective agreement has been concluded. If this has been done, there will be a national collective agreement which applies to the individual workers and employers. This national agreement can in certain Member States be extended erga omnes by the national authorities. ${ }^{100}$ This means that the agreement will apply to all workers and employers in the whole branch of industry, regardless of whether they are a member of a trade union or employers' organisation. If a European collective agreement has been implemented through national collective agreements, the terms of the European collective agreement will be reflected in the national agreements. In what way the individual workers and employers will be bound to the collective agreement depends on the law of the Member State in question. The legal effects for individual workers and employers as a result of the European collective agreement will be derived from national law. Collective agreements at national level can however also be terminated. The harmonisation of working conditions would remain very weak if national social partners' organisations could simply terminate collective agreements which they have concluded to implement a European collective agreement. ${ }^{101}$ It is therefore important to lay down that as long as the European collective agreement is in force, national collective agreements may not be contrary to them. So even if a national collective agreement were to be terminated, a new agreement would still have to respect the terms of the European collective agreement as long as this European collective agreement remains in force. This also implies in my view that the European collective agreement itself has to be reviewed regularly, for example every two years. The time-table for review depends on the content of the European collective agreement. If it is a framework agreement which contains very generally formulated clauses, the need for a timely review will be lesser than for an agreement with detailed clauses on, for example, pay.

\subsubsection{The European collective agreement has not been implemented through national collective agreements, or has been implemented incorrectly}

It is also possible that the national social partners' organisations take no account at all of the European collective agreement if they start negotiations at national level. In other words: the European collective agreement will be

100 For example in The Netherlands and in Belgium.

101 See also G. Schnorr, De mogelijkheid van collectieve arbeidsovereenkomsten op Europees niveau, p. 33. 
ignored. Another situation that can occur is that the European collective agreement is implemented, though incorrectly. The question is whether the European collective agreement in either such case still has legal effects on individuals, even if it has not been implemented through national collective agreements or has been implemented incorrectly. I will try to answer this question by using several legal bases.

\subsubsection{Community law}

The formulation of Article 139(2) EC Treaty gives the impression that direct legal effect of European collective agreements was not the intention of the Treaty makers. The provision explicitly states that European collective agreements "shall be implemented". The provision continues by stating which implementation methods are to be used. These are either a Council decision or implementation by the national social partners' organisations. So the Treaty does not give a legal basis for the presumption that European collective agreements have direct legal effects on individuals. It is, however, thinkable that this will be desirable in the future. I have argued ${ }^{102}$ that the national affiliates of the European organisations have a duty to implement European collective agreements. But what if these national organisations fail to implement the European collective agreement for whatever reason? In such a case, the individual (mostly the employee) can be the victim of the non-implementation. Take the example of the recommendation framework agreement in the agricultural sector. Article 16.1 of this agreement says that "after a full year of employment, employees shall be entitled to four weeks annual leave". Suppose that in a certain Member State employees are only entitled to three weeks paid annual leave. By not implementing the European collective agreement, employees will miss the right to four weeks paid annual leave. The only way in which direct effect of European collective agreements for individuals can be made possible on the basis of Community law is by means of specific Community legislation on European Collective Agreements. Such legislation however, does not exist yet. But that does not mean that it will never be drafted. It is therefore interesting to give some (theoritical) thoughts about the conditions which could be stipulated in such legislation for direct effect of European collective agreements.

\section{A. Conditions for the entering of direct effect}

The main rule should remain that European collective agreements have to be implemented by the national affiliates. This means however, that there should be a certain time limit within which they should implement the European collective agreement. Only if this time limit has expired, should direct effect apply. This time limit could be put into the European collective

102 Para. 5.6.4. 
agreement itself. Also if the European collective agreement has been implemented, though incorrectly, direct effect should apply.

There are also conditions which are specific for collective labour agreements ${ }^{103}$ which should be fulfilled if these agreements were to have direct effect on individuals.

In the first place, it is important to determine whether the individual worker or employer who claims that direct effect should apply, is a member of one of the national organisations which in turn is affiliated to the European organisations that concluded the European collective agreement in question. I would suggest that direct effect of European collective agreements can only apply if both the worker and the employer are a member of a social partners' organisation which in turn is affiliated to a European organisation.

In the second place, we have to look at the rationae personae of the European collective agreement. The individual who wants to derive rights from the European collective agreement has to be covered by its terms. For example, an employee working in the transport sector cannot derive rights from a European collective agreement concluded in the metal sector. Usually, a collective labour agreement contains a provision which sets out to whom the agreement applies. For example, the European Framework Agreement on Parental Leave states in Clause 1(2) that it applies to all workers who have an employment contract or employment relationship as defined by the law, collective agreement or practice in force in each Member State. It is thus clear that this agreement is an intersectoral agreement. It applies to all workers, regardless in which sector they work. The European Agreement on the Organisation of Working Time for Seafarers lays down in Clause 1(1) that the agreement applies to seafarers on board every seagoing ship, whether publicly or privately owned, which is registered in the territory of any Member State and is ordinarily engaged in commercial maritime operations. Strangely enough, the agreement in the agricultural sector does not contain a specific provision stating to whom the agreement applies. However, it frequently uses the term "agricultural workers" and it is clear that COPA and EFA represent the social partners in the agricultural sector.

\section{B. Conditions on the provisions to be directly applicable}

It can be argued that for the direct effect of provisions of European collective agreements, one should look at the agreement as a whole. For example one should scrutinise what the idea behind the European collective agreement is. It could be considered that the European collective agreement is formulated as a recommendation, rather than an instrument which creates concrete

103 I argued in para. 5.2. that the European agreements concluded so far are to be regarded as collective labour agreements. 
rights and obligations for workers and employers. I would regard such kind of agreements as undesirable, that is to say if they are explicitly concluded on the basis of Article 139(1) EC Treaty. If the European social partners' organisations want to formulate recommendations or programmes for the future, they already have a very good instrument at their disposal, namely the joint opinion. In these joint opinions (sometimes also called a joint declaration, proposal, resolution, guidelines, memorandum), the broad policy lines for a specific sector or for a specific subject are laid down. Examples at sectoral level are the opinion on the social aspects of the common agricultural policy, the opinion concerning Community action in the forestry sector, the opinion concerning the development of combined transport. Examples at intersectoral level are the joint opinion on vocational qualifications and certification, the joint opinion on women and training and the framework for the broad economic policy guidelines. ${ }^{104}$ So far, more than 150 joint texts have been concluded at sectoral level and about 35 joint texts at intersectoral level. ${ }^{105}$ I would therefore say that, even though the agreement in the agricultural sector of 1997 has the title "recommendation framework agreement", it cannot be regarded as just a recommendation but as a real agreement which creates legal effects for the signatory parties, their national affiliates and also, if the theory of direct effect is accepted, for individual workers and employers. It is generally taken that this agreement is different from the many joint opinions that have been concluded in this sector. ${ }^{106}$ The agreement itself does not explicitly say that it has been concluded within the framework of Article 139(1) EC Treaty, although it says in the preamble that the concluding parties "recognise each other's independent power of negotiations under (...) Article 4(1) of the Agreement on Social Policy" (now Article 139(1) EC Treaty, E.F.). Furthermore, the preamble says that "collective bargaining is an effective means of developing and implementing policies, aimed at promoting and improving employment". These phrases indicate that it was the intention of COPA and EFA to enter into negotiations with the aim of concluding an agreement on the basis of Article 139(1) EC Treaty. Otherwise, it would not be necessary to refer to Article 139(1) EC Treaty at all.

I think that we cannot suppose that the whole European collective agreement will be directly effective, but only certain provisions of it. I would say that the provisions should be unconditional and sufficiently precise in order to be directly effective on individuals. The provision should be precisely described

104 The text of these joint opinions can all be found in Social Europe, 2/95.

105 Industrial relations in Europe, 2000, Publication of the European Commission, DGV/D, Brussels, 2000, p. 17 and 20.

106 Industrial relations in Europe, 2000, p. 22; see also Framework agreement in agriculture: milestone in the European sectoral social dialogue, In: EIRONLINE, September 1997; see also European Social Dialogue of June 1998 (status report on the social dialogue 1997) in which the authors speak of a "real contractual relationship" between the concluding parties of the agreement, p. 13. 
in such a way that it is clear what the rights and/or obligations are for individuals. These rights and obligations should not be dependent on further implementation orders. In her thesis on good employment practice, de Wit poses the question whether recommendations of the Dutch Labour Association (STAR) should have direct effects on the relation between an individual worker and employer, without these recommendations first having to be implemented through collective agreements. ${ }^{107}$ In order to answer that question, she describes five groups of recommendations. I would like to draw inspiration from her thesis in order to make a classification of provisions in European collective agreements which are in my opinion suitable for direct effect. I will refer to provisions in the agreement in the agricultural sector and the Framework Agreement on Telework as much as possible when I use illustrative examples. However, I will also use other European collective agreements concluded on the basis of Article 139(1) EC Treaty as illustration.

In the fifth group, de Wit argues, there are recommendations which deal with subjects that are not at all suitable for direct effect on individual workers and employers. For example, obligatory provisions which regulate the relation between the signatory parties, or provisions which only contain vague declarations of intent. ${ }^{108}$ As regards the agreement in the agricultural sector, Article 1, first sentence would be such an obligatory provision. This provision states:

"The signatory parties agree to take concerted action to implement measures to improve the employment situation in the agricultural and rural sector in the European Union."

This provision is clearly directed towards the signatory parties, i.e. GEOPA/ COPA for the employers' side and EFA/ETUC for the workers' side. It can therefore not work between an individual employers and employee. A provision which only contains a vague declaration of intent is for example Article 3. This states:

"The signatory parties see the need to look for job-creating forms of synergy with other sectors of production: rural tourism, the environment and regional development."

In the fourth group there are the recommendations which are a little more concrete. They require more action from the parties than the mere promise that they will think about certain issues. However, they still remain quite vague. These recommendations should, according to de Wit, only be directly

107 M.A.C. de Wit, Het goed werkgeverschap als intermediair van normen in het arbeidsrecht, Deventer, 1999, especially para. 9.4.-9.8.

108 M.A.C. de Wit, Het goed werkgeverschap als intermediair van normen in het arbeidsrecht, p. 105-106. 
effective if the employer does nothing at all to implement them, without any motivation. ${ }^{109}$ An example could be Clause 6(2) of the European Framework Agreement on Fixed Term Work, stating:

"As far as possible, employers should facilitate access by fixed-term workers to appropriate training opportunities to enhance their skills, career development and occupational mobility."

The employer has an obligation, but this obligation is so vague that it is difficult to acquire direct enforceable rights from it. In the first place, the obligation exists only "as far as possible", as the provision states. Secondly, it is not clear what is meant by "facilitate access". How far does the obligation go to facilitate access? What kind of action is specifically necessary to facilitate access? Thirdly, what is meant by "appropriate training opportunities"? Who determines what is appropriate?

In the third group, there are recommendations which incite to a certain policy, but where the employer still has a huge amount of freedom in the way he implements this policy. ${ }^{110}$ For example Article 13a of the agreement in the agricultural sector, relating to the rest periods, states:

"daily rest: generally 12 hours during each 24 -hour period (...)".

The word "generally" suggests that deviation is possible from the 12-hours rest rule per day. There are no rules on when deviation is possible. If an employer deviates from this rule, I think that he should motivate it, but the fact remains that he has a certain amount of freedom. Another example is Clause $7(1)$ of the European Agreement on the Organisation of Working Time for Seafarers, stating:

"The master of a ship shall have the right to require a seafarer to perform any hours of work necessary for the immediate safety of the ship, persons on board or cargo, or for the purpose of giving assistance to other ships or persons in distress at sea."

On the basis of the European collective agreement, the master of the ship is bound by the provisions on working time. Under certain circumstances, however, he can deviate from these provisions. The question whether these circumstances are present is a question for the master of the ship. In this case, it is he who determines what is necessary for the safety of the ship or the per-

109 M.A.C de Wit, Het goed werkgeverschap als intermediair van normen in het arbeidsrecht, p. 106.

110 M.A.C de Wit, Het goed werkgeverschap als intermediair van normen in het arbeidsrecht, p. 106-107. 
sons on board. It is also he who determines whether other ships or persons are in distress at sea and therefore should be given assistance.

In the second group, there are provisions which lay down certain rules very clearly. The employer has almost no scope for policy making and the rules are not susceptible to more than one interpretation. There is, however, still no absolute obligation for the employer to follow the rule. ${ }^{111}$ Examples in the agreement in the agricultural sector cannot be found, but one can think of Clause 5(2) of the European Agreement on the Organisation of Working Time for Seafarers stating:

"Hours of rest may be divided into no more than two periods, one of which shall be at least six hours in length and the interval between consecutive periods of rest shall not exceed 14 hours."

This means that the employer has the choice between giving one period of rest or two periods of rest. The choice is thus very limited, though still present.

In the first group, there are the recommendations which create absolute and unconditional rights and obligations, which cannot be deviated from and which can only be interpreted in one way. ${ }^{112}$ An example in the agreement in the agricultural sector is Article 16.1:

"After a full year of employment, employees shall be entitled to four weeks' paid annual leave (...)."

Another example is Clause 11 on the European Agreement on the Organisaion of Working Time for Seafarers stating:

"No person under 16 years of age shall work on a ship."

The Framework Agreement on Telework contains many articles which create absolute and unconditional rights and obligations. For example Article 3, $4^{\text {th }}$ recital says:

"A worker refusal to opt for telework is not, as such, a reason for terminating the employment relationship or changing the terms and conditions of employment of that worker."

111 M.A.C. de Wit, Het goed werkgeverschap als intermediair van normen in het arbeidsrecht, p. 108.

112 M.A.C. de Wit, Het goed werkgeverschap als intermediair van normen in het arbeidsrecht, p. 108. 
I would say that the provisions falling in the fifth group are never directly effective, since they are either addressed to the signatory parties of the European collective agreement, which are not individuals, or because they contain very vague declarations of intention. The provisions of the fourth group can also hardly be directly effective. They only provide that the employer should have a certain policy in his company, but the way how to carry this out, or the conditions under which this should be done are not clear and concrete at all. The provisions of the third group are in my view directly effective, although there remains a certain amount of freedom as regards the way in which the obligations of the provision should be implemented. Provisions falling in the second group and first group should always be directly effective. For these provisions it is rather easy to determine whether they are to be obeyed by the workers or employer.

\section{Direct effect from one individual towards another}

European collective agreements, at least the two concluded so far that will be implemented throught the national affiliates, contain mainly rights and obligations for employers and workers. They will therefore be invoked by workers and employers towards each other. Claims from individuals towards the ones that should implement the European collective agreement, i.e. the national social partners' organisations, will be difficult because it is not always clear whom to address. For the implementation of European collective agreements, workers' and employers' organisations at national level are responsible together. In such case it is not always clear who exactly is to blame for the non-implementation. It is possible that a trade union wants to implement the European collective agreement, but that the employers' organisation is not willing to start collective bargaining and vice versa. Therefore, it should be stipulated in a future Community legislation on European collective agreements, that in case of non-implementation the European collective agreement can work directly from one individual towards another.

\subsubsection{Private international law}

As regards the conclusion of European collective agreements, Jacobs and Ojeda-Aviles argue that there is a chain of mandates. National organisations have given a mandate to the European organisation because these national organisations have already received a mandate from their individual members. According to Jacobs and Ojeda-Aviles, the power of this chain of mandates cannot be stopped halfway but resides in the whole length of the chain. Workers and employers are bound by what their final representatives have signed at European level. ${ }^{113}$ This would mean that direct effect of European collective agreements on individual workers and employers could be derived

113 A. Jacobs and A. Ojeda-Aviles, The European social dialogue - Some legal issues. In: A legal framework for European industrial relations. Report by the ETUI Research Network on Transnational trade union rights, Brussels, June 1999, p. 67. 
from the "mandate-chain". Seen from a private-law view, this might be correct. However, the fact remains that Article 139(2) EC Treaty explicitly stands in the way of direct effect of European collective agreements. Moreover, not all provisions of European collective agreements are suitable for direct effect, as stated in para. 5.7.1.1. I would therefore maintain the rule that European collective agreements as such have no direct effect. Only if certain conditions are fulfilled, as described in par. 5.7.1.1., could direct effect be allowed. National social partners' organisations should be given due time to implement European collective agreements. Only if they refuse to do this, or if they do this incorrectly direct effect can, in my opinion, direct effect occur.

\subsubsection{Conclusions}

Legal effects for workers and employers will be derived from national law if the European collective agreement has been correctly implemented by the national social partners' organisations. Difficulties only arise if European collective agreements have not been implemented or have been implemented incorrectly. To conclude that European collective agreements are directly effective on the basis of private international law is in my view not possible since the Treaty stands in the way of this. The EC Treaty does not give any rules for these situations. This would only be the case if there would be Community legislation on the legal effects of European collective agreements. The conditions for the application of direct effect should in the first place be that the time limit for the implementation of the European collective agreement has expired. Secondly, direct effect for individuals should only apply if they are a member of a social partners' organization which in turn is affiliated to a European organization. Thirdly the individual must fall under the rationae personae of the European collective agreement. Fourthly, only certain types of provisions can provide direct effect. The provisions of European collective agreements can be divided into five groups. Only provisions which fall into the fourth and the fifth group cannot be directly applicable in my view. It should be possible that provisions of European collective agreements have direct effect from one individual towards another. Claims against the national affiliates of the European employers' and workers' organisations will be difficult since it is often difficult to determine who exactly is to blame for the non-implementation.

\subsection{The legal effects of European collective agreements on the Member States}

When the Agreement on Social Policy was effected by signature of the Maastricht Treaty, the Member States added a declaration by Article 4(2), ${ }^{114}$ stating that: 


\begin{abstract}
"The eleven High Contracting Parties declare that the first of the arrangements for application of the agreements between management and labour, at Community level -referred to in Article 4(2)- will consist in developing, by collective bargaining according to the rules of each Member State, the content of the agreements, and that consequently this arrangement implies no obligation on the Member States to apply the agreements directly or to work out rules for their transposition, nor any obligation to amend national legislation in force to facilitate their implementation".
\end{abstract}

"The first of the arrangements" to which the Declaration refers is the implementation of European collective agreements through national collective agreements.

I will first discuss the legal status of this Declaration. After that, I will discuss the content of the Declaration.

\title{
5.8.1. The legal status of the Declaration by Article 139(2) EC Treaty
}

After the conclusion of the Amsterdam Treaty, Article 4(2) was renumbered as Article $118 \mathrm{~B}$ and the Declaration was put in italics. The front page of the Treaty stated clearly that "Declarations to the Final Act are in italics, in order to distinguish them from legally binding Treaty texts". In the consolidated version of the Amsterdam Treaty, when Article 118B was renumbered as Article 139, the Declaration has been numbered as Declaration no. 27. In an analytical explanation of the Amsterdam Treaty, done by the European Policy Centre in 1997, it is stated that:

"Declarations have no legally binding effects and do no more than express the intentions, policies or wishes of the parties to them - who may be all the Member States or, in some cases, one or two or more, but less than fifteen, Member States. However, they should not be ignored."

According to Bercusson, declarations such as the one by Article 139(2) EC Treaty are not granted any status before the ECJ.115 The Declaration was adopted by the Conference on the occasion of the signature of the Final Act of the Treaty of Amsterdam. ${ }^{116}$ In this regard the paper written by Toth in 1986, on the legal status of the Declarations, annexed to the Single European Act, is interesting. ${ }^{117}$ Toth compares the Declarations with the concept of "reservation" as defined by Article 2(1)(d) of the Vienna Convention on the Law of Treaties of 1969. A reservation is:

115 B. Bercusson, European labour law, p. 545

116 P.J.G. Kapteyn and P. VerLoren van Themaat, Introduction to the law of the European Communities, p. 1062.

117 A.G. Toth, The legal status of the Declarations annexed to the Single European Act. In: CMLR, vol. 23, no. 6, 1986, p. 803-812. 
"a unilateral statement, however phrased or named, made by a State, when signing, ratifying, accepting, approving or acceding to a treaty, whereby it purports to exclude or to modify the legal effect of certain provision of the treaty in their application to that state".

Toth concludes that the Declarations by the Single European Act could not be regarded as reservations because they expressed the common intentions of all the contracting states and could not be described as unilateral statements made by any one of them. ${ }^{118}$ This goes also for the Declaration by Article 139(2) EC Treaty. The Declaration is part of the Final Act of the Amsterdam Treaty. This Final Act has been signed by all Member States.

If the Declaration cannot be regarded a reservation, it might be regarded as an interpretative declaration, and as such may have to be taken into account in the interpretation of that Treaty. ${ }^{119}$ The Declaration may be so closely connected to the Treaty that it must be regarded an "integral part" thereof. In the Ambatielos case, ${ }^{120}$ the International Court of Justice held that the Declaration by the Anglo-Greek Treaty of Commerce and Navigation of 1926, formed an integral part of the Treaty because it was recorded as a common understanding between the parties ard because it was ratified and published as a single document by both governments. In Article 313 EC Treaty it is stated that the Treaty shall be ratified and that it can only enter into force if it has been ratified by all signatory states. The EC Treaty contains 314 Articles, 2 annexes and a number of Protocols. ${ }^{121}$ This means that the Declarations are excluded in the sense that they do not form part of the Treaty. This is confirmed by Article 311 EC Treaty stating that the Protocols form an integral part of the Treaty. There is no such provision for Declarations. Moreover, the Final Act, in which the Declarations are included, has been signed, but there is no provision, either in the EC Treaty, or in the Final Act itself, stating that ratification is required. The result is that since the Declarations are not subject to ratification they cannot enter into force and consequently cannot form an integral part of the Treaty. As the International Court of Justice already stated in the Ambatielos case:

"The ratification of a Treaty which provides for ratification is an indispensable condition for bringing it into operation. It is not, therefore, a mere formal act, but an act of vital importance."122

118 A.G. Toth, The legal status of the Declarations annexed to the Single European Act. In: CMLR, vol. 23, no. 6, 1986, p. 804.

119 A.G. Toth, The legal status of the Declarations annexed to the Single European Act. In: CMLR, vol. 23, no. 6, 1986, p. 806-807.

120 Greece vs. UK (Preliminary Objection), I.C.J. Rep. 1952, p. 28.

121 R. Barents and LJ. Brinkhorst, Grondlijnen van Europees recht, p. 12.

122 See also A.G. Toth, The legal status of the Declarations annexed to the Single European Act. In: CMLR, vol. 23, no. 6, 1986, p. 809. 
However, a Declaration can also be taken into account in the interpretation of the Treaty if it forms part of the wider context in the light of which the Treaty has to be interpreted. Article 31 of the Vienna Convention on the Law of Treaties states that the terms of a treaty must be interpreted "in their context", and that for this purpose the "context" shall comprise, in addition to the text, preamble and annexes:

"(a) any agreement relating to the Treaty which was made between all the parties in connection with the conclusion of the Treaty;

(b) any instrument which was made by one or more parties in connection with the conclusion of the Treaty and accepted by the other parties as an instrument related to the Treaty."

There is no doubt that the Declaration by Article 139(2) EC Treaty fulfils the conditions under (a) and forms therefore part of the "context" in the sense of Article 21 of the Vienna Convention. The question is, however, whether they are within the jurisdiction of the ECJ, since the ECJ shall, according to Article 220 EC Treaty, "ensure that in the interpretation and application of this

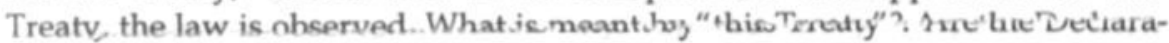
tions also part of "this Treaty"? I do not think so. Only the Protocols are part of the Treaty, as Article 311 EC Treaty states. Furthermore, in the Final Act, to which the Declaration is annexed, nothing is stipulated about the jurisdiction of the ECJ either. So it might be true that the Declaration forms part of the context of the Treaty, but the ECJ will not be able to give a ruling on the meaning of the Declaration.

Since the Declaration has not been subject to ratification and is not within the jurisdiction of the ECJ, it has to be regarded as a legally non-binding, judicially non-enforceable arrangement.

\subsubsection{The content of the Declaration}

The foregoing does not mean that it is not worth while to look at the content of the Declaration. What did the Member States intend with it? Since there is hardly any information about the meaning of the Declaration, I will scrutinise the several parts of the Declaration and try to work out what could be meant.

Implementation as described in the first part of Article 139(2):

- will consist in developing the content of the agreements

- by collective bargaining

- according to the rules of each Member State.

The Member States are not obliged to:

- apply the agreements directly or

- to work out rules for their transposition or 
- to amend national legislation in force to facilitate their (= the agreements) implementation.

\section{Developing the content of the agreements}

Implementation by the national social partners will consist of developing the content of the agreements concluded at European level. This is in itself a remarkable phrase since the content of the agreement is already described in the European collective agreements itself. It is possible however, that the European collective agreement serves as a framework in which minimum rules are laid down, as we have seen with the agreement in the agricultural sector. At national level, these rules can be worked out in detail, as long as the minimum level, laid down in the European collective agreement, is being respected.

\section{By collective bargaining}

This implies that only the national social partners can implement the European collective agreement if this route is chosen. It goes without saying that only the organisations who are affiliated to the European social partners, have to start collective bargaining. Non-affiliated national organisations can do this as well, but this is purely voluntary. There is no legal basis for the presumption that they are bound by the European collective agreement.

\section{According to the rules of each Member State}

Each Member State has its own legislation on the organisation and legal implications of collective bargaining and collective agreements. This means that the way European collective agreements are implemented varies from Member State to Member State. If the European social partners' organisations want to avoid this, they should submit their agreement to the Council and ask the Council to turn it into a Directive.

\section{Member States are not obliged to apply the agreements directly}

The second part of the Declaration lays down certain rules for the Member States. The statement that Member States are not obliged to apply the agreements directly means that if the agreements concluded at European level are implemented, this will always be done via the national social partners' organisations. European social partners' organisations can thus never oblige Member States to draw national legislation on the basis of the European collective agreement if the national social partners' organisations are unwilling to start collective bargaining. This is different from my plea for the direct effect of European collective agreements on individuals as I described in para. 5.7. It goes without saying that if European collective agreements are contrary to national law, they cannot be implemented by the national social partners' organisations because legislation is a higher source of law than collective agreements in all Member States. Only when the European collective agreement is more favourable than the national legislation for the one 
that is to be protected by it, mostly the worker, could one say that deviation from the national legislation should be possible.

\section{Member States are not obliged to work out rules for the transposition of agreements} This means that the Member States cannot be forced to draft special legislation in order to make collective bargaining possible on the basis of European collective agreements. This is not necessary either, since the right to collective bargaining is a fundamental social right, laid down in several ILO documents and the European Social Charter. National social partners' organisations are free to start collective bargaining on the basis of a European collective agreement, as long as their collective agreements are not contrary to national legislation.

Member States are not obliged to amend national legislation in force to facilitate the implementation of agreements

If the national social partners implement the agreement through collective bargaining, they have to do this in accordance with the existing legislation on collective labour law in the Member States. Member States do not have to change their legislation because of the fact that national social partners' organisations want to implement a European collective agreement.

Kapteyn and VerLoren van Themaat regard the Declaration as somewhat curious. "It is obvious that agreements concluded at national level will need to be worked out in collective negotiations under national law, and equally obvious that such national private law agreements cannot oust national legislation or oblige the Member States to amend existing national legislation to facilitate the implementation of those agreements." 123 I agree with them. For me, the value of the Declaration is not very clear either. Maybe the Member States wanted to avoid the idea that European collective agreements could be put on the same footing as Directives. For me, it is obvious that these two instruments are not the same as regards their legal implications. For Directives, the Treaty states clearly in Article 249, that it is binding upon the Member States. Such provision does not exist for European collective agreements. Binding rules on the Member States can only be created by the Community institutions. ${ }^{124}$ The European social partners' organisations are not regarded as Community institutions. ${ }^{125}$ Legal consequences of European collective agreements for the Member States can only exist if the agreement is turned into Community law in accordance with the procedure mentioned in Article 139(2) EC Treaty. ${ }^{126}$

123 P.J.G. Kapteyn and P. VerLoren van Themaat, Introduction to the law of the European Communities, p. 1062.

124 See Articles 249-256 EC Treaty.

125 See Article 7 EC Treaty.

126 See otherwise Birk, R. Birk, Vereinbarungen der Sozialpartner im Rahmen des Sozialen Dialogs und ihre Durchführung. In: EuZW, vol. 8, no. 15, 1997, p. 458. See also 


\subsubsection{Conclusions}

It is not very clear what the value is of the Declaration by Article 139(2) EC Treaty. In the first place is it a legally non-binding document which cannot be taken into account by the ECJ when interpreting Article 139(2) EC Treaty. Second, its content is rather superfluous. Therefore legal consequences for the Member States cannot be derived from this Declaration. Legal consequences for Member States are only created when the European collective agreement is turned into Community legislation, but as long as that is not the case, no legal rights or obligations are created for them.

\subsection{Conclusions}

According to the global definition of collective agreements, laid down in ILO documents, the European agreements concluded so far can be regarded as collective agreements. It can also be concluded from the European Social Charter and the case law of the ECJ in the cases Albany, Brentjens, and Drijvende Bokken that the European agreements fulfil all conditions of collective agreements. In most Member States specific rules on valid collective agreements exist. These rules can be divided in four categories: rules concerning the concluding parties, rules concerning the decision-making procedure, rules concerning the form of the collective agreement, and rules which deal with the $y$ content of the agreements. For European collective agreements no such rules have yet been formulated. For the future it is recommended that such rules be formulated in order to increase the legitimacy of the European collective agreements. Important requirements with regard to the concluding parties to a European collective agreement are in my view that they have democratic internal decision-making procedures and that they are independent from each other and from the European, national, and local authorities. An important requirement with regard to the bargaining procedure is that the European organizations have a clear mandate from their national affiliates to bargain on their behalf. It is also recommended that they are authorized in their statutes by their national affiliates to conclude valid collective agreements. With regard to the form of the agreement, it is recommended that the agreement is in writing and that the agreement stipulates which language version is the official version. Furthermore the public should be made more aware of European collective agreements. This could be done by publishing the agreement in the O.J. of the EC and on the internet. With regard to the contents of the agreement, it is important that they are not contrary to Community law, fundamental human rights or the public order. Since European collective agreements will be implemented by the national affiliates of the European organisations, the last mentioned have to make

Bodding who is of the same opinion. B. Bodding, Die europarechtlichen Instrumentarien der Sozialpartner, p. 99. 
sure that the European collective agreement is not contrary to the national legislation of the Member States except in the case that the European agreement contains provisions that are more favourable for those that are to be protected by this agreement.

There are various actors who can be legally affected by European collective agreements. These are in the first place the signatory parties. Secondly, there are the national affiliates of the signatory parties. Finally, individual workers and employers can be affected by them. To determine the legal effects on the signatory parties it is first important to determine the legal character of the European agreement. Since the agreements concluded so far have all been concluded in Brussels and the signatory parties also all resided in Brussels, Belgian law is applicable to the agreements. Applying the definition of a contract laid down in the Belgian civil code, leads to the conclusion that the European collective agreements concluded so far can be regarded as contracts in the sense of Belgian private law. For the future it is recommended to use international legal sources since it concerns European collective agreements concluded between European organizations. The instruments which have been adopted at Community level so far which harmonize certain aspects of contract law, are, however, not useful for European collective agreements. The Principles of European Contract Law could however serve as a valid inspiration source to determine the legal character of European agreements. Applying the contract definition laid down in these Principles leads to the conclusion that the European collective agreements concluded so far can be regarded as contracts. Another valid touchstone for the legal effects on the signatory parties of European collective agreements is ILO Recommendation no. 91 which states that collective agreements bind the signatory parties. In my view there should always be two basic obligations for the signatory parties: the obligation to exercise influence on their members to implement the European agreement and the peace obligation. Other rights and obligations should be stipulated in the European collective agreement itself.

Legal effects on the national affiliates of the signatory parties can not be based on Community public law. The legal rights and obligations for the national affiliates should derive from the internal rules of the European organizations in combination with private international law. I think that already at this moment the legal effects for the national affiliates can be derived from concepts such as mandate and agency. For the future it is however recommended that the national affiliates of the European organizations sign the European collective agreement as well. In this way they will be directly bound and not indirectly through a complicated construction of mandate or agency, which concepts by the way differ from country to country. It should also be laid down in the European collective agreement which law is applicable to it. The obligations for the national affiliates should consist of imple- 
mentation of the European collective agreement within a certain time, in such a way that the European collective agreement serves as a minimum basis for collective agreements at national level.

As regards the legal effects of European collective agreements on individual workers and employers, two situations have to be distinguished. The first is that the European collective agreement is implemented through national agreements. The second situation is that the European agreement has not or has not been correctly implemented. If the first situation applies, the European agreement is reflected in the national agreement. The legal effects for the individual workers and employers will be derived in such a case from the national law on collective agreements of their Member State. It is important to lay down that as long as the European collective agreement is in force, national agreements may not be contrary to them. This is important because otherwise national agreements could be concluded to implement the European collective agreement and after a certain time be terminated and replaced by agreements that are contrary to the European agreement. If the European collective agreement has not been implemented by national collective agreements or has been implemented incorrectly there is at present nothing that individual workers and employers can do. European agreements do not create direct effects on individuals because Article 139(2) EC Treaty specifically states that European agreements have to be implemented. For the future, direct effect of European agreements can only be developed if there is specific Community legislation on the legal effects of European collective agreements. Anticipating such legislation, I have given some ideas on the conditions for the entering of direct effect, the conditions on the provisions to be directly applicable, and direct effect from one individual towards another. 


\section{CHAPTER 6}

\section{ENFORCEMENT OF EUROPEAN COLLECTIVE AGREEMENTS}

\subsection{Introduction}

In Chapter 5, the legal effects of European collective agreements for the various actors involved in the conclusion and implementation of these agreements were discussed as well as the legal bases from which these legal effects can be derived. In this Chapter, the central question is whether and how the legal effects can be enforced and by whom. In para. 6.2. enforcement against the signatory parties of European collective agreements will be discussed. In para. 6.3. the same will be done for the national affiliates of the signatory parties of the European collective agreements. In para. 6.4. enforcement against individual workers and employers will be discussed. Finally, in para. 6.5. some conclusions will be drawn.

\subsection{Enforcement against the signatory parties}

It was concluded in Chapter 5 that at this moment the legal relations between the signatory parties can only be determined on the basis of Belgian contract law.' In the future, however, it would be better to develop more international-based legal sources, such as European contract law, or even European collective labour law. ${ }^{2}$ Therefore, in para. 6.2.1. first the enforcement possibilities in Belgian contract law will be discussed because that is the legal source we shall have to use at this moment. In para. 6.2.2. some ideas for enforcement in the future will be given. In para. 6.2.3. some conclusions will be drawn.

\subsubsection{According to Belgian contract law}

At this moment Belgian contract law is applicable as regards the legal consequences of the conclusion of European collective agreements for the signatory parties. According to Belgian contract law, such an agreement can be regarded a synallagmatic contract. A synallagmatic or bilateral contract is a contract which creates reciprocal obligations, each party having both rights and duties. ${ }^{3}$ For example in Article 1 of the Recommendation Framework

See para. 5.5.1.

See para. 5.5.2. for the underlying reasoning.

J. Herbots, Contract law in Belgium, Deventer/Boston/Brussels, 1995, point 55. This book was originally published as a monograph in the International Encyclopedia of Laws/Contracts. 
Agreement on the Improvement of Paid Employment in Agriculture concluded between GEOPA/COPA (the employers' side) and EFA/ETUC (the trade unions), it is stated that "The signatory parties agree to take concerted action to implement measures to improve the employment situation in the agricultural and rural sector in the European Union". These measures should be concerned primarily with, among others, "preventing occupational risks specific to the sector". This means in my view that the European social partners' organisations who signed the agreement, i.e. GEOPA/COPA and EFA/ ETUC, can address each other if one of the parties does not undertake any effort at all to implement measures to improve the employment situation, despite invitations of the other party to take certain concrete concerted actions. Another example is Clause 6(6) of the European Framework Agreement on Part Time Work stating that "The signatory parties will review this agreement five years after the date of the Council decision, if requested by one of the parties to this agreement". ${ }^{4}$ This provision contains a very clear and concrete obligation for the signatory parties. The question is what, according to Belgian contract law, are the consequences if one of the signatory parties does not keep to its obligations. For example, what if EFA/ETUC would consistently propose all sorts of measures to prevent occupational risks in the agricultural sector and GEOPA/COPA would consistently refuse to co-operate? Or as regards the European Framework Agreement on Part Time Work if UNICE asks ETUC and CEEP on 15 December $2002^{5}$ to sit around the table for a review of the agreement, and they refuse?

In Belgian contract law, the effect of a contract is to create an obligation, and the effect of an obligation is either that it is performed, or that a substitute for performance is provided by way of damages. ${ }^{6}$ There will be a breach of contract when, in the case of an obligation to produce a result the promised result is not attained, or in the case of an obligation to use best efforts, the efforts which could be expected from a reasonable person were not made, and when the breach is attributable to the defaulting party. The breach is attributable to the defaulting party if it is not caused by an outside factor.? The claimant must prove that the defaulter breached the contract. ${ }^{8}$ The breach of Article 1 of the Recommendation Framework Agreement on the Improvement of Paid Employment in Agriculture will be more difficult to prove than the breach of Clauses 6 (6) of the Agreement on Part Time Work. on Working Time of Mobile Staff in Civil Aviation (Clause 10), in the European Framework Agreement on Fixed-Term Work (Clause 8 para. 6), in the European Framework Agreement on Parental Leave (Clause 4, para. 7) and in the Framework Agreement on Telework(Article 12, 5th recital).

8 J. Herbots, Contract law in Belgium, point 375. 
In the Recommendation Framework Agreement on the Improvement of Paid Employment in Agriculture, there is no time limit given, which states when this "concerted action" has to be taken. Clause 6(6) of the European Framework Agreement on Part Time Work, on the other hand, lays down a clear obligation with a clear time limit.

The competent court to deal with the enforcement of contracts is the Belgian civil court. The signatory parties of the Recommendation Framework Agreement on the Improvement of Paid Employment in Agriculture thus have to go to the Belgian civil court if they think that the other party has acted contrary to the European agreement. It is possible that provisions of European agreements are ambiguous. In Belgian law, the process of determining the meaning of ambiguous or incomplete expressions is called "construction". Construction is called for when it is known what the parties said or wrote, but it is not obvious what they meant by it. ${ }^{9}$ The Civil Code contains a number of rules intended to guide the courts when interpreting a contract whose terms are obscure. ${ }^{10}$ In accordance with classical doctrine, Belgian law takes as its starting point the common intention of the parties." It is not, however, always clear what this intention is. What matters, therefore, is not the real intention which lay behind what one party said but what the other party must in the circumstances have understood him to mean. The addressee's justifiable reliance on the objective meaning of the declaration deserves protection. Construction must be in accordance with good faith and with reference to normal usage. ${ }^{12}$ The court will, however, pay attention not only to the actual words of the contract, but also to the extrinsic circumstances. The court may refer to all the circumstances surrounding the making of the declaration. ${ }^{13}$ Words may have a very different meaning not only according to the context in which they are found, but also according to the circumstances in which they are employed. ${ }^{14}$

The four basic courses of action potentially open to the aggrieved party in the case of non-performance by the other party are specific performance, money (damages), exceptio non adimpleti contractus and termination. ${ }^{15}$

\section{Specific performance}

If one of the signatory parties does not fulfil its obligations, the other party can ask the civil court to rule that this party has to perform. However, this

9 J. Herbots, Contract law in Belgium, point 268.

10 Articles 1157-1164 of the Belgian Civil Code.

11 Articles 1134 and 1156 Belgian Civil Code.

12 J. Herbots, Contract law in Belgium, point 269 and 270; See also L. Cornelis, Algemene theorie van de verbintenis, point 228-230.

13 Cass., 5 March 1984, Pas. , 1984, I, p. 764; Cass., 10 November 1988, Arr. Cass., 19881989, p. 287.

14 J. Herbots, Contract law in Belgium, point $2 \pi 1$.

15 J. Herbots, Contract law in Belgium, point 370. 
judgement can only be effective if at the same time economic pressure is placed on the party who has to perform. A court can attach to its judgement an order that the defendant shall pay to the claimant a specified sum for each day that he remains in default. This is called an astreinte. ${ }^{16}$ The problem, however, is that certain European social partners' organisations, for example the ETUC, lack legal personality. The astreinte can thus not be put on the ETUC as an organisation. Besides, I consider that the claim of specific performance only makes sense if it is clear what the performance precisely consists of, and if it is clear at which moment performance has to take place. Most provisions found in the European agreements concluded so far are too vague. What, for example is precisely meant by "concerted action" in Article 1 of the Recommendation Framework Agreement on the Improvement of Paid Employment in Agriculture? How far should this concerted action go? It is clear that if EFA were to consistently propose all sorts of measures to prevent occupational risks in the agricultural sector and COPA consistently refused to cooperate, there would be a breach of contract on the part of COPA. How far the duty of effort to take concerted action reaches is not, however, described. Does it mean that COPA has to take every proposal of EFA seriously into account and that it has to give good reasons if it refuses to co-operate? Nothing is stipulated about this in the Recommendation Framework Agreement on the Improvement of Paid Employment in Agriculture. Also the clauses on the review of the agreement, as included in several sectoral and intersectoral agreements, are not specific enough. It is, for example, possible that the signatory parties will meet in order to review the agreement, and discuss several items, but that nothing else happens. The parties cannot be forced to accept amendments to the agreement. The only real obligation is that the signatory parties should at least come together and have a discussion on the question whether the agreement should be reviewed. A blunt refusal by one or more of the signatory parties to meet could be regarded a breach of contract. Even if a meeting could be enforced, however, that would not bring the party who started the enforcement procedure any further. To meet in order to discuss the review of an agreement does not mean that proposals for amendments should be accepted. The vagueness of the provisions can of course be reduced by the civil court when it determines the meaning of these provisions by means of construction. Only when it is clear what exactly can be expected from the other party, and at what time, can the claim for performance be effective.

16 Article 1142 of the Belgian Civil Code; J. Herbots, Contract law in Belgium, point 389. See also W. van Gerven and S. Covemaeker, Verbinteneissenrecht, Leuven/Leusden, 2001, p. 102 and p. 115-116. 


\section{Damages ${ }^{17}$}

In order to be able to claim a remedy in damages, the plaintiff must have suffered a loss. Loss includes any harm to the person or property of the plaintiff, and any other injury to his economic position. Damage is any disadvantage caused to a person. It may affect either the person's property, real or personal, or interests not connected with property. ${ }^{18}$ The loss will usually be pecuniary, though according to the case law there is also dommage moral which includes a very wide range of non-pecuniary loss. ${ }^{19}$ With the clauses directed to the signatory parties in the European agreements concluded so far, it is difficult to envisage the kind of loss that will be suffered if one of the parties does not fulfil his obligations. At national level, collective agreements often contain an explicit or implicit peace obligation. If the trade union calls a strike during the lifetime of the collective agreement, the other party can, in certain Member States, claim damages for breach of the agreement. Explicit peace obligations are not included in the European agreements concluded so far. Perhaps an implicit peace obligation can be assumed, but that is certainly not self-evident. There is no legislation, nor any case law at European level to assume an implicit peace obligation in the European agreements concluded so far. Nor can we state that it is common practice in the Member States that a peace obligation be included in collective agreements. In a number of Member States strikes can be called at any time. ${ }^{20}$ The most important problem as regards damages is, however, as already said under the head performance, that certain European organisations lack legal personality. An organisation such as the ETUC cannot be obliged to pay damages. In Chapter 2 I concluded that Belgian law is applicable to most European social partners' organisations, since they are resident in Brussels. ${ }^{21} \mathrm{~A}$ comparison can therefore be drawn with Belgian trade unions. Belgian trade unions who are confronted with a legal claim to pay damages for the calling a strike can only be ordered to pay damages in so far as this is explicitly foreseen in the collecive agreement that they have concluded. ${ }^{22}$ So Belgian trade unions possess a certain degree of immunity with regard to claims for damages. This immunity extends to claims based on Articles 1142, 1146, 1153 and 1382 of the Belgian Civil Code, in so far as these claims flow from the non-fulfilment of contractual obligations. ${ }^{23}$ Even if Belgian trade unions could be ordered to pay damages it is, however, often difficult to execute this order since the

17 Articles 1146-1155 of the Belgian Civil Code.

18 J. Herbots, Contract law in Belgium, point 409.

19 Cass., 3 February 1987, R.W., 1987-1988, p. 220.

20 France, Italy, Great Britain, Ireland, Denmark, In: R. Blanpain (ed. in Chief), International Encyclopedia for Labour Law and Industrial Relations.

21 See para. 2.5.2.

22 See Article 4 of the Belgian Act Respecting Collective Bargaining Agreements and Joint Committees of 5 December 1968.

23 M. Rigaux, Actuele problemen van het Arbeidsrecht, Deel 3, Antwerpen, 1990, point 448. 
trade unions largely lack legal personality. The trade unions do not have a separate and identifiable patrimony on which the damage can be recovered. ${ }^{24}$ Apparently it is not possible in Belgian law to recover the damages from individual committee members of the trade unions. There is thus no reason to see why this would be different for European social partners' organisations such as the ETUC, which are subject to Belgian law as well. So even if we were to assume an implicit peace obligation in the European agreements, the remedy of damages cannot be used against certain organisations, among which the most important one from the workers' side.

\section{Exceptio non adimpleti contractus}

This remedy, which is available only in the case of a contract in which the duties of the parties are concurrent (synallagmatic contract), consists in the refusal by one party to perform his duty unless the other party performs his. ${ }^{25}$ This remedy is only effective if the duties which both parties have to perform are of similar importance. In the case of collective labour agreements, the strongest weapon that a trade union has is the weapon of strike. The ETUC could of course use this weapon as an enforcement mechanism if the European employers' organisation does not meet its obligations. As regards the European agreements concluded so far, a peace obligation can certainly not be assumed yet. It would not therefore be a breach of contract on the part of the ETUC if it were to call a strike. Industrial action at European level is, however, rare, although it does occur. For example, a demonstration of lorry and bus drivers was organised by the European Transport Workers' Federation on 5 October 1999. ${ }^{26}$ They demanded European-level legislation from the Community institutions on working time in order to prevent social dumping. In the shipbuilding industry, a day of action took place on 5 November 1999, co-ordinated by the European Metalworkers' Federation and carried out by affiliated trade unions in the Member States. ${ }^{27}$ This action also was directed towards the Community institutions. There were also a number of cross-border European actions and protests within multinational companies in 1999, usually reacting to restructuring and cutbacks. For example a European day of action was organised at Unilever in February 1999 by trade unions, protesting against an alleged lack of information and consultation prior to the closure of a number of sites. ${ }^{28}$ The

24 M. Rigaux, Actuele problemen van het Arbeidsrecht, Deel 3, point 450.

25 J. Herbots, Contract law in Belgium, point 377.

26 Annual review for the European Union level, In: EIRONLINE, December 1999.

27 Annual review for the European Union level, In: EIRONLINE, December 1999.

28 Annual review for the European Union level, In: EIRONLINE, December 1999; Other examples are the demonstration in Liege on 21 September 2001 organised by the ETUC, where the demonstrators called for measures to sustain economic activities and jobs in Europe and protested against the deregulation in the public transport sector. The demonstration was supported by the EPSU and the ETF, as well as by Belgian trade union confederations. Furthermore, on 26 March 2002 trade unions representing 
actions are so far mainly directed towards either the Community institutions or against multinationals. However, that does not exclude that they can also be directed towards European employers' organisations in the future. We have to bear in mind though that people are usually willing to strike only if the most important working conditions are directly affected, such as a reduction in salary or the danger of the loss of jobs. These working conditions can be laid down in collective agreement which already exists, but action can also be undertaken to force employers to the negotiating table in order to conclude a new collective agreement on working conditions which is better than the existing one.

\section{Termination}

Termination is also possible in case of a breach of contract. It is a fundamental principle of the Belgian law of contract that when there are reciprocal obligations, and one of the parties has performed or is prepared to perform his part, and the other party has failed or refuses to perform his part, the contract may be set aside by the courts without prejudice to any claim for damages. ${ }^{29} \mathrm{I}$ think that this is at this moment the most obvious remedy for the enforcement of European agreements. One of the signatory parties can threaten to ask the Belgian civil court to terminate the agreement if the other party fails to fulfil his duties. As with the remedy of specific performance, however, the court first has to determine whether there is a breach of contract and it might therefore have to use the mechanism of construction.

The foregoing assumes the enforcement from one signatory party to the other. Enforcement from the national affiliates towards the signatory parties is not really thinkable, when it comes to the rights and obligations of the signatory parties. These rights and obligations are directed from one signatory party towards another. It is they, therefore, who should enforce the obligation.

\subsubsection{Options for the future}

As for the future, I have argued in Chapter 5 that the basic obligations for the signatory parties, as a result of the conclusion of a European agreement, should be twofold. First, they should have an obligation to exercise influence on their members to implement the European agreement and second, they should have an obligation to refrain from industrial action as long as the

rail workers organised an international day of action in support of safety and social standards in the sector. The action was organised by the International Transport Workers' Federation and was coordinated in Europe by the European Transport Workers' Federation (ETF). EU-level developments, In: EIRONLINE, October 2001 and April 2002.

29 J. Herbots, Contract law in Belgium, point 391. See also W. van Gerven and S. Covemaeker, Verbinteneissenrecht, Leuven/Leusden, 2001, p. 125-126. 
European agreement is in force and the other party meets its obligations. I will discuss these two obligations briefly hereafter and give some ideas on the prevention and resolution of industrial disputes to be laid down in a future European collective labour law.

\subsubsection{Obligation to influence their members}

The Recommendation Framework Agreement on the Improvement of Paid Employment in Agriculture contains a number of clauses making recommendations from the signatory parties towards their national affiliates. If the national affiliates start collective bargaining at national level, they have to take the European agreement as a minimum basis. ${ }^{30}$ What if one of the national affiliates, however, (for example a national employers' organisation) did not take account of the European agreement in the collective negotiations with the national trade union. What would be the role in such case of the European employers' organisation, i.e. COPA, seen in the light of its obligation to influence its members? I consider that COPA should use all means at its disposal on the basis of the statutes to persuade its members to implement the European agreement. EFA could explicitly ask COPA to exercise influence on its unwilling national affiliate if it thought that COPA did not undertake enough efforts to influence its affiliates. If COPA still did not undertake any action, there would be a breach of the agreement on the part of COPA which could lead to an industrial dispute.

\subsubsection{Obligation to refrain from industrial action}

Industrial action by European trade unions to force European employers' organisations to the negotiation table has not yet occurred. Neither have we seen industrial action in breach of an already existing European agreement. Industrial action is mainly undertaken by workers' organisations, although in certain Member States, employers' organisations can use the right of lockout. In Chapter 5, I have discussed in which cases a peace obligation should in my view be obeyed. ${ }^{31}$ The question is what should happen if this peace obligation is violated, because in that case we have an industrial dispute.

\subsubsection{Prevention and resolution of industrial disputes}

Industrial disputes can be divided into disputes over rights which arise from the application or interpretation of a rule in an existing collective agreement, and disputes of interest, which arise out of the making of new agreements or the renewal of agreements, which already have expired or are about to expire. Since this Chapter is about the enforcement of European collective

30 Article 7, second sentence of the agreement.

31 See para. 5.5.5. 
agreements which have actually been concluded my focus will be on the disputes over rights.

If one of the signatory parties acts contrary to its obligations arising out of the European agreement and the other party does not accept this, there will be an industrial dispute. Industrial disputes can be prevented by avoiding vague provisions in the European agreement and by describing the rights and obligations of the signatory parties and their national affiliates in such a way that there can be hardly any misunderstanding as to their interpretation. Some provisions which can be interpreted in several ways might remain. The signatory parties can differ in their opinion as regards this interpretation. As industrial disputes will certainly occur in the future if the European social dialogue develops further, the question is which methods for prevention and resolution of these disputes have to be developed at European level. Furthermore, the question is which institutions are needed for this resolution. A third question is whether these methods and institutions should be determined by legislation or by collective agreements. These questions will be dealt with hereafter.

\section{Methods for prevention and resolution of industrial disputes}

In most Member States it is possible to go to court in the case of industrial disputes of rights. ${ }^{32}$ Many Member States even have specialised Labour Courts. ${ }^{33}$ However, there are also other methods of resolution of industrial disputes. These can be classified as conciliation, mediation and arbitration.

Conciliation refers to a voluntary, informal process of dispute resolution, whereby an independent third party assists the parties to a dispute to clarify the points of disagreement and attempts to promote a settlement. No binding award is made and any agreement reached is the responsibility of the par-

32 This is however not possible in Ireland. Furthermore, in Great Britain, collective disputes, in sofar as they give rise to civil action, are dealt with by the ordinary civil courts. In: Report on the occasion of the International Conference: The resolution of industrial disputes, the use and development of conciliation and mediation procedures, Organised jointly by the European Commission and the Irish Labour Relations Commission, 5/6 October 1993, Part I, A. Jacobs, A synopsis of national rules and practices in the countries of Western Europe, pp. 1/1-1/53. In Belgium, industrial disputes cannot be brought before a court as such. However, such disputes can be considered within the framework of an individual dispute between an employer and an employee. In: M. Rigaux (ed.), CAO-recht, afl. 1, Diegem, September 1994, Chapter 5, part 2: M. Rigaux and G. Cox, Afdwingbaarheid van de obligatoire bepalingen, point 530 and 550 .

33 I.e. Luxembourg, France, Spain, Portugal, Germany, Ireland, Sweden, Finland, Austria, Denmark, and Belgium; In: The resolution of industrial disputes, the use and development of conciliation and mediation procedures, Part I, A. Jacobs, A synopsis of national rules and practices in the countries of Western Europe, pp. 1/1-1/53. 
ties. ${ }^{34}$ The number of representatives of both sides attending conciliation procedures may have an influence on their outcome. Often, the first joint or separate meetings are attended by a large number of representatives from both sides. In the course of the proceedings conciliators hold their discussions with the main representatives or even with only one spokesman of either side since experience has shown that in the case of difficult negotiations real progress can best be made through such personal and informal discussion. It is possible to put a fixed time limit on this conciliation procedure. This is especially helpful when a failure of conciliation is to be followed by compulsory arbitration or the parties are not permitted to take direct action while the conciliation is in process. If the conciliation succeeds, the settlement of the dispute could be generally set out in a memorandum which has to be signed by both parties. ${ }^{35}$

Mediation is used to describe a more positive form of conciliation in which the third party recommends solutions, which the parties are free to accept or reject. In practice, the line between mediation and conciliation may be difficult to draw. ${ }^{36}$

Arbitration differs from conciliation and mediation, because the parties hand over the determination of their dispute to a third party. The final product of the arbitration is an award. ${ }^{37}$

34 The resolution of industrial disputes, the use and development of conciliation and mediation procedures, Part I, A. Jacobs, A synopsis of national rules and practices in the countries of Western Europe, p. 1/1. Conciliation exists in Belgium (suppl. 238, points 752 and 773-777), France (suppl. 77, point 685), Ireland (suppl. 178, points 433434), Italy (suppl. 207, point 466), Luxembourg (suppl. 123, points 529-537), The Netherlands (suppl. 222, point 221), and Portugal (suppl. 107, points 163-168), In: R. Blanpain (ed. in Chief), International Encyclopedia for Labour Law and Industrial Relations.

35 K. Zweigert (responsible ed.), International encyclopedia of comparative law, volume XV, O. Kahn-Freund (ed.), Labour Law, Chapter 14, J. de Givry, Prevention and settlement of labour disputes other than conflicts of rights, point 58-60.

36 The resolution of industrial disputes, the use and development of conciliation and mediation procedures, Part I, A. Jacobs, A synopsis of national rules and practices in the countries of Western Europe, p. 1/1. Mediation exists in Denmark, (suppl. 209, points 672 and 433-469), France (suppl. 77, point 686), Great Britain (suppl. 251, points 48 and 505), and Greece suppl. 252, points 1011-1013), In: R. Blanpain (ed. in Chief), International Encyclopedia for Labour Law and Industrial Relations.

37 K. Zweigert (responsible ed.), International encyclopedia of comparative law, volume XV, O. Kahn-Freund (ed.), Labour Law, Chapter 14, J. de Givry, Prevention and settlement of labour disputes other than conflicts of rights, point 113. Arbritration exist in Austria (suppl. 131, point 581), Denmark (suppl. 209, points 672 and 433-469), France (suppl. 77, point 688), Great Britain (suppl. 251, points 505 and 48), Greece (suppl. 252, points 1014-1019), Luxembourg (suppl. 123, points 538-543), and Sweden (suppl. 134, points 622 and 397-398), In: R. Blanpain (ed. in Chief), International Encyclopedia for Labour Law and Industrial Relations. 
There is voluntary and compulsory arbitration. When arbitration is totally voluntary the procedure is embarked upon with the consent of both parties and with the understanding that they will abide by the outcome. ${ }^{38}$ Arbitration is compulsory if, once the point of impasse is reached, resort to the arbitrator is mandatory, i.e. when it can be set in motion ex officio or at the request of either party. Moreover, once arbitration is introduced, the arbitrators' award has a binding character. It may be binding in the sense that it produces contractual relations between organisations on both sides. Compulsory reference of a dispute to arbitration may take different forms. It can be automatic in the case of failure of conciliation; it can be mandatory upon submission of either party regardless of the consent of the other party or it can be imposed by the government at its discretion if it is deemed advisable.

While voluntary arbitration has often been a very effective means of settlement of disputes, it will be noted that when the parties remain free to accept or reject the arbitration award the procedure may resemble a process of fact-finding or mediation under, which the mediator or fact-finder is entitled to submit a recommendation to the parties concerned, rather than a process of arbitration in the true sense. ${ }^{39}$ Compulsory arbitration, on the other hand, also has its disadvantages. It exposes both parties to the possible incompetence or partiality of the arbitrator. ${ }^{40}$ Reasons for employers to oppose compulsory arbitration are that they refuse to accept an intervention of arbitrators in the affairs of undertakings which would infringe managerial authority.

Conciliation, mediation, and arbitration machinery is a phenomenon which can take many forms. It can take place in individual as well as collective labour disputes. It might be used in conflicts of interest but also in conflicts over rights. Conciliation, mediation, and arbitration might be effectuated by institutions set up by the social partners themselves or by legislation. Such machinery might have a completely voluntary character or manifest some compulsory aspects. The definitions of conciliation, mediation, and arbitration as mentioned above are very general. It is therefore not fruitful to adhere narrowly to their specific legal definitions. What is called mediation in one

38 The resolution of industrial disputes, the use and development of conciliation and mediation procedures, Part I, A. Jacobs, A synopsis of national rules and practices in the countries of Western Europe, p. I/1.

$39 \mathrm{~K}$. Zweigert (responsible ed.), International encyclopedia of comparative law, volume XV, O. Kahn-Freund (ed.), Labour Law, Chapter 14, J. de Givry, Prevention and settlement of labour disputes other than conflicts of rights, point 86.

$40 \mathrm{~K}$. Zweigert (responsible ed.), International encyclopedia of comparative law, volume XV, O. Kahn-Freund (ed.), Labour Law, Chapter 14, J. de Givry, Prevention and settlement of labour disputes other than conflicts of rights, point 128 . 
country can be very much the same as what is called conciliation in another country. ${ }^{41}$

It is thinkable that the settlement of disputes over rights regarding European collective agreements consists of a two stage process. First, the signatory parties try to reach an agreement themselves through conciliation. If necessary, an independent third party, for example someone from the Commission, can attend the meetings between the parties. He or she can help to remove misunderstandings and fulfil a mediatory role. A fixed time limit could be placed on this conciliation phase in order to prevent negotiations resulting in endless discussions with no result. It should however, be possible to extend this time limit if both parties think that an agreement is close. If agreement has been reached, it could be laid down in a memorandum and annexed to the European agreement. If conciliation does not succeed, it is clear that the discussion between the two parties is not successful. It is better, therefore, in such a case to hand over the settlement of the conflict to another institution. In the Member States disputes of rights are mostly handed to the (labour) courts. ${ }^{42}$ Establishing such a (labour) court at European level for disputes of rights would therefore best fit in with the traditions in the Member States. However, the installation of such a (labour) court can encounter much resistance in countries who are not familiar with the resolution of industrial disputes by courts, such as Belgium, Great Britain, and Ireland. I will therefore put forward another suggestion which is discussed hereafter.

\section{Institutions for the prevention and resolution of industrial disputes}

What would constitute an adequate body for the conciliation phase? In Chapter $3^{43}$ it was discussed that the Commission has established Sectoral Dialogue Committees (SDCs) to promote the dialogue between the social partners at a European sectoral level. Their functions as consultation bodies and for a for social dialogue at sectoral level, could be broadened with conciliation services in collective labour disputes. SDCs are familiar with the specific problems of that sector. The ones that already exist are established permanently. The advantage of permanent committees is that they are ready to intervene as soon as a dispute breaks out, whereas the establishment of a committee for the specific purpose of settling a given dispute may involve the loss of valuable time and create difficulties in the event of a serious difference between employers and workers. ${ }^{44}$ The SDCs can develop their own

41 The resolution of industrial disputes, the use and development of conciliation and mediation procedures, Part L, A. Jacobs, A synopsis of national rules and practices in the countries of Western Europe, p. I/4.

42 The resolution of industrial disputes, the use and development of conciliation and mediation procedures, Part I, A. Jacobs, A synopsis of national rules and practices in the countries of Western Europe, p. I/3-1/4.

43 Para. 3.2.2.

44 K. Zweigert (responsible ed.), International encyclopedia of comparative law, volume 
rules of procedure, as is also stipulated in the Commission Decision of $1998 .^{45}$ Article 5(2) of Commission Decision 98/500/EC states that the SDCs can be chaired by a representative of the Commission if the employers and employees delegations request this. It could for example be stipulated in the rules of procedure of the SDCs that if these committees fulfil their role as a conciliation committee they will also be chaired by an independent person from the Commission. The disadvantage of the SDCs is that they consist of the representatives of the signatory parties, who can be entangled in their own interests in such a way that it is hard to handle the dispute in a neutral way. One could say that this disadvantage can be taken away by the establishment of a (labour) court at European level to which the parties can turn if conciliation does not provide any satisfactory results. But, as I already argued before, this can meet substantial resistance from countries which are not familiar with the resolution of industrial disputes by courts. A compromise could therefore consist of an institution similar to the Federal Mediation and Conciliation Service (FMCS), as established in the USA. The FMCS is set up as an independent agency of the U.S. government. Its principal function is to provide mediation assistance to private sector labour and management negotiators in reaching agreement over their labour contracts. The mediators are drawn from the ranks of experienced labour and management negotiators. They are used voluntarily by labour and management negotiators. The mediators act never as representatives of the government. The outcome of labour negotiations remains entirely the responsibility of the labour and management negotiators whether they use the service of a mediator or not. ${ }^{46}$ The mediators of the FMCS can make informal recommendations to one or other of the parties in separate meetings during the negotiations on the collective agreement. A second function of the FMCS is that of arbitrator in case of disputes which arise during the term of the collective agreement. In case of disputes on the content of an already concluded collective agreement, the parties first use a multi-stage grievance procedure during which labour and management representatives address the problem through negotiations. Almost every collective agreement in the USA contains a grievance and arbitration procedure to address disputes which arise during the term of the labour agreement. Should one side, however, be dissatisfied with the outcome of the grievance procedure that side may refer the matter to the FMCS. FMCS mediators are in a unique position to help because they already have established a special relationship of confidence with the parties during the

XV, O. Kahn-Freund (ed.), Labour Law, Chapter 14, J. de Givry, Prevention and settlement of labour disputes other than conflicts of rights, point 50 .

45 Article 5(1).

46 J.F. Power, Resolving industrial disputes, the experience of the USA. In: The resolution of industrial disputes. The use and development of conciliation and mediation procedures. International Conference organised by the European Commission and the Irish Labour Relations Commission. A report of the conference prepared by A. Kerr, p. 33. 
negotiations on the collective agreement. During this time, they are able to experience first hand, the relationships which exist between the parties and are often able to identify problems that could be a source of trouble in the future. The suggestions of the FMCS are more likely to be accepted than those from an outsider with whom the parties have no prior relationship. ${ }^{47}$ At European level as well a mediation and conciliation service could be installed. Such a European mediation and conciliation service (EMCS) not only has the advantage that it will consist of independent and neutral persons (contrary to the Sectoral Dialogue Committees), but also that these persons can be selected on the basis of their judicial or other qualifications. ${ }^{48}$ These qualifications could consist of personal experience, special mediation skills or being an authority in the field of industrial relations. The EMCS could provide mediation assistance to management and labour who are negotiating a European collective agreement in the SDCs. If such an agreement has been reached and a dispute might arise out of it, the EMCS could serve as an arbitration body if conciliation within the SDCs might not prove very helpful.

\section{Estublishment by luw or by collective ugreement?}

I think that as long as the prevention and resolution of industrial disputes continues to have a voluntary character, regulation on the prevention and resolution of such disputes should be done by the European social partners' organisations themselves. This regulation could be laid down in European collective agreements. If the social partners' organisations were to opt for an EMCS, they should realize that they also have to bear the costs of this service. Another option is that such a service is financed by the Commission. This could, however, imply that the Commission also wants to determine the composition and rules of procedure of this service. If the European social partners' organisations do not want this, they better keep the financing of the service in their own hands.

\section{Sanctions}

I already have discussed possible sanctions in case of breach of the European agreement in para. 6.2.1. These sanctions are possible according to Belgian contract law. Also, if a European collective labour law were developed, we should think of sanctions in case of breach of a European collective agreement. The same problems will, however, occur as discussed under Belgian contract law. Demanding specific performance is only effective if it can be enforced through economic sanctions like an astreinte. Since European organisations are not always legal persons, this will be difficult. The same goes for

47 J.F. Power, Resolving industrial disputes, the experience of the USA, p. 35-37.

48 K. Zweigert (responsible ed.), International encyclopedia of comparative law, volume XV, O. Kahn-Freund (ed.), Labour Law, Chapter 14, J. de Givry, Prevention and settlement of labour disputes other than conflicts of rights, point 105. 
the claim for damages in case one of the contracting parties acts in breach of the peace obligation. Effective sanctions could be strikes organised by the trade unions on the basis of the principle exceptio non adimpleti contractus and the termination of the European agreement by the trade union or employers' organisation at European level. The question of possible sanctions, however, is of course related to the question of the institution(s) which will be competent to handle industrial disputes over rights. If such an institution will be a European labour court the above mentioned sanctions could be applied. If such an institution would however be an EMCS the question arises as to which powers such an institution should have. If the EMCS serves as an arbitration body, it could give a binding award. Such an award could produce contractual relations between the signatory parties involved in the dispute. If the parties however remain free to accept or reject the arbitration award of the EMCS it will be impossible to impose real sanctions. One should however also bear in mind that if a particular European organisation consistently acts in breach of the European agreements which it has signed, it will gain a reputation as dubious and unreliable. Such an organisation will find it more and more difficult to participate in the process of concludino European agreements with other organisations. Given this, it can be expected that if the European social partners' organisations choose for the installation of an EMCS they will probably follow an arbitration award given by this institution.

\subsubsection{Conclusions}

At this moment, enforcement of European agreements by one signatory party against another has to be done on the basis of Belgian contract law, at least if the European agreement can be regarded a contract according to Belgian contract law. For such an enforcement procedure the parties have to turn to the Belgian civil court. The most effective remedies will be strikes and the termination of the European agreement. For the future there are several options. One is to install a (labour) court at European level for the prevention and resolution of industrial disputes. This option can, however, meet a lot of resistance in countries which are not familiar with leaving the resolution of industrial disputes to courts. Another option is that already existing Sectoral Dialogue Committees will be provided with conciliation services. The disadvantage of this option is that such committees can not operate entirely independently because they consist of members of the European social partners' organisations themselves. An alternative option could therefore be to set up a European mediation and conciliation service, analogous to the Federal Mediation and Conciliation Service in the USA, which could serve as a body of appeal in case conciliation within the SDCs were to prove fruitless. Such a service does not have the status of a court and will therefore more easily be accepted by countries such as Belgium, Great Britain, and Ireland. Moreover, it can consist of independent persons with experience and know- 
ledge in the field of industrial relations. The regulation on the prevention and resolution of industrial disputes should be laid down in European collective agreements as long as resolution and prevention of industrial disputes is voluntary. Also in the future it will be difficult to impose financial sanctions against organisations that lack legal personality. It can be assumed, however, that if organisations really want to take part in the European social dialogue and want to be taken seriously, they will fulfil their obligations under the European collective agreements that they have concluded.

\subsection{Enforcement against the national affiliates}

In Chapter 5, I concluded that if the European collective agreement is not implemented through Council decision, for whatever reason, the national affiliates of the European signatory parties have an obligation to implement the European collective agreement, unless the European signatory parties decide to withdraw the agreement. ${ }^{49} \mathrm{~A}$ more practical problem is that not all national union centres represented in the ETUC have the power to conduct collective bargaining, including two of the largest, the Deutscher Gewerkschaftsbund (DGB) and the British Trade Union Congress (TUC). ${ }^{50}$ This means that only those national affiliates who are able to conclude collective agreements at national level could be forced to implement the European collective agreement. I think that the obligation to implement European collective agreements through national collective agreements is only suitable for sectoral European collective agreements. Intersectoral European collective agreements should be implemented through Community legislation. In Chapter 5, I have also given some other reasons for the argument that only sectoral European collective agreements are suitable for implementation through national collective agreements. ${ }^{51}$

Let us suppose that the European collective agreement is not implemented through Council decision. The national affiliates should be given a certain time limit to implement the European collective agreement. Such time limit should be included in the European collective agreement itself. Two problems can occur. The first is that the national affiliates do not implement the agreement at all. The second is that the European collective agreement is

49 See para. 5.6.2.

50 W. Lecher and H.W. Platzer, European Union-European industrial relations? London/New York, 1998, p. 14.

51 See para. 5.6. The rules of procedure of the Executive Committee meeting of the ETUC however, provide in Article 14 for implementation of European agreements by the national affiliates of the ETUC. This means thus that the ETUC does not exclude the possibility of implementation through national collective agreements. This is further demonstrated by the fact that recently an agreement on telework has been concluded between the ETUC, CEEP and UNICE/UEAPME (see annex), which will not be implemented through a Council decision but by means of the national affiliates of the signatory parties. 
implemented but not correctly. I will discuss these two problems in separate paragraphs.

\subsubsection{Non-implementation}

A European collective agreement is concluded between European social partners' organisations. However, before such an agreement is concluded, an internal decision-making process has taken place. The European organisations have first discussed with their national affiliates on the question whether a European collective agreement should be concluded and what the content of such an agreement should be. It is possible that during this internal decisionmaking process, certain national affiliates express their opposition to a European collective agreement, or to a European collective agreement with a certain content. These organisations could, however, be overruled if the majority of the national affiliates does not agree with the reasons for its opposition. This is the case when internal decision-making takes place by (qualified) majority voting. Although (qualified) majority voting has certain advantages, especially in cases when quick decision-making is necessary, it carries the danger that obstinate national affiliates are unwilling to implement the European collective agreements in their respective countries, because they have voted against it during the internal decision-making process. It is possible that both employers' and workers' organisations are unwilling to implement the European collective agreement. Another possibility is that, for example, the national workers' organisation wants to implement, but the national employers' organisation does not cooperate. In Chapter 5, I argued that the words of Article 139(2) EC Treaty suggest that there is a legal obligation to implement the European collective agreement on the basis of Community law. ${ }^{52}$ This legal obligation can however, also be derived from the internal rules of procedure of the European organisations. In para. 6.3.1.1., I will discuss whether there are any enforcement possibilities on the basis of Community law. In para 6.3.1.2. enforcement possibilities on the basis of the internal rules of the European organisations will be scrutinized.

\subsubsection{Community law}

In Chapter 5, I have argued that it is incompatible with the ILO Conventions that public authorities intervene in the right to bargain collectively. ${ }^{53}$ This means that the words in Article 139(2) EC Treaty can never be so interpreted as to suggest that the Community government or the national governments can oblige the national social partners' organisations to implement European collective agreements. Therefore on the basis of Community law, there are no enforcement procedures possible from the European social partners' organi-

\footnotetext{
52 See para. 5.6.1.
}

53 See para. 5.6.1. 
sations towards their national affiliates to implement the European collective agreement. This goes also for the relation from one national social partners' organisation towards another.

\subsubsection{Internal rules of procedure}

If the actors involved in the European social dialogue really want a harmonisation of the working conditions by means of collective agreements, enforcement procedures and sanctions should be included in the internal rules of the European social partners' organisations. Practically all European organisations have a constitution or statutes and/or internal rules of procedure. Explicit provisions which describe sanctions if national affiliates do not implement European agreements do not exist so far in the constitutions/ statutes of sectoral European organisations. General provisions on expulsion of national members if they do not obey the internal rules are, however, included in almost all statutes. Article 7.1. of the CESI statutes for example, states that member organisations may be expelled if they have acted in violation of the Decisions of CESI, against the interests of CESI or if they no longer fulfil the requirements for CESI affiliation. In Article 10(2) of the EFA statutes it is stated that member organisations may be expelled if they have repeatedly violated the Decisions of EFA. ${ }^{54}$ On the basis of these internal rules, the European organisations can control their national affiliates and if necessary impose sanctions on them. It is also possible that a trade union, which is being confronted with the refusal of a national employers' organisation to start collective bargaining, informs the European "mother-organisation" of which this employers' organisation is a member and requests it to impose a sanction on its affiliate. If the European employers' organisation does not undertake any action against its recalcitrant affiliate, the national trade union could call a strike in order to force the national employers' organisation to the negotiation table. I would, however, say that a strike is the ultimate remedy. First, the method of internal pressure should be used. The concept of agency can probably serve as a legal basis to defend enforcement from the European organisation towards the national affiliates of the other European organisation. The enforcement mechanisms would be the same as the ones based on contract law, because according to the agency theory, the European organisation has concluded a contract with the national affiliates of the other European organisation. I have indicated, however, that applying the agency concept can lead to different outcomes, since it has to be determined each time which national agency concept is to be used. I have

54 See also the statutes of EURATEX (Article 9 para. 2), the statutes of EUROFEDOP (Article 7), the statutes of EUROPECHE, (Article 6.2), the statutes of FIEC (Article 4 para. 3), the statutes of HOTREC (Article 5 sub b)1), the Constitution of PEARLE, the statutes of UEAPME (article 2 sub c), the statutes of CIC-Europe (Article 8 para. 3 sub b), the statutes of the EBU (Article 6 para. 2), the Constitution of the ECA (Article 8), the statutes of EMCEF (Article 12) and the Articles of Association of ERA (Article 6.4.). 
therefore recommended that the national affiliates of the European signatory parties sign the European collective agreement as well and that the agreement stipulates which national law applies to it. ${ }^{55}$ In this way, the European organisations can directly address the national affiliates of the other European organisations in accordance with the national law that is applicable to the European collective agreement.

In most of the cases I think that the national social partners' organisations will voluntarily implement the European agreements. Even if a national affiliate is outvoted in the internal decision-making procedure with regard to European agreements, we may assume that it will be reasonable enough to accept Decisions which are taken by a certain majority and that it can therefore sometimes be outvoted. The situation could, however, occur that a national affiliate is utterly against the conclusion of a certain European agreement. In that case it could threaten the European mother organisation with resignation. The European mother organisation could in such a case either not conclude the European agreement or make an exception for that particular organisation. In order to minimise the chance that the national affiliates refuse to implement the agreement, clear internal consultation processes are necessary. This can be very time-consuming because the social partners at EC level are complex organisations, comprising a multitude of very different national organisations, often confederations of national trade unions or employers' organisations, which in turn have complex internal procedures requiring consultation of their affiliates. ${ }^{56}$ But the advantage will be that implementation of European agreements will be better secured. An attempt in this direction has been undertaken by the European Metal Federation (EMF). Within the EMF, a working group has been installed in which every national member organisation of the EMF can participate. All important EMF collective bargaining policy documents are first drafted in this working group. The group performs an important dual function: on the one hand, it plays a role of "collective bargaining policy pioneer", promoting policy developments in both the EMF and the national affiliates, while on the other hand it functions as a policy "clearing house", where the feasibility of controversial initiatives is first evaluated. ${ }^{\text {7 }}$ By using a good internal procedure, implementation of European agreements will be better secured, because possible barriers to the implementation will be removed.

55 See para. 5.6.2.

56 B. Bercusson in his research study on trade union rights in the Member States of the EU, point 142.

57 J. Gollbach and T. Schulten, Cross-Border collective bargaining networks in Europe. In: European Journal of Industrial Relations, vol. 6, no. 2, July 2000, p. 165-166. 


\subsubsection{Incorrect implementation}

In the foregoing paragraph, I argued that the chance that the national social partners' organisations refuse to implement European agreements will be small, especially if clear internal consultation processes accompany the negotiations between the European social partners' organisations. However, the fact that they implement the European agreement does not mean that they will always implement it correctly. In other words: It is possible that the national affiliates interpret the agreement in a different way than was probably intended by the signatory parties. For example, Article 13 sub b in the Recommendation Framework Agreement on the Improvement of Paid Employment in Agriculture states that the period of weekly rest should be 48 hours if possible. But what does "if possible" mean? In which situations is it not possible to grant a weekly rest of 48 hours? This is not included in the European agreement. If there is no description of these situations, the provision in Article 13 sub b can be easily undermined by the national affiliates. They could simply state that it is not possible to grant a weekly rest of 48 hours to the workers. These kinds of problems are related to the interpretation of the European agreement. In para. 6.2.2.3., I suggested the setting up of an EMCS for the prevention and resolution of possible industrial disputes between the signatory parties of a European collective agreement. For the relation between the signatory parties and their national affiliates I suggest a broadening of the tasks of the already existing Sectoral Dialogue Committees. ${ }^{58}$ These committees can already be involved in an early stage of the implementation. They can serve as a helpdesk if the national organisations start to implement the European agreement, and have questions as to the meaning of certain provisions in the European agreement. The Sectoral Dialogue Committees can also fulfil a role as supervisor, to make sure that the European agreement is implemented correctly and in due time. If the implementation flags for whatever reason, the Sectoral Dialogue Committee should give an advice to the national social partners' organisations on how or when to implement the European agreement. If the national organisations, or one national organisation remain(s) unwilling to start collective bargaining in order to implement the agreement, the Sectoral Dialogue Committee could request the European mother-organisation to expel its national affiliate. If the European mother-organisation does not undertake any action to sanction its national affiliate, this can lead to a conflict between the European signatory parties themselves. It is assumed that the European signatory parties have a duty to influence their national affiliates to implement the European collective agreement. ${ }^{59}$ The conflict could be brought before the EMCS. It is, for example, possible that the European mother-organisation of the recalcitrant national affiliate is of the opinion that this national affiliate has implemented 
the European collective agreement correctly. The EMCS could in such a case scrutinize whether the Sectoral Dialogue Committee has given a correct advice on the way how the European collective agreement should be implemented. Like the members of the Sectoral Dialogue Committees, members of the EMCS have also attended the negotiations on the European collective agreement. The advantage of using the members of the EMCS however is that they are more independent than the members of the Sectoral Dialogue Committees.

\subsubsection{Conclusions}

If the national affiliates of European social partners' organisations do not implement a European agreement, there are no enforcement procedures possible against them on the basis of Community law at this moment. ${ }^{60}$ The only enforcement possibilities exist on the basis of the internal rules of the European organisations and of course the enforcement mechanism of a strike for the trade unions. If in the future the national affiliates sign the European agreements as well, and if the European agreement stipulates which law applies to it, as I pleaded for in Chapter 5, enforcement towards national affiliates will probably be easier. If the national affiliates apply European collective agreements incorrectly, enforcement will only be possible if there is an institution which can give a final decision on how the collective agreement should be implemented. The already existing Sectoral Dialogue Committees can be helpful in the supervision on the correct and timely implementation of European agreements and furthermore in the interpretation of the European agreement if a difference of opinion between the national affiliate and its European mother-organisation exists in this regard. If this difference of opinion between the European signatory parties continues to exist, the EMCS could fulfil a role as interpretation body to control whether the Sectoral Social Dialogue Committees have given a right interpretation of the European collective agreement. The most drastic sanction based on the internal rules of the European organisations is expulsion of the national affiliate.

\subsection{Enforcement against individual workers or employers}

As stated in chapter $5,{ }^{61}$ we should distinguish two situations. The first is when the European collective agreement has been correctly implemented by the national affiliates of the signatory parties. The second is when the European collective agreement has not been implemented or has been implemented incorrectly. What are the enforcement mechanisms in each of these situations? This question will be answered in the next paragraphs.

\footnotetext{
60 L.e. April 2002

61 Para. 5.7.
} 


\subsubsection{The European collective agreement has been implemented correctly}

If the European collective agreement has been implemented correctly by the national affiliates, the terms of the agreement will be reflected in national collective agreements. For the enforcement of these national agreements, the individual worker or employer has to rely on the national law of his Member State. In many Member States there are specialised committees for the interpretation of collective agreements. These committees consist mainly of representatives of the employers' and workers' organisations. The courts serve as an appeal body if one of the parties does not agree with the advice of the committees. $^{62}$ If the European collective agreement has been implemented correctly, it is no longer necessary to look at it, when the national agreement is being interpreted, as the terms of the agreement are a correct reflection of the European collective agreement.

\subsubsection{The European collective agreement has not been implemented or has been implemented incorrectly}

In Chapter 5, I have argued that in case of non-implementation or incorrect implementation it should be possible for individuals to directly rely on a European collective agreement towards each other. ${ }^{63}$ This would mean, however, that specific Community legislation on the legal effects of European collective agreements is necessary which is not the case yet. ${ }^{64}$ The signatory parties could put a time limit in the European collective agreement for implementation by their national affiliates. If that time limit has passed and the national affiliates still have not implemented the European collective agree-

62 l.e. in Germany, Austria, The Netherlands, Luxembourg, Spain, Ireland, Sweden and Great Britain. In Great Britain, collective disputes are only dealt with by civil courts in Great Britain in so far as they give rise to civil action. In France the regular civil court has jurisdiction over the meaning of the provisions of a collective agreement. In Italy, the civil courts deal with disputes of rights, but only brought through individual claims, even if the dispute involves a collectivity of employers or employees. In Greece, collective labour disputes are only up to conciliation and arbitration. In Portugal and Finland, collective labour disputes are for the labour courts to be settled. In Denmark, individual labour disputes which have a relation with the collective agreement can not be decided up on by the ordinary courts. Such disputes are to be decided by the institutions of the system of trade jurisdiction, to which, however, only the parties to the collective agreement have access. See: The resolution of industrial disputes, the use and development of conciliation and mediation procedures, Part I, A. Jacobs, A synopsis of national rules and practices in the countries of Western Europe, pp. 1/1-1/53. In Belgium, disputes about the interpretation of a collective agreement can be considered within the framework of an individual dispute between an employer and an employee. In: M. Rigaux (ed.), CAO-recht, afl. 1, Diegem, September 1994. Chapter 5, part 2: M. Rigaux and G. Cox, Afdwingbaarheid van de obligatoire bepalingen, point 530 and 550 .

63 See para. 5.7.2

64 At least not in April 2002. 
ment, direct effect could apply, provided that the conditions are met as described in Chapter 5. ${ }^{\circ 5}$ Individual workers could rely on certain provisions in European collective agreements towards employers and vice-versa. As I said above, in para. 6.4.1., it depends on the national law of the Member States whether individuals have to go to a court or to a specialised committee.

The direct effect of European agreements can take several forms. An individual worker or employer can ask the national institution which is entrusted with the interpretation of the collective agreement to interpret the provisions of that agreement in conformity with the European agreement. This will be the case when the national agreement is not in conformity with the European agreement. It is also possible that a national collective agreement does not give any rules for a particular situation, while the European agreement does. This means that the national institutions would have to apply the provisions of the European agreement to the facts of the case. When it comes to the question whether certain provisions of a European collective agreement have direct effect, the national institution can not ask the ECJ for a preliminary opinion. In this sense the comparison with Directives can not be made, for Directives are Community law which are subject to legal review by the ECJ. European collective agreements are not Community law and thus can not be subject to such legal review. The role of the ECJ could, when it comes to the question whether provisions of the European collective agreements have direct effect, be fulfilled by the Sectoral Dialogue Committees. Invoking damages for the non-implementation of the European collective agreement is a possibility that could be introduced, analogous to the Francovich doctrine for Directives. However, as stated in Chapter $5,{ }^{66}$ it is sometimes difficult to determine who is responsible for the non-implementation of European collective agreements. Only when there is a blunt refusal from one of the national organisations to start collective bargaining, it is clear that this organisation is to blame. However, it is also possible that both organisations are willing to implement, but that this implementation is being held up because the parties cannot agree on the question as to a correct implementation of a certain provision in the European collective agreement. In such a case it requires substantial fact-finding to determine which organisation is to blame for the non-implementation and to what extent. I would therefore say that invoking damages for the non-implementation of European collective agreements is too far-reaching at the moment.

65 No time limit has been included in the agreement in the agricultural sector with regard to itsimplementation. Moreover, Article 19(2) of the agreement states that existing national collective agreements remain in force until a new one is concluded. So direct effect in case the national affiliates do not undertake any action to implement the European agreement does not seem to be possible here. 


\subsubsection{Conclusions}

If the European collective agreement has been implemented correctly and within due time by the national social partners' organisations, the enforcement procedures for the rights and obligations of the individuals are determined by national law. In case of non-implementation or incorrect implementation, individuals can only do something if the theory of direct effect be introduced. Individuals can go to a court or specialised committee, depending on what the national law prescribes, to enforce the provisions of the European collective agreement towards each other. Preliminary rulings on the question whether certain provisions of European collective agreements have direct effect can be given by the Sectoral Dialogue Committees. Invoking damages for the non-implementation or incorrect implementation from the national social partners' organisations is no suitable option, because it can be very difficult to determine who is responsible for the incorrect implementation of European collective agreements.

\subsection{Conclusions}

At this moment enforcement by one signatory party of a European collective agreement against another has to be done on the basis of Belgian contract law, provided that the European collective agreement fulfils the conditions of a contract in accordance with Belgian law. On the basis of Belgian contract law there are four basic courses of action: Specific performance, damages, exceptio non adimpleti contractus, and termination. Specific performance is only effective when it can be combined with economic pressure, for example in the form of an astreinte. This will be difficult because certain European social partners' organisations lack legal personality. A claim for an astreinte can therefore not be made effective. Furthermore specific performance only makes sense when it is very clear what can be expected from the party who has to perform. This means that the claim of performance has to concern clear rights and obligations. The action for damages can not be made effective either, for the same reason as the astreinte: the lack of legal personality of certain European social partners' organisations. The action of exceptio non adimpleti contractus could be effective. For example, if the employers' organisations refuse to obey the European collective agreement, the European trade union can call a strike. Furthermore, termination of the European collective agreement can also be effective. For the future, prevention and resolution of industrial disputes could be realized by means of a conciliation, mediation, or arbitration machinery. The already existing Sectoral Dialogue Committees could be given conciliation tasks. If this conciliation were to fail for whatever reason, the dispute could be handed over to a European Conciliation and Mediation Service, analogous to the Federal Mediation and Conciliation Service as established in the USA. The EMCS could serve as a sort of body of appeal. The advantage of an EMCS above the SDCs is that the persons in the 
EMCS could consist of independent and neutral persons and be selected on the basis of certain qualifications such as special mediation skills and knowledge in the field of industrial relations. Such an EMCS could be established by a European collective agreement. It will remain difficult to impose effective sanctions as long as certain European social partners' organisations lack legal personality. It should, however, not be forgotten that an obstinate and recalcitrant attitude of European social partners' organisations will result in isolation of these organisations and in their exclusion from important decision making in the industrial relations at European level.

Community law does not give any possibilities for the enforcement of the European collective agreement towards national social partners' organisations. Nor do I think that it should do so as already argued in Chapter 5. On the basis of internal rules of procedure, national organisations can be expelled if they do not act in conformity with these internal rules. This could be the case if they do not implement European collective agreements. Clear internal consultation processes can avoid national organisations being unwilling to implement European collective agreements. These consultation processes could make sure that possible barriers for the national organisations to the implementation of the European collective agreements can be removed. More difficult is the situation when the national affiliates implement the European collective agreement, though not correctly. This could be the case if the European collective agreement contains provisions which are very vague or could be interpreted in several ways. Incorrect implementation could be avoided if the SDCs could play an active role as supervisor and body of advice when it comes to questions how certain provisions of European collective agreements should be interpreted. It is clear that if - despite a clear advice of the SDC on how to implement the European collective agreement - is national affiliates still implement the agreement incorrectly, the European mother-organisation could be asked to expel this affiliate or impose some other sanction on it. If the European-mother organisation is, however, of the opinion that the national affiliate should not have sanctions imposed, the conflict could be brought before the EMCS.

The enforcement against individual workers and employers will be done in accordance with national law if the European agreement has been implemented correctly by the national affiliates of the European signatory parties. If the European collective agreement, however, has not been implemented or has been implemented incorrectly, there is nothing that individual workers or employers can do at this moment. I have given some ideas on the possible direct effect of European collective agreements in Chapter 5 If direct effect would be possible, national collective agreements could be interpreted in conformity with the European collective agreement. This interpretation could be done by the national institution which is entrusted with the interpretation of the national collective agreement. This could be a court or joint committee 
depending on the law of the Member State in question. The national institution could ask the advice of the SDCs on the question whether certain provisions of the European collective agreement can have direct effect. I do not support the idea of invoking damages for the non-implementation of the European collective agreement. It is not very practical, since it will sometimes be difficult to determine who is exactly responsible for the non-implementation of European collective agreements. There are always more parties who are responsible for this implementation. This is the difference with Directives, for which the national government is always ultimately responsible when it comes to its implementation.

There remains thus much to be done if the European social partners' organisations want to secure the correct and timely implementation of their agreements. In this Chapter I have therefore given some possibilities to be used for a future European collective labour law. 


\section{PART III}

THE CONVERSION OF EUROPEAN COLLECTIVE AGREEMENTS INTO COMMUNITY LAW 


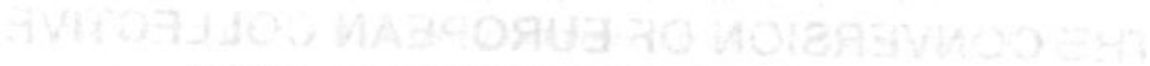

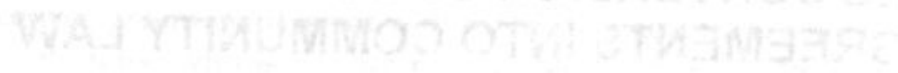




\section{CHAPTER 7}

\section{IMPLEMENTATION OF EUROPEAN COLLECTIVE AGREEMENTS BY COUNCIL DECISION}

\subsection{Introduction}

On the basis of Article 139(2) EC Treaty, European collective agreements can be implemented by a Council decision:

\footnotetext{
"Agreements concluded at Community level shall be implemented either in accordance with the procedures and practices specific to management and labour and the Member States or, in matters covered by Article 137, at the joint request of the signatory parties, by a Council decision on a proposal from the Commission."
}

Turning a European agreement into a Council decision means that the agreement will also apply to those workers/employers who are not a member (directly or indirectly), of the signatory parties. Taking a close look at Article 139(2), shows that several conditions have therefore to be fulfilled. The question is what exactly these conditions amount to. In the first place, the European agreement has to cover matters which fall under the subject matter of Article 137 EC Treaty. This requirement will be discussed in para. 7.2. Secondly, the signatory parties have to make a joint request for implementation by Council decision. This item will be dealt with in para. 7.3. Thirdly, the Commission has to draw a proposal for legislation. This point will be discussed in para. 7.4. Fourthly, the Council has to take a decision. This procedure will be described in para. 7.5. Another question is why the EP and ESC are excluded from the decision-making process prescribed in Article 139(2) EC Treaty and whether this exclusion is desirable. This will be discussed in para. 7.6. Finally, in para. 7.7., some conclusions will be drawn.

It can occur that the European social partners' organisations do not agree with the decisions of the Commission and/or the Council to accept or to reject their agreement. The possibilities for them to institute legal proceedings against the Commission and/or the Council will be discussed in Chapter 8 .

\subsection{The European collective agreement has to cover matters of Article 137 EC Treaty}

According to the words of Article 139(2), a Council decision is only possible if the agreement covers matters which are within the scope of Article 137. 
These matters are:

- improvement in particular of the working environment to protect workers' health and safety;

- working conditions;

- the information and consultation of workers;

- the integration of persons excluded from the labour market, without prejudice to Article 150;

- equality between men and women with regard to labour market opportunities and treatment at work;

- social security and social protection of workers;

- protection of workers where their employment contract is terminated;

- representation and collective defence of the interests of workers and employers, including co-determination;

- conditions of employment for third-country nationals legally residing in Community territory;

- financial contributions for promotion of employment and job-creation, without prejudice to the provisions relating to the Social Fund.

So, if the social partners want their agreement to be implemented by Council decision, they have to stick to the matters mentioned in Article 137 EC Treaty.' This requirement has to do with the legislative competence of the Council. The Council can only act if this is explicitly allowed in the EC Treaty. ${ }^{2}$ This does not, however, have to be a problem, since Article 137 mentions almost all fields of social policy. But are certain subjects nevertheless excluded and why? This question will be answered in para. 7.2.1.

We have to bear in mind that Article 137 EC Treaty has been changed by the Treaty of Nice. This Treaty will enter into force on the first day of the second month after the lodging of the ratification instrument by the Member State which is the last to complete this formality. ${ }^{3}$ So far, Denmark, Spain, France, Luxembourg, The Netherlands and Austria have ratified the Treaty of Nice. The other Member States are still in the ratification procedure. This means that the Treaty of Nice has not yet entered into force. I will, however, briefly discuss the changes within Article 137 EC Treaty where appropriate.

In the Treaty of Nice, two new subjects have been added to the fields in which the Community shall act: the combating of social exclusion and the modernisation of social protection systems.

1 The Commission confirms this again. See COM(98) 322, p. 16.

2 See Article 5 EC Treaty, first sentence and Article 7(1) EC Treaty, last sentence.

3 Home-page EU http://europa.eu.int/index-eng.htm. 


\subsubsection{Excluded subjects?}

Certain issues are explicitly excluded from Community legislation. According to para. 6 of Article 137 EC Treaty, the Council is not allowed to adopt measures on pay, the right of association, the right to strike, or the right to impose lock-outs. No further definition is given of these concepts. The Treaty of Nice has not changed anything in the content of this paragraph. Only the numbering of the paragraph has been changed. ${ }^{4}$ Does the exclusion of Article 137(6) EC Treaty also apply if the Council adopts a measure on the basis of Article 139(2) EC Treaty instead of on the basis of Article 137(2) EC Treaty? Reading Article 137(6) EC Treaty closely, it states that "The provisions of this Article (i.e. Article 137, E.F.), shall not apply to pay, the right of association, the right to strike, or the right to impose lock-outs." That would imply that if the Council adopted a measure on the basis of Article 139(2), it could very well legislate on these matters. However, Article 139(2) EC Treaty clearly states that a European agreement can only be implemented by a Council decision if it covers matters dealt with under Article 137. Article 137 excludes certain matters from Community legislation in para. 6 . If one presumes that the exclusion of Article 137(6) EC Treaty is not applicable in case of legislation on the basis of Article 139(2), this means that the Council could easily introduce legislation on pay, the right of association, the right to strike, or the right to impose lock-outs through the back door of implementing European collective agreements. ${ }^{5}$ Whether that was the intention of the Treaty makers depends on the reason for including Article 137(6) EC Treaty. Lange argues that there is a general hesitance of the Community to intervene in institutional areas that are central to the complex national and regional systems of investment and production. Therefore governments want to retain their ability to determine the collective bargaining conditions prevailing nationally and to influence, should they wish, the institutional balance of power between unions and employers. ${ }^{6}$ The Council cannot, therefore, adopt legislation on the subjects of Article 137(6), even if that legislation is the result of an agreement between the European social partners. This means that if the social partners want their agreements implemented by Council decision, the topics of Article 137(6) cannot be subject of their agreement.' It is also possible that the reason to include Article 137(6) into the EC Treaty is the fear for resistance of the social partners' organisations in the several Member States. The subjects mentioned in Article 137(6) EC Treaty are often the heart

4 In the Treaty of Nice, it is Article 137(5).

5 See also K. Piazolo, Der Soziale Dialog nach dem Abkommen uber die Sozialpolitik und dem Vertrag von Amsterdam, p. 127-128.

6 P. Lange, Maastricht and the Social Protocol: Why did they do it? In: Politics \& Society, vol. 21, no. 1, 1993, p. 11.

7 B. Hepple, European labour law: the European Community, In: R. Blanpain and C. Engels (eds.), Comparative labour law and industrial relations in industrialized market economies, Deventer, 1993, p. 158. 
of collective agreements at national level. Community legislation on these subjects would mean an interference in these national collective agreements. This interference would be absent however if it would consider the implementation of a European collective agreement. In that case it would not be the Community legislator who determines the content of the legislation but the social partners' organisations at European level. I think that this reason is more obvious than the reason which is brought forward by Lange. Otherwise the Community legislator would have put the excluded subjects of Article 137(6) EC Treaty in Article 139(2) EC Treaty as well.

\subsubsection{Conclusions}

Also if the European collectve agreement covers subjects mentioned in Article 137(6) ECT, it can nevertheless be implemented by Council Decision. The prohibition of Community legislation on the subjects covered by Article 137(6) ECT only applies if the Council does not legislate on the basis of a European collective agreement.

\subsection{The signatory parties have to make a joint request}

If the social partners want their agreement implemented by Council decision, they have to request this jointly. This means that all parties who signed the agreement have to agree that their agreement should be turned into a Council decision. Does this raise any difficulties? So far not. In practice, the social partners decide already beforehand what they want with their agreement. This appears from the text of the agreements concluded so far. In the European Framework Agreement on Parental Leave as well as the European Framework Agreement on Part-Time Work and the European Framework Agreement on Fixed Term Work, obligations are not only put on the individual workers and employers, but also on the Member States. For example Clause 2(7) of the European Framework Agreement on Parental Leave states:

"Member States and/or Social Partners shall define the status of the employment contract or employment relationship for the period of parental leave."

Clause 5(1A) of the European Framework Agreement on Part-Time Work states:

"Member States, following consultations with the Social Partners in accordance with national law or practice should identify or review obstacles of a legal or administrative nature which may limit the opportunities for part-time work and, where appropriate, eliminate them." 
The social partners' organisations themselves cannot put obligations on the Member States, because the Treaty does not give them such powers. ${ }^{8}$ It is therefore obvious that the intention of their agreement was to have it implemented by Council decision, because the Council can put obligations on the Member States. Looking at the Recommendation Framework Agreement on the Improvement of Paid Labour in Agriculture, which will be implemented by the national affiliates of the signatory parties, we see that the provisions are mostly directed to the national affiliates. The signatory parties make recommendations to them. Provisions directed to the Member States are absent. In the three sectoral agreements on working time, no provisions are explicitly directed to the Member States. However, it is clear that the signatory parties wanted these agreements to be turned into a Council decision. The European Agreement on the Organisation of Working Time of Mobile Staff in Civil Aviation and the European Agreement on the Organisation of Working Time for Seafarers, both contain a phrase in their Considerations in which a request is made to the Council to turn their agreement into a Council decision on the basis of Article 139(2) EC Treaty.

How does a joint request of the signatory parties to the Commission take form in practice? Special formal requirements are not given. Preferably the request should be done in writing and contain at least the agreement itself. ${ }^{9}$ This will be the most practical, since in such a case it can be proved that the signatory parties have made a request and it will always be clear to what the request refers. The request should also contain the reasons why the signatory parties want it to become Community law. After all, the institutions of the Community can only act within the limits of the powers conferred upon by this Treaty. ${ }^{10}$ The activities of the Community as mentioned in Article 3 EC Treaty have to serve the purposes of Article 2." This means that the subjects of the agreements between the social partners have to contribute to the realisation of the aims of the Community.

Can the social partners' organisations also withdraw their request to turn their agreement into a Council decision? And what will be the consequences of such withdrawal? The signatory parties make their request to the Commission and not to the Council. They request the Commission to submit their agreement as a proposal to the Council. Nothing in the Treaty prohibits them from withdrawing their request. The question is, however, what the reaction of the Commission should be to such withdrawal. I would say that as long as

\footnotetext{
8 See also Chapter 5, para. 5.8 .
}

9 See also B. Bödding, Die europearechtlichen Instrumentarien der Sozialpartners, pp. 105-106 and C. Calliess and M. Ruffert (eds.), Kommentar des Vertrages uber die Europăische Union und des Vertrages zur Gründung der Europăische Gemeinschaft EUV/EGV-, Article 139, point 25.

10 Article 7 EC Treaty.

11 See also R. Barents and L.J. Brinkhorst, Grondlijnen van Europees recht, p. 126. 
the Commission has not sent the agreement to the Council, the signatory parties to the European agreement should have the possibility to withdraw their request for extension. Since they have to make the request jointly, their decision to withdraw their request should also be made jointly. If the Commission nevertheless wants to continue its legislative procedure, by submitting the agreement to the Council, I think that it cannot base this on the procedure of Article 139(2) EC Treaty. This provision explicitly states that there should be a joint request of the signatory parties. If the social partners withdraw their joint request, it is apparent that there is no joint request anymore. If the Commission nevertheless wants to formulate a legislative proposal for the Council, it would have to use another procedural basis. This will always imply involvement of the EP. The question is, however, whether it should start the whole process over again and consult the social partners again on the basis of Article 138(2) and (3) EC Treaty. If the Commission wants to formulate a proposal on exactly the same subject as the withdrawn agreement of the social partners, I do not think that a new consultation is necessary. After all, the Commission has already done this the first time the social partners decided to start negotiations. That these negotiations led to an agreement which the social partners on second sight decided not to have implemented by Council decision, does not alter the fact that a new consultation is doing things all over again. In my opinion this is needless and superfluous. I would, however, suggest that as soon as the Commission has submitted the agreement to the Council, there should be no further possibility for the social partners' organisations to withdraw their request. In scheme this would give the picture as shown in figure 1.

In can be concluded that the signatory parties have to ask the Commission jointly to turn their agreement into a Council decision. Formal requirements for the request of the signatory parties are not given in the Treaty. However, it follows from the legislative competence of the Community institutions that the request should be motivated. For practical reasons it should be in writing. Furthermore, the signatory parties should have the possibility to withdraw their request as long as the Commission has not submitted their agreement to the Council. If the Commission nevertheless wants to continue its legislative process, it cannot do this anymore on the basis of Article 139(2) EC Treaty, since a joint request of the signatory parties is required for this. 
Figure 1

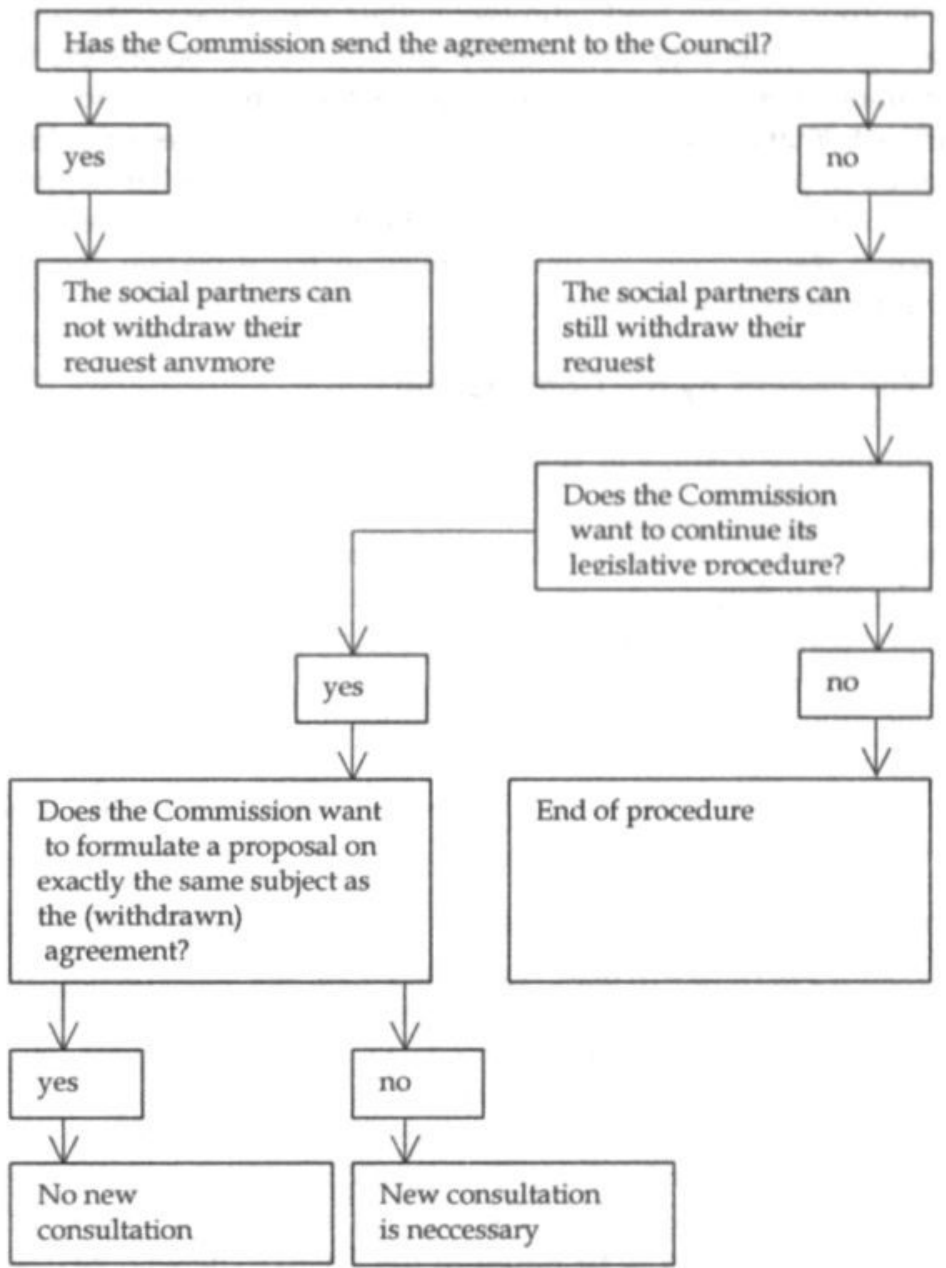




\subsection{The Commission has to formulate a proposal}

Without a proposal from the Commission, the Council cannot turn European collective agreements into Community law. However, before the Commission formulates a proposal, it checks whether the agreement and the concluding parties to that agreement fulfill certain conditions. These conditions will be discussed in para. 7.4.1. Furthermore, the question is what happens if the Commission rejects the agreement. This question will be answered in para. 7.4.2. Finally, the proposal of the Commission has a certain specific form, which will be outlined in para. 7.4.3.

\subsubsection{The checks by the Commission}

If the Commission decides to formulate a proposal for the Council, it will carry out a number of checks on the agreement. The Commission does this "by virtue of its role as guardian of the Treaties". ${ }^{12}$ The Commission will consider the following:

- the representative status of the contracting parties;

- their mandate;

- the "legality" of each clause in the collective agreement in relation to Community law;

- the provisions regarding small and medium-sized enterprises (SMEs) set out in Article 137(2) EC Treaty. ${ }^{13}$

In the EC Treaty, nothing at all is stated about these checks. There are only general Treaty provisions which can be used by the Commission to justify the application of the third and fourth check. According to Article 211 EC Treaty, first sentence, the Commission's tasks are, among others, "to ensure that the provisions of the Treaty (...) are applied". An agreement containing provisions which are contrary to the Treaty can thus never be implemented by a Council decision, at least not the specific provisions of the agreement which run counter to the Treaty. For the first and second check, however, there is no real legal basis to be found in the Treaty. The CFI, has, however, given a reason for the Commission to check the representativity of the signatory parties in the UEAPME-case. UEAPME, a European organisation representing small and medium-sized enterprises, on 5 September 1996, submitted a claim before the CFI, seeking the annulment of the Directive on Parental Leave. ${ }^{14}$ This case is interesting in more than one aspect. The material aspects will be discussed in this chapter, the procedural aspects will be discussed in Chapter 8. An important material aspect of this case is that the

$12 \operatorname{COM}(93) 600$ final, point 39 , last sentence.

$13 \operatorname{COM}(93) 600$ final, point 39.

14 Case T-135/96, Judgment of 17/06/1998, UEAPME / Council (Rec.1998, p.II-2335), Order of 18/03/1997, UEAPME / Council (Rec.1997, p.II-373). 
CFI said some important things about the representativity of European social partners' organisations. This will be discussed in para. 7.4.1.1. It also gave a reason why the Commission should check whether the signatory parties to a European agreement that is to be implemented by a Council decision, are representative. It stated that the legislative procedure prescribed in Article 139(2) EC Treaty does not provide for the participation of the European Parliament (EP):

"However, the principle of democracy on which the Union is founded requires in the absence of the EP in the legislative process that the participation of the people be otherwise assured, in this instance through the parties representative of management and labour who concluded the agreement which is endowed by the Council, (...), with a legislative foundation at Community level. In order to make sure that that requirement is complied with, the Commission and the Council are under a duty to verify that the signatories to the agreement are truly representative."15

I agree with this reasoning. The representativity of the signatory parties is important if the agreement will also apply on those workers/employers who are not a member (directly or indirectly), of the signatory parties. This has happened with the European Framework Agreement on Parental Leave, the European Framework Agreement on Part-Time Work, the European Framework Agreement on Fixed Term Work, the European Agreement on the Organisation of Working Time for Mobile Staff in Civil Aviation and the European Agreement on the Organisation of Working Time for Seafarers, all of which have been turned into a Council Directive. If the signatory parties of these agreements would only represent a small amount of workers and employers, the question is whether the people of the Community, to whom the Directive applies, would have sufficiently participated in the creation of Community law. The ECJ has more than once decided that democratic representation is a fundamental principle of Community law. The people of the Member States should be able to participate in the creation of Community law, directly or indirectly. This is the fundamental principle of democratic legitimacy. ${ }^{16}$

This reasoning is also applicable to legitimate the check on the mandate. If the signatory parties are not mandated by their national affiliates to conclude a specific European agreement, it is questionable whether the will of these national affiliates is reflected in the European agreement. After all, the national affiliates represent the individual workers and employers in the Member

15 Cons. 89.

16 Case C-300/89, Judgment of 11/06/1991, Commission/Council (Rec.1991,p.1-2867), Case C-65/93, Judgment of 30/03/1995, Parliament/Council (Rec.1995,p.1-643), Case C-21/94, Judgment of 05/07/1995, Parliament/Council (Rec.1995,p.1-1827), Case C392/95, Judgment of 10/06/1997, Parliament/Council (Rec.1997,p.I-3213). 
States. The last-mentioned have to identify themselves in the European agreement. I will discuss the checks of the Commission hereafter in more detail.

\subsubsection{The representativity of the signatory parties}

In some Member States, social partners' organisations need to fulfill certain representativity criteria, otherwise it will be difficult or even impossible for them to have their collective agreements recognized by law, even if these agreements are not being extended erga omnes. ${ }^{17}$ This idea has not been taken over at European level. The Commission has stated that only the social partners themselves can develop their own dialogue and negotiating structures, and that it cannot impose participants on a freely undertaken negotiation. ${ }^{18}$ Article 139(1) EC Treaty does not state that management and labour have to be representative. If, however, the European social partners' organisations want their agreement to be turned into a Council decision, the Commission plays an active role in the determination of the representativity of the signatory parties. What are these criteria? We have seen in Chapter 4 that the Commission applies certain criteria to the representativity of the social partners' organisations in order to determine whether it will consult these organisations under Article 138(2) and (3) EC Treaty. ${ }^{19}$ Let me repeat these criteria here. To be representative enough for consultation, an organisation must be:

- cross-industry or relate to specific sectors or categories and be organised at European level;

- consist of organisations which are themselves an integral and recognised part of Member State social partner structures;

- have the capacity to negotiate agreements;

- are representative of all Member States, as far as possible;

- have adequate structures to ensure their effective participation in the consultation process or currently comply broadly with these criteria.

These criteria were drafted in the 1993 Communication of the Commission. In its 1996 Communication, the Commission states that in cases where Article 139 (2) is being applied, the Commission has the responsibility to assess the validity of an agreement in light of its content. This among others requires an assessment of whether those affected by the agreement have been represented. The Commission must therefore examine whether:

17 For example in Belgium, Spain, Greece and France, In: R. Blanpain (ed. in Chief), International Encyclopedia for Labour Law and Industrial Relations.

$18 \operatorname{COM}(96) 448$ final, point 70 . As well as $\mathrm{COM}(98) 322$, p. 5.

19 Para. 4.3.4.1. 
- those involved in the negotiation have a genuine interest in the matter and

- can demonstrate significant representation in the domain concerned. ${ }^{20}$

The criteria in the 1996 Communication are different from the ones with regard to the consultation procedure described in the 1993 Communication. The reason for this could be that the criteria of the 1993 Communication shall be applied in case of consultation on the basis of Article 138(2) and (3) EC Treaty and that the criteria of the 1996 Communication will be applied in case of implementation of the agreement on the basis of Article 139(2) EC Treaty. In the 1996 Communication, nothing is said about the organisational structure of the European organisations, for example whether or not they have to be organised at European level, or whether their national affiliates are recognised in the respective Member States. The criteria of the 1996 Communication especially seem to ensure that the concluding parties are representative in the domain that is the subject of the agreement. For example: a trade union in the agricultural sector cannot comply with the criteria of the 1996 Communication as regards an agreement in the metal sector. The words "genuine interest in the matter" and "significant representation in the domain concerned" indicate this. In its 1998 Communication, the Commission is even briefer about the representativity criteria. It just states that the signatory parties have to be sufficiently representative in relation to the scope of their agreement. ${ }^{21}$

Let us take a look at the several Commission proposals formulated on the basis of European collective agreements so far, to see how the Commission has dealt with the issue of representativity. After the European agreement has been concluded, the Commission sends it to organisations who have not participated in the negotiations. The Commission organises a meeting in which these organisations can give their views on the agreement. ${ }^{22}$ The organisation of such meetings depends entirely on the will of the Commission. ${ }^{23}$ The character of such a meeting is informal and the purpose for the Commission is to obtain information on possible defects in the agreement, for example with regard to the representativity of the concluding parties or with regard to incompatibilities of the agreement with Community law. This meeting is, for the organisations who could not participate in the negotiations, an opportunity to influence the follow-up of such an agreement. In its explanatory memorandums to its proposals for a Council decision on the three inter-professional agreements as well as two sectoral agreements, the

\footnotetext{
$20 \operatorname{COM}(96) 448$ final, point 71.

$21 \mathrm{COM}(98) 322$, para. 5.4 .2$.

22 Proposal for a Council Directive on the European Framework Agreement on Parental Leave, $\operatorname{COM}(96) 26$ final, point 14.

23 Interview with DG V on 1 April 1998.
} 
Commission applied a representativity check. It did not, however, use the criteria which it mentioned in its 1996 Communication, but the criteria of its 1993 Communication which it uses for consultation. ${ }^{24}$ This implies that all organisations, which are listed in the annex by the 1993 Communication ${ }^{25}$ are, according to the Commission, representative enough to conclude European collective agreements. Furthermore, with regard to the intersectoral agreements, the Commission says that the ETUC, UNICE and CEEP are the only three general cross-industry organisations which fulfill these criteria. ${ }^{26}$ More specifically, the Commission states that UNICE is the most representative of all industrial sectors and categories of enterprises because "in all the Member States, the organisations affiliated to the UNICE are by far the most representative cross-industry employers' organisations. All the affiliated organisations at national level are directly or indirectly involved in collective bargaining and participate in the ILO." ${ }^{27}$ The same reasoning goes for the ETUC. ${ }^{28}$ Apparently, the fact that these national affiliates of the European organisations participate in the ILO is also an important aspect for the Commission, although it does not mention this in its representativity criteria, neither in the criteria mentioned in the 1993 Communication, nor in the ones mentioned in its 1996 Communication. The representativity of CEEP is merely defended by stating that "CEEP provides significant representation of public enterprises or enterprises with public participation in the Member States." ${ }^{29}$ So, given the character of the agreement (general agreement applying to all workers and employers in the EU), the Commission thinks that the representation of workers and employers is sufficiently covered by ETUC, UNICE and CEEP. In its proposal on the European Framework Agreement on Part-Time Work, the Commission adds the comment that "having verified the relevant clauses, the Commission feels that the framework agreement makes reference on a number of occasions to the social

$24 \operatorname{COM}(96) 26$ final, point 11 and Proposal for a Council Directive concerning the Framework Agreement on Part-Time Work concluded by UNICE, CEEP, and the ETUC, COM(97) 392 final, point 14 and Proposal for a Council Directive concering the Framework Agreement on Fixed Term Work concluded by UNICE, CEEP, and the ETUC, COM(99) 203 final, point 15; Proposal for a Council Directive concerning the European Agreement on the organisation on Working Time of Mobile Workers in Civil Aviation concluded by the AEA, ETF, ECA, ERA, and the IACA, COM(2000) 382, point 6; Proposal for a Council Directive concerning the Agreement on the organisation of Working Time of Seafarers concluded by the ECSA and the FST, COM(98) 662 final, point 6.

25 See also Chapter 4, para. 4.3.4.1.

$26 \operatorname{COM}(96) 26$ final, point 12 and $\operatorname{COM}(97) 392$ final, point 15 and $\operatorname{COM}(99) 203$ final, point 16 .

$27 \mathrm{COM}(96) 26$ final, point 12.1 and $\operatorname{COM}(97) 392$ final, point 16 and $\operatorname{COM}(99) 203$ final, point 18 .

$28 \mathrm{COM}(96) 26$ final, point 12.2 and $\operatorname{COM}(97) 392$, point 17 and $\operatorname{COM}(99) 203$ final, point 19.

$29 \operatorname{COM}(96) 26$ final, point 12.1 and $\operatorname{COM}(97) 392$ final, point 16 and $\operatorname{COM}(99) 203$ final, point 18. 
partners at the appropriate level and to national law, collective agreements or practice, and thus very largely preserves the role of the non-signatory social partners and their members at national level". ${ }^{30}$ In other words the Commission says that the Framework Agreement is very generally formulated. It leaves a lot of freedom to the national organisations to regulate certain issues in their own Member States. Therefore, the interests of the workers and employers who are not a member, directly or indirectly, of the signatory parties, will be sufficiently taken into account. With regard to the European Agreement on the Organisation of Working Time of Mobile Staff in Civil Aviation, the Commission uses clear figures to determine the representativity of the signatory parties. It states that on the employers' side (AEA, IACA and ERA), the members of the 3 signatory parties employ nearly $95 \%$ of all mobile staff. On the workers' side, there are 2 signatory parties: the ECA and ETF. The ECA represents more than $80 \%$ of the European pilots and flight engineers and the ETF represents some $70 \%$ of the cabin crew. ${ }^{31}$ In its proposal on the European Agreement on the Organisation of Working Time for Seafarers, the Commission just states that it has taken the representativity of the signatory parties into account. ${ }^{32}$

Not only the Commission, but also the CFI has dealt with the representativity question of European social partners' organisations. In the UEAPME case, already mentioned in the beginning of para. 7.4., UEAPME was of the opinion that the small and medium-sized enterprises were not sufficiently represented by UNICE. UEAPME should therefore have participated in the negotiations on the European Framework Agreement on Parental Leave. The CFI first made an interesting distinction by denying that every organisation of labour and management, recognised as 'representative' by the Commission for its consultation under Art. 138(2) EC Treaty, also has the right to participate in the negotiations of the social partners, leading to social agreements under art. $139 .^{33}$ The negotiation stage, according to the CFI, depends exclusively on the initiative of those representatives of management and labour who wish to launch such negotiations. ${ }^{34}$ What are the criteria for the CFI to determine whether a European agreement has been concluded by sufficiently representative organisations? The CFI states that the Commission and the Council have to ascertain whether, having regard to the content of the agreement in question, the signatories, taken together, are sufficiently representative to justify the Council to turn a European agreement into a Directive. ${ }^{35}$

$30 \operatorname{COM}(97) 392$ final, point 23, repeated in $\operatorname{COM}(99) 203$ final, point 25.

$31 \operatorname{COM}(2000) 382$, point 7.

$32 \mathrm{COM}(1998) 662$ final, 14 th whereas.

33 Cons. 75-82. At the time that this case was brought before the CFI, the Articles 138 and 139 EC Treaty, were still numbered as the Articles 3 and 4 of the Agreement on Social Policy.

34 Cons. 75.

35 Cons. 90. 
Reading the considerations of the CFI, it becomes clear that the CFI looks at the categories of workers and employers who will be covered by the agreement. Regarding the fact that the subject matter at stake (i.e. parental leave) was an all-industry agreement covering all types of working relations, the CFI formulated as its own criterion that the various signatory parties should represent all categories of workers and enterprises at European level. ${ }^{36}$ The CFI then performed this verification itself as far as the employers' side is concerned. It established that the collective representativity of the signatory parties on the employers' side - UNICE and CEEP - of the contested agreement was sufficient in relation to the content of that agreement, having regard to their cross-industry character and the general nature of their mandate. ${ }^{37}$ The CFI dismissed the claim of UEAPME that, taking into account the number of SMEs it represents, it should have been among the signatory parties. The CFI stated that since the agreement concerns all employment relationships, it is not so much the status of the undertakings which is important (i.e. small, medium-sized or big enterprises, E.F.), but the status of the employer. Furthermore, the CFI stated that among the SMEs represented by UEAPME in the 14 Member States concerned by the Agreement, 'a third, (...) perhaps as many as two-thirds (...) of those SMEs are also affiliated to one of the organisations represented by UNICE'. Therefore the CFI stated that UEAPME cannot argue that its level of representativity is so big that it's nonparticipation in the conclusion of an agreement between general crossindustry organisations automatically means that the requirement of sufficient collective representativity was not satisfied. ${ }^{38}$ It is also interesting that the CFI asserted that had CEEP not been among the signatory parties this would on the contrary really have destroyed the sufficient representativity of the signatory parties. Because then, one particular category of undertakings, that of the public sector, would have been wholly without representation. ${ }^{39}$ It is thus not so much the content of the provisions of the agreement which are taken into account by the CFI, but more the scope of the agreement. The CFI tries to indicate who is covered by the agreement. If the agreement would have been concluded between ETUC and UNICE, excluding CEEP, the CFI would have rejected it, although ETUC and UNICE can definitely sustain the representativity checks of the Commission. The CFI has thus looked at the scope of the agreement, then related this scope to the categories of workers and employers represented by the signatories to the agreement, and subsequently verified whether they were, taken together, sufficiently representative.

This approach is in fact also followed by the Commission in its 1996Communication. The Commission takes the content of the agreement into

36 Cons. 94

37 Cons. 96 ,

38 Cons. 102-104.

39 Cons. 100. 
account when assessing the validity of an agreement. ${ }^{40}$ And furthermore that those who signed the agreement must demonstrate significant representation in the domain concerned. The clearest demonstration of this approach can be found in the European Agreement on the Organisation of Working Time of Mobile Staff in Civil Aviation, where the Commission actually counts the number of workers/employers covered by the signatory parties to the agreement.

Gilles has stated that the number of people covered by the European agreement should be compared to the number of people covered by the Directive in order to determine the representativity of the European social partners' organisations. ${ }^{41}$ The Commission could easily make this comparison by counting. He does not, however, mention a specific criterion. For example, if at least $50 \%$ of the people who will be covered by the Directive are also already covered by the European agreement, the organisations can be regarded representative. Betten also thinks that the signatory parties to a European agreement should at least represent a majority of employers and workers for an agreement to be turned into a Council decision. ${ }^{42}$ I think however, that if this criterion is taken into account, very few European collective agreements will be turned into a Council decision. Only in four EC Member States is the rate of union membership more than $50 \%^{43}$ and it is expected than union density will further decline in the future. ${ }^{44}$ The European social dialogue would in such a case be restricted to no more than the consultation procedure of Article 138 EC Treaty and to European collective agreements which will be implemented by the national affiliates of the signatory parties, as described in Chapter 5. Schmidt also signals another problem. She states first that many national trade unions and employers' organisations are not a member of the ETUC and UNICE. Second, decision-making structures within them based on the majority principle often exclude important and significant minority views. ${ }^{45}$ It is thus only a part of these organisations that really wants to conclude a European agreement. This means that not even all the members of the signatory parties are represented by the European agreement. In my opinion, majority voting is a legitimate element of democratic decision-making. The disadvantage of unanimity is than one

$40 \operatorname{COM}(96) 448$ final, point 71.

41 T. Gilles, Das Zustandekommen und die Durchführung von Sozialpartnervereinbarungen im Rahmen des europăischen sozialen Dialogs, p. 295.

42 L. Betten, The Democratic Deficit of Participatory Democracy in Community Social Policy, European Law Review, vol. 23, no. 1, 1998, p. 32.

43 I.e. Belgium, Denmark, Finland and Sweden, In: Industrial relations in Europe 2000, p. 9.

44 T. Boeri, A. Brugiavini and L. Calmfors, The role of unions in the twenty-first century, Oxford, 2001, p. 115-116.

45 M. Schmidt, Representativity - A claim not satisfied: The social partners' role in the EC law-making procedure for social policy. In: IJCLLIR, vol. 15, no. 3, 1999, p. 265. 
affiliate can block the whole decision-making process. We have to face the dilemma between the will to promote the European social dialogue on the one hand, and the danger that decisions will be taken by organisations that do not represent the majority of the people to whom these decisions will apply. One can argue that this dilemma can easily be solved if more employers and workers would be a member of an employers' organisation and a trade union. We should not, however, create a society in which the people's interests can only be represented if these same people become a member of an employers' organisation or a trade union. The freedom of association as laid down in the international documents described in Chapter 1, also implies the freedom not to become a member of an employers' organisation or trade union. I think therefore that the role of the EP in the decision-making process of Article 139(2) EC Treaty should be stronger than it is now. I will discuss this more extensively in para. 7.6. We should also bear in mind that the fact that the rate of union membership is low in most Member States, does not mean that the workers who are not a member of a union reject the work and decisions of trade unions. In The Netherlands, for example, there has been a discussion between the Minister of Social Affairs and a member of the Parliament about this issue. The member of the Parliament stated that the Dutch unions are not representative because the rate of union membership is very low. The Minister however, referred to a study which concluded that the majority of the Dutch people (53\%), had confidence in the work of the unions. The Dutch FNV, the largest intersectoral trade union, also undertook a study on this subject. They found that $80 \%$ of the non-members considered the work of the unions important. ${ }^{46}$

I think that the representativity criteria as formulated by me in para. 4.3.5. should also be applied if a European agreement is turned into a Council decision. If European-level organisations consist of national organisations that are not regarded as representative in their own country, European collective agreements cannot be expected to become operative in the individual EU Member States. ${ }^{47}$ Whether national organisations are representative in their own country depends on the representativity criteria of those respective countries. These vary from Member State to Member State. Furthermore, if organisations want to conclude agreements at European level, they should at least be European and not just national. ${ }^{48}$ Blanpain is of the opinion that the requirement that the organisations should be organised at a European level is not supported by the text of Article 139 EC Treaty. ${ }^{49}$ I do not agree with this

46 NRC-Handelsblad of 9 February 2001, "Niet-leden liften mee met bonden".

47 See also C.S. Jensen, J.S Madsen and J. Due, A role for a pan-European trade union movement? Possibilities in European IR regulation. In: Industrial Relations Journal, vol. 26, no. 1, 1995, p. 10.

48 See also K. Piazolo, Der Soziale Dialog nach dem Abkommen über die Sozialpolitik und dem Vertrag von Amsterdam, p. 184.

49 R. Blanpain, Sociale partners en de Europese Unie; taak en legitimatie. In: L. Betten 
point of view. It is true that the text of Article 139 EC Treaty does indeed not state anything about the European-level organisation of trade unions and employers' organisations. However, Article 139(2) speaks of "agreements concluded at Community level". This implies that it concerns European-level agreements. I also think that European-level agreements should reflect the will of workers and employers in more than just one Member State. Therefore, as I already said in para. 4.3.5., membership of European social partners' organisations should be equally spread over the Member States of the EU. Finally, national organisations which are in their respective country only representative for one specific sector, should not apply for membership of an inter-professional European organisation. ${ }^{50}$ In para. 4.3.5., I said that in order to be regarded as sufficiently representative for consultation, European organisations should have democratic internal decision-making procedures. I think that this also applies in case of implementation of European collective agreements by Council decision. I consider, however, that this is more something which falls under the check on the mandate, which will be discussed in the next paragraph.

\subsubsection{The mandate of the signatory parties}

Besides the representativity check, the Commission also checks whether the concluding parties were sufficiently mandated by their national affiliates. It is not clear how the Commission exactly checks the mandate. In its proposal regarding the three intersectoral agreements, the Commission notes that "the members of these three organisations (i.e. ETUC, UNICE and CEEP), at national level have given them a specific mandate for negotiations (...) and have ratified the framework agreement. The three organisations have concluded the framework agreement on behalf of their national members." ${ }^{51}$ Strangely enough, the Commission does not say anything of this kind in its proposal on the European Agreement on the Organisation of Working Time for Seafarers, nor in the one on the European Agreement on the Organisation of Working Time for Mobile Staff in Civil Aviation. The mandate check thus

(ed.), Ongelijkheidscompensatie als rode draad in het recht, p. 295 . See also Guery who thinks that trade union organisations that are representative in the Member State but that are not affiliated to a representative trade union organisation at Community level should also be given an opportunity to make themselves heard in the European social dialogue. However, he does not give a specific reason for this statement. G. Guery, European collective bargaining and the Maastricht Treaty. In: International Labour Review, vol. 131, no. 6, 1992, p. 594.

50 See also Advice of the SER (Dutch Social Economic Council), Commissie Internationale Sociaal-Economische Aangelegenheden, "Europese sociale dialoog", 98/18, 27 november 1998, p. 26.

51 See $\operatorname{COM}(96) 26$ final, point $13, \operatorname{COM}(97) 392$ final, point 18 and $\operatorname{COM}(99) 203$ final, point 20. 
leaves questions with regard to the method of the check and with regard to the frequency of it.

I think that the mandate check touches a broader aspect, namely the internal decision-making process within the European social partners' organisations. Of course it is important that the Commission checks whether the signatory parties were sufficiently mandated by their national affiliates but the more important question is how this mandate was drawn up. What was the internal decision-making process leading to the mandate? I already said in the beginning of para. 7.4.1., that in my opinion, the mandate check is an application of the principle of democracy upon which the Union is founded. If the drafting of the mandate, however, took place under a decision-making procedure that can hardly be called democratic, the mandate-check is just for show. If the Commission considers it important to check the mandate of the European social partners organisations, it should also check the internal decision making process of these organisations. The three intersectoral organisations, ETUC, UNICE and CEEP have developed a specific internal decision-making procedure when it comes to the conclusion of European collective agreements.

\section{The ETUC}

Article 13 of the ETUC Constitution gives some general rules on the internal decision-making process of ETUC as regards negotiations with European employers' organisations. Besides this provision there are also internal Rules of Procedure for implementing this article. These internal rules were adopted by the Executive Committee on 10 October 1996. It is the Executive Committee that determines the composition and mandate of the delegation for negotiations with European employers' organisations. ${ }^{52}$ The internal rules of procedure make clear how the delegation of ETUC is composed and what the delegation is allowed to do in the negotiations. First the Secretariat sends all information and details of proposals concerning the potential negotiations to the member organisations. ${ }^{53}$ The information which is sent to the member organisations shall address in particular:

- the cross-sectoral nature of the issue and of the right to be negotiated;

- the appropriateness of opening negotiations on the issue on which consultations have been opened by the Commission;

- the priority objectives for the negotiations;

- the composition of the delegation likely to take part in the negotiations;

- the objective sought: agreement to be implemented voluntarily, agreement to be extended by a Council decision etc.;

- the cross-sectoral approach proposed by the Commission may be of particular importance to certain sectors/categories. In this case the negotiating

52 Article 13 of the Constitution.

53 Rule 3. 
mandate will take account of the problems of the sectors and categories concerned, both in the content of the mandate and in the composition of the delegation responsible for the negotiations. ${ }^{5.4}$

The member organisations have four weeks to reply, and on the basis of these replies, the Secretariat shall submit a draft decision to the Executive Committee. The Executive Committee then determines the negotiating mandate and the composition of the delegation that is going to negotiate." The comments of the member organisations are taken into account but the Executive Committee takes the eventual decision with a qualified majority. ${ }^{56}$ This determination will take place in accordance with the voting procedure of Article 18 of the Constitution. In practice this means that the Executive Committee has to take the decision with $2 / 3$ of the votes when at least $3 / 4$ of all the members of this Committee are present. Besides this, the decision also needs the support of at least $2 / 3$ of the member organisations directly concerned by the negotiations. ${ }^{57}$ Now what is meant by "organisations concerned"? Rule 7 clarifies this. "Organisations concerned" are all confederations affiliated to the ETUC from EU Member States, confederations from EEA countries, European Industry Federations and the Women's Committee. ${ }^{58}$ The negotiating delegation does not always have the same composition. This depends on the nature of the agreement to be reached. The bargaining delegation is lead by the Secretariat. ${ }^{59}$ The Industrial Relations Committee, which is one of the Standing Committees as described in Article 17 of the ETUC Constitution, shall monitor the negotiations. ${ }^{60}$ "Monitoring" means that if the negotiating delegation has certain difficulties during the negotiation process, it can discuss these problems with the Industrial Relations Committee. However, the Industrial Relations Committee has no decisionmaking powers. ${ }^{61}$ If the negotiations with the employers' organisation(s) lead to a draft agreement, this draft shall be sent to the member organisations concerned, these member organisations have six weeks to hold internal consultations and determine the voting mandate. ${ }^{62}$ After these six weeks, the Executive Committee shall take a decision on the draft agreement. ${ }^{63}$ It is also

\section{Rule 4.}

55 Rule 5.

56 Interview with ETUC on 28 July 1997.

57 Article 18 of the Constitution.

58 Normally a negotiating delegation is composed as follows: 17 countries which are affiliated to ETUC are represented. This means in practice 33 national federations. Then also 14 European Industry Federations are included as well as 2 people from the Secretariat. But when the agreement to be negotiated has more consequences for one specific sector, than the delegation will be more composed out of European Industry Federations than national federations. (Interview with ETUC on 28 July 1997).

59 Rule 9.

60 Rule 10.

61 Interview with ETUC on 28 July 1997.

62 Rule 12

63 Rule 13. 
possible that the negotiations with the employers' organisations fail. In that case the further strategy will be determined by the Executive Committee.

\section{UNICE}

Neither in the Constitution, nor in the Rules of Procedure are there rules for the internal decision-making process with regard to the European social dialogue. The rules on this process are laid down on an ad hoc basis by the Council of Presidents. After the receipt of the second consultation document of the Commission on the basis of Article 138(3) EC Treaty and the decision that the social partners want to take over the legislative initiative from the Commission on the basis of Article 138(4), a negotiating mandate is drafted by the Social Affairs Committee (SAC). Usually, a working group is also established for the technical aspects of the issue at stake. The SAC then sends the draft mandate to the Executive Committee together with an explanatory memorandum. The Executive Committee approves or rejects the draft mandate. All affected organisations have to agree unanimously. UNICE calls this "decision-making by consensus". In case of approval by the Executive Committee, the draft is sent to the Council of Presidents. They can approve or reject it. Also here decision-making by consensus takes place. As soon as the Council of Presidents has approved the negotiation mandate, the negotiations with the trade unions can start. During the negotiations, the negotiating team reports constantly to the SAC. The SAC advises them. The advice has always been followed because the SAC is acquainted with all the political sensitivities and informs the negotiating team on their chances of success. If the negotiations succeed and a European collective agreement is concluded, the negotiating team asks the SAC to submit the agreement to the Executive Committee and the Council of Presidents to approve it. If the agreement is approved by them it can be signed. The decisions at all stages are taken by unanimity. ${ }^{64}$

\section{CEEP}

When it comes to European collective bargaining within Article 139(1) of the EC Treaty, the following internal procedure is applicable:

The General Assembly decides whether CEEP is going to enter into the negotiations after it has consulted the Social Affairs Committee. If CEEP enters into the negotiations, the Social Affairs Committee is given a negotiating mandate, which specifies the purpose of the negotiations. ${ }^{65}$ Then, the Social Affairs Committee proposes the composition of the negotiating delegation and the name of the leader of this delegation. In any case the delegation must include the Secretary-General or his deputy. It has to represent, where possible, national sections that are concerned by the subject of the negotia-

64 Interview with UNICE on 27 August 1997.

65 Article 45 Rules of Procedure. 
tions. It is possible that the national sections do not approve the membership of the delegation. If this is the case (the Secretary-General will ask their opinion), the General Assembly shall take the comments of the National Sections into account and determine the final membership of the delegation. ${ }^{66}$ When the membership of the delegation is determined, the Social Affairs Committee proposes the terms of a negotiating mandate which is submitted by the General Assembly for approval. ${ }^{67}$ During the negotiations, the General Assembly may revise the terms of the previous mandate. ${ }^{6 s}$ As soon as the negotiations are completed, the outcome is sent to the General Assembly, which has to ratify the agreement. It does this in accordance with the voting procedures of Article 12 of the Statutes. ${ }^{69}$

The internal decision-making process of the three intersectoral organisations mentioned above can certainly not be regarded as undemocratic. However, whether the Commission has dug deep into these decision-making processes is not clear.

\subsubsection{The legality of the European collective agreement}

The Commission sees it also as its task to check the legality of each clause in the European agreement in relation to Community law. This means that it has to be seen whether certain clauses of the agreement of the social partners are contrary to Community law. This check can find its basis in the Treaty. One of the tasks of the Commission is to "ensure that the provisions of this Treaty and the measures taken by the institutions pursuant thereto are applied." ${ }^{70}$ The Commission should also check whether the Clauses of the European collective agreements are not contrary to fundamental human rights, since fundamental rights form an integral part of Community law. ${ }^{71}$ The ECJ has stated that fundamental human rights are enshrined in the general principles of Community law and are protected by the ECJ. ${ }^{72}$ The fundamental rights are enshrined in the national constitutions or constitutional law, but they embrace also the rights guaranteed by the ECHR. The ECJ has stated that, even though the Community itself is not a party to the $\mathrm{ECHR}$, the international treaties for the protection of human rights on which

\footnotetext{
66 Article 46 Rules of Procedure.

67 This mandate is thus different from the one mentioned in Article 45 of the Rules of Procedure. The last one just specifies the purpose of the negotiations.

68 Article 48 Rules of Procedure.

69 Article 49 Rules of Procedure.

70 Article 211 EC Treaty.

71 P.J.G. Kapteyn and P. VerLoren van Themaat, Introduction to the law of the EC, p. 79; Also A. Adinolfi, Admissibility of action for annulment by social partners and "sufficient representativity" of European agreements, In: European Law Review, vol. 25, no. 2, 2000, p. 175.

72 Case 29/69, Judgment of 12/11/1969, Stauder / Stadt Ulm (Rec.1969,p.419).
} 
the Member States have collaborated or to which they are signatories, can supply guidelines which should be followed within the framework of Community law. ${ }^{73}$ If certain national rules fall within the scope of Community law, and a national court seeks a preliminary ruling, then the ECJ will give the necessary criteria of interpretation to the national court to enable it to determine whether the national rules concerned are compatible with the fundamental rights the observance of which the ECJ ensures, and which derive in particular from the ECHR. ${ }^{74}$

\subsubsection{The position of small and medium sized enterprises (SMEs)}

The Commission will also check whether Article 137(2) EC Treaty regarding SMEs is respected. This provision states:

“(...) the Council may adopt, by means of directives, minimum requirements for gradual implementation, having regard to the conditions and technical rules obtaining in each of the Member States. Such directives shall avoid imposing administrative, financial and legal constraints in a way which would hold back the creation and development of small and medium-sized undertakings (....)"

According to the words of this article, the obligation to look after the special needs of SMEs is only applicable in case of Directives of the Council. However, as we shall see later, ${ }^{75}$ a Directive is not the only instrument for implementing a European agreement. The obligation of Article 137(2) could thus simply be avoided by implementing a European agreement through a Recommendation or Regulation. In its proposals for implementing the European collective agreements concluded so far, the Commission interpreted Article $137(2)$ in such a way that it thinks that all legislation should avoid imposing administrative, financial and legal constraints in a way which would hold back the creation and development of small and medium-sized undertakings. It says that "Article 2(2) of the Agreement on Social Policy (now Article 137(2) EC treaty, E.F.), provides that legislation on social policy shall avoid imposing administrative, financial and legal constraints in a way which would hold back the creation and development of SMEs" ${ }^{76}$ I think that this is also in line with the intention of the Treaty drafters. Why would SMEs not have to be protected if it concerns a Recommendation or Regu-

73 Case 4/73, Judgment of 14/05/1974, Nold KG / Commission (Rec.1974,p.491), Order of 24/09/1975, Nold KG/ Commission (Rec.1975,p.985), Order of 11/01/1977, Nold KG / Commission (Rec.1977,p.1).

74 Case C-260/89, Judgment of 18/06/1991, ERT / DEP (Rec.1991,p.I-2925).

75 Para. 7.5.3.

76 See COM(97)392 final, point 24, COM(2000)382, point 10, COM(99)203 final, point 26 , $\mathrm{COM}(96) 26$ final, point 17. 
lation? Like the Commission, I am inclined to state that SMEs have to be protected if it concerns all Community legislation.

Furthermore, I consider that the SME check is a duplication of the legality check and therefore superfluous. Article 137(2) EC Treaty is Community law and therefore already falls under the legality check, discussed before.

In all proposals for implementing European collective agreements, the Commission regards SMEs sufficiently protected in accordance with Article 137(2) EC Treaty. Let us take a look at the agreements themselves to see what they say about SMEs. The European Agreement on the Organisation of Working Time for Seafarers and the European Agreement Organisation of Working Time for Mobile Staff in Civil Aviation do not say anything about SMEs. In the General Considerations of the European Framework Agreement on Parental Leave, as well as the European Framework Agreement on PartTime Work and the European Framework Agreement on Fixed Time Work, it is stated that:

\begin{abstract}
"Whereas the agreement takes into consideration the need to improve social policy requirements, to enhance the competitiveness of the Community economy and to avoid imposing administrative, financial and legal constraints in a way which would hold back the creation and development of small and medium-sized undertakings." 77
\end{abstract}

In the European Framework Agreement on Part-Time Work, there is, apart from the general consideration which I just mentioned, no reference made to SMEs. The clauses 5(1) and (2) of the agreement establish the need to eliminate by law or agreement any legal and administrative obstacles which might militate against part-time working. In its proposal based on the agreement, the Commission states that "although the reference to the development of part-time work relates to all undertakings in general, regardless of their size and staff, it is evident that SMEs should derive the greatest benefit from such a provision." ${ }^{78}$ However, the Commission does not explain in what way SMEs shall derive the greatest benefit. The Commission says furthermore that:

"A number of clauses (i.e. 2(2), 3(3), 4(3), 6(2) in the European Framework Agreement on Part-Time Work, E.F.), refer to national laws, collective agreements or practice and/or to the social partners at the appropriate level, leaving plenty of room for manoeuvre at enterprise level. Despite

\footnotetext{
77 General Cons. no. 12 in the European Framework Agreement on Parental Leave, no. 7 in the European Framework Agreement on Part-Time Work and no. 11 in the European Framework Agreement on Fixed Term Work.

78 $\operatorname{COM}(97) 392$ final, point 26.
} 
not explicitly mentioning SMEs, these provisions do enable national provisions to be adopted if necessary to take account of their special needs." 79

In the European Framework Agreement on Parental Leave, a clause is inserted which states:

"Member States and/or Social Partners may in particular:

(...)authorise special arrangements to meet the operational and organisational requirements of small undertakings. ${ }^{180}$

The position of SMEs was also raised in the UEAPME case. UEAPME was of the opinion that SMEs were not sufficiently protected in the Directive on Parental Leave, because of the vague clauses referring to the SMEs as mentioned above. None of the Clauses in the Directive, referring to SMEs, puts an obligation on the Member States to take the special needs of the SMEs into account. Therefore, the protection of SMEs could not be guaranteed by the Directive. The CFI stated that:

"The purpose of Article 137(2) EC Treaty is not to prohibit the adoption of measures entailing administrative, financial and legal constraints for the SMEs, but rather to ensure that measures adopted in the social field do not disproportionately affect the creation and development of SMEs by imposing particular administrative, financial and legal constraints. It is also apparent that, in conformity with the nature of the Council measure implementing the framework agreement, the Member States and/or management and labour still enjoy a discretion vis-à-vis the transposition of the minimum requirements adopted in that agreement." ${ }^{81}$

The CFI also gave an interpretation of certain Clauses of the Directive on Parental Leave and came to the conclusion that Article 137(2) EC Treaty, which is a protective provision for SMEs, had not been violated by the Directive. ${ }^{82}$ I think that most Community legislation on social policy will affect SMEs more than big enterprises. The question is whether the Member States are left a certain discretion to protect these SMEs when they implement this Community legislation. This is the case at least as regards the intersectoral European collective agreements concluded so far. Apart from the specific references to SMEs in the European collective agreements mentioned above a lot of issues are left to be regulated by the Member States. The Member States are given a considerable amount of freedom to regulate the issues covered by

$79 \operatorname{COM}(97) 392$ final, point 27.

80 Clause 2(3) sub f.

81 Cons. 106.

82 Cons. 107. 
Implementation of European collective agreements by Council decision

the European collective agreements as long as the minimum requirements of the agreement are respected. ${ }^{\mathbf{s}}$

\title{
7.4.1.5. The assessment of the European collective agreement
}

It has to be mentioned that in all proposals so far to implement European collective agreements by Council decision, the Commission applied another check: the assessment of the agreement. The assessment check is to verify whether the agreement is necessary. In the proposal for the Directive on Parental Leave the Commission states that:

"The Commission considers parental leave to be an important factor in reconciling family and working life. It also constitutes an important element in the introduction of the new, flexible ways of organizing work and time."

In the proposal for the Directive on Part-Time Work, the Commission says:

\begin{abstract}
"In the light of the conclusions of the Essen European Council and of subsequent European Councils, the Commission considers part-time work to be an important factor in promoting employment and equal opportunities for women and men. It also helps to boost the employment-intensity of growth, more particularly by way of more flexible working patterns designed to meet both workers' desires and the requirements of competition." ${ }^{185}$
\end{abstract}

In its 1993 Communication, the Commission says that "at all events, the Commission intends to provide an explanatory memorandum on every proposal presented to the Council in this area, giving its comments and assessment of the agreement concluded by the social partners". ${ }^{86}$ The Commission has stated in its 1998 Communication that, if the concluding parties want their agreement to be implemented by Council decision, agreements on a matter within the scope of Article 137, but negotiated outside the consultation procedure, will be checked by the Commission on its appropriateness against Community action in that field. ${ }^{87}$ It does not check this agreement on the issues mentioned in para. 7.4.1.1.-7.4.1.4. Assessment of the agreement is necessary because Article 294(1) EC Treaty states that the institutions of the

83 See for example Clause 2(3) of the European Framework Agreement on Parental Leave; Clause 4(3) of the European Framework Agreement on Part Time Work; Clause 5(1) of the European Framework Agreement on Fixed Term Work.

$84 \operatorname{COM}(96) 26$ final, point 22.

$85 \mathrm{COM}(97) 392$ final, point 31 . The assessment check has also been made in all other Commission proposals which are based on European agreements.

$86 \operatorname{COM}(93) 600$ final, point 39.

$87 \operatorname{COM}(98) 322$, p. 16. 
Community may only adopt acts for the achievement of their tasks in accordance with this Treaty. This means that the agreement has to fall within the purpose and tasks mentioned in Article 2 and 3 EC Treaty. If this is not the case, the agreement cannot stand the assessment check and can therefore not be turned into Community law.

\subsubsection{Rejection of the European collective agreement by the Commission}

It is possible that the Commission wants Community legislation on a certain subject and has therefore consulted the social partners in accordance with Article 138(2) and (3) EC Treaty. The social partners subsequently conclude an agreement on the subject, and ask the Commission, in accordance with Article 139(2) EC Treaty, to submit this to the Council. It can, however, occur that the Commission does not accept the European agreement, because it cannot stand up to one or more of the checks discussed in para. 7.4.1.1. 7.4.1.5. Whether the social partners have legal means to attack such a decision from the Commission will be discussed in Chapter 8. The Commission cannot amend the agreement, however, and subsequently continue the Article 139(2) EC Treaty procedure. This provision prescribes that agreements shall be implemented. Amendments made by the Commission have the consequence that it is no longer an agreement, but just a new legislative proposal of the Commission. In fact this is the same as if the Commission were to reject the agreement. I will therefore consider amendments made by the Commission as the same as rejection of the agreement by the Commission. In this paragraph, I want to scrutinise which procedure the Commission has to follow if it rejects the agreement, but nevertheless wants to formulate a proposal for Community legislation on the subject covered by the (rejected) agreement.

If the Commission wants to issue legislation on the points covered by the (rejected) agreement, it could start the legislative process again. The question is, however, whether the Commission is obliged to consult the social partners again on the basis of Article 138(2) and (3) EC Treaty. I think that the answer to this question depends on the reasons why the previously concluded agreement has been rejected by the Commission. Let me scrutinise what would happen in the various situations in which the Commission might reject an agreement.

\section{Rejection because of lack of representativity}

From the UEAPME-case it is clear that the Commission not only has to look at the organisations as such, but also at the content of the agreement that they have concluded. If the signatory parties taken together, are sufficiently representative, having regard to the content of their agreement, the Commission cannot reject the agreement for lack of representativity. This still means 
however, that the organisations concluding an agreement have to fulfill the representativity-criteria of the Commission (whether these will be the ones of the 1993 Communication or the ones of the 1996-Communication is not clear yet), regardless what the content of the agreement might be. If organisations are consulted by the Commission and these same organisations conclude an agreement, this agreement cannot be rejected by the Commission for the reason that the organisations as such did not fulfill the representativitycriteria. The Commission has already checked this representativity at the moment that it decided to consult these organisations. The situation is different when the social partners start negotiating with each other, without first having been consulted by the Commission. In Chapter 4, I have stated that this can occur. ${ }^{88}$ If these organisations subsequently conclude a European agreement and ask the Commission to submit it as a proposal to the Council, it can happen that the Commission rejects the agreement, because it is of the opinion that the signatory parties do not fulfill the representativitycriteria. If the Commission nevertheless wants to have legislation on the subject covered by the European agreement, it will have to start the consultation procedure of Article 138(2) and (3) EC Treaty. The list of organisations that are regarded representative by the Commission for consultation contains more organisations than the ones that concluded the (rejected) agreement. By means of the consultation procedure, all relevant organisations have the chance to submit their opinion or recommendation on the proposal to the Commission. They did not have this chance before, because the rejected agreement was concluded without a prior consultation procedure.

\section{Lack of a sufficient mandate}

If certain organisations conclude an agreement with each other, after first having been consulted by the Commission, it is nevertheless possible that the Commission rejects the agreement because it thinks that the signatory parties, although representative, lack a sufficient mandate. In such a case, I think that the Commission should give the signatory parties a certain period to repair this defect. If the signatory parties do nothing, and the Commission wants legislation on the subject covered by the agreement, I do not think it necessary that the consultation procedure be restarted. After all, consultation has already taken place before the (rejected) agreement was concluded and all representative organisations have been given the opportunity to submit their comments to the Commission. The situation can be different however, in case of a "spontaneous" agreement, that is to say, without there having been a consultation procedure first. Also in this case, the signatory parties should first be given a certain time to repair the defect. If they however remain passive during that time, there are two possibilities. If the circle of organisations for consultation is broader than the circle of organisations that concluded the agreement (which will mostly be the case), I think that 
consultation should take place in order to give all relevant organisations the opportunity to submit their opinion on a legislative proposal. However, if there are, say, three organisations that concluded the rejected agreement and only these same three organisations are eligible for consultations, new consultation is not necessary.

\section{Legality/SMEs/Assessment}

These three requirements have to do with the content of the agreement. I consider that the same applies here as for the mandate check. If the European agreement cannot withstand the legality check, the SME check, or the assessment check, the signatory parties should be given a certain period to repair these defects. If they do not, new consultation is not necessary if the agreement has been concluded on the occasion of the consultation procedure. In case of a "spontaneous" agreement, consultation is only necessary if the circle of organisations eligible for consultation is broader than the circle of organisations that concluded the agreement. In schematic form this would give the picture as shown in figure 2.

In practice, the situation can occur that the Commission in principle accepts the agreement, but that it would nevertheless like to see some changes in it. For example because it is of the opinion that the agreement can not sustain the SME-check. The Commission could propose such changes to the social partners. If the last mentioned would agree with these changes, the agreement could be amended by them. This of course depends entirely on the willingness of the signatory parties. If the signatory parties do not want to change their agreement, the Commission can conclude that the agreement can not be submitted to the Council and the social partners can implement it through the national affiliates. Also during the negotiations it could become clear that the Commission will not accept certain clauses. That means however that there have to be frequent contacts between the Commission and the European social partners' organisations during the negotiations on a European collective agreement. According to the Commission however, such contacts are not usual.

\subsubsection{Form of the Commission proposal}

The Commission proposal to implement agreements of the social partners, has a special form. The Commission drafts a document with certain general articles of a procedural nature and it annexes the agreement of the social partners thereto. The reason is that the Commission is of the opinion that the Council decision must be limited to making binding the provisions of the agreement concluded between the social partners. ${ }^{90}$ Therefore the Commis-

89 Interview with DGV, March 2002.

$90 \mathrm{COM}(93) 600$ final, point 41. 
sion will not amend the proposal. However, the Commission can in any case change the general articles, preceding the agreement. It drafted these articles itself and it is on the basis of Article 250(2) EC Treaty allowed to change them.
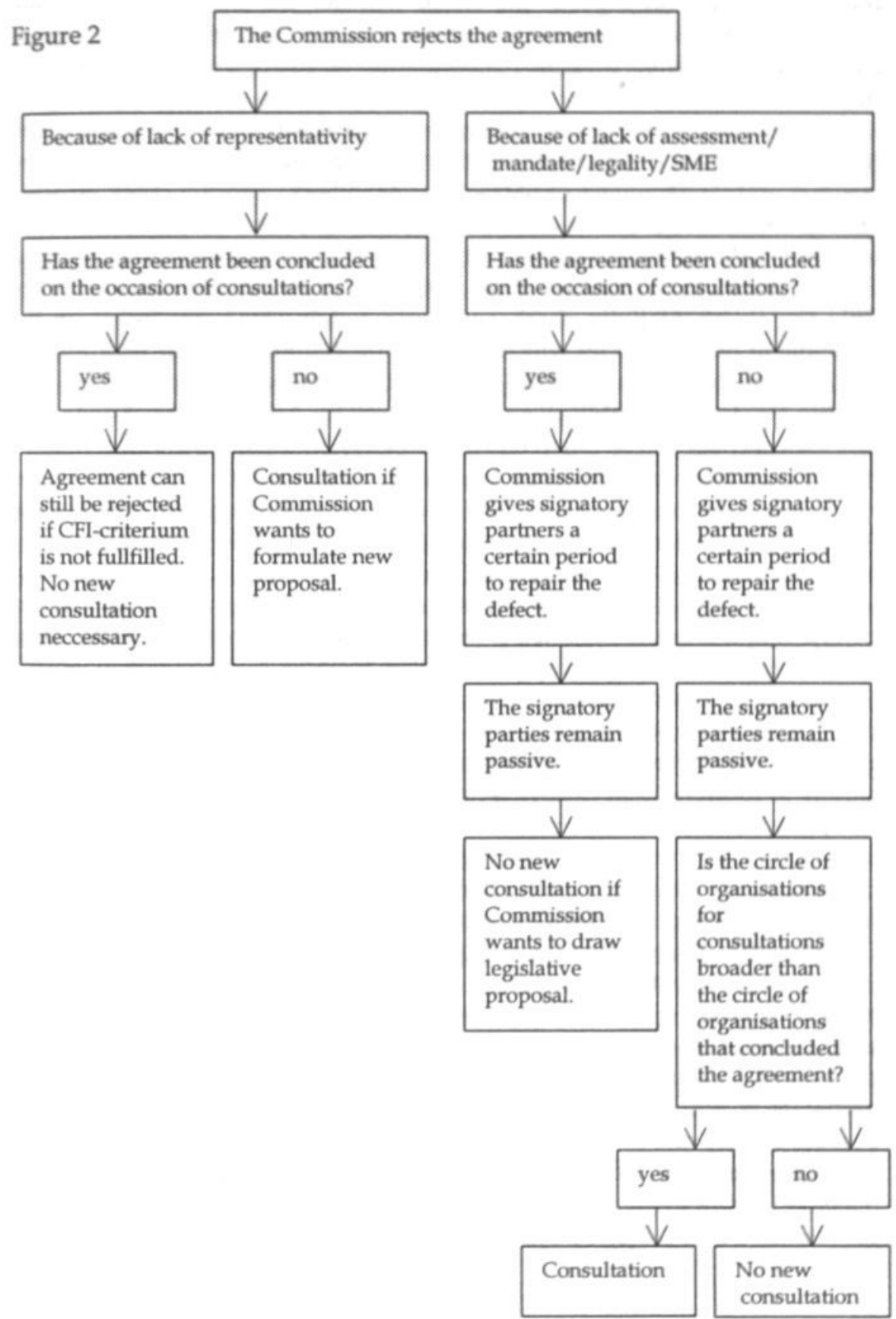


\subsubsection{Conclusions}

Before the Commission decides to submit a European agreement to the Council for a decision, it applies five checks on the agreement. Two checks relate to procedural aspects: the check whether the signatory parties are representative (the representativity check) and the check whether they were sufficiently mandated by their national affiliates to conclude the agreement (the mandate check). The three other checks relate to the content of the agreement: the check whether the agreement is not contrary to Community law (the legality check), the check whether the agreement does not hinder the creation and development of SMEs (the SME check) and the check whether the agreement is necessary (the assessment check). The checks of the Commission on the European agreement before submitting it as a proposal for a Council decision, all find their basis in the EC Treaty and the case law of the CFI. The representativity check and the mandate check are based on the principle of democracy on which the Union is founded, which requires that the participation of the people in the legislative process be assured. The legality check and the SME check can be based on Article 211 EC Treaty. The assessment check can be based on Article 249(1) EC Treaty.

As regards the representativity check, the Commission applies the same criteria as it formulated in its 1993 Communication to check whether the European organisations are representative enough to be consulted on the basis of Article 138(2) and (3) EC Treaty, but also looks at the number of workers/employers covered by the signatory parties. This is in line with the criteria that it formulated in it's 1996-Communication. In the UEAPME case, the CFI looked at the signatory parties taken together to determine whether a European agreement can meet the representativity check. It has not, however, given a judgement on the representativity criteria as such. I think that, as long as it regards the organisations as such, the same criteria on representativity as formulated in Chapter 4 for the consultation procedure should also be applied in case of implementation of a European agreement by Council decision. An important criterium has however been added by the CFI in the UEAPME-case which has been applied by the Commission as well in the European Agreement on the Organisation of Working Time of Mobile Staff in Civil Aviation. Even if the signatory parties fulfill the representativity criteria as formulated by the Commission in its 1993-Communication, it is still possible that the agreement be rejected. This is the case if they are taken together not sufficiently representative having regard to the content of the agreement. I do not support the view of certain authors that the signatory parties to a European agreement should represent a numerical majority, because in that case it will practically be impossible to turn European collective agreements into a Council decision. However, the absence of a numerical majority implies in my view a stronger role for the EP in the decision-making process of Article 139(2) EC Treaty. 
It is not clear how the Commission exactly checks whether the signatory parties of a European agreement were sufficiently mandated by their national affiliates. Moreover, the Commission should also check whether the internal decision-making procedures which led to this mandate were democratic. At least the ETUC, UNICE and CEEP have such internal decisionmaking procedures.

The legality check implies that the European agreement is in conformity with Community law. However, this implies that it should be checked whether the agreement is not contrary fundamental human rights.

Community legislation in the social policy field has to take account of the special needs of SMEs. The Commission therefore applies the SME check. This SME check is, however, superfluous, because the Commission already applies a legality check on the European agreement. From the case-law of the CFI, it can be derived that social policy Directives which leave a lot of freedom of implementation to the Member States, do not per se hold back the creation and development of SMEs.

Although the assessment check is not mentioned in conjunction with the other checks, it has to be seen in the light of the purposes and tasks of the Community mentioned in Article 2 and 3 EC Treaty and taken together with Article 249(1) EC Treaty. If the Commission rejects the agreement, it can restart its legislative procedure. New consultation on the basis of Article 138(2) and (3) EC Treaty is not necessary if the rejected agreement was concluded on the occasion of the consultation procedure. In case of a spontaneous agreement, however, that means if the agreement has been concluded without there first having been a consultation procedure, the situation can be different. If the circle of relevant organisations that should be consulted is broader than the circle of organisations that concluded the agreement, the Commission should follow the consultation procedure. The Commission proposal on the basis of a European agreement contains a few procedural articles and also annexes the European agreement to these articles.

\subsection{The Council has to take a decision}

If the Commission has checked the European agreement and concluded that it wants to turn it into Community legislation, it formulates a proposal for a Council decision. Three questions arise in this respect. The first question is how the decision-making procedure within the Council takes place. This will be discussed in para. 7.5.1. The second question is what happens if the Council rejects the Commission proposal. This will be scrutinised in para. 7.5.2. Finally, the question is which form the Council decision should take. This will be discussed in para. 7.5.3. 


\subsubsection{Decision-making procedure}

The Council decides on the Commission proposal in accordance with the procedure of Article 139(2) EC Treaty, second sentence, which states:

"The Council shall act by qualified majority, except where the agreement in questions contains one or more provisions relating to one of the areas referred to in Article 137(3), in which case it shall act unanimously."

Hereafter, I will discuss the reasons for the difference between qualified majority voting and voting by unanimity and will answer the question whether the Council is allowed to amend the Commission proposal.

\subsubsection{Qualified majority or unanimity}

The general rule is that the Council has to act by qualified majority voting. However, the Council has to act unanimously if the agreement covers the subject-matters of Article 137(3). These areas are:

a. social security and social protection of workers;

b. protection of workers where their employment contract is terminated;

c. representation and collective defence of the interests of workers and employers, including co-determination, subject to paragraph 6;

d. conditions of employment for third-country nationals legally residing in Community territory;

e. financial contributions for promotion of employment and job-creation, without prejudice to the provisions relating to the Social Fund.

With the establishment of the EC Treaty, the main function of a common social policy was to prevent distortions in competition between the Member States as a result of the differences in the levels of social protection. Social policy was in the first place to be regulated at national level. That this is in fact still the case, is illustrated by Article 137(1) EC Treaty, in which is stated that the Community "shall support and complement the activities of the Member States" in a number of social policy fields. Accordingly, para. 2 of Article 137 EC Treaty, defines the use of Directives and moreover states that these Directives have to be limited to minimum requirements. The subjects mentioned in para. 3 of Article 137 EC Treaty, are more important than the ones in para. 1. It has to be born in mind that these issues in particular are very sensitive. National provisions on social policy, and especially the issues of para. 3, reflect fundamental preferences of national legislators and governments. Levels of social protection are a key plank of governments' political programmes. ${ }^{91}$ Harmonisation of the subject matters of para. 3 will be very

91 D. Galloway, The Treaty of Nice and beyond, Sheffield, 2001, p.104. 
difficult, because the views of the Member States on these issues vary to a wide degree. ${ }^{92}$

I already mentioned that Article 137 EC Treaty has been changed by the Treaty of Nice. ${ }^{93}$ This is also so for the voting procedures. The future Article $137(1)$ reads as follows:

"With a view to achieving the objectives of Article 136, the Community
shall support and complement the activities of the member States in the
following fields:

a. improvement in particular of the working environment to protect workers' health and safety;

b. working conditions;

c. social security and social protection of workers;

d. protection of workers where their employment contract is terminated;

e. the information and consultation of workers;

f. representation and collective defence of the interests of workers and employers, including co-determination, subject to paragraph 6;

g. conditions of employment for third-country nationals legally residing in Community territory;

h. the integration of persons excluded from the labour market, without prejudice to Article 150;

i. equality between men and women with regard to labour market opportunities and treatment at work;

j. the combating of social exclusion;

k. the modernisation of social protection systems without prejudice to point (c)."

If one compares this to the present Article 137, one sees that almost all subjects mentioned in the present Article 137(1) and (3) are grouped together in the future Article 137(1). However, one subject in the present Article has disappeared from the future one: the financial contributions for promotion of employment and job-creation, without prejudice to the provisions relating to the Social Fund. Furthermore, in the future Article 137(1), two new subjects have been added: the combating of social exclusion and the modernisation of social protection systems. The areas under $c, d, f$ and $g$ are subject to unanimity voting in the present Article 137. In principle, this has not been changed in the new Article 137. The future Article 137(2) states:

"The Council shall act in accordance with the procedure referred to in Article 251 after consulting the ECOSOC and the Committee of the Regions, except in the fields referred to in para. 1(c), (d), (f) and (g), where

92 See also R. Barents and LJ. Brinkhorst, Grondlijnen van Europees recht, p. 440.

93 See para. 7.2. 
the Council shall act unanimously on a proposal from the Commission, after consulting the EP and the abovementioned Committees."

However, the door is left open for qualified majority voting for decisions in certain fields, because the future Article 137(2) continues by stating:

"The Council, acting unanimously on a proposal from the Commission, after consulting the EP, may decide to render the procedure referred to in Article 251 applicable to paragraph 1(d), (f) and (g)."

This means that the field of social security and social protection of workers remains subject to unanimity voting. As regards the protection of workers where their employment contract is terminated, the representation and collective defence of the interests of workers and employers, including codetermination, and the conditions of employment for third-country nationals legally residing in Community territory, decision-making in the Council can take place by qualified majority voting if the Council decides this, unanimously, on a proposal from the Commission, after consulting the EP. Thus a slight move has been made towards more qualified majority voting in social policy issues. This development reflects the fact that a Community social policy has become more and more important over the years. On the occasion of the Treaty of Nice, the Commission stated that further development will not be possible in the areas still subject to the unanimity rule if the right to veto is retained in a Union of some thirty Member States. ${ }^{94}$ This is the reason why the Treaty of Nice includes a modest change to Article 137 as regards the voting procedures, although the extension of qualified majority voting was much less ambitious than many originally sought. ${ }^{95}$ During the negotiations on the Treaty of Nice, delegations positioned themselves into three broad camps on the question of the voting procedures: those with no particular difficulties and who could accept a move to qualified majority voting, those with fundamental problems of principle and those in the middle ground with political or practical difficulties, but open to seeking ways for resolving them. The result was a provision allowing for the possibility of a Council decision by unanimity to render qualified majority voting and codecision applicable to the areas where unanimity continues to apply (with the exception of social security and social protection of workers). ${ }^{96}$

The question of unanimity versus qualified majority can influence the content of a European agreement. If a subject matter needs a unanimity vote in the Council, the negotiating social partners' organisations can easily presume that it is more difficult to attain that vote than under a qualified majority. For example, if the European social partners' organisations conclude an

94 Homepage European Commission http://europa.eu.int/comm/index_en.htm.

95 D. Galloway, The Treaty of Nice and beyond, p. 102

96 D. Galloway, The Treaty of Nice and beyond, p. 104. 
agreement on the protection of workers against unfair dismissals (a subject which would fall under unanimity voting in the Council), it would probably be an agreement that contains general guidelines, leaving a lot of freedom to the Member States for further implementation. The chance that such an agreement will be accepted by the Member States in the Council is greater than if it concerned an agreement containing clear obligations, leaving little room for the Member States to adapt their national legislation to its terms. However, whether the Council should act by qualified majority or by unanimity is not always clear. It is, for example, arguable that with regard to the Directive on Parental Leave a qualified majority was enough. If, however, we look closely at clause 2(4) of the European Framework Agreement on Parental Leave, which is annexed to the Directive, 77 we see that this clause touches on the law of dismissals, while Article 137(3) prescribes a unanimity vote in case of protection of workers where their employment contract is terminated. The same is true for Clause 2(5) of the European Framework Agreement on Parental Leave. ${ }^{98}$ I think that the Council will look at the core provisions of the European agreement. If these core provisions cover one or more of the issues mentioned in Article 137(3) EC Treaty, the Council will adopt a decision by unanimity voting. Otherwise it will use the qualified majority voting procedure.

\subsubsection{Amendments by the Council?}

Article 250(1) EU Treaty states that:

"Where, in pursuance of this Treaty, the Council acts on a proposal from the Commission, unanimity shall be required for an act constituting an amendment to that proposal, subject to Article 251(4) and (5),"

The question is whether the Council is allowed to amend a proposal of the Commission that is based on a European agreement between the social partners. Article 250(1) EC Treaty suggests that this is possible. The conditions for Article 250(1) EC Treaty to be applicable are that "the Council acts in pursuance of this Treaty" (which will be the case if it acts on the basis of Article 139(2) EC Treaty) and that there is "a proposal from the Commission" (which is also the case, since Article 139(2) EC Treaty prescribes that a proposal of the Commission is needed).

97 Clause 2(4) of the European Framework Agreement on Parental Leave states: "In order to ensure that workers can exercise their right to parental leave, Member States and/or Social Partners shall take the necessary measures to protect workers against dismissal on the grounds of an application for, or the taking of, parental leave in accordance with national law, collective agreements or practice."

98 Clause 2(5) states: "At the end of parental leave, workers shall have the right to return to the same job or, if that is not possible, to an equivalent or similar job consistent with their employment contract or employment relationship." Both Directives have been adopted by means of qualified majority voting. 
In their Joint Agreement of 1991, which was the basis for the Article 138 and 139 EC Treaty, the three intersectoral organisations, the ETUC, UNICE and CEEP, opposed the possibility for the Council to amend Commission proposals based on European collective agreements. In the Joint Agreement, it was specified that implementation of a European agreement by Council decision should be "on a proposal from the Commission, with regard to the agreements as they have been concluded". ${ }^{99}$ This requirement that the Commission's proposal should follow exactly the social partners' agreement has, however, been dropped from the EC Treaty.

The Commission's view is that implementing an agreement concluded at Community level by means of a Council decision on a proposal from the Commission at the joint request of the social partners would give the Council no opportunity to amend the agreement. The Commission will therefore merely propose the adoption of a decision on the agreement as concluded. ${ }^{100}$ The Commission confirms this statement in the explanatory memorandums accompanying the proposals for the Directive on Parental Leave, the Directive on Part-Time Work and the Directive on Fixed Term Work, as well as the Directives on the Organisation of Working Timo for Soafarcrs and the Directive on the Organisation of Working Time for Mobile Workers in Civil Aviation. In these memoranda, the Commission made clear that "if the Council amends the agreement concluded between the social partners, it will withdraw its proposal". ${ }^{101}$ One could read from this formulation that the Commission implicitly recognizes the competence of the Council to make amendments, because it takes the possibility that the Council will do so into account. At the same time, the impression is given that the Commission thinks that the Council cannot make amendments because the agreement is annexed to the proposed decision. In the same explanatory memoranda, the Commission says

"The Council decision must be limited to making binding the provisions
of the agreement concluded between the social partners, so the text of the
agreement would not form part of the decision but would be annexed
thereto." 102

Moreover, the European Parliament is of the opinion that the Council cannot make amendments to agreements between management and labour. If the Council nevertheless does so, the procedure should start all over again, in the sense that the agreement shall be deemed to have been repudiated and Parlia-

99 Article $118 \mathrm{~B}(2)$ of the Joint Agreement.

$100 \mathrm{COM}(93) 600$ final, point 38.

$101 \mathrm{COM}(96) 26$ final, point $30 . \mathrm{COM}(99) 203$ final, point $42, \mathrm{COM}(97) 392$ final, point 39 , $\operatorname{COM}(2000) 382$, point $25, \operatorname{COM}(98) 662$ final, point 24.

$102 \mathrm{COM}(96) 26$ final, point 28 and $\mathrm{COM}(97) 392$ final, point 37, COM(98) 662 final, points 22 and 24, $\operatorname{COM}(2000) 382$, point 23 and 25, COM(99) 203 final, points 40 and 42. 
ment shall call on the Commission, in accordance with the procedure pursuant to Article 192(2) EC Treaty, to initiate forthwith the legislative process in accordance with the procedure pursuant to Articles 138 and $139 .{ }^{103}$

With regard to all European collective agreements concluded so far which have been turned into a Council decision, the Council made no amendments, ${ }^{104}$ that is to say, as far as the words of the agreement itself are concerned. Looking at the Directives on Parental Leave and Part-Time Work for example, we see that there are a few articles which precede the actual agreement. In these articles, changes have been made by the Council in relation to the proposal of the Commission. For example in the proposal for the Directive on Parental Leave, Article 1 stated:

"The framework agreement on parental leave concluded on 14 December 1995 between the general cross-industry organisations (UNICE, CEEP and the ETUC) and annexed to this Directive is made obligatory"..$^{105}$

In the eventual Directive, the provision stated:

"The purpose of this Directive is to put into effect the annexed framework agreement on parental leave concluded on 14 December 1995 between the general cross-industry organisations (UNICE, CEEP and the ETUC)."

It is not clear yet what the exact reasons were for the Council to make these changes. It has also occurred that the Commission put certain provisions in its proposal which were not taken over at all by the Council. For example: in the Commission proposal with regard to the Directive on Parental Leave, a provision was included which stated:

"When the Member States adopt the provisions under paragraph 1 these shall prohibit any discrimination based on race, sex, sexual orientation, colour, religion or nationality." ${ }^{106}$

103 Resolution A3-0091/94 of the European Parliament of 24 February 1994, on the new social dimension of the Treaty on European Union, OJ C 77/30, 14-3-1994, p. 31. See also the report of the Committee on Social Affairs, Employment and the Working Environment, on the new social dimension of the Maastricht Treaty, 1 September 1993, A $3-0247 / 93$, PE 205.366/ fin., p. 7.

104 UNICE welcomed the Councils recognition that it could not change the European Framework Agreement on Parental Leave. If this were not the case, the legislation produced could not be regarded as an agreement between the social partners and the procedure would than have to be resumed from the stage were it was suspended and follow the procedures foreseen in the Treaty for development of EU legislation. (UNICE position paper on the Commission Communication, concerning the development of the social dialogue at Community level, 26 February 1997).

105 Article 1 of $\operatorname{COM}(96) 26$ final.

106 Article 2(5) of COM(96) 26 final. 
This provision has not been taken over by the Council in its Directive. With regard to all other Commission proposals based on European collective agreements, changes have been made by the Council in the preceding articles to the agreement. Furthermore, certain articles which have been drafted by the Commission were not taken over by the Council. The changes made by the Council, however, never concerned the European agreement itself, but only the preceding Articles which were added by the Commission.

It is my opinion that for the question whether the Council can amend a Commission proposal based on a European agreement, the same answer can be given as to the question whether the Commission can amend a European agreement. It is argued in para. 7.4.2. that the Commission cannot amend an agreement of the social partners and subsequently submit it to the Council on the procedural basis mentioned in Article 139(2) EC Treaty. The same reasoning applies for the Council. If the Council were to amend a European agreement, it would not implement the agreement as stated in Article 139(2) EC Treaty. The European social dialogue would be useless if the Council could just amend the Commission proposal in such a way that the agreement of the social partners would be totally changed. Changing the agreement implies that it is no longer an agreement concluded by the European social partners' organisations, but a Commission proposal which is amended by the Council. ${ }^{107}$ If this proposal covers the subject matters of Article 137, one of the two decision-making procedures referred to in Article 137(2) and (3), will apply. The question is, however, whether the social partners should be consulted again on the basis of Article 138(2) and (3) EC Treaty, since these provisions prescribe that the Commission has to consult management and labour before submitting proposals in the social policy field. Whether the social partners conclude an agreement after the consultation, or whether they remain passive is not important. For all social policy proposals consultation of management and labour is required. Perhaps a comparison can be made with the position of the EP. If the Treaty provisions refer to the decisionmaking procedure of Article 251 EC Treaty or 252 EC Treaty, the Council has to consult the EP before it takes a decision. The ECJ has consistently held that due consultation of the EP in the cases provided for by the Treaty constitutes an essential formal requirement, disregard of which means that the measure concerned is void. ${ }^{108}$ However, the Council also has the right to amend Commission proposals according to Article 250(1) EC Treaty. The ECJ has therefore decided that the duty to consult the EP in the cases provided for by

107 See also E. Kampmeyer, Protokoll und Abkommen über die Sozialpolitik der Europaischen union, p. 99 as well as K. Piazolo, Der Soziale Dialog nach dem Abkommen uber die Sozialpolitik und dem Vertrag von Amsterdam, p. 143. See furthermore C. Calliess and M. Ruffert (eds.), Kommentar des Vertrages über die Europatische Union und des Vertrages zur Gründung der Europäische Gemeinschaft -EUV/EGV-, Article 139 , point 27 .

108 Case 138/79, Judgment of 29/10/1980, Roquette/Council (Rec.1980,p.3333). 
the Treaty include a requirement that the EP be re-consulted on each occasion on which the text finally adopted, viewed as a whole, departs substantially from the text on which the EP has already been consulted. Several cases have come before the ECJ where the Council made substantive amendments to Commission proposals, without re-consulting the EP. ${ }^{100}$ In the European social dialogue process, it is the Commission who performs the consultation. Nevertheless, I think that the same reasoning can be applied as has been done for the consultation of the EP by the Council. In the UEAPME case, the $\mathrm{CFI}$, stated that consultation of management and labour is mandatory for all Commission initiatives based on the Agreement (on Social Policy, E.F.). ${ }^{110}$ This means that for Commission proposals with regard to the subjects mentioned in Article 137 EC Treaty (ex Article 2 Agreement on Social Policy), the social partners should be consulted. When the Commission sends its proposal to the Council, this proposal will not only contain the view of the Commission, but also the views of the social partners who have been consulted thereon. I consider therefore that if the Council decides to make substantial amendments to the Commission proposal, the social partners should be given a renewed opportunity to state their views on the amended proposal. "II Whether the Council is obliged to take over these views, will be discussed in Chapter 8. This is also so in case the social partners have not concluded an agreement on the first occasion that they have been consulted. They should furthermore even be given a renewed opportunity to conclude an agreement. In case of small, insubstantial amendments, the procedure could be different. Whenever a European agreement is amended, the agreement should be regarded as repudiated, since even a small amendment to a European agreement can have major consequences for the balanced relationship that is reflected in such an agreement. A renewed consultation is not, however, necessary in my view. Nor would this be necessary if social partners were consulted and the Commission followed the legislative route of Article 250 or 251 , without the consulted organisations concluding an agreement. In schematic form this would give the picture as shown in figure 3 .

109 Case C-65/90, Judgment of 16/07/1992, Parliament/Council (Rec.1992,p.I-4593), Case C-388/92, Judgment of 01/06/1994, Parliament/Council (Rec.1994,p.I-2067), Case C417/93, Judgment of 10/05/1995, Parliament/Council (Rec.1995,p.I-1185), Case C21/94, Judgment of 05/07/1995, Parliament/Council (Rec.1995,p.I-1827), and Case C392/95, Judgment of 10/06/1997, Parliament/Council (Rec.1997,p.I-3213).

110 Cons. 72.

111 Britz and Schmidt are of the opinion that the Council can not amend European collective agreements. G. Britz and M. Schmidt, The Institutionalised Participation of Management and Labour in the Legislative Activities of the European Community: A Challenge to the Principle of Democracy under Community Law, In: European Law Journal, vol. 6 , no. 1,2000 , p. 56 . 
Figure 3

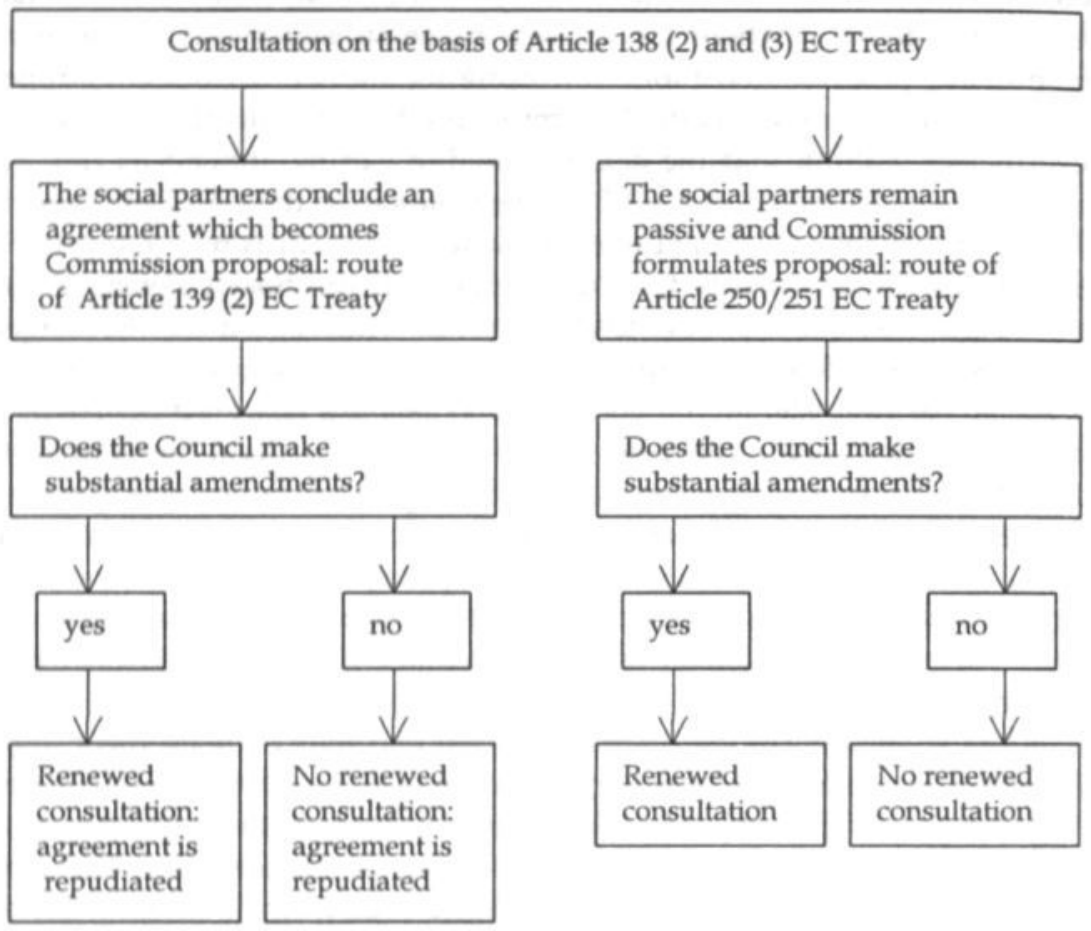

Legal arguments apart, it would not be wise for political reasons for the Council to amend a Commission proposal without the social partners being re-consulted. The Commission proposal is based on a European agreement which reflects the balance of power between the organisations that concluded the agreement. Such an agreement is often the result of long and extensive negotiations which leads to a result that is satisfying for all negotiating parties. Amending such agreements so casually would probably mean the end of the European social dialogue. ${ }^{112}$ Social partners' organisations will not be motivated to conclude European collective agreements if it is not certain that the content of their agreements remain the same if they are turned into a Council decision. Negotiations on European collective agreements will be useless in such cases.

112 See also J.P.M. Zeijen, Europees sociaal beleid na Maastricht: een ratjetoe? In: Sociaal Recht, vol. 7, no.5, 1992, p. 137. 


\subsubsection{Rejection of the Commission proposal by the Council}

It is possible that the Council rejects the proposal from the Commission. This will happen if the necessary qualified majority or unanimity cannot be obtained within the Council. ${ }^{13}$ Whether the decision to reject or accept the Commission proposal can be subject to legal review will be discussed in Chapter 8. In this paragraph, I only want to discuss whether the consultation procedure should be followed again if the Commission, after the rejection by the Council of its proposal, nevertheless wants to have Community legislation on the topic of its proposal. I believe that the answer to this question depends on the previous history of the European agreement. If the agreement has been concluded on the occasion of the consultation procedure of Article 138(2) and (3) EC Treaty, a new consultation would not be necessary, if the Commission wants to legislate on the same issue. However, whether this will occur is questionable, since the Commission then already knows that the required majority or unanimity will not be obtained within the Council. A new proposal of the Commission immediately, or shortly after, the rejection of the previous one by the Council, would not make any sense, and therefore there is no likelihood that this will happen. Attitudes within the Council can, however, change over the years. It is very possible that the same proposal of the Commission that was once rejected by the Council, will be adopted a few years later, when the composition of the Council has changed due to new governments in the Member States. ${ }^{114}$ Should the Commission in such a case consult the social partners' organisations again on the basis of Article 138(2) and (3) EC Treaty? I believe that if, during these years, new organisations have been added to the list, which are eligible for consultation on the issue covered by the Commission proposal, new consultation should always take place. After all, these organisations did not have the opportunity to submit their opinion the first time. What is the position if the list of organisations to be consulted has remained exactly the same as during the first time that they were consulted? In my opinion the Commission should at least ask these organisations whether their views have changed and whether they would now conclude a different agreement. As in the Council, the attitude within the social partners' organisations towards certain social policy issues can have changed during the years. If that is the case, there should be a renewed consultation and the organisations should be granted a renewed opportunity to conclude an agreement. If, however, the social partners indi-

113 Also G. Britz and M. Schmidt, The Institutionalised Participation of Management and Labour in the Legislative Activities of the European Community: A Challenge to the Principle of Democracy under Community Law, In: European Law Journal, vol. 6, no. 1,2000, p. 54.

114 The Agreement and Protocol on Social Policy was included in the Treaty thanks to the fact that there was a change of government within the UK towards Labour. And although it did not concern a Commission proposal here, it illustrates that political views can rapidly and radically change within the Council. 
cate that their attitude has not changed, the Commission could easily take over their agreement that they concluded on the occasion of the first consultations and send it to the Council, to see whether the Council is now willing to implement it. It goes without saying that if the Commission wants to formulate a new proposal which differs from the previous one, it should consult the social partners again, analogously to the reasoning with regard to amendments, as given in para. 7.5.1.2.

If the social partners conclude an agreement on their own initiative, that is to say without first being consulted by the Commission, the situation can be different. Spontaneously concluded agreements can also be turned into a Council decision. However, it is possible that the Council rejects the Commission proposal based on such agreement. After a certain time the Commission can try again whether this proposal will be accepted by the Council. If the circle of organisations to be consulted on this matter is broader than the circle of organisations that concluded the (rejected) agreement, consultation should always take place. If the organisations that concluded the rejected agreement are the same as those now eligible for consultation, the Commission can follow the same procedure as described above: The Commission can check whether the views of the social partners' organisations have changed. In that case, the consultation procedure should be started again. In schematic form this would give the picture as shown in figure 4 . 


\section{Figure 4}

The Council rejects the Commission proposal which is based on a European agreement

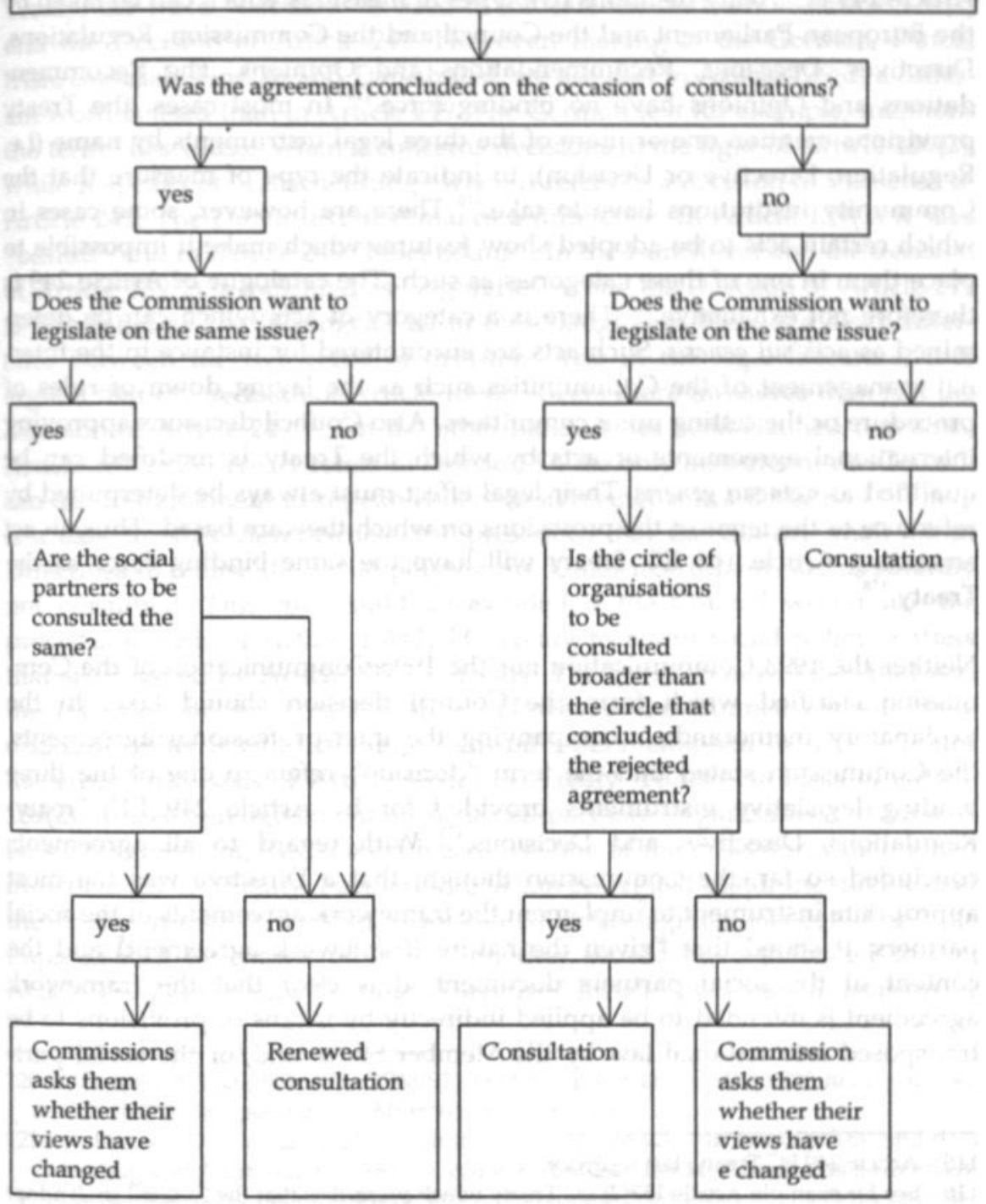




\subsubsection{Form of the Council Decision}

Article 139(1) states that "agreements (...) shall be implemented..by a Council decision." The question is which form this decision of the Council can take. Article 249 EC Treaty mentions five types of measures which can be taken by the European Parliament and the Council and the Commission: Regulations, Directives, Decisions, Recommendations and Opinions. The Recommendations and Opinions have no binding force. ${ }^{115}$ In most cases, the Treaty provisions mention one or more of the three legal instruments by name (i.e. Regulation, Directive or Decision), to indicate the type of measure that the Community institutions have to take. ${ }^{116}$ There are however, some cases in which certain acts to be adopted show features which make it impossible to place them in one of these categories as such. The catalogue of Article 249 is therefore not exhaustive. ${ }^{117}$ There is a category of acts which can be determined as acts sui generis. Such acts are encountered for instance in the internal management of the Communities such as the laying down of rules of procedure or the setting up of committees. Also Council decisions approving international agreements or acts by which the Treaty is modified can be qualified as acts sui generis. Their legal effect must always be determined by reference to the tenor of the provisions on which they are based. Thus an act amending Article 166 EC Treaty will have the same binding force as the Treaty. ${ }^{118}$

Neither the 1993 Communication nor the 1996 Communication of the Commission clarified which form the Council decision should take. In the explanatory memoranda accompanying the inter-professional agreements, the Commission stated that the term "decision" refers to one of the three binding legislative instruments provided for by Article 249 EU TreatyRegulations, Directives and Decisions. ${ }^{119}$ With regard to all agreements concluded so far, the Commission thought that a Directive was the most appropriate instrument to implement the framework agreements of the social partners. It stated that "given the nature (framework agreement) and the content of the social partners document, it is clear that the framework agreement is intended to be applied indirectly by means of provisions to be transposed into national law by the Member States and/or the social part-

115 Article 249 EC Treaty, last sentence.

116 See for example Article 137(2) EC Treaty which prescribes that the Council shall adopt Directives.

117 Case $90 / 63$ and 91/63, Judgment of 13/11/1964, Commission EEC/Luxembourg and Belgium (Rec.1964,p.1217).

118 P.J.G. Kapteyn and P. VerLoren van Themaat, Introduction to the law of the EC, p. 322.

$119 \operatorname{COM}(96) 26$ final, point 33 and $\operatorname{COM}(97) 392$ final, point 42 . See also A. Höland, Partnerschaftliche Setzung und Durchfuhrung von Recht in der Europarischen Gemeinschaft. In: ZIAS, 1995, p. 446. 
ners. Hence, in that case, the most suitable instrument for its application is a Council Directive". ${ }^{120}$

In the English, French, Spanish, Portuguese and Italian version of the EC Treaty, the word "decision" is used to indicate the decision of Article 139(2) and the Decision of Article 249. However, looking at the German, Dutch, Irish, Swedish, Finnish and Danish text, we see that in Article 139(2) a different word is used than in Article 249. The German text for example, mentions the term "Beschluss" when it concerns decisions in the light of Article 139(2), while it speaks of "Entscheidung" when it refers to a decision in the sense of Article 249. The Dutch text also makes a difference. In Article 139(2) it says "besluit" and in Article 249 "beschikking". In the Danish version the decision of Article 139(2) is indicated as "afgorelse", while the Decision of Article 249 is translated as "beslutninger". So in these languages there is a clear difference between the two types of decision. Also in the legal literature, it is argued that the decision of Article 139(2) covers more measures than just the Decision of Article 249. ${ }^{121}$ On the other hand, it has been claimed that since Article 139(2) EC Treaty refers to Article 137, the only instrument the Council can use to implement European collective agreements is a Directive. ${ }^{122}$ There is a case for this view. Article 137 prescribes that the Council shall adopt Directives to realise the social policy aims. Other instruments are apparently not permitted. This rule could be avoided if the Council would use the procedural basis of Article 139(2) EC Treaty to adopt social policy matters that are covered by Article 137 EC Treaty. The question is whether that was the intention of the Treaty drafters. However, the Council cannot freely decide whether it will use the procedural basis mentioned in Article 137 or the procedural basis of Article 139(2) EC Treaty. To use the basis of Article 139(2), it needs an agreement of the social partners' organisations. If there is no such agreement, the Council has to use one of the procedures mentioned in Article 137 EC Treaty. Furthermore, it can be argued that if the intention of the Treaty drafters were that European collective agreements could only be implemented by means of Directives, they would have indicated this in Article 139(2) by stating "Council Directive" instead of "Council decision". I

$120 \operatorname{COM}(96) 26$ final, point 33; $\operatorname{COM}(97) 392$ final, point 42; $\operatorname{COM}(99) 203$ final, point 46, $\operatorname{COM}(2000) 382$, point $28, \operatorname{COM}(98) 662$ final, point 27.

121 K. Piazolo, Der Soziale Dialog nach dem Abkommen über die Sozialpolitik und dem Vertrag von Amsterdam, p. 151, as well as C. Calliess and M. Ruffert (eds.), Kommentar des Vertrages über die Europăische Union und des Vertrages zur Gründung der Europăische Gemeinschaft -EUV/EGV-, Article 139, point 29 and C.O. Lenz (ed.) EGVertrag, Köln, 1999, Article 139, point 6. See furthermore, B. Bercusson, European labour law, p. 549; R. Blanpain and C. Engels, European labour law, Deventer, p. 528; B. Hepple, European social dialogue -Alibi or opportunity?-, 1993, p. 31 and B. Bödding, Die europearechtlichen Instrumentarien der Sozialpartners, p. 123.

122 J. Schwarze (ed.), EU-Kommentar, Article 139, point 5. See also M. Blank, Europalische Kollektivvertråge und Sozialer Dialog. In: W. Däubler and K. Kehrmann (ed.), Arbeit und Recht, Festschrifte für Albert Gnade, p. 656. 
think therefore that the choice of instrument depends on the content and character of the agreement concluded between the social partners. ${ }^{123}$ However, Recommendations and Opinions are out of the question, since they do not have any binding force. ${ }^{124}$ The three intersectoral organisations, the ETUC, UNICE and CEEP made clear that by sending their agreement to the Commission with a request to forward it to the Council, they want their agreement to become a Community legal instrument. ${ }^{125}$ The question which then remains is which type of measure is the most appropriate to be used when it comes to the implementation of European collective agreements.

In my opinion a Decision is not a very suitable instrument for implementing European collective agreements. A Decision has an individual character; it applies to a limited number of specified or identifiable natural or legal persons, while European collective agreements will usually be directed towards an abstract number of workers and employers. ${ }^{126}$ Birk thinks that for reasons of efficiency, a Regulation would be the most appropriate instrument. ${ }^{127}$ Without excluding the instrument of the Regulation out of hand, I believe that it will hardly ever be used to implement agreements that cover issues of social policy. It is not common practice to use Regulations as a means for implementing social policy measures. Article 137 EC Treaty, for example, explicitly prescribes that the Council shall adopt Directives. The measures on equal treatment between men and women, as a result of Article 141 EC Treaty, are also Directives. Only on the co-ordination of social security systems under Article 42, has a Regulation been adopted. ${ }^{128}$ In most cases Directive will probably be the most suitable instrument to implement European collective agreements. We have to bear in mind that there are major differences of views between the Member States over the objectives and shaping of social policy, and on the demarcation between the public, intermediate, and private sectors in that area. The national social structure is

123 See also K. Piazolo, Der Soziale Dialog nach dem Abkommen über die Sozialpolitik und dem Vertrag von Amsterdam, p. 152.

124 Also A. Adinolfi, Admissibility of action for annulment by social partners and "sufficient representativity" of European agreements, In: European Law Review, vol. 25, no. 2, 2000, p. 166.

125 Proposals by the social partners for the implementation of the Agreement on Social Policy annexed to the Protocol on Social Policy of the Treaty on the European Union, 29 October 1993. In: Social Europe 2/95, p. 164.

126 Case $16 / 62$ and $17 / 62$, Judgment of $14 / 12 / 1962$, Confédération nationale des producteurs de fruits et des legumes and others/Council EEC (Rec.1962,p.901). See also E. Kampmeyer, Protokoll und Abkommen uber die Sozialpolitik der Europăischen union, p. 95 and 96.

127 R. Birk, Vereinbarungen der Sozialpartners im Rahmen des Sozialen Dialogs und ihre Durchführung. In: EuZW, vol. 8, no. 15, 1997, p. 459. See also E. Campbell, Remedies after the social policy agreement. In: J Loubay and A. Biondi (ed.), Remedies for breach of EC law, Chichester, 1997, p. 180-181.

128 See also E. Kampmeyer, Protokoll und Abkommen uber die Sozialpolitik der Europäischen union, p. 96 . 
the prime expression of national ideological, cultural and social traditions. It is thus extremely sensitive about external interventions. ${ }^{129}$ On the other hand, forms of extremely low levels of protection in the social field may have serious cross-border effects for other Member States. This does not imply, however, that a complete harmonisation of public law rules within the Community in the social policy field is necessary. The major divergence of rules within the Community in this area makes such an imposition of uniformity undesirable. ${ }^{130}$ For these reasons, Directives are considered a suitable instrument of Community intervention. Harmonisation by means of Directives represents a form of limited intervention. The Member States are required to adapt their laws only to a certain extent, namely as far as necessary to achieve the objectives set out in the relevant Treaty provision which serves as the legal basis for the Directive. The Directive is by its nature most suitable for bringing about the necessary changes in national laws while respecting as far as possible the national legal systems, with their own conceptions and terminology. ${ }^{131}$ A Directive seems therefore in most cases the best instrument to implement European collective agreements.

\subsubsection{Conclusions}

If the Council decides to turn a European agreement into a Council decision, it has to act by qualified majority. This is only different when the European agreement contains one or more provision relating to one of the areas referred to in Article 137(3) EC Treaty. In such cases it has to act unanimously. Article 137 has undergone some slight changes by the Treaty of Nice, which has not entered into force yet (February 2002). Under the Treaty of Nice the possibilities to act by qualified majority voting will be broadened. Whether the Council will act by qualified majority voting or by unanimity will depend on the content of the core provisions in the European agreement. If these core provisions cover one or more of the issues of Article 137(3) EC Treaty, the Council shall act unanimously. If the Council decides to amend a Commission proposal that is based on a European agreement, it cannot continue by taking a decision on the basis of Article 139(2) EC Treaty. This article prescribes that agreements shall be implemented. If the Council makes amendments, we can no longer speak of an agreement, but have to speak of a Commission proposal to which one of the decision making procedures referred to in Article 137(2) or (3) EC Treaty will be applicable, depending on the content of the proposal. If the Council makes substantial amendments to the Commission proposal, the social partners should be consulted again on the basis of Article 138(2) and (3) EC Treaty, regardless of whether these

129 P.J.G. Kapteyn and P. VerLoren van Themaat, Introduction to the law of the EC, p. 1045-1046.

130 P.J.G. Kapteyn and P. VerLoren van Themaat, Introduction to the law of the EC, p. 1054.

131 S. Prechal, Directives in European Community law, 1994, p. 3-4. 
amendments consider a Commission proposal based on a European agreement or a proposal whose content comes from the Commission itself. If the Council rejects the Commission proposal which was based on a European agreement, the social partners should always be (re)consulted if the Commission, after that rejection, wants to legislate on a new issue. If the Commission wants to legislate on the same issue, the social partners have to be (re)consulted if the (rejected) agreement was concluded on the occasion of the consultation procedure and the social partners to be consulted are not exactly the same as the ones that have been consulted the first time. If, however, the social partners to be consulted are exactly the same as the ones that were first consulted, the Commission could just ask whether their views have changed on the subject. If this is not the case, the Commission can bring the (rejected) agreement again before the Council to see whether the last mentioned is willing to turn it into a Council decision this time. If the (rejected) agreement was concluded spontaneously, consultation should take place if the circle of organisations to be consulted is broader than the circle of organisations that concluded the (rejected) agreement. If, however, the circle of organisations to be consulted is exactly the same as the circle of organisations that concluded the (rejected) agreement, the Commission could just ask whether their views have changed on the subject. If this is not the case, the Commission can bring the (rejected) agreement again before the Council to see whether the last mentioned is willing to turn it into a Council decision this time. The form of the Council decision depends on the content and character of the agreement concluded between the social partners. Nevertheless, it shall have to be a decision which has binding force, which excludes the instruments of the Recommendation and the Opinion. The most suitable instrument is a Directive, given the fact that it will always concern the social policy field and given the wide differences in views between the Member States with regard to this field.

\subsection{The role of the European Parliament and the Economic and Social Committee}

Article 139(2) EC Treaty prescribes the decision-making procedure when it comes to the implementation of European collective agreements by Council decision. It is remarkable that in this decision-making procedure, two institutions are excluded: the European Parliament (EP) and the Economic and Social Committee (ECOSOC). The questions are what the reasons are for this exclusion and whether this exclusion is desirable. I will answer these questions hereafter for each institution.

\subsubsection{The European Parliament}

The interests of the peoples of the Community are in fact represented by two institutions: through the representatives of the democratically chosen gov- 
ernments in the Council and through the representatives of all peoples in the Community, represented in the European Parliament (EP). ${ }^{132}$ The way, however, in which they represent the peoples is different. In the Council of Ministers, the people of the Member States are represented in the sense that in the Council the national representatives of the democratically chosen governments of the Member States are seated. ${ }^{133}$ The members of the Council do not sit as individuals, but as representatives of their Member State. Each of them acts on the instructions of or by a mandate from his or her government. In the Council, therefore, the Community interest (which the Council as an institution is as much required to protect as the Commission), will be viewed through the spectacles of national interests. ${ }^{134}$ The EP however, represents all peoples of the Community collectively and independently. As representatives of the peoples, the members of the EP are not bound by instructions of their governments, or of the national parliaments. It is the European political party groups within the EP, rather than the national parties which put their stamp on the work of the EP. ${ }^{135}$ Since the Council adopts Community acts which have consequences for all people living in the $\mathrm{EC}$, it is important that not only the Council and the Commission decide on the content of these acts, but also the representatives of the peoples of the Community: the EP. Dederer argues that the less power the national representatives in the Council have, the greater the power of the EP should be. This is, for example, the case if the Council acts by qualified majority voting. In such a case, certain national representatives will be outvoted. This is however acceptable if the content of these acts can be controlled by the EP. ${ }^{136}$ The growing importance of the EP has also been reflected in the Treaty. Initially, there was only the consultation procedure, whereby the Council consults the EP to ascertain its views on a proposal of the Commission. ${ }^{137}$ With the coming into force of the SEA on 1 July 1987, a second procedure was established, the cooperation procedure. ${ }^{138}$ With the changes made by the TEU, a third procedure was introduced, the co-decision-procedure. ${ }^{139}$

Through this procedure, the EP has the most far-reaching influence on decision making within the Council. This development emphasises that Community decision-making is no longer primarily a matter of interplay between the Council and the Commission, but is truly a tripartite affair, in-

132 H.G. Dederer, Durchführung von Vereinbarungen der europăischen Sozialpartner. In: Recht der Arbeit, vol. 53, no. 4, 2000, p. 218.

133 See Article 203 EC Treaty.

134 P.J.G. Kapteyn and P. VerLoren van Themaat, Introduction to the law of the EC, pp. 187-188.

135 P.J.G. Kapteyn and P. VerLoren van Themaat, Introduction to the law of the EC, pp. 209-210.

136 H.G. Dederer, Durchführung von Vereinbarungen der europăischen Sozialpartner. In: Recht der Arbeit, vol. 53, no. 4, 2000 , p. 219.

137 Article 250 EC Treaty.

138 Article 252 EC Treaty.

139 Article 251 EC Treaty 
volving the EP, the Council and the Commission. In a sense the improvements have proceeded through a "salami-approach", so that by each major revision of the Treaties the position of the EP has been strengthened. ${ }^{140}$ The importance of involving the EP in the decision making process has been confirmed by the ECJ. In its case law, the ECJ emphasised that consultation of the EP is the means which allows the EP to play an actual part in the legislative process of the Community. Such power represents an essential factor in the institutional balance intended by the Treaty. Although limited, it reflects at Community level the fundamental democratic principle that the peoples should take part in the exercise of power through the intermediary of a representative assembly. Due consultation of the EP in the cases provided for by the Treaty therefore constitutes an essential formality, disregard of which means that the measure is void. ${ }^{141}$ This intention to increase the legitimacy of Community policy is being undone by withholding a decisionmaking role for the EP as soon as it regards the implementation of agreements of the social partners. ${ }^{142}$ If the EP is excluded from the legislative procedure, as in the case the procedure of Article 139(2) EC Treaty, there has to be a very good reason. ${ }^{143}$ Such reason could lie in the fact that democratic legitimisation is present through the participation of other groups representing the peoples of the EC. For example the social partners in the decisionmaking process. ${ }^{144}$ This argument was also used by the CFI in the UEAPME case. ${ }^{145}$ This could indeed be a valid reason. ${ }^{146} \mathrm{I}$ have already argued in para. 7.4.1.1., that the social partners' organisations who were involved in the conclusion of the European collective agreements so far, do not represent the majority of the people of the Member States ${ }^{147}$ and not even a majority of the workers and employers to whom the agreements apply if they are implemented by Council decision. Moreover, I argued in para. 7.4.1.2., that it is not clear whether all organisations that are listed by the Commission as representative enough to be consulted, have democratic internal decision-making procedures. This is not being checked by the Commission if it decides to turn

140 P.J.G. Kapteyn and P. VerLoren van Themaat, Introduction to the law of the EC, p. 222.

141 Case 138/79, Case 139/79, Judgment of 29/10/1980, Maizena/Council (Rec.1980, p.3393), Case 114/81, Judgment of 30/09/1982, Tunnel Refineries/Council (Rec.1982, p.3189).

142 See also T. Gilles, Das Zustandekommen und die Durchfuhrung von Sozialpartnervereinbarungen im Rahmen des europăischen sozialen Dialogs, p. 136.

143 H.G. Dederer, Durchführung von Vereinbarungen der europăischen Sozialpartner. In: Recht der Arbeit, vol. 53, no. 4, 2000, p. 220.

144 B. Bodding, Die europearechtlichen Instrumentarien der Sozialpartner, p. 114.

145 Cons. 89.

146 See also B. Hepple, Towards a European social constitution. In: C. Engels and M. Weiss (eds.), Liber Amicorum for R. Blanpain, The Hague, 1998, p. 303.

147 Also G. Britz and M. Schmidt, The Institutionalised Participation of Management and Labour in the Legislative Activities of the European Community: A Challenge to the Principle of Democracy under Community Law, In: European Law Journal, vol. 6, no. 1, 2000, p. 66 . 
the European agreement into a Commission proposal. Furthermore, it is difficult to get clear view on these internal decision-making procedures since the statutes of most European social partners' organisations do not foresee a special procedure for the conclusion of European collective agreements. Besides, meetings of the social partners take place behind closed doors. ${ }^{148}$ This is also a difference with the EP, which meets in public. ${ }^{149}$

But is the fact that the social partners' organisations do not represent a numerical majority such a big problem? It can be argued that a comparison can be drawn between the Council decision to implement a European agreement and the extension erga omnes of collective agreements at national level. By this procedure at national level, the parliament is not involved either, ${ }^{150}$ which means that the situation at Community level is just a copy of the situation in the several Member States. This comparison is not, however, totally correct. At national level, ministers are politically responsible for their acts towards the national parliaments. So although the national parliament is not directly involved in the extension erga omnes of collective agreements, it has an indirect influence on the Minister because it can force him/her to resign This, at present, is not the case at European level. Although the Council and the EP have developed a number of formal contacts outside the legislative process, ${ }^{151}$ the Council is not responsible to the EP in any formal sense. The individual members of the Council are still responsible to their own national parliaments for their individual part in the decision-making, which means that a minister who has voted for a measure which is unpopular at home, will have some explaining to do. There are, however, no direct ways for the EP to influence the decisions of the Council. The only thing that the EP can do is to influence the Council in a more indirect way, namely via the Commission. The Commission is the initiator of Community legislation and the EP can influence the composition of the Commission. It has the power to dismiss the Commission through the adoption of a motion of censure. ${ }^{152}$ Furthermore, the EP plays an important role in the process of appointing new Commissioners. Only after first consulting the EP, will the governments of the Member States nominate, by common accord, the person they intend to

148 See also H.G. Dederer, Durchführung von Vereinbarungen der europăischen Sozialpartner. In: Recht der Arbeit, vol. 53, no. 4, 2000, p. 222.

149 Article 104 Rules of Procedure EP (OJ 1997 L 49/1), Article 199 and 200 EC Treaty.

150 See also H.G. Dederer, Durchführung von Vereinbarungen der europăischen Sozialpartner. In: Recht der Arbeit, vol. 53, no. 4, 2000, p. 220, footnote 43.

151 The Council is prepared to answer written and oral questions from members of the EP and to inform the EP about its intended programme and the progress in its activities (See Article 197 EC Treaty. See also the Council's Rules of Procedure (Dec 93/662, OJ 1993 L 268/1, as amended by Dec. 95/24, OJ 1995 L 31/14), Rule 25 and the EP's Rules of Procedure, No. 40-42. See also P.J.G. Kapteyn and P. VerLoren van Themaat, Introduction to the law of the EC, p. 226). Article 201 EC Treaty. 
appoint as President of the Commission. ${ }^{153}$ Subsequently, the other Commissioners are nominated by the governments of the Member States and they are then subject, as a body, to a vote of approval by the EP. ${ }^{154}$ The censure motion is, however, a weapon not readily taken up and the procedure is difficult. ${ }^{155}$ The chance is very small that it will be used to influence indirectly the decision-making within the Council.

If the EP could obtain an official role in the decision-making procedure of Article 139(2) EC Treaty, how would such an involvement have to take form? It is suggested by the EP that the Council may not decide to accept or refuse an agreement of the European social partners' organisations until it has consulted, and received the opinion of, the European Parliament. ${ }^{156} \mathrm{I}$ would plead for a role of the EP in line with its role as prescribed in Article 137 EC Treaty. A European agreement which is implemented by Council decision always covers matters of Article 137, since it is otherwise not possible to have it implemented by Council decision. If the agreement covers matters of Article 137(1) EC Treaty, the EP should have a strong role, analogous to Article 251 EC Treaty. After all, Article 137(2) EC Treaty prescribes that the procedure of Article 251 EC Treaty is applicable when it comes to the adoption of Directives on matters covered by Article 137(1) EC Treaty. I would however not recommend taking over the whole procedure of Article 251 EC Treaty, since, according to this procedure, the EP has the right to make amendments. When it comes to the implementation of European collective agreements, the EP should not have the right of amendment, just like the Council and the Commission. I suggest the following procedure: The European agreement should be sent by the Commission to the EP and the Council. The EP should have the possibility to advise either the acceptance of the agreement or the rejection of it. If the EP advises to accept the agreement, the Council can decide by qualified majority voting to either reject the agreement or to turn it into a Council decision. If the EP advises to reject the agreement, the Council shall adopt a common position and communicate this to the EP. The Council should inform the EP fully of the reasons which led it to adopt this common position. If within three months of such communication the EP approves the common position or has not taken a decision, the Council adopts its decision in line with its common position. If the EP, however, rejects by an absolute majority of its component members the common position of the Council, the Council cannot turn the European agreement into a decision.

153 Article 214(2) EC Treaty.

154 Article 214(2) EC Treaty.

155 P.J.G. Kapteyn and P. VerLoren van Themaat, Introduction to the law of the EC, p.224.

156 Second report of the Committee on Social Affairs, Employment and the Working Environment, on the new social dimension of the Treaty on European Union, 18 February 1994, A3-0091/94, PE 205.366/ II/ fin., p. 7. 
If the European agreement covers matters of Article 137(3) EC Treaty, the Council should act unanimously after it has consulted the EP. The Council should, however, not be obliged to follow the advice of the EP.

The fact that the EP at this moment has no official role in the procedure of Article 139(2) EC Treaty, does not mean that is has no role at all. In practice, the Commission informs the EP and ESC by sending them the text of the agreement of the social partners, together with its proposal for a decision and the explanatory memorandum. The EP and ESC may, should they consider it advisable, deliver their opinion to the Commission and to the Council. ${ }^{157}$ However, even amendments suggested by the EP with regard to the provisions which the Commission added to the European Framework Agreement on Part-Time Work, were not taken over by the Council, although the amendments did not concern the content of the European agreement itself. With regard to the European Framework Agreement on Fixed Term Work and the European Framework Agreement on Parental Leave, the EP advised the Council to implement the agreements by a Council decision. This advice has been followed by the Council. Whether the Council would also follow an advice of the EP to reject a European agreement, remains to be seen.

\subsubsection{The Economic and Social Committee}

Within the Communities, provision has been made for an institutionalised representation of economic and social life, the organisations and duties of which are laid down by the Treaties. ${ }^{158}$ All sectors of economic and social life are represented in the Economic and Social Committee (ECOSOC). ${ }^{159}$ The 222 seats in the ECOSOC have been divided into three groups: these groups are

$157 \operatorname{COM}(93) 600$ final, point 40 . See also the 14th and 15th "whereas" in the Parental Leave Directive. These state:"Whereas the Commission, in accordance with its Communication of 14 December 1993 concerning the implementation of the Protocol on social policy, informed the European Parliament by sending it the text of the framework agreement, accompanied by its proposal for a Directive and the explanatory memorandum; Whereas the Commission also informed the Economic and Social Committee by sending it the text of the framework accompanied by its proposal for a directive and the explanatory memorandum." Words of a similar formulation can be found in the 19th and 20th "whereas" of the Directive on Part-time Work, the 19th whereas in the Directive on Fixed Term Work, the 17th whereas in the Directive on the Organisation of Working Time of Mobile Workers in Civil Aviation and the 15th whereas in the Directive on the Organisation of Working Time for Seafarers. The EP gave in Resolution A4-0064/96 (OJ C 96/248, 1-4-1996) its comments on the European Framework Agreement on Parental Leave. It did the same for the European Framework Agreement on Fixed Term Work in its Resolution A4-0261/99 of 30 April 1999 and for the European Framework Agreement on Part-Time Work in its Resolution A4$352 / 97$ of 6 November 1997.

158 P.J.G. Kapteyn and P. VerLoren van Themaat, Introduction to the law of the EC, p. 300.

159 See Article 257-262 EC Treaty. 
the Employers' Group, the Workers' Group (consisting mainly of trade union representatives) and the Miscellaneous Activities Group. The last-mentioned group includes representatives from farmers' organisations, small businesses, the crafts sector, co-operatives and non-profit associations, science, the professions, consumers' organisations, environmental organisations, and family organisations, as well as organisations representing women and persons with disabilities. ${ }^{160}$ Members of the ECOSOC are bound to act independently of their governments. ${ }^{161}$ Like the EP, the ECOSOC is an advisory body. Consultation of the ECOSOC is mandatory where the Treaty so prescribes. However, in cases where the Council is not obliged by the Treaty to consult the ECOSOC, it also does so frequently. ${ }^{162}$ Although the opinions of the ECOSOC are not binding, the organisation can indirectly influence the decision making within the Council. As long as the Council has not taken a decision, the Commission can amend its proposal. ${ }^{163}$ So it is possible that the Council asks the opinion of the ECOSOC and that subsequently the Commission amends its proposal on the basis of the opinion of the ECOSOC. Although the Commission rarely amends its proposals purely on the basis of ECOSOC opinions, it often includes its suggestions where the proposal is amended for other reasons. ${ }^{164}$ The views of ECOSOC are a valuable indicator of the potential reactions of the various social groups throughout the Community to a particular piece of legislation. Thus, for the Commission, consultation of the ECOSOC can complement and sometimes even replace separate consultations with a multitude of pan-European trade associations, professional bodies and trade unions. ${ }^{165}$ One can argue that this can also be turned around: since the Commission has already consulted the social partners on the basis of Article 138 EC Treaty, it is not necessary anymore to consult the ECOSOC if an agreement of the European social partners is to be turned into a Council decision. As regards the Employers and Workers Group within the ECOSOC, I think that this is true. These Groups do not embrace all existing European social partners' organisations and not even all the organisations which are considered as representative by the Commission. The members of the Employers' Group are individuals from the several Member States. There are regular exchanges of information between this group and European employers' organisations, such as UNICE, CEEP, EUROCOMMERCE and EUROCHAMBRES. Besides this, exchange of information on an ad hoc basis takes place within the sectoral industry organisations at European level. ${ }^{160}$ There are, however, no European-level employers' organisations represented

160 Home page ECOSOC.

161 Article 258 EC Treaty.

162 P.J.G. Kapteyn and P. VerLoren van Themaat, Introduction to the law of the EC, p.302

163 Article 250(2) EC Treaty.

164 P. Raworth, The legislative process in the European Community, Deventer/Boston 1993, p. 57.

165 P. Raworth, The legislative process in the European Community, p. 58.

166 Home-page ECOSOC. 
in ECOSOC. This means that the European employers' organisations which are listed in the 1993 Communication of the Commission, cannot be replaced by the ones seated in the Employers' Group of the ECOSOC. The vast majority of Workers' Group belongs to the ETUC. Other European trade unions are, however, not represented. The representation of the European social partners' organisations is thus minimal within the ECOSOC. Thus also here, the list of European trade unions in the 1993 Communication of the Commission, will contain far more European workers' organisations than the ones seated in the ECOSOC. The views of the Employers' and Workers' Group can, however, remain valuable when it comes to the implementation of spontaneously concluded agreements. I have argued in Chapter $4^{167}$ that the European social partners' organisations do not necessarily have to await a Commission consultation before they can conclude an agreement. They can do this also on their own initiative. It is very well possible that such a spontaneously concluded agreement will be implemented by a Council decision. The view of the Employers' and the Workers' group of the ECOSOC should in such case be taken into account, because prior consultation of the workers and employers' organisations has not taken place. However, an important drawback of excluding the ECOSOC in the Article 139(2)-procedure is that the Miscellaneous Activities Group will be ignored if the ECOSOC is not consulted by the Council. The presence of this group, alongside the Employers' and the Workers' Group, ensures that the ECOSOC is able to give full voice to the concerns of the various social, occupational and cultural organisations that make up civil society. The Miscellaneous Activities Group cannot be replaced by the European social partners' organisations. Both groups represent different interests. It is nevertheless to be recommended that the ECOSOC redefine its role and restrict itself to issues which are not suitable for the social dialogue at European level. ${ }^{168}$ It is for example possible that associations representing the family, which form part of the Miscellaneous Activities Group, give their opinion on the European Framework Agreement on Parental Leave from a family point of view and not from a labour point of view. As with the EP, the ECOSOC is consulted by the Commission so far when it comes to the implementation of European collective agreements by Council decision. This consultation is, however, not mandatory, since Article 139(2) EC Treaty does not prescribe that the ECOSOC should be consulted. The consultation remains noncommittal. I think therefore that it should explicitly be put in Article 139(2) EC Treaty that the ECOSOC has to be consulted.

167 Para. 4.4.1.

168 A. Jacobs, The role of the EU institutions in the European social dialogue. In: P. Herzfeld Olsson, B. Bercusson and N. Bruun (eds.),Transnational trade union rights in the EU, p. 39. 


\subsubsection{Conclusions}

The EP should have an official role in the decision-making procedure of Article 139(2) EC Treaty. In the first place because it represents the interests of the peoples of the Community in a different way than the Council. Secondly, these interests cannot be sufficiently represented (yet) by the European social partners' organisations. Thirdly, the Council of Ministers is, unlike the ministers in the Member States, not formally responsible towards the EP. For the decision making on matters covered by Article 137(1) EC Treaty, the EP should have a more or less similar role as it has in the procedure of Article 251 EC Treaty, with the difference that the EP should not be allowed to amend the European agreement. For matters falling within Article 137(3), the EP should have the right to give a (non-binding) advice to the Council.

Consultation of the Employers' and Workers' Group within the ECOSC will not be necessary anymore if the Commission has already consulted the social partners' organisations on the basis of Article 138(2) and (3) EC Treaty. However, the Miscellaneous Activities Group cannot be replaced by the European social partners' organisations. Consultation of ECOSOC remains necessary when it comes to the implementation of European collective agreements. The Employers' and Workers' Group could still fulfill a useful role when it comes to the implementation of spontaneously concluded agreements.

\subsection{Conclusions}

If European collective agreements are to be implemented by Council decision, a first requirement is that the agreement has to cover matters mentioned in Article 137 EC Treaty. The drafting of Article 137 is so broad that it covers practically all social policy subjects. It can be argued that the Council can legislate on subjects mentioned in Article 137(6) EC Treaty as long as this legislation is based on Article 139(2) ECT.

The second requirement for implementation of a European agreement by Council decision is that the signatory parties have to make a joint request. It is recommended that certain practical requirements with regard to such a request have to be fulfilled. The social partners' organisations should be able to withdraw their request to turn their agreement into a Council decision, as long as the Commission has not send their agreement to the Council. If, after such withdrawal, the Commission nevertheless wants to continue its legislative procedure, it should start the consultation procedure of Article 138(2) and (3) EC Treaty again if it wants to formulate a proposal on a subject different from the subject of the (withdrawn) agreement of the social partners.

A third requirement for a European agreement to be turned into a Council decision is that the Commission has to formulate a proposal. Before it does so, it applies five checks on the agreement: the representativity check, the mandate check, the legality check, the SME check and the assessment check. 
The application of these checks is legitimated by the Treaty (as regards the legality check, the SME check and the assessment check) and by the CFI in the UEAPME case (as regards the representativity check and the mandate check). The Commission has formulated different representativity criteria in its 1993 Communication and its 1996 Communication. However, from the explanatory memoranda, accompanying the Commission proposals based on European collective agreements, it can be concluded that the Commission applies in most cases the criteria of its 1993 Communication to the agreements. In the UEAPME case, the CFI has dealt with the representativity issue as well. The CFI did not give a verdict on the representativity criteria of the Commission, but it did give a criterion for the determination whether a European agreement has been concluded by sufficiently representative organisations. I recommend that the representativity criteria as formulated by me in Chapter $4,{ }^{169}$ should also be applied if a European agreement is being turned into a Council decision. The mandate check in itself is necessary, but an aspect related to this check is even more important: the internal decision-making procedures of the European social partners' organisations. These processes should be democratic. This does not mean that all decisions of the social partners should be taken unanimously, but that the decision making should be organised in such a way that the will of the majority of the national affiliates is reflected in the decisions of the European organisations. The legality check should not only comprise the check whether the agreement is not contrary to Community law, but also whether it is not contrary to fundamental human rights. The SME check is in my view not necessary, since it already falls under the legality check. In the UEAPME case, the CFI gave its view on how the SME check should be applied. The assessment is applied in order to verify whether the European agreement is necessary. If the Commission rejects the European agreement because it cannot stand up to the checks, it is possible that the Commission after such rejection wants to formulate a new legislative proposal. Depending on the reasons for the rejection and on the question whether the agreement has or has not been concluded spontaneously, the Commission should start the consultation procedure of Article 138(2) and (3) EC Treaty (again). So far the Commission proposal has taken the form of a few preceding Articles, formulated by the Commission itself and an annex containing the European agreement.

The fourth requirement for a European agreement to become a Council decision is that the Council takes a decision on the basis of the Commission proposal. The Council has to decide either by qualified majority or by unanimity. The subjects for which unanimity is required are very sensitive issues and the views of the Member States on these issues vary widely. Although the Treaty of Nice has opened the door a little bit more for qualified majority voting on these issues, it remains to be seen whether the Council will use this opportunity in the future. In my view, the Council is, just like the 
Commission, not allowed to amend the European agreement. If the Council nevertheless does make amendments, it cannot continue the decision-making procedure prescribed in Article 139(2) EC Treaty. The "normal" legislative route of Article 250 or 251 EC Treaty has then to be followed. In case of substantial amendments made by the Council, a new consultation on the basis of Article 138(2) and (3) EC Treaty will be necessary. For all amendments made by the Council, whether they are substantial or not, the European agreement shall have to be considered repudiated. It is also possible that the Council rejects the European agreement. Also in this case, it cannot continue the procedure of Article 139(2) EC Treaty. If the Commission and Council nevertheless want to have legislation on the subject of the (rejected) agreement, a new consultation on the basis of Article 138(2) and (3) EC Treaty will under certain circumstances be necessary. This depends on the question whether the agreement was concluded spontaneously or on the occasion of the consultation procedure and on the question whether the Commission wants to legislate on the same issue as the issue of the (rejected) agreement, or on a different issue. The form of the Council decision has in any case to be a legally binding act, which excludes the instruments of the Recommendation and Opinion. The most suitable will be a Directive. So far, all European collective agreements which have been implemented by Council decision, have been turned into a Directive.

It is undesirable that the EP and ECOSOC not be involved in the procedure of Article 139(2) EC Treaty. When the agreement covers subjects of Article 137(1) EC Treaty, the EP should have strong role in the decision making process, analogous to its role in the procedure of Article 251 EC Treaty, with the difference that the EP cannot amend the European agreement. If the agreement covers subjects of Article 137(3) EC Treaty, the Council should be obliged to ask the (non-binding) advice of the EP. The Council should also be obliged to ask the advice of the ECOSOC. This advice should be non-binding. In this way the two organisations representing all peoples of all sectors of economic and social life within the Community will be involved in the important process of a European agreement becoming Community law. 


\section{CHAPTER 8}

\section{ACCESS TO THE COURT OF JUSTICE AND/OR COURT OF FIRST INSTANCE FOR THE EUROPEAN SOCIAL PARTNERS' ORGANISATIONS}

\subsection{Introduction}

The possibilities for natural and legal persons to submit a legal claim by the ECJ against the Community institutions, are prescribed in Articles 230 and 234 EC Treaty. According to Council Decision 93/350, of 8 June 1993, however, the CFI has jurisdiction to deal with all annulment actions, all actions for a failure to act and all actions for damages brought by private parties. The question is whether Articles 230 and 232 EC Treaty offer sufficient possibilities for the European social partners' organisations, being such private parties, to act against the Commission and the Council. This question is important because in Chapter 4 and Chapter 7, I have set out the role of the Commission and Council in the European social dialogue process. The Commission plays a decisive role when it comes to the granting of support to the European social partners, and also when it comes to the consultation of these organisations on the basis of Article 138(2) and (3) EC Treaty. Besides this, the law-making on the basis of Article 139(2) EC Treaty, lies exclusively in the hands of the Council and the Commission, when it comes to the implementation of European agreements into Council decisions. We have seen in Chapter 7, that the EP and ECOSOC are formally excluded from this process.

In para. 8.2., I will scrutinise the possibilities for the European social partners' organisations to submit legal claims against the Commission and the Council on the basis of Article $2304^{\text {th }}$ sentence EC Treaty. In para. 8.3., some alternative procedures will be discussed. Finally, in para. 8.4. some conclusions will be drawn.

\subsection{Article 230 EC Treaty and private parties: conditions for admissibility}

According to Article 230 EC Treaty acts of the Community institutions can be legally reviewed by the ECJ. Precedings can be instituted by a Member State, the Council or the Commission. But also natural or legal persons may do so. Para. 4 of Article 230 reads:

"Any natural or legal person may, under the same conditions, institute proceedings against a Decision addressed to that person or against a Deci- 
sion which, although in the form of a Regulation or a Decision addressed to another person, is of direct and individual concern to the former."

So, according to the text of Article 230 EC Treaty, there are four conditions which have to be fulfilled if European social partners' organisations are to be admissible under Article 230(4) EC Treaty:

A they have to be a natural or legal person;

$B$ it has to concern:

I. a Decision addressed to the social partners' organisation that submits the legal claim (Article 230, $4^{\text {th }}$ sentence) or

II. a Decision which, although in the form of a Regulation or a Decision addressed to another person, is of direct and individual concern to the social partners' organisation that submits the legal claim (Article 230, $4^{\text {th }}$ sentence);

C the ground of action has to be lack of competence, infringement of an essential procedural requirement, infringement of this Treaty or of any rule of law relating to its application, or misuse of powers (Article 230, $2^{\text {nd. }}$. sentence);

D the social partners' organisation shall have to institute proceedings before the CFI/ECJ within two months of the publication of the measure, or of its notification to the organisation, or, in the absence thereof, of the day on which it came to the knowledge of the latter, as the case may be (Article $230,5^{\text {th }}$ sentence).

Besides this, it is settled case law that a claim for annulment is not admissible unless the applicant has an interest in seeing the contested measure annulled. ${ }^{2}$ Such an interest can be present only if the annulment of the measure is of itself capable of having legal consequences. ${ }^{3}$

It has been argued that on the basis of Article 6 of the ECHR, private parties should have access to the CFI/ECJ. This argument was brought forward in the Kik case. ${ }^{4}$ However, the CFI rejected this argument by stating:

"that Article, which guarantees a fair trial for all persons, cannot preclude certain criteria regarding admissibility from being set for the institution for proceedings."

On the other hand, the ECJ already in the Plaumann case, ${ }^{6}$ said with regard to Article $230,4^{\text {th }}$ sentence that:

2 Case T-46/92, Judgment of 09/11/1994, Scottish Football/Commission (Rec.1994, p.II1039), and Joined Cases $\mathrm{T}-480 / 93$ and $\mathrm{T}-483 / 93$, Judgment of $14 / 09 / 1995$, Antillean Rice Mills and others/Commission (Rec.1995,p.II-2305).

3 Case 53/85, Judgment of 24/06/1986, AKZO Chemie/Commission (Rec.1986, p.1965).

4 Case T-107/94, Order of 19/06/1995, Kik/Council and Commission (Rec.1995,p.II1717).

5 Case T-107/94, para. 39. 
"The words and the natural meaning of this provision justify the broadest interpretation. Moreover provisions of the Treaty regarding the right of interested parties to bring an action must not be interpreted restrictively. Therefore, (...) a limitation in this respect may not be presumed."

In para. 8.2.1., I will discuss the concept of "natural and legal person" and apply it to the European social partners' organisations. In para. 8.2.2., the nature of the contested measure will be scrutinised. In para. 8.2.3. the general case law on the nature of the contested measure will be applied on Commission decisions with regard to the procedure of Article 139(2) EC Treaty. The same will be done for the Council decisions with regard to the procedure of Article 139(2) EC Treaty in para. 8.2.4. In para. 8.2.5., the time limit to institute proceedings under Article $2304^{\text {th }}$ sentence EC Treaty and the grounds of annulment will be discussed briefly.

\subsubsection{Natural or legal person}

There is some case law on the concepts of natural and legal person. I will discuss the general case law on these concepts in para. 8.2.1.1. and subsequently apply this case law to the European social partners' organisations in para. 8.2.1.2.

\subsubsection{General remarks}

What have the ECJ and CFI said so far on the concepts of legal and natural person?

In the Lasalle case, ${ }^{7}$ this issue was raised with regard to the right to intervene in a procedure which was brought before the ECJ. The Staff Committee of the EP made an application to intervene in a case of Claude Lasalle (an official of the EP) against the EP. The Staff Committee stated that the word "person" in Article 37 of the Protocol on the Statute of the ECJ applies to all parties representing an organised focus of legitimate interests. Whether it regarded a natural or legal person was not important, according to this Staff Committee. The ECJ dismissed the application to intervene because:
"(...) there is no reason to believe that the authors of the EEC (...) Treaties wished to extend the opportunities to intervene to the point of allowing intervention by entities lacking legal personality or even its basic aspects; Whereas in particular, these aspects include independence and responsibi- lity even if limited".

Although the issue of natural/legal person was not raised within Article 230 EC Treaty, we can conclude from this case that the ECJ is apparently of the 
opinion that the basic aspects of legal personality are independence and responsibility. The notion of independence is not difficult to understand, but what does the ECJ mean by "responsible"? The ECJ did not expand on these concepts in this case.

In the Syndicat Général du Personnel-case' a Commission Decision was challenged by a union. A so-called warning strike of the staff of the institutions of the EC took place at the end of 1972. The Commission issued, in 1973, a decision in which it decided to deduct the salary of these strikers for the three days that they had been on strike. A Luxembourg union, representing these employees, sought the annulment of this decision. The Commission argued that the applicant union lacked legal personality. It stated that in certain legal systems de facto groups, lacking legal personality, nevertheless had a right of action. In such cases, however, they are legally recognised as having the power to act in a clearly identified field. The Commission refers as an example to the Luxembourg legislation. The union on the other hand, stated that the ECJ should not look at the Luxembourg law, but develop a "Community personality". Therefore, three qualifications are necessary, according to the Union: legitimate interests, worthy of protection by society and of recognition by the law; a definite connection between these interests, bringing them together on common ground and enabling them to share the same objectives and to adopt the same methods to achieve them; and ability to do or say whatever is necessary for the furtherance of those interests. The ECJ did not go into these requirements. It did not give a Community definition of "legal personality". It simply stated that:

"the applicant is an association organising a substantial number of officials and servants of the Community institutions and component bodies, established in Luxembourg and there is no reason to doubt its representative character. Under its rules, its constitutional structure is such as to endow it with the necessary independence to act as a responsible body in legal matters. The Commission officially recognises it as a negotiating body on questions involving the collective interests of the staff. It is, therefore impossible to deny the applicant union's capacity to institute proceedings". ${ }^{10}$

It seems that there are three characteristics on the basis of which the EC] concludes that the union is question was able to institute proceedings. Firstly, because it was a representative union. Secondly, it was an independent and responsible body (here, the Lasalle criteria are repeated). Thirdly because the Commission officially recognised it as a negotiating body on certain matters.

9 Case $18 / 74$, Judgment of $08 / 10 / 1974$, Syndicat géneral du personnel des organismes européens/Commission (Rec.1974,p.933).

10 Case $18 / 74$, cons. 6-9. See also Case $175 / 73$, Judgment of $08 / 10 / 1974$, Union Syndicale and others/Commission(Rec.1974,p.917), cons. 10-13, in which the same reasoning was applied on the Union Syndicale, a union of officials and agents of the European institutions and other European organisations located in Brussels. 
So we see here that two criteria are added to the Lasalle criteria: the representativity and the official recognition by the Commission as a negotiating body.

In the Groupement des Agences de Voyages-case," a Luxembourg association representing travel agencies instituted a procedure on the basis of Article 230 $4^{\text {th }}$ sentence, against the Commission decision to accept a tender from another travel agency, following an invitation of the Commission to tender. The Commission stated that the travel agency should be declared inadmissible because it concerned a non-profit-making association. Such an association could under Luxembourg law not engage in industrial or commercial transactions or seek to obtain material profit for its members. The association however stated that according to Luxembourg case law a non-profit making association of the representatives of a trade or profession may engage in proceedings before the courts in order to defend the interests of their members. The ECJ stated:

"It must (...) be observed that although the problem has been placed by the parties on the footing of the municipal law of the applicant, the admissibility of an action for a declaration of nullity brought pursuant to the second para. of Article $173(\ldots)$ is subject to specific conditions which are more restrictive than those placed on actions of the same kind brought before the national courts.

(...) it is apparent from the file on the case that the Commission's decision (...) to exclude the Société Européenne de Voyages from the tendering procedure was adopted (...), on the ground that the Société Européenne de Voyages "does not in practice offer a concrete guarantee for the proper performance of the requisite services". Further it is apparent from a letter dated (...) from the (...) Commission that the decision was adopted "after a comparative examination of all the firms which submitted tenders". That obviously shows that the Commission recognised the validity of the tender submitted by the Société Européenne de Voyages. It may not therefore challenge the capacity to institute proceedings of a body which it allowed to take part in a tendering procedure and whose tender it rejected after a comparative examination of all those who submitted tenders.

Further, it should be pointed out that, as may be inferred from the judgements of the Court (...) in Case 18/74 (...) and Case 175/73 (...) that the meaning of "legal person" in the second para. of Article 173 EC Treaty is not necessarily the same as in the various legal systems of the Member States.

In the present case, since the Société Européenne de Voyages, which is an ad hoc association of ten travel agencies grouped together in order to respond jointly to an invitation to tender, was allowed by the Commission itself to take part in the invitation to tender and was considered and its tender rejected, it fulfils the conditions required by Community law for

11 Case $135 / 81$, Judgment of $28 / 10 / 1982$, Groupement des agences des voyages/Commission (Rec.1982,p.3799). 
the purpose of recognition as having the character of a "legal person" within the meaning of Article 173.

The objection to the admissibility of the action based on the lack of capacity to institute proceedings is therefore unfounded as far as concerns the Société Européenne de Voyages." ${ }^{12}$

It is also obvious in this case that the ECJ is inclined to give its own definition of "legal person" in Article 230 EC Treaty, $4^{\text {th }}$ sentence. The ECJ seems to attach great importance to the fact that the Commission has involved the Société Européenne de Voyages in its tendering procedure, even if it has rejected its tender.

A more or less similar case in this respect was the Fediol case, ${ }^{13}$ in which a trade union without legal personality was permitted to bring an action because the Regulation which was being challenged by the union, accorded to it a well-defined legal position. It concerned the right to lodge a complaint, the right to have that complaint considered by the Commission with proper care and the right to receive information and the right to receive information if the Commission decides not to proceed with the complaint. ${ }^{14}$

Isuppro't athe uteveibpment of a Community concept of legal personality. The right to institute proceedings under Article 230(4) EC Treaty would, if the possession of legal personality were to differ from country to country, depend on the law of the state in which the entity was organised. This result would run directly counter to the basic policy of the Treaty, which is to abolish discrimination based on nationality and to secure uniform treatment to all persons subject to Community law. ${ }^{15}$

Another line of approach which can be followed is to introduce a Community concept of the "association". In 1991, the Commission formulated a proposal for a Council Regulation on the statute for a European association (EA). ${ }^{16}$ The reason was that cross-border cooperation between associations was hampered by legal and administrative difficulties. The introduction of an EA should enable all associations to operate outside their own national borders. The Community therefore wanted to provide associations with an adequate legal instrument capable of facilitating the development of their transnational activities. ${ }^{17}$ The idea was that two or more legal entities from different Member States could form an EA. The EA had to demonstrate that it carried out genuine and effective cross-border activities. An annex was

12 Cons. 6-12 of Case 135/81.

13 Case 191/82, Judgment of 04/10/1983, FEDIOL/Commission (Rec.1983,p.2913).

14 Cons. 28 of Case $191 / 82$.

15 Smit and P. Herzog, The law of the EC, A commentary on the EEC Treaty, New York, 1996, p. 5-391.

$16 \operatorname{COM}(91) 273$ final, Brussels, 5 March 1992

17 Considerations by $\mathrm{Com}(91) 273$ final. 
included with the proposal, in which these legal entities for each Member State were listed. In general, it concerned associations which had been formed in the respective countries in accordance with the national rules. The proposal formulated rules with regard to the internal organisation of such EAs. It also stated that EAs were to have legal personality. ${ }^{18}$ This would mean that such a European association would always pass the test of "legal person" in Article 230 EC Treaty. However, an important disadvantage of the proposal was that it complicated the legal systems of all Member States. Each EA was to be governed by two legal systems: Community law and the law of the Member State in which it was established. Each Member State had to create legislation for EAs which were established on its territory. ${ }^{19}$ Probably for these reasons the proposal has never been adopted.

So since there is no uniform statute for European associations like the European social partners' organisations are, we have to see whether the criteria as formulated by the ECJ so far, can be applied on them.

\subsubsection{Application of the ECJ case law to the European social partners' organisations}

Can the criteria of the ECJ be applied to the European social partners organisations? The answer to this question depends, I believe, on the particular organisation at stake. When an organisation is independent and responsible is still not clear. With regard to the representativity, the ECJ just states in the Syndicat Général du Personnel case that the organisation in question organises a substantial number of the people it represents. In the UEAPME case, the CFI did not really give a definition of representativity either. So this criterion also remains rather vague. The only clear criteria which can de derived from the case law so far are the involvement in the formulation of Commission decisions and the fact that Community law gives certain private parties a well-defined legal position. These criteria were used in the Syndicat Général du Personnel case, as well as in the Groupement des Agences de Voyage -case and the Fediol case. Applying them to the European social partners, one could say that all organisations consulted by the Commission on the basis of Article 138(2) and (3) EC Treaty, should also have the right to institute proceedings on the basis of Article 230 EC Treaty. That is to say, their admissibility should not be blocked because of the fact that they lack legal personality (like the ETUC and UNICE). They still have, however, to fulfill the other conditions laid down in Article 230, 4 th sentence, EC Treaty.

18 Article 2 of $\operatorname{COM}(91) 273$ final.

19 See W.C.L van der Grinten, Europese verenigingen? In: Stichting \& Vereniging, vol. 7 , no. 6, 1992, p. 145 and H.L. Kaemingk, IPR aspecten van Europese rechtspersonen. In: AA, vol. 42 , no. $7 / 8,1993$, p. 521 and further. 


\subsubsection{The nature of the contested measure}

The nature of the contested measure is important for the question whether the European social partners' organsations can attack Council decisions taken on the basis of Article 139(2) EC Treaty. According to Article 230(4) EC Treaty, only Decisions may be attacked by natural or legal persons. There is substantial case law of the ECJ and CFI on the concept of "Decision" and on the question whether other measures than Decisions can be attacked. We shall see that the last question is narrowly related to the concepts of "direct and individual concern". These concepts are mentioned in Article 230(4) EC Treaty. Also on these concepts, there are a great number of cases. The question which type of Community measures can be attacked is important for the European social partners' organisations. In Chapter 7, it was argued that the term "Council decision" in Article 139(2) EC Treaty can mean more than "Decision" in the sense of Article 249, fourth sentence EC Treaty. It can also comprise a Regulation or a Directive. As a matter of fact all European collective agreements which have been turned into Community legislation have taken the form of a Directive. It is therefore important to know whether and when the ECJ/CFI have allowed claims against other measures that Decisions. Therefore, the evolution of this case law will be prescribed. Since the concepts of "direct and individual concern" are narrowly related to the question whether other measures than Decisions can be legally attacked, the case law on these concepts will also be prescribed. Also in this case law there is a certain evolution. Therefore, it will not be enough to discuss the general case law on the nature of the contested measure too briefly. Only if we understand the evolution of the views of the ECJ/CFI, which is reflected in the case law, it can be determined whether claims of the European social partners' organisations against certain decisions of the Commission and Council will be succesful.

I will first give a general overview of the case law with regard to the Decision concept (para. 8.2.2.1.). Then, the question whether other measures can be attacked as well will be answered in para. 8.2.2.2. The concepts of direct and individually concern will be discussed in para. 8.2.2.3. Finally, in para. 8.2.2.4. some conclusions will be drawn.

\subsubsection{The Decision-concept}

Article 249 EC Treaty states that a Decision shall be binding in its entirety upon those to whom it is addressed. Decisions are the means by which Community law is applied in specific cases. ${ }^{20}$ The case law of the ECJ has frequently dealt with the problem of how to distinguish a Decision from nonbinding communications, opinions or recommendations. A decisive point is 
the ECJs definition of a Decision in the Compagnie des Forges de Châtillon case, ${ }^{21}$ as:

"a measure emanating from the competent authority, intended to produce legal effects and constituting the culmination of a procedure within that authority, whereby the latter gives its final ruling in a form from which its nature can be identified." ${ }^{22}$

The judgements relating to whether these conditions have been met is strongly casuistic in nature and it appears that the ECJ is heavily influenced by the importance which a positive or negative answer may have for the legal protection of private parties. ${ }^{23}$ While a Decision is distinguished from mere communications, opinions and recommendations by its binding character, it differs from a Regulation by its individual character. ${ }^{24}$ If a specific provision applies in a general manner to an abstractly defined category of persons, the members of which can change over time, this specific provision is a Regulation, ${ }^{25}$ whereas if the provision only applies to named or individually identifiable persons, it is a Decision in substance. ${ }^{26}$ The ECJ considers the limitation of the persons to whom the decision is addressed as a characteristic feature; it applies to a limited number of specified or identifiable natural or legal persons. ${ }^{27}$ Although this does not appear to be prescribed as a formal requirement in the legal definition, as a rule a Decision will be recognisable by the fact that it mentions by name the persons to whom it "is addressed". If this is not the case, the identifiability of the persons bound when a Decision is taken will usually be sufficient to qualify it as a Decision. ${ }^{28}$ Furthermore, where the ECJ finds that the purpose of the measure is general, it is irrelevant that there are identifiable persons affected by the

21 Case 54/65, Judgment of 16/06/1966, Forges de Chatillon (Rec.1966,p.265).

22 Case 54/65, at 195.

23 P.J.G. Kapteyn and P. VerLoren van Themaat, Introduction to the law of the EC, p. 333.

24 P.J.G. Kapteyn and P. VerLoren van Themaat, Introduction to the law of the EC, p. 334.

25 See for example Case 242/81, Judgment of 30/09/1982, Roquette Frères/Council (Rec.1982,p.3213).

26 M. Nettesheim, Article 173 of the EC Treaty and Regulations: towards the development of uniform standing requirements. In: H.W. Micklitz and N. Reich, Public Interest Litigation before European courts, Baden-Baden, 1996, p. 227. See also Cases 16/62 and 17/62, Judgment of 14/12/1962, Confédération nationale des producteurs de fruits and legumes and others/Council EEC (Rec.1962,p.901), 16/62, Order of 24/10/ 1962, Confédération nationale des producteurs de fruits and legumes and others/ Council EEC (Rec.1962,p.937), Case 64/69, Judgment of 16/04/1970, Compagnie française commerciale and financière/Commission (Rec.1970,p.221, and Case 45/81,

28 P.J.G. Kapteyn and P. VerLoren van Themaat, Introduction to the law of the EC, p. 335. 
measure. ${ }^{29}$ There are a few exceptions to this approach, namely where the ECJ has been influenced by the fact that those affected by the measure were very few in number. ${ }^{30}$

The most important feature of a Decision is that it produces legal effects. When is this the case?

In the Borromeo case ${ }^{31}$ and the Chevally case, ${ }^{32}$ the ECJ said that if private parties just ask the advice of the Commission on the course of conduct to be followed in the event of conflict between their national legislation and certain provisions of Community law, such an advice cannot produce legal effects and does not therefore constitute a Decision. ${ }^{33}$

In the IBM case, ${ }^{34}$ IBM regarded a letter in which the Commission informed IBM that it was about to take a decision concerning infringements of Article 82 EC Treaty. The ECJ stated:

"(...) it is clear from the case law that in principle an act is open to review only if it is a measure definitively laying down the position of the Commission or the Council on the conclusion of the procedure, and not a provisional measure intended to pave the way for the final decision. ${ }^{135}$

The ECJ therefore declared IBM inadmissible. Also in the Dysan Magnetics and Review Magnetics case, ${ }^{36}$ a Commission decision to initiate proceedings was attacked. The CFI declared the action inadmissible on the same grounds as in the IBM case. It added furthermore that although the Commission is the institution that is responsible for carrying out anti-dumping investigations and deciding whether or not to start proceedings.

29 Cases 789/79 and 790/79, Judgment of 17/06/1980, Calpak/Commission (Rec.1980, p.1949), Cons. 9.

30 Case 41-44/70, Judgment of 13/05/1971, International Fruit Company and others/ Commission (Rec.197-1,p.411), Case 100/74, Judgment of 18/11/1975, CAM SA/ Commission (Rec.1975,p.1393), Case 100/74, Order of 12/05/1975, CAM SA/ Commission and Council (Rec.1975,p.1417),Case 113/77, Judgment of 29/03/ 1979, NTN Toyo Bearing/Council (Rec.1979,p.1185), Case 113/77, Order of 14/10/1977, NTN Toyo Bearing/Council (Rec.1977,p.1721), Case 239/82 and Case 275/82, Judgment of 21/02/1984, Allied Corporation and others/Commission (Rec.1984, p.1005), See also R. Greaves, The nature and binding effect of Decisions under Article $189 \mathrm{EC}$. In: European Law Review, vol. 21, no. 1, 1996, p. 7-8.

31 Case 6/70, Judgment of 15/07/1970, Borromeo/Commission (Rec.1970,p.815).

32 Case 15/70, Judgment of 18/11/1970, Chevalley/Commission (Rec.1970,p.975).

33 Cons. 6 in Case $6 / 70$ and cons. 10 in Case $15 / 70$.

34 Case 60/81, udgment of 11/11/1981, IBM/Commission (Rec.1981,p.2639).

35 Cons. 10 in Case $60 / 81$.

36 Case T-134/95, Order of 14/03/1996, Dysan Magnetics and Review Magnetics/Commission. 
"The final decision however, is a matter for the Council; it may refrain from taking any decision if it disagrees with the Commission, or else take a decision on the basis of the Commission's proposals.

The Commission's role forms an integral part of the Council's decision making process.

(...) the initiation of anti-dumping procedures is not capable of immediately and irreversibly affecting the legal position of the undertakings concerned. (...) initiation of proceedings does not automatically entail the imposition of anti-dumping duties; the proceedings may be terminated without measures being imposed." ${ }^{37}$

In the UK case, ${ }^{38}$ an act of the Commission was attacked as being a Decision. The act was one where the Commission took into account the nationality of firms in drawing up lists of candidates for service contracts concluded within the framework of the Second ACP-EEC Lomé Convention. The Commission was authorised to compile, for the purposes of the award of service contracts, a list of selected candidates 'selected according to criteria guaranteeing their qualifications, experience and independence and taking into account their availability for the proposed undertaking'. The Commission had applied internal instructions for the purposes of compiling the list in question. The EC] stated:

"It appears from the documents before the Court that in this case the contested act reflects the intention of the Commission (...) to follow a particular line of conduct with regard to the establishment of restricted lists of candidates for the service contracts in question. However, it is not the announcement of that intention but the drawing-up of the lists themselves which is capable of having legal effects, in so far as it may result in the omission of certain undertakings from those lists and thus deprive them of the possibility of participating in the contracts in question." ${ }^{39}$

In the Sveriges Betodlares Centralförening and Hendrikson case, ${ }^{40}$ the applicants asked the Commission to amend a certain Commission Regulation. The Commission refused this. The applicants subsequently sought the annulment of this refusal, stating that it was a Decision. The CFI said that the refusal to withdraw or amend an act may constitute an act whose legality may be reviewed under Article 230 only if the act which the Community institution refuses to withdraw or amend could itself have been contested under that provision. $^{41}$

37 Cons. 22, 23 and 27 in Case T-134/95.

38 Case 114/86, Judgment of 27/09/1988, United Kingdom/Commission (Rec.1988, p.5289).

39 Cons. 13 in Case 114/86.

40 Case T-5/96, Order of 04/10/1996, Sveriges Betodlares Centralförening and Henrikson/Commission (Rec.1996,p.II-1299).

41 Cons. 28 in Case T-5/96. 
Nor can a purely confirmatory act produce legal effects in so far as the effects result from the act which it confirms. In the Cementir case, ${ }^{42}$ the CFI stated that a letter merely stating the reasons underlying a particular point of a decision cannot constitute a Decision that can be attacked under Article 230 EC Treaty. ${ }^{43}$

\subsubsection{Claims against measures other than Decisions}

The applicant is not only allowed to submit a legal claim against a Decision addressed to him, but also against Decisions that have taken the form of a Regulation which are of direct and individual concern to him, or against Decisions addressed to another person which are of direct and individual concern to him. In the Plaumann case, ${ }^{44}$ the ECJ gave a ruling on the term "another person". This term could, according to the ECJ, encompass a Member State as well as an individual person. ${ }^{45}$ From the text of Article 230 EC Treaty $4^{\text {th }}$ sentence, it is clear that a Regulation which is not a disguised Decision and a Directive cannot be challenged by a private party. Let us take a look at the case law of the ECJ and CFI to see whether these courts take the same view as the Community legislator.

Already in the Alcan case, ${ }^{46}$ the ECJ seemed to consider that the form of the Community measure is not the most important aspect when it comes to the question of admissibility under Article $2304^{\text {th }}$ sentence EC Treaty. The ECJ stated:

"The aim of this provision (i.e. Article $230,4^{\text {th }}$ sentence, E.F.) is to ensure the legal protection of individuals in all cases in which they are directly and individually concerned by a Community measure -in whatever form it appears- which is not addressed to them. ${ }^{147}$

In the IBM case, ${ }^{48}$ the contested measure was, according to the Commission, who was the defendant in this case, a procedural step whereby the Commission only expressed its opinion, which it may later change. Those preparatory steps to a final decision cannot constitute a Decision in the sense of Article 230 EC Treaty. The ECJ said:

"According to the consistent case law of the Court any measure the legal effects of which are binding on, and capable of affecting the interests of,

42 Case T-116/95, Order of 10/06/1998, Cementir/Commission (Rec.1998,p.II-2261).

43 Cons. 19-21 in Case T-116/95.

44 Case 25/62.

45 Cons. 107 in Case 25/62

46 Case 69/69, Judgment of 16/06/1970, Alcan/Commission (Rec.1970,p.385).

47 Cons. 4 in Case 69/69. The contested measure in this case was a Decision of the Commission. 
the applicant by bringing about a distinct change in his legal position is an act or decision which may be subject to an action under Article 173 (now Article 230, E.F.), for a declaration that it is void. However, the form in which such acts or decisions are cast, is in principle, immaterial as regards the question whether they are open to challenge under that article. "N9

The claims of private parties against Regulations are numerous. ${ }^{50}$ According to the words of Article $230,4^{\text {th }}$ sentence EC Treaty is it only possible to submit a legal claim against a Regulation which is in fact a disguised Decision. "Real" Regulations cannot be subject to legal review, at least when the Regulation is being attacked by a private party. The case law takes, however, a different view. The line of approach that started with the Alcan case was continued in the UNICME case. ${ }^{51}$ The contested measure was a Regulation. The EC] said:

"It is unnecessary to consider whether the contested measure may be regarded as a Regulation and it is sufficient to establish whether it is in fact of direct and individual concern to the applicants." ${ }^{52}$

Also in the Sofrimport case, ${ }^{53}$ the contested measure was a Regulation. The question whether the Regulation was in fact a disguised Decision was not

49 Cons. 9 in Case 60/81. The CFI repeated this reasoning in Case T-64/89, Judgment of 10/07/1990, Automec/Commission (Rec.1990,p.II-367) and Case T-3/93, Judgment of 24/03/1994, Air France/Commission (Rec.1994,p.II-121).

50 For example Case C-87/95, Order of 24/04/1996, Cassa nazionale di previdenza ed assistenza a favore degli avvocati e procuratori/Council (Rec.1996,p.I-2003), Case C10/95, Order of 23/11/1995, Asocarne/Council (Rec.1995,p.I-4149), Case T-298/94, Judgment of 07/11/1996, Roquette Frères/Council (Rec.1996,p.II-1531), Case T-482/ 93, Judgment of 10/07/1996, Weber/Commission (Rec.1996,p.II-609), Case 26/86, Judgment of 24/02/1987, Deutz und Geldermann/Council (Rec.1987,p.941) Case C270/95, Order of 28/03/1996, Kik/Council and Commission (Rec.1996,p.I-1987), Case C-209/94, Judgment of 15/02/1996, Buralux and others (Rec.1996,p.I-615), Case C$15 / 91$ and C-108/91, Judgment of 24/11/1992, Buckl and others/Commission (Rec. 1992,p.I-6061), Case C-168/93, Order of 12/07/1993, Gibraltar and Gibraltar Development/Council (Rec.1993,p.I-4009), Case 6/68, Judgment of 11/07/1968, Zuckerfabrik Watenstedt GmbH/Council (Rec.1968,p.595), Case T-480/93, T-183/94, Order of 29/06/1995, Cantina cooperativa fra produttori vitivinicoli di Torre di Mosto and autres/Commission (Rec.1995,p.II-1941), Case C-309/89, Judgment of 18/05/1994, Codorniu/Council (Rec.1994,p.I-1853), Case C-358/89 Judgment of 11/06/1992, Extramet Industrie/Council (Rec.1992,p.I-3813) Case T-14/97 and T-15/97, Order of 25/06/1998, Sofivo and others/Council (Rec.1998,p.II-2601), Case T-18/95, Order of 10/12/1996, Atlanta and Internationale Fruchtimport Gesellschaft Weichert/Commission (Rec.1996,p.II-1669).

51 Case 123/77, Judgment of 16/03/1978, UNICME/Council (Rec.1978,p.845).

52 Cons, 7 in Case $123 / 77$.

53 Case C-152/88, Judgment of $26 / 06 / 90$, Sofrimport SARL/Commission of the European Communities (Rec.1990,p.I-2504). 
even considered by the ECJ. It simply stated that the measure was of direct and individual concern to the applicant. ${ }^{54}$

In the Extramet case, ${ }^{55}$ the ECJ said that a certain measure could be a Regulation, but at the same time also be of individual concern in certain circumstances to certain private persons. These persons could therefore have standing under Article $2304^{\text {th }}$ sentence EC Treaty. ${ }^{56}$

In the Exporteurs in levende Varkens and Others case, ${ }^{57}$ this reasoning was repeated by the CFI. The CFI stated moreover that in such circumstances, a Community measure could be of a legislative nature and, at the same time, in the nature of a decision. ${ }^{58}$ So even if a measure cannot pass the Decision-test, because it is of general application, it can still be subject to the direct and individual concern-test. ${ }^{59}$

And what about Directives? According to Article $230,4^{\text {th }}$ sentence EC Treaty, Directives are excluded from legal review, at least in cases brought by private applicants. In the Fedesa case, ${ }^{60}$ the contested measure was a Directive. This Directive was attacked by an association for the protection of animals. The Council, who was the defendant in this case, stated that Directives are excluded from the ambit of individual actions under Article $2304^{\text {th }}$ sentence EC Treaty. The applicant on the other hand, stated that observance of the principles of law and justice and the rule of law should lead to a broad interpretation of this Article. The ECJ did not go into this argument, but it did not follow the Council's view that Directives can never be pursuant to actions under Article $2304^{\text {th }}$ sentence. It rejected the claim of the association, but not on the ground that the contested measure was a Directive. The claim was rejected because the contested Directive was not of individual concern to the applicant. ${ }^{61}$ This means that the European courts do not a priori exclude the possibility that Directives can be subject to legal attack by individuals. ${ }^{62}$

54 Cons. 8-13 in Case C-152/88.

55 Case C-358/89.

56 Cons. 14. Repeated in Case C-309/89, where this reasoning was applied on a case which was not in the anti-dumping field.

57 Joined Cases T-481/93 and T-484/93, Judgment of 13/12/1995, Vereniging van Exporteurs in Levende Varkens and Nederlandse Bond van Waaghouders van Levend Vee/ Commission (Rec.1995,p.Il-2941),

58 Cons. 50 in Case T-481/93. See also Case T-47/95, Judgment of 09/04/1997, Terres Rouges and others/Commission (Rec.1997,p.II-481), at 43.

59 See also J. Schwarze (ed.), EU-Kommentar, Artikel 230 EGV, point 33.

60 Case 160/88, Order of 13/07/1988, Fédération européenne de la santé animale and others/Council (Rec.1988,p.4121), Case 160/88 Order of 07/12/1988, Fédération européenne de la santé animale and others/Council (Rec.1988,p.6399).

61 Cons. 13 in Case $160 / 88$.

62 See also O. Lenz (ed.), EG-Vertrag Art. 230, point 45. 
In the Gibraltar case, ${ }^{63}$ the contested measure was a particular provision of a Directive, thus not the Directive itself. The Council, who was the defendant, stated that a Directive cannot be subject to proceedings for annulment brought by a private party under Article 230 EC Treaty, thus neither could a certain article of that Directive be attacked on that basis. The ECJ did not go into that argument. It tested the attacked article of the Directive by checking whether that article was of general application, and thus a legislative measure, or whether it could constitute a Decision in the sense of Article 249 EC Treaty. ${ }^{64}$ The ECJ stated that:

"(...) the general application, and thus the legislative nature, of a measure is not called into question by the fact that it is possible to determine more or less precisely the number or even the identity of the persons to whom it applies at any given time, as long as it is established that such application takes effect by virtue of an objective legal or factual situation defined by the measure in question in relation to its purpose. ${ }^{105}$

The ECJ concluded in this case that the attacked article of the Directive could not sustain the test of general application and was thus a measure of the same general nature as the Directive. ${ }^{66}$

In the Asocarne case, ${ }^{67}$ the applicant brought an appeal against an order of the $\mathrm{CFI}^{68}$ before the ECJ. The CFI had declared the applicant inadmissible because the contested measure was a Directive and the CFI concluded, after a test, that this Directive did not constitute a disguised Decision, nor did it contain any specific provision which had the character of an individual decision. ${ }^{69}$ The ECJ followed the CFI. In fact, the same test was done as in the Gibraltar case. It is, however, strange that even after the CFI and ECJ concluded that the Directive at issue could not sustain the test of disguised Decision, and that it did not contain a specific provision which had the character of an individual Decision, they still tested whether the Directive was of individual concern to the applicant. ${ }^{70}$ This seems to indicate that in principle "real" Directives can also be subject to attacks by private parties, when these parties can prove that they are of individual and direct concern to

63 Case C-298/89, Judgment of 29/06/1993, Gibraltar/Council (Rec.1993,p.I-3605).

64 Cons. 15 in Case C-298/89.

65 Cons. 17 in Case C-298/89. See also case 64/69, cons. 11; Case 242/81, Judgment of 30/09/1982, Roquette Frères/Council (Rec.1982,p.3213), cons. 7; Joined Cases 97/86, $193 / 86,99 / 86$ and 215/86, Judgment of 26/04/1988, Asteris/Commission

66 Cons. 23 in Case C-298/89.

67 Case C-10/95 P.

68 Case T-99/94, Order of 20/10/1994, Asocarne/Council (Rec.1994,p.II-871).

69 Cons. 18 in Case T-99/94.

70 See also C. Calliess and M. Ruffert (eds.) Kommentar des Vertrages uber die Europăische Union und des Vertrages zur Gründung der Europarischen Gemeinschaft EUV/EGV-, Artikel 230, point 41. 
them. The ECJ had already suggested in the Fedesa case. The CFI followed the reasoning of the ECJ in the Guna case."

The UEAPME case ${ }^{72}$ is of great importance in this respect. In Chapter $7,,^{73}$ it is indicated that this case is interesting in more than one respect. In Chapter 7 the substantial aspects of the case are discussed. Here, I will discuss the procedural aspects. UEAPME, the European association of small and medium-sized enterprise, submitted a legal claim against the Council, under Article $2304^{\text {th }}$ sentence EC Treaty, challenging a Directive which was adopted under the procedure of Article 139(2) EC Treaty. The attacked Directive on Parental Leave was based on the European Framework Agreement on Parental leave, as concluded between the ETUC, UNICE and CEEP. The Council submitted that the action was inadmissible by reason of the nature of the measure contested (the Directive). In the alternative, the Council stated that the Directive was not of direct and individual concern to UEAPME. ${ }^{74}$ The CFI started by stating that:

"(...) it is clear from the case law of the ECJ that the mere fact that the contested measure is a Directive is not sufficient to render such an action inadmissible."

The CFI refers in this respect to the Gibraltar case and the Asocarne case. The CFI subsequently tested whether the Directive had to be regarded as a Decision in the form of a Directive. It concluded, however, that this was not the case. ${ }^{76}$ Then the CFI continues by stating:

"(...) it is necessary to determine whether, notwithstanding the legislative character of Directive 96/34, the applicant may be regarded as directly and individually concerned by it." 77

The CFI then stated that:

"(...) even a legislative measure which applies to the economic operators concerned in general may, according to the case law, be of individual concern to some of them."

The CFI refers in this respect to the Extramet case and the Codorniu case. These are cases where the ECJ has taken a liberal approach towards Regula-

71 Case T-463/93, Order of 29/10/1993, Guna/Council (Rec.1993,p.II-1205).

72 Case T-135/96, Judgment of 17/06/1998, UEAPME/Council (Rec.1998,p.II-2335), T135/96 Order of 18/03/1997, UEAPME/Council (Rec.1997,p.II-373).

73 Para. 7.4.1.

74 Cons. 24 in Case T-135/96.

75 Cons. 63 in Case T-135/96.

76 Cons. 64-67 in Case T-135/96.

77 Cons. 68 in Case T-135/96.

78 Cons. 69 in Case T-135/96. 
tions which are not disguised Decisions. The CFI is thus now willing to take that same liberal approach towards Directives. The CFI subsequently declares UEAPME not admissible because it is not individually concerned. ${ }^{70}$ It can thus be concluded that the main hurdle for private parties to be admissible are the concepts of direct and individual concern. I will scrutinise these concepts hereafter.

\subsubsection{Direct and individual concern}

\section{Direct concern}

The decision must be of direct concern to the applicant. It is necessary that such a decision be the direct cause of the damage suffered. ${ }^{80}$ In its case law regarding decisions addressed to Member States, the ECJ has often stated that if the Member State, to which the decision was addressed, still enjoyed a degree of discretion, the applicant challenging that decision could not claim to be directly concerned by it. ${ }^{81}$ In the Bock case, ${ }^{82}$ however, the ECJ ruled that even if the Member State addressee enjoyed a certain degree of discretion, a natural or legal person could be directly concerned if the Member State had expressly declared beforehand how the discretion would be used. "B But what if the Member State did not make such an express declaration of intention? In the Piraika-Patraiki case, ${ }^{84}$ the ECJ ruled that even in that case, an applicant could be directly concerned, namely when it is clear in advance how the Member State addressee would use its degree of discretion. ${ }^{85}$ So even if there is not an express declaration from a Member State on how to use the degree of discretion, an applicant can be directly concerned if it can be predicted how the Member State will use its degree of discretion. ${ }^{86}$ When it comes to decisions addressed to private parties, the issue of discretion is not at stake. A private party does not enjoy discretion in the same sense as a Member State does. In the Les Verts case, ${ }^{87}$ the EP enacted a decision whereby it decided to allocate money to political parties that were going to participate in the forthcoming elections. The decision allocated the bulk of funds to parties

79 Cons. 112 in Case T-135/96. The CFI applied the same reasoning in the Salamandercase: Joined Cases T-172/98, T-175/98, T-176/98 and T-177/98, Judgment of 27/06/ 2000, Salamander and others/Parliament and Council (Rec.2000,p.II-2487).

80 A. Albors-Llorens, private parties in European Community law; Challenging Community measures, Oxford, 1996, p. 63.

81 Cases 10/68 and 18/68, Judgment of 10/12/1969, Eridania Zuccherifici and others/ Commission (Rec.1969,p.459), Case 69/69. See Cases 41-44/70, cons. 25 and Case 113/ 77 , cons. 11, where the Member State did not enjoy this discretion and the applicant was therefore considered directly concerned.

82 Case 62/70, Judgment of 23/11/1971, Bock/Commission (Rec.1971,p.897).

83 Cons. 6-8 in Case 62/70.

84 Case 11/82, Judgment of 17/01/1985, Piraiki-Patraiki/Commission (Rec.1985,p.207).

85 Cons. 6-10 in Case 11/82.

86 See also A. Albors-Llorens, private parties in European Community law; Challenging Community measures, p. 69-70.

87 Case 294/83, Judgment of 23/04/1986, Les Verts/Parliament (Rec.1986,p.1339). 
already present, thus discriminating against parties that were newcomers to the elections. A political party belonging to the latter category brought an action against this decision. The ECJ stated:

"It must be pointed out that the contested measures are of direct concern to the applicant's association. They constitute a complete set of rules which are sufficient in themselves and which require no implementing provisions, since the calculation of the share of the approbation to be granted to each of the political groupings concerned is automatic and leaves no room for discretion. ${ }^{88}$

Although, the ECJ also here used the concept of discretion, it is thought that the requirement of direct concern reflects the concern of the Treaty drafters that the Community measure at issue be the direct cause of damage to the interests of the private applicant. Albors-Llorens points out that in the cases concerning competition proceedings, the tests of direct and individual concern were always treated as one, so there was no explicit indication of the criterion followed by the ECJ to determine direct concern. It is clear in that context, she argues, that the issue did not relate to the fact that the addressee enjoyed a degree of discretion but to the existence of a certain negative effect on the interests of the applicants derived from the decision at issue. ${ }^{80}$ Nevertheless, the ECJ maintained its reasoning with regard to the relation between direct concern and the margin of discretion that an institution has when it implements Community rules. In the Dreyfus case, ${ }^{90}$ the ECJ stated, by referring to earlier case law:

"The Court's case law shows that, for a person to be directly concerned by a Community measure, the latter must directly affect the legal situation of the individual and leave no discretion to the addressees of that measure who are entrusted with that task of implementing it, such implementation being purely automatic and resulting from Community rules without the application of other intermediate rules." ${ }^{\prime 91}$

The only other instances in the case law of the decisions addressed to private parties were those involving the award of contracts by the Commission to successful tenderers. In these instances, the issue of admissibility did not arise, given that the Commission always accepted that the applicants had locus standi. ${ }^{92}$

88 Cons. 31 in Case 294/83.

89 A. Albors-Llorens, private parties in European Community law; Challenging Community measures, p. 74, at footnote no. 291.

90 Case C-386/96, Judgment of 05/05/1998, Dreyfus/Commission (Rec.1998,p.1-2309).

91 Cons. 43 in Case C-386/96.

92 See also A. Albors-Llorens, private parties in European Community law; Challenging Community measures, p. 75. 
Most of the case law has been developed on the concept of "individual concern". I will discuss this case law hereafter.

\title{
Individual concern
}

A general definition of individual concern has been given in the Plaumann case. ${ }^{93}$ The ECJ stated:

\begin{abstract}
"Persons other than those to whom a decision is addressed may only claim to be individually concerned if that decision affects them by reason of certain attributes which are peculiar to them or by reason of circumstances in which they are differentiated from all other persons and by virtue of these factors distinguished them individually just as in the case of the person addressed." ${ }^{\prime 94}$
\end{abstract}

The ECJ said in this case that the decision was addressed to the applicant as an importer of clementines, thus by reason of a commercial activity which may be practised at any time and by any person. The applicant was therefore not individually concerned.

In the Bock case, ${ }^{95}$ the ECJ acknowledged that the applicant was individually concerned because he formed part of a closed category and the Commission was in a position to be aware of his existence and the fact that the provision was going to affect him alone. ${ }^{96}$ The important characteristic of a closed category is the fact that nobody may become part of it, after the measure enters into force; in other words, it contains a certain element of retroactivity. ${ }^{97}$

Individual concern is also there if a private party is in one way or another involved in the Community decision-making. In the Metro case, ${ }^{98}$ the applicant (a self-service wholesale trading undertaking), was, on the basis of a Regulation, entitled to request the Commission to find an infringement of the anti-cartel provisions. The ECJ stated that these private persons:

"(...) should be able, if their request is not complied with either wholly or in part, to institute proceedings in order to protect their legitimate inte-

93 Case $25 / 62$.

94 The CFI followed this reasoning in Case T-83/92, Judgment of $28 / 10 / 1993$, Zunis Holding and others/Commission (Rec.1993,p.II-1169).

95 Case $62 / 70$, Cases 41 to $44 / 70$, Case 38/64, Judgment of 01/04/1965, Getreide-Import Gesellschaft/Commission EEC (Rec.1965,p.263), Cases 106/63 and 107/63, Judgment of 01/07/1965, Toepfer/Commission EEC (Rec.1965,p.525), Case 106/63, Order of 25/06/1964, Toepfer/Commission EEC (Rec.1965,p.553), Case 88/76, Judgment of 31/03/1977, Exportation des Sucres/Commission, Case 88/76, Order of 19/10/1976, Exportation des Sucres/Commission (Rec.1976,p.1585).

96 Case $62 / 70$, at 10.

97 A. Albors-Llorens, private parties in European Community law; Challenging Community measures, p. 51 , footnote 140 .

98 Case 26/76, Order of 23/07/1976, Metro/Commission (Rec.1976,p.1353). 
rests. In those circumstances the applicant must be considered to be directly and individually concerned $(. . .)^{\prime \prime} .99$

In the Timex case, ${ }^{100}$ the ECJ refined this reasoning somewhat. The applicant, a manufacturer of mechanical watches, requested the Commission to open an anti-dumping procedure for watches originating in the Soviet Union. Timex was allowed to do this under Regulation no. 3017/79. For determining the individual concern, the ECJ found it necessary to examine the role that Timex played in this procedure. It stated that the fact that the undertaking was at the origin of the complaint which led to the opening of the investigation procedure, the fact that its views were heard during that procedure and the fact that the conduct of the procedure was largely determined by its observations was enough to consider Times individually concerned. ${ }^{101}$

The CFI has followed the ECJ, as regards the participation rights in the decision-making and the concept of individual concern. In the Air France case, ${ }^{102}$ the applicant was asked by the Commission to give his findings on a certain concentration of undertakings. The applicant subsequently informed the Commission of his critical observations. The Commission responded to the applicant that his criticisms would be taken fully into consideration. This was also what eventually happened when the Commission took its decision. The CFI stated that this meant that the applicant was individually concerned by this decision. ${ }^{103}$

In the CCE de Vittel and Others case, ${ }^{104}$ one of the questions was whether the private party should actually make use of his right to take part in a certain procedure, in order to be individually concerned. In Council Regulation no. $4064 / 89$ on the control of concentrations between undertakings, certain private parties, among which the applicant, were specifically mentioned among the third parties showing a sufficient interest to submit their observations to the Commission on certain concentrations of undertakings. The applicant however, had not made use of this right. Nevertheless, he submitted a legal claim against the Commission Decision, based on the Regulation. The Commission stated that since the applicant had not made use of his

99 Cons. 13 in Case 26/76.

100 Case 264/82, Judgment of 20/03/1985, Timex/Council and Commission (Rec.1985, p.849).

101 Cons. 14-16 in Case 64/82. See also Case 191/82, cons. 28 and Case 169/84, Judgment of 28/01/1986, Cofaz/Commission (Rec.1986,p.391), cons. 26.

102 Case T-2/93, Judgment of 19/05/1994, Air France/Commission (Rec.1994,p.II-323), ) Case T-2/93 Order of 08/03/1995, Air France/Commission (Rec.1995,p.II-533) Case T2/93 Order of 17/04/1996, Air France/Commission (Rec.1996,p.II-235).

103 Cons. 44-45 in Case T-2/93.

104 Case T-12/93, Judgment of 27/04/1995, CCE Vittel and others/Commission, Case T12/93, Order of 02/04/1993, CCE Vittel and CE Pierval/Commission (Rec.1993,p.Il449) Case T-12/93 Order of 06/07/1993, CCE Vittel and CE Pierval/Commission (Rec.1993,p.II-785). 
procedural rights, before the Commission took this decision, he could not be regarded individually concerned. ${ }^{105}$ The CFI said:

"An analysis of the case law of the ECJ confirms that the standing to bring proceedings of third parties who show a sufficient interest to be heard during the administrative procedure is not necessarily subject to their taking part in that procedure (...) the ECJ, in matters of competition and state aid as in matters of dumping and subsidies, has taken the participation of specified third parties in the administrative procedure into consideration solely to hold that under certain particular conditions it raises a presumption that their application is admissible, so that the Community judicature can review not only whether the decision adopted following that procedure is vitiated by a manifest error of assessment or a misuse of powers. The ECJ has never held their participation in the procedure to be a necessary condition for acknowledging that the Commission's decision is of individual concern to those third persons.

The mere fact that the Regulation mentions the applicant expressly and specifically among the third persons showing a 'sufficient interest' to submit their observations to the Commission is enough to differentiate them from all other persons and enough for it to be considered that the decision adopted under that Regulation is of individual concern to them, whether or not they have made use of their rights during the administrative procedure." 106

From this case law, it can be derived that especially in economic regulation, special standing requirements have been developed which allow for flexible adjustment of the direct and individual concern criteria. ${ }^{107}$ From the Greenpeace-case, ${ }^{108}$ however, we can learn that this broad approach is not easily followed in other fields. In this case, three associations concerned with the environment, together with a number of individuals, sought the annulment of a Commission decision granting Spain financial assistance towards the construction of two electric power stations in the Canary Islands. The applicant specifically asked the CFI to take a liberal approach on the question of admissibility. They asked the CFI to recognise that their locus standi can depend not only on a purely economic interest, but also on the interest in the protection of the environment. This went against the approach adopted in the past in cases concerning purely economic interests. ${ }^{109}$ The CFI stated that the Plaumann criteria remained applicable, whatever the nature, economic or

105 Cons. 15 in Case T-12/93.

106 Cons. 47-48 in Case T-12/93. The ECJ had already taken this view in earlier cases. See Case $191 / 82$, cons. 28 and Case 264/82, cons. 12-16.

107 See also N. Reich, Public interest litigation before European jurisdictions. In: H.W. Micklitz and N. Reich, Public Interest Litigation before European courts, p.11.

108 Case T-585/93, Order of 09/08/1995, Greenpeace and others/Commission (Rec.1995, p.II-2205).

109 Cons. 32 in Case T-585/93. 
otherwise of those of the applicant's interests which are affected. ${ }^{110}$ The CFI concluded that the applicant were not individually concerned. ${ }^{111}$ From this case we can also learn that not any intervention in the procedure leading to the adoption of a Community measure is sufficient to conclude individual concern. This is for example not the case if a private party sends letters to the competent Community institution, criticising a measure which that institution has already adopted and seeking to influence its future action. ${ }^{112}$

In the UEAPME case, mentioned earlier, ${ }^{113}$ the concept of individual concern was broadened by the CFI. Although the main issue at stake was the issue of representativity, ${ }^{\prime \prime 4}$ from a legal-technical point of view UEAPME could do nothing other than to ask the CFI to test the Directive of Parental Leave against the EC Treaty. As regards the material aspects, UEAPME requested the CFI primarily to annul the Directive, or, alternatively, to annul it with respect solely to its application to the small and medium-sized undertakings referred to in Art. 137(2) EC Treaty. ${ }^{115}$ It was clear, however, that the UEAPME case would have as its main hurdle the problem of admissibility, which had to be judged on the basis of the text of Art. 230 EC Treaty. ${ }^{116}$

UEAPME meant that it had a legal right to participate in the negotiations leading to the European Framework Agreement on Parental Leave. This agreement had been turned into a Council Directive on the basis of Article 139(2) EC Treaty. UEAPME stated that because of the fact that it had been consulted by the Commission on the basis of Article 138(2) and (3) EC Treaty, it also had the right to participate in the negotiations on the agreement. ${ }^{117}$ Furthermore, it stated that because it was the most important representative of medium-sized and small enterprises, it had the right to participate in the negotiations, because Article 137(2) EC Treaty foresees a special protection

110 Cons. 50 in Case T-585/93.

111 Cons. 51-55 in Case T-585/93.

112 Cons. 56 in Case T-585/93, The ruling of the CFI has been confirmed on appeal by the ECJ. See Case C-391/95, Judgment of 17/11/1998, Van Uden Maritime/Kommanditgesellschaft in Firma Deco-Line and others (Rec.1998,p.I-7091). See also the Cases T$481 / 93$ to $\mathrm{T}-484 / 93$, cons. 59.

113 Para. 8.2.2.2.

114 UEAPME argued: "During the initial consultations with management and labour, in accordance with Article 3(2) of the Agreement, the applicant was (...) consulted, together with other organisations. It was, by contrast, systematically excluded from the negotiations, which led to the adoption of the measure, even though it had on several occasions expressed the wish to be included and given reasons why it should be." See OJ C 318/21, 26-10-1996.

115 In the Amsterdam Treaty this is Art. 118(2) and in the consolidated version it is Art. $137(2)$.

116 Also Schmidt has discussed the admissibility of UEAPME in this case See M. Schmidt, Parental Leave: Contested Procedure, Creditable Results. In: IJCLLIR, vol. 13, no. 2 , 1997, p. 123-124. See also R. Blanpain and C. Engels, European Labour Law, p. 101. 
for SME's. ${ }^{\text {Is }}$ Because the ETUC, UNICE and CEEP negotiated the agreement among themselves, excluding UEAPME, the last mentioned submitted a claim against the Council Directive. UEAPME claimed, among other matters, that, because of its right to participate in the procedure leading to the European agreement, it was individually concerned. UEAPME refers hereby to the CCE de Vittel and Others case. ${ }^{119}$ The CFI stated:
“(...) Article 3(2), (3) and (4) and Article 4 of the Agreement (now Article 138(2), (3) and (4) and Article 139 EC Treaty, E.F.), do not confer on any representative of management and labour, whatever the interests purpor- tedly represented, a general right to take part in any negotiations entered into in accordance with Article 3(4) of the Agreement (now Article 138(4) EC Treaty), even though it is open to any representative of management and labour which has been consulted pursuant to Article 3(2) and (3) of the Agreement to initiate such negotiations. ${ }^{120}$

With regard to the protection for SMEs, the CFI states:

\begin{abstract}
“Article 137(2) EC Treaty does not provide that representatives of SMEs are automatically entitled to participate in any negotiations entered into by management and labour pursuant to Article 138(4) EC Treaty." ${ }^{121}$
\end{abstract}

But that is not the end of the story. UEAPME had asked the CFI to assess its admissibility in the light of the specific nature of the contested Directive. After all it was a Directive whose content was determined by the social partners and not by the Community institutions. ${ }^{122}$ The CFI did indeed meet this request of UEAPME:
"In view of the particular features of the procedure which led to the adoption of Directive 96/34 on the basis of Article 139(2) EC Treaty, it is also necessary to determine whether any right of the applicant has been infringed as the result of any failure on the part of either the Council or the Commission to fulfill their obligations under that procedure (...)." ${ }^{123}$

The words "that procedure" seem to refer to the procedure mentioned in Article 139(2) EC Treaty, since that Article is mentioned in the same sentence of the CFI. Thus the CFI says nothing about the consultation procedure, mentioned in Article 138(2) and (3) EC Treaty.

\footnotetext{
118 Cons. 51 in Case T-135/96.

119 Cons. 50-52 in Case T-135/96.

120 Cons. 79 in Case T-135/96.

121 Cons. 80 in Case T-135/96.

122 Cons. 44 in Case T-135/96.

123 Cons. 83 in Case T-135/96.
} 
The CFI subsequently said what the obligations of the Council and Commission were under the procedure of Article 139(2) EC Treaty. According to the CFI, the Commission must in particular check whether the signatory parties were sufficiently representative. ${ }^{124}$ The Council, for its part, is required to verify whether the Commission has fulfilled its obligations under the Treaty, because, if that is not the case, the Council runs the risk of ratifying a procedural irregularity capable of vitiating the measure ultimately adopted by it. ${ }^{125}$ The CFI then explained that representative organisations could fulfill the requirement of direct and individual concern:

"(...) the representatives of management and labour which were consulted by the Commission in accordance with Article 138(2) and (3) EC Treaty, but which were not parties to the agreement, and whose particular representation again in relation to the content of the agreement, is necessary in order to raise the collective representativity of the signatory parties to the required level, have the right to prevent the Commission and the Council from implementing the agreement at the Community level by means of a legislative instrument. The judicial protection to which the existence of such a right gives rise implies that, were non-signatory representatives with those characteristics bring an action for annulment of the Council measure giving effect to the agreement at Community level on the basis of Article 139(2) EC Treaty, they must be regarded as directly and individually concerned by that measure. ${ }^{126}$

The CFI considered that in the first place, the Commission and Council indeed have verified the representativity of the signatory parties. ${ }^{127}$ Subsequently the CFI also concluded that the Commission and Councils examination of the representativity satisfied the requirements in that respect. ${ }^{128}$ The conclusion of the CFI was that UEAPME is not representative enough to state that its absence in the negotiations on the parental leave agreement resulted in a lack of representativity of the agreement itself. Thus, according to the CFI, UEAPME cannot be regarded directly and individually affected and thus UEAPME is non-admissible on the basis of Article 230(4) EC Treaty. ${ }^{129} \mathrm{~A}$

124 Cons. 85 in Case T-135/96. See also Chapter 7, para. 7.4.1. on this point.

125 Cons. 87 in Case T-135/96.

126 Cons. 90 in Case T-135/96.

127 Consideration 91 in Case T-135/96.

128 Considerations 93 and 110 in Case T-135/96.

129 Considerations 93 and 110 in Case T-135/96. The problem of UEAPME has been solved in a very pragmatic way. On 12 November 1998, the presidents of UNICE and UEAPME decided to promote closer cooperation between their organisations. (Bulletin Quotidien Europe, no. 7342, 14 November 1998, p. 16.) They have therefore signed an agreement. They agreed that all employer representatives will have the same rights in preparatory meetings. UNICE has undertaken to consult UEAPME before expressing positions on behalf of employers (Bulletin Quotidien Europe, no. 7358, 7/8 December 1998, p. 16.) So claims of UEAPME on lack of representativity of an agreement which has been signed by UNICE, will no longer be submitted. The problem is not however yet solved. Other organisations will come with their complaints and one way 
revolutionary judgement has been given by the CFI in the beginning of May in the Jégo-Quéré case. ${ }^{130}$ Jégo-Quéré et Cie S.A. is a French fishing company operating on a regular basis in the waters south of Ireland. It owns four fishing boats over 30 metres in length and uses nets having a mesh of $80 \mathrm{~mm}$, which have been banned by a new Community regulation. It applied to the CFI for annulment of two provisions of the regulation in question, which require fishing vessels operating in certain defined zones to use nets having a minimum mesh for beam trawling. The Commission argued that CFI should declare the action inadmissible. According to the EC Treaty, "Any natural or legal person may (...) institute proceedings against a decision addressed to that person or against a decision which, although in the form of a regulation or a decision addressed to another person, is of direct and individual concern to the former". Whilst not denying that the contested provisions are of direct concern to Jégo-Quéré, it claimed that the applicant is not individually concerned, inasmuch as the rules governing mesh sizes apply equally to all operators fishing in the Celtic Sea and not just to that operator.

The CFI finds that the effect of that case-law is to prevent many individuals from challenging measures of general application which directly affect their legal position. The Court considers in that regard that none of the other possible procedural routes constitutes a suitable vehicle for challenging the legality of a Community measure. It is unacceptable that, where no implementing measures exist at national level in respect of which an action may be brought before the national courts, an individual should be forced knowingly to infringe Community law in order to gain access to a national court and thereby, as the case may be, to procure a reference to the ECJ for a preliminary ruling on the point at issue. The CFI points out that, according to the case-law of the ECJ, access to the courts is one of the fundamental elements of a community based on the rule of law, as guaranteed by the legal order based on the EC Treaty, which has established a complete system of legal remedies and procedures designed to permit the ECJ to review the legality of measures adopted by the institutions. The Court of Justice has held that the right to an effective remedy before a court of competent jurisdiction is based on the constitutional traditions common to the Member States and on the European Convention for the Protection of Human Rights and Fundamental Freedoms. That right is reaffirmed by Article 47 of the Charter of fundamental rights of the European Union, proclaimed in Nice on 7 December 2000. The CFI therefore rules that, in order for individuals to be properly protected by the courts, a natural or legal person is to be regarded as individually concerned by a Community measure of general application that concerns him directly, if the measure in question affects his legal position, in a manner which is both definite and immediate, by restricting his rights or by imposing obligations on him. The number and the position of

or another, there has to be means to give them legal redress.

130 Case T-177/01, Jégo-Quéré et Ciev. Commission, judgement of the CFI of 3 May 2002. 
other persons who are likewise affected by the measure, or who may be so, are of no relevance in that regard. In the present case, the contested provisions undoubtedly impose obligations on Jégo-Quéré, requiring it to use in its fishing operations nets of a particular mesh size. It is therefore both individually and directly concerned by the contested provisions. Consequently, the objection of inadmissibility raised by the Commission must be dismissed.

In a press release the CFI says it is aware of the need to ensure effective protection of the legal rights of European citizens and businesses and redefines the rules governing individual access to the Community courts. The concept of individual concern should no longer be interpreted in a way that limits the right of individuals to challenge Community regulations to exceptional cases, it argues. The CFI recognised that under the existing case law of the Community courts, the applicants action would have to be dismissed but ruled that this was unsatisfactionary in that it prevents many individuals and businesses, in situations similar to that of the applicant, from challenging measures of general application which directly affect their legal position. ${ }^{131}$ The CFI took on board part of the conclusion of the A-G Francis Jacobs in a case involving the "Union of Pequeños Agricultores" currently before the ECJ. Jacobs proposed in his opinion on this case a new definition of what could be an individual or company concerned "individually" by a Community measure: an applicant is individually concerned by a Community measure where the measure has, or is liable to have, a substantial effect on his interests. The CFI used a unusual procedure that consists in using the conclusions of an A-G of the ECJ in a case on which the ECJ has not yet ruled. It remains to be seen if the ECJ will consider that the time has come to broaden its case law and if so, to what extent. ${ }^{132}$ In the Jégo-Quéré case an appeal may be brought before the ECJ against the decision of the CFI. Whether the Commission will do this remains to be seen.

Another relevant question relevant on this aspect is whether and when associations have standing in the course of proceedings based on Article 230, $4^{\text {th }}$ sentence EC Treaty. The main question of this Chapter is, after all, on the access of European social partners' organisations to the CFI and ECJ. In the Confédération nationale des producteurs des fruits et légumes case, ${ }^{133}$ the $\mathrm{ECJ}$ stated:

"(...) one cannot accept the principle that an association, in its capacity as the representative of a category of businessmen (an association representing fruit producers), could be individually concerned by a measure affecting the general interests of that category $(. . .)^{\prime \prime 134}$

131 Bulletin Quotidien Europe no. 8206, 6 \& 7 May 2002

132 Bulletin Quotidien Europe no. 8209, 11 May 2002.

133 Cases 16 and $17 / 62$.

134 Cons. 477 in Case 16 and $17 / 62$. 
In that ruling it is not clear whether the ECJ rejected the action's admissibility because of an absence of individual concern with regard to the association and its members, or because the Regulation was not in reality a decision. ${ }^{135}$ There are in fact three circumstances in which associations are admissible under Article 230 EC Treaty. The first circumstance is when it is the addressee of the contested measure. This was for example the case in the Groupement des Agences de Voyages case. ${ }^{136}$ The Commission had invited this association to respond to a tender, it was subsequently allowed by the Commission to take part in the invitation to tender, but its tender was subsequently rejected, because the Commission accepted the tender of another association. The Groupement des Agences de Voyages submitted a legal claim against this Commission decision to accept the tender of the other association. The ECJ said:

\begin{abstract}
"The contested decision may (...) be regarded as having caused 'direct and individual' injury to the association constituted by the ten agencies (i.e. the Groupement des Agences de Voyages E.F.), since if the association could submit a tender (...) it obviously had an interest in having its tender accepted." 137
\end{abstract}

The second circumstance is where the association, by bringing its action, has substituted itself for one or more of the members whom it represents, on condition that those members where themselves in a position to bring an admissible action. This occurred for example in the AITEC case. ${ }^{138}$ The association AITEC (an Italian cement producers' association), sought the annulment of a Commission decision, acting on behalf of the individual interests of certain of its members, while at the same time attempting to protect those of the sector as a whole. The CFI stated:

“(...) the applicant, in bringing its action, may be regarded as having substituted itself for at least three of its members who could themselves

(...) have brought an admissible action." ${ }^{139}$

The CFI thus considered AITEC individually concerned. ${ }^{140}$ It can be argued that, even if individual workers and/or employers were to have standing under Article 230 EC Treaty, $4^{\text {th }}$ sentence, it would nevertheless be recommendable to act through a representative body such as a union or employers'

135 See also N. Reich, Public interest litigation before European jurisdictions. In: H.W. Micklitz and N. Reich, Public Interest Litigation before European courts, p. 14.

136 Case 135/81.

137 Cons. 13.

138 Cases T-447/93, T-448/93, and T-449/93, Judgment of 06/07/1995, AITEC and others/Commission (Rec.1995,p.II-1971), T-447/93 Order of 28/11/1996, AITEC/ Commission (Rec.1996,p.II-1631).

139 Cons. 60 in Cases T-447 to $449 / 93$.

140 Cons. 62 in Cases T-447 to $449 / 93$. 
association. Such a body is more likely to have comprehensive and up-todate information and statistics. Conferring standing on a representative body may also promote the efficient conduct of litigation by allowing a series of disputes which raise similar issues to be resolved in one set of proceedings. Some of these advantages were recognised in the AITEC case by the CFI. ${ }^{141}$

The third circumstance occurs where the association has played a role in a procedure which led to the adoption of an act within the meaning of Article 230. This was for example the case in the Van der Kooy and Others case. ${ }^{142}$ The Landbouwschap, a Dutch body governed by public law, submitted a legal claim against the Commission decision no. $85 / 215$, on the preferential tariff charged to glasshouse growers for natural gas in The Netherlands. The ECJ said:

\begin{abstract}
"Although the Landbouwschap cannot be considered directly and individually concerned by Decision $85 / 215$ as a recipient of the contested aid, it is nonetheless true that, as the Landbouwschap rightly argues, its position as negotiator of gas tariffs in the interests of the growers is affected by Decision 85/215.

Furthermore, in that capacity the Landbouwschap has taken an active part in the procedure under Article $88(2)$ by submitting written comments to the Commission and by keeping in close contact with the responsible officials throughout the procedure.

Lastly, the Landbouwschap is one of the parties to the contract which established the tariff disallowed by the Commission, and in that capacity is mentioned several times in Decision 85/215." ${ }^{143}$
\end{abstract}

\title{
8.2.2.4. Conclusions
}

The most important feature of a Decision addressed to a private party is that it produces legal effects. A non-binding advice does not produce these legal effects. Neither are preparatory steps leading to the final decision a Decision in the sense of Article 230, $4^{\text {th }}$ sentence EC Treaty. This is also true for the announcement that proceedings will be started against a private party, without it being certain that this proceedings will lead to the imposition of measures. Purely confirmatory acts also cannot produce legal effects. Furthermore, an important feature of a Decision is that it applies to a limited number of specified or identifiable natural or legal persons. This is different where the purpose of the measure is general. In such a case it is not relevant

141 Cons. 51 in Cases T-447/93 to T-449/93, See also A. Arnull, Challenging Community acts - An introduction. In: H.W. Micklitz and N. Reich, Public Interest Litigation before European courts, p. 54.

142 Case $67 / 68$ and $70 / 85$, Judgment of $02 / 02 / 1988$, Van der Kooy and others/Commission (Rec.1998,p.219).

143 Cons. 21-23. See also Case C-313/90, Judgment of 24/03/1993, CIRFS and others/ Commission (Rec.1993,p.I-1125), cons. 29-30. 
whether there are identifiable persons affected. This rule has only a few exceptions. There are Decisions that apply law and Decisions that make law. Although Article $2304^{\text {th }}$ sentence EC Treaty only permits actions against Decisions, there have been claims against other measures such as Regulations and even Directives. The ECJ and CFI seem in principle willing to grant standing in these cases, but only if the contested measure is of direct and individual concern to the applicant. A Community measure is of direct concern if it immediately affects the legal position of the applicant, i.e. without further implementation measures being necessary or possible. Also when it is clear in advance which implementation measures will be used, the Community measure is of direct concern. The general definition of individual concern has been given in the Plaumann case. Important elements are that the Decision affects the applicant by reason of certain attributes which are peculiar to them or by reason of circumstances in which the applicant is differentiated from all other persons. Individual concern can occur when the applicant forms part of a closed category. Individual concern is also there when a private party is in one way or another involved in the Community decision making, even if the applicant does not make use of his right to take part in that decision making. This does however not mean that every intervention in the procedure leading to the adoption of a Community measure is sufficient to conclude individual concern. When it comes to Community measures whose content is being determined by the European social partners' organisations, the CFI is willing to broaden the concepts of direct and individual concern, because of the specific nature of the contested Community measure. The CFI is willing to accept direct and individual concern, if there is any failure on the part of either the Council or the Commission to fulfill their obligations under the procedure leading to the adoption of the Community measure. This procedure is prescribed in Article 139(2) EC Treaty. Associations are admissible under Article $2304^{\text {th }}$ sentence EC Treaty if they are either the addressee of the contested measure, or if they have substituted themselves for one or more of the members they represent on the condition that these members themselves would be admissible, or finally when they have played a role in the procedure leading to the adoption of the contested act.

\subsubsection{The nature of the contested measures applied to Commission decisions}

Now that we have an idea of the general case law on the Decision-concept and the concept of direct and individual concern, it is time to see whether these concepts can be applied in legal claims from European social partners' organisations against the Commission. It is clear that, being natural or legal persons, the social partners have only Article 230, $4^{\text {th }}$ sentence EC Treaty at their disposal to seek the annulment of certain Commission decisions. In para. 8.2.3.1. I will discuss whether the decision of the Commission to 
grant/refuse support to certain organisations is legally reviewable. In para. 8.2.3.2. the legal review of the Commission decision to consult certain organisations on the basis of Article 138(2) and (3) EC Treaty will be discussed. In para. 8.2.3.3. it will be discussed whether the Commission decision to formulate or not formulate a legislative proposal can be legally reviewed In para. 8.2.3.4. some conclusions will be drawn.

\subsubsection{The support for the European social partners' organisations}

In Chapter 4, ${ }^{144}$ I have explained that the Commission gives several kinds of support to the European social partners, on the basis of the budget headings for "industrial relations and social dialogue" and for "information and training measures for workers' organisations". Social partners' organisations can submit proposals for financial aid to the Commission, which will be considered by the last-mentioned on the basis of certain award criteria.

Article 138(1) EC Treaty prescribes that Commission support shall be balanced. The Treaty does however not explain what is meant by the word "balanced" and what is meant by "support". When it comes to financial support, however, the Commission is in any case bound to the budget. Article 268 EC Treaty states that all items of revenue and expenditure of the Community shall be included in estimates to be drawn up for each financial year and shall be shown in the budget. This budget is adopted in cooperation with the Council and the EP. ${ }^{145}$ This means that the Council and the EP can influence the amount of support given to the social partners. The question is, however, whether a European social partners' organisation can submit a legal claim against the Commission when it has not received any financial support or has received less support than other organisations. Perhaps an answer can be found in the Les Verts case. ${ }^{146}$

In the Les Verts case, a political party for the EP, the Parti écologiste Les Verts requested the $\mathrm{ECJ}$ to declare void:

- a decision of the bureau of the EP concerning the allocation of appropriations entered under the general budget of the EC and

- a decision of the enlarged bureau of the EP adopting rules governing the use of appropriations for reimbursement of expenditure incurred by political groupings having taken part in the 1984 European elections.

Those rules specified the basis on which the money was allocated for support of political groupings which wanted to take part in the elections for the EP. The Parti écologiste Les Verts attacked these rules, since it could not fulfill the requirements of the rules. One of the questions was whether the rules were measures intended to produce legal effects. The ECJ stated:

144 Para. 4.2.

145 Article 272 EC Treaty.

146 Case 294/83. 
"The two contested measures both concern the allocation of the appropriations entered into the budget of the EP to cover the cost of preparations for the 1984 European elections. They deal with the allocation of those appropriations to third parties for expenses relating to activities to take place outside the EP. In that regard they govern the rights and obligations both of political groupings which were already presented in the $\mathrm{EP}$ in 1979 and of those which were to take part in the 1984 elections. They determine the proportion of the appropriations to be received by each of the groupings, either on the basis of a number of seats obtained in 1979 or on the basis of the number of votes obtained in 1984. For that reason, the measures in question were designed to produce legal effects vis-à-vis third parties and may therefore be the subject of an action under Article 173 (now 230, E.F.) EC Treaty." ${ }^{\prime 47}$

The ECJ also said something in relation to the budget. It stated:

"The argument that the Court of Auditors' power of review under Article 206A (now repealed, E.F.) of the Treaty precludes any review by the EC] must be rejected. The Court of Auditors only has power to examine the legality of expenditure with reference to the budget and the secondary provision on which the expenditure is based (commonly called 'the basic measure'). Its review is thus in any event distinct from that exercised by the ECJ, which concerns the legality of the basic measure. The measures contested in this case are in reality the equivalent of a basic measure, inasmuch as they provide in principle for the expenditure and lay down the detailed rules according to which the expenditure is being effected." 148

The decision to grant financial support to a certain organisations was thus regarded as a Decision addressed to those organisations. But what about the organisations that received nothing? Can that Decision then be characterised as a Decision which is addressed to another person, but of direct and individual concern to the former? Also on this aspect the ECJ said something in the Les Verts case. The Parti écologiste Les Verts did not receive any appropriations from the EP and submitted a legal claim against the decision of the EP to grant appropriations to other organisations. The question was therefore whether the Parti écologiste Les Verts was directly and individually concerned. The ECJ stated:

"It must first be pointed out that the contested measures are of direct concern to the applicant association. They constitute a complete set of rules which are sufficient in themselves and which require no implementation provisions, since the calculation of the share of the appropriations to be granted to each of the political groupings concerned is automatic and leaves no room for any discretion." 
The ECJ was also of the opinion that the political party was individually concerned:

"This action concerns a situation which has never before come before the court. Because they had representatives in the institution, certain political groupings took part in the adoption of a decision which deals both with their own treatment and with that accorded to rival groupings which were not represented. In view of this, and in view of the fact that the contested measure concerns the allocation of public funds for the purpose of preparing for elections and it is alleged that those funds were allocated unequally, it cannot be considered that only groupings which were represented and which were therefore identifiable at the date of the adoption of the contested measure are individually concerned by it.

Such an interpretation would give rise to inequality in the protection afforded by the ECJ to various groupings competing in the same elections. Groupings not represented could not prevent the allocation of the appropriations at issue before the beginning of the election campaign because they would be unable to plead the illegality of the basic decision except in support of an action against the individual decisions refusing to reimburse sums greater than those provided for. It would therefore be impossible for them to bring an action for annulment before the $\mathrm{ECJ}$ prior to the elections or to obtain an order from the ECJ under Article 185 of the Treaty (now Article 242 EC Treaty, E.F.), suspending application of the contested basic decision.

Consequently, it must be concluded that the applicant association, which was in existence at the time when the 1982 decision was adopted and which was able to present candidates at the 1984 elections, is individually concerned by the contested measures." ${ }^{149}$

What can we learn from this case with regard to the support of the Commission to the European social partners' organisations? First of all, the decision to grant financial support produces legal effects vis-à-vis the organisations that receive such support. Secondly, the fact that the financial support falls under the budget which has to be approved by the EP and the Council, is not sufficient to preclude any review by the European courts. Thirdly, organisations that receive no financial support can be individually concerned by the fact that other organisations do receive such support. However, with regard to the concept of direct concern, the comparison between the political parties in the EP and the social partners' organisations falls short. In the Les Verts case, the calculation of the share of the appropriations to be granted to each of the political groupings concerned, was automatic and left no room for any discretion. The share of the appropriations was namely determined either on the basis of the number of seats obtained in 1979, or on the basis of the number of votes obtained in 1984 . So it was simply a matter of counting the seats or the votes to determine the proportion of the appropriations to be

149 Cons. $35-37$ in Case 294/83. 
granted. The criteria that the Commission applies for granting financial support to the social partners are not that strict. The award criteria for proposals under Budget Heading B3-4000 (industrial relations and social dialogue) and Budget Heading B3-4002 (information and training measures for workers' organisations), are amongst others:

- the extent to which the operation meets the objectives of the budget heading; the expected results of the operation;

- the involvement of the social partners in the operation and/or link with the European social dialogue;

- the transnational dimension of the operation;

- the Community social policy dimension of the subject of the operation.

The application of these criteria leaves a wide margin of discretion to the Commission. The reasoning, therefore, of the ECJ with regard to the question of direct concern in the Les Verts case, cannot simply be applied to the situation of the European social partners' organisations in regard to the financial support under Article 138(1) EC Treaty.

There is, however, other case law, from the CFI, from which a comparison can be drawn with the social partners. In the Murgia Messapica case, ${ }^{150}$ a group of entrepreneurs (called "the Consorzio"), set up to develop economic activities, in particular rural activities in the Italian Murgia Messapica region, submitted a project for which it wanted financial assistance from the Commission under the so-called "Leader Programme". This assistance would not be granted directly to the Consorzio, but to the Italian Ministry of Agriculture. The Ministry submitted a number of projects to the Commission, for it wanted this financial assistance. Among these projects, there was the project of the Consorzio, which was examined several times by the Commission. On the basis of certain comments made by the Commission, the Consorzio adapted and modified its project. After this modification it was sent back to the Commission. The Commission nevertheless rejected the project proposal of the Consorzio. Thereupon the Ministry submitted four new projects, which did not include the project of the Consorzio. These new projects were all approved by the Commission. The result was that the Consorzio did not receive financial assistance from the Commission for its activities. The Consorzio submitted a legal claim under Article 230, $4^{\text {th }}$ sentence against the Commission for the rejection of its project. With regard to the admissibility, the CFI stated:

"It has been consistently held that persons other than the addressees may claim that a decision is of direct concern to them within the meaning of the fourth para. of Article 173 (now 230) of the Treaty only if that decision affects them by reason of certain attributes which are peculiar to them or

150 Case T-465/93, Judgment of 19/05/1994, Consorzio gruppo di azione locale "Murgia Messapica"/Commission (Rec.1994,p.II-361). 
by reason of circumstances in which they are differentiated from all other persons and by virtue of these factors distinguished them individually just as in the case of the person addressed". ${ }^{151}$

It is remarkable that the CFI applied the Plaumann criteria to individual concern to explain the concept of direct concern. The CFI subsequently stated:

"The applicant was not entitled to any financial assistance from the Community. The provisional acceptance of its project by the MAF (i.e. the Ministry of Agriculture) and the inclusion of the project among those accorded secondary priority and the applicants' repeated participation in the meetings organised by the Commission and the MAF, and thus in the procedure on conclusion of which the contested decision was adopted, may (...) have given rise to interests to which the loss was of individual concern to the applicant. Moreover the contested decision produced direct legal effects vis-à-vis the applicant without any involvement on the part of other Community or national authorities." ${ }^{152}$

Applying this case to the situation of the social partners who receive no financial assistance from the Commission after they have made a proposal for such assistance, leads to the conclusion that the rejection of their proposal can be of direct and individual concern to them and that they are thus admissible under Article $2304^{\text {th }}$ sentence EC Treaty. Whether their claim as regards the content will be successful, is another issue, which has to be determined for every case separately. However, from the Pesquerias de Bermeo and Naviera Laida case, ${ }^{153}$ it can be derived that where the Community institutions have the power of appraisal, respect for the rights guaranteed by the Community legal order in administrative procedures is of fundamental importance. Those guarantees include, in particular, the obligation to give an adequate statement of the reasons for the decision. That statement of reasons must show, clearly and unequivocally, the reasoning of the author of the measure, so that the person concerned can, in order to defend his rights, ascertain the grounds on which it was adopted, and the ECJ can undertake its review. ${ }^{154}$

\subsubsection{The decision to consult the European social partners' organisations}

As already said in Chapter $4,{ }^{155}$ the Commission is obliged to consult the social partners on proposals in the social policy field on the basis of Article

151 Cons. 25 in Case T-465/93.

152 Cons. 26 in Case T-465/93.

153 Joined cases C-258/90 and C-259/90, Judgment of 07/05/1992, Pesquerias De Bermeo and Naviera Laida/Commission (Rec.1992,p.1-2901).

154 Cons. 26 in cases C-258/90 and C-259/90.

155 Para. 4.3.1. 
138(2) and (3) EC Treaty. The problem is that the Treaty does not say which organisations should be consulted. It just speaks of "management and labour". Interpreting Article 138 EC Treaty strictly, it would suffice were the Commission to consult one trade union and one employers' organisation at European level, because Article 138 does not say how many organisations should be consulted. Which organisations will be consulted and which ones not, depends all on the assessment of the Commission with regard to the representativity of a certain organisation. ${ }^{156}$ The consultation procedure is a preparatory step for the eventual legislation. First, there is consultation, then there is a Commission proposal and finally, there will be a Council decision. 1 think that it can be derived from the IBM case ${ }^{157}$ that these preparatory steps cannot constitute a Decision, since they do not produce legal effects. Only the eventual Council decision produces these effects. The question is therefore whether European social partners' organisations can claim the annulment of a Community measure which has been adopted without them having been consulted by the Commission on the basis of Article 138(2) and (3) EC Treaty, provided, of course, that it concerns a Community measure of social policy. This Community measure should either be a Decision addressed to the complaining organisation, or a Decision addressed to another person which is of direct and individual concern to the complaining organisation. We have seen, however, that the ECJ and CFI have developed a relaxed approach during the years when it comes to the legal review of other measures than Decisions. So whether the Community measure in question will be a Regulation or Directive is (no longer) the most important. The most important criterion is whether the measure will be of direct and individual concern to the organisation seeking its annulment. From the Metro case, the Timex case, the Air France case and the CCE de Vittel and Others case, ${ }^{158}$ we can learn that a private party can be individually concerned if he is in one way or another involved in the decision making procedure leading to the adoption of the contested Community measure. The problem is, however, that if the Commission does not consult the complaining European social partners they will not be involved in the decision making procedure leading to the contested Community measure. It is therefore perhaps better to compare the position of the social partners in this respect with that of other organisations that have sometimes to be consulted by the Commission/Council, such as, for example, the EP ${ }^{159}$ and the ECOSOC. ${ }^{160}$ From the Parliament case, ${ }^{161}$ we can draw some analogies.

\footnotetext{
156 See Chapter 4, para. 4.3.4.

157 See para. 8.2.2.1.

158 See para. 8.2.2.3.

159 See for example Article 93 EC Treaty.

160 See for example Article 95(1) EC Treaty.

161 Case C-70/88, Judgment of 22/05/1990, Parliament/Commission (Rec.1999,p.I-2041).
} 
In this case, the EP sought the annulment of a Council Regulation which had been adopted without the EP having been consulted. ${ }^{162}$ The EP could not, however, unlike now, bring an action against the Council under Article 230 EC Treaty (at that time Article 173). In a landmark judgement of the ECJ, the locus standi of the European Parliament was recognised by the ECJ. The EC] stated that the EP had certain prerogatives, which included the participation in the drafting of legislative proposals. These prerogatives are one of the elements of the institutional balance created by the Treaties. Although the Treaties contain no provision giving the Parliament the right to bring an action for annulment, it would be incompatible with the fundamental interest in the maintenance and observance of that institutional balance which they establish for it to be possible to breach the Parliament's prerogatives without that institution being able, like the other institutions, to have recourse to one of the legal remedies provided for by the Treaties which may be exercised in a certain and effective manner. ${ }^{163}$

The ECJ came to this judgement on the basis of the principle of institutional balance, which it considered of fundamental importance, to grant the EP its right of action. Here lies the difference with the position of the European social partners' organisations, for they are not institutions of the EC, as is the EP. So the principle of institutional balance is not relevant here. However, from the Germany, France, Netherlands, Denmark and UK case, ${ }^{164}$ the conclusion could be drawn that also the lack of consultation of organisations that are not institutions of the Community can lead to annulment of the final act. In this case, the applicants argued that a certain Commission Decision should be declared void since the ECOSOC was not consulted, although this was required according to the procedure under which the Decision was adopted. The ECJ rejected the claim because it was of the opinion that consultation of the ECOSOC in this specific case was not required. However, it is clear that the ECJ was willing to investigate whether the claim of the applicants was right. It implicitly accepted the possibility of annulment of a Decision because the ECOSOC was not consulted. The ECJ did however, not scrutinise whether the ECOSOC itself would be able to bring such action. In this case it was the Member States that brought the action. The question whether the ECOSOC was able to do so remains thus open.

And although an exact comparison with the position of the EP cannot be made, there are arguments thinkable that plead for a comparison of the posi-

162 Actually, the EP was of the opinion that the Commission should have used another procedural basis for this Community measure, under which the EP had to be consulted. The Commission did not, however, comply with that request and therefore the Regulation was adopted under another procedural basis, under which the EP did not have to be consulted.

163 Cons. $20-27$ in Case C-70/88.

164 Joined cases $281 / 85,283 / 85,285 / 85$, and $287 / 85$, Judgment of $09 / 07 / 1987$, Germany, France, Netherlands, Denmark and United Kingdom/Commission (Rec.1987,p.3203). 
tion of the EP with that of the European social partners' organisations. The European social partners' role is extended by the Maastricht Treaty in such a way that they now play a considerable role in the drafting of Community legislation through the consultation procedure and through the possibility of their agreements becoming Community law. In this sense they are comparable to the EP, which also had, at the time of the Parliament case, the right to participate in the drafting of legislative proposals. ${ }^{165}$ One could say that the right to legal protection flows from the right to participate in the legislative procedure. ${ }^{166}$ Legal protection could be interpreted as the possibility for any holder of a right, a power or prerogative to have recourse to judicial authority on his own initiative, that is to say, as and when he sees fit, in order to have that right, power or prerogative protected. ${ }^{167}$ As long as Community law or the CFI or ECJ have not given a clear definition of "management and labour" it can be presumed that in principle all organisations of workers and employers, organised at European level have the right to be consulted on the basis of Article 138(2) and (3) EC Treaty. This could be the reason to grant European social partners' organisations a right of action against a Community measure under Article 230 EC Treaty if they have not been consulted by the Commission. That however requires an assessment by the CFI on the complaining organisation while it is not even clear how this assessment should be made. The Treaty does not say which requirements management and labour should fulfill in order to be consulted by the Commission. This means that every organisation that considers itself as management or labour at Community level and has not been consulted by the Commission can be encouraged to undertake action to seek the annulment of the Community measure. Given the enormous caseload of the CFI and ECJ already, it would perhaps be better to take another approach at this stage.

The Commission proposal for the first consultation on the basis of Article 138(2) EC Treaty could be published in the Official Journal. In this way all organisations are informed about the proposal and the Commission need not worry about the question of which organisations to consult and which ones not. All organisations which consider themselves a representative social partners' organisation at European level could have the opportunity to give comments and advice to the Commission concerning this proposal. The Commission could pick those comments which it considers useful. The Commission could then publish a revised proposal for second consultation again in the $\mathrm{OJ}$ and follow the same procedure. Here it could also explain

165 See also Heinze who draws the comparison between the EP and the social partners' organisations as well. M. Heinze, Die Rechtsgrundlagen des sozialen Dialogs auf Gemeinschaftsebene. In: Zeitschrift für Arbeitsrecht, vol.4, no. 28, 1997, p. 513.

166 See also A. Arnull, Challenging Community acts - An introduction. In: H.W. Micklitz and N. Reich, Public Interest Litigation before European courts, p. 40, as well as H.W. Micklitz, The interest in public interest litigation. In: H.W. Micklitz and N. Reich, Public Interest Litigation before European courts, p. 21-37.

167 See also the Opinion of AG van Gerven in Case C-70/88. 
why it did or did not choose to adopt the suggestions made by the participating organisations. Although the scientific studies and other evidence relied upon by the Commission could not, for obvious reasons, be published along with the proposed rule, such studies and evidence could be made available through other means. ${ }^{168}$ This procedure of publishing a proposal in the $\mathrm{OJ}$ and picking all useful comments of social partners'organisations has several advantages. The vitality and diversity of the social dialogue will be better assured than in case where the Commission just sends its proposal to certain organisations. All organisations are fully informed about the possibility to negotiate on the basis of a Commission proposal and they have a chance to express their wish to participate in these negotiations. Furthermore, the issue of representativity can at this stage be avoided. ${ }^{169}$

Whether the Commission is obliged to follow the advice of the social partners' organisations is another issue. If many organisations react at the first and second consultation, it will be impossible for the Commission to take all these reactions into account in its eventual proposal, especially when some reactions contradict others. Besides this, the Commission has, according to Article 211 EC Treaty, its own decision-making powers. The obligation to consult social partners'organisations is not the same as the obligation to follow their advice. Nevertheless, I think that it can be required that the Commission makes clear why it has taken a certain decision and why it has followed the advice of certain organisations and rejected the advice of other organisations. Consultation means more than just compiling information or organising a meeting. ${ }^{170}$ These are purely preparatory and procedural acts and do not touch on the substance of the matter. The ECJ is in principle willing to investigate whether the opinion of an organisation which has to be consulted on the basis of the Treaty, has been taken into account. This has occurred for example with regard to the EP in the Andersen case. ${ }^{171}$ In this case the ECJ concluded on the basis of underlying documents, that the opinion of the EP was sufficiently taken into account. ${ }^{172}$ What would constitute a real consultation of the social partners' organisations? What the Commission could do is to compile a contemporaneous record, including the scientific evidence and reasoning that served as the foundation for its decision and justifying the rejection of other opinions of relevant organisations. This has several advantages. Information, participation, and judicial review

168 F. Bignami, The administrative state in a separation of powers constitution: Lessons for European Community rulemaking from the United States, Jean Monnet Working Paper no. 5/99.

169 See also B. Bodding, Die europarechtlichen Instrumentarien der Sozialpartners, p. 131, as well as T. Gilles, Das Zustandekommen und die Durchführung von Sozialpartnervereinbarungen im Rahmen des europăischen sozialen Dialogs, p. 180.

170 Joined cases 281,283 to 285 and $287 / 85$.

171 See Case 260/80, Judgment of 19/01/1984, Andersen and others/Council (Rec.1984, p.177).

172 Cons. 25 in Case 260/80. 
are inextricably linked. More information about a rule lays the groundwork for interest group critique (in this case interest groups of workers and employers), and thorough judicial review. ${ }^{173}$ The combination of information, interest participation and judicial review would also guarantee greater accountability to the EP, which currently has inadequate control instruments, as well as the Council, which has very little effective power over the tightly knit network of national experts and Commission civil servants. ${ }^{174}$ There is a general trend in the EC to move towards a more open Community with greater access for the public to documents in which it can find thorough information on the background of Community decisions. ${ }^{175}$ If individuals have access to rulemaking record, they have far stronger grounds on which to challenge implementing rules. The CFI can therefore better consider the merits of an argument challenging the reasonableness of a policy choice. ${ }^{176}$

If the Commission ignores the advice of certain organisations, these organisations could try to seek the annulment of the legislative act adopted on the basis of the Commission proposal. If a European social partners' organisation is of the opinion that its advice was not taken into account by the Commission, without any reason, and that therefore the eventual act adopted infringes upon its rights or the rights of its members, it should be able to ask the CFI to review the Community act on the point of the decision making of the Commission. We have seen in the case law of the ECJ and CFI that also associations can have standing. Especially the reasoning of the ECJ in the Van der Kooy and Others case ${ }^{177}$ could be applied here to grant such an association standing. The CFI should annul the act if it finds that the act is arbitrary, capricious, an abuse of discretion or otherwise not in accordance with the law. Another option is that if the CFI thinks that the decision of the Commission is not sufficiently founded, it could send the rule back to the Commission for further explanation or development of the evidentiary record.

\subsubsection{The Commission proposal based on the European collective agreement}

As we have seen in Chapter 7, the Commission performs certain checks on the European agreement and on the basis of this performance it decides

173 F. Bignami, The administrative state in a separation of powers constitution: Lesons for European Community rulemaking from the United States, Jean Monnet Working Paper no. 5/99.

174 F. Bignami, The administrative state in a separation of powers constitution: Lesons for European Community rulemaking from the United States, Jean Monnet Working Paper no. 5/99.

175 See Regulation (EC) 1049/2001 of the EP and of the Council of 30 May 2001 regarding public access to EP, Council and Commission documents, OJ L 145/43, 31-5-2001.

176 F. Bignami, The administrative state in a separation of powers constitution: Lesons for European Community rulemaking from the United States, Jean Monnet Working Paper no. 5/99.

177 See para. 8.2.2.3. 
whether or not to submit the agreement to the Council. ${ }^{178}$ Also here, questions of legal review arise. The first question is whether the social partners can act against the Commission if the last mentioned does not react to the request of the social partners to turn their agreement into a legislative proposal. The second question is whether the refusal of the Commission to turn the agreement into a legislative proposal can be legally attacked. The third question is whether social partners' organisations which have not been involved in the conclusion of a European agreement, can legally attack the Commission decision to turn the agreement into a legislative proposal. I will try to answer these questions hereafter.

\section{The Commission does not react on a request of the social partners}

What if the social partners request the Commission to turn their agreement into a legislative proposal and the Commission does not give any reaction at all? After all, this could mean that the Commission could block the route of an agreement becoming Community legislation by not giving any reaction to the request of the social partners. Perhaps a comparison can be made with the position of the EP and the Council. The EP and the Council are also sometimes accorded a quasi-right of initiative in that they may request the Commission to submit a legislative proposal. ${ }^{179}$ Some authors argue that since there is a specific legal basis for such a request, the way would appear open for the EP and the Council to bring an action for failure to act on the basis of Article 232 EC Treaty, if there is no response from the Commission to their request. ${ }^{180}$ The first three sentences of this provision state that:

"Should the European Parliament, the Council or the Commission, in infringement of this Treaty, fail to act, the Member States and the other institutions of the Community may bring an action before the ECJ to have the infringement established.

The action shall be admissible only if the institutions concerned have first been called upon to act. If within two months of being so called upon, the

178 See para. 7.4.

179 See for the EP Article 192 EC Treaty and for the Council Article 208 EC Treaty.

180 E. Grabitz and M. Hilf (eds.), Das Recht der Europalischen union, Band II EUV/EGV, München, 2001, Article 192 EGV, no. 31, as regards the enforcement possibilities for the EP and C. Calliess and M. Ruffert (eds.), Kommentar des Vertrages über die Europäische Union und des Vertrages zur Gründung der Europăische Gemeinschaft EUV/EGV-, p. 1686 and H. von der Groeben, J. Thiesing and C.D. Ehlermann, Kommentar zum EWG-Vertrag, Band 3, Artikel 152, no. 4, Baden-Baden, 1991, as regards the enforcement possibilities for the Council. Campbell and Cotter have a more balanced opinion on the enforcement possibilities for the Council, D. Campbell and S. Cotter (eds.), The law of the European Community, A commentary on the EC Treaty, no. 152.05. P.J.G. Kapteyn and P. VerLoren van Themaat, Introduction to the law of the EC, p. 410. These authors however, seem to have a different opinion when it comes to the quasi right of initiative of the Council, see p. 410-411. See however otherwise: R. Barents and L.J. Brinkhorst, Grondlijnen van Europees recht, p. 147; J. Schwarze (ed.), EU-Kommentar, Artkel 250 EC Treaty, points 6 and 7. 
institution concerned has not defined its position, the action may be brought within a further period of two months.

Any natural or legal person may, under the conditions laid down in the preceding paragraphs, complain to the ECJ that an institution of the Community has failed to address to that person any act other than a recommendation or an opinion."

Moreover, they argue, the duty of inter-institutional cooperation, laid down in Article 10 EC Treaty, lies behind the obligation of the Commission to submit a legislative proposal. Gilles draws a comparison with the position of the European social partners, who can also on the basis of Article 139(2) EC Treaty request the Commission to draft a legislative proposal. He states that the failure of the Commission to react can be subject to a procedure on the basis of Article 232(3) EC Treaty, because Article 139(2) reflects the cooperation between the European social partners' organisations and the Commission to transpose a European agreement into Community law. ${ }^{181}$ Several conditions have to be met in order to use Article 232 EC Treaty. The most important in this respect is that the institution must have an obligation to act. $^{182}$ This raises the question whether the Commission has a legal obligation to react to the request of the social partners. Having such a legal obligation would mean that the failure to react would constitute an infringement of the Treaty, as Article 232(1) EC Treaty prescribes. Academic writers have agreed that, although that there is no case law on this matter, such expression would be interpreted widely and would include the failure to act in violation of a general principle of law and in misuse of powers. ${ }^{183}$ Perhaps the refusal to react could constitute an infringement of the Treaty. A more important hurdle however, is that non-privileged applicants such as the social partners may only review Decisions, because these are the only acts that may be addressed to a private party. ${ }^{184} \mathrm{~A}$ reaction of the Commission to the request of the social partners would be addressed to them. But would it also produce legal effects, because that is an essential feature of a Decision. We have therefore to scrutinise two things. In the first place whether the explicit refusal of the Commission to formulate a proposal can be regarded a Decision. In the second place whether the decision to formulate a legislative proposal is a Decision. These are namely the only two options that the Commission has, as already stated in Chapter $7 .^{185}$

181 T. Gilles, Das Zustandekommen und die Durchführung von Sozialpartnervereinbarungen im Rahmen des europäischen sozialen Dialogs, p. 274-275.

182 A. Albors-Llorens, private parties in European Community law; Challenging Community measures, p. 210.

183 These academic writers are cited in A. Albors-Llorens, private parties in European Community law; Challenging Community measures, p. 212

184 A. Albors-Llorens, private parties in European Community law; Challenging Community measures, p. 212

185 Para. 7.4.2. 
The Commission refuses to turn the European agreement into a legislative proposal In Chapter $7,{ }^{186}$ I have described that it could occur that the Commission rejects the European agreement because it thinks that it cannot meet one or more of the checks it applies. Suppose the Commission did react to the request of the social partners, and that this reaction constitutes a refusal to turn their agreement into a legislative proposal. Could this refusal be regarded a Decision in the sense of Article 230 EC Treaty which could be attacked by the requesting social partners' organisations? Since a Decision addressed to a private party is always of direct and individual concern to that party, we just have to look whether the Decision concept is applicable. From the Compagnie des Forges de Chatillon case, ${ }^{187}$ it is clear that the most important feature of a Decision is that it produces legal effects. Does the refusal of the Commission produce legal effects for the requesting social partners? I do not think so. The legal position of the requesting organisations does not change as a result of the refusal of the Commission to formulate a legislative proposal, because even if the Commission were to formulate a proposal, this would not constitute an act producing legal effects. That would only be the case if the Council adopted the proposal and turned it into legislation. This reasoning can be derived from the IBM case. ${ }^{188}$

Another question is, however, whether the Commission should have in every case the freedom to reject a European agreement, in the sense that it refuses to turn it into a legislative proposal. Gilles is of the opinion that if the agreement of the social partners would meet all checks, mentioned in para. 7.4.1.1.-7.4.1.5., the Commission should be obliged to submit it to the Council. ${ }^{189}$ Heinze goes even a step further than Gilles and argues that because of the special character of Article 139(2) EC Treaty, the Commission should only be allowed to refuse to turn an agreement into a legislative proposal if it concludes that the agreement is contrary to Community law. It does not concern an ordinary social policy proposal, he states, but an agreement which is the result of negotiations between workers and employers. Therefore the normal decision-making power of the Commission on the question whether or not to formulate a proposal for legislation should be restricted. ${ }^{190} \mathrm{I}$ have a different opinion. The general rule of Community law is that the Commission is not obliged to submit a legislative proposal to the Council. The Commission is the initiator of EC legislation and has its own decision-making powers. ${ }^{191}$ Besides this, the members of the Commission are completely in-

186 Para. 7.4.2.

187 See para. 8.2.2.1.

188 See para. 8.2.2.1.

189 T. Gilles, Das Zustandekommen und die Durchführung von Sozialpartnervereinbarungen im Rahmen des europaischen sozialen Dialogs, Frankfurt, p. 279.

190 M. Heinze, Die Rechtsgrundlagen des sozialen Dialogs auf Gemeinschaftsebene. In: Zeitschrift für Arbeitsrecht, vol. 4, no. 28, 1997 , p. 518.

191 Article 211 EC Treaty, third point. See also J. Schwarze (ed.), EU-Kommentar, Artikel 139 EGV, point 8; see also C. Calliess and M. Ruffert (eds.), Kommentar des Vertrages 
dependent in the performance of their duties and they may neither seek nor take any instructions from governments or other bodies. ${ }^{192}$ Moreover, I think that the final decision to formulate a proposal on the basis of a European agreement should always lie with the Commission. The Commission as an independent institution and guardian of the Treaties is more able to determine whether and when legislation in a certain field is opportune. After all, it has to serve the general interests of the Communities as a whole. ${ }^{193}$ The social partners in turn are better equipped to determine what the content of legislation in the social policy field should be. Nevertheless I think that the rejection of an agreement by the Commission should always be motivated. ${ }^{194}$ This motivation should be stronger the more the Commission has stimulated and supported the agreement concluded by the social partners. For example when there has first been a consultation procedure, which resulted in negotiations and the conclusion of an agreement that can meet all checks of the Commission. I think that if the Commission in such a case still refuses to turn the agreement into a legislative proposal, this refusal should be very well motivated. After all, the Commission has made clear that it wants legislation, otherwise it would not have started the consultation procedure. Moreover, it has subsequently remained passive during the negotiations between the social partners, which indicates that it expects an agreement that can be turned into legislation. Finally, the agreement can meet all checks. Rejection of such an agreement by the Commission without a good motivation will easily be considered as arbitrary. The situation is different in case the social partners start negotiating on their own initiative, that is to say without there having been any initiative from the side of the Commission. Although it is possible that the agreement will meet all checks, the Commission can still consider that it is not opportune to initiate legislation at that moment. This flows from the fact that it has not started the consultation procedure. I think, however, that also in this case, a good motivation is necessary. The Commission could for example explain why it thinks that legislation is not opportune. An obligation for the statement of reasons is also prescribed in Article 253 EC Treaty. This Article states:

"Regulations, directives and decisions adopted jointly by the European Parliament and the Council, and such acts adopted by the Council or the Commission, shall state the reasons on which they are based and shall

über die Europäische Union und des Vertrages zur Gründung der Europäische Gemeinschaft -EUV/EGV-, Artikel 139, point 26.

192 Article 213(2) EC Treaty. See also K. Piazolo, Der Soziale Dialog nach dem Abkommen über die Sozialpolitik und dem Vertrag von Amsterdam, p. 133.

193 P.J.G. Kapteyn and P. VerLoren van Themaat, Introduction to the law of the EC, p. 197.

194 The Commission has already said that if it rejects the agreement, it will immediately inform the signatory parties of the reasons of its decision $(\mathrm{COM}(93) 600$ final, point 39). 
refer to any proposals or opinions which were required to be obtained pursuant to this Treaty."

This provision however, only applies to Regulations, directives and decisions. In any case it has to regard acts having legal effects. ${ }^{195}$ However, given the special circumstances here, I would recommend an obligation to state the reasons for the Commission if it rejects the European agreement.

If it were possible that the refusal of the Commission to make a legislative proposal without there being a good motivation for it, were legally reviewable (which is not the case at the moment), then such legal review could in my view never result in an obligation for the Commission to draw up a legislative proposal. It could only result in an obligation to state the reasons for its refusal.

\section{The Commission formulates a legislative proposal}

The Commission can also reply in a positive way to the request of the social partners and formulate a legislative proposal after it has performed its checks on the European agreement. The signatory parties of the European agreement will support this decision of course. But it is thinkable that other organisations, which have been excluded from the negotiations on the agreement, are not very pleased with the Commission decision. This may be, for example because they were not allowed to participate in the negotiations on the agreement and they think that the concluding parties cannot be regarded as sufficiently representative. Can they act against the Commission on the basis of Article 230(4) EC Treaty? That would require that the decision to send the agreement to the Council would be a Decision addressed to the social partners that made the request, which is of direct and individual concern to the social partners that oppose the decision of the Commission to send the agreement to the Council. I think that in line with the IBM case, the formulation of a legislative proposal can never be a Decision, since legal consequences are not yet created. These are only created if the Council turns the proposal into legislation. Although there have been successful claims against other measures than Decisions, ${ }^{196}$ it remains essential that the measure has legal effects which are binding on and capable of affecting the interests of the applicant by bringing about a distinct change in his legal position. ${ }^{197}$ It is therefore not necessary to investigate whether the Commission decision to draw a legislative proposal is of direct and individual concern to organisations who oppose this decision.

In order to increase legal certainty, it would be recommendable that the Commission would develop clear policy rules in which it lays down the

195 T.C. Hartley, The Foundations of European Community law, Oxford, 1998, p. 124.

196 See para. 8.2.2.2.

197 See cons. 9 in Case 60/81. 
procedure and criteria for the examination of European agreements. ${ }^{198}$ The procedure to be laid down in the policy rules could be as follows. Any request by management and labour to have an agreement implemented by a Council decision is to be published in the Official Journal of the EC. European organisations of management and labour opposing such an implementation can lodge a complaint within for instance two months after its publication, by sending a letter to the Commission in which they set out their views. The Commission can hear the claimant and the signatory parties concerned and make further investigations if necessary. Subsequently, the Commission decides on the complaint. Also here the Commission decision should be motivated, in the same way as it should motivate its refusal to formulate a legislative proposal. As regards the criteria, the Commission could use the checks it already uses at the moment as a starting point and develop them further in these policy rules. The policy rules could be drawn up together with the European social partners' organisations already recognised by the Commission as representative. It this way it would be clearer from the outset when the Commission will reject or accept an agreement. Social partners' organisations, negotiating an agreement which they want to have implemented by Council decision, can already take these policy rules of the Commission into account during their negotiations. In this way the situation can be avoided that after long negotiations resulting in an agreement, this agreement is subsequently rejected by the Commission. This is all the more important, since during the negotiations, the Commission has no contact with the social partners. ${ }^{199}$ It is therefore important that the social partners know the policy rules of the Commission before and during their negotiations on a European agreement.

\subsubsection{Conclusions}

From the Murgia Messapica case, it can be derived that the European social partners' organisations have legal possibilities to challenge Commission decisions with regard to the granting of financial support.

The Commission decision to consult certain social partners' organisations can in itself not be legally attacked, because legal consequences are not yet created. This can be derived from the IBM case. If Community measures have been adopted without (certain) European organisations having been consulted, the lack of consultation itself would probably be legally reviewable, even if the social partners are not institutions of the Community. This can be derived from the Germany, France, Netherlands, Denmark and UK case. However, in this case, it was not the organisation itself (i.e. ECOSOC), who submitted a claim, but certain Member States, so the basis for the claim was not Article $2304^{\text {th }}$ sentence EC Treaty. An action on the basis of Article 230, $4^{\text {th }}$ sentence EC Treaty by the social partners themselves for the lack of con-

198 This has for example been done in The Netherlands.

199 Interview with M. Thozet on 25 March 2002. 
sultation would therefore only be possible if the CFI was willing to adopt a broad interpretation of "legal protection" as mentioned by the AG in the Parliament case. An analogy with the Parliament case itself cannot be drawn, because the $\mathrm{ECJ}$ based its judgement on the principle of institutional balance. Since the European social partners are not institutions of the EC, this principle cannot be invoked here. The question of whom to consult could be avoided by an open procedure, whereby the Commission proposal for the first and second consultation would be published in the OJ and whereby every organisation considering itself a European social partners' organisation, can submit comments and critics. The Commission could pick those comments which it considers useful. From the Andersen case, it is clear that the $\mathrm{ECJ}$ in certain circumstances investigates whether an opinion (in this case of the EP), has been taken into account by the organisation that asked for the opinion. It remains to be seen whether the ECJ or CFI are also willing to apply this case law to the situation of the social partners. If they are, their work would be easier if the Commission would compile a record, including the evidence and reasoning for its decision from which it is clear why certain opinions have been taken into account and why other opinions have been rejected. This would increase the legitimacy of Commission decisions and the European courts would be better able to assess whether a certain Commission decision was unreasonable. The CFI could apply the sanction of annulment or send the rule back to the Commission for further statement of reasons.

If the social partners request the Commission to formulate a legislative proposal on the basis of their agreement, it can occur that the Commission does not give any reaction to this request. The social partners can however, not submit a legal claim against the Commission on the basis of Article 232, $3^{\text {rd }}$ sentence EC Treaty, because non-privileged applicants may only review Decisions. This implies that the action which the Commission refuses to undertake, must be a Decision. There are only two actions which the Commission can undertake: either the decision to draw a legislative proposal or the refusal to do so. The refusal to draw a proposal cannot be a Decision because legal effects are not created. This can be concluded from the IBM case. I think however, that the Commission should be obliged to motivate its decision. At this moment, such legal review is not possible since Article 253 EC Treaty prescribes that the obligation to state the reasons only applies for Regulations, Directives and Decisions. The lack of motivation should in my view be legally reviewable, given the special character of the procedure. Such legal review could only result in an obligation for the Commission to state its reasons for the refusal to draw a proposal. The decision to draw a proposal cannot constitute a Decision either. This also flows from the IBM case. For the sake of legal certainty, it is recommendable that the Commission develops clear policy rules in which it lays down the procedure and criteria for the examination of European agreements. In this way, it would be easier for the social partners to predict whether the Commission would reject or accept a European agreement. 


\subsubsection{The nature of the contested measures applied to Council decisions}

If the Council adopts a decision on the basis of a Commission proposal, legal consequences will be created. In Chapter $7,{ }^{200}$ I have made clear that in my view the Council can only adopt legally binding acts, since that is the whole intention of the procedure of Article 139(2) EC Treaty. There are several possibilities for the Council to react on the basis of a Commission proposal. In the first place it is possible that the Council rejects the proposal and thus refuses to turn the agreement into Community legislation. In the second place it is possible that the Council amends the proposal. The Commission has already made clear that in such a case it will withdraw its proposal. ${ }^{201}$ However, if the Commission does not withdraw its proposal, the procedure leading to the adoption of the Community act can no longer be the one prescribed in Article 139(2) EC Treaty, as explained in Chapter 7. ${ }^{202}$ Under certain conditions a new consultation of the social partners by the Commission will have to take place. ${ }^{203}$ If no such consultation takes place, and the Council adopts a Decision on the basis of a Commission proposal, this decision has been adopted without the consultation of the social partners. Whether the social partners can legally attack the fact that they have not been consulted is an issue which I have discussed in para. 8.2.3.2. In this paragraph I will therefore only discuss two situations: either the Council refuses to turn the agreement into Community legislation, or the Council does turn the agreement into legislation and other organisations than the signatory ones want to protest against this decision. The first situation will be discussed in para. 8.2.4.1., the second situation in para. 8.2.4.2. In para. 8.2.4.3. some conclusions will be drawn.

\subsubsection{The Council refuses to turn the European collective agreement into legislation}

It is possible that the Council refuses to adopt a decision. The Commission and Council both consist of different persons with different interests. The Commission looks at the interests of the Community as a whole, while the Council looks at the interests of the Member States. Their opinion on the question whether legislation is appropriate can differ. Can the social partners' organisations act against a refusal of the Council to turn a European agreement into legislation on the basis of Article 230 EC Treaty? I do not think so. The Council is not obliged to take a decision. This also flows from Article 139(2) EC Treaty which states that the Council takes a decision with qualified majority or by unanimity. Presuming that the Council were obliged

\footnotetext{
200 Para. 7.5.3.

201 See Chapter 7, para. 7.5.1.2.

202 Para. 7.5.1.2.

203 For the underlying reasoning, see Chapter 7, para. 7.5.1.2.
} 
to take a decision would make nonsense of the distinct voting requirements. There would be no point in maintaining that distinction between unanimity and qualified majority voting if the Council had to act in only one manner. ${ }^{204}$ If this qualified majority or unanimity cannot be reached, there will be no Council decision. ${ }^{205}$ The Commission has stated that in such a case it will withdraw its proposal and will examine, in the light of the work done, whether a legislative instrument in the area in question would be appropriate. ${ }^{206}$ The question is whether this examination makes sense, since the Council, by rejecting the proposal, already made clear that it does not want to legislate on the issue at stake. If the Council rejects the Commission proposal, the European social partners' organisations can implement their agreement via the national affiliates, or decide to terminate or change it. It is of course possible that after they have changed their agreement, the Commission and/or Council are more willing to turn the agreement into EC legislation.

Another question is whether the Council is obliged to motivate its decision to reject the agreement. According to Höland, the Council has an obligation to motivate this decision. If there is no such motivation, the social partners would be admissible under Article $2304^{\text {th }}$ sentence EC Treaty to submit a legal claim against this Council decision for infringement of an essential procedural requirement. Höland bases this presumption on his opinion that the request of the social partners to turn their agreement into legislation has legal consequences, because on the occasion of the request, the agreement can be turned into legislation. ${ }^{207} \mathrm{I}$ do not agree with Höland on this point. The request of the social partners as such, like the Commission proposal, does not create legal consequences for anyone. This is supported by the case law of the $\mathrm{ECJ} / \mathrm{CFI}$ (see amongst others the IBM case). I think that the obligation to state the reasons as prescribed in Article 253 EC Treaty, is not applicable here, since the refusal of the Council to turn the European agreement into legislation cannot constitute an act having legal effects. Nevertheless, as I have also pleaded with regard to the Commission decision to reject the agreement, I think that the Council should motivate its refusal to turn the agreement into legislation, given the special character of the procedure. This would also enhance the understanding of the social partners with regard to the feasibility of their agreements becoming Community law. It is useful for them to know the policies followed by the Council so that they can appreciate the

204 P.J.G. Kapteyn and P. VerLoren van Themaat, Introduction to the law of the EC, P. 1062.

205 See also M. Heinze, Die rechtsgrundlagen des sozialen Dialogs auf Gemeinschaftsebene. In: Zeitschrift für Arbeitsrecht, vol. 4, no. 28, 1997, p. 519.

$206 \operatorname{COM}(93) 600$ final, point 42. See also K. Piazolo, Der Soziale Dialog nach dem Abkommen über die Sozialpolitik und dem Vertrag von Amsterdam, p. 135; also C. 0. Lenz, EG-Vertrag, Artikel 139, point 5; as well as J. Schwarze (ed.), EU-Kommentar, Artikel 139 EGV, point 8.

207 A. Holland, Partnerschaftliche Setzung und Durchführung von Recht in der Europaischen Gemeinschaft. In: ZIAS,1995, p. 449. 
way the power of the Council is likely to be exercised in the future. If they know, from the reasoning of the Council, that certain issues in their agreements are politically very sensitive, they could avoid them or reformulate them in future agreements. If the Council does not motivate its refusal to turn the European collective agreement into a Council decision, the sanction could be introduced that the Council is obliged to take the agreement again into consideration. But it is my opinion that neither the Commission nor the Council can or should be legally forced to turn the European collective agreement into Community law.

\subsubsection{The Council turns the European collective agreement into legislation}

The Council can also decide to take over he Commission proposal and turn the European agreement into Community legislation. In Chapter $7,{ }^{208}$ I have prescribed the conditions and procedure leading to this Council decision. In this Chapter, I will only scrutinise whether social partners' organisations can legally attack the Council decision. In most cases, the social partners who formulated and signed the European agreement will not protest against the Council decision to turn it into Community law. However, it is not to be excluded that it can happen in the future. For example, when after the European collective agreement has been signed, one of the signatory parties changes his mind and wants to implement the agreement through the natonal organisations and not by means of a Council decision. It is, however, possible that other organisations, who were not a party to the European agreement, want to prevent the agreement becoming Community law, and will therefore try to seek the annulment of the Council decision. The question is whether this is possible on the basis of Article $2304^{\text {th }}$ sentence EC Treaty. From the case law, and in particular the UEAPME case, it is clear that the ECJ and CFI have loosened the criterion that individuals can only seek the annulment of Decisions. The criterion of individual and direct concern has become the most important. It is therefore not excluded that even Directives can be annulled on the basis of Article $2304^{\text {th }}$ sentence EC Treaty. The reason to seek the annulment will however, not lie so much in the Council decision itself, but more in the procedure preceding the Council decision. In Chapter $7{ }^{209}$ I have suggested that the Commission apply a number of checks to the agreement. This is in fact the most important stage of the procedure of Article 139(2) EC Treaty. If there is no organisation having any problems with the way the Commission has applied these checks on a certain agreement, no organisation will submit a legal claim against the Council decision. The Council just tries to seek the required qualified majority or unanimity to turn the Commission proposal into legislation, although it is required to verify

\footnotetext{
208 Para. 7.5.

209 Para. 7.4.
} 
whether the Commission has performed its checks in the right way. ${ }^{210}$ The main problems will therefore arise during the assessment of the European agreement by the Commission. That this assessment can indirectly be subject to legal review is proved by the UEAPME case. As explained before, ${ }^{21}$ UEAPME meant that its representativity was such that it should have participated in the negotiations leading to the European Framework Agreement on Parental Leave and this was one of the reasons that the Directive on Parental Leave should be annulled. UEAPME in fact asked the CFI to review the way in which the Commission applied the representativity-check on the European agreement. This review was indeed made by the CFI, but turned out to be negative for UEAPME. Moreover, the CFI made an interesting consideration. It stated:

\begin{abstract}
"Furthermore, by contrast with the applicant's situation (i.e. UEAPME), it is clear that if CEEP had not been one of the signatories to the framework agreement, this alone would have fundamentally affected the sufficiency of the collectively representational character of those signatories in view of the contents of that agreement, because then one particular category of undertakings, that of the public sector, would have been wholly without representation." ${ }^{212}$
\end{abstract}

In my view this implies that the CFI would have been willing to annul the Directive if the underlying European agreement had been concluded without the participation of the CEEP. It remains to be seen whether in the future more European social partners' organisations will try to seek the annulment of Community acts based on European agreements. The case law of the ECJ/ CFI proves that this in principle is possible.

The UEAPME case also gives an indication of the way the CFI judges the acts of the Commission. First, the CFI scrutinised (in particular) whether the Commission (and Council), have performed the representativity-check at all. The CFI therefore looked at the documents submitted by the Council which proved that the question of the representativity of the signatory parties was discussed within the Council. ${ }^{213}$ On the basis of the Commission's study on the representativity of European social partners' organisations, it is clear, according to the CFI, that the Commission also keeps itself informed on the representativity of these organisations. ${ }^{214}$ Second, the CFI scrutinised whether this check was performed in the right way. ${ }^{215}$ It therefore used a representativity-criterion which it developed itself, ${ }^{216}$ and concluded that the

210 Cons. 87 of the CFI in Case T-135/96.

211 Para. 8.2.2.3.

212 Cons. 100 in Case T-135/96.

213 Cons. 91 in Case T-135/96.

214 Cons. 92 in Case T-135/96.

215 Cons. 93 in Case T-135/96.

216 This criterion is laid down in Cons. 90 in Case T-135/96. See also Chapter 7, para 
Commission and Council have performed the representativity-check correctly. ${ }^{217}$

It is thus possible in the future, that the CFI will develop its own criteria with regard to the other checks of the Commission (legality, mandate, SME's) as well. This work of the CFI would be made easier if the Commission would, together with the European social partners' organisations, develop clear and elaborated policy rules with regard to the assessment of European agreements. ${ }^{218}$ If the ECJ will confirm the judgement of the CFI in the Jégo-Quéré case (that is to say if the Commission will bring an appeal), it will even be easier for the European social partners' organisations to challenge Regulations and Directives based on European collective agreements. The fact that other persons are also affected by these Regulations and Directives will be no longer important anymore.

\subsubsection{Conclusions}

The Council can decide to reject the Commission proposal, which is based on the European agreement, or to accept it and turn it into Community law.

If the Council rejects the proposal, this means that the European agreement cannot become Community law. From the voting requirements within the Council (qualified majority or unanimity), it can be derived that the Council cannot be obliged to turn the proposal into Community law. On the basis of current Community legislation the Council is neither obliged to motivate its decision to reject the Commission proposal. For the future, however, I recommend a legal obligation for the Council to state its reasons if it rejects the Commission proposal, given the special character of the procedure under Article 139(2) EC Treaty and the need to enhance the understanding of the social partners on the feasibility of their agreements.

The Council can also decide to turn the Commission proposal into Community law. The case law of the ECJ/CFI, and in particular the UEAPME case and the Jégo-Quéré case, proves that it is in principle possible to seek the annulment of such a Council decision. It is not so much the Council decision itself which will be attacked, but more the decision of the Commission to formulate a legislative proposal on the basis of a certain European agreement. Since this Commission decision cannot be legally attacked, the social partners shall have to wait for the Council decision, in order to start a procedure on the basis of Article $2304^{\text {th }}$ sentence EC Treaty. The UEAPME case proves furthermore that the CFI is willing to review the assessment of the European agreement by the Commission and that it is even willing to formulate its own

\subsubsection{1.}

217 Cons. 110 in Case T-135/96.

218 As I pleaded already in para. 8.2.3.3. 
criteria for this assessment. In the UEAPME case, the CFI developed these criteria with regard to the assessment of the representativity of the social partners. In the future it is however thinkable that the CFI will also develop its own criteria with regard to the other checks of the Commission, like for example the mandate-check or legality-check.

\subsubsection{Time limit and grounds of annulment}

Article $230,5^{\text {th }}$ sentence states that the proceedings provided for in this article shall be instituted within two months of the publication of the measure, or of its notification to the plaintiff, or, in the absence thereof, of the day on which it came to the knowledge of the latter, as the case may be. The reason for the strict time limit is the wish to strike a balance between the principle of legal certainty and the principles of legality and of adequate protection of individual interests. ${ }^{219}$

Furthermore, one of the four grounds of annulment mentioned in Article 230(2) EC Treaty must be applicable. These are:

- lack of competence;

- infringement of an essential procedural requirement;

- infringement of the Treaty or of any rule of law relating to its application;

- misuse of powers.

The first ground, lack of competence, occurs in four instances. Firstly, when a certain subject does not fall within the competence of the EC. ${ }^{220}$ Secondly, when a Community institution acts in the place of another institution, for example where the Commission acts when the Council should have acted. ${ }^{221}$ Thirdly, when a certain act applies on territory outside the EC. ${ }^{222}$ Fourthly, when the wrong instrument has been used for a certain act, for example when a Directive has been used where a Regulation should have been used. $^{223}$

219 Cases 42/59 and 49/59, Judgment of 22/03/1961, S.N.U.P.A.T./ECSC High Authority (Rec.1961,p.103), 42/59 Order of 30/06/1961, Breedband N.V./Société des Aciéries du Temple and others (Rec.1962,p.323), ), 42/59 Third-party proceedings of 12/07/1962, Breedband N.V./Société des Aciéries du Temple and others (Rec.1962, p.271). See also A. Albors-Llorens, private parties in European Community law; Challenging Community measures, p. 16.

220 Case 6/69 and 11/69, Judgment of 10/12/1969, Commission/France (Rec.1969, p.523).

221 Case C-202/88 Judgment of 19/03/1991, France/Commission (Rec.1991,p.I-1223).

222 Cases 89/85, 104/85, 114/85, 116/85, 117/85, 125/85, 126/85, 127/85, 128/85 and 129/85, Judgment of 27/09/1988, Ahlstrom/Commission (Rec.1988,p.5193), ) 89/85 Judgment of 31/03/1993, Ahlström/Commission (Rec.1993,p.I-1307) 89/85 Order of 20/01/1994, Ahlström and others/Commission (Rec.1994,p.I-99),

223 Case $228 / 82$ and $229 / 82$, Judgment of 28/02/1984, Ford/Commission (Rec.1984, p.1129), 228/82 Order of 29/09/1982, Ford/Commission (Rec.1982,p.3091), and 229/ 82 Order of 06/09/1982, Ford AG/Commission (Rec.1982,p.2849). 
Examples of the second ground are the failure to give adequate reasons or to obtain the required proposals or opinions. ${ }^{224}$

The third ground has the widest scope. All Community institutions must act in a way that respects the rule of law. ${ }^{225}$ The rule of law implies that the European institutions are bound in the performance of their functions by the Constitutional Charter of the EC, i.e. by the Treaties and their subsequent amendments, their Annexes and Protocols, and the Treaties of Accession of new Member States. They are also bound by the general principles of law as developed by the case law of the $\mathrm{ECJ}^{226}$ and by the international agreements concluded by the Community. ${ }^{227}$

The fourth ground, misuse of powers, occurs, according to the ECJ, when a decision appears, on the basis of objective, relevant and consistent factors to have been taken with the exclusive purpose, or at any rate the main purpose, of achieving an end other than that stated or evading a procedure specifically prescribed by the Treaty for dealing with the circumstances of the case. ${ }^{228}$

\subsection{Alternatives}

Apart from the procedures prescribed in Article 230 and 232 EC Treaty, there might be some other possibilities for the European social partners' organisations to at least influence the outcome of proceedings where implemented European agreements are at stake. Some of these possibilities already exist, like the possibility of intervention, which will be discussed in para. 8.3.1. Another possibility is to bring or to intervene in a preliminary procedure, which will be discussed in para. 8.3.2. A possibility which does not (yet) exist is the action by a European social partners' organisation against a Member State, which will be discussed in para. 8.3.3.

224 P.J.G. Kapteyn and P. VerLoren van Themaat, Introduction to the law of the EC, p. 464.

225 Case $294 / 83$.

226 See for example Case 4/73 (respect for fundamental human rights), Judgment of 14/05/1974, Nold KG/Commission (Rec.1974,p.491), 4/73 Order of 24/09/1975, Nold KG/Commission (Rec.1975,p.985), 4/73 Order of 11/01/1977, Nold KG/Commission (Rec.1977,p.1); Case18/57 (principle of proportionality), Judgment of 20/03/1959, Nold KG/ECSC High Authority (Rec.1959,p.89), 18/57 Order of 04/12/1957, Nold KG/ECSC High Authority (Rec.1957,p.233); Case 112/77 (legitimate expectations), Judgment of 03/05/1978, Töpfer/Commission (Rec.1978, p.1019); Case 169/80 (legal certainty), Judgment of 09/07/1981, Gondrand (Rec.1981, p.1931), Case 106/83 (equality), Judgment of 13/12/1984, Sermide (Rec.1984,p.4209), and Case 17/74 (fair hearing), Judgment of 23/10/1974, Transocean Marine Paint Association/Commission (Rec.1974,p.1063).

227 Cases 21-24/72Judgment of 12/12/1972, International Fruit Company and others/ Produktschap voor Groenten en Fruit (Rec.1972,p.1219).

228 Case C-331/88, Judgment of 13/11/1990, The Queen/Mistry of Agriculture, Fisheries and Food ex parte FEDESA and others, (Rec.1990,p.I-4023), at 4065. 


\subsubsection{Intervention}

Article 37 of the Statute of the ECJ states:

"Member States and institutions of the Community may intervene in cases before the Court. The same right shall be open to any other person establishing an interest in the result of any case submitted to the Court, save in cases between Member States, between institutions of the Community or between Member States and institutions of the Community. Submissions made in an application to intervene shall be limited to supporting the submissions of one of the parties".

The Rules of Procedure of the CFI also allow intervention. ${ }^{229}$ Harlow is of the opinion that the most economical way to increase interest representation without overloading the ECJ/CFI is not by changing the locus standi rules, but through the intervention procedure. ${ }^{230}$ With regard to the concept of "other person" in Article 37, there is no distinction between individuals and associations. This means that European social partners' organisations in principle can intervene in cases before the ECJ. There are, however, some limitations. In the first ${ }_{\text {f }}$ nlace thev mav not intervene in cases between Member States, between institutions of the Community or between Member States and institutions of the Community. Their right of intervention is thus limited to cases where individuals are the applicant or the defendant, or both. This limitation is not included, however, in the intervention rule of the CFI. Furthermore, the organisations can only support the position of one of the parties and has no control over the proceedings as such, as Article 37, $3^{\text {rd }}$ sentence of the Statute prescribes. As regards the CFI, the intervener may also intervene to oppose the form of order sought by the party that instituted the procedure. ${ }^{231}$ Finally, Article 93(4) of the Rules of Procedure of the ECJ provides that an intervener must accept the case as he finds it at the time of his intervention, and cannot raise arguments referring to his own interests. This is also so for intervention before the CFI. ${ }^{232}$

\subsubsection{Preliminary procedures on the basis of Article 234 EC Treaty}

Article 234 EC Treaty states:

"The Court of Justice shall have jurisdiction to give preliminary rulings concerning:

a) the interpretation of this Treaty;

229 Article 115 of the Rules of Procedure of the CFI.

230 C. Harlow, Towards a theory of access for the European Court of Justice, Yearbook of European Law no. 12, 1992, Oxford, 1993, p. 246.

231 Article 115, para. 4a.

232 Article 115, para. 3. 
b) the validity and interpretation of acts of the institutions of the Community and of the ECB;

c) the interpretation of the statutes of the bodies established by an act of the Council, where those statutes so provide.

Where such a question is raised before any court or tribunal of a Member State, that court or tribunal may, if it considers that a decision on the question is necessary to enable it to give judgement, request the Court of Justice to give a ruling thereon."

In several cases, the preliminary rulings of the $\mathrm{ECJ}$ may have a huge impact on the social law of the EU and thus strongly affect the role of the social partners, for example in the Borsana case ${ }^{233}$ and the Albany case. ${ }^{234}$ This will become even more obvious when, in the future, the ECJ is requested to give its interpretation of acts made by the EU that have their origin in European agreements, for example the Directive on Parental Leave.

The preliminary procedure could enable European social partners to support individuals in cases they bring before national courts where they refer questions of EC law. However, also this procedure has several disadvantages. If individuals want the question of the validity of a Community act to be referred to the ECJ, they will have to conduct themselves in a way which contravenes the act in question (and which may expose them to criminal penalties), in order to provoke an action against them in the national courts. Many potential applicants would justifiably find such a course of action fraught with danger. ${ }^{235}$ This argument was also recognised by the CFI in the Jégo-Quéré case. Another disadvantage is that the decision whether or not to make a reference to the European court lies with the national court. If the national court decides not to make a reference, the parties will have to appeal against that decision, until they reach the highest court that can judge the case. That involves extra delay and extra costs. ${ }^{236}$ However, even then, there remains uncertainty. The highest court may decide that the Community act is an acte clair. The acte clair doctrine implies that a court will not ask for a reference when it is thought that the answer is sufficiently clear. ${ }^{237}$ Once a reference is made, there are two other limitations: First private parties may

233 Case C-2/97, Judgment of 17/12/1998, IP (Rec.1998,p.I-8597).

234 Case C-67/96, Judgment of 21/09/1999, Albany (Rec.1999,p.I-5751). Bercusson mentions in his paper "The ETUC and the European Court of Justice: action or re-action?" some pending cases and complaints which could lead to Commission action against Member States, p. 3.

235 A. Arnull, Challenging Community acts - An introduction. In: H.W. Micklitz and N. Reich, Public Interest Litigation before European courts, p. 52. See also A. AlborsLlorens, private parties in European Community law; Challenging Community measures, p. 192.

236 A. Albors-Llorens, private parties in European Community law; Challenging Community measures, p. 188-189.

237 A. Albors-Llorens, private parties in European Community law; Challenging Community measures, p. 189. 
not contest the description of the facts submitted by the national court. ${ }^{238}$ Second, it is also for the national court to decide the scope of the questions referred. ${ }^{239}$ It is also possible that the European court refuses to give a preliminary ruling. This has occurred in the past, for example because the question asked by the national court was one of national law, ${ }^{240}$ or when no question of EC law arose, ${ }^{241}$ or when at the time the preliminary reference was made the national proceedings had been terminated. ${ }^{242}$

\subsubsection{Action against Member States on the basis of Article 226 EC Treaty}

The possibilities discussed under para. 8.3.1. and 8.3.2. are directed towards the Community act itself. It is however also thinkable that there are no objections against the Community act, but that the European social partners want to control the correct implementation of this Community act. In particular, this is so when it concerns Community acts that are based on European agreements, like the Parental Leave Directive. At this moment, that it not possible according to current EC law.

Article 226 EC Treaty states:

"If the Commission considers that a Member State has failed to fulfill an obligation under this Treaty, it shall deliver a reasoned opinion on the matter after giving the state concerned the opportunity to submit its obervations.

If the State concerned does not comply with the period laid down by the Commission, the latter may bring the matter before the Court of Justice."

In this procedure, there is no official role for the European social partners' organisations. It can be argued that they should have an official role when it comes to Community law which is the result of a European agreement, such as the Directive on Parental Leave. The European social partners have a vested interest in controlling its implementation by the Member States, since it was their intention after all to turn their agreement in an instrument which also produced legal effects on individuals who were not a member of the signatory parties. An analogy can be drawn with the procedures in the

238 Case 104/77, Judgment of 16/03/1978, Öhlschläger/Hauptzollamt Emmerich (Rec 1978,p.791), and Case C-364/92, Judgment of 19/01/1994, SAT Fluggesellschaft/ Eurocontrol (Rec.1994,p.I-43).

239 A. Albors-Llorens, private parties in European Community law; Challenging Community measures, Oxford, 1996, p. 190.

240 Case $93 / 75$, Judgment of $17 / 12 / 1975$, Adlerblum/Caisse nationale d'assurance vieillesse des travailleurs salariés (Rec.1975,p.2147).

241 Case 132/81, Judgment of 16/09/1982, ONTPS/Vlaeminck (Rec.1982,p.2953).

242 Case 338/85, Judgment of 21/04/1988, Pardini/Ministero del commercio con l'estero (Rec.1988,p.2041). See also A. Albors-Llorens, private parties in European Community law; Challenging Community measures, Oxford, 1996, p. 193. 
framework of the ILO and the ESC of the Council of Europe, where the national social parties are formally in a position to be consulted and to present their observations on the compliance of their State with the international documents. Those well-established and functional traditions can be an argument to improve the involvement of the European social partners in the supervisory process in relation to the improvement of EU social law. One could even go a step further and entitle the European social partners to a right of their own to bring infraction procedures before the ECJ/CFI. ${ }^{243}$ This right should only belong to those organisations that have been a party to the European agreement which has been implemented into Community legislation.

\subsubsection{Conclusions}

Apart from seeking the annulment of a Council decision, the European social partners' organisations can also try to influence proceedings where implemented European agreements are at stake. They can do this through the method of intervention. The main disadvantages of this method are, however, that the social partners are in such a case dependent on another party who has to bring a case before the ECJ/CFI, and that the social partners must accept the case as they find it at the moment of intervention.

Another method is the preliminary proceeding. Through the preliminary proceeding, the European social partners' organisations can play a supportive role for individuals that bring cases before national courts. This is especially relevant where it concerns questions on Community legislation which is based on European agreements. Individuals might however hesitate to start such proceedings because they will have to contravene the act in question. Furthermore, it depends to a great extent on the national courts whether the case will eventually come before the European court.

When it comes to the implementation of Community law which is based on a European agreement, I recommend that the authors of the European agreement get an official role in controlling the correct implementation by the Member States. For example by giving them the right to start infraction procedures against a Member State, like the Commission now has on the basis of Article 226 EC Treaty.

\subsection{Conclusions}

For private parties such as European social partners' organisations, there are several ways to have access to the ECJ/CFI. The only direct possibility, however, for them to seek the annulment of Commission and Council decisions,

243 See also A. Jacobs, The European Court of Justice, social law and the European social partners. In: R. Blanpain (ed.) Labour law, human rights and social justice, 2001, Deventer, p. 150. 
is stipulated in Article 230, $4^{\text {th }}$ sentence EC Treaty. During the years, an enormous case law has been developed with regard to this provision. As regards the possibilities for European social partners' organisations to seek the annulment of Commission and Council decisions in the context of the procedure of Article 139(2) EC Treaty, there are reasons to be optimistic.

As long as they fulfill the conditions which the ECJ has formulated on legal personality, they can, as an organisation, start proceedings. These conditions are that the organisation is responsible and independent. Furthermore it must be representative. An organisation can in any case institute proceedings on the basis of Article $2304^{\text {th }}$ sentence if it has been involved in the decision making process leading to the contested measure. It is thus not necessary that the organisation fulfil national conditions on legal personality. This makes it possible that also de facto organisations, such as the ETUC and UNICE, can institute proceedings in the name of the organisation itself. It goes without saying that also the other conditions of Article $2304^{\text {th }}$ sentence EC Treaty have to be fulfilled in order to be admissible. These other conditions are related to the nature of the contested measure, the grounds of annulment and the time limit to institute proceedings.

Most case law has been developed on the nature of the measure that is being attacked by the private party. According to the words of Article 230, 4th sentence, private parties may only attack Decisions. However, over the years, the ECJ and CFI have taken a more relaxed approach towards this condition. The European courts are, in principle, willing to allow proceedings against Regulations and even Directives as well, as long as the contested measure produces legal effects. If a private party seeks the annulment of a measure which is not addressed to him, the measure must be of direct and individual concern to him in order to be successfully attacked. Direct concern means that the measure must be the direct cause of the damage suffered and that it constitutes a rule which is sufficient in itself and requires no further implementation measures. For individual concern the Plaumann criteria remained the most important formula for a long time. In the UEAPME case, the CFI was willing to accept that a European social partners' organisations could be directly and individually concerned if the Commission or Council had failed to fulfill their obligations under the procedure of Article 139(2) EC Treaty. The Jégo-Quéré case has broadened the concept of individual concern.

The decision of the Commission to grant financial support to certain European social partners' organisations, can be regarded a Decision addressed to them. This flows from the Les Verts case. The refusal to give financial support to certain European social partners' organisations can, under certain circumstances, be of direct and individual concern to them. This will especially be the case if their application for such support has been seriously taken into account by the Commission. This can be derived from the Murgia Messapica case. 
The decision of the Commission to consult the social partners will only be attacked (if it is to be attacked at all), by organisations that have not been consulted. However, for a successful attack of this decision, they shall, in any case, have to wait until the Council has taken a decision which produces legal effects. This flows from the IBM case. At this moment, it is however not at all certain whether the European social partners' organisations that have not been consulted with regard to certain Community legislation can seek the annulment of that legislation. Their situation is not exactly comparable to the situation of the EP in the Parliament case, because, unlike the EP, they are not Community institutions. Only if the CFI would be willing to adopt a broad approach of the right to legal protection, would they have a chance to win such an annulment procedure. For the future, I recommend that the Commission develops a method through which the decision whom to consult and whom not to consult can be avoided. This method would consist of publishing the Commission proposal for the first and second consultation in the OJ. All organisations who wish to do so can give their comments and criticisms. The Commission picks all useful comments and gives a thorough reasoning, which must be available to the public, with regard to the final proposal it has formulated. This obligation to give a reasoning would also make the work of the CFI easier in investigating whether certain opinions have sufficiently been taken into account. The Andersen case shows that the $\mathrm{ECJ}$ is in principle willing to make such an investigation, although in that case it concerned the opinion of the EP. The CFI should, in case of arbitrary or capricious decisions either annul the Community act or send the rule back to the Commission for further explanation.

A refusal of the Commission to react on a request of the social partners to turn their agreement into a legislative proposal, does not constitute the failure to give a Decision and can therefore not be subject to legal review under Article 232 EC Treaty. The explicit refusal to draw a legislative proposal as well as the decision to draw such a proposal, both cannot be regarded Decisions creating legal effects and can therefore not be subject to legal review under Article $2304^{\text {th }}$ sentence EC Treaty. This flows from the IBM case. At this moment, there is no legal obligation for the Commission to motivate its decision whether or not it will draw a legislative proposal. The obligation to state the reasons as laid down in Article 253 EC Treaty is not applicable, since this provision only applies to acts having legal effects. For the future, however, I recommend that this obligation should be introduced, especially where the Commission has consulted the social partners and subsequently remained passive during their negotiations. This duty of motivation could be made easier for the Commission if it develops clear and elaborated policy rules in which the procedure and criteria for the acceptance of European agreements is laid down. The European agreement could be published in the OJ and comments be delivered by other organisations who did not participate in the procedure leading to the conclusion of the agreement. The 
assessment of it by the Commission could be done on the basis of the (more elaborated) criteria it already applies now. Also here, the way the Commission came to the decision of whether or not turn the agreement into a legislative proposal should be made available for the public.

If the Council refuses to adopt the Commission proposal formulated on the basis of a European agreement, there is nothing the European social partners' organisations can do. The Council is not obliged to take a decision. This flows from the voting requirements within the Council. For the future, I recommend an obligation for the Council to motivate its refusal, given the special character of the procedure of Article 139(2) EC Treaty and the advantage that the social partners can take the arguments of the Council into account by the formulation of new European agreements. If the Council turns the Commission proposal into Community law, for example a Directive, the European social partners' organisations are in principle admissible to seek the annulment of this decision, as the UEAPME case has proved. The complaints of the social partners' organisations seeking the annulment of the Council decision, will be mainly directed towards the way the Commission has assessed the agreement before it turned it into a legislative proposal. It remains to be seen whether in the future the legal review of this assessment, for which an initial impetus has been given by the CFI in the UIEAPME case, will be expanded by the CFI/ECJ.

There are also some alternative procedures. These are the intervention based on the Rules of Procedure of the CFI/ECJ and the preliminary procedure, based on Article 234 EC Treaty. In these procedures, the European social partners' organisations are not the applicants themselves, which is at the same time the main disadvantage of these procedures. A procedure which could be developed for the future is the infraction procedure against Member States, brought by the European social partners' organisation on the basis of Article 226 EC Treaty. This should only be possible for Community law that is the result of a European agreement (such as the Directive on Parental Leave) and the organisations starting the procedure would only be those that were the authors of the underlying European agreement. 
PART IV

CONCLUSIONS AND RECOMMENDATIONS 



\section{CHAPTER 9}

\section{CONCLUSIONS AND RECOMMENDATIONS}

\section{The inclusion of the Articles 138 and 139 in the EC Treaty}

Article 138 EC Treaty lays down certain obligations of the Commission with regard to the support given to the European social partners' organisations and with regard to their consultation. The Sectoral Dialogue Committees (SDCs) installed by the Commission in 1998 serve as consultation bodies for the Commission and as fora for the promotion and development of the social dialogue at sectoral level. These SDCs consist of European social partners' organisations at sectoral level. Article 139 EC Treaty lays down that agreements at Community level can be concluded and that these agreements can be turned into Community legislation. The articles were originally included in the Agreement on Social Policy which was annexed to the Protocol on Social Policy by the Maastricht Treaty of 1992. The Commission, the Council, consisting of all Member States and the European employers' and workers' organisations all had their own reasons to support the inclusion of these articles in the Agreement. The conclusion of agreements at European level between the European social partners' organisations, has, however always been possible. It was not necessary to put that explicitly in the EC Treaty. Meetings between the social partners' organisations at European level already took place before the Maastricht Treaty, but these meetings never resulted in the conclusion of binding agreements. New aspects of the Maastricht Treaty are that the European social partners' organisations are officially involved in the drafting of European social legislation, and that their agreements can be turned into Community legislation. This means that they fulfil a role as advisory organs and as semi-legislators.

\section{Reasons to conclude European agreements}

Agreements are concluded between European social partners' organisations at intersectoral as well as sectoral level. The intersectoral organisations ETUC, UNICE, and CEEP play the most active role when it comes to the conclusion of European intersectoral agreements. European workers' organisations such as the ETUC consider the conclusion of European agreements as a way to participate actively in the making of European labour law. They are, however, at this moment still very dependent on Community institutions such as the Commission and the Council. Because of the active role of the Commission in the field of social policy legislation, employers' organisations seem willing to come to the negotiation table in order to conclude European agreements with trade unions. This means that the European trade unions are still dependent on the "threat of legislation". They are at this moment, as 
Bercusson has rightly put it, "bargaining in the shadow of the law". ${ }^{1}$ This is illustrated by the fact that the agreements concluded so far all covered subjects which had already been on the agenda for legislation since a long time. The threat of legislation is absent in the fields where the Community institutions do not want or are not allowed to legislate. An important instrument for trade unions at national level to force employers' organisations to negotiate with them is the threat of strikes. This instrument has not yet been used very much at European level. The fact that there is no express right to strike at Community level does not stimulate the use of this instrument because it is not clear what the limits to this right are and which types of strikes are permitted. Without a right to strike at Community level it will be difficult to develop a genuine European social dialogue.

\section{Legal character of and conditions for European agreements}

\section{Present situation}

So far, three intersectoral agreements have been concluded and four sectoral agreements. These agreements are all cautiously formulated and can certainly not be called very revolutionary as regards their content. The fact that they have been concluded at all is more important than their content. Community law does not say anything about the legal character of European agreements. Since it regards international agreements, international legal sources should be used to determine their legal character. The now existing European agreements can be regarded collective agreements because they fulfil global definitions of collective agreements laid down in ILO documents, in the ESC and as given by the ECJ in the Albany case.

\section{Recommendations for the future}

If a European collective labour legislation were to be developed in the future it is recommended that it determines what the legal character is of the European collective agreements. Inspiration could be found in the Principles of European Contract Law or international legal sources, such as ILO documents, the ESC or the case law of the ECJ. In such a European collective labour legislation it should also be determined that European collective agreements fulfil certain conditions with regard to the concluding parties, the bargaining procedure, their form and their content. This is also the case with regard to collective agreements in most Member States. It would increase the legitimacy of European collective agreements. Important requirements with regard to the concluding parties of a European collective agreement are in my view that they have democratic internal decision-making procedures and that they be independent from each other and from the European, national, and local authorities. An important requirement with regard to the bargain-

1 B. Bercusson, European labour law, p. 538-539. 
ing procedure is that the European social partners' organisations have a clear mandate from their national affiliates to bargain on their behalf. They should also be authorised in their statutes by their national affiliates to conclude valid collective agreements. With regard to the form of the agreement it is recommended that the agreement be in writing and that it be stipulated in the agreement which language version is the official one. Furthermore, awareness of European collective agreements should become more available to the public. This could be done by publishing the agreement in the Official Journal of the EC and on the internet. With regard to the content of the agreement, it is important that it is not contrary to Community law, fundamental human rights or the public order. Since European collective agreements will be implemented by the national affiliates of the European organisations, the latter have to make sure that the agreement is not contrary to the national legislation of the Member States unless it contains provisions that are more favourable to those to be protected by it.

\section{Legal consequences of European collective agreements}

\section{Present situation}

Indicating the legal character of agreements concluded between the European social partners' organisations is one thing. Finding out what the legal consequences are of the conclusion of such agreements is another. In the following, I will make the assumption that the European collective agreement will not be turned into Community legislation but will be implemented by the national affiliates of the signatory parties, in accordance with the procedure of Article 139(2), first part, EC Treaty. There are several actors involved in the conclusion of European collective agreements. These are the European social partners' organisations, their national affiliates - is consisting of national trade unions and national employers organisations - and the individual workers and employers in the various Member States. Since Community legislation does not give any hints as to the legal consequences of the conclusion of European collective agreements for the various actors, I have tried to indicate these consequences mainly on the basis of (private) international law. If European collective agreements have legal consequences there should also be possibilities to enforce these consequences. Community legislation is also silent on this point. So here, I have used (private) international law as well to indicate enforcement possibilities.

Legal consequences for the signatory parties are created as soon as a European collective agreement has been concluded, even before it is implemented in any way whatsoever. I have argued in Chapter 5, that there are reasons to assume that the European collective agreements concluded so far are contracts between the signatory parties in accordance with Belgian private law. This means that the enforcement of the compliance with the provisions addressed to the signatory parties also has to be done in accordance with 
Belgian contract law. Belgian contract law indicates four basic courses of action: Specific performance, damages, exceptio non adimpleti contractus, and termination. Specific performance is only effective when it can be combined with economic pressure, for example in the form of an astreinte. This will be difficult because certain European social partners' organisations lack legal personality. Therefore the claim of an astreinte can not be made effective. Furthermore, specific performance only makes sense when it is very clear what can be expected from the party who has to perform. This means that the claim of performance has to concern clear and concrete rights and obligations. The rights and obligations for the signatory parties in the European collective agreements concluded so far are often not sufficiently concrete to make the claim of specific performance effective. The action of damages can not be made effective either, for the same reason as the astreinte: the lack of legal personality of certain European social partners' organisations. The action of exceptio non adimpleti contractus could be effective. For example, if the European employers' organisations were to obstruct the realisation of the aims set out in the European collective agreement, the European trade union could call a strike. Furthermore, the threat to terminate the European collective agreement can also be an effective enforcement mechanism. This instrument in particular will not, however, readily be used by the trade unions, since it is very difficult to conclude European collective agreements at all, due to the reluctant attitude of the employers' organisations. This means that the European trade unions have at this moment only one real enforcement mechanism: the strike at European level. I very much doubt however, whether this instrument will or can very often be used. It would require that individual workers in several Member States would be willing to strike in order to enforce the compliance with the European collective agreement. The law on strikes differs from Member State to Member State and it is therefore questionable whether such a European strike could be made effective. The trade unions can of course always ask the Commission and Council to issue legislation if the European collective agreement is not complied with by the employers' organisations. This means, however, that their dependency on the Community legislator is maintained. But also the employers' organisations are benefited by compliance with the European collective agreement by the trade unions. Collective agreements generally contain obligations for employers and workers. This will not be different for collective agreements at European level. Moreover, the Commission might want to issue legislation on the field covered by the European collective agreement if it concludes that this agreement is not effective. This will be the case if the European trade unions do not comply with its provisions. This legislation could turn out worse for employers than the European collective agreement. The European employers' organisations can of course terminate the European collective agreement in case of non- compliance by the trade unions. I think however that this will not be very fruitful for them since also in that case the Commission could decide to propose legislation in the field covered by the 
(terminated) agreement. Therefore the enforcement mechanisms of specific performance (together with an astreinte) and damages must not be underestimated. Effective use of these enforcement mechanisms could prevent the termination of the European collective agreement - and thus prevent Community legislation - or the outbreak of strikes in which probably very few workers would participate. The use of enforcement mechanisms such as specific performance and damages requires however that the European social partners' organisations acquire legal personality in accordance with Belgian law. This is something that could easily and quickly be done at this moment.

As soon as the European collective agreement has been concluded, legal consequences for the national affiliates of the signatory parties can only derive from the internal rules of the European social partners' organisations in combination with private international law. Private law concepts such as mandate and agency could be used to answer the question whether the national affiliates are obliged to implement the European collective agreement. But since the concepts of mandate and agency differ from country to country, the question as to the obligations for the national affiliates can lead to different answers as well. Even if on the basis of these concepts rights and obligations for the national affiliates can be assumed, enforcement will be difficult. The European organisation can of course expel its national affiliate in accordance with its internal rules of procedure. The internal rules of procedure of most European social partners' organisations do not, however, give any specific rules with regard to the obligations of the national affiliates flowing from the conclusion of the European collective agreements.

European collective agreements do not create direct legal consequences for individuals because Article 139(2) EC Treaty specifically states that European agreements have to be implemented. This means that European collective agreements only have legal consequences for individuals if they have been implemented by national collective agreements. It is from these national agreements that rights and obligations can be derived for individual workers and employers, in accordance with the national law of the Member States. If European collective agreements have not correctly been implemented, individual workers and employers can not undertake any legal actions. The enforcement of the terms of the European collective agreement against individual workers and employers will be done in accordance with national law if the European collective agreement has been implemented by the national affiliates of the European signatory parties.

For the Member States legal consequences will never be created by European collective agreements. That is so, at least, not as long as these agreements have not been turned into Community law. The Declaration of the Member States which was added by Article 139(2) EC Treaty in 1992 was therefore not 
really necessary. This Declaration confirms that European collective agreements can never impose any obligations whatsoever on Member States.

\section{Recommendations for the future}

Complicated problems with regard to the legal consequences and enforcement of European collective agreements can easily be avoided if all agreements are turned into a Council decision on the basis of Article 139(2) EC Treaty. However, this has several disadvantages. In the first place, it will make the European social partners' organisations very dependent on Community institutions such as the Commission and the Council. In the second place, the subjects of the European collective agreements will be limited. A European agreement can only be turned into a Council decision if it covers subjects that are mentioned in Article 137 EC Treaty. If the European social partners' organisations want a genuine European social dialogue without too much involvement from the Community institutions, they have to develop clear rules on the legal consequences and enforcement mechanisms with regard to European collective agreements. In Chapters 5 and 6, I have given some ideas for the future as regards the legal consequences of the conclusion of European collective agreements and the enforcement of these legal consequences for the various actors. The best option would be to develop a European collective labour legislation. In this legislation, the legal consequences of the conclusion of European collective agreements could be clearly laid down, as well as the means to enforce these legal consequences. It will probably take a long time before such a collective labour law is developed, apart from the question whether the actors in the European social dialogue want such legislation. Therefore, where possible, I have also given some ideas which can be used in the near future, without having to develop a specific European collective labour legislation.

The rights and obligations for the signatory parties should be clearly laid down in the European collective agreements themselves. A future European collective labour legislation could provide that European collective agreements create legal consequences for the signatory parties, unless they stipulate in the agreement itself that they do not want to create legal consequences. Whatever legal consequences for the signatory parties will be created, I think that every European collective agreement should imply at least two basic obligations for the signatory parties. The first is the obligation to exercise influence on their members to implement the European agreement. The second is the peace obligation. For the supervision on the compliance with these obligations a conciliation, mediation, or arbitration service could be developed. The already existing Sectoral Dialogue Committees could fulfil a useful role as a conciliation organ. These Committees could provide conciliation services if one of the signatory parties is of the opinion that the other one(s) do(es) not comply with its/their obligations. There should however also be a 
body of appeal which I have called a European Conciliation and Mediation Service (EMCS). This service could already play a role during the negotiations on the European collective agreement and could fulfil arbitration tasks if conciliation prove fruitless. The advantage of an EMCS above the SDCs is that the members of the EMCS could be selected on their independence from the signatory parties and on the basis of certain qualifications such as special mediation skills and knowledge in the field of industrial relations. Such an EMCS could be established by a European collective agreement. In this way the European social partners' organisations are free to determine its functions and powers.

In the near future, clear internal consultation processes during the negotiations on European collective agreements can prevent national organisations being unwilling to implement these agreements. These consultation processes could make sure that possible barriers for the national organisations to the implementation of the European collective agreements can be removed. Enforcement of the European collective agreement towards the national affiliates could in the near future be made easier if these national affiliates sign the European agreement as well. In this way they are directly bound to the European agreement without complicated theories on mandate and agency having to be applied. If at the same time it is laid down which national law applies to the European collective agreement, enforcement against the national affiliates can be done in accordance with this national law. It is also important to lay down that as long as the European collective agreement is in force, national agreements must not be contrary to them. This is important because otherwise national agreements could be concluded to implement the European collective agreement and after a certain time be terminated and replaced by agreements that are contrary to the European collective agreement. A future European collective labour legislation could more precisely lay down what the legal consequences of a European collective agreement are for the national affiliates of the signatory parties. The obligation for the national affiliates in the future should in my view be that they implement the European collective agreement within a certain time by using it as a basis for negotiations at national level. Practically this can mean that it is stipulated in the national collective agreement that the European collective agreement will be incorporated in it. Also here the Sectoral Dialogue Committees could play a useful role. They could help the national affiliates to implement the European collective agreement by advising them on how certain provisions of the European agreement should be implemented and/or interpreted. The EMCS could play a role again if non-implementation of the European collective agreement leads to a conflict between the signatory parties themselves. This could occur, for example, if the European employers' organisation is of the opinion that the European trade union does not put enough pressure on its national affiliates to implement the agreement. 
Individual workers and employers could gain a stronger position in the future if European collective agreements could under certain conditions have direct legal consequences for them. In this way individuals would not be completely dependent on national trade unions and employers organisations. National organisations would at the same time be stimulated to implement the European collective agreement. The question whether certain provisions of the European agreement have direct effect could be answered by the Sectoral Dialogue Committees. The national court or institution, to which the individual worker or employer has to go to seek the direct effect, could ask a preliminary advice from these Sectoral Dialogue Committees. Direct effect of European agreements can only be developed if Community legislation on the legal effects of European collective agreements would be developed. I have give some ideas for such legislation with regard to the conditions for the entering of direct effect, the conditions on the provisions to be directly applicable, and direct effect from one individual towards another. The idea of individuals invoking damages from the national organisations for the nonimplementation of a European collective agreement is not preferred by me. It is not very useful since it will sometimes be difficult to determine who exactly is responsible for the non-implementation of European collective agreements. There are afways more parties who are responsible for this implementation.

\section{Representativity of the European social partners' organisations in the consultation phase}

\section{Present situation}

The new role of the European social partners' organisations since the Maastricht Treaty poses questions as to their representativity. This is a subject which is important when it comes to the question which organisations are to be consulted by the Commission. On the basis of Article 138(2) and (3) EC Treaty, the Commission has a legal obligation to consult the social partners before submitting proposals in the social policy field. By its first Communication on the European social dialogue of 1993, the Commission has annexed a list of European social partners' organisations which it considers representative enough to be consulted. It has formulated this list on the basis of certain representativity criteria. These are that the organisations should:

- be cross industry or relate to specific sectors or categories and be organized at European level;

- consist of organisations which are themselves an integral and recognised part of Member State social partner structures and with the capacity to negotiate agreements, and which are representative of all Member States, as far as possible; 
- have adequate structures to ensure their effective participation in the consultation process.

On the basis of these criteria the Commission will keep under review the list of organisations to be consulted. The European Parliament, the ECOSOC, and the social partners' organisations ETUC, UNICE and CEEP have formulated a number of representativity criteria as well. These criteria have not been taken over by the Commission.

\section{Recommendations for the future}

Certain of the criteria formulated within the EP, ECOSOC, and ETUC, UNICE, and CEEP are very valuable and should be seriously considered by the Commission. On the basis of the suggestions of these other groups, I have formulated a list of representativity criteria myself in Chapter 4, which in my view should be used by the Commission. Nevertheless, with regard to the representativity issue, differences of opinion can remain between the Commission and the European social partners' organisations. The Commission can for example decide not to consult certain organisations because it does not consider them representative. This problem can easily be avoided without giving a verdict on the representativity criteria of the Commission. The Commission could publish its proposal for the first and second consultation on the basis of Article 138(2) and (3) EC Treaty in the Official Journal. All organisations who want to give their comments and critics can do this. The Commission can consider the comments and take a well founded decision, which must be available for the public, with regard to the final proposal it has formulated. In my opinion, the Commission is certainly not obliged to take over all the comments of the social partners if it consults them on the basis of Article 138(2) and (3) EC Treaty. Arbitrary decisions can however be avoided by stating the reasons for the ultimate Commission proposal. I think that this procedure would be the best option at the moment since it is absolutely not certain whether European social partners' organisations could legally attack Community measures on the basis of Article 230(4) EC Treaty which have been taken without them having been consulted. Such an attack will only be successful if the CFI/ECJ would be willing to adopt a broad approach to the right to legal protection.

\section{Representativity of the European social partners' organisations in the implementation phase}

\section{Present situation}

The other moment in the European social dialogue in which the representativity is important is when it comes to the implementation of European collective agreements by means of a Council decision. This is done in accordance with the procedure prescribed in Article 139(2) EC Treaty. The conse- 
quence of this implementation is that agreements concluded between private parties, i.e. the European social partners' organisations, become Community law, which applies on all Community citizens. This includes those who are not represented by the parties that concluded the agreement. The parties to these agreements should therefore be representative. For Council decisions on the basis of Article 139(2) EC Treaty the Commission first has to formulate a legislative proposal on the basis of the European collective agreement. The representativity of the European social partners' organisations is checked by the Commission. It thereby uses the same criteria as when it consults them on the basis of the Articles 138(2) and (3) EC Treaty. If it considers the European social partners' organisations not representative, it can refuse to formulate a legislative proposal for the Council on the basis of their agreement. The European social partners' organisations can not legally attack the refusal of the Commission to formulate a legislative proposal. The situation is different when they want to attack Community measures which have been taken in accordance with the procedure of Article 139(2) EC Treaty. This implies that the Commission first has formulated a legislative proposal on the basis of a European agreement. It has therefore checked the representativity of the signatory parties to this agreement and concluded that this representativity was sufficient. It is possible that certain European social partners' organisations consider themselves representative but nevertheless have been excluded from the negotiations on the European agreement. These organisations might want to seek the annulment of the Council decision, because they are of the opinion that the Commission has not applied the representativity check correctly. This was, among others, at stake in the UEAPM case. The UEAPME case has proved that a Council Directive which has been adopted in accordance with the procedure of Article 139(2) EC Treaty can in principle be legally attacked on the basis of Article 230(4) EC Treaty. Although formally the legal claim was submitted against the Council Decision taken on the basis of Article 139(2) EC Treaty, the complaint of UEAPME was directed against the way the Commission had applied its representativity criteria. The CFI said that the signatory parties to the underlying agreement must taken together be sufficiently representative. If an organisation, whose particular representation is necessary for that degree of representativity, has been excluded from the negotiations on the European collective agreement, the Council and the Commission must refuse to implement the agreement at Community level. Although UEAPME lost the case, the CFI has stated that the claim in itself was in principle admissible. This is supported by its consideration in which it states that if, for example, CEEP had not been one of the signatory parties to the said agreement, and subsequently submitted a legal claim against the Directive, it would have been admissible. In that case the Directive would probably have been annulled. 


\section{Recommendations for the future}

I support the fact that the Commission checks the representativity of the signatory parties of a European collective agreement, before it formulates a legislative proposal on the basis of such an agreement. Nevertheless, I think that the representativity criteria should be broadened with the other criteria that I have mentioned in Chapter 4. Furthermore, to avoid arbitrariness in the application of the representativity criteria, I support the introduction of a motivation duty. The motivation duty could be introduced when the Commission submits a European collective agreement to the Council in the form of a legislative proposal on the basis of Article 139(2) EC Treaty. The proposal, which will in fact consist of the European collective agreement, could be published in the Official Journal and all European social partners' organisations could submit their comments on it. Serious comments and objections should be taken into consideration by the Commission. If the Commission, notwithstanding serious objections, formulates a legislative proposal, it should give a clear motivation for it. A rejection of the European collective agreement should also be motivated by the Commission, especially when it has consulted the social partners and gave them the opportunity to negotiate an agreement in accordance with Article 138(4) EC Treaty. In my opinion, the Commission can not refuse to formulate a legislative proposal on the basis of such an agreement for lack of representativity.

\section{Role of the Commission in the European social dialogue}

\section{Present situation}

The representativity issue is only one example which proves that the role of the Commission is very substantial compared to the role of the other Community institutions such as the Council or the European Parliament (EP). The Commission also takes important decisions with regard to the financial and technical support given to European social partners' organisations on the basis of Article 138(1) EC Treaty. In Chapter 4, I have described how these decisions are taken. This support must be seen in the light of the development of the European social dialogue. The development of European industrial relations can not be compared to the development of industrial relations in the Member States. The relations between the social partners in the Member States often have a long history involving many social and economic aspects. This is less the case for the development of industrial relations at European level. In this sense, the European social dialogue could be regarded as a less spontaneous development. It was created mainly by the Commission to give more legitimacy to European social policy. The Commission is not completely free in determining whether and how much support the European social partners' organisations receive. In the first place, the budget for its support is subject to control by the European Parliament. In the second 
place the decision of the Commission to grant or refuse financial support car if the case law of the ECJ is consequently applied, be legally attacked, fo example by organisations who did not receive such support. This will espe cially be the case if their application for support has been seriously taken int account by the Commission. This can be derived from the Murgia Messapic case.

Also when it comes to their role as advisors, the European social partners organisations are less dependent on the Commission than the words of th Articles 138(2), (3), and (4) EC Treaty suggest at first sight. The Europea social partners' organisations do not have to wait passively until the Com mission consults them. Nothing in the Treaty or anywhere else forbids then to advise the Commission on their own initiative. The Commission, on th other hand, is legally obliged to consult the European social partners' organi sations before it submits proposals in the social policy field. The subjects or which the Commission has to consult the social partners are not limited t the ones mentioned in Title XI of the EC Treaty. The social partners have ti be consulted with regard to all proposals having a social or socio-economi significance. This means that they should also be consulted if the Commis sion subimits proposals on the basis of the Articles $42,158-162$, and $125-130$ EC Treaty. If a Council decision in the field of social policy is taken without any social partners' organisation being consulted by the Commission, this measure can successfully be attacked by the European social partners' organisations under Article 230(4) EC Treaty. However, I do not think that this will ever be the case. More realistic is the scenario that certain organisations will be consulted and others not. When discussing the representativity issue, I have given a possible solution to avoid this problem.

The social partners' organisations can negotiate and conclude European collective agreements at any moment they want. They do not have to wait for consultation by the Commission, as Article 138(4) EC Treaty seems to suggest. There are no legal obstacles at all to start negotiating and to conclude agreements at any given moment. This competence does not derive from Community law but from private law. There might be political obstacles however. If the social partners' organisations want their agreement to be turned into a Council decision in accordance with the procedure mentioned in Article 139(2) EC Treaty, they should rather cooperate with the Commission as much as possible. In particular in the procedure leading to negotiations between the social partners' organisations, the interplay between these organisations and the Commission is important. By means of the consultation phase the social partners can find out whether a certain agreement concluded by them will be accepted by the Commission as a basis for a legislative prot osal. 
If a European collective agreement is concluded, whether or not the European social partners' organisations first have been consulted, the signatory parties can ask the Commission to formulate a legislative proposal for the Council on the basis of their agreement. Also here, the important role of the Commission is clear. The Commission is in the first place not obliged to formulate a legislative proposal on the basis of a European collective agreement. Secondly, if it does, it applies five checks on the agreement: the representativity check (which I already discussed above), the mandate check, the legality check, the SME check and the assessment check. The application of these checks is legitimated by the Treaty (as regards the legality check, the SME check and the assessment check) and by the Court of First Instance in the UEAPME case (as regards the representativity check and the mandate check). It is possible that certain European social partners' organisations want to submit protests against the way the Commission applies these checks. Legal claims can however only be submitted against the Council decision, because only then will legal consequences be created, which is a requirement for admissibility under Article 230(4) EC Treaty. The UEAPME case proves that the application of the checks by the Commission can be subject to legal attack, at least when it considers the application of the representativity check, which will probably be the most attacked.

\section{Recommendations for the future}

If the European social partners' organisations want to become strong and independent actors in the formulation of European social policy it is recommended that they do not depend too much on financial support from (European) government institutions. National trade unions and employers' organisations should therefore make sure that the European mother organisation in Brussels receives enough money. I have made some suggestions with regard to the application of certain checks of the Commission. The mandate check in itself is necessary, but an aspect related to this check is even more important: the internal decision-making procedures of the European social partners' organisations. These processes should be democratic. This does not mean that all decisions of the social partners should be taken unanimously, but that the decision making should be organised in such a way that the will of the majority of the national affiliates is reflected in the decisions of the European organisations. The legality check should not only comprise the check whether the agreement is not contrary to Community law, but also whether it is not contrary to fundamental human rights. The SME check is in my view not necessary as a separate check, since it already falls under the legality check. The motivation duty, which I already discussed under the representativity issue, should also apply with regard to the other checks. This motivation duty could be made easier for the Commission if it develops clear and elaborated policy rules in which the procedure and criteria for the acceptance of European collective agreements as legislative proposals is laid down. These 
policy rules of the Commission could be based on the (more elaborated) checks it already applies now to European collective agreements.

\section{Role of the Council in the European social dialogue}

\section{Present situation}

The ultimate decision to turn the agreement into legislation is with the Council on the basis of Article 139(2) EC Treaty. The Council is not obliged to take a decision. This flows from the voting requirements within the Council. The Council has to decide either by qualified majority or by unanimity. The form of the Council decision shall in any case have to be a legally binding act, which excludes the instruments of the Recommendation and Opinion. The most suitable instrument will be a Directive. So far, all European collective agreements which have been implemented by Council decision have been turned into a Directive. If there have been no objections against the way the Commission checked the agreement of the social partners organisations or against the way the Commission has followed the consultation procedure, there will be no legal objections against the Council decision implementing the European collective agreement either.

\section{Recommendations for the future}

I recommend an obligation for the Council to motivate its decision if it refuses to take over the legislative proposal of the Commission. This means that the European collective agreement does not become Community law. Given the special character of the procedure of Article 139(2) EC Treaty I think that the European social partners' organisations have a right to know why the Council rejected their agreement. Motivation also has the advantage that the social partners can take the arguments of the Council into account by the formulation of new European collective agreements.

\section{Role of the EP and the ECOSOC in the European social dialogue}

\section{Present situation}

At present there is no official role for the EP and ECOSOC in the decision making procedure of Article 139(2) EC Treaty. In practice the Commission sends the agreement of the social partners' organisations to the EP and ECOSOC for an opinion, before it is submitted to the Council.

\section{Recommendations for the future}

I do not see a clear reason why the EP and ECOSOC have been excluded from the legislative procedure of Article 139(2) EC Treaty. There are strong 
reasons to give them a role in this procedure. When the European collective agreement covers subjects of Article 137(1) EC Treaty, the EP should have strong role in the decision making process, analogous to its role in the procedure of Article 251 EC Treaty, with the difference that the EP cannot amend the European collective agreement. If the agreement covers subjects of Article 137(3) EC Treaty, the Council should be obliged to ask the (nonbinding) advice of the EP. The Council should also be obliged to ask the advice of the ECOSOC. This advice should be non-binding. In this way the two organisations representing all peoples of all sectors of economic and social life within the Community will be involved in the important process of a European collective agreement becoming Community law.

\section{Procedure after amendments to or rejection of the European collective agreement}

Amendments to the European collective agreement can be made by the Commission as well as the Council when they turn the agreement into Community legislation. This means, however, that the procedure of Article 139(2) EC Treaty can not be followed anymore. Article 139(2) EC Treaty explicitly prescribes that agreements of the European social partners' organisations can be turned into Community law. In case of amendments, one can not speak of agreements of the European social partners' organisations anymore, since their content has been changed by the Community institutions. Amendments made by the Commission or Council means that the "normal" legislative route of Article 250 or 251 EC Treaty have then to be followed. It also implies in my view that the European social partners organisations should under certain circumstances be consulted again. This is especially the case if it regards substantial amendments.

It is also possible that the Commission or Council reject the European collective agreement. After all, neither of the two institutions is obliged to accept the agreement as a basis for Community legislation. Nevertheless, I have stated above that under certain circumstances the Commission may in my view not reject the European collective agreement for lack of representativity of the signatory parties. If the Commission, after rejection of the European collective agreement, wants to issue legislation, it shall sometimes have to start the consultation procedure of Article 138(2) and (3) EC Treaty (again). This depends on the reasons for the rejection and on the question whether the agreement has or has not been concluded spontaneously. If the Council rejects the European agreement, it can not continue the procedure of Article 139(2) EC Treaty for the same reasons as if it amends the agreement. If it nevertheless wants to have legislation on the subject of the (rejected) ment, if shall have to ask the Commission to formulate a new legislative proposal. A new consultation on the basis of Article 138(2) and (3) EC Treaty will under certain circumstances be necessary. This is dependent on the question 
whether the agreement was concluded spontaneously or on the occasion of the consultation procedure and on the question whether the Commission wants to legislate on the same issue as the issue of the (rejected) agreement. The consequences of amendment or rejection of European collective agreements by the Commission and/or Council have been put in a scheme in Chapter 7.

\begin{tabular}{|c|c|}
\hline Present situation & Future Recommendations \\
\hline $\begin{array}{l}\text { European agreement is collective } \\
\text { agreement. }\end{array}$ & $\begin{array}{l}\text { European collective labour legislation } \\
\text { should lay down what the legal cha- } \\
\text { racter is of European agreements and } \\
\text { what the conditions are for valid Euro- } \\
\text { pean agreements. }\end{array}$ \\
\hline $\begin{array}{l}\text { suivpeai cuiecuve agreemenis are } \\
\text { contracts between the signatory par- } \\
\text { ties according to Belgian private law } \\
\text { if they fulfil the conditions given by } \\
\text { this Belgian private law. There are } \\
\text { four instruments to enforce compli- } \\
\text { ance with European collective agree- } \\
\text { ments. Only two of them - exceptio } \\
\text { non adimpleti contractus and termi- } \\
\text { nation - can be effective, but will pro- } \\
\text { bably not be used very much. The } \\
\text { other two instruments cannot be used } \\
\text { effectively since many European so- } \\
\text { cial partners' organisations lack legal } \\
\text { personality. }\end{array}$ & $\begin{array}{l}\text { In ue near rature, curopean sociai } \\
\text { partners' organisations could acquire } \\
\text { legal personality. In this way, the en- } \\
\text { forcement mechanisms of specific per- } \\
\text { formance and damages could be used } \\
\text { effectively. A future European collec- } \\
\text { tive labour legislation should lay down } \\
\text { what the rights and obligations are for } \\
\text { the signatory parties; at least two obli- } \\
\text { gations: obligation to influence natio- } \\
\text { nal affiliates to implement the Europe- } \\
\text { an collective agreement and the peace } \\
\text { obligation. Conciliation by SDCs in } \\
\text { case of conflicts between the signatory } \\
\text { parties. If conciliation is fruitless, medi- } \\
\text { ation by EMCS, consisting of indepen- } \\
\text { dent experts in industrial relations. The } \\
\text { EMCS could give a binding award. }\end{array}$ \\
\hline $\begin{array}{l}\text { European collective agreements cre- } \\
\text { ate legal consequences for the natio- } \\
\text { nal affiliates of the signatory parties } \\
\text { on the basis of the internal rules of the } \\
\text { European organisations. If internal } \\
\text { rules are absent, legal consequences } \\
\text { on the basis of theories like mandate } \\
\text { and agency in combination with }\end{array}$ & $\begin{array}{l}\text { In the near future, national affiliates } \\
\text { should sign the European collective } \\
\text { agreement as well. It should also be } \\
\text { laid down which law is applicable to } \\
\text { the European collective agreement. } \\
\text { Clear internal consultation processes } \\
\text { during the negotiations on the Euro- } \\
\text { pean collective agreements can remove }\end{array}$ \\
\hline
\end{tabular}


private international law. This leads to different outcomes for the various national affiliates since the concepts of mandate and agency differ from Member State to Member State. possible barriers for the national affiliates to implement them. In a future European collective labour legislation, the legal consequences for the national affiliates could be stipulated. SDCs could be helpful for the national affiliates in advising them how to interpret and implement European collective agreements.

Under certain circumstances direct effect of European collective agreements for individuals. National institutions could ask preliminary advice from SDCs on the question whether certain provisions of European collective agreements have direct effect. The question on whether or not European collective agreements have direct effect on individuals could be laid down in a future European collective labour legislation.

No recommendation

Representativity criteria should be broadened. Commission proposal should be published in the Official Journal, whereby all European social partners' organisations could submit comments. Useful comments can be selected by the Commission and the final proposal should be thoroughly motivated.

Motivation duty for the Commission if it decides that the signatory parties are (not) representative. 


\begin{tabular}{|c|c|}
\hline $\begin{array}{l}\text { Commission decision is legally re- } \\
\text { viewable of a Council decision is } \\
\text { taken (UEAPME case). }\end{array}$ & \\
\hline $\begin{array}{l}\text { Commission gives financial and } \\
\text { technical support to the European so- } \\
\text { cial partners' organisations. Control } \\
\text { by EP. Commission decision to refuse } \\
\text { support can be legally attacked by } \\
\text { European social partners' organisa- } \\
\text { tions (Murgia Messapica case). Com- } \\
\text { mission is legally obliged to consult } \\
\text { European social partners' organisa- } \\
\text { tions with regard to all proposals } \\
\text { having a socio-economic significance. } \\
\text { European social partners' organisa- } \\
\text { tions do not have to await a request } \\
\text { from the Commission to give their } \\
\text { advice. European social partners' } \\
\text { organisations can also start negotia- } \\
\text { tions at any moment they want. } \\
\text { Commission is not obliged to formu- } \\
\text { late a legislative proposal on the basis } \\
\text { of a European collective agreement. If } \\
\text { it formulated a proposal, it applies } \\
\text { five checks on the European collective } \\
\text { agreement. UEAPME case proves that } \\
\text { the application of the representativity } \\
\text { check is legally reviewable, but only } \\
\text { after the Council decision is taken on } \\
\text { the basis of Article 139(2) EC Treaty. }\end{array}$ & $\begin{array}{l}\text { European social partners' organisations } \\
\text { should become financially independent } \\
\text { from the Commission. The Com- } \\
\text { mission should also check whether } \\
\text { European social partners' organisations } \\
\text { have democratic internal decision } \\
\text { making procedures, and whether the } \\
\text { European collective agreement is not } \\
\text { contrary to fundamental human rights. } \\
\text { The SME check is a duplication of the } \\
\text { legality check and therefore not necess- } \\
\text { ary. Motivation duty of the Commis- } \\
\text { sion with regard to the application of } \\
\text { the checks. Commission should devel- } \\
\text { op elaborated policy rules for the ac- } \\
\text { ceptance of European collective agree- } \\
\text { ments as legislative proposals. }\end{array}$ \\
\hline $\begin{array}{l}\text { Council decision based on Article } \\
139(2) \text { EC Treaty must be a legally } \\
\text { binding act. Council is not obliged to } \\
\text { turn the European collective agree- } \\
\text { ment into legislation. }\end{array}$ & $\begin{array}{l}\text { Motivation duty for the Council if it } \\
\text { rejects the European collective agree- } \\
\text { ment. }\end{array}$ \\
\hline $\begin{array}{l}\text { No official role for the EP and the } \\
\text { ECOSOC in the procedure of Article } \\
139(2) \text { EC Treaty. }\end{array}$ & $\begin{array}{l}\text { If the European collective agreement } \\
\text { covers subjects mentioned in Article } \\
\text { 137(1) EC Treaty, the EP should have } \\
\text { co-decision, but not the right to amend } \\
\text { the agreement. If the European collec- } \\
\text { tive agreement covers subjects men- }\end{array}$ \\
\hline
\end{tabular}




\begin{tabular}{|l|l|}
\hline & $\begin{array}{l}\text { tioned in Article 137(3) EC Treaty, the } \\
\text { EP should be asked its non-binding } \\
\text { advice. The ECOSOC should be asked } \\
\text { its non-binding advice. }\end{array}$ \\
\hline $\begin{array}{l}\text { Amendments to the European collec- } \\
\text { tive agreement may be made by the }\end{array}$ & No recommendation. \\
Commission or Council. However, \\
the route of Article 139(2) EC Treaty \\
will be closed then. The route of \\
Article 250 or 251 EC Treaty shall \\
have to be followed. European social \\
partners' organisations have under \\
certain circumstances to be consulted \\
again. Commission and Council may \\
reject the European collective agree- \\
ment. If the Commission wants legis- \\
lation it shall sometimes have to \\
consult the European social partners' \\
organisations again. If the Council \\
after rejection of the European collec- \\
tive agreement wants legislation, the \\
Commission first has to formulate a \\
new proposal. New consultation of \\
the European social partners' organi- \\
sations will under certain circum- \\
stances be necessary.
\end{tabular}





\section{DUTCH SUMMARY}

Dit proefschrift gaat over de juridische problemen die samenhangen met de Europese sociale dialoog, zoals omschreven in de artt. 138 en 139 EGVerdrag. Deze artikelen zijn bij het Verdrag van Maastricht in 1992 in het EGVerdrag gezet. Met het begrip "Europese sociale dialoog" worden twee dingen bedoeld: enerzijds het sluiten van overeenkomsten op communautair niveau tussen Europese organisaties van werknemers en werkgevers (Europese sociale partners), die arbeidsvoorwaarden bevatten. Anderzijds de samenwerking tussen de EG-instellingen en de Europese sociale partners.

In hoofdstuk 1 wordt een introductie gegeven van het onderzoek. Hoewel het onderzoek zich richt op de juridische aspecten van de Europese sociale dialoog, wordt in para. 1.5. kort ingegaan op een politiek aspect, namelijk de vraag of cao's op Europees niveau wenselijk zijn. Deze vraag wordt bevestigend beantwoord. Met name arbeiders die werkzaam zijn in de grensgebieden zouden kunnen profiteren van Europese cao's. Daarnaast zijn Europese cao's nodig vanwege de toenemende internationalisering van het bedrijfsleven. Door op Europees niveau eenvormige afspraken te maken over bepaalde arbeidsvoorwaarden, kan sociale dumping voorkomen worden. De komst van de Euro maakt het bovendien eenvoudiger om de lonen voor dezelfde arbeid in de verschillende lidstaten met elkaar te vergelijken. Dit geldt eens te meer als de harmonisatie op het gebied van de belastingwetgeving en sociale zekerheidsstelsels verder doorzet. Hierdoor wordt het vastleggen van loonafspraken in Europese cao's gemakkelijker. Voorts wordt kort ingegaan op de drie elementen van cao-recht: het recht van vakvereniging, het recht op collectief overleg en het stakingsrecht. Het is raadzaam om in elk geval het stakingsrecht als zodanig in het EG-Verdrag neer te leggen. Te verwachten is dat het recht van vakvereniging en het recht op collectief overleg door het Hof van Justitie/Gerecht van Eerste Aanleg erkend zal worden.

In hoofdstuk 2 wordt een aantal Europese sociale partners kort besproken. Aangezien er momenteel meer dan 60 van zulke organisaties bestaan, is het in het kader van dit proefschrift te veel om die allemaal te bespreken. $\mathrm{Er}$ is dan ook voor gekozen om de drie belangrijkste intersectorale organisaties te bespreken, zijnde het EVV, CEEP en UNICE. Daarnaast wordt UEAPME besproken omdat laatstgenoemde een belangrijke kwestie bij het Gerecht van Eerste Aanleg heeft gebracht in het kader van de Europese sociale dialoog. Hun structuur en werkwijze wordt globaal beschreven. Daarnaast wordt kort een aantal sectorale organisaties besproken die betrokken zijn geweest bij het afsluiten van overeenkomsten op communautair niveau als omschreven in art. 139(1) EG-Verdrag. De meeste organisaties hebben statuten waarin hun structuur en werkwijze is vastgelegd. Een ander punt dat in dit hoofdstuk aan de orde komt is dat van de juridische status van de Europese sociale partners: het al dan niet bezitten van rechtspersoonlijkheid. Aangezien 
Belgisch recht van toepassing is op de Europese sociale partners die in Brussel gevestigd zijn, kunnen deze organisaties kiezen voor het al dan niet hebben van rechtpersoonlijkheid. Sommige organisaties hebben deze rechtspersoonlijkheid inderdaad aangenomen, andere wijzen haar uitdrukkelijk van de hand. Als de Europese sociale partners de intentie hebben om juridisch afdwingbare overeenkomsten met elkaar te sluiten, is het raadzaam dat zij de rechtspersoonlijkheid aannemen. Voor de verdere toekomst zou het het beste zijn om een eenvormig concept van de Europese vereniging te hebben voor de hele EU. De definite en voorwaarden voor het ontstaan van zo'n Europese vereniging zou neergelegd kunnen worden in een verordening. Gezien de pogingen die hiertoe gedaan zijn in het verleden, is er echter weinig hoop dat dit gaat gebeuren.

In hoofdstuk 3 wordt een globaal overzicht gegeven van de geschiedenis van de Europese sociale dialoog, vanaf het Verdrag van Rome in 1957 tot heden ${ }^{1}$. Twee aspecten worden belicht. Enerzijds de rol van de Europese sociale partners als lid van diverse commissies en comités die adviseren aan de Europese Commissie. Het verschil tussen de diverse gremia waarin de Europese sociale partners zitting hebben, is niet altijd even helder. Wellicht dat men in de toekomst toe kan met minder commissies c.q. comité's die duidelijker omschreven en afgebakender bevoegdheden hebben. Duidelijk is in elk geval dat de rol van de Europese sociale partners als adviesorgaan voor de Commissie aanzienlijk is toegenomen in de loop van de tijd. De Commissie kan nu zelfs geen voorstellen op het gebied van sociale politiek meer indienen zonder tevoren de Europese sociale partners te raadplegen. Dit is uitdrukkelijk in Art. 138 EG-Verdrag vastgelegd. Anderzijds spelen de Europese sociale partners een rol als cao-partij. Als het gaat om het sluiten van overeenkomsten op communautair niveau, zoals omschreven in art. 139(1) EG-Verdrag, zijn de Europese werkgeversorganisaties tot op heden zeer terughoudend gebleken. Alleen als de Commissie op de achtergrond "dreigt" met wetgeving op een bepaald gebied zijn de werkgevers bereid tot onderhandeling. De overeenkomsten die tot nu toe gesloten zijn, zijn niet meer dan raamakkoorden die zeer omzichtig geformuleerd zijn. Wellicht dat hier in de toekomst verandering in komt als Europese werknemersorganisaties meer dan nu in staat zijn een vuist te maken door b.v. met een staking(sdreiging) op Europees niveau druk op de werkgevers uit te oefenen. In hoofdstuk 4 wordt ingegaan op de raadplegingsprocedure zoals beschreven in art. 138 EG-Verdrag. Alvorens deze procedure wordt uiteengezet, wordt iets gezegd over de fianciële en technische ondersteuning die de Commissie geeft aan de Europese sociale partners. De Europese sociale partners kunnen een aanvraag voor financiële steun indienen bij de Commissie en deze zal de aanvraag beoordelen aan de hand van bepaalde, door haar zelf opgestelde, criteria. Met name waar het gaat om financiële steun is het raadzaam dat de Europese sociale partners hier niet afhankelijk van blijven. 
De Commissie is juridisch verplicht om de Europese sociale partners te raadplegen alvorens voorstellen te doen op het gebied van sociale politiek. Dit behelst meer onderwerpen dan alleen welke vermeld staan in Titel XI van Deel 3 van het EG-Verdrag. De Europese sociale partners kunnen bovendien ook op eigen initiatief de Commissie adviseren. De Commissie selecteert de te raadplegen Europese sociale partners aan de hand van bepaalde representativiteits-criteria welke zij zelf heeft geformuleerd. Deze criteria zijn vrij summier en niet altijd even helder. $\mathrm{Zij}$ zouden voor de toekomst aangevuld moeten worden. Naar aanleiding van de raadpleging kunnen de Europese sociale partners besluiten om met elkaar onderhandelingen te starten teneinde tot een overeenkomst te komen. $\mathrm{Zij}$ zijn echter niet verplicht om een raadpleging van de Commissie af te wachten. Politiek-strategische overwegingen kunnen echter een rol spelen bij de vraag of zij een dergelijke raadpleging afwachten. Verder zijn zij geheel vrij in het kiezen van hun onderhandelingspartners.

In hoofdstuk 5 komen de procedurele aspecten en juridische gevolgen van het sluiten van overeenkomsten tussen de Europese sociale partners aan de orde. De overeenkomsten die tot nu toe in het kader van art. 139(1) EGVerdrag gesloten zijn, kunnen beschouwd worden als collectieve arbeidsovereenkomsten (cao's), in het licht van de definities van een cao zoals neergelegd in documenten van de Internationale Arbeids Organisatie (IAO), het Europees Sociaal Handvest (ESH) en gegeven door het Europese Hof van Justititie (HvJ). Het is raadzaam om bepaalde voorwaarden te verbinden aan rechtsgeldige Europese cao's. Deze voorwaarden zouden betrekking moeten hebben op de partijen bij de Europese cao, de onderhandelingsprocedure, de vorm van de Europese cao, en de inhoud ervan. Juridische gevolgen van Europese cao's zijn er voor diverse partijen. In de eerste plaats voor de ondertekenende partijen: de Europese sociale partners. De juridische gevolgen voor hen vloeien voort uit het Belgisch contractenrecht, aangezien de Europese cao's die tot nu toe gesloten zijn, gedefinieerd worden worden als een contract naar Belgisch recht. Voor de toekomst is het wellicht aan te bevelen om meer internationale rechtsbronnen te gebruiken om het rechtskarakter van Europese cao's -en dus de juridische gevolgen ervan voor de ondertekenende partijen- te definiëren. B.v. de Principles of European Contract Law of Aanbevelingen en Conventies van de IAO. De verplichtingen van de Europese sociale partners zouden in elk geval tweërlei moeten zijn: enerzijds de vredesplicht en anderzijds de plicht om invloed op hun nationale leden uit te oefenen teneinde de Europese cao ten uitvoer te leggen door middel van cao's op nationaal niveau. In de tweede plaats zijn er juridische gevolgen voor de nationale werkgevers- en werknemersorganisaties, die lid zijn van de Europese sociale partners welke de Europese cao hebben ondertekend. Hulpconstructies zoals de leerstukken van vertegenwoordiging en mandaat kunnen op zichzelf bruikbaar zijn om deze juridische gevolgen te bepalen. Deze hulpconstructies zijn echter niet ideaal en het is derhalve voor de nabije toekomst raadzaam dat de nationale organi- 
saties de Europese cao ook ondertekenen, net als de Europese organisaties. Op die wijze zijn zij direct aan de Europese cao gebonden. De nationale organisaties zouden in elk geval verplicht moeten zijn om de Europese cao binnen een bepaalde termijn ten uitvoer te leggen door middel van nationale cao's, waarbij de Europese cao als minimumbasis geldt. In de derde plaats zijn er juridische gevolgen voor individuele werkgevers en werknemers in de lidstaten. Als de Europese cao tijdig en op correcte wijze ten uitvoer is gelegd door middel van nationale cao's, dan vloeien de juridische gevolgen van de Europese cao's voor individuele werkgevers en werknemers voort uit deze nationale cao's in overeenstemming met nationaal recht. Als de Europese cao niet of niet correct ten uitvoer is gelegd, dan is er op dit moment niets dat individuen kunnen doen. Directe werking van Europese cao's voor individuen is alleen mogelijk als er communautaire wetgeving inzake Europese cao's komt in de vorm van een Europese Wet op de Cao. Ik heb enige ideeën gegeven omtrent de voorwaarden en gevolgen van zulk een directe werking voor de toekomst.

Hoofdstuk 6 gaat over de wijze waarop de verplichtingen voortvloeiend uit Europese cao's kunnen worden afgedwongen. De verplichtingen voor de partijen die de cao hebben ondertekend kunnen op dit moment alleen op basis van het Belgisch contractenrecht worden afgedwongen, d.w.z. als de Europese cao voldoet aan de eisen voor een geldig Belgisch contract. Volgens Belgisch contractenrecht zijn er vier acties mogelijk die de ondertekenende partijen van een Europese cao tegen elkaar kunnen ondernemen: nakoming eisen, schadevergoeding eisen, exceptio non adimpleti contractus en tenslotte beëindiging van het contract. Van deze vier acties zouden momenteel alleen de actie van exceptio non adimpleti contractus en beëindiging van het contract succesvol zijn. Voor de toekomst zou men een systeem van conciliatie, bemiddeling en/of arbitrage in het leven kunnen roepen. Bemiddeling zou verleend kunnen worden door de reeds bestaande Sectorale Dialoog Comités. Indien bemiddeling geen resultaat zou opleveren zou men een Europese Bemiddelings- en Conciliatie Dienst kunnen oprichten die als een soort beroepsinstantie zou kunnen fungeren. Het opleggen van concrete sancties blijft echter moeilijk zolang bepaalde Europese sociale partners geen rechtspersoonlijkheid bezitten.

Verplichtingen voor nationale organisaties kunnen afgedwongen worden via de interne procedures en regels van de Europese organisaties. Een nationale organisatie zou als lid geroyeerd kunnen worden als zij haar verplichtingen b.v. niet mee te werken aan de tenuitvoerlegging van de Europese cao middels een nationale cao- niet nakomt. Als een nationale organisatie de Europese cao weliswaar ten uitvoer legt, doch daarbij de Europese cao verkeerd interpreteert kan de kwestie voorgelegd worden aan de Sectorale Dialoog Comité's en eventueel de Europese Bemiddelings- en Conciliatie Dienst.

Als de Europese cao correct ten uitvoer gelegd is door middel van nationale cao's, zullen de verplichtingen van de Europese cao voor individuele 
werkgevers en werknemers afgedwongen kunnen worden overeenkomstig het nationale recht van de lidstaten. Is de Europese cao niet (correct) ten uitvoer gelegd, dan kunnen de verplichtingen voor individuen alleen afgedwongen worden als er een Europese Wet op de Cao is die directe werking van de Europese cao onder bepaalde omstandigheden toestaat. De nationale instantie of rechter die belast is met de interpretatie van de nationale cao's zou deze interpretatie conform de Europese cao kunnen doen, analoog aan de Richtlijnconforme interpretatie van nationale wetgeving. De instantie/ rechter zou hierbij een prejudicieël advies kunnen vragen aan de Sectorale Dialoog Comité's.

Hoofdstuk 7 gaat over de implementatie van Europese cao's door middel van een besluit van de Raad van Ministers. Hiervoor moet aan een aantal voorwaarden zijn voldaan. In de eerste plaats moet de Europese cao gaan over zaken die onder art. 137 EG-Verdrag vallen. Dit betekent echter niet dat communautaire wetgeving op de gebieden die genoemd zijn in art 137(6) EGVerdrag uitgesloten is. Naar mijn mening is dat wel degelijk mogelijk, zolang deze wetgeving maar een implementatie is van een Europese cao. In de tweede plaats moeten de ondertekenende partijen van een Europese cao gezamenlijk een verzoek doen om implementatie van deze cao middels een Raadsbesluit. In de derde plaats moet de Commissie een voorstel van wetgeving formuleren. Dit zal zij alleen doen nadat zij de Europese cao heeft gecontroleerd op een vijftal aspecten: de representativiteit van de ondertekenende partijen, het mandaat dat zij hebben, de eventuele strijdigheid van de Europese cao met communautair recht, de eventuele belemmering van de oprichting en ontwikkeling van kleine en middelgrote ondernemingen en tenslotte de wenselijkheid van communautaire wetgeving op het gebied dat bestreken wordt door de Europese cao. De representativiteits-controle heeft reeds een uitspraak van het Gerecht van Eerste Aanleg opgeleverd. In elk geval ben ik van mening dat de criteria voor het bepalen van de representativiteit zoals de Commissie die nu heeft geformuleerd, zouden moeten worden uitgebreid. De Commissie is niet verplicht om een wetsvoorstel te formuleren op basis van een Europese cao. Als zij de Europese cao afwijst en niettemin een wetgevingsvoorstel op het betrokken gebied wil formuleren voor de Raad, dient zij onder bepaalde voorwaarden de Europese sociale partners wederom te raadplegen. In de vierde plaats dient de Raad van Ministers een besluit te nemen. Dit dient in elk geval een juridisch bindend besluit te zijn, aanbevelingen op basis van een Europese cao zijn dus uitgesloten. De Raad is niet verplicht om op basis van een Europese cao een besluit te nemen. Indien zij de Europese cao afwijst en niettemin wetgeving op het betrokken gebied wil, kan zij deze wetgeving in elk geval niet uitvaardigen op basis van art. 139(2) EG-Verdrag. Als de Raad de Europese cao als basis voor haar besluit neemt, maar amenderingen daarin aanbrengt, is de weg van art. 139(2) EG-Verdrag eveneens afgesloten. Onder bepaalde voorwaarden dient er bij afwijzing en amendering van de Europese cao opnieuw raadpleging van de Europese sociale partners plaats te vinden. 
Officieel hoeven het Europees Parlement en het Economisch en Sociaal Comité momenteel niet geraadpleegd te worden als de Europese cao wordt geïmplementeerd middels communautaire wetgeving. Naar mijn mening is dit onwenselijk. De rol van het Europees Parlement moet aanzienlijk versterkt worden in die zin dat ze in bepaalde gevallen het recht van co-decisie dient te hebben. Het Economisch en Sociaal Comité moet in elk geval in de gelegenheid worden gesteld een niet-bindend advies te geven.

Hoofdstuk 8 gaat over de mogelijkheden voor de Europese sociale partners om een procedure op basis van het EG-Verdrag tegen de Raad van Ministers en/of de Commissie te voeren bij het HvJ of Gerecht van Eerste Aanleg. Met name de procedure beschreven in art. 230 EG-Verdrag is van belang. Om in een dergelijke procedure ontvankelijk te zijn dient aan een aantal criteria te zijn voldaan. In de eerste plaats moet de klager een natuurlijke of rechtspersoon te zijn. Het HvJ heeft in haar jurisprudentie eigen criteria geformuleerd met betrekking tot het al dan niet hebben van rechtspersoonlijkheid. Als de Europese sociale partners hieraan voldoen, kunnen zij in principe een procedure starten. In de tweede plaats is de aard van de maatregel waartegen geageerd wordt van belang. Art. 230(4) EG-Verdrag laat in principe alleen beroep toe tegen beschikkingen. Echter de rechtspraak van het HvJ en Gerecht van Eerste Aanleg heeft zich in de loop der jaren meer en meer gericht op het criterium van "rechtstreeks en individueel geraakt" zijn. Met name door de zeer recente Jégo-Quéré-zaak is dit criterium zodanig opgerekt dat het voor natuurlijke en/of rechtspersonen steeds eenvoudiger wordt om toegang tot het Hof te krijgen. Voor de Europese sociale partners is met name de UEAPME-zaak van groot belang geweest. Ik voorzie dan ook geen echte problemen voor hen om ook andere besluiten dan alleen beschikkingen aan te vechten. Besluiten van de Commissie met betrekking tot financiële steun aan de Europese sociale partners kunnen onder bepaalde voorwaarden door laatstgenoemden worden aangevochten. Indien er voorstellen op het gebied van sociale politiek in de vorm van communautaire wetgeving worden aangenomen zonder dat de Europese sociale partners geraadpleegd zijn is het geenszins zeker dat zij deze wetgeving kunnen aanvechten op basis van art. 230 EG-Verdrag. Om problemen hieromtrentte vermijden kan de Commissie beter een "open" raadpleging doen in die zin, dat zij aan alle Europese sociale partners de gelegenheid geeft om te reageren op haar voorstellen en niet een bepaald aantal organisaties selecteert met betrekking tot de raadplegingsprocedure van art. 138 EG-Verdrag. Voorts is het raadzaam dat de Commissie uitgebreidere en duidelijker omschreven criteria aanlegt om een Europese cao te beoordelen in het kader van de procedure van art. 139(2) EGVerdrag. Dat een Richtlijn van de Raad op basis van een Europese cao in principe kan worden aangevochten, bewijst de UEAPME-zaak, ook al werden de klagers in deze zaak niet-ontvankelijk verklaard. Al met al kan worden geconcludeerd dat, hoewel art. 230 EG-Verdrag zeker niet geschreven is voor situaties met betrekking tot de Europese sociale dialoog, er toch mogelijk- 
heden zijn voor de Europese sociale partners om actie te ondernemen tegen de Commissie en/of Raad van Ministers.

Het proefschrift wordt in hoofdstuk 9 wordt afgesloten met een overzicht van alle conclusies en aanbevelingen die in de voorgaande hoofdstukken zijn gedaan. Tevens is nog een bijlage opgenomen waarin een overzicht wordt gegeven van alle communautaire wetgeving waarbij de Europese sociale partners zijn betrokken. 



\section{ANNEX I \\ OVERVIEW OF COMMUNITY LEGISLATION WITH THE INVOLVEMENT OF THE EUROPEAN SOCIAL PARTNERS' ORGANISATIONS'}

\section{A. Intersectoral agreements which have been turned into Community legislation}

\section{European Framework Agreement on Parental Leave}

24 November 1983: Commision proposal submitted to the Council. The legal basis is Article $100 \mathrm{EC}$ Treaty, and thus requires unanimity. This unanimity is not forthcoming, with the UK government the main obstacle. The other Member States seem to have supported the draft.

22-23 September 1993: At an informal Council meeting, the Belgian presidency revives the proposal with a new text. This proposal is discussed in the Council and the UK and Luxembourg opposes it.

19 April 1994: Council meeting. The Commission announces that it is to consider using the 11-state-only procedure under the Agreement on Social Policy.

22 February-3 May 1995: First stage of consultation of the European social partners' organizations. Responses received from 17 EU-level trade union and employers' organisations.

21 June 1995-2 August 1995: Second stage of consultation of the European social partners' organizations. In its second stage consultation document the Commission sets out a number of principles.

5 July 1995: The ETUC, UNICE and CEEP, write to the Commission, stating that they would attempt to negotiate an agreement on the issue, and calling for the legislative procedure to be suspended.

6 November 1995: Draft agreement reached between ETUC, UNICE, and CEEP.

14 December 1995: Draft agreement formally signed. The agreement has been submitted to the Council by the Commission for a decision rendering it binding.

1 The sources for the information in this Annex are: European Industrial Relations Review, Eironline, and Bulletin Quotidien Europe. 
31 January 1996: The proposal for a Council Directive transposing into Community law the agreement on parental leave is adopted by the Commission.

29 February 1996: The Commission submits a proposal for a Directive implementing the agreement to the Council.

29 March 1996: Political agreement in the Council reached.

3 June 1996: The Directive on Parental Leave is formally adopted by the Council and notified to the Member States.

15 December 1997: The Directive is extended to the UK.

\section{European Framework Agreement on Part-Time Work}

Already in the 1980s, draft Directives on this issue were submitted unsuccessfully, and again in 1990 as part of the Social Charter Action Programme. In 1981, a draft Directive on voluntary part-time working was submitted. In 1982, a draft Directive on temporary work was submitted.

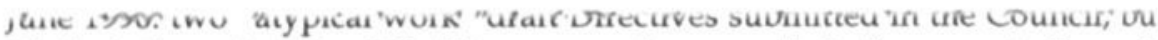
blocked there by the UK. The proposal was called: "proposed Council Directive relating to certain employment contracts and employment relationships involving distortions of competition". A new merged text produced by the Belgian Presidency is discussed in the Council with little progress made.

1993: The Belgian presidency produces a text entitled: Council Directive on the promotion of employment and the protection of part-time and fixed-term employment relationships. It was discussed, but little progress was made.

Second half of 1994: The German Presidency issues a new text. This is again discussed in the Council and the UK confirms its opposition. With no progress likely among all Member States, the Commission announces its decision to reintroduce the proposal under the procedures of the Agreement on Social Policy.

27 September 1995-8 November 1995: First consultation round with the social partners

18 April 1996-16 June 1996: Second stage of consultation.

19 June 1996: The social partners ETUC, UNICE, and CEEP announced that they want to start negotiations. As with the parental leave agreement, also here have been protests of organizations which felt excluded from the negotiation process. UEAPME has written to UNICE, ETUC and the Commission, asking to be allowed to participate in the negotiations.

21 October 1996: ETUC, UNICE and CEEP launch formal negotiations over the atypical work agreement. 
14 May 1997: The social partners reach a draft agreement.

1 July 1997: Commissioner Flynn announces that he is going to prepare a Commission proposal aimed at transforming the collective agreement on part-time work into a true European directive. Euro-groups which had not participated in the negotiations were invited at an information meeting on the agreement, sponsored by DG V.

23 July 1997: The European Commission adopts the proposal for a Directive on Part-Time Work.

18 November 1997: Opinion given by the EP.

15 December 1997: The Council adopts the Directive on Partime Work.

\section{European Framework Agreement on Fixed-Term Work}

Early 1980s: Draft Directives issued by the Commission in 1980 and 1981 on part-time work and temporary work. However, despite numerous amendments to the texts, the proposals failed to reach an agreement on.

27 September 1995: Commission consults the social partners for the first time.

18 April 1996: Commission consults social partners for the second time.

15 June 1996: The social partners announce their intention to seek to negotiate an agreement on part-time work.

11 March 1998: ETUC, UNICE and CEEP agree to start negotiations on the right of workers with fixed contracts.

14 January 1999: Agreement reached between ETUC, UNICE, and CEEP.

18 March 1999: Agreement signed by ETUC, UNICE and CEEP.

18 March 1999: Commission adopts proposal for Directive on the basis of the agreement.

28 June 1999: Council adopts Directive on fixed-time work.

\section{B. Sectoral agreements which have been turned into Community legislation}

\section{European Agreement on the Organization of Working Time for Seafarers}

18 December 1997: The FST and ECSA conclude an agreement.

30 September 1998: The general secretary of the FST (Federation of Transport Trade Unions) stresses that this agreement has been reached on the basis of the Agreement on Social Policy. This means that the European Commission will prepare a covering directive and include it in the texts of the agreements signed. 
25 May 1999: Commission proposal on the basis of the agreement concluded between the FST and ECSA discussed in the Social Affairs Council.

21 June 1999: Council adopts Directive on the basis of the Agreement between FST and ECSA.

European Agreement on the Organization of Working Time of Mobile Staff in Civil Aviation

December 1998: The social partners inform the Commission about their intention to start negotiations on the working time for the mobile personnel in the civil aviation.

22 March 2000: Agreement reached between AEA, ETF, ECA, ERA and IACA. In the agreement itself, the signatory parties ask the EC-institutions to turn the agreement into Community legislation.

27 November 2000: Council Directive adopted on the basis of the agreement of AEA, ETF, ECA, ERA, and IACA.

\section{Agreements which will be implemented by the national social partners'organisations}

Recommedation Framework Agreement on the Improvement of Paid Employment in Agriculture in the Member States of the European Union

Background of the agreement: EFA has always been keen on issues such as the reducing of working time and the improvement of working conditions in the agricultural sector. However, until the mid-80' the European social dialogue remained toothless in this sector. When Delors gave new impetus to the European social dialogue through the Val Duchesse initiative, EFA felt supported by the Commission and renewed its demands for real negotiations at the European level. On 15 February 1989, it introduces specific demands on working time and annual holidays. However, the employers (COPA/GEOPA) remain unwilling. In June 1994, EFA issues a quasiultimatum, but this is fruitless. Therefore, EFA refuses to endorse a new chair of the Joint Committee on Social Problems of Agricultural Workers at the Committees plenary meeting in January 1995. According to the Committees statutes this meant that the existing (EFA-nominated) chair had to remain in place. In June 1995, the Commission urges the organizations to start negotiations again. A small working group was set up, which formulated a common agreement.

24 July 1997: The European social partners from the world of farming, GEOPA/COPA for the employers, EFA/ETUC for the trade unions- sign a framework agreement aimed at improving paid employment in the 
agricultural sector in the European Union. The agreement will be sent to the national social partners as basis for negotiations.

April 2000: The impact of the agreement on national collective agreements is still hardly notable.

April 2002: There is no control on whether and how this agreement is implemented.

\section{Framework Agreement on Telework}

26 June 2000: Commission issues a consultation document to the Europeanlevel social partners asking for their views on which to modernise and improve employment relations. The document invites the social partners to give their views on the possible future direction of Community action. It is thus the first stage-consultation procedure.

8 March 2001: UNICE writes to ETUC, stating that it would be willing to open negotiations on a non-legally binding agreement on teleworking. However, ETUC wants the agreement to have a legal status.

19 March 2001: The Commission launched the second stage of consultations on teleworking. The Commission provides a list of general principles that should serve as a framework for practical implementation. UNICE proposed to ETUC to negotiate a legally non-binding agreement on the issue. However, ETUC answered that such an agreement should be binding for the signatory social partners.

12 October 2001: UNICE, ETUC, and CEEP start negotiations on teleworking. Their aim is to adopt an agreement that regulates teleworking and that is applied by their affiliates in all Union countries.

15 May 2002: UNICE, ETUC, and CEEP alsmost reach the conclusion of a draft agreement that will be finalised at the next negotiating meeting of 23 May.

16 July 2002: Framework agreement on telework signed by the ETUC, EUROCADRES, CEC, UNICE/UEAPME and CEEP.

\section{Community legislation on subjects were the social partners' organisations failed to reach an agreement}

Council Directive on the establishment of a European Works Council or a procedure in Community scale undertakings and Community scale groups of undertakings for the purposes of informing and consulting employees

1989 Social Charter Action Programme: The idea of a specific European Works Councils Directive is first raised. 
12 December 1990: A proposal is submitted to the Council. It was called "Proposed Council Directive on the establishment of a European Works Council in Community-scale undertakings for the purposes of informing and consulting employees", and its legal basis was Article 100 EC Treaty.

16 September 1990: the Commission adopts an amended version.

September 1991: Draft Directive on European Works Councils put before the Council for adoption. Fails to make progress. This is largely due to UK opposition. Therefore it becomes the first item to proceed under the Agreement on Social Policy.

October 1993: the Commission announces that the proposal is now to be progressed under the 11-state-only arrangements of the Agreement on Social Policy.

18 November 1993 to 30 December 1993: First stage of consultation of management and labour conducted.

Second half of 1993: Belgian presidency prepares a compromise text. This compromise is a draft Directive on "the establishment of European Works Councils or procedures in Community-scale undertakings and groups of undertakings for the purposes of informing and consulting employees.

8 February 1994: The Commission adopts a new proposal for a draft Directive on "procedures for informing and consulting employees in Community-scale undertakings". The draft has been submitted to the European social partners as the second stage of consultation.

17 March 1994: A social dialogue committee meeting is held for more formal discussions. However, the negotiations have broken down.

29 March 1994: The British CBI, which had been participating as a member of UNICE, pulls out of the talks. The CBI, given that many British multinationals would be affected by the agreement, was in favour of a more flexible agreement. The CBI has therefore told the UNICE that it did not regard the draft as an acceptable basis for negotiation. ETUC than announced that the CBI's position has contested the very substance of the preliminary understanding and completely closed off the avenue leading towards negotiations. In ETUC's view, the second phase of consultation was now over. UNICE, on its turn claimed that the CBI pull-out was being used by ETUC as an excuse for its own preference for the legislative option.

22 June 1994: Political agreement on a common position is reached by 11 Member States on the draft Directive on European information and consultation.

22 September 1994: The Directive on the establishment of a European Works Council or a procedure in Community-scale undertakings and Community- 
scale groups of undertakings for the purposes of informing and consulting employees, is adopted.

15 December 1997: The Directive is extended to the UK.

Council Directive on the burden of proof in cases of discrimination based on sex

27 May 1988: Commission proposal submitted to the Council.

22-23 September 1993: The Belgian presidency revives the proposal with a new text at the Council meeting.

23 November 1993: The revived proposal is discussed in the Council, when opposition of the UK and Denmark is reported.

19 April 1994: At the Council meeting, the Commission announces that it is to consider using the 11-state-only procedure.

5 July-16 August 1995: The first stage of consultation of management and labour takes place.

7 February 1996: The Commission starts the second round of consultation. On the occasion of the second consultation the social partners make clear that they do not want to negotiate on this issue.

20 September 1996: The Commission proposal is submitted to the Council.

2 December 1996: A broad agreement is reported, but adoption of a common position must await the EP's opinion.

15 December 1997: The Council adopts the Directive.

\section{Combating sexual harassment at work}

24 July 1996: The social partners are consulted for the first time.

20 March 1997: The Commission launches the second stage of consultation. The consultation document encourages the social partners to negotiate a collective agreement, but the Commission stresses that it is willing to pursue action if such an agreement is not concluded. However, UNICE is not prepared to negotiate on the subject, since it is of the opinion that in the first place there is already in all Member States a legal framework as regards sexual harssment at work and secondly, the definition of sexual harassment is very much subject to the culture and traditions in the various Member States. This would make it difficult to find an overall definition of sexual harassment which would be suitable for all Member States. The ETUC and the European Women's Lobby have expressed their disappointment over UNICE's view. They call the European Commission to take legislative measures in this area. 
7 June 2000: Commission issues a proposal to amend the 1976 equal treatment Directive to include the issue of sexual harassment.

July 2001: Council reaches common position.

October 2001: EP proposes a number of amendments to the Council's common position, which the Commission and Council can not accept. A joint Council/EP conciliation Committee is set up.

18 April 2002: Council/EP conciliation Committee agrees on joint text of a draft Directive, updating Directive 76/207/EEC. The conciliation Committee text will be forwarded to the EP for final approval by a plenary session in May 2002 and to the Council for final approval at a forthcoming meeting.

\section{Council Directive on worker information and consultation at national level}

15 November 1995: The Commission issues a Communication on worker information and consultation. The Communication is discussed by the Social Affairs Council and the social partners. The Commission believes that it is necessary to evaluate some of the main features of information and consultation in the national framework, in the light of the growing concern of European citizens about the social consequences of corporate restructuring. It adds that the need to ensure proper information and consultation of workers has also increased in response to the completion of the single market and moves towards globalisation.

4 June 1997: The Commission decides to consult the social partners. It wants to examine with them the need to create a framework to complement national practices and underpin existing EU legislation which provides for information and consultation in specific circumstances (transfer of undertakings, collective redundancies). The consultation comes within the framwork of recent events (like the Renault affaire in Vilvoorde), that have undermined the faith of Europeans in a social Europe, and also comes within the extension of the analysis made by the Davignon Group on the issue of employee participation on the issue of the status of the European company.

5 November 1997: The Commission decides to consult the social partners for the second time.

16 March 1998: UNICE states that its national affiliates do not want to negotiate anymore on this subject. According to UNICE, the EU should not interfere with information of employees at national level. This is something which should be regulated between the national social partners in each Member State.

11 March 1998: ETUC states that negotiations over worker information and consultation at national level should transform into a fundamental right for workers and their representatives the right to be informed and consulted over all decisions concerning them and contain a non-regression clause. 
13 March 1998: ETUC calls on the Commission to start its legislative procedure on this issue, since UNICE refuses to start negotiating.

16/17 March 1998: UNICE confirms that they do not want to negotiate anymore. European employers consider that the subject on which the Commission plans to propose legislation takes on a clearly national character, following the principle of subsidiarity. UNICE recalls furthermore that worker information and consultation at European level was already regulated by the directive on European works councils, that on collective dismissals, that on company transfers, and the legislation relating to health protection and work security. They mean that it is therefore not necessary to begin negotiations on this point today. Moreover, UNICE states that a substantial body of statutory and negotiated instruments already exists in 13 out of 15 Member States, and as a result there is no valid justification for a new intervention. ETUC secretary general Gabaglio states that only a minority within UNICE blocked the negotiations (Germany, Portugal, England and Greece).

Commissioner Flynn says that he will submit to the Commission a draft directive on worker information and consultation at national level.

July 1998: The new president of UNICE has indicated a willingness on the part of the European employers to reconsider their decision not to negotiate. The change in the attitude of UNICE is probably the result of the circulation of a leaked text of the European Commission, contaning a proposal for a draft Directive on national information and consultation. As a result of UNICE's apparent last minute change of heart, Commissioner Flynn postpones the publication of the draft Directive.

16 July 1998: In a press statement of 16 July 1998, ETUC said that it sees no point in negotiations unless the parties go into them with a commitment to get a result in a short, preset time frame and accepting that information and consultation is a fundamental right of all workers. It is a right which must be exercisable well before any decisions affectong jobs and employment conditions are taken, even if those rights necesarily have to be filled out and adapted as necessary at national level. If UNICE is not willing to address these demands, the legislators must, according to ETUC, do what they have to do.

19 August 1998: In a press statement of 19 August 1998, ETUC demands that the Commission brings forward an early proposal for a Directive.

16 October 1998: UNICE decides not to enter into negotiations with the ETUC and CEEP on worker information and consultation.

5 November 1998: Following the decision of the Levi Strauss group to close 4 plants in Europe, the ETUC urges Commissioner Flynn to undertake action at Community level in order to prevent hat these things happen again in the future. 
11 November 1998: The European Commission adopts a proposal for a Directive on worker information and consultation.

June 2001: The Council approves a compromise text on the basis of the Commission proposal. This text will be sent to the EP, which aims to dopt an opinion at the beginning of October 2001.

October 2001: EP puts forward a series of amendments to the Council's common position. As not all of these were acceptable to the Council the draft Directive enteres the conciliation stage of the EU's co-decision procedure.

17 December 2001: Agreement reached within the EP/Council conciliation Committee.

February 2002: Adoption of the Directive.

\section{Working time in the road transport sector}

October 1997: Social partners started talks.

31 March 1998: The Commission launched the second phase of consultations on the content of future legislation to amend the Directive of 1993, concerning certain aspects of the organisation of working time. ETUC, UNICE and CEEP are invited to negotiate a framework agreement in this area which may lead to the formulation of a Community Directive. The aim of the initiative is to include sectors and activities so far excluded from the 1993 Directive (air, rail, road, sea and inland waterway transport, sea fishing, offshore workers and doctors).

September 1998: Negotiations on working time in the road transport sector brake down.

8 September 1998: The Commission announces that it will present a proposal to the Joint Committee on Road Transport on working time. If this Joint Committee fails to reach an agreement, the Commission will bring forward its own proposals which will of course take account of the elements of convergence reached during the discussions in this Joint Committee.

18 November 1998: Commission issues a proposal for a Directive.

6 October 1999: Discussion in the Council.

22 December 2000: Political agreement reached in the Council to extend some of the protection of the 1993 working time Directive to the road transport sector.

23 March 2002: EU Directive extending some of the protection of the 93/104/EC Directive concering certain aspects of the organisation of working time to mobile workers in the road transport comes into force. 
Temporary agency work

3 May 2000: UNICE announces its decision to open European-level negotiations on temporary agency work, after pressure from the ETUC. The ETUC had stated that it would ask the Commission to propose legislation if UNICE kept unwilling to start negotiations. CEEP and UEAPME had already indicated their willingness to negotiate.

3 March 2001: The end of the nine-month period for negotiations on the basis of Article 138(4) is reached. Both ETUC and UNICE ask the Commission for one month of extension.

22 March 2001: Negotiations brake down. ETUC wanted equal treatment between the temporary agency workers and the user company workers, in order to prevent abuse. However, UNICE only wanted the comparison to be made with the user company only for health and safety conditions and maximum working time or minimum rest periods. ETUC now called the Commission to draw up a proposal for a Directive temporary agency work.

6 April 2001: The Commission gives ETUC, UNICE and CEEP untill May to reach an agreement.

10 May 2001: Meeting between the Commission, ETUC, UNICE and CEEP. Impossible to reach an agreement. Employers and workers cannot agree on the conditions of recourse to temporary agency work and equal treatment between temporary agency workers and user company employees. Commission announces that it will launch a legislative proposal on the issue.

October 2001: EU level sectoral social partners in the temporary agency work sector (UNI-Europa and EURO-CIETT) conclude a joint declaration. The declaration was negotiated within the framework of the European sectoral social dialogue Committee for temporary agency work. The signatories have forwarded the text to the European Commission, stating that they hope that it will serve as a basis for a future EU Directive on temporary work.

20 March 2002: European Commission issues a proposal for a Directive on working conditions for temporary agency workers. The draft Directive has been criticised by UNICE who wants to launch an appeal to the Council and the EP "to find a simpler and more balanced solution". The ETUC thinks that the Commissions decision to put forward a Directive on temporary work is a good idea. 


\section{E. Pending negotiations on European agreements}

\section{Industrial restructuring}

15 January 2002: Commission launches first stage of consultation of the European social partners on the subject of anticipating and managing the social effects of corporate restructuring.

April 2002: UNICE says that it sees no need for further regulation on this issue at Community level, although it would be willing to enter into exchanges of experience while ETUC has invited UNICE and CEEP to enter into substantive discussions. ETUC also calls for several Community instruments, either legislative and/or contractual instruments, to be adopted so that decisions relating to corporate restructuring may be taken with the long term in mind and managed in a socially acceptable way. UNICE and ETUC decide to spend three months analysing the question of company restructuring with the aim of reaching operational conclusions by June. 


\section{ANNEX II}

\section{BIBLIOGRAPHY}

\section{Periodicals}

Addison, J.T. and Siebert, W.S., Recent developments in social policy in the new European Union. In: Industrial and Labor relations Review, vol. 48, no. 1, 1994, pp. 5-27.

Adinolfi A., Admissibility of action for annulment by social partners and "sufficient representativity" of European agreements, In: European Law Review, vol. 25, no. 2, 2000, pp. 165-177.

Albeda, W., Sociale dimensie van Europa. In: Tijdschrift voor Arbeidsvraagstukken, vol. 9, no. 1, 1993, pp. 4-27.

Ashiagbor, D., EMU and the Shift in the European Labour Law Agenda: From 'Social Policy' to 'Employment Policy', In: European Law Journal, vol. 7 no. 3, 2001, pp. 311-330.

Barents, R., The internal market unlimited: some observations on the legal basis of Community legislation, In: Common Market Law Review, vol. 30, no. 1, 1993, pp. 85-109.

Barnard, C., The Social Partners and the Governance Agenda, In: European Law Journal, vol. 8, no. 1, 2002, pp. 80-101.

Bercusson B., Maastricht: a fundamental change in European labour law. In: Industrial Relations Journal, vol. 23, 1992, pp. 177-190.

Bercusson, B., European labour law and sectoral bargaining. In: Industrial Relations Journal, vol. 24, no. 4, 1993, pp. 257-272.

Bercusson, B., The dynamic of European Labour Law after Maastricht. In: Industrial Law Journal, vol. 23, no. 1, 1994, pp. 1-31.

Bercusson, B., The conceptualization of European Labour Law. In: Industrial Law Journal, vol. 24, no. 1, 1995, pp. 3-18.

Bercusson B. and van Dijk J.J., The implementation of the Protocol and Agreement on social policy of the Treaty on European Union. In: International Journal of Comparative Labour Law and Industrial Relations, vol. 11, Spring 1995, pp. 3 30.

Bercusson B. and others, A manifesto for social Europe. In: European Law Journal, vol. 3, no. 2, 1997, pp. 189-205.

Bercusson B., Democratic legitimacy and European labour law. In: Industrial Law Journal, vol. 28, no. 2, 1999, pp. 153-170.

Bercusson B., Labour regulation in a transnational economy. In: Maastricht Journal of European and Comparative Law, vol. 6, no. 3, 1999, pp. 244-270. 
Bergh, R.J. van den, and Camesasca, P.D., Irreconcidable Principles? The Court of Justice Exempts Collective Labour Agreements from the Wrath of Antitrust, In: European Law Review, vol. 25, no. 5, 2000, pp. 492-508.

Betten L., De oplossing van de Maastrichtse overeenkomst inzake sociale politiek: erger dan de kwaal? In: Sociaal Maandblad Arbeid, vol. 48, no. 12, 1993, pp. $742-$ 745.

Betten L., The democratic deficit of participatory democracy in Community social policy. In: European Law Review, vol. 23, no. 1, 1998, pp. 20-36.

Betten, L., The EU Charter on Fundamental Rights: a Trojan Horse or a Mouse?, In: The International Journal of Comparative Labour Law and Industrial Relations, vol. 17, no. 2, 2001, pp. 151-164.

Biagi M., Fortune smiles on the Italian EU Presidency: talking half-seriously about the posted workers and parental leave directives. In: The International Journal of Comparative Labour Law and Industrial Relations, vol. 12, no. 2, 1996, pp. 97-109.

Biagi M., The European Monetary Union and industrial relations. In: The International Journal of Comparative Labour Law and Industrial Relations, vol. 16, no. 1, 2000, pp. 39-45.

Birk R., Vereinbarungen der Sozialpartners im Rahmen des Sozialen Dialogs und ihre Durchführung. In: Europäisches Zeitschrift für Wirtschaftsrecht, vol. 8, no. 15, 1997, pp. 453-459.

Bogdandy A. von, The European Union as a Human Rights Organisation? Human Rights and the Core of the European Union, In: Common Market Law Review, vol. 37, no. 7, 2000, pp. 1307-1338.

Britz G. and Schmidt M., Die institutionalisierte Mitwirkung der Sozialpartner an der Rechtsetzung der Europäischen Gemeinschaft. In: Europarecht, vol. 32, no. 4, 1997, pp. 467-498.

Britz G. and Schmidt M., The institutionalised Participation Management and Labour in the Legislative Activities of the European Community: A Challenge to the Principle of Democracy under Community Law, In: European Law Journal, vol. 6 , no. 1, 2000, pp. 45-71.

Crouch C.J., From the neo-liberal decade to beyond Maastricht. In: Tijdschrift voor Arbeidsvraagstukken, no. 1, 1993, pp. 17-27.

Curtin D. and Ooik R. van, The Sting is Always in the Tail. The Personal Scope of Application of the EU Charter of Fundamental Rights, In: Maastricht Journal of European and Comparative Law, vol. 8, no. 1, 2001, pp. 102-114.

Dåubler, W., Grundprobleme des Internationalen Arbeitsrechts. In: Auszenwirtschaftsdienst des Betriebsberaters, vol. 18, no. 1, 1972, pp. 1-12.

Dăubler, W., Europăische Tarifvertrăge nach Maastricht. In: Europăisches Zeitschrift für Wirtschaftsrecht, vol. 3, no. 11, 1992, pp. 329-336. 
Dederer, H.G., Durchführung von Vereinbarungen der europăischen Sozialpartner, In: Recht der Arbeit, vol. 53, no. 4, 2000, pp. 216-222.

Dowling, D.C., EC employment law after Maastricht: Continental social Europe? In: The international lawyer, vol. 27, no. 1, 1993, pp. 1-26.

Drongelen, J. van, and Rijs, A.D.M. van, Het toetsingskader algemeen verbindend verklaring CAO-bepalingen, In: Sociaal Maandblad Arbeid, vol. 57, no. 2, 2002, pp. 124-137.

Erdmann K., Europåische Tarifvertrăge? In: Sozialer Fortschritt, vol. 12, no. 10, 1963, pp. 217-220.

Evju S., Collective Agreements and Competition Law. The Albany Puzzle, and van der Woude, In: The International Journal of Comparative Labour Law and Industrial Relations, vol. 17, no. 2, 2001, pp. 165-184.

Falkner G., The Maastricht Protocol on social policy: theory and practice. In: Journal of European social policy, vol. 6, no. 1, 1996, pp. 1-16.

Fitzpatrick, Community social law after Maastricht. In: Industrial Law Journal, vol. 21, no. 3, 1992, pp. 199-213.

Franssen E.J.A., Implementation of European Collective Agreements: Some Troublesome Issues, In: Maastricht Journal of European and Comparative Labour Law, vol. 5, no.1, 1998, pp. 53-66.

Franssen E.J.A., and Jacobs A.T.J.M., The Question of Representativity in the European Social Dialogue, In: Common Market Law Review, vol. 35, no. 6, 1998, pp. 1295-1312.

Franssen E.J.A., Jacobs A.T.J.M., Jaspers A.Ph.C.M., and Mortelmans K.J.M., Cao's en mededingingsrecht, In: Sociaal Maandblad Arbeid, vol. 55, no. 7/8, 2000, pp. 324-339.

Gamillscheg F., Ein gesetz über das internationale Arbeitsrecht. In: Zeitschrift für Arbeitsrecht, vol. 4, no. 14, 1983, pp. 307-373.

Germanotta P. and Novitz T., Globalisations and the Right to Strike: The Case for European-Level Protection of Secondary Action, In: The International Journal of Comparative Labour Law and Industrial Relations, vol. 18, no.1, 2002, pp. 67-82

Gernigon B., Odero A., Guido H., ILO principles concerning collective bargaining, In: International Labour Review, vol. 139, no. 1, 2000, pp. 34-55.

Gerver P.H.M., Naar een onderlinge Europese vereniging, coöperatie en onderling? In: Stichting en Vereniging, vol. 7, no. 6, 1992, pp. 139-146.

Geyer R., EU social policy in the 1990s: Does Maastricht matter? In: Journal of European Integration, no. 1, Fall 1996, pp. 5-33.

Gijzen M., The Charter: A Milestone for Social Protection in Europe?, In: Maastricht Journal of European and Comparative Law, vol. 8, no. 1, 2001, pp. 33-48.

Gollbach J. and Schulten T., Cross-border collective bargaining networks in Europe. In: European Journal of Industrial Relations, vol. 6, no. 2, 2000, pp. 161-179. 
Greaves R., The Nature and Binding Effect of Decisions under Article 189 EC, In: European Law Review, vol. 21, no. 1, 1996, pp. 3-16.

Grinten W.C.L. van der, Europese verenigingen? In: Stichting \& Vereniging, vol. 7, no. 6, 1992, pp. 142-144.

Guery G., European collective bargaining and the Maastricht Treaty. In: International Labour Review, vol. 131, no. 6, 1992, pp. 581-599.

Hansen L.L., Madsen J.S. and Jensen C.S., The Complex Reality of Convergence and Diversification in European Industrial Relations Systems: A Review of the 1996 IREC Conference. In: European Journal of Industrial Relations, vol. 3, no. 3, 1997, pp. 357-376.

Harlow C., A Community of interests? Making the Most of European Law, In: The Modern Law Review, vol. 55, no. 3, 1992, pp. 331-350.

Heijden P.F. en Sjerps C.M., Het Verdrag van Amsterdam en een sociaal Europa. In: NJB, vol. 74, no. 22, 1999, pp. 990-998.

Heinze M., Die Rechtsgrundlagen des sozialen Dialogs auf Gemeinschaftsebene, In: Zeitschrift für Arbeitsrecht, vol. 4, no. 28, 1997, pp. 505-521.

Heringa A.W., Towards an EU Charter of Fundamental Rights?, In: Maastricht Journal of European and Comparative Law, vol. 7, no. 2, 2000, pp. 111-116.

Herschel W., Grenzüberschreitende Tarifverträge. In: Betriebs-Berater, vol. 18, 1962, pp. 1255-1258.

Heynig E., Europäische Tarfivertrăge? In: Aussenwirtschafsdienst des BetriebsBeraters, no. 6, 1968, pp. 212-216.

Hoek van A.A.H., De CAO in het internationale arbeidsrecht. In: Sociaal Maandblad Arbeid, vol. 45, no. 9, 1990, pp. 512-519.

Höland A., Partnerschaftliche Setzung und Durchführung von Recht in der Europäischen Gemeinschaft. In: Zeitschrift für Internationales und Auslandisches Recht, 1995, pp. 425-451.

Huiskamp R., Vos K., EMU, Nederlandse bedrijven en arbeidsvoorwaardenoverleg, Tijdschrift voor arbeidsvraagstukken, vol. 17, no. 2, 2001, pp. 137-149.

Hyman R., National Industrial Relations Systems and Transnational Challenges: An Essay in Review. In: European Journal of Industrial Relations, vol. 5, no. 1, 1999, pp. 89-110.

Jacobs F.G., Human Rights in the European Union: the role of the Court of Justice, In: European Law Review, vol. 26, no. 4, 2001, pp. 331-341.

Jensen, C.S., Madsen, J.S., and Due, J., A role for a pan-European trade union movement? Possibilities in European IR-regulation. In: Industrial Relations Journal, vol. 26, no. 1, 1995, pp. 4-18.

Jensen C.S., Madsen J.S. and Due J., Phases and dynamics in the development of EU industrial relations regulation. In: Industrial Relations Journal, vol. 30, no. 2 , 1999, pp. 118-134. 
Kaemingk H.L., IPR-aspecten van Europese rechtspersonen, In: Ars Aequi, vol. 42, no. 7/8, 1993, pp. 521-533.

Karthaus B., Subsidiarităt: Rechtsgrundlage europăischer Tarifvertrăge. In: Arbeit und Recht, vol. 45, no. 6, 1997, pp. 221-223.

Keller B., Sozialdialoge als Instrument europăischer Arbeits- und Sozialpolitik? In: Industrielle Beziehungen, vol. 3, no. 3, 1996, pp. 207-227.

Keller B. and Sörries B., The Sectoral social Dialogue and European Social Policy: More Fantasy, Fewer Facts, In: European Journal of Industrial Relations, vol. 4, no. 3, 1998, pp. 331-348.

Keller B. and Sörries B., The new European social dialogue: old wine in new bottles? In: Journal of European Social Policy, vol. 9, no. 2, May 1999, 111-125.

Keller B. and Sörries B., Sectoral social dialogues: new opportunities or more impasses? In: Industrial Relations Journal, vol. 30, no. 4, 1999, pp. 330-344.

Krogsgaard L.B., Fundamental rights in the European Community after Maastricht, In: Legal Issues of European Integration, no. 1, 1993, pp. 99-113.

Krueger A.B., From Bismarck to Maastricht: The march to European Union and the labor compact. In: Labour Economics, vol. 7, no. 2, 2000, pp. 117-134.

Lange P., Maastricht and the Social Protocol: Why did they do it? In Politics \& Society, vol. 21, no. 1, 1993, pp. 5-36.

Lemmens P., The Relation between the Charter of Fundamental Rights of the European Union and the European Convention on Human Rights - Substantive Aspects, In: Maastricht Journal of European and Comparative Law, vol. 8, no. 1, 2001, pp. 49-67.

Lenaerts K. and Foubert P., Social Rights in the Case-Law of the European Court of Justice, In: Legal Issues of Economic Integration, vol. 28, no. 3, 2001, pp. $267-$ 296.

Lenaerts K. and Smijter E. de, The Charter and the Role of the European Courts, In: Maastricht Journal of European and Comparative Law, vol. 8., no. 1, 2001, pp. 90-101.

Mahnkopf B., Transmission belts of transnational competition? Trade unions and collective bargaining in the context of European integration. In: European Journal of Industrial Relations, vol. 1, no. 1, 1995, pp. 101-117.

Marginson P. and Sisson K., European collective bargaining: A virtual prospect? In: Journal of Common Market Studies, vol. 36, no. 4, 1998, pp. 505-520.

Nagelkerke A.G. and Nijs de W.F., Institutional dynamics in European industrial relations. In: Labour, vol. 12, no. 4, 1998, pp. 745-771.

Obradovic, D., Prospects for corporatist decision-making in the European Union: the social policy agreement. In: Journal of European Public Policy, vol. 2, no. 2, June 1995, pp. 261-283. 
O'Rourke R., EU social policy after the Treaty of Amsterdam. In: New Law Journal, vol. 147, no. 6803, 1997, p. 1158.

Peijpe van T., EU en het stakingsrecht. In: Sociaal Maandblad Arbeid, vol. 53, no. 4, 1998, pp. 149-150.

Platzer H.W., Die EU-Sozial und Beschăftigungspolitik nach Amsterdam: Koordinierte und verhăndelte Europăisierung? In: Integration, vol. 22, no. 3, 1999, pp. 176-190.

Rhodes, M., The future of the "social dimension", labour market regulation in post-1992 Europe. In: Journal of Common Market Studies, vol. 30, no. 1, 1992, pp. 23-51.

Riley A.J., The European Social Charter and Community Law, In: European Law Review, vol. 14, no. 2, 1989, pp. 80-86.

Rojot J., Le Flanchec A., Voynnet-Fourboul C., European Collective Bargaining, new Prospects or much Ado about Little?, In: The International Journal of Comparative Labour Law and Industrial Relations, vol. 17, no. 3, 2001, pp. 345-370.

Sadtler G., Europäische Tarifverträge. In: Neue Juristische Wochenschrift, vol. 22, no. 22, 1969, pp. 962-965.

Schmidt M., Parental leave: contested procedure, creditable results. In: International Journal of Comparative Labour Law and Industrial Relations, vol 13, no. 2, 1997, pp. 113-126.

Schmidt M., Representativity - a claim not satisfied: the social partners' role in the EC law-making procedure for social policy. In: The International Journal of Comparative Labour Law and Industrial relations, vol. 15, no. 3, 1999, pp. 259-267.

Schüster G., Rechtsfragen der Maastrichter Vereinbarungen zur Sozialpolitik. In: Europăische Zeitschrift für Wirtschaftsrecht, vol. 3, no. 6, 1992, pp. 178-187.

Schnorr G., Rechtsfragen Europäischer Tarifverträge. In Sozialer Fortschritt, vol. 12 , no. 7/8, 1963, pp. 155-162.

Schwarze R., Legitimation kraft vitueller Repräsentation - ein gemeinschaftsrechtliches Prinzip? In: Recht der Arbeit, vol. 54, no. 4, 2001, pp. 208-218.

Smismans S., The European Economic and Social Committee: towards deliberative democracy via a functional assembly, European Integrations Online Papers, vol. 4, no. 12, 2000 (http://eiop.or.at/eiop/texte/2000-012a.htm, published at 199-2000).

Steinberg F., Der Europåische Tarifvertrag. In Recht der Arbeit, vol. 24, no. 1/2, 1971, pp. 18-25.

Sterner S.E., European collective bargaining, the Union's point of view. In: Bulletin of Comparative Labour Relations, vol. 4, no. 10, 1979, pp. 421-423.

Supiot A., The transformation of work and the future of labour law in Europe: a multidiciplinary perspective. In: International Labour Review, vol. 138, no. 1, 1999, pp. 31-46. 
Szyszczak E., The New Paradigm for Social Policy: a Virtuous Circle?, In: Common Market Law Review, vol. 38, no. 4, 2001, pp. 1125-1170.

Tacke B., Tarifvertragsfreiheit und supranationale Tarifvertrăge. In: Sozialer Fortschritt, vol. 12, no. 5, 1963, pp. 102-106.

Toth A.G., The legal status of the Declarations annexed to the single European Act, In: Common Market Law Review, vol. 23, no. 6, 1986, pp. 803-812.

Traversa E., The consequences of European Monetary Union on collective bargaining and the national security systems. In: The International Journal of Comparative Labour Law and Industrial Relations, vol. 16, no. 1, 2000, pp. 47-54.

Treu T., A New Phase of European Social Policy: the EMU and beyond, In: International Journal of Comparative Labour Law and Industrial Relations, vol. 17 , no. 4, 2001, pp. 461-472.

Vobruba, G., Social policy on tomorrow's Euro-corporatist stage. In: Journal of European social policy, vol. 5, no. 4,1995, pp. 303-315.

Vos C.J., Het verdrag van Amsterdam: Vooruitgang op sociaal terrein? In: Sociaal Maandblad Arbeid, vol. 53, no. 6, juni 1998, pp. 257-261.

Wedderburn L., Consultation and collective bargaining in Europe: Success or ideology? In: Industrial Law Journal, vol. 26, no. 1, 1997, pp. 1-34.

Weiss M., The significance of Maastricht for EC social policy. In: The International Journal of Comparative Labour Law and Industrial Relations, vol. 8, no. 1, 1992, pp. 3-14.

Wilts A., Europeanization and Means of Interest Representation by National Business Associations, In: European Journal of Industrial Relations, vol. 7, no. 3, 2001, pp. 269-286.

Witte B. de, The Legal Status of the Charter: Vital Question or Non-Issue?, In: Maastricht Journal of European and Comparative Law, vol. 8, no. 1, 2001, pp. 8189.

Zabel H., Europăische Tarifverträge und gemeinsamer Markt, in Sozialer Fortschritt, no. 12, 1958, pp. 268-271.

Zeijen J.P.M., Europees sociaal beleid na Maastricht: een ratjetoe? In: Sociaal Recht, vol. 7, no. 5, 1992, pp. 132-139

\section{Parts of books}

Arnull A., Challenging Community Acts - An Introduction, In: Micklitz H.W., and Reich N.(eds.), Public Interest Litigation before European Courts, BadenBaden: Nomos Verlagsgesellschaft 1996, pp. 39-55.

Bercusson, B., Social policy at the crossroads: European labour law after Maastricht. In: R. Dehousse (ed.), Europe after Maastricht. An ever closer union?, München: Law Books in Europe 1994, pp. 149-185. 
Bercusson B., Globalizing Labour Law: Transnational Private Regulation and Countervailing Actors in European Labour Law, In: G. Teubner (ed.), Global Law Without a State, Aldershot/Brookfield USA/Singapore/Sydney: Darthmouth 1997, pp. 133-178.

Bercusson B., Public Interest Litigation in Social Policy, In: Micklitz H.W., and Reich N.(eds.), Public Interest Litigation before European Courts, Baden-Baden: Nomos Verlagsgesellschaft 1996, pp. 261-295.

Bercusson B., Trade Union Rights in EU Law, In: F. Snyder (ed.), The Europeanisation of Law: The Legal Effects of European Integration, Oxford/Portland Oregon: Hart Publishing 2000, pp. 195-209.

Bernard N., Legitimising EU Law: Is the Social Dialogue the Way Forward? Some Reflections Around the UEAPME Case, In: J. Shaw (ed.), Social Law and Policy in an Evolving European Union, Oxford/Portland: Hart Publishing 2000, pp. 279302.

Betten L., The role of social partners in the Community's social policy lawmaking: participatory democracy or furthering the interest of small elites, In: C. Engels and M. Weiss (eds.), Labour Law and Industrial Relations at the Turn of the Century, Liber Amicorum in Honour of Roger Blanpain, The Hague/ London/Boston: Kluwer Law International 1998, pp. 239-260.

Blank M., Europäische Kollektivvertrăge und Sozialer Dialog. In: W. Däubler, M. Bobke and K. Kehrmann (ed.), Arbeit und Recht. Festschrifte für Albert Gnade, Köln: Bund-Verlag 1992, pp. 649-660.

Blanpain R., Efforts to bring about Community-level collective bargaining. In: $\mathrm{H}$. Günter, Transnational industrial relations, London: MacMillan 1972, pp. 275-308.

Blanpain R., Sociale partners en de Europese Unie: taak en legitimatie. In: Betten L., Boelhouwer F., Fleuren van Walsum J., van Peijpe T., and Schut L.A.J. (eds.), Ongelijkheidscompensatie als rode draad in het recht, Liber Amicorum voor prof. M. Rood, Deventer: Kluwer 1997, pp. 285-298.

Blank M., Europäische Kollektivverträge und Sozialer Dialog. In: W. Däubler, M. Bobke, and K. Kehrmann (eds.), Arbeit und Recht, Festschrift für Albert Gnade zum 65. Geburtstag, Köln: Bund-Verlag 1992, pp. 649-660.

Boockmann B., Das Verhandlungsverfahren nach dem Maastrichter Sozialpolitischen Abkommen. In: P. Oberender en M.E. Streit (eds.), Europas Arbeitsmarkt im Integrationsprozess, Baden-Baden: Nomos Verlagsgesellschaft 1995, pp. 193-215.

Buda D., Auf dem Weg zu Europåischen Arbeitsbeziehungen? In: M. Mesch (ed.), Sozialpartnerschaft und Arbeitsbeziehungen in Europa, Wien: Manz Verlag 1995, pp. 289-321.

Buda D., On course of European labour relations? In: W.E. Lecher and H.W. Platzer (eds.), European Union - European industrial relations?, London/New York: Routledge, 1998, pp. 21-46. 
Campbell E., Remedies after the social policy agreement. In: J Loubay and A. Biondi (ed.), Remedies for breach of EC law, Chichester: John Wiley \& Sons, 1997, pp. 173-184.

Dăubler W., Möglichkeiten und Grenzen Europäischer Tarifvertrăge. In: Heinemann H. (ed.) Das Kollektive Arbeitsrecht in der Europäischen Gemeinschaft, Berlin: Erich Sschmidt Verlag GmbH \& Co. 1991, pp. 16-36.

Dorssemont F., De rechtspositie van de representatieve werknemersorganisaties. In: M. Rigaux, and W. van Eeckhoutte (eds.), Actuele problemen van het arbeidsrecht 5, Gent: Mys \& Breesch, pp. 241-307.

Dowling D.C., Employment Matters and the Social Charter, In: R.H. Folsom, R.B. Lake, and V.P. Nanda (eds.), European Community Law after 1992. A Practical Guide for Lawyers outside the Common Market, Deventer: Kluwer Law and Taxation Publishers 1993, pp. 596-607.

Hall M., Industrial relations and the social dimension of European integration: before and after Maastricht. In: R. Hyman and A. Ferner (Eds.), New frontiers in European industrial relations, Oxford: Blackwell Businesses, 1994, pp. 281-312

Hartkamp A., Principles of contract law. In: A Hartkamp, M. Hesselink, E. Hondius, C. Joustra and E du Perron (eds.), Towards a European civil code, Nijmegen: Ars Aequi Libri, and The Hague/London/Boston: Kluwer Law International 1998, pp. 105-120.

Hepple B., European labour law: the European Community. In: R. Blanpain, and C. Engels (eds.), Comparative labour law and industrial relations in industrialized market economies, Deventer: Kluwer 1993, pp. 143-166.

Hepple B., Towards a European constitution? In: C. Engels and M. Weiss (eds.), Liber Amicorum for R. Blanpain, The Hague: Kluwer Law International 1998, pp. 291-304.

Jacobi O., Der Soziale Dialog in der Europäischen Union. In: M. Mesch (ed.), Sozialpartnerschaft und Arbeitsbeziehungen in Europa, Wien: Manz Verlag 1995, pp. 257-287.

Jacobs A., From the Belgian national labour council to the European social dialogue. In: Liber Amoricum for R. Blanpain, The Hague: Kluwer Law International, pp. 305-328.

Jacobs A., The European Court of Justice, Social Law, and the European Social Partners, In: R. Blanpain (ed.), Labour Law, Human Rights and Social Justice, The Hague: Kluwer Law International 2001, pp. 141-152.

Korinek K., "Sozialpartnerschaft" als europăische Institution? In: Merten D., and Pitschas R. (eds.), Der europäische Sozialstaat und seine Institutionen, Berlin: Duncker \& Humblot 1993, pp. 119-147.

Lecher W., Perspektiven Europăischer Kollektivverhandlungen. In: Bispinck R., and Lecher W., (eds.), Tarifpolitik und Tarifsysteme in Europa, Köln: Bund-Verlag 1993, pp. 401-420. 
Lodge, J., Social Europe: fostering a people's Europe? In: J. Lodge (ed.), The European Community and the challenge of the future, London: Pinter Publishers 1989, pp. 303-318.

Micklitz H.W., The Interest in Public Interest Litigation, In; Micklitz H.W., and Reich N.(eds.), Public Interest Litigation before European Courts, Baden-Baden: Nomos Verlagsgesellschaft 1996, pp. 21-37.

Nettesheim M., Article 173 of the EC Treaty and Regulations: Towards the Development of Uniform Standing Requirements, In: Micklitz H.W., and Reich N.(eds.), Public Interest Litigation before European Courts, Baden-Baden: Nomos Verlagsgesellschaft 1996, pp. 225-240.

Ojeda Avilés A., Sind Europäische Tarifverträge "Blosse Empfehlungen"?, In: T. Klebe, P. Wedde, and M., Wolmerath (eds.), Recht und soziale Arbeitswelt, Festschrift für Wolfgang Dăubler zum 60. Geburtstag, Frankfurt am Main: BundVerlag 1999, pp. 519-542.

Oliver P., Fundamental rights in European Union law after the Treaty of Amsterdam, In: D. O'Keeffe, and A. Bavasso (eds.), Judicial Review in European Union Law, Liber Amicorum in Honour of Lord Slynn of Hadley, The Hague: Kluwer Law International 2000, pp. 319-342.

Reich N., Public Interest Litigations before European Jurisdictions, In: H.W. Micklitz, and N. Reich(eds.), Public Interest Litigation before European Courts, Baden-Baden: Nomos Verlagsgesellschaft 1996, pp. 3-19.

Shaw J., Citizens' Rights and Access to Law, In: H.W. Micklitz, and N. Reich (eds.), Public Interest Litigation before European Courts, Baden-Baden: Nomos Verlagsgesellschaft 1996, pp. 243-260.

Sciarra S., Collective Agreements in the Hierarchy of European Community Sources, In: P. Davies, A. Lyon-Caen, S. Sciarra, and S. Simitis (eds.), European Community Labour Law: Principles and Perspectives, Liber Amicorum Lord Wedderburn of Carlton, Oxford: Clarendon Press, 1996, pp. 189-212.

Slagter W.J., Grensoverschrijdende contracten. In: B. Wessels and T.H.M. van Wechem (eds.), Contracteren in de internationale praktijk, Deventer: Kluwer, 1994, pp. 1-19.

Szyszczak E., Social policy: a happy ending or a reworking of the fairy tale? In: D. O'Keefe, and P.M. Twomey (eds.), Legal issues of the Maastricht Treaty, London: Chancery Law Publishing 1994, pp. 313-327.

Traxler F. and Schmitter P.C., Arbeitsbeziehungen und Europăische Integration. In: M. Mesch (ed.), Sozialpartnerschaft und Arbeitsbeziehungen in Europa, Wien: Manz Verlag 1995, pp. 231-256.

Treu T., European collective bargaining levels. In: P. Davies, A. Lyon-Caen, S. Sciarrra, and S. Simitis (eds.), European Communities labour law: principles and perspectives, Liber Amicorum Lord Wedderburn of Carlton, Oxford 1996, pp. 169-187. 
Weiss M., Social dialogue and collective bargaining in the framework of social Europe. In: G. Spyropoulos, and G. Fragnière (eds.), Work and social policies in the new Europe, Brussels: European Interuniversity Press 1991, pp. 59-115.

Weiss M., Der Soziale Dialog als Katalysator koordinierter Tarifpolitik in der EG. In: M. Heinze, and A. Sollner (eds.), Arbeitsrecht in der Bewăhrung, Festschrift für Otto Rudolf Kissel zum 65. Geburtstag, München: C.H. Beck'sche Verlagsbuchhandlung 1994, pp. 1253-1267.

\section{Books}

Albors-Llorens A., private parties in European Community law; Challenging Community measures, Oxford: Clarendon Press, 1996.

Barents R., Het Verdrag van Amsterdam, Deventer: Kluwer 1997.

Barents R., and Brinkhorst L.J., Grondlijnen van Europees Recht, Deventer: W.E.J. Tjeenk Willink 2001.

Barnard C., EC Employment Law, Chichester: John Wiley \& Sons 1996.

Barnouin B., The European Labour movement and European integration, London: Frances Pinter (Publishers) 1986

Bercusson B., European Labour Law, London: Butterworths 1996.

Betten L, The Right to Strike in Community Law, Amsterdam/New York/ Oxford: North-Holland 1985.

Betten L., and Mac Devitt D., The protection of fundamental social rights in the European Union, The Hague: Kluwer 1996.

Blanpain R. (ed. in chief), Encyclopedia of Labour Law and Industrial Relations (various supplements), Deventer: Kluwer 1977.

Blanpain R., Labour law and Industrial Relations of the European Union. Maastricht and beyond: from a Community to a Union, Deventer: Kluwer 1992.

Blanpain R., and Engels C., European Labour Law, Deventer: Kluwer Law and Taxation Publishers 1995.

Blanpain R., and Vanachter O., Schets van het Belgisch arbeidsrecht, K.U. Leuven: Instituut voor arbeidsrecht 1997.

Blanpain R., Colucci M., Engels C., Hendrickx F., Salas L., and Wouters J., Europa na het Verdrag van Amsterdam, Institutioneel en Sociaal, Leuven: Peeters 1998.

Bödding B., Die europarechtlichen Instrumentarien der Sozialpartner, BadenBaden: Nomos Verlagsgesellschaft 1996.

Calliess C., and Ruffert M. (eds.), Kommentar des Vertrages über die Europäische Union und des Vertrages zur Gründung der Europäischen Gemeinschaft -EUV/ EGV, Neuwied: Hermann Luchterhand Verlag 1999.

Campbell D., and Cotter S., (eds.), The Law of the European Community, New York: Matthew Bender 1996. 
Church C.H., and Phinnemore D., European Union and European Community. A handbook and commentary on the post-Maastricht Treaties, New York: Harverster Wheatsheaf 1994.

Cornelis L., Algemene theorie van de verbintenis, Antwerpen: Intersentia, 2000.

David R., Egawa H., Graveson R., Knapp V., Mehren A.T. von, Noda Y., Rozmaryn S., Tschchikvadze V.M., Valladão H., Yntema H., Arbor A., Zweigert K. (eds.), International Encyclopedia of Comparative Law, Tübingen/Alphen aan de Rijn: J.C.B. Mohr/Sijthoff \& Noordhoff 1978.

Devroe W., and Wouters J., De Europese Unie, Leuven: Peeters 1996.

Dijk P. van, and Hoof G.J.H. van, Theory and Practice of the European Convention on Human Rights, The Hague/London/Boston: Kluwer Law International 1998.

Dolvik J.E., Redrawing boundaries of solidarity?, ETUC, social dialogue and the Europeanisation of trade unions in the 1990s, Arena Report No 5, Fafo Report No 238, Oslo December 1997.

Dorssemont F., De rechtspositie van de representatieve werknemersorganisaties, Dissertation, Antwerpen 2001.

Drobnig U., and Puttfarken H.J., Arbeitskampf auf Schiffen fremder Flagge, Kehl am Rhein/ Strassbourg/ Arlington: N.P. Engel Verlag 1982.

Eeckhoutte van W., Sociaal Compendium Arbeidsrecht 1997-98, Diegem: Kluwer/Ced Samson 1997

Falkner G., EU Social Policy in the 1990s, London/New York: Routledge 1998.

Galloway D., The Treaty of Nice and Beyond, Sheffield: Sheffield Academic Press Ltd. 2001.

Geers A.J.C.M., and Heerma van Voss G.J.J., Inleiding Europees arbeidsrecht, Monografieën Sociaal Recht, nr. 2, Deventer: Kluwer 1995.

Gervan van W. and Covemaeker S., Verbintenissenrecht, Leuven/Leusden: Acco 2001

Gilles T., Das Zustandekommen und die Durchführung von Sozialpartnervereinbarungen im Rahmen des europåischen sozialen Dialogs, Dissertation, Frankfurt am Main/New York: Peter Lang, 1999.

Grabitz E., and Hilf M., Das Recht der Europäischen Union, München: Verlag C.H. Beck 2001.

Groeben H. von der, Thiesing J., and Ehlermann C.D., Kommentar zum EWGVertrag, Baden-Baden: Nomos Verlagsgesellschaft 1991.

Harlow C., Towards a theory of access for the European Court of Justice, Yearbook of European Law no. 12, 1992, Oxford: Clarendon Press, 1993, pp. 213248.

Harris D., and Darcy J., The European Social Charter, Ardsley/New York: Transnational Publishers Inc. 2001. 
Hartley T.C., The Foundations of European Community Law, Oxford: Oxford University Press 1998.

Hepple B., European social dialogue - Alibi or opportunity?, London: Institute of Employment Rights 1993.

Herbots J., Contract law in Belgium, Deventer: Kluwer Law and Taxation Publishers 1995.

Herk L. van, Arbeidsvoorwaardenvorming op Europees niveau, Dissertation, Utrecht 1998, published at the internet: www.library.uu.nl/ proefsch/welcome.

Humblet P., Janvier R., Rauws W., Rigaux M., Synopsis van het Belgisch arbeidsrecht, Antwerpen/Groningen: Intersentia Rechtswetenschappen 1999.

Jacobs A., Het recht op collectief onderhandelen in rechtsvergelijkend en Europees perspectief, Alphen a/d Rijn: Samson H.D. Tjeenk Willink 1986.

Kampmeyer E., Protokoll und Abkommen über die Socialpolitik der Europăischen Union, Köln/Berlin/Bonn/München: Carl Heymans Verlag KG, 1998.

Kapteyn P.J.G., and VerLoren van Themaat P., Introduction to the Law of the European Communities, London/The Hague/Boston: Kluwer Law International 1998.

Keller B., Europäische Arbeits- und Sozialpolitik, München: Oldenbourg Verlag 1997.

Kötz H., and Flessner A., European Contract Law, Oxford: Clarendon Press 1997.

Lechner W.E., and Platzer H.W., European Union - European Industrial Relations, Global challenges, national developments and transnational dynamics, London/New York: Routledge 1998.

Lenz C.O., EG-Vertrag, Köln: Bundesanzeiger (etc.) 1999.

Lo Faro A., Regulating Social Europe, Reality \& Myth of Collective Bargaining in the EC Legal Order, Oxford/Portland Oregon: Hart 2000.

Morgenstern F., International conflicts of labour law, Geneva: International Labour Office 1984.

Nielsen R., and Szyszczak E., The Social Dimension of the European Union, Copenhagen: Handelshojskolens Forlag 1997.

Niland J.K., Lansbury R.D., and Verevis C., The future of industrial relations, London: Sage Publications 1994.

N.N., Freedom of association, Digest of decisions and principles of the Freedom of Association Committee of the Governing Body of the ILO, Geneva: Publication of the International Labour Office 1996.

N.N., De toekomst van de Europese sociale Dialoog, The Hague: Huisdrukkerij SER 1998.

Osieke E., Consitutional Law and Practice in the International Labour Organisation, Dordrecht/Boston/Lancaster: Martinus Nijhoff Publishers 1985. 
Piazolo K., Der Soziale Dialog nach dem abkommen über die Sozialpolitik und dem Vertrag von Amsterdam, Frankfurt am Main/Berlin/Bern/New York/ Paris/Wien: Peter Lang 1999.

Prechal S., Directives in European Community Law, Dissertation, UVA 1995.

Raworth P., The Legislative Process in the European Community, Deventer/ Boston: Kluwer Law and Taxation Publishers 1993.

Rigaux M., Actuele problemen van het Arbeidsrecht, Deel 3, Antwerpen: Kluwer Rechtswetenschappen 1990.

Rigaux M. (ed.), Cao-Recht, aflevering 1, Diegem, Ced Samson September 1994

Rojot J., International collective bargaining. An analysis and case study for Europe, Deventer: Kluwer 1978.

Roo A. de, and Jagtenberg R., Settling labour disputes in Europe, Deventer: Kluwer Law and Taxation Publishers 1994.

Ruysseveldt J. van, and Visser J., Industrial relations in Europe, London: Sage 1996.

Schermers H.G., Judicial protection in the European Communities, Deventer: Kluwer 1996.

Schwarze J.(ed.), EU-Kommentar, Baden-Baden: Nomos Verlagsgesellschaft 2000.

Smit H., and Herzog P., The law of the EC, A commentary on the EEC Treaty, New York: Matthew Bender 1996.

Smits J.M., Europees privaatrecht in wording, Ius Comune Reeks no. 32, Antwerpen: Intersentia 1999

Sörries B., Europäisierung der Arbeitsbeziehungen; Der soziale Dialog und seine Akteure, München/Mering: Rainer Hamp Verlag 1999.

Strikwerda L., De overeenkomst in het IPR, Praktijkreeks IPR, deel 11, Deventer: Kluwer 1995.

Teague P., The European Community: The social dimension, London: Kogan Page Ltd. 1989.

Teague P., and Grahl J., Industrial relations and European integration, London: Lawrence \&Wishart 1992.

Verhagen H.L.E., Agency in private international law, The Hague/Dordrecht: TMC Asser Instituut/Nijhoff 1995.

Vlas P., Rechtspersonen in het internationaal privaatrecht, Deventer: Kluwer 1982.

Vlas P. en Smits R.J.H., De 'apatride' vereniging; Rechtspersonen op het snijpunt van (internationaal) privaat- en publiekrecht (preleminary advises), no. 97, NVIR Oktober 1988.

Vlas P., Rechtspersonen, Praktijkreeks IPR, deel 9, Deventer: Kluwer 1999. 
Walz S., Multinationale Unternehmen und internationaler Tarifvertrag, BadenBaden: Nomos Verlagsgesellschaft 1981.

Wimmer N., Die Gestaltung internationaler Arbeitsverhăltnisse durch Kollektive Normenvertrăge, Baden-Baden: Nomos Verlagsgesellschaft 1992.

Wit M.A.C. de, Het goed werkgeverschap als intermediair van normen in het arbeidsrecht, Kluwer: Deventer, 1999.

\section{EC Documents}

\section{Council of Ministers}

\section{Regulations}

Council Regulation (EEC) No. 1408/71 of 14 June 1971, on the application of social security systems to employed persons and their families within the Community.

Council Regulation (EEC) No. 1612/68 of 15 October 1968, on freedom of movement for workers within the Community.

\section{Directives}

Council Directive 96/34/EC of 3 June 1996, concerning the framework agreement on parental leave concluded by UNICE, CEEP and the ETUC, OJ L 145/4, 19-61996.

Council Directive 97/81/EC of 15 December 1997, concerning the framework agreement on part-time work concluded by UNICE, CEEP, and the ETUC, OJ L 014, 20-1-1998

Council Directive 1999/63/EC of 21 June 1999, concerning the agreement on the organisation of working time of seafarers concluded by the ECSA and the FST, OJ L 167, 2-7-1999.

Council Directive 1999/70/EC of 28 June 1999, concerning the framework agreement on fixed term work concluded by ETUC, UNICE, and CEEP, OJ L 175, 10-71999 .

Council Directive 2000/79/EC of 27 November 2000, concerning the European agreement on the organisation of working time of mobile workers in civil aviation concluded by the AEA, the ETF, the ECA, the ERA, and the IACA, OJ L 302 , $1-12-2000$.

\section{Resolutions}

Council Resolution 94/C 368/03, of 6 December 1994, on certain aspects for a European Union social policy: a contribution to economic and social convergence in the Union. OJ C 368/6, 23-12-1994. 


\section{Decisions}

Council Decision No. 63/226/EEC of 2 April 1963, laying down general principles for implementing a common vocational training policy, OJ L 063/1338, 204-1963.

Council Decision No. 70/532 of 14 December 1970, setting up the Standing Committee on Employment in the European Communities, as amended by Decision $75 / 62$ of 20 January 1975, OJ L 273/25, 17-12-1970.

Council Decision No. 74/325/EEC of 27 June 1974, on the setting- up of an advisory committee on safety, hygiene and health protection at work, OJ L 185/15, 9-7-1974..

Council Decision No. 75/62/EEC of 20 January 1975, amending Decision No 70/532/EEC, OJ L 021/17, 28-1-1975.

Council Decision No. 1999/207/EC of 9 March 1999 on the reform of the Standing Committee on Employment and repealing decision 70/532/EEC OJ L 072, 18-3-1999.

Council Decision No. 2000/98/EC of 24 January 2000, establishing the Employment Committee, OJ L 29/21, 04-2-2000.

\section{Other documents}

Council report on the Convention on the law applicable to contractual obligations by M. Giuliano and P. Lagarde, OJ C 282/1, 31-10-1980.

\section{Commission}

\section{COM-documents}

$\operatorname{COM}(91) 273$ final, Proposal for a Council Regulation on the statute for European association, Brussels, 5-3-1992.

$\operatorname{COM}(93) 600$ final, Communication from the Commission concerning the application of the Agreement on Social Policy, presented by the Commission to the Council and to the European Parliament, Brussels, 14-12-1993.

$\operatorname{COM}(96) 26$ final, Draft proposal and explanatory memorandum for a Council Directive on the Framework Agreement on Parental Leave concluded by UNICE, CEEP and the ETUC, Brussels, 31-1-1996.

$\operatorname{COM}(96) 448$ final, Communication from the Commission concerning the Development of the Social Dialogue at Community level, Brussels, 18-9-1996.

$\operatorname{COM}(97) 392$ final, Proposal for a Council Directive concerning the framework agreement on part-time work concluded by UNICE, CEEP, and the ETUC, Brussels 23-7-1997.

$\operatorname{COM}(98) 322$, Adapting and promoting the social dialogue at Community level, Brussels, 20-5-1998. 
COM(98) 662 final, Proposal for a Council Directive concerning the agreement on the organisation of working time of seafarers concluded by the ECSA and the FST, Brussels, 18-11-1998.

$\operatorname{COM}(99) 203$ final, Proposal for a Council Directive concerning the framework agreement on fixed-term work concluded by UNICE, CEEP, and the ETUC, Brussels, 1-5-1999.

COM (2000) 379 final, Social Policy agenda, Brussels, 28-6-2000.

$\operatorname{COM}(2000) 382$, Proposal for a Council Directive concerning the European agreement on the organisation of working time of mobile workers in civil aviation concluded by the AEA, the ETF, the ECA, the ERA, and the IACA, Brussels, 23-62000.

$\operatorname{COM}(2001) 398$ final, Communication from the Commission to the Council and the European Parliament on European contract law, Brussels, 11-7-2001.

\section{Decisions}

Commission Decision 98/500/EC of 20 May 1998 on the establishment of Sectoral Dialogue Committees promoting the dialogue between the social partners at European level, OJ L 225, 12-8-1998.

\section{Other documents}

Social Partners' Study 1993, Main findings of the Social Partners' Study (Annex I), Summary Tables presenting an overview of the national affiliates of twelve European Federations covered by the Social Partners' Study (Annex II), Key elements on Representation Social Partners' Study (Annex III), Doc. No. V/6141/93/E.

Social Europe, 2/95, Social Dialogue - The Situation in the Community in 1995 , Publication of the European Commission, DG V, Luxembourg, 1996.

Industrial relations in Europe, 2000, Publication of the European Commission, DG-V/D, Brussels, 2000.

Budget Heading B3-4000, Industrial relations and social dialogue, Call for proposals, VP/2002/001.

Budget Heading B3-4002, Information and training measures for workers' organisations, Call for proposals, VP/2002/002.

\section{Economic and Social Council}

\section{Opinions}

Opinion 88/C 208/12 of 2 June 1988, on social developments in the Community in 1987, OJ C 208/39, 8-8-1988

Opinion $87 / \mathrm{C} 356 / 08$ of 19 November 1987 , on social aspects of the internal market, OJ C 356/31, 31-12-1987. 
Opinion 94/C $397 / 17$ of 24 November 1994, on the communication concerning the application of the Agreement on Social Policy presented by the Commission to the Council and to the European Parliament, OJ C 397/40, 31-12-1994.

Opinion CES 106/97 AH/ss of 29 January 1997, on the Commission communication concerning the development of the social dialogue at Community level.

\section{European Parliament}

\section{Resolutions}

Resolution A2-144/86 of 11 November 1986, on the role of the social partners in the labour market, OJ C 322/51, 15-12-1986.

Resolution A2-141/86 of 11 November 1986, on the European social area, OJ C $322 / 48,15-12-1986$.

Resolution A3-0091/94 of 24 February 1994, on the new social dimension of the Treaty on European union, OJ C 77/30, 14-3-1994.

Resolution A3-0269/94 of 3 May 1994, on the application of the Agreement on Social Policy, OJ C 205/86, 25-7-1994.

Resolution A4-0064/96 of 14 March 1996, on the Commission proposal for a Council Directive on the framework agreement concluded by UNICE, CEEP and ETUC on parental leave, OJ C 96/284, 1-4-1996.

Resolution A4-0261/99, on the European Framework Agreement on Fixed Term Work, OJ C 279/430, 1-10-1999.

Reports

Report A3-0247/93, of 1 September 1993, of the Committee on Social Affairs, Employment and the Working Environment, on the new social dimension of the Maastricht Treaty, PE 205.366/ fin.

Second report A3-0091/94, of 18 February 1994, of the Committee on Social Affairs, Employment and the Working Environment, on the new social dimension of the Treaty on European Union, PE 205.366/II/ fin.

Report A3-0269/94, of 20 April 1994, of the Committee on Social Affairs, Employment and the Working Environment, on the application of the Agreement on social policy, PE 207.928/fin.

Report A4-0226/97, of 27 June 1997, on the Commission Communication concerning the development of the social dialogue at Community level, PE 222.498/ fin.

Report A4-0352/97, of 6 November 1997, of the Committee on Employment and Social Affairs on the Commission proposal for a Council Directive concerning the framework agreement on part-time work concluded by UNICE, CEEP, and the ETUC, PE 222.513/fin. 
Report A4-0261/99, of 30 April 1999, of the Committee on Employment and Social Affairs, on the Commission proposal for a Council Directive concerning the framework agreement on fixed-term work concluded by UNICE, CEEP, and the ETUC, PE 230.208/fin 1.

\section{Other documents}

Working paper on strikes and secondary industrial action in the EU Member States, Social affairs series, W-8, PE 165.402.

Research study on trade union rights in the Member States of the European Union, undertaken by B. Bercusson for the European Parliament.

\section{European social dialogue (newsletter from the European Commission, DGVID)}

No. 0 (1996) - No. 16 (2000)

\section{"Europe"}

No. 1684 (25 January 1991) - No. 7242 (15/16 June 1998).

\section{Bulletin Quotidien Europe}

No. 7296 (9 September 1998) - No. 8113 (16 May 2002).

\section{European Industrial Relations Review}

No. 220 (May 1992) - No. 318 July 2000).

\section{EIROnline}

http://www.eiro.eurofound.ie

February 1997-May 2002.

\section{Reports and working papers}

Bercusson B., The ETUC and the European Court of Justice: Action or Re-Action, Report for the ETUC on the occasion of the Netlex meeting.

Bercusson B., Labour Regulation in a Global Economy, Discussion paper on the occasion of the conference: Ius Commune in a World Context, Maastricht April 1999.

Bignami F., The administrative state in a separation of powers constitution: Lessons for European Community rulemaking from the United States: The Jean Monnet Working Papers no. 5/99 
Boeri T., Brugiavini A., Calmfors L., The Role of Unions in the Twenty-First Century: A Report for the Fondazione Rodolfo Debendetti, New York: Oxford University Press 2001.

Dercksen W.J. (ed.), The Future of Industrial Relations in Europe, Proceedings of a conference in honour of prof. W. Albeda, The Hague: SDU uitgeverij 1990.

ETUC: Towards a European System of Industrial Relations, Adopted by the IXth Statutory Congress of the European Trade Union Confederation Helsinki, 29/0602/07/99.

Jacobs A., and Ojeda-Aviles A., The European social dialogue - Some legal issues. In: A legal framework for European industrial relations. Report by the ETUI Research Network on Transnational trade union rights, Brussels, June 1999.

Kerr A., The use and development of conciliation and mediation procedures, Report on the occasion of the international conference on the resolution of industrial disputes, Organised jointly by the European Commission and the Irish Labour Relations Commission, Dublin October 1993.

Lyon-Caen G., Op zoek naar de Europese collectieve arbeidsovereenkomst, Report for the European Commission, October 1972, V/855/72-N.

Marginson P. and Sission K., European collective bargaining: A virtual prospect? Paper for the IREC Conference "Industrial relations in Europe: Convergence or diversification?" Copenhagen 19-21 September 1996.

Herzfeld-Olsson P., Bercusson B. and Bruun N. (eds.), Transnational trade union rights in the European Union. Report for the Workshop summary, Department of labour market research, 1998:36.

Report on the occasion of the international conference on the resolution of industrial disputes, Organised jointly by the European Commission and the Irish Labour Relations Commission, Dublin October 1993.

Rodrigues M.J., c.s., Report of the High Level Group on Industrial Relations and Change in the European Union, Report for the European Commission, DG V, Unit EMPL/D.1, January 2002.

Schnorr G., De mogelijkheid van collectieve arbeidsovereenkomsten op Europees niveau, Report for the European Commission, March 1961, V/2128/61-N.

Streeck W., The Internationalisation of Industrial Relations in Europe: Prospects and Problems, Working Paper Series in European Studies, vol. 1, no. 1, 1998.

Turner L., Beyond National Unionism? Cross-National Labour Collaboration in the European Community, Discussion paper, June 1993.

\section{Agreements between European social partners' organisations}

Memorandum of understanding on engagement in a social dialogue between CEI-Bois and EFBWW, Brussels, 17 June 1994. 
European Framework Agreement between ETUC-UNICE-CEEP on Parental Leave, Brussels, 14 December 1995.

Agreement between the ECF-IUF and GITES to set up a Joint Information and Consultation Structure, Brussels, April 1997.

European Framework Agreement between ETUC-UNICE-CEEP on Part-time Work, Brussels, 6 June 1997.

Recommendation Framework Agreement between GEOPA/COPA and EFA/ ETUC on the Improvement of Paid Employment in Agriculture in the Member States of the European Union, Brussels, 24 July 1997.

ETUC-UNICE-CEEP Framework Agreement on Fixed-term Work, Brussels, 18 March 1998.

Agreement between ECF-IUF and HOTREC on the Framework of their Social Dialogue at European Level, Brussels, 28 September 1998.

Agreement between the Community of the European Railways and the Federation of the Transport Workers' Unions in the European Union on some aspects of the organisation of Working Time in the Rail Transport Sector, Brussels, 30 September 1998.

European Agreement between the FST and the ECSA on the Organisation of Working Time of Seafarers, Brussels, 30 September 1998.

Cooperation agreement between UNICE and UEAPME, Brussels, 12 November 1998.

Agreement between EuroCommerce and Euro-FIET on the Establishment of a Sectoral Dialogue Committee in Commerce, Brussels, 30 November 1998.

Agreement between EFCI and Euro-FIET on the Establishment of a Sectoral Social Dialogue Committee in the Cleaning Industry, Brussels, 18 December 1998.

Protocol between EUROCADRES and CEC for the European social dialogue, Brussels, 8 July 1999.

European Agreement between the AEA, ETF, ECA, ERA, and IACA on the Organisation of Working Time of Mobile Staff in Civil Aviation, Brussels, 22 March 2000.

Framework Agreement on Teleworking between the ETUC, EUROCADRES, CEC, UNICE/UEAPME and CEEP, Brussels, 16 July 2002. 



\section{ANNEX III}

\section{TABLE OF CASES}

\section{European Court of Justice}

Case 18/57 Judgment of 20/03/1959, Nold KG/ECSC High Authority (Rec. 1959, p. 89)

Case 18/57 Order of 04/12/1957, Nold KG/ECSC High Authority (Rec. 1957, p. 233)

Case 42/59 Judgment of 22/03/1961, S.N.U.P.A.T./ECSC High Authority (Rec. 1961, p. 103)

Case 42/59 Order of 30/06/1961, Breedband N.V./Société des Aciéries du Temple and others (Rec. 1962, p. 323)

Case 42/59 Third-party proceedings of 12/07/1962, Breedband N.V./Société des Aciéries du Temple and others (Rec. 1962, p. 271)

Case 49/59 See Case 42/59

Case 16/62 Order of 24/10/1962, Confédération nationale des producteurs de fruits et des legumes and others/Council EEC (Rec. 1962, p. 937)

Case 16/62 Judgment of 14/12/1962, Confédération nationale des producteurs de fruits et des legumes and others/Council EEC (Rec. 1962, p. 901)

Case 17/62 See Case 16/62, Prod. de raisins de table/Council

Case 25/62 Judgment of 15/07/1963, Plaumann/Commission EEC (Rec. 1963, p. 99)

Case 25/62 Order of 31/08/1962, Plaumann/Commission EEC (Rec. 1963, p. 253)

Case 25/62 Order of 21/12/1962, Plaumann/Commission EEC (Rec. 1963, p. 263)

Case 26/62 Judgment of 05/02/1963, Van Gend en Loos/Administratie der Belastingen (Rec. 1963, p. 3)

Case 15/63 Judgment of 04/03/1964, Lasalle/Parliament (Rec. 1964, p. 57)

Case 15/63 Order of 13/03/1963, Lasalle/Parliament (Rec. 1964, p. 115)

Case 15/63 Order of 14/11/1963, Lasalle/Parliament (Rec. 1964, p. 97 )

Case 90/63 Judgment of 13/11/1964, Commission EEC/Luxembourg and

Belgium (Rec. 1964, p. 1217)

Case 91/63 See Case 90/63, Commission de la EEC/Belgium

Cases 106-107/65 Judgement of 01/07/1965, Toepfer/Commission of the EEC (Rec. 1965, p. 525) 
Case 38/64 Judgment of 1/04/1965, Getreide-Import Gesellschaft/Commission of the EC (Rec. 1965, p. 263)

Case 54/65 Judgment of 16/06/1966, Forges de Chatillon (Rec. 1966, p. 265)

Case 6/68 Judgment of 11/07/1968, Zuckerfabrik Watenstedt GmbH/Council (Rec. 1968, p. 595)

Case 10/68 Judgment of 10/12/1969, Eridiana Zuccherifici and others/

Commission (Rec. 1969, p. 459)

Case 6/69 Judgment of 10/12/1969, Commission/France (Rec. 1969, p. 523)

Case 11/69 See Case 6/69, France/Commission

Case 29/69 Judgment of 12/11/1969, Stauder/Stadt Ulm (Rec. 1969, p. 419)

Case 64/69 Judgment of 16/04/1970, Compagnie française commerciale and financière/Commission (Rec. 1970, p. 221)

Case 69/69 Judgment of 16/06/1970, Alcan/Commission (Rec. 1970, p. 385)

Case 6/70 Judgment of 15/07/1970, Borromeo/Commission (Rec. 1970, p. 815)

Case 11/70 Judgment of 17/12/1970, Internationale Handelsgesellschaft mbH/ Einfuhr- und Vorratsstelle für Getreide und Futtermittel (Rec. 1970, p. 1125)

Case 15/70 Judgment of 18/11/1970, Chevalley/Commission (Rec. 1970, p. 975)

Case 41/70 Judgment of 13/05/1971, International Fruit Company and others/ Commission (Rec. 1971, p. 411)

Case 42/70 See Case 41/70, Velleman \& Tas

Case 43/70 See Case 41/70, van den Brink

Case 44/70 See Case 41/70, Kooy Rotterdam

Case 62/70 Judgment of 23/11/1971, Bock/Commission (Rec. 1971, p. 897)

Case 21/72 Judgment of 12/12/1972, International Fruit Company and others/ Produktschap voor Groenten en Fruit (Rec. 1972, p. 1219)

Case 22/72 See Case 21/72, Kooy Rotterdam

Case 23/72 See Case 21/72, Velleman

Case 24/72 See Case 21/72, van den Brink

Case 4/73 Judgment of 14/05/1974, Nold KG/Commission (Rec. 1974, p. 491)

Case 4/73 Order of 24/09/1975, Nold KG/Commission (Rec. 1975, p. 985)

Case 4/73 Order of 11/01/1977, Nold KG/Commission (Rec. 1977, p. 1)

Case 175/73 Judgment of 08/10/1974, Union Syndicale and others/Commission (Rec. 1974, p. 917)

Case 17/74 Judgment of 23/10/1974, Transocean Marine Paint Association/ Commission (Rec. 1974, p. 1063) 
Case 18/74 Judgment of 08/10/1974, Syndicat général du personnel des organismes européens/Commission (Rec. 1974, p. 933)

Case 41/74 Judgment of 04/12/1974, Van Duyn/Home Office (Rec. 1974, p. 1337) Case 100/74 Order of 12/05/1975, CAM SA/Commission and Council (Rec. 1975, p. 1417)

Case 100/74 Judgment of 18/11/1975, CAM SA/Commission (Rec. 1975, p. 1393)

Case 36/75 Judgment of 28/10/1975, Rutili/Ministre de l'intérieur (Rec. 1975, p. 1219)

Case $93 / 75$ Judgment of 17/12/1975, Adlerblum/Caisse nationale d'assurance vieillesse des travailleurs salariés (Rec. 1975, p. 2147)

Case 118/75 Judgment of 07/07/1976, Watson and Belman (Rec. 1976, p. 1185)

Case 26/76 Order of 23/07/1976, Metro/Commission (Rec. 1976, p. 1353)

Case 88/76 Judgment of 31/03/1977, Exportation des Sucres/Commission (Rec. 1977, p. 709)

Case 104/77 Judgment of 16/03/1978, Öhlschläger/Hauptzollamt Emmerich (Rec. 1978, p. 791)

Case 112/77 Judgment of 03/05/1978, Töpfer/Commission (Rec. 1978, p. 1019).

Case 113/77 Order of 14/10/1977, NTN Toyo Bearing/Council (Rec. 1977, p. 1721)

Case 113/77 Judgment of 29/03/1979, NTN Toyo Bearing/Council (Rec. 1979, p. 1185)

Case 123/77 Judgment of 16/03/1978, UNICME/Council (Rec. 1978, p. 845)

Case $148 / 78$ Judgment of 05/04/1979, Ratti (Rec. 1979, p. 1629)

Case 149/77 Judgment of 15/06/1978, Defrenne/Sabena (Rec. 1978, p. 1365)

Case 209/78 Order of 30/10/1978, Van Landewyck/Commission (Rec. 1978, p. 2111)

Case 209/78 Judgment of 29/10/1980, Van Landewyck/Commission (Rec. 1980, p. 3125)

Case 210/78 See Case 209/78, Fedetab/Commission

Case 211/78 See Case 209/78, Gosset/Commission

Case 212/78 See Case 209/78, BAT Benelux/Commission

Case 213/78 See Case 209/78, Cinta/Commission

Case 214/78 See Case 209/78, Weltab/Commission

Case 215/78 See Case 209/78, Jubilé/Commission.

Case 218/78 See Case 209/78, Vander Elst/Commission 
Case 136/79 Judgment of 26/06/1980, National Panasonic/Commission (Rec. 1980, p. 2033)

Case 138/79 Judgment of 29/10/1980, Roquette/Council (Rec. 1980, p. 3333)

Case 139/79 Judgment of 29/10/1980, Maizena/Council (Rec. 1980, p. 3393)

Case 789/79 Judgment of 17/06/1980, Calpak/Commission (Rec. 1980, p. 1949)

Case 790/79 See Case 789/79, Società emiliana frutta/Commission

Case 169/80 Judgment of 09/07/1981, Gondrand (Rec. 1981, p. 1931)

Case 260/80 Judgment of 19/01/1984, Andersen and others/Council (Rec. 1984, p. 177)

Case 8/81 Judgment of 19/01/1982, Becker (Rec. 1982, p. 53)

Case 45/81 Judgment of 25/03/1982, Moksel/Commission (Rec. 1982, p. 1129)

Case 60/81 Order of 07/07/1981, IBM/Commission (Rec. 1981, p. 1857)

Case 60/81 Judgment of 11/11/1981, IBM/Commission (Rec. 1981, p. 2639)

Case 114/81 Judgment of 30/09/1982, Tunnel Refineries/Council (Rec. 1982, p. 3189)

Case 132/81 Judgment of 16/09/1982, ONTPS/Vlaeminck (Rec. 1982, p. 2953)

Case 135/81 Judgment of 28/10/1982, Groupement des agences des voyages/ Commission

Case 242/81 Judgment of 30/09/1982, Roquette Frères/Council (Rec. 1982, p. 3213)

Case 270/81 Judgment of 15/07/1982, Felicitas Rickmers-Linie (Rec. 1982, p. 2771)

Case 11/82 Judgment of 17/01/1985, Piraiki Patraiki/Commission (Rec. 1982, p. 325)

Case 191/82 Judgment of 04/10/1983, FEDIOL/Commission (Rec. 1983, p. 2913)

Case 228/82 Order of 29/09/1982, Ford/Commission (Rec. 1982, p. 3091)

Case 228/82 Judgment of 28/02/1984, Ford/Commission (Rec. 1984, p. 1129)

Case 229/82 See Case 228/82

Case 229/82 Order of 06/09/1982, Ford AG/Commission (Rec. 1982, p. 2849)

Case 239/82 Judgment of 21/02/1984, Allied Corporation and others/

Commission (Rec. 1984, p. 1005)

Case 264/82 Judgment of 20/03/1985, Timex/Council and Commission (Rec. 1985, p. 849)

Case 275/82 See Case 239/82, Kaiser Aluminium/Commission

Case 63/83 Judgment of 10/07/1984, Kirk (Rec. 1984, p. 2689) 
Case 106/83 Judgment of 13/12/1984, Sermide (Rec. 1984, p. 4209)

Case 294/ 83 Judgment of 23/04/1986, Les Verts/Parliament (Rec. 1986, p.1339)

Case 169/84 Judgment of 28/01/1986, Cofaz/Commission (Rec. 1986, p. 391)

Case 222/84 Judgment of 15/05/1986, Johnston/Chief Constable of the Royal Ulster Constabulary (Rec. 1986, p. 1651)

Case 53/85 Judgment of 24/06/1986, AKZO Chemie/Commission (Rec. 1986, p. 1965).

Cases 67, 68 and 70/85 Judgment of 02/02/1985, Van der Kooy and others/ Commission (Rec. 1988, p. 219)

Case 71/ 85 Judgment of 04/12/1986, Netherlands State/Federatie Nederlandse Vakbeweging (Rec. 1986, p. 3855)

Case 89/85 Judgment of 27/09/1988, Ahlström/Commission (Rec. 1988, p. 5193)

Case 89/85 Judgment of 31/03/1993, Ahlström/Commission (Rec. 1993, p.I-1307)

Case 89/85 Order of 20/01/1994, Ahlström and others/Commission (Rec. 1994, p. I-99)

Case 104/85 See Case 89/85

Case 114/85 See Case 89/85, Pulp/Commission

Case 116/85 See Case 89/85, St. Anne-Nackawic

Case 117/85 See Case 89/85, Pulp

Case 125/85 See Case 89/85, Westar Timber

Case 126/85 See Case 89/85, Weldwood

Case 127/85 See Case 89/85, MacMillan Bloedel

Case 128/85 See Case 89/85, Canadian Forest Products

Case 129/85 See Case 89/85, British Columbia Forest Products (Rec.1982,p.3799)

Case 281/85 Judgment of 09/07/1987, Germany, France, Netherlands, Denmark and United Kingdom/Commission (Rec.1987,p.3203)

Case 283/85 See Case 281/85, France/Commission

Case 285/85 See Case 281/85, Denmark/Commission

Case 287/85 See Case 281/85, United Kingdom/Commission

Case 338/85 Judgment of 21/04/1988, Pardini/Ministero del commercio con l'estero (Rec. 1988, p. 2041)

Case 24/86 Judgment of 02/02/1988, Blaizot/Université de Liège and others (Rec. 1988, p. 379) 
Case 26/86 Judgment of 24/02/1987, Deutz und Geldermann/Council (Rec. 1987, p. 941)

Case 97/86 Judgment of 26/04/1988, Asteris/Commission (Rec.1988,p.2181)

Case 99/86 See Case 97/86, Greece/Commission

Case 114/86 Judgment of 27/09/1988, United Kingdom/Commission (Rec.1988, p. 5289)

Case 193/86 See Case 97/86, Asteris/Commission

Case 215/86 See Case 97/86, Greece/Commission

Case 222/86 Judgment of 15/10/1987, Unectef/Heylens (Rec. 1987, p. 4097)

Case 386/96 Judgment of 05/05/1998, Dreyfus/Commission (Rec. 1988, p. I-2309)

Case 46/87 Order of 26/03/1987, Hoechst/Commission (Rec. 1987, p. 1549)

Case 46/87 Judgment of 21/09/1989, Hoechst/Commission (Rec. 1989, p. 2859)

Case 85/87 Order of 28/10/1987, Dow Chemical Nederland/Commission (Rec. 1987, p. 4367)

Case 85/87 Judgment of 17/10/1989, Dow Benelux/Commission (Rec. 1989, p. 3137)

Case 97/87 Judgment of 17/10/1989, Dow Chemical Ibérica and others/

Commission (Rec. 1989, p. 3165)

Cases 193-194/87 Judgment of 11/05/1989, Maurissen and Union Syndicale/ Court of Auditors (Rec. 1989, p. 1045)

Case 236/87 Judgment of 22/09/1988, Bergemann/Bundesanstalt für Arbeit (Rec. 1988, p. 5125)

Case 5/88 Judgment of 13/07/1989, Wachauf/Bundesamt für Ernährung und Forstwirtschaft (Rec. 1989, p. 2609)

Case 70/88 Judgment of 22/05/1990, Parliament/Commission (Rec. 1999, p. I-2041)

Case 152/88 Judgment of 26/06/1990, Sofrimport/Commission (Rec. 1990, p. I-2477)

Case $160 / 88$ Order of $07 / 12 / 1988$, Fédération européenne de la santé animale and others/Council (Rec. 1988, p. 6399)

Case 160/88 Order of 13/07/1988, Fédération européenne de la santé animale and others/Council (Rec. 1988, p. 4121)

Case 202/88 Judgment of 19/03/1991, France/Commission (Rec. 1991, p. I-1223)

Case 331/88 Judgment of 13/11/1990, The Queen/Ministry of Agriculture,

Fisheries and Food ex parte FEDESA and others (Rec. 1990, p. I-4023)

Case C-260/89 Judgment of 18/06/1991, ERT/DEP (Rec. 1991, p. I-2925) 
Case C-298/89 Judgment of 29/06/1993, Gibraltar/Council (Rec. 1993, p. I-3605)

Case C-300/89 Judgment of 11/06/1991, Commission/Council (Rec. 1991, p. I-2867)

Case C-309/89 Judgment of 18/05/1994, Codorniu/Council (Rec. 1994, p. I-1853)

Case C-358/89 Judgment of 16/05/1991, Extramet Industrie/Council (Rec. 1991, p. I-2501)

Case C-358/89 Order of 14/02/1990, Extramet Industrie/Council (Rec. 1990, p. I-431, Summ. pub.)

Case C-358/ 89 Judgment of 11/06/1992, Extramet Industrie/Council (Rec. 1992, p. I-3813)

Case C-65/90 Judgment of 16/07/1992, Parliament/Council (Rec. 1992, p. I-4593)

Case C-258/90 Judgment of 07/05/1992, Pesquerias De Bermeo and Naviera

Laida/Commission (Rec. 1992, p. I-2901)

Case C-259/90 See Case C-258/90, Naviera Laida/Commission

Case C-15/91 Judgment of 24/11/1992, Buckl and others/Commission (Rec.

1992, p. I-6061)

Case C-108/91 See Case C-15/91, Buckl/Commission

Case C-364/92 Judgment of 19/01/1994, SAT Fluggesellschaft/Eurocontrol (Rec. 1994, p. I-43)

Case C-388/92 Judgment of 01/06/1994, Parliament/Council (Rec. 1994, p. 1-2067)

Case C-404/92 Judgment of 05/10/1994, X/Commission (Rec. 1994, p. I-4737)

Case C-65/93 Judgment of 30/03/1995, Parliament/Council (Rec. 1995, p. I-643)

Case C-168/93 Order of 12/07/1993, Gibraltar and Gibraltar Development/

Council (Rec. 1993, p. I-4009)

Case C-415/93 Judgment of 15/12/1995, Union royale belge des sociétés de football association and others/Bosman and others (Rec. 1995, p. I-4921)

Case C-417/93 Judgment of 10/05/1995, Parliament/Council (Rec. 1995, p. 1-1185)

Case C-21/94 Judgment of 05/07/1995, Parliament/Council (Rec. 1995, p. I-1827) Case C-209/94 Judgment of 15/02/1996, Buralux and others (Rec. 1996, p. I-615) Case C-10/95 Order of 23/11/1995, Asocarne/Council (Rec. 1995, p. I-4149)

Case C-84/95 Judgment of 30/07/1996, Bosphorus/Minister for Transport, Energy andCommunications and others (Rec. 1996, p. I-3953)

Case C-87/95 Order of 24/04/1996, Cassa nazionale di previdenza ed assistenza a favore degli avvocati e procuratori/Council (Rec. 1996, p. 1-2003) 
Case C-177/95 Judgment of 27/02/1997, Ebony Maritime and Loten Navigation (Rec. 1997, p. I-1111)

Case C-265/95 Judgment of 09/12/1997, Commission/France (Rec. 1997, p. I-6959)

Case C-270/95 Order of 28/03/1996, Kik/Council and Commission (Rec. 1996, p. I-1987)

Case C-392/95 Judgment of 10/06/1997, Parliament/Council (Rec. 1997, p. I-3213)

Case C-67/96 Judgment of 21/09/1999, Albany (Rec. 1999, p. I-5751)

Case C-2/97 Judgment of 17/12/1998, IP (Rec. 1998, p. I-8597)

Case C-115/97 Judgment of 21/09/1999, Brentjens' (Rec. 1999, p. I-6025)

Case C-116/97 See Case C-115/97, Brentjens' Handelsonderneming

Case C-117/97 See Case C-115/97, Brentjens' Handelsonderneming

Case C-173/99 Judgment of 26/06/2001, BECTU (Rec. 2001, p. I-4881)

\section{Opinions of the European Court of Justice}

Opinion 2/94, of 28/03/1996 (Rec. 1996, p. I-1759)

\section{Court of First Instance}

Case T-64/89 Judgment of 10/07/1990, Automec/Commission (Rec. 1990, p. II-367).

Case T-19/91 Order of 07/06/1991, Vichy/Commission (Rec. 1991, p. II-265)

Case T-19/91 Judgment of 27/02/1992, Vichy/Commission (Rec. 1992, p. II-415)

Case T-46/92 Judgment of 09/11/1994, Scottish Football/Commission (Rec. 1994, p. II-1039)

Case T-2/93 Judgment of 19/05/1994, Air France/Commission (Rec. 1994, p. II-323)

Case T-2/93 Order of 08/03/1995, Air France/Commission (Rec. 1995, p. II-533)

Case T-2/93 Order of 17/04/1996, Air France/Commission (Rec. 1996, p. II-235)

Case T-3/93 Judgment of 24/03/1994, Air France/Commission (Rec. 1994, p. II-121).

Case T-12/93 Order of 02/04/1993, CCE Vittel and CE Pierval/Commission (Rec. 1993, p. II-449)

Case T-12/93 Order of 06/07/1993, CCE Vittel and CE Pierval/Commission (Rec. 1993, p. II-785) 
Case T-12/93 Judgment of 27/04/1995, CCE Vittel and others/Commission (Rec. 1995, p. II-1247)

Case T-447/93 Judgment of 06/07/1995, AITEC and others/Commission (Rec. 1995, p. II-1971)

Case T-447/93 Order of 28/11/1996, AITEC/Commission (Rec. 1996, p. II-1631)

Case T-448/93 See Case T-447/93

Case T-449/93 See Case T-447/93, Titan Cement/Commission

Case T-463/93 Order of 29/10/1993, Guna/Council (Rec. 1993, p. II-1205)

Case T-465/93 Judgment of 19/05/1994, Consorzio gruppo di azione locale "Murgia Messapica"/Commission (Rec. 1994, p. II-361)

Case T-480/93 Judgment of 14/09/1995, Antillean Rice Mills and others/ Commission (Rec. 1995, p. II-2305)

Case T-481/93 Judgment of 13/12/1995, Vereniging van Exporteurs in Levende Varkens and Nederlandse Bond van Waaghouders van Levend Vee/Commission (Rec. 1995, p. II-2941)

Case T-482/93 Judgment of 10/07/1996, Weber/Commission (Rec. 1996, p. II-609)

Case T-483/93 See Case T-480/93, European Rice Brokers/Commission

Case T-484/93 See Case T-481/93, Exporteurs in Levende Varkens/Commission

Case T-585/93 Order of 09/08/1995, Greenpeace and others/Commission (Rec. 1995, p. II-2205)

Case T-99/94 Order of 20/10/1994, Asocarne/Council (Rec. 1994, p. II-871)

Case T-107/94 Order of 19/06/1995, Kik/Council and Commission (Rec. 1995, p. II-1717)

Case T-183/94 Order of 29/06/1995, Cantina cooperativa fra produttori vitivinicoli di Torre di Mosto and autres/Commission (Rec. 1995, p. Il-1941)

Case T-298/94 Judgment of 07/11/1996, Roquette Frères/Council (Rec. 1996, p. II-1531)

Case T-18/95 Order of 10/12/1996, Atlanta and Internationale Fruchtimport Gesellschaft Weichert/Commission (Rec. 1996, p. Il-1669)

Case T-47/95 Judgment of 09/04/1997, Terres Rouges and others/Commission (Rec. 1997, p. II-481)

Case T-116/95 Order of 10/06/1998, Cementir/Commission (Rec. 1998, p. II-2261)

Case T-134/95 Order of 14/03/1996, Dysan Magnetics and Review Magnetics/ Commission (Rec. 1996, p. II-181) 
Case T-5/96 Order of 04/10/1996, Sveriges Betodlares Centralförening and Henrikson/Commission (Rec. 1996, p. II-1299)

Case T-135/96 Order of 18/03/1997, UEAPME/Council (Rec. 1997, p. II-373)

Case T-135/96 Judgment of 17/06/1998, UEAPME/Council (Rec. 1998, p. II-2335)

Case T-14/97 Order of 25/06/1998, Sofivo and others/Council (Rec. 1998, p. II-2601)

Case T-15/97 See Case T-14/97, Kermene and Vals/Council

\section{European Commission of Human Rights/ European Court of Human Rights}

National Union of Belgian Police v. Belgium, 27 October 1975, Eur. Court HR Rep., Series A, 19 (1975), para. 40

Swedish Engine Drivers Union Case, 20 Eur. Ct. H.R. (ser. A) (1976)

Schmidt and Dahlström v. Sweden, 6 February 1976, Eur. Court HR Rep., Series A, 21 (1976), para.36

Appl. 10365/83, S. v. Federal Republic of Germany, D\&D 39 (1984), p. 237 (240)

Appl. 10550/83, Cheall v. the United Kingdom, D\&R 42 (1985), p. 185; See also P. van Dijk and G.J.H. van Hoof (eds.), Theory and Practice of the European Convention on Human Rights, p. 597

Gustafsson Case, 25 April 1996, Reports 1996-II, Vol. 9

Decision of the European Commission for Human Rights of 9 February 1990, M. \& Co. v. Germany, Case 13258/87, Y. ECHR (1990), 46

Judgement of the European Court of Human Rights of 18 February 1999, Matthews v. United Kingdom, Case 24833/94, Reports (1999-I), para. 32

\section{European Committee of Social Rights}

C II 184 (Cyprus); Also D. Harris and J. Darcy, The European Social Charter, p. 94 .

\section{Record of Proceedings of the Strasbourg Tripartite Conference of December 1958 convened by the ILO at the request of the CE, ILO Publication, 1959}

Rec Proc TC 205

International Court of Justice

Greece vs. UK (Preliminary Objection), I.C.J. Rep. 1952, p. 28 


\section{Belgian Civil Court}

Cass., 5 March 1984, Pas., 1984, I, p. 764; Cass., 10 November 1988, Arr. Cass., 1988-1989, p. 287

Cass., 3 February 1987, R.W., 1987-1988, p. 220 



\section{ANNEX IV}

\section{INDEX}

Accession by the Communities to the ECHR, opinion ..............................................11

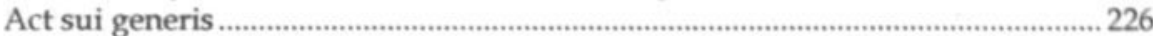

Agency.....

$133-134,172$

Agreement on Social Policy

Agreements, definition.

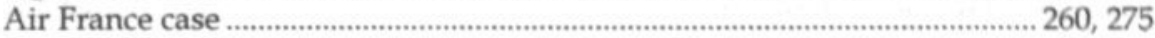

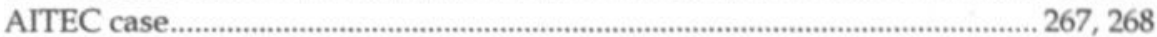

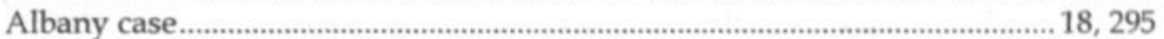

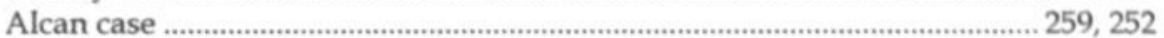

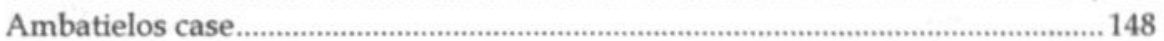

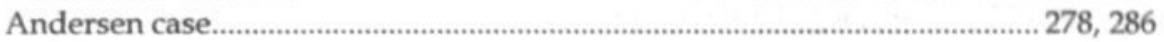

Arbitration

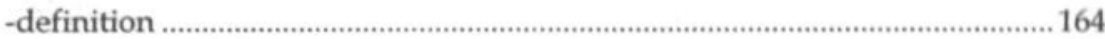

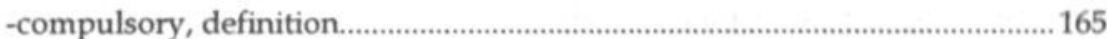

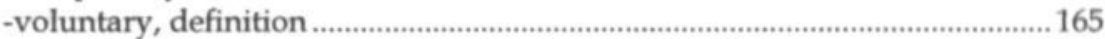

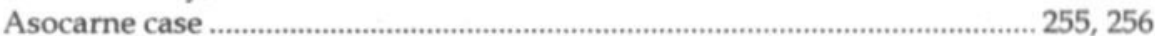

Association, Community concept ...................................................44-45, 246-247

Association, freedom of........................................................................16-20, 198

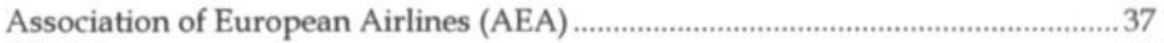

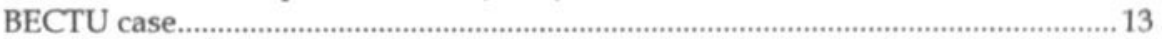

Belgian contract law ...............................................................117-118, 155-161

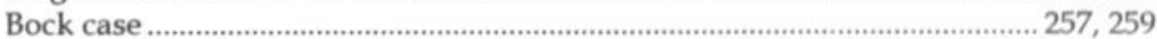

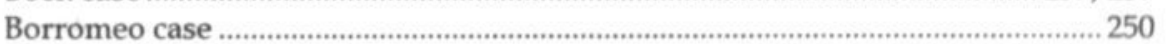

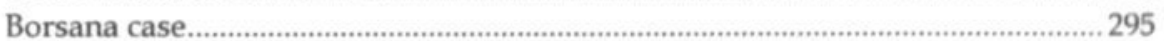

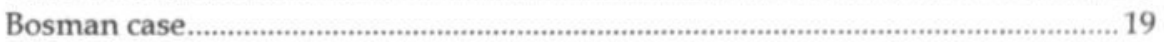

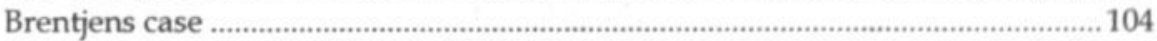

CCE de Vittel and Others case ........................................................ 260, 263, 275

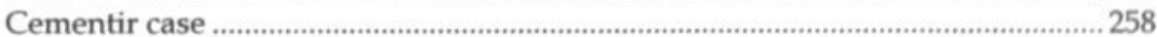

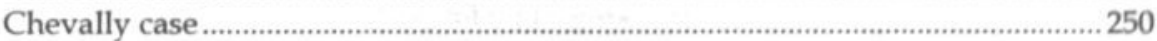

Codorniu case .............................................................................................................. 256

Collective agreement, definition, ...............................................................101-105

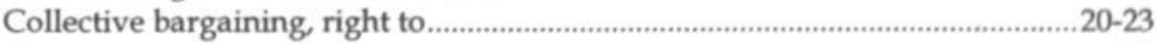

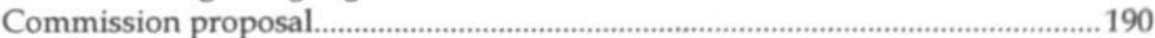

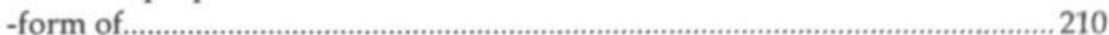

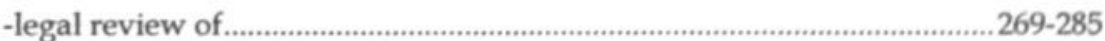

-rejection of by the Council..................................................................222-224

Committee of Agricultural Organisations

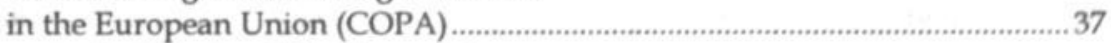

Community Charter of Fundamental

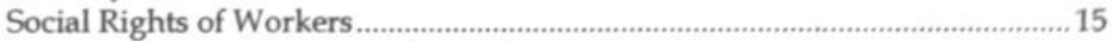

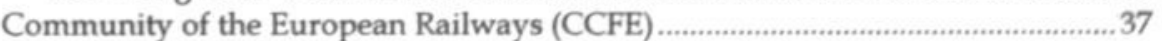

Compagnie des Forges de Châtillon case …............................................ 249, 282 
Conciliation, definition 163

Confédération Europeénne de Cadres (CEC)

Confédération Nationale des Producteurs des

Fruits et légumes case

Consultation

-obligation to

$221,274-279$

-procedure.

-promotion of

-subjects for.

-time limit for

79,81

Contractual relations, definition

101-102

Council decision

-decision-making procedure.

-form of.

-legal review of.

287-291

Council of Ministers, legislative competence

Cross-industry advisory committees

Decision, definition 226-228, 248-252

Declaration by Article 139(2) EC Treaty.

146-147

-content.

149-151

-legal status

Direct concern. 257-259

Directive on Parental Leave -content.

-development

annex

Directive on Part Time Work -content.

-development annex

Directive on Fixed Time Work

- development. annex

Directive on the Organisation of Working Time for Mobile Workers in Civil Aviation -development annex

Directive on the Organisation of Working Time for Seafarers -development annex

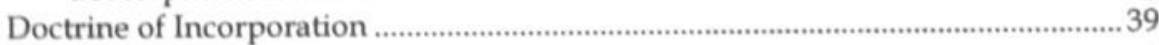

Doorn-group.

Draft Charter of Fundamental Rights of the

European Union (EU Charter)

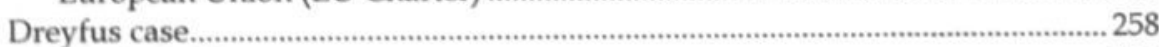

Drijvende Bokken case ................................................................................................ 104

Dysan Magnetics and Review Magnetics case ........................................................ 250

Economic and Social Committee (ECOSOC)...................................................49-50, 89

-role in the procedure of Article 139(2) EC Treaty.......................................235-237

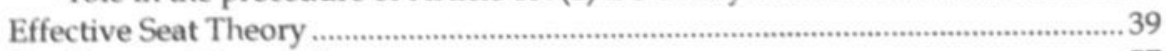

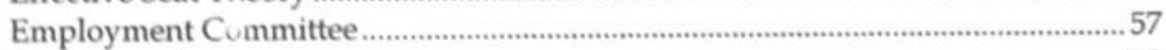

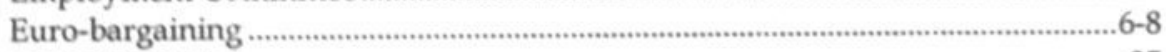

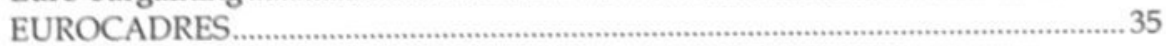


EUROCOMMERCE

European Agreement on the Organisation of Working

Time of Mobile Staff in Civil Aviation

-content.

-development

.annex

European Agreement on the Organisation of Working

Time of Seafarers

-content.

$143,144,146$

-development annex

European agreements - definition ..... 3

European Association of Craft and Small and

Medium-sized Enterprises (UEAPME)

European Centre for Public Enterprises (CEEP) ......................................................33-34

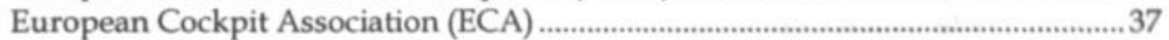

European collective agreement

-amendments to

$211,217-222$

-assessment of

207-208

-definition

101-105

-direct effect of.

139-145

-enforcement of

155

-against the signatory parties

$155-169$

-against the national affiliates .............................................................170-175

-against individuals..........................................................................175-180

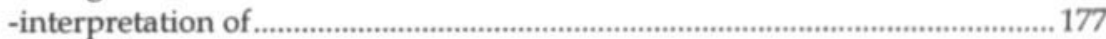

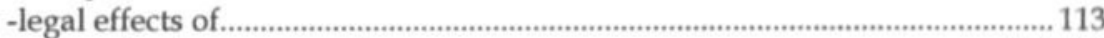

-on the signatory parties ........................................................................116-127

-on the national affiliates .....................................................................128-136

-on individual workers and employers ...............................................137-146

-on the Member States .........................................................................146-151

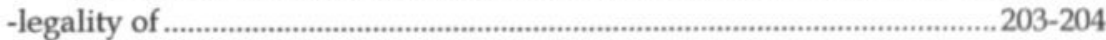

-rejection of by the Commission ..............................................................208-210

-requirements for .......................................................................................105-106

-with regard to the concluding parties ................................................106-107

-with regard to the bargaining procedure ...........................................107-111

-with regard to the form .....................................................................110-111

-with regard to the content...................................................................111-112

European Community Shipowners' Association (ECSA) ......................................... 37

European contract law...................................................................................122-125

European Convention on Human Rights (ECHR) ................................................ 10

European Federation of Agricultural

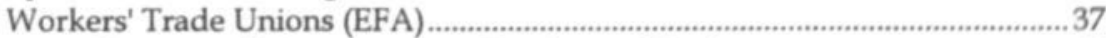

European Framework Agreement on Fixed-term Work........................................6 69

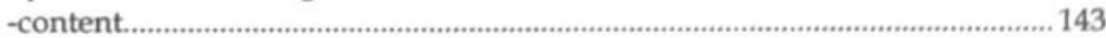

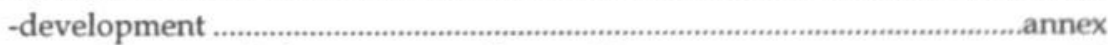

European Framework Agreement on Parental Leave...........................................69

-content........................................................................................ 140, 186, 207

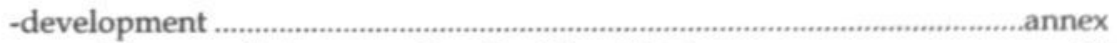

European Framework Agreement on Part-time Work ...........................................69 
-content.

$156,157,191,199,207$

-development

annex

European Mediation and Conciliation Service $168,174-175$

European Parliament. 88

-role in the procedure of Article 139(2) EC Treaty. 230-235

European Regional Airline Association (ERA) ….........................................................37

European Social Charter (ESC) ....................................................................................... 14

European social dialogue - definition ...............................................................................

European social partners' organisations

-bargaining procedure between. $107-110$

-definition

-internal decision making procedure

$109,200-203$

-internal rules

$.132-133,172-173$

European Trade Union Confederation (ETUC) .....................................................30-32

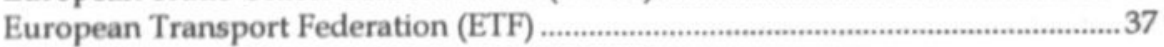

Exporteurs in levende Varkens and Others case ...................................................... 2254

Extramet case.............................................................................................................. 254, 256

Federal Mediation and Conciliation Service ...................................................167-168

Federation of the Transport Workers Unions

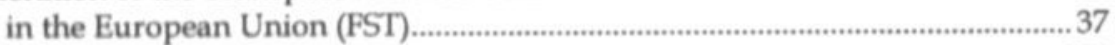

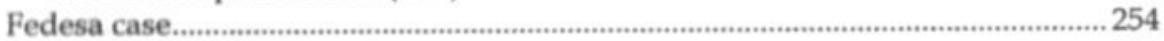

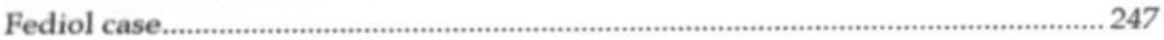

Financial support of the European social partners' organisations.

$.75-78,270-274$

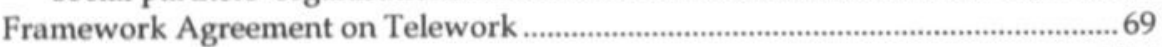

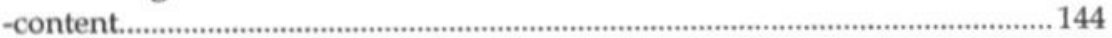

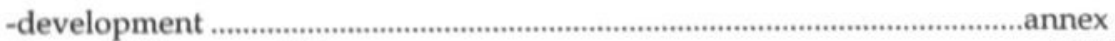

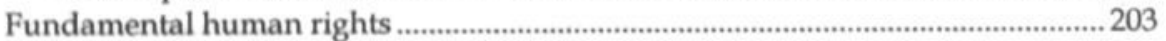

Germany, France, Netherlands, Denmark and UK case ............................... 276, 285

Gibraltar case ................................................................................................. 255, 256

Greenpeace case ........................................................................................................... 261

Groupement des Agences de Voyages case ........................................... 245, 247, 267

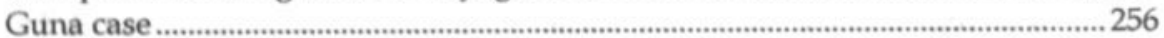

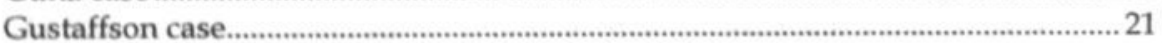

Hague Convention on the Law applicable to Agency .............................................135

Human rights protection

-in general .............................................................................................................14

-socio-economic..............................................................................................14-16

IBM case $250,252,275,282,284,285,286,288,299$

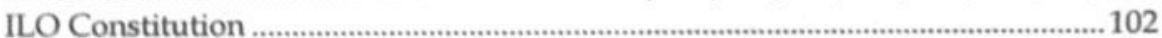

ILO Convention no. 87 ..............................................................................103, 107

ILO Convention no. 98 .......................................................................................... 130

ILO-Recommendation no. 91.....................................................................102, 127

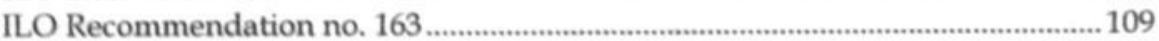

Individual concern ................................................................................................259-268

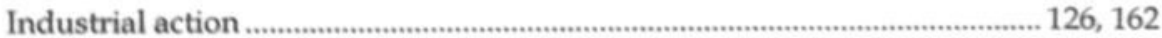

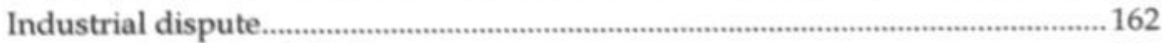

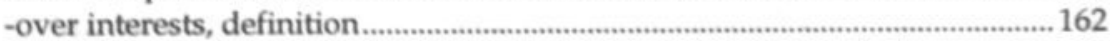


-over rights, definition .................................................................................... 162

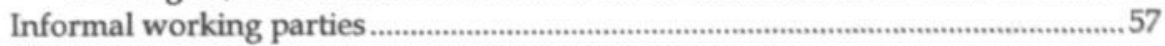

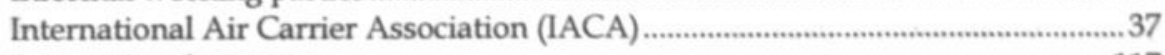

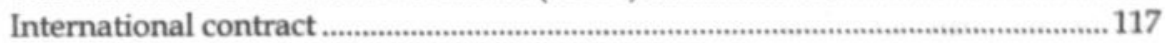

Internationale Handelsgesellschaft case ................................................................. 9

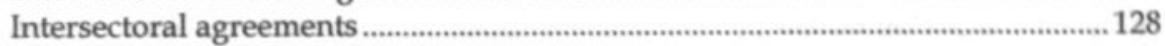

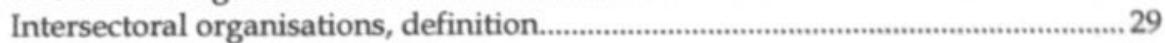

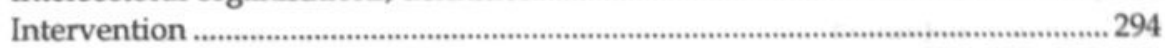

Jégo-Quéré case ............................................................................ 265, 291, 295, 298

Joint Agreement (of 31 October 1991) ...............................................................62-65

Joint committees...........................................................................................51-52, 57

Joint request of the European social partners'organisations ................................186

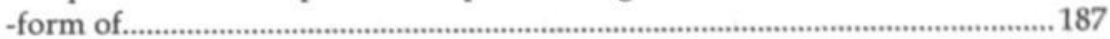

-withdrawal of ...............................................................................................187-188

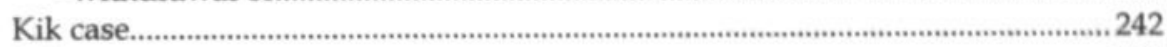

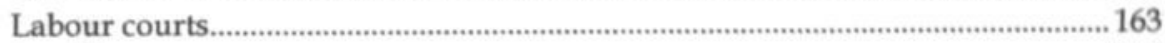

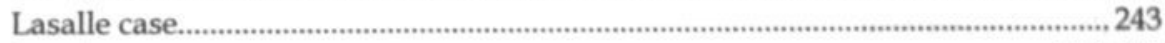

Legal person ...................................................................................................243-247

Legal personality

-Community concept of ...........................................................................244-246

-in general ...........................................................................................................38-39

-of the European social partners ....................................................................4 42

Les Verts case ....................................................................... 257, 270, 271, 273, 298

Management and labour, definition....................................................................95-96

Mandate .............................................................................108-110, 133-134, 199-200

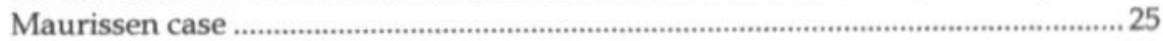

Mediation, definition ............................................................................................... 164

Metro case .................................................................................................2259, 275

Murgia Messapica case.............................................................................. 273, 298

Negotiations between the European social partners' organisations

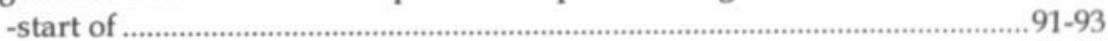

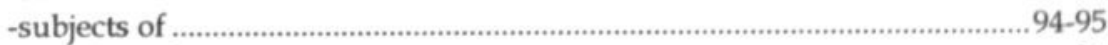

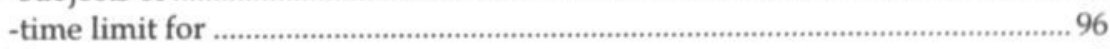

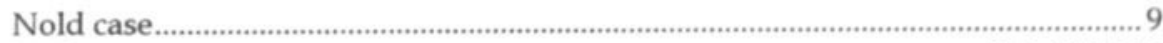

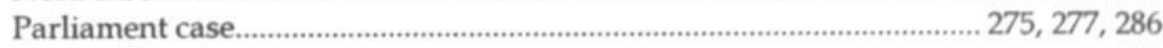

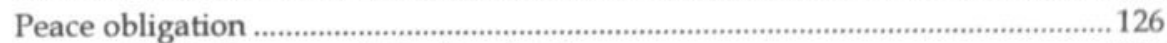

Pesquerias de Berneo and Naviera Laida case......................................................2.274

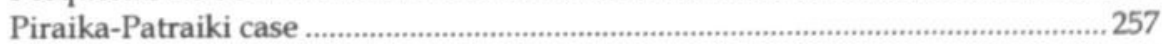

Plaumann case.................................................................................2242, 252, 259

Preliminary procedures..................................................................................294-296

Principles of European Contract Law ........................................................122-125

Private international law...............................................................115, 131, 145-146

Recommendation Framework Agreement on the

Improvement of Paid Labour in Agriculture ......................................................38

-content................................................................135, 139, 140, 141, 142, 143, 144

-development ..............................................................................................nnex

Representativity

-criteria

$84-90,95,106,192-199$ 
Sectoral agreements

128-129

Sectoral Dialogue Committees

$52,166-168,177$

Sectoral organisations, definition

Single European Act (SEA)

61-62

Small and medium-sized enterprises 204-207

Social Dialogue Committee

Social Partners Study

Social policy, definition.

$82-83$

Sofrimport case.

Standing Committee on Employment (SCE) ......................................................52-54

Stauder case

Steering group

Sveriges Betodlares Centralförening and Hendrikson case

Swedish Engine Drivers' Union case.

Syndicat Général dus Personnel-case.

Timex case. 260,275

Treaty of Amsterdam .68

Treaty of Maastricht.

Treaty of Nice

Tripartite conferences

54-55

UEAPME-case

$22,195,206,221,232,247,256,262,289,291,292,298,300$

UK case.

UNICME case

Union of Industrial and Employers' Confederation (UNICE)

32-33

Union Syndicale, Massa and Kortner case...

Van der Kooy and Others case

Val Duchesse meeting

Van Gend en Loos case

Vienna Convention on the Law of Treaties

Wachauf case 


\section{CURRICULUM VITAE}

Edith Franssen werd geboren op 31 december 1965 te Geleen. Van 1978 tot 1986 volgde zij de HAVO en het VWO en studeerde vervolgens Nederlands recht aan de Universiteit Maastricht (UM), waar zij in 1992 haar BUL behaalde. $\mathrm{Na}$ enige tijd als docente en derde geldstroomonderzoekster te hebben gewerkt, was zij van 1997 tot 2002 aio aan de UM. Sinds juni 2002 werkt zij deels als universitair docent aan de UM en deels als advocate te Heerlen. 
This thesis deals with certain legal aspects of the European social dialogue as described in the Articles 138 and 139 EC Treaty. On the one hand, legal problems with regard to the conclusion and implementation of agreements between the European social partners' organisations are discussed. On the other hand, the relation between the European social partners' organisations and the EC institutions is scrutinised. The thesis also gives some ideas for the content of a (possible) future European collective labour legislation.

Part I is an introduction in which certain European social partners' organisations are discussed and the development of the European social dialogue is described. Part II deals with the consultation of the European social partners' organisations, which is done by the European Commission. It also discusses the legal aspects of the conclusion of agreements between the social partners and the enforcement of the rights and obligations flowing from these agreements. In Part III, the conversion of these agreements into Community legislation is discussed. Furthermore, the possibilities for the European social partners' organisations to submit a legal claim against the European Commission or Council of Ministers are scrutinised. Finally, in Part IV, some conclusions and recommendations are made. The thesis also contains an annex. In this annex, an overview is given of all Community legislation, in which the European social partners' organisations were involved, either because they have been consulted with regard to that legislation, or because the legislation is based on an agreement concluded between them.

Edith Franssen (1965), works as a lecturer at the University of Maastricht in The Netherlands, where she teaches Dutch and European labour law. She also works as a lawyer at a law firm in Heerlen. She has published some articles on the European social dialogue in various reviews. 